\title{
Archaeological Survey of Lackland Air Force Base, Bexar County, Texas
}

\author{
David L. Nickels \\ David W. Pease \\ Center for Archaeological Research \\ C. Britt Bousman \\ Department of Anthropology, Texas State University
}

Follow this and additional works at: https://scholarworks.sfasu.edu/ita

Part of the American Material Culture Commons, Archaeological Anthropology Commons, Environmental Studies Commons, Other American Studies Commons, Other Arts and Humanities Commons, Other History of Art, Architecture, and Archaeology Commons, and the United States History Commons

Tell us how this article helped you.

This Article is brought to you for free and open access by the Center for Regional Heritage Research at SFA ScholarWorks. It has been accepted for inclusion in Index of Texas Archaeology: Open Access Gray Literature from the Lone Star State by an authorized editor of SFA ScholarWorks. For more information, please contact cdsscholarworks@sfasu.edu. 


\section{Archaeological Survey of Lackland Air Force Base, Bexar County, Texas}

Creative Commons License

(c) (i) (8)

This work is licensed under a Creative Commons Attribution-NonCommercial 4.0 International License 


\title{
Archaeological Survey of Lackland Air Force Base, Bexar County, Texas
}

\section{David L. Nickels, David W. Pease, and C. Britt Bousman}

\author{
with contributions by \\ Jeffrey Durst, James O. Jones, Lee C. Nordt, \\ Gerry R. Raymond, Robert R. Rector, and Anna Jean Taylor
}

Robert J. Hard and C. Britt Bousman

Principal Investigators

${ }^{\circ}$ copyright

Archaeological Survey Report, No. 248

Center for Archaeological Research

The University of Texas at San Antonio

1997 
The following information is provided in accordance with the General Rules of Practice and Procedure, Chapter 41.11 (Investigative Reports), Texas Antiquities Committee:

1. Type of investigation: Survey and testing

2. Project name: Lackland Air Force Base Survey

3. County: Bexar

4. Principal investigators: Robert J. Hard and C. Britt Bousman

5. Name and location of sponsoring agency: National Park Service, Rocky Mountain Region, Denver, Colorado 80225-0287

6. Texas Antiquities Committee Permit No.: n/a

7. Published by the Center for Archaeological Research, The University of Texas at San Antonio, San Antonio, Texas 78249-0658, 1997

A list of publications offered by the Center for Archaeological Research is available. Call (210) 458-4378; write to the Center for Archaeological Research, The University of Texas at San Antonio, 6900 N. Loop 1604 W., San Antonio, Texas 78249-0658; e-mail to car@lonestar.utsa.edu; or visit CAR's Web site at http://www.csbs.utsa.edu/research/car/index.htm. 


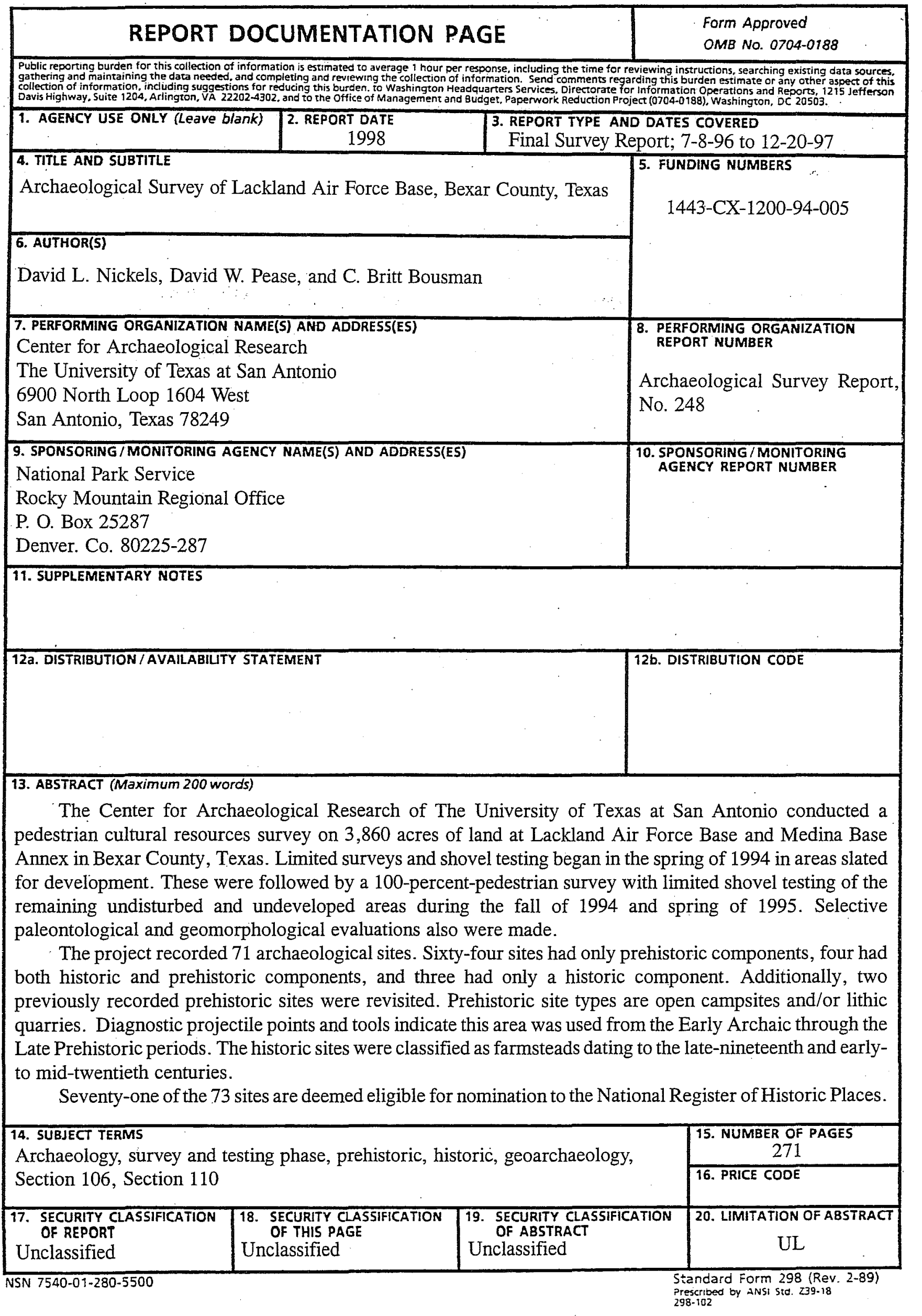





\begin{abstract}
The Center for Archaeological Research of The University of Texas at San Antonio conducted a pedestrian cultural resources survey on 3,860 acres of land at Lackland Air Force Base and Medina Base Annex in Bexar County, Texas. Base boundaries contain parts of three tributaries of the Medina River: Leon Creek, Medio Creek, and the upper reaches of Long Hollow. Limited surveys and shovel testing began in the spring of 1994 in areas slated for development. These were followed by a 100-percent-pedestrian survey with limited shovel testing of the remaining undisturbed and undeveloped areas during the fall of 1994 and spring of 1995. Selective paleontological and geomorphological evaluations also were made.

The project recorded 71 archaeological sites. Sixty-four sites had only prehistoric components, four had both historic and prehistoric components, and three had only a historic component. Additionally, three previously recorded prehistoric sites were revisited. Prehistoric site types are open campsites and/or lithic quarries. Fortunately, some of the prehistoric sites yielded diagnostic projectile points and tools. These indicate human presence in the survey area from the Early Archaic through the Late Prehistoric periods. The historic sites were classified as farmsteads dating to the late-nineteenth and early to mid-twentieth centuries.
\end{abstract}

Seventy-one of the 74 sites are deemed eligible for nomination to the National Register of Historic Places. 


\section{Contents}

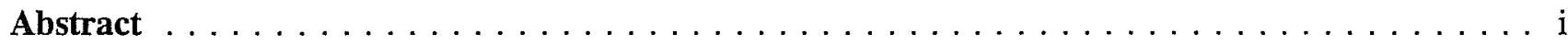

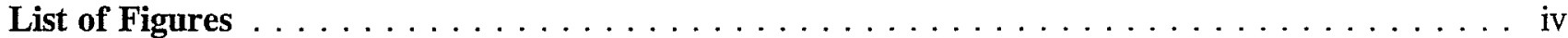

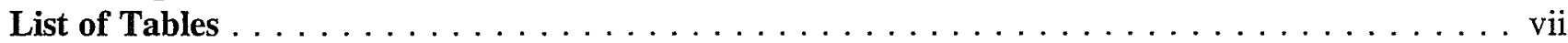

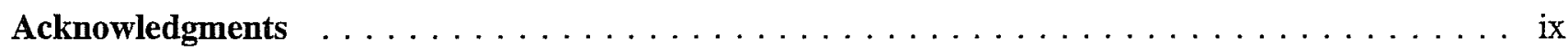

Part I. Project Background

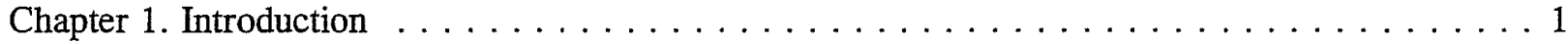

Chapter 2. The Project Area . . . . . . . . . . . . . . . . . . . . . . 5

Chapter 3. Fluvial Geomorphology and Geoarchaeology of Medio and Leon Creek

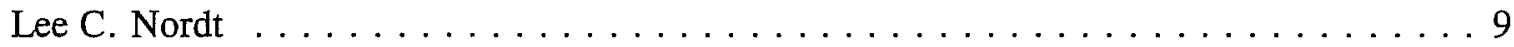

Chapter 4. Paleontology and Stratigraphy

James O. Jones . . . . . . . . . . . . . . . . . . . . . . . . . . 20

Chapter 5. Previous Archaeological Research $\ldots \ldots \ldots \ldots \ldots \ldots \ldots \ldots \ldots \ldots . \ldots \ldots 27$

Chapter 6. Methodology . . . . . . . . . . . . . . . . . . . . . . . . 41

Part II. Prehistoric Sites

Chapter 7. Theoretical Background and Research Design for Prehistoric Sites . . . . . . . . . . 49

Chapter 8. Archaeological Sites . . . . . . . . . . . . . . . . . . . . . . . . . . . . . 59

Leon Creek Prehistoric Sites . . . . . . . . . . . . . . . . . . . . . . . . . . . 59

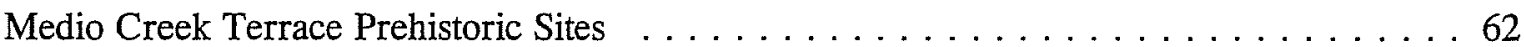

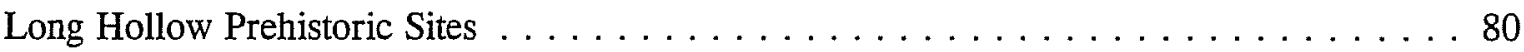

The Upland Periphery Prehistoric Sites $\ldots \ldots \ldots \ldots \ldots \ldots \ldots \ldots \ldots \ldots . \ldots \ldots$

Chapter 9. Isolated Finds . . . . . . . . . . . . . . . . . . . . . . 117

Chapter 10. Analysis of the Prehistoric Survey Data $\ldots \ldots \ldots \ldots \ldots \ldots \ldots \ldots$

\section{Part III. Historic Sites}

Chapter 11. Historical Background and Research Design for Historic Sites . . . . . . . . . . 136

Chapter 12. Historic Sites . . . . . . . . . . . . . . . . . . . . . . . . . . . . . . . . . 144

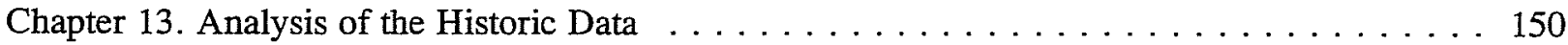

\section{Part IV. Summary and Recommendations}

Chapter 14. Summary . . . . . . . . . . . . . . . . . . . . . . . . . . . . . . . . . . 169

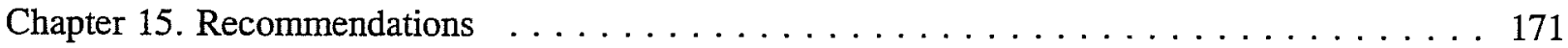

\section{Part V. References and Appendixes}

References Cited ...

Appendix A. Soil-stratigraphic Descriptions

Lee C. Nordt . . . . . . . . . . . . . . . . . . . . . . . . . . . . . . . . . 199

Appendix B. Taxonomic Lists of Fossils

James O. Jones . . . . . . . . . . . . . . . . . . . . . . . . . . . . . . . . . . 204

Appendix C. Prime Beef-Prime Rib Combat Arms Area Letter Report

Anna Jean Taylor . . . . . . . . . . . . . . . . . . . . . . 211

Appendix D. Wherry Housing Letter Report

Gerry R. Raymond 
Appendix E. Special Areas Letter Report

Jeffrey Durst . . . . . . . . . . . . . . . . . . . . . . . . . . . . . . . 223

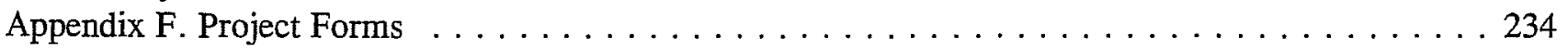

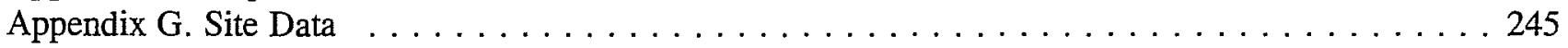

Appendix H. Phase II Testing of 41BX1065, A Prehistoric Uplands Site on Leon Creek

Robert R. Rector . . . . . . . . . . . . . . . . . . . . . . . . . . . 253 


\section{Figures}

1-1. Location of Lackland Air Force Base . . . . . . . . . . . . . . . . . . . . . 2

3-1. Geomorphic map of the Medio Creek alluvial valley in the project area showing

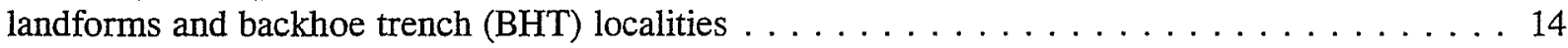

3-2. Composite alluvial stratigraphic cross section of the south transect of Medio Creek . . . . . . . 15

3-3. Composite alluvial stratigraphic cross section of the north transect of Medio Creek . . . . . . 16

3-4. Map of the Leon Creek alluvial valley in the project area showing

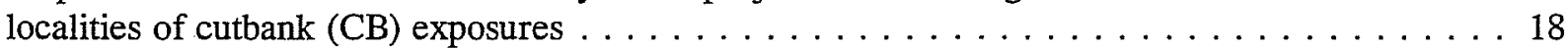

4-1. Location of paleontological sites on Lackland AFB and Medina Annex . . . . . . . . . . . . 22

4-2. Navarro Formation exposed in Medio Creek valley at coordinates L21 . . . . . . . . . . . 23

4-3. Upper Taylor Marl exposed in the south bank of the west side of Leon Creek

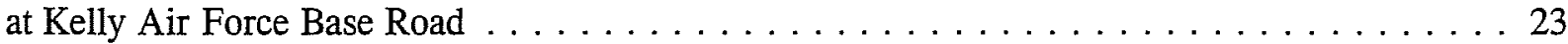

4-4. Upper Taylor Marl exposed in the south side of the east bank of a tributary to Leon Creek . . . 24

4-5. Megafossils from the Navarro Marl in Medio Creek . . . . . . . . . . . . . . . . . . 25

6-1. Lackland AFB, Medina Annex . . . . . . . . . . . . . . . . . . . . . . 43

6-2. Lackland AFB, Main Base . . . . . . . . . . . . . . . . . . . . . . . . . 44

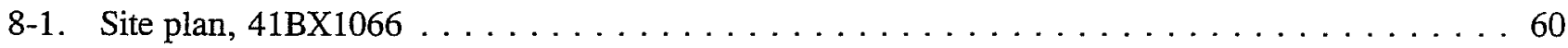

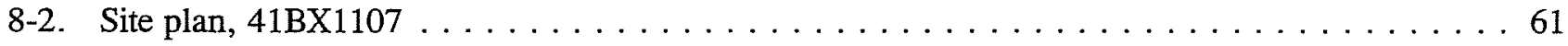

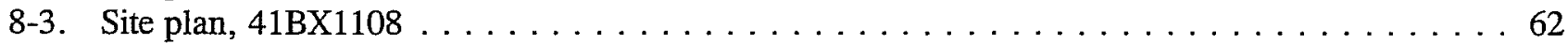

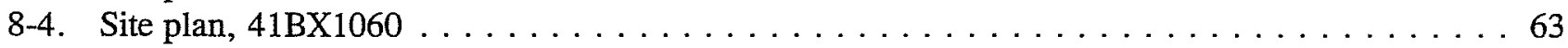

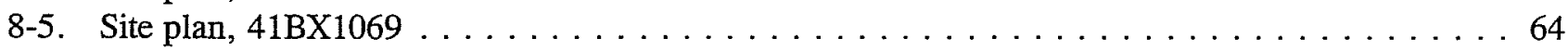

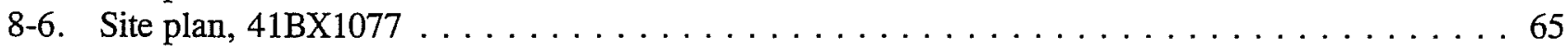

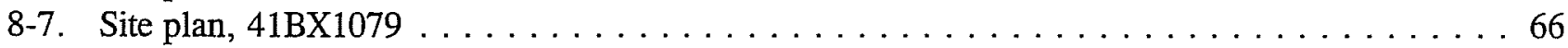

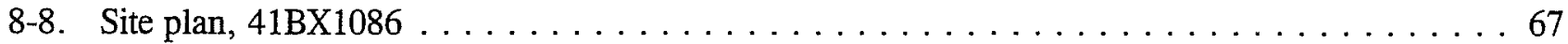

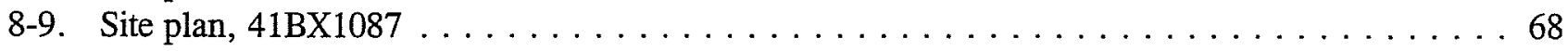

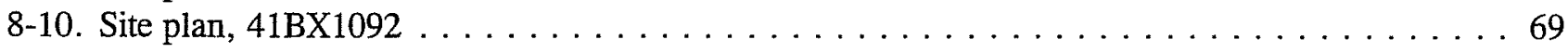

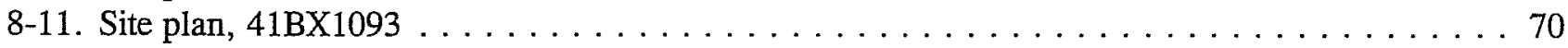

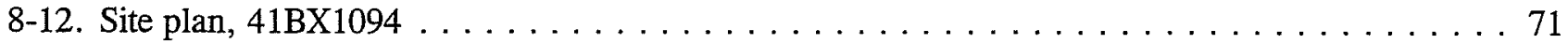

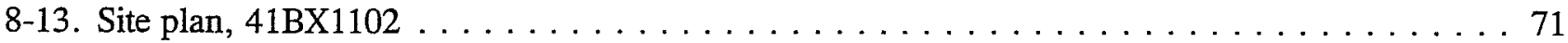

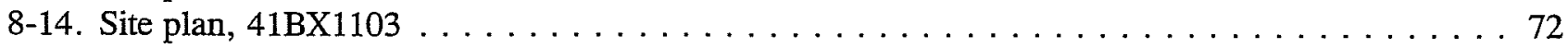

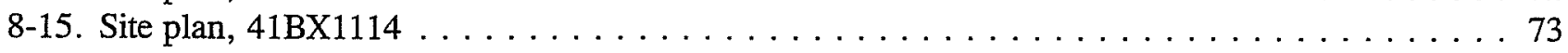

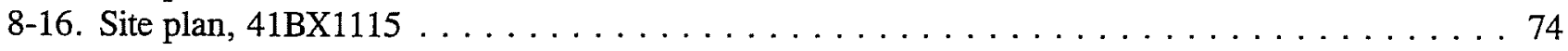

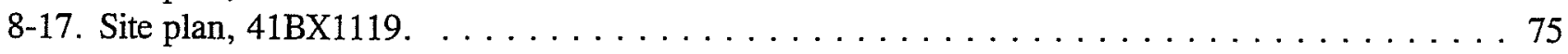

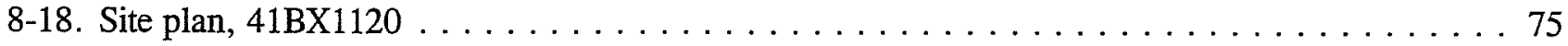

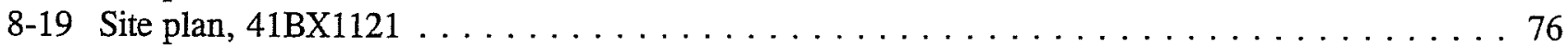

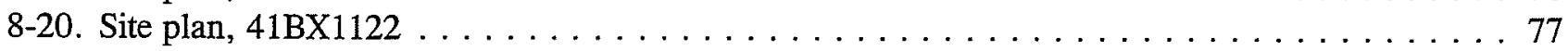

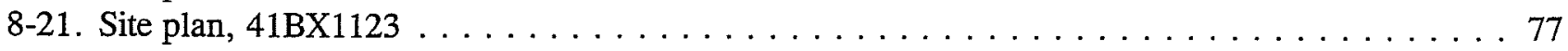

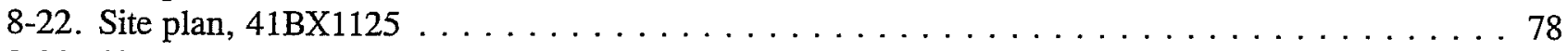

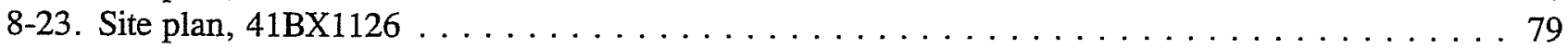

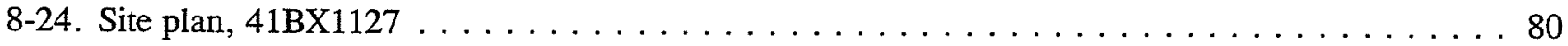

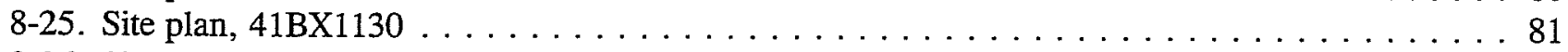

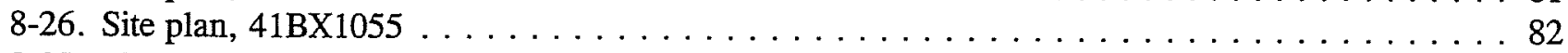

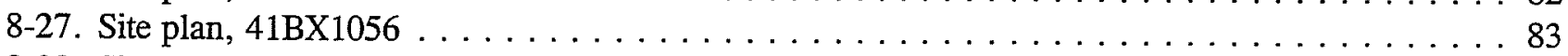

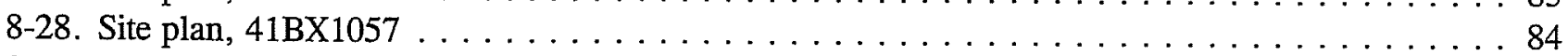

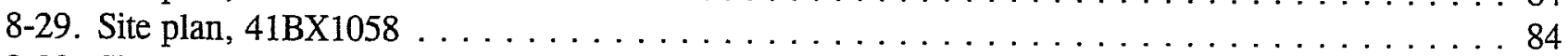

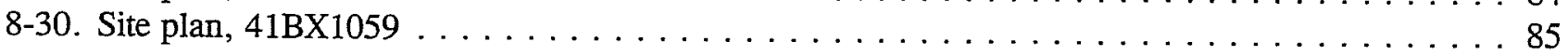




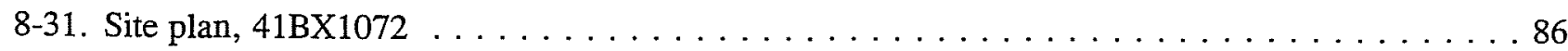

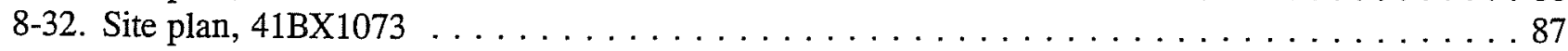

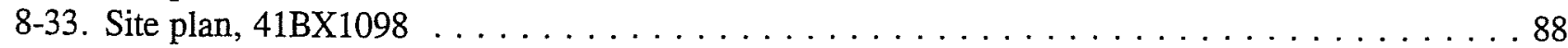

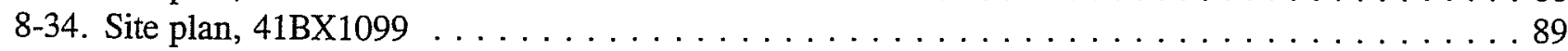

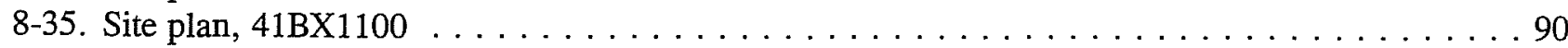

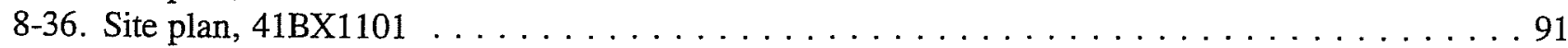

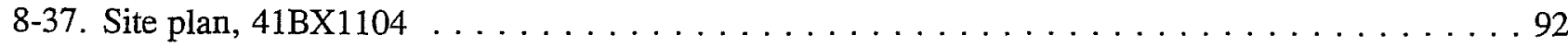

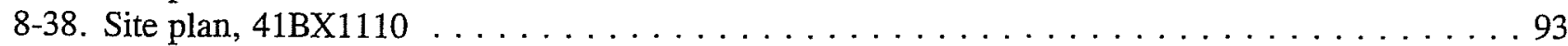

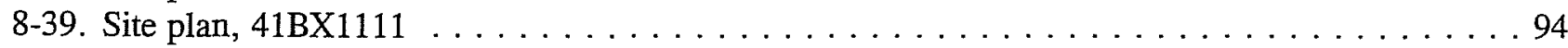

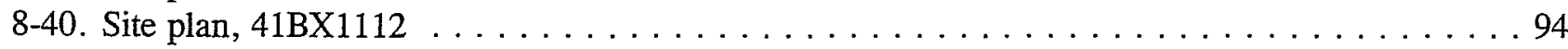

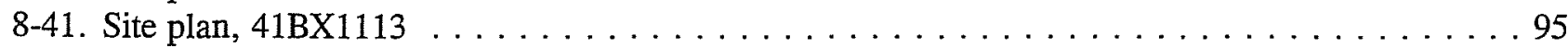

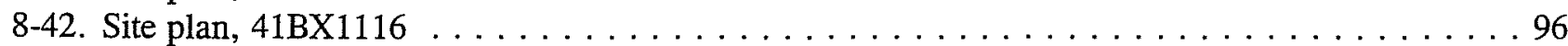

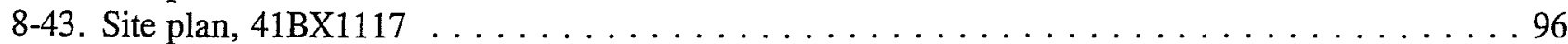

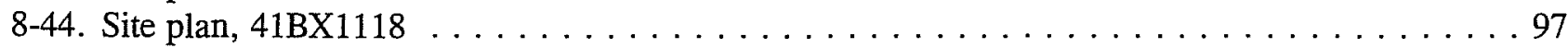

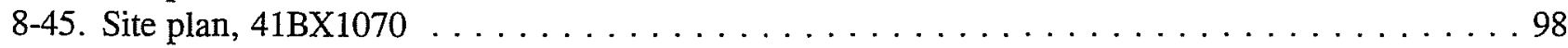

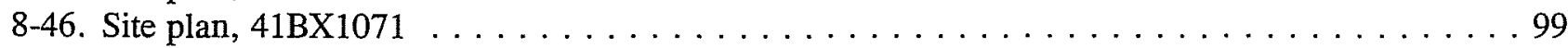

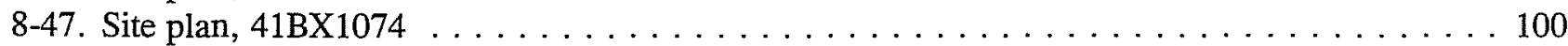

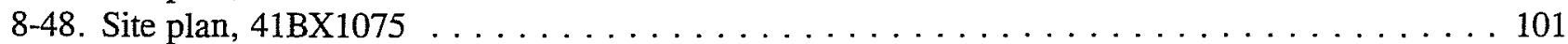

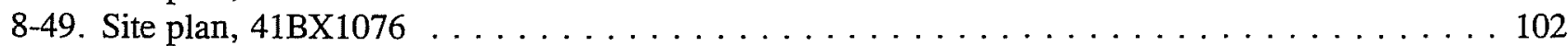

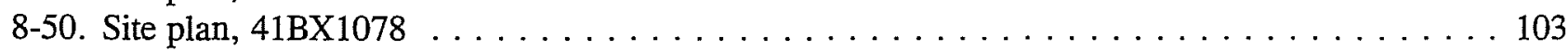

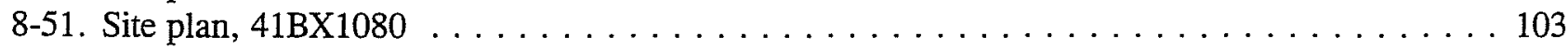

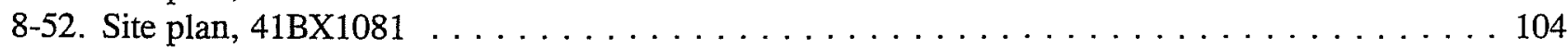

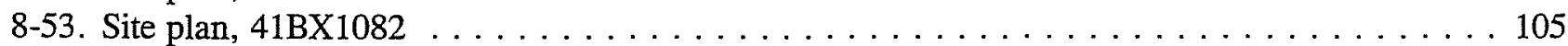

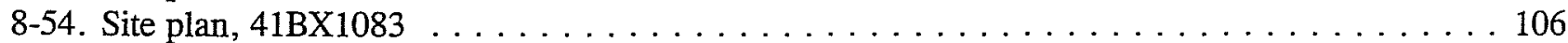

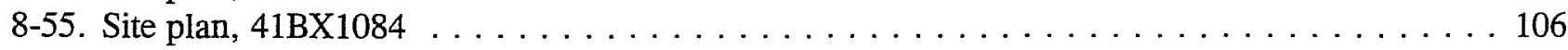

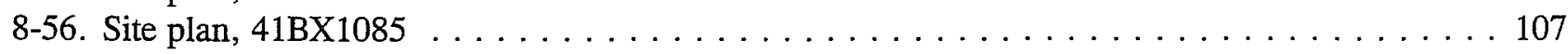

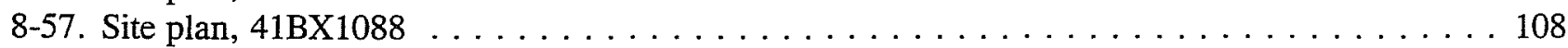

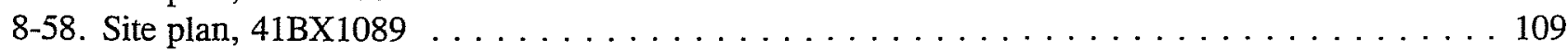

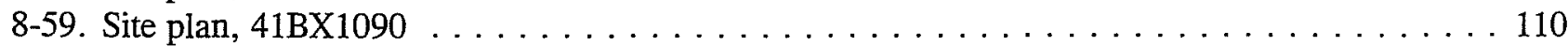

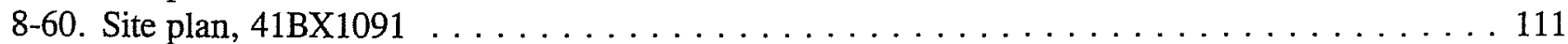

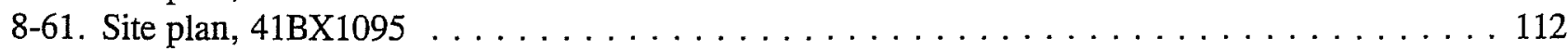

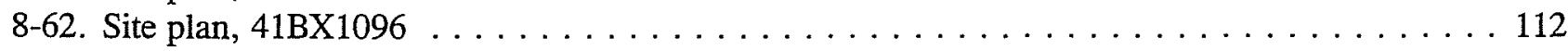

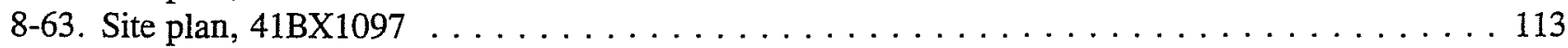

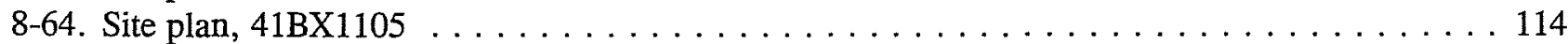

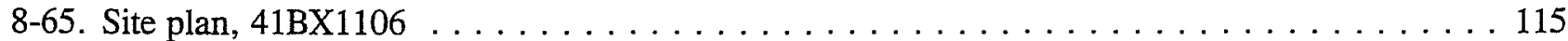

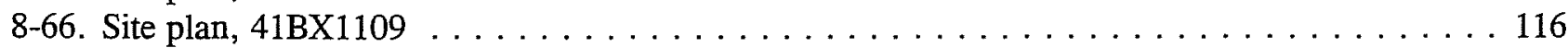

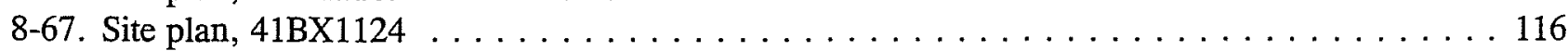

10-1. Early Archaic diagnostic artifacts . . . . . . . . . . . . . . . . . . . . 125

10-2 Early Archaic diagnostic artifacts . . . . . . . . . . . . . . . . . . . . . . 126

10-3 Middle Archaic diagnostic artifacts . . . . . . . . . . . . . . . . . . . . 128

10-4. Late Archaic diagnostic artifacts . . . . . . . . . . . . . . . . . . . . . . . . . . 129

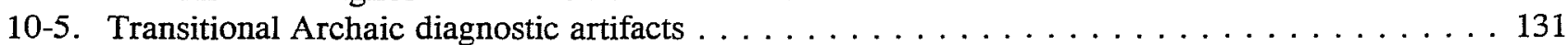

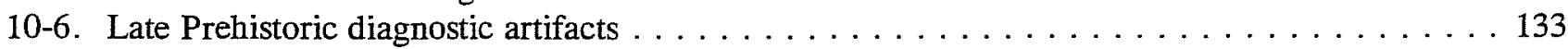

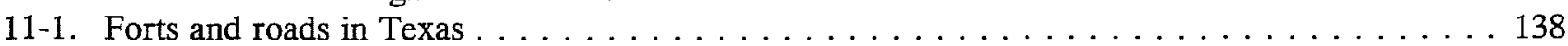

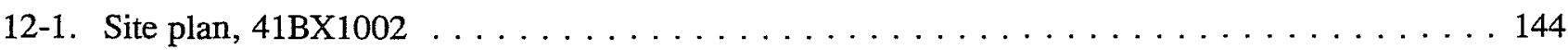

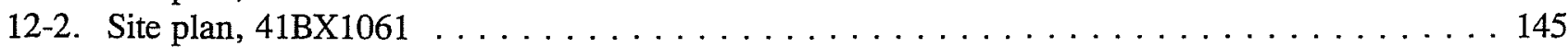

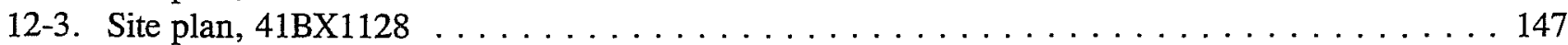

12-4. Site plan, $41 \mathrm{BX} 1129 \ldots \ldots \ldots \ldots \ldots \ldots \ldots$

13-1. Landowners on the Medina Annex property . . . . . . . . . . . . . . . . 151 


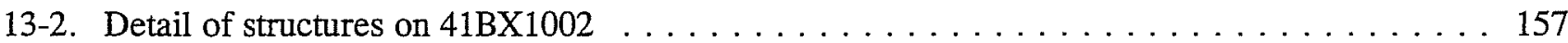

13-3. Royal Crown Cola bottle . . . . . . . . . . . . . . . . . . . . . . . 158

13-4. Remnants of sandstone-slab structure at $41 \mathrm{BX} 1121 \ldots \ldots \ldots \ldots \ldots \ldots$

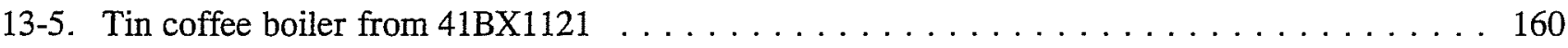

13-6. Uhl Pottery Company stoneware sherds from $41 \mathrm{BX} 1124 \ldots \ldots \ldots \ldots \ldots$

13-7. Advertisement in the 1898 San Antonio City Directory . . . . . . . . . . . . . . . . 162

13-8. Sale of the Bexar Brick and Tile Manufacturing Company (41BX1128) . . . . . . . . . 163

13-9. Collapsed cypress water tower at 41BX1128. . . . . . . . . . . . . . . . . . 164

13-10. Barbed wire from 41BX1129. . . . . . . . . . . . . . . . . . . . . 166

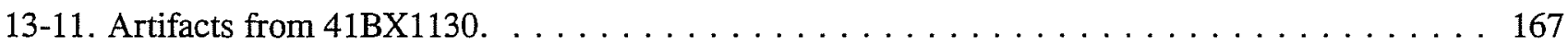

C-1. Location of Prime Beef-Prime Ribs area. . . . . . . . . . . . . . . . . . . . . 212

D-1. Location of Wherry Housing area. . . . . . . . . . . . . . . . . . . . . . . . . 219

D-2. Shovel test locations. . . . . . . . . . . . . . . . . . . . . . . . . . . 220

E-1. Space Command Area, survey and testing area. . . . . . . . . . . . . . . . . . . . . . 224

E-2. Area 300 Road Project, survey and testing area. . . . . . . . . . . . . . . . . . . . . 226

E-3. Leon Creek Channel Modification Project, survey and testing area. . . . . . . . . . . . . . 228

E-4. Housing Expansion Project, survey and testing area. . . . . . . . . . . . . . . . . . . . . 229

E-5. Diagnostic projectile points. a. Ensor; b. Tortugas; c. Langtry; d. Tortugas. . . . . . . . . . . 232

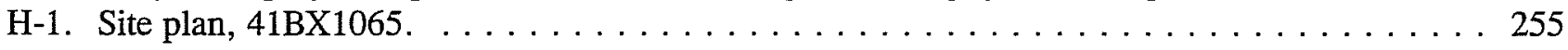

$\mathrm{H}-2$. Gradall Trenches $1-4$, profiles. . . . . . . . . . . . . . . . . . . . . . . 256

H-3. Gradall Trenches $5-7$, profiles. . . . . . . . . . . . . . . . . . . . 257

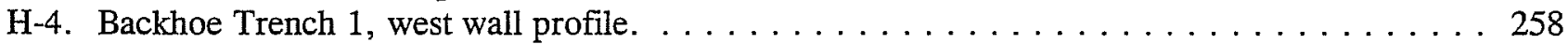

H-5. Backhoe Trench 2 , north wall profile. . . . . . . . . . . . . . . . . . . 260 


\section{Tables}

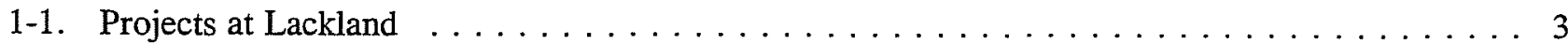

2-1. Common Flora Within the Project Area $\ldots \ldots \ldots \ldots \ldots \ldots \ldots \ldots \ldots \ldots \ldots \ldots \ldots \ldots \ldots \ldots$

2-1. Common Fauna Within the Project Area $\ldots \ldots \ldots \ldots \ldots \ldots \ldots \ldots \ldots \ldots$

4-1. Stratigraphic Column at Lackland Air Force Base $\ldots \ldots \ldots \ldots \ldots \ldots \ldots \ldots \ldots \ldots \ldots$

6-1. Lackland Air Force Base Pedestrian Survey Areas . . . . . . . . . . . . . . . . 41

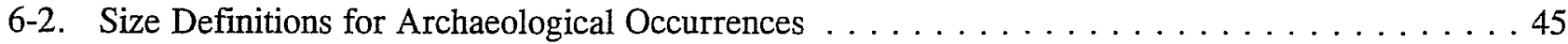

9-1. Isolated Finds Inventory . . . . . . . . . . . . . . . . . . . . . . . . 117

10-1. Frequency and Percentage of Site Types Recorded in Project Area . . . . . . . . . . . . . 119

10-2. Distribution of Archaeological Sites on Medina Annex . . . . . . . . . . . . . . . . . . . 120

10-3. Distribution of Archaeological Sites across Medio Creek Terraces . . . . . . . . . . . . . 120

10-4. Frequency and Percentage of Prehistoric Site Types by Geographic Area . . . . . . . . . 121

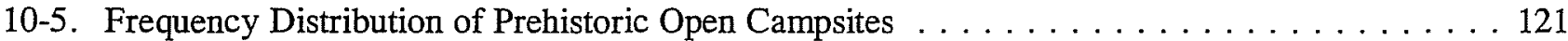

10-6. Frequency Distribution of Prehistoric Quarry/Workshops . . . . . . . . . . . . . 122

10-5. Frequency Distribution of Prehistoric Camp/Quarry Sites . . . . . . . . . . . . . . 122

10-8. Distribution of Prehistoric Site Types across Medio Creek Terraces . . . . . . . . . . 123

10-9. Early Archaic Artifacts by Location . . . . . . . . . . . . . . . . . . . . 124

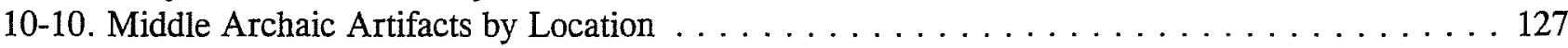

10-11. Middle to Late Archaic Artifacts by Location . . . . . . . . . . . . . . . . . . . . . . 127

10-12. Late Archaic Artifacts by Location . . . . . . . . . . . . . . . . . . . . . . . . 130

10-13. Transitional Archaic Artifacts by Location . . . . . . . . . . . . . . . . . . . . . 130

10-14. Late Prehistoric Artifacts by Location . . . . . . . . . . . . . . . . . . . . . . . 132

10-15. All Lackland Temporal Diagnostics Grouped by Period and Area . . . . . . . . . . . . . 133

10-16. Frequency and Percentage Distribution of Medina Annex Shovel Tests . . . . . . . . . 134

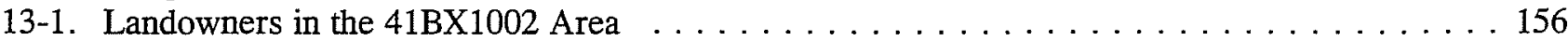

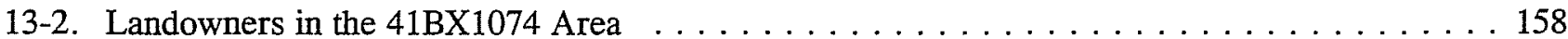

13-3. Landowners in the 41BX1121 Area . . . . . . . . . . . . . . . . . . . 160

13-4. Landowners in the $41 \mathrm{BX} 1129$ Area . . . . . . . . . . . . . . . . . . . 165

13-5. Frequency and Percentage of Historic Component Types by Geographic Area . . . . . . . . 168

14-1. Distribution of Prehistoric Components by Time Period and Area at Medina Annex . . . . . . 170

15-1. Leon Creek Prehistoric Sites . . . . . . . . . . . . . . . . . . . . . . . . . 172

15-2. Medio Creek Districts Prehistoric Sites . . . . . . . . . . . . . . . . . . . . . 173

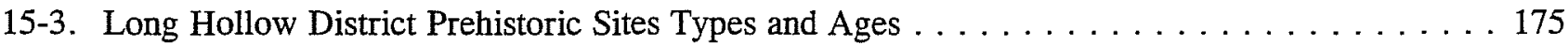

15-4. Upland Periphery Prehistoric Sites . . . . . . . . . . . . . . . . . . . . 176

B-1. Microfossils Recovered From The Navarro Group,

Medina Annex-Medio Creek Valley, L21, G21 . . . . . . . . . . . . . . . . . . . . 204

B-2. Megafossils Recovered From The Navarro Formation, Medina Annex-Medio Creek Valley, L21, G21 . . . . . . . . . . . . . . . . . . . . . . . 207

B-3. Microfossils Recovered From The Upper Taylor Group,

Lackland Air Force Base-Leon Creek Valley, J8, L3 … . . . . . . . . . . . . . 208

B-4. Megafossil Recovered From The Upper Taylor Group,

Lackland Air Force Base-Leon Creek Valley, J8, L3 . . . . . . . . . . . . . . . . . . 210

C-1. Listing of Dimensions and Area of Sites Prime 1 through Prime $5 \ldots \ldots \ldots \ldots \ldots \ldots 211$

C-2. Artifacts Recovered from Shovel Tests on the Prime Beef-Prime Rib Combat Arms Area . . . 213

D-1. Listing of Dimensions and Area of Sites Wherry 1 and Wherry $2 \ldots \ldots \ldots \ldots \ldots \ldots 221$

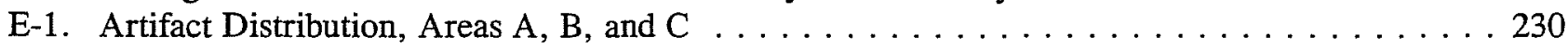

E-2. Artifacts from Shovel Tests . . . . . . . . . . . . . . . . . . 231 
G-1. Prehistoric Site Testing Data . . . . . . . . . . . . . . . . . . . . . . . . 246

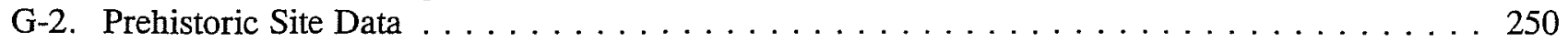

H-1. Sediment Descriptions from Gradall Trenches . . . . . . . . . . . . . . . . . . . 257

H-2. Artifacts Recovered from Gradall Trenches . . . . . . . . . . . . . . . . . . . . . 258

H-3. Sediment Descriptions from Backhoe Trench $1 \ldots \ldots \ldots \ldots \ldots \ldots \ldots$

$\mathrm{H}-4$. Sediment Descriptions from Backhoe Trench $2 \ldots \ldots \ldots \ldots \ldots \ldots \ldots$

H-5. Material Counts by Unit Level, 41BX1065 . . . . . . . . . . . . . . . . . . . . . . 263 


\section{Acknowledgments}

The staff members of The Center for Archaeological Research (CAR) wish to thank the Commander and staff at Lackland Air Force Base for allowing our crews access to the Base and Annex, and for supporting our effort in every aspect. Mr. Gabriel Gonzales, Community Planner with the 37th Civil Engineering Squadron was particularly helpful throughout the project. His knowledge of the survey area and willingness to provide maps and documents were extremely helpful. The Range Operations personnel were cooperative in coordinating mandatory firing schedules, while allowing our crews on the ranges as often as possible. Mr. Jack Siegal and Mr. Jaime Cantu, of the Air Education Training Command, Randolph Air Force Base assisted with early preparations for the survey. The staff at the National Parks Service, specifically Mr. Steven De Vore and Dr. George Teague were always available to answer our numerous questions relating to the project. The total commitment and cooperative spirit of all Air Force and Parks personnel made this project a very professional and rewarding experience.

CAR crew members in the field were John Arnn, Sandra Billingsley, Ward Bramlett, Florencio Delgado, Jeffery Durst, Kevin Gross, Johanna Hunziker, Anne Jung, Anthony Lyle, Barbara Meissner, Antonio Muñoz, David Nickels, Gerry Raymond, Robert Rector, Ricky Robinson, Andrew Scease, and Cynthia Tennis. The project archaeologists were Anna J. Taylor and David W. Pease. The principal investigator was Robert J. Hard and the co-principal investigator was C. Britt Bousman. 


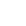




\section{Part I: Project Background}

\section{Chapter 1. Introduction}

In January 1994, the Center for Archaeological Research contracted with the National Park Service (NPS) to survey most of the undisturbed areas of Lackland Air Force Base (AFB) and Medina Base Annex in southwestern Bexar County, Texas (Figure 1-1). This area is $25 \mathrm{~km}$ south of the Balcones Escarpment in the Nueces-Guadalupe River Basins Region (Bureau of Economic Geology, San Antonio and East-Llano Sheets, 1985).

The Balcones Escarpment and Edwards Plateau in northern Bexar County have been studied far more intensively than the southern half of Bexar County, including the area of Lackland AFB (Potter et al. 1992:5). With the exception of a few rare surveys conducted in the area (McGraw 1977; McGraw and Hindes 1987; Thoms 1992), little has been done to demonstrate the potential for finding prehistoric sites in the riverine and upland environments adjacent to the Medio Creek, Leon Creek, and Long Hollow drainages. The Lackland AFB survey presented an opportunity to fill in this data gap as well as to study nineteenth- and early twentieth-century farming and stock raising in the area.

The first archaeological assessments of Lackland AFB were conducted in connection with the Base Comprehensive Plans for Kelly AFB and Lackland. A complete list of archaeological projects at Lackland AFB and the legal statutes that stimulated the work (Table 1-1). In 1989, Espey, Huston and Associates (1989:5-1) performed a 100-percent pedestrian survey of Leon Creek as part of the Kelly AFB project and found no archaeological sites on either base. The U.S. Army Corps of Engineers, Fort Worth District, made a preliminary assessment of cultural resources on Lackland to assist the base in ascertaining and fulfilling its responsibilities under the National Historic Preservation Act of 1966 and the Section 106 process (Dalbey 1993). Dalbey (1993:56-58) identified several historic and prehistoric sites on the Medina Annex and determined that the Medio Creek drainage had high potential for archaeological sites.

The NPS Rocky Mountain Regional Office subsequently conducted a week-long visit to assess the potential for finding significant cultural resources on the base (De Vore 1993). The survey focused special attention on drainages, erosional exposures, and fence lines, followed up on the findings reported by Dalbey (1993), and concentrated on areas identified by base personnel as proposed construction areas (De Vore 1993:21). One of these areas, the Prime RIBS (Prime Readiness in Base Support) training area at the Medina Annex had been surveyed. The 20-acre site, surveyed in December 1993 with a pedestrian walkover and stratified subsurface shovel testing, was determined to lack depositional integrity and not recommended for further archaeological work (Petraglia and Knepper 1993). Meanwhile, GeoMarine prepared a study for the U. S. Army Corps of Engineers of the prehistoric and historic cultural background of Lackland and the San Antonio area (Reese et al. 1994).

The current NPS Contract (No. 1443-CX-1200-94$005)$ required that this archaeological survey be conducted to assist the U.S. Air Force in meeting its responsibilities as outlined by federal cultural resource laws and mandates (NPS 1993:6). Mr. Gabriel Gonzales, Community Planner for Lackland AFB, served as the Air Force contracting officer's representative. 


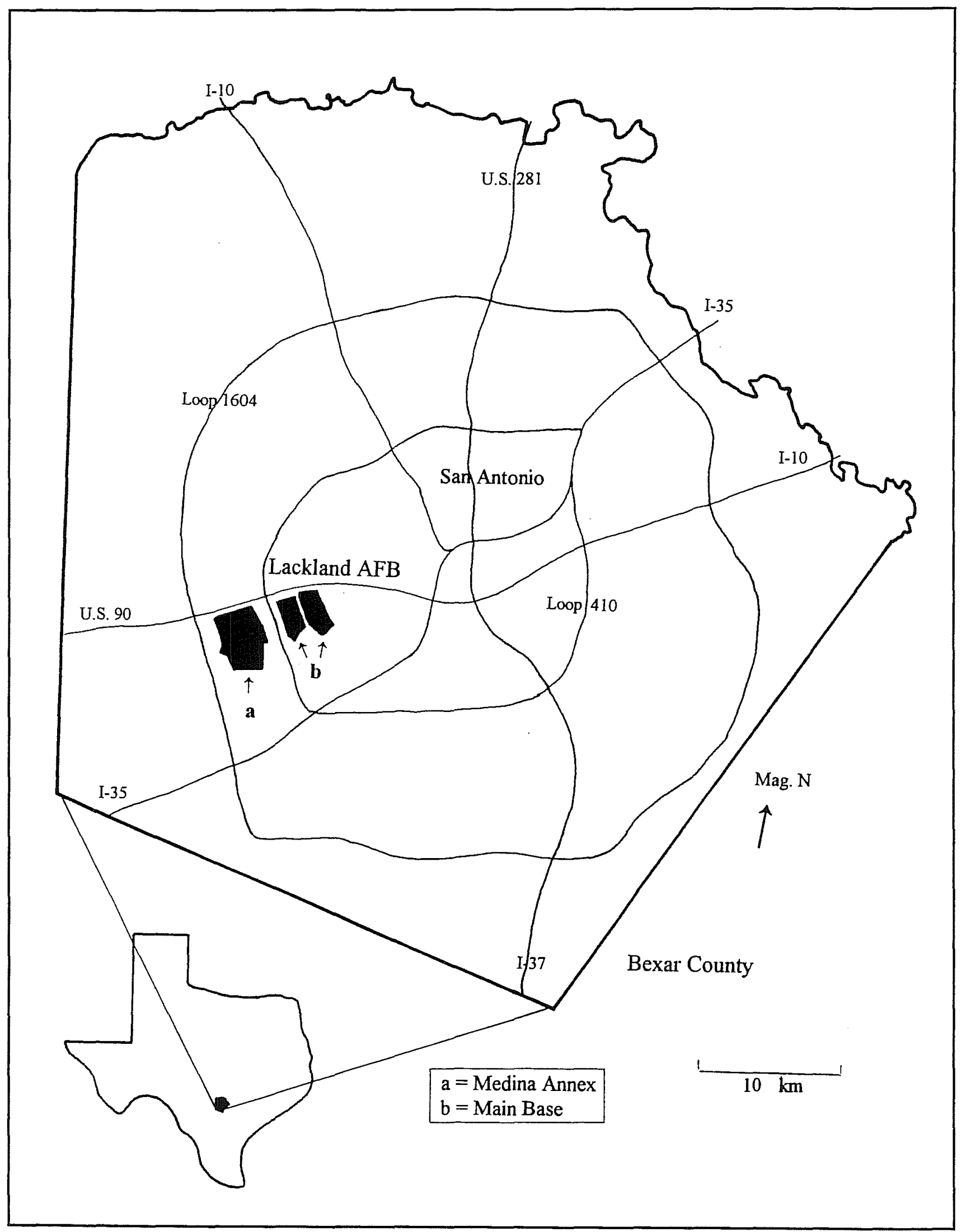

Figure 1-1. Location of Lackland Air Force Base. 
Table 1-1. Projects at Lackland

\begin{tabular}{|c|c|c|c|}
\hline Contractor & Project & Reference & $\begin{array}{l}\text { ferenced Applicable } \\
\text { Legal Statutes }\end{array}$ \\
\hline $\mathrm{E}, \mathrm{H} \& \mathrm{~A}$ & Kelly AFB \& Leon Creek Survey & $\overline{\mathrm{E}, \mathrm{H} \& \mathrm{~A}(1989)}$ & $2,3,4,5,6$ \\
\hline Corps Engineers & Preliminary Assessment of Lackland AFB & Dalbey (1993) & 3 \\
\hline NPS & Preliminary Assessment of Lackland AFB & De Vore (1993) & $2,4,6,7,8,9,10$ \\
\hline $\begin{array}{l}\text { Environmental- } \\
\text { Sciences }\end{array}$ & Prime Beef Survey & Petraglia and Knepper (1993) & $2,4,6,8,10,14$ \\
\hline Geo-Marine & Overview of Lackland AFB & Reese et al. (1994) & $2,3,4,5$ \\
\hline UTSA & Lackland Survey & Current report & $1,2,4,7,8,10,11,12,13,1$ \\
\hline UTSA & Prime Beef-Prime Ribs (mod $1 \& 5$ ) & Taylor (Appendix C) & 13 \\
\hline UTSA & South Wherry Housing (mod 5) & Raymond (Appendix D) & $2,4,5,7$ \\
\hline UTSA & Space Command $(\bmod 5)$ & Durst (Appendix E) & $2,4,5,7$ \\
\hline UTSA & North Wherry Housing Expansion & Rector (Appendix H) & $2,13,15$ \\
\hline \multicolumn{4}{|c|}{ Legal Statues } \\
\hline \multicolumn{4}{|c|}{ 1: Historic Sites Act of 1935 (Public Law 74-292) } \\
\hline \multicolumn{4}{|c|}{ 2: National Preservation Act of 1966 (Public Law 96-515), as amended } \\
\hline \multicolumn{4}{|c|}{ 3: National Environmental Policy Act of 1969 (Public Law 90-190) } \\
\hline \multicolumn{4}{|c|}{ 4: Archaeological and Historic Preservation Act of 1974 (Public Law 93-291), as amended } \\
\hline \multicolumn{4}{|c|}{ 5: Executive Order No. 11593, "Protection and Enhancement of the Cultural Environment". } \\
\hline \multicolumn{4}{|c|}{ 6: Procedures of the Advisory Council on Historic Preservation (36 CFR 800) } \\
\hline \multicolumn{4}{|c|}{ 7: Archaeological Resource Protection Act of 1979 (Public Law 96-95) } \\
\hline \multicolumn{4}{|c|}{ 8: Air Force Regulations (AFR) 126-7 } \\
\hline \multicolumn{4}{|c|}{ 9: Department of Defense Directive 4710.1-Archeological and Historic Resources Management } \\
\hline \multicolumn{4}{|c|}{ 10: Secretary of the Interior's Standards and Guidelines for Archaeology and Historic Preservation } \\
\hline \multicolumn{4}{|c|}{ 11: Native American Indian Religious Freedom Act of 1978 (Public Law 95-341) } \\
\hline \multicolumn{4}{|c|}{ 12: Native American Graves Protection and Repatriation Act of 1990 (Public Law 101-601) } \\
\hline \multicolumn{4}{|c|}{ 13: National Register of Historic Places (36 CFR 60) } \\
\hline \multicolumn{4}{|c|}{ 14: Texas State Historic Preservation Office guidelines } \\
\hline & & & \\
\hline
\end{tabular}


Seven primary objectives guided the project. These were to:

1) conduct a baseline, 100-percent pedestrian cultural resources survey of the 3,860 acres of undisturbed land on the Main Base and the Medina Annex of Lackland AFB (the project area);

2) perform an intensive literature and archival search to determine the probable nature and distribution of cultural and natural resources within the project area;

3) develop a formal research design to serve as the basis for the field survey and subsequent evaluations of site significance;

4) evaluate prehistoric and historic cultural resources for National Register of Historic Places eligibility (Option 1);

5) review literature and conduct limited field observations of paleontological deposits within the project area;

6) review literature and conduct preliminary geomorphological reconnaissance of the project area.

7) prepare a popular narrative describing the prehistoric and historic archaeology of the Base (Option 2).

Areas scheduled by the Air Force for immediate modification were given priority (De Vore 1993:21). Eventhough Petraglia and Knepper (1993) recommended no further work at 41BX1006, the Texas Historical Commission were unable to make a National Register Determination based on the information provided in their report (Letter to $\mathrm{Mr}$. A. P. Gianotti from Dr. James Bruseth and Timothy Perttula, March 8, 1994). Thus, additional testing was requested for site 41BX1006 in the Prime RIBS area to determine its National Register eligibility. NPS requested that CAR submit a proposal, and the work was conducted in July 1994 . These areas included the Prime Beef-Prime Ribs Combat Arms Area (Appendix C). Additional survey and shovel testing of areas scheduled for imminent development include areas in the South Wherry Housing area (Appendix D), and the Space Command expansion at the Medina Annex (Appendix E). The first two projects were accomplished in March 1994, the third in August 1994. One of the areas surveyed during the second project, the North Wherry Housing expansion, underwent Phase II testing in May 1995 (Appendix H). These appendixes were originally circulated as letter reports, but are included here to provide the reader with a more complete record of the archaeological investigations at Lackland AFB. The remainder of the project area was surveyed and evaluated from November 1994 through May 1995. 


\section{Chapter 2: The Project Area}

\section{Location}

The Lackland Main Base and Medina Annex, comprising 2,752 acres and 3,972 acres respectively, are located in southwestern San Antonio in Bexar County, Texas (Figure 1-1). The project area is within the Nueces-Guadalupe Plain, a northern biogeographical subarea of the South Texas Plains. Adjoining the Nueces-Guadalupe Plain on the east is the Gulf Coastal Plain, and beyond that is the Gulf of Mexico, approximately $224 \mathrm{~km}$ to the east. Twenty-five kilometers to the north, plains give way to an abrupt rise-the prominent Balcones Escarpment and adjoining Edwards Plateau. The Balcones Escarpment serves as a physical division between the central Texas and south Texas archaeological regions (Black 1989a:39-41).

\section{Modern Environment}

\section{Climate}

The project area has a modified subtropical climate, with cool winters and hot summers (Taylor et al. 1991:118), primarily influenced by its low altitude, its low relief, and its proximity to the Gulf of Mexico to the east. Daytime humidity ranges from 50 to 80 percent throughout the year, while clear skies prevail over 70 percent of the summer and 50 percent of the winter. The coldest average month is January, with an average temperature of $62.3^{\circ} \mathrm{F}$, and the hottest month on average is August, with a mean temperature of $94.2^{\circ} \mathrm{F}$. (Taylor et al. 1991:Table 11). Rainfall averages 27.89 inches (Taylor et al. 1991:Table 11), but a great deal of variation exists from year to year, with 10.11 inches recorded in 1917 and 52.28 inches recorded in 1973 (McGraw and Hindes 1987:37). South of the Balcones Escarpment the growing season averages 275 days between March 1 and December 1. Light snowfalls occur every three or four years (Taylor et al. 1991:118-119).

\section{Biotic Resources of the Project Area}

Three major geographic regions are present in Bexar County: the Edwards Plateau, the Blackland Prairie, and the South Texas Plain (also known as the Rio Grande Plain). The Edwards Plateau, with elevations between $338 \mathrm{~m}$ and $585 \mathrm{~m}$ above mean sea level (amsl), slopes gradually to the southeast and ends in the Balcones Escarpment (Taylor et al. 1991:119). The escarpment lies along a major fault zone that begins near Del Rio, runs through the center of Bexar County, then turns northward toward Waco (Abbott and Woodruff 1986:Preface, Figure 2). The escarpment consists of blocky limestone, chalk, shale, and marl, and slopes to the southeast from about 308 $\mathrm{m}$ to $215 \mathrm{~m}$ amsl (Taylor et al. 1991:119). A strip of the Blackland Prairie runs below the Balcones Escarpment from the Brazos River to the Nueces River, separating the escarpment from the Gulf Coastal and South Texas Plains. The escarpment is incised by numerous creeks and rivers, forming what is known as the Balcones Canyonlands, characterized by steep canyons and narrow divides (Riskind and Diamond 1986:21). In Bexar County, the escarpment is drained by several watercourses: the San Antonio and Medina rivers and Cibolo Creek, and their tributaries, including Leon, Salado, Culebra, Helotes, and Medio creeks, and Long Hollow. 
Lackland AFB lies almost at the foot of the Balcones Escarpment, on the edge of the Blackland Prairie where it merges with the South Texas Plain (Dalbey 1993:22). Leon Creek briefly passes through Lackland's Main Base, while Medio Creek and Long Hollow drain Medina Annex.

The most characteristic flora on the Edwards Plateau include juniper (Juniperus ashei), plateau live oak (Quercus fusiformis), Texas persimmon (Diospyros texana), and agarita (Berberis trifoliata) (Van Auken 1988:45). In the western part of the region, mesquite (Prosopis glandulosa) and live oak (Quercus virginiana) are the dominant woody species (Blair 1950:112). The floral species of the escarpment are the same as those of the Edwards Plateau, with the addition of numerous riparian species in the canyonland river and creek bottoms (Van Auken 1988:55). The most economically important of these are nut trees, including oak, walnut, and pecan (Dalbey 1993:22).

The Blackland Prairie is a rolling and well-dissected plain representing the southern extension of the true prairie running through the center of North America. The prairie was once dominated by tallgrass species such as little bluestem (Schizachyrium scoparium), big bluestem (Andropogon gerardi), indiangrass (Sorghastrum nutans), tall dropseed (Sporobolus asper), and silveus dropseed (Sporobolus silveanus). Oaks (Quercus species), elms (Ulmus), cottonwoods (Populus), and native pecan (Carya illinoinensis) are common along drainages.

The South Texas Plain is the western extension of the Gulf Coastal Plain. It is a nearly level to rolling plain that is moderately dissected by major river drainages through its northern half and by numerous intermittent creeks and the Bordas Escarpment in the south. It was originally an open grassland mixed with brushy chaparral. Oaks, pecan, and ash (Zanthroxylum fagara) were common along streams (Black 1989b:12; Hester 1980:31,33).

Both the plains and the prairies have apparently undergone dramatic vegetational change in the past 300 years. Due in part to overgrazing and range-fire suppression, much of the original vegetation has been replaced by woody invader species, transforming the grassland into the "South Texas Brush Country" dominated by mesquite, huisache (Acacia smallii), granjeno or spiney hackberry, brasil (Condalia hookeri), lotebush, whitebrush (Aloysia ligustrina), and cenizo (Leucophyllum frutescens) (Black 1989b14-16; Hester 1980:34-37).

The area around Lackland AFB is an ecotone in which diverse ecological communities intermingle. On a broad regional scale, three biotic provinces meet in Bexar County: the Texan Province with its riparian plant and animal associations from the east, the Balconian Province with its varied plateau biota, and the Tamaulipan Province of the arid coastal plain. (Blair 1950:112). These plant and animal communities include the Juniper-OakMesquite Savanna and Balcones Canyonlands of the Balconian Province, the Oak-Hickory Forest and Mesquite-Chaparral Savanna of the plain, and the Blackland Prairies. An important recent study (Ellis et al. 1995) emphasizes the extreme variation among the natural subregions of central Texas and the complex interaction of changing precipitation regimes and natural environments. In the light of this study, it no longer suffices simply to attribute consistencies in regional manifestations, such as Pedernales dart points or burned rock middens, to supposed regional biotic uniformities. The cautions contained in this study and its implications for the understanding and interpretation of aboriginal cultural remains in central Texas and surrounding areas are only beginning to be recognized.

The interaction of the diverse biotic communities and landforms in the Lackland subregion results in a patchwork mosaic dominated by two broad ecological zones: uplands and drainages. Descriptions of the project area prior to 1900 reveal that the uplands were once dominated by tall grasses, with occasional stands of brush and mesquite (Inglis 1964). Historic alterations to the landscape such as plowing, overgrazing, stream rechannelization, controlled burning, and the introduction of deep wells have undoubtedly lowered water tables, thereby altering the plant and 
animal communities. Many springs emanating from the Balcones Fault are now either dry or do not discharge sufficient flows to reach the Lackland area before evaporating or seeping into the sandy soils upstream (Brune 1981:75). Although both Leon Creek and Medio Creek are currently flowing, they are supplemented artificially.

Even with the significant environmental changes occurring in the area over the past 12 millennia, the rich diversity of contemporary flora and fauna is remarkable (Tables 2-1 and 2-2). Today more than 200 native species of plants and a wide variety of fish, reptiles, and mammals thrive in the drainages and uplands of the project area (Cleveland and McLain 1992:1-5, 26-28). Some 29 mammal species and 95 species of birds are seen at least occasionally in the project area (Cleveland and McLain 1992:Tables X, XI). The most common fish is the bluegill (Lepomis macrochirus), a species introduced from the eastern United States (Cleveland and McLain 1992:26).

Table 2-1. Common Flora Within the Project Area

\begin{tabular}{|c|c|c|}
\hline $\begin{array}{l}\text { Ecological } \\
\text { Setting }\end{array}$ & Common Name & Scientific Name \\
\hline \multirow{7}{*}{ creek } & bog rush & Juncus texanus \\
\hline & cattails & Typha angustiflora \\
\hline & greenbriar & Smilax bona-nox \\
\hline & pecan & Carya illinoinensis \\
\hline & poison ivy & Rhus toxicodendron \\
\hline & river walnut & Juglans microcarpa \\
\hline & yaupon & Ilex vomitoria \\
\hline \multirow{4}{*}{ creeklupland } & coastal live oak & Quercus virginiana \\
\hline & hackberry & Celtis laevigata \\
\hline & honey mesquite & Prosopis glandulosa \\
\hline & huisache & Acacia smallii \\
\hline \multirow{16}{*}{ upland } & agarita & Berberis trifoliolata \\
\hline & blackbrush acacia & Acacia rigidula \\
\hline & buckthorn & Rhamnus caroliniana \\
\hline & catclaw & Acacia greggii \\
\hline & guayacan & Guaiacum angustifolium \\
\hline & horse crippler & Echinocactus texensis \\
\hline & javelina bush & Condalia ericoides \\
\hline & lace cactus & Echinocereus \\
\hline & lime prickly ash & Zanthroxylum fagara \\
\hline & snakewood & Colubrina texensis \\
\hline & tasajillo & Opuntia leptocaulis \\
\hline & Texas persimmon & Diospyros texana \\
\hline & Texas prickly pear & Opuntia lindheimeri \\
\hline & trecul yucca & Yucca treculeana \\
\hline & viscid acacia & Acacia neovernicosa \\
\hline & whitebrush & Alovsia ligustrina \\
\hline
\end{tabular}


Table 2-2. Common Fauna Within the Project Area

\begin{tabular}{||l|l||}
\hline \multicolumn{1}{|c|}{ Common Name } & \multicolumn{1}{c|}{ Scientific Name } \\
\hline opossum & Didelphis virginiana \\
\hline raccoon & Procyon lotor \\
\hline guano bat (freetailed bat) & Tadarida mexicana \\
\hline nine-banded armadillo & Dasypus novemcinctus \\
\hline gray fox & Urocyon cinereoargenteus \\
\hline eastern cottontail & Sylvilagus floridanus \\
\hline jackrabbit & Lepus californicus \\
\hline striped skunk & Mephitis mephitis \\
\hline collared peccary (javelina) & Pecari tajacu \\
\hline white-tailed deer & Odocoileus virginianus \\
\hline fox squirrel & Sciuris niger \\
\hline bobcat & Lynx rufus \\
\hline kingsnake & Lampropeltis sp. \\
\hline diamond-backed rattlesnake & Crotalus atrox \\
\hline Texas patch-nosed snake & Salvadora grahamiae \\
\hline \hline
\end{tabular}

\section{Geology}

During the Upper Cretaceous period, approximately 78 million years ago, Navarro Group limestones and marls began forming and now make up the bedrock underlying the project area (Judson and Kauffman 1990:150). Leona Formation fluviatile terrace deposits formed in the early to middle Pleistocene in main base area. Low terrace deposits adjacent to Leon Creek formed during the Holocene and are still developing today. Plio-Pleistocene Uvalde Gravels cover the uplands of Medina Annex. Upper Cretaceous Marlbrook Marl is exposed in some areas of Long Hollow, while the terraces along Medio Creek are mapped as Holocene alluvial deposits (Barnes 1983).

\section{Soils}

Houston Black clays and gravelly clays of varying slopes cover the uplands and some creek terraces. This series is generally dark gray to black in color, and calcareous with a blocky structure that tends to crack and shift with episodes of wetting and drying. Archaeological investigations are often hampered by these soil dynamics because artifacts may be displaced to deeper sediments (Hester 1980).

Alluvial soils of the Trinity, Frio, Venus, and Patrick series lie in the modern floodplain and basin areas of Leon and Medio creeks and Long Hollow. They are deep, calcareous, clayey loams associated with bottom lands and terraces (Taylor et al. 1991:18-34). 


\section{Lithic Resources}

Rich sources of chert crop out in the Edwards Plateau, where nodules and cobbles of good quality are commonly found eroding out of the limestone and in creekbed gravels (Black and McGraw 1985; Potter et al. 1992). Within the project area, Houston Black gravelly clays found on the uplands have fist-size or larger chert cobbles in varying quantities. Extensive exposures of chert gravels are common along the slopes of Long Hollow. Large and small quarry sites abound in the project area, indicating that the gravel exposures were heavily exploited by prehistoric inhabitants. Thus, these groups were not required to travel to the Edwards Plateau for lithic raw materials.

\section{Paleoenvironment}

To understand past human behavior we must know something of the environment in which prehistoric groups contended for resources. The changing scope and breath of paleoenvironmental studies provides broadly applicable schemes on climatic and vegetation shifts that have occurred over the past 18,000 years. More recent research continues to refine (and complicate) the picture of Late Quaternary climatic change. (Collins 1995:Table 2; Ellis et al. 1995)

\section{Late Pleistocene}

Some variables of the modern environment, specifically climate and biotic resources, have not been constant through time. Just after the last full glacial episode, around 18,000 B.P., Texas and northern Mexico were much wetter and colder than they are at present (Bryant and Holloway 1985:50). The South Texas Plain was a mosaic of woodlands, parklands, and scrub grasslands (Bryant and Holloway 1985:56). Between 20,000 B.P. and 14,000 B.P., pollen samples show that forests (pinyon-juniper woodlands in the Trans-Pecos area of west Texas and spruce-fir woodlands in central Texas) began to be replaced by grass and scrub species, presumably because of increasingly warmer and drier conditions (Bryant and Holloway 1985:51-52). In the South Texas Plains, scrub grasslands began to dominate (Bryant and Holloway 1985:56).

In central Texas, pollen spectra from Boriack Bog suggest a shift from grasslands before 16,500 B.P. to woodlands before 12,500 B.P. in a moist and cool climate (Bousman 1994:79). The same spectra reveal a decline in spruce (probably cold-adapted) pollen by 15,000 B.P., indicating a trend towards a warmer climate. Bousman's (1992) oxygen isotope evidence from south Texas complements the bog pollen data, and suggests early warming by 15,000 B.P.

The analysis by Nordt et al. (1994:80) of $\mathrm{C}_{3}-\mathrm{C}_{4}$ plant ratios based on $\delta^{13} \mathrm{C}$ values of organic carbon from the Applewhite Reservoir project shows two shifts occurring in vegetation and climate during the Late Pleistocene. An increase in $\mathrm{C}_{4}$ grasses (and temperature) is indicated for the thousand-year intervals of 14,000 to 13,000 B.P. and 11,000 to 10,000 B.P. These indicators do not agree with beetle fossils from pond sediments in north Texas (Elias 1994, as cited in Potter 1995) that suggest a much cooler (less $10^{\circ} \mathrm{C}$ ) than modern average climate between 14,200 and 13,500 B.P. Citing data from Hall's Cave in the Edwards Plateau, much closer to the project area, Toomey et al. (1993) argue that summer temperatures in the Late Pleistocene were $6^{\circ} \mathrm{C}$ cooler than present averages, and that by 13,000 B.P. (or 12,500 B.P. [Toomey and Stafford 1994]) the climate had become warmer and more arid. Between 12,500 and 11,800 B.P., the Boriack Bog data indicate a drier episode stimulated a brief shift to grasslands, again corroborated by oxygen-isotope ratios showing a cooler setting in south Texas (Bousman 1992, 1994:80). The Hall's Cave record indicates a wetter interval around 11,000 B.P. (Toomey and Stafford 1994).

\section{Early Holocene}

Analysis of pollen samples from the Llano Estacado and the dry caves of the Trans-Pecos region prompted Bryant and Shafer (1977:15-19) to 
suggest a trend of gradual warming and drying throughout the Holocene (after about 10,000 B.P.). Aten (1979), Gunn and Mahula (1977), and MacNeish (1958:199) use data from Oklahoma, Eastern Texas, and the Sierra de Tamaulipas in Mexico to propose a more variable change from the colder, wetter Pleistocene to the modern climate.

More than 15 years ago, innovative research in opal phytolith analysis from archaeological sites on the Coastal Plain of south Texas (Robinson 1979) also showed that, at least since the Early Holocene, climatic change has been highly variable. Fluctuations in the Holocene trend are also suggested by Bousman (1994), again based on the Boriack Bog and Weakly Bog data from central Texas. Toward the Pleistocene-Holocene boundary at about 10,000 B.P., arboreal species in the Boriack Bog spectra show a return of woodlands until about 9500 B.P., after which grasses again predominated. Woodlands that had been reestablished by 8750 B.P. were again replaced by grasslands by 7500 B.P. (Bousman 1994:80). Although poorly dated, Robinson (1979:109) associated his oldest phytolith sample with "Late Paleo-Indian or Pre-Archaic" and suggested an age of about 8000 B.P. The predominance of tall grass species, white oak, a generally high frequency of other tree species (unidentifiable) in the phytolith record, and generally small size of the grass phytoliths combined to indicate a wet environment.

\section{Middle Holocene}

The continuous decline of the woodlands in the Early Holocene was briefly checked around 6000 B.P., but resumed its slide until 5000 B.P. when arboreal pollen slowly increased with the appearance of a wetter climate (Bousman 1994:80). This Mid-Holocene arid period indicated at Boriack Bog agrees with data presented by Nordt et al. (1994) from the Applewhite project in San Antonio, where a dry period for roughly the same time frame (6000 to 4800 B.P.) is indicated. Humphrey and Ferring (1994) discovered the same arid episode in north central Texas, but with greater duration (6500 to 4000 B.P.), agreeing with the revised interpretation from Hall's Cave that gives an episode between 7000 and 2500 B.P. (Toomey and Stafford 1994). A later occurrence between 5000 and 2500 B.P. is reported by Johnson and Goode (1994). The opal phytolith records from the Wilson-Leonard site in central Texas (Fredlund 1994) and two sites on Coleto Creek in south Texas (Robinson 1979:111) agree with increasing aridity in the Middle Holocene, indicated by spreading grasslands around 4400 B.P. and ca. 4500 B.P., respectively. However, samples from slightly higher in the Coleto Creek strata with roughly the same age argue for a sudden and brief wet episode (Robinson 1979:111, Sample 4), followed by a return to an arid climate that continued to ca. 2750 B.P.

Phytolith analyses of sediments from the Choke Canyon project (Robinson 1982:597-610) add to the claim of considerable climatic variability. Between 5300 and 4300 B.P., Robinson (1982:598) infers a cool, mesic climatic regime that shifts to a more arid period and then returns by 3250 B.P. to conditions both cooler and wetter than today's.

\section{Late Holocene}

Although it is clear that the climate continued to fluctuate during the Late Holocene, some disagreement remains concerning the timing of events. Nordt et al. (1994) suggest a warm and dry episode between 3000 and 1500 B.P. based on deposits from San Antonio. Toomey and Stafford (1994) see a wet period appearing about 2500 B.P. at Hall's Cave. Their observations suggesting a very wet episode agree with those of Robinson (1979:112). Ricklis's (1994) study of oyster growth patterns on the Texas Gulf Coast tentatively implies a shift to a cooler climate at ca. 3000 B.P., emerging out of a much warmer Middle Holocene. The Gulf Coast data tends to agree with the Choke Canyon analysis, both suggesting that more mesic conditions similar to today's were present by 2450 B.P. (Robinson 1982:598-599). Afterwards, a shift to more xeric conditions occurred by 1000 B.P., but Robinson suggests that they may have been more mesic than modern conditions. The predominance 
of short grass species agrees nicely with the large quantities of bison remains documented in an archaeological context at Choke Canyon (Robinson 1982:599). Grass species in the Boriack Bog and Weakly Bog pollen spectra indicate drying episodes at 1600 to 1500 B.P. and 500 to 400 B.P. (Bousman 1994:80).

\section{Early European Observations}

Early descriptions (1675-1722) of plant life by pretwentieth century observers, who left a written record of the area around Lackland AFB, suggest that mesquite and other thorny scrub were present in scattered mottes, while the land immediately to the south of the base was open grasslands with little or no brush (Inglis 1964:Plate 1). Later observers documented the change on the South Texas Plain from grassland/scrub grassland mosaic to the domination of thorny brush (Inglis 1964:Plates 1-3). By 1900, the Lackland area was described as "dense brush or chaparral" (Inglis 1964:Plate 3). Likely causes for this change in plant communities (when there were no discernable changes in climate) are a combination of over-grazing and human interference with natural range fires (Black 1989b:15). 


\title{
Chapter 3. Fluvial Geomorphology and Geoarchaeology of Medio and Leon Creeks
}

\author{
Lee C. Nordt
}

\section{Introduction}

The purpose of this investigation was to identify alluvial deposits possibly containing buried prehistoric cultural components within the Lackland Main Base and Medina Annex project area. Medio and Leon creeks were the focus of this investigation because they were the major tributaries flowing through the project area. The specific fluvial geomorphic objectives were to:

1) map the alluvial landforms,

2) describe the alluvial stratigraphy,

3) determine landform and stratigraphic ages, and

4) make inferences about prehistoric site preservation potentials.

\section{Methods}

A geomorphic map for Medio Creek was constructed using field observations, the Soil Survey of Bexar County, Texas (Taylor et al. 1991), the San Antonio sheet of the Geologic Atlas of Texas (Barnes 1983), and the Department of Air Force topographic maps (1992). Construction of the geomorphic map relied on relative elevations above the modern channel, and may require adjustments with the collection of more field data.

Soil-stratigraphic descriptions were written for 10 backhoe trenches (BHT) along Medio Creek. The backhoe trenches were aligned to represent two north and south cross-valley transects. Because the alluvial valley of Leon Creek has been greatly altered by military activity, only two natural cutbank exposures were available for describing and interpreting stratigraphic relations.

Soil descriptions were written following standards and procedures of the Soil Survey Staff (1981). Stratigraphic units were identified as packages of sediment bounded by unconformities or erosional or sedimentary breaks in deposition. Buried unconformities between stratigraphic units were marked by erosional contacts. Surface unconformities were formed by terraces, floodplains, and surface soils.

Four bulk soil humate samples were collected for carbon-14 $\left({ }^{14} \mathrm{C}\right)$ assay. Analysis was performed by Beta Analytic, Inc. Ages are reported in years before present (B.P.) and corrected for variations in carbon-13 $\left({ }^{13} \mathrm{C}\right)$.

\section{Medio Creek}

Medio Creek is a low-order tributary of the Medina River. The Medio Creek drainage basin begins in the eastern part of Medina County, flows through Lackland AFB at about its mid-point, and finally empties into the Medina River in southwest Bexar County. The drainage basin covers primarily upper Cretaceous limestones and chalks (Barnes 1983). A high plateau on the western flank of the Medio 
Creek valley in the project area is mapped as the early Pleistocene Uvalde Gravel. Within the project area, the alluvial valley of Medio Creek is mapped as a combination of terrace and floodplain deposits of Quaternary age (Barnes 1983).

The Soil Survey of Bexar County, Texas (Taylor et al. 1991: Sheets 60-61) shows a narrow floodplain along Medio Creek averaging about $100 \mathrm{~m}$ wide. The "Trinity and Frio soils, frequently flooded" are mapped in this setting. These soils are clayey throughout and exhibit weak profile development. The "Lewisville silty clay 0 to $1 \%$ slopes," the "Houston Black clay terrace, 0 to $1 \%$ slopes," and the "Houston Black gravelly clay, 1 to $3 \%$ slopes," are mapped on alluvial terraces between the floodplain and adjacent Cretaceous uplands. These terraces are as much as $1.5 \mathrm{~km}$ wide throughout most of the drainage basin (Taylor et al. 1991:20-21, 25, 32).

\section{Geomorphology}

The modern Medio Creek meanderbelt contains meanders with both high and low radii of curvature. The larger meander loops were either inherited from a previous flow regime, or created by structural control from the underlying limestone.

Three alluvial landforms were identified within the alluvial valley of Medio Creek in the project area: terrace 2 (T2), flood terrace 1 (T1), and the modern floodplain (T0) (Figure 3-1). Those areas mapped as uplands may include localized alluvial deposits not evident on topographic and soil survey maps.

\section{Terrace 2 (T2)}

The $\mathrm{T} 2$ terrace is the highest and oldest alluvial landform mapped in the project area. It occurs as nonpaired remnants on both sides of the Medio Creek valley at an elevation of 7-10 $\mathrm{m}$ above the modern low-water channel. T2 presumably does not flood because of its elevation above the floodplain. The Uvalde Gravel, as mapped by Barnes (1983) on the west side of the valley, appears to form a broad interfluvial strath terrace $15-20 \mathrm{~m}$ above the $\mathrm{T} 2$ terrace.

\section{Terrace 1 (T1)}

The $\mathrm{T} 1$ flood terrace, the most extensively mapped alluvial landform in the project area, is situated 3-5 m above the modern low-water channel (Figure 3-1). This terrace may flood for brief periods during lowfrequency, high-intensity rainstorms. For the most part, $\mathrm{T} 1$ is confined to the modern meanderbelt. An exception occurs in the northwestern part of the project area where an extensive area of $\mathrm{T} 1$ is mapped outside of the modern meanderbelt (Figure 3-1). Consequently, further fieldwork may show that T1 should be subdivided into an older and slightly higher $\mathrm{T} 1$ terrace along the outer valley margin, and a younger and slightly lower $\mathrm{T} 1$ terrace within the modern meanderbelt.

\section{Terrace 0 (T0)}

The actively aggrading modern floodplain is mapped as terrace 0 (T0) (Figure 3-1). This surface is situated $2-3 \mathrm{~m}$ above the modern low-water channel and primarily within large meanders immediately adjacent to the modern channel. As mapped here, the TO floodplain is at least two times wider than the floodplain as mapped in the local soil survey (Taylor et al. 1991). As discussed later, modern flood deposits appear to extend as much as $150-200 \mathrm{~m}$ away from the modern channel, particularly on the inside of modern meander bends. The frequency of inundation of the TO surface is unknown but probably occurs annually.

\section{Alluvial Stratigraphy}

Three alluvial stratigraphic units were recognized along Medio Creek in the project area. From oldest to youngest, they are: Unit I, Unit II, and Unit III. 


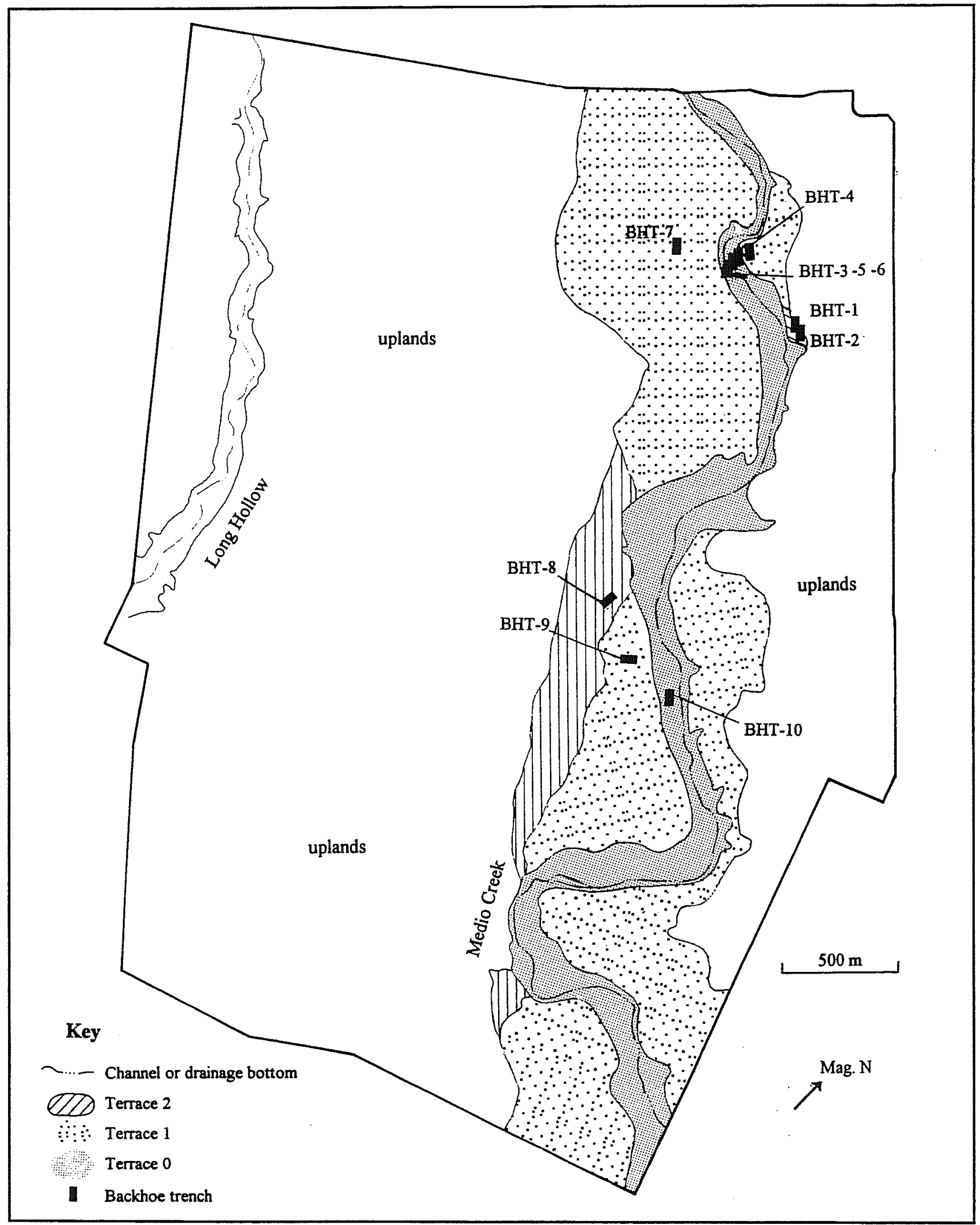

Figure 3-1. Geomorphic map of the Medio Creek alluvial valley in the project area showing landforms and backhoe trench (BHT) localities. 


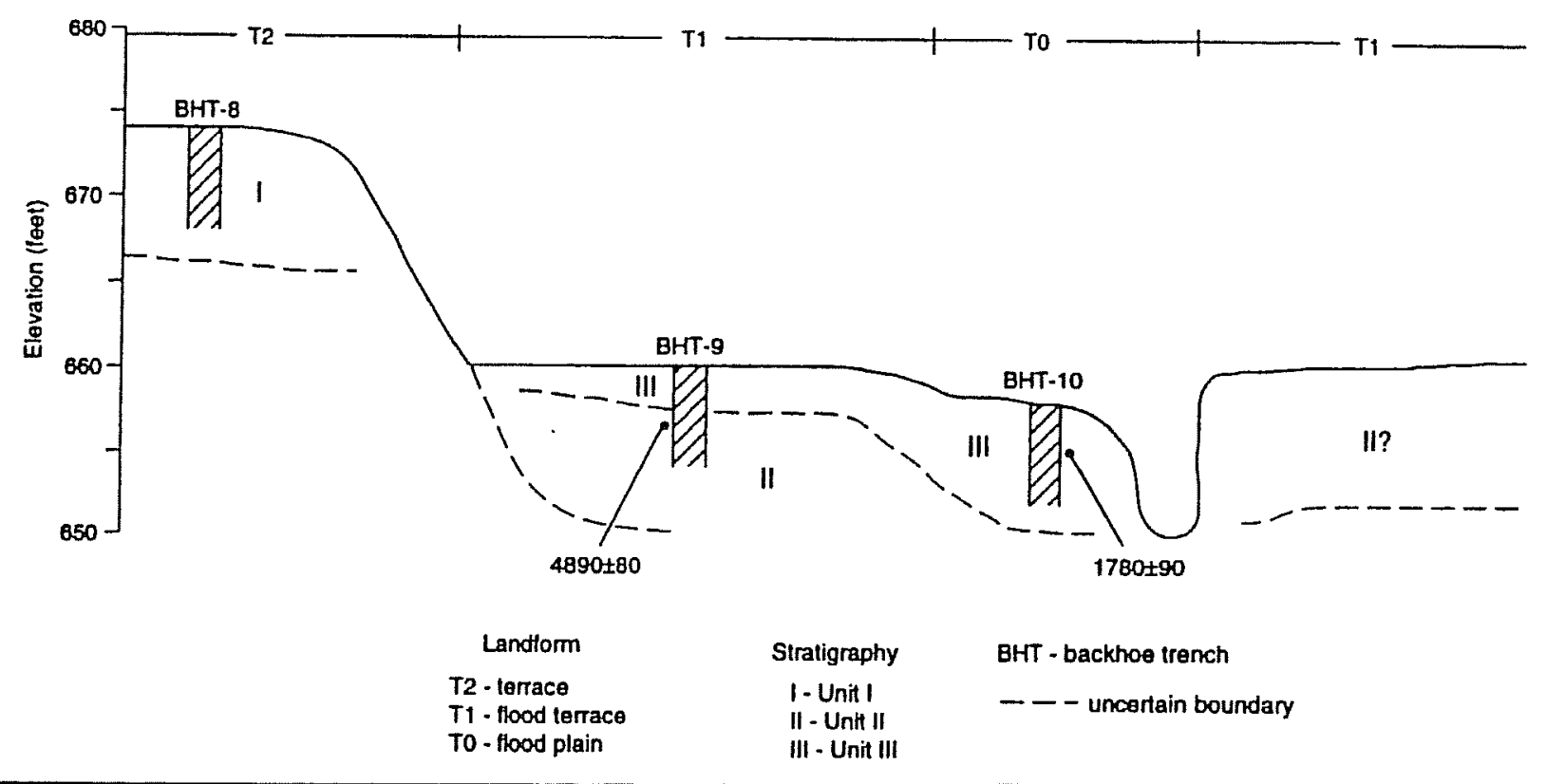

Figure 3-2. Composite alluvial stratigraphic cross section of the south transect of Medio Creek (schematic). Laboratory numbers are given in Appendix A.

\section{Unit I}

Based on stratigraphic position and degree of soil development, the oldest alluvial unit in the project area is associated with $\mathrm{T} 2$. This alluvium, designated Unit $I$, represents a fine-grained floodbasin facies in the vicinity of BHT 8 on the west side of the valley (Figures 3-1 and 3-2). Unit I has been pedogenically weathered to a black silty clay loam surface horizon over a subsoil consisting of very dark grayish brown to brownish yellow silty clays (Appendix A; BHT 8). Slickensides and $\mathrm{CaCO}_{3}$ nodules have also developed in the subsoil. Significant weathering and age for Unit $\mathrm{I}$ is indicated by the increase of clay with depth, decalcification of the surface horizon, and $\mathrm{CaCO}_{3}$ accumulation in the subsoil. Based on the oldest ${ }^{14} \mathrm{C}$ age from the Holocene valley fill, Unit $I$ is older than approximately 5000 B.P., and perhaps as old as late Pleistocene.

Cretaceous bedrock was encountered in BHTs 1 and 2 beneath a remnant of $\mathrm{T} 2$ on the northeast side of the valley (Figure 3-3; Appendix A). Apparently the associated alluvial deposits have been eroded.
Because there is no alluvial fill, $\mathrm{T} 2$ is designated as a strath terrace in this area.

\section{Unit II}

After an episode of channel downcutting, deposition of Unit II began along Medio Creek. Unit II occurs beneath the $\mathrm{T} 1$ flood terrace based on exposures provided by BHTs 4,7 , and 9 (Figures 3-1, 3-2, and 3-3). Where not buried in the vicinity of BHT 7 , this unit forms the constructional $\mathrm{T} 1$ flood terrace surface (Figure 3-3). Here, the deposits are pebbly to cobbley throughout the upper part, which is typical for a channel facies (Appendix A). These deposits have been weathered to soils with calcareous, black to dark grayish brown, silty clay loam surface horizons over yellowish brown subsoils having $\mathrm{CaCO}_{3}$ pendants on the bottoms of cobbles. Furthermore, the Unit II channel facies exposed in BHT 9 may be truncated and buried in the lower part of BHT 4 (Figure 3-3; Appendix A).

In the lower part of BHT 9 is a truncated and buried fine-grained deposit typical of a floodbasin facies. It has been pedogenically altered to a yellowish brown 


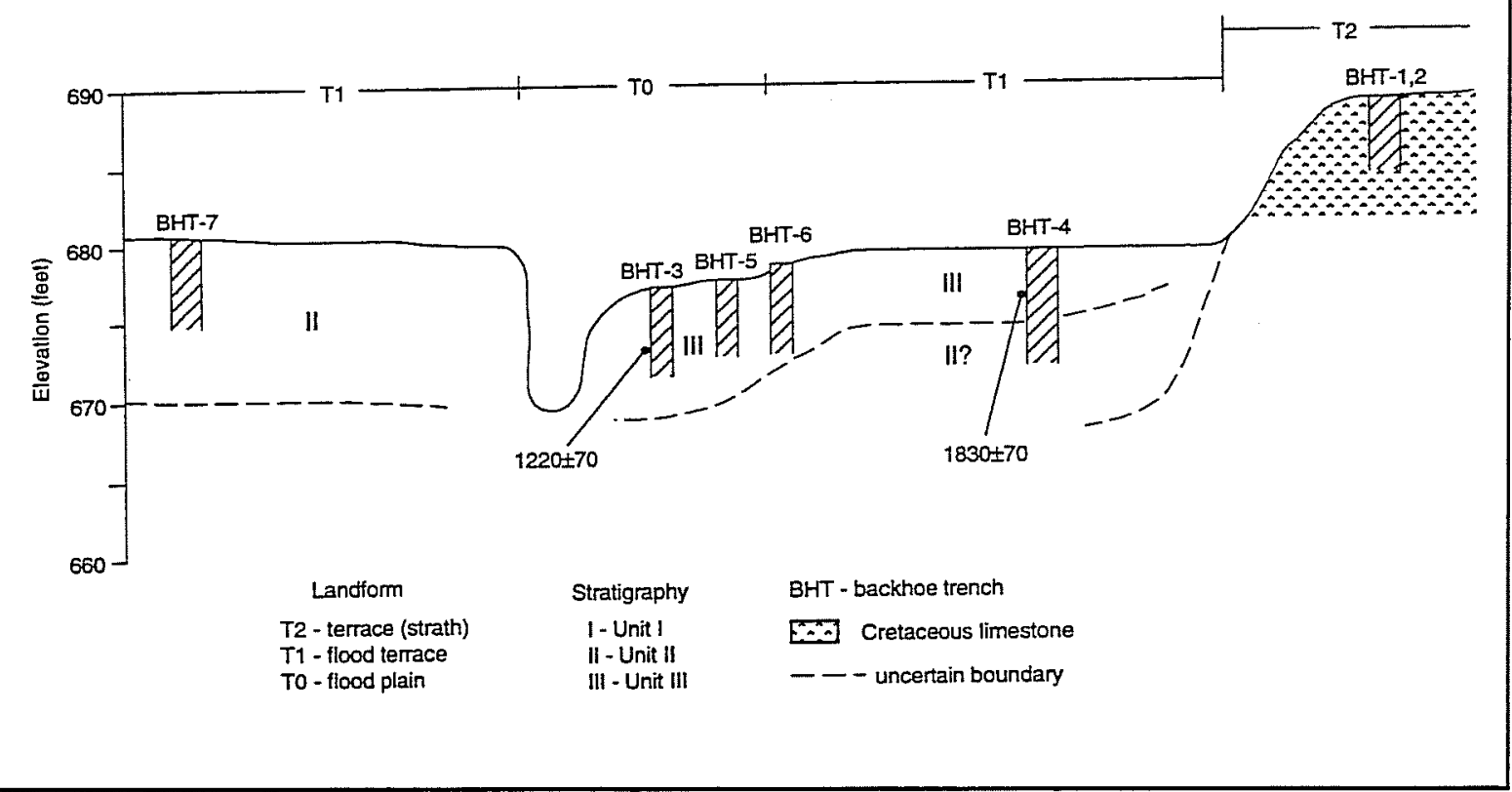

Figure 3-3. Composite alluvial stratigraphic cross section of the north transect of Medio Creek (schematic). Laboratory numbers are given in Appendix A.

clay loam with $\mathrm{CaCO}_{3}$ nodules (Figure 3-2; Appendix A). According to stratigraphic position, sediment color, and carbonate development, this unit is tentatively correlated as a floodbasin facies to the Unit II channel identified in BHT 7.

In Unit II of BHT 9, a ${ }^{14} \mathrm{C}$ age of $4890 \pm 80$ B.P. was obtained from a bulk humate sample collected at a depth of 120 to $130 \mathrm{~cm}$. Consequently, Unit II was probably deposited during the early Holocene. Deposition apparently terminated in the middle Holocene and was followed by a period of pedogenesis. In the vicinity of BHTs 4 and 9 , pedogenesis proceeded to no later than about 2000 B.P. based on the oldest ${ }^{14} \mathrm{C}$ age from Unit III. It is at this time that truncation and burial of Unit II occurred. In the vicinity of BHT 7, pedogenesis has been ongoing since about 4000 to 5000 B.P.

\section{Unit III}

Unit III was exposed in BHTs 3, 5, 6, and 10, and in the upper part of BHTs 4 and 9 (Figures 3-1, 3-2, and 3-3). The majority of these deposits occur beneath the T0 floodplain, but they also unconformably overlap Unit II and T1 in some areas. Apparently the Unit II channel down cut at the current topographic contact between $\mathrm{T} 1$ and $\mathrm{T} 0$, while simultaneously eroding its own fill along the edge of T1. Unit III deposits and construction of T0 subsequently proceeded at a slightly lower elevation as the channel continued to migrate away from the erosional scarp.

The stratigraphy of Unit III is more complex than that of the other units. Several punctuating intervals of landscape stability and soil formation occurred during deposition. This complexity is reflected in the presence of several stacked packages of sediment that fine upward from basal cobbles to black and very dark grayish brown silty clay and silty clay loams. The upper fine-grained sediments were altered to A horizons that were subsequently buried. This sedimentological sequence indicates shifts in flood magnitude not evident in the older stratigraphic units.

Bulk humate ${ }^{14} \mathrm{C}$ ages were obtained from the lower of two buried A horizons in BHTs 3, 4, and 10. 
These ages were $1220 \pm 70$ B.P., $1830 \pm 70$ B.P., and $1780 \pm 90$ B.P., respectively. These ages demonstrate that Unit II is late Holocene in age, forms the constructional surface of $\mathrm{TO}$ in all areas, and forms the constructional surface of $\mathrm{T} 1$ in areas where Unit III overlaps Unit II.

A veneer of loamy historic alluvium appears to bury Unit III within the confines of the T0 floodplain. However, because of its limited extent, the historic alluvium was not formally recognized.

\section{Leon Creek}

Leon Creek is a low-order tributary draining mostly lower Cretaceous limestones and marls (Barnes 1983). It begins in northern Bexar County, flows through the project area at its mid-point, and finally empties into the Medina River. Both floodplain and terrace deposits of Quaternary age are mapped in the project area (Barnes 1983). The Leona Formation is mapped along the high plateau adjacent to the project area on the west side. This deposit is slightly lower and younger than the Uvalde Gravel to the west of Medio Creek (Barnes 1983).

Only one segment of the Leon Creek alluvial valley, a large meander loop, is situated within the Lackland AFB project area (Figure 3-4). The Soil Survey of Bexar County, Texas (Taylor et al. 1991:Sheet16, 33-34) shows two soil mapping units in this area: the "Frio clay" and the "Venus clay loam, 3 to $5 \%$ slopes." Frio soils are mapped in occasionally flooded floodplains. These soils are loamy and exhibit weak pedogenesis. Venus soils are mapped on terraces. They are loamy and have $\mathrm{CaCO}_{3}$ nodules in the subsoil, reflecting greater pedogenesis than the Frio soils. Large delineations of Lewisville and Houston Black soils are mapped on higher terraces just to the east of the project area.

A special "Pit" mapping unit occurs in the middle of the Leon Creek floodplain in the project area (Taylor et al. 1991:Sheet 16). This unit is used to designate highly disturbed areas, typically from human activity.

\section{Geomorphology}

Two alluvial landforms were identified along Leon Creek in the project area. A terrace covers the eastern half of the alluvial valley approximately six meters above the modern low-water channel (Figure 3-4). The modern floodplain is within the large meander adjacent to the Leon Creek channel to the east. The floodplain is about three meters above the modern low-water channel.

\section{Alluvial Stratigraphy}

\section{Unit I}

The oldest stratigraphic unit along Leon Creek occurs beneath the alluvial terrace on the east side of the valley. Cutbank 1 (CB 1) revealed a complex alluvial sequence for this terrace fill (Figure 3-4). In general, a thin loamy surface layer overlies a thick sequence of massive to cross-bedded pebbles and cobbles of channel origin. The coarse fragments are clast supported, moderately well sorted, and subrounded, suggesting deposition by a coarsegrained meanderbelt. Small channel fills could be observed within the larger channel sequence.

The soil that formed in this unit consists of a black clay loam surface layer grading down into a brown to yellowish brown sandy clay loam subsoil (Appendix A). The subsoil contained $\mathrm{CaCO}_{3}$ pendants on cobble bottoms down to a depth of over three meters. The soil has not undergone any significant decalcification. The age of Unit $\mathrm{I}$ is unknown, but the absence of pedogenic carbonate nodules suggest that it may be Holocene in age.

\section{Unit II}

A channel cutbank exposure on the east side of Leon Creek revealed contorted beds of olive, yellow, and green clays and shales, and matrixsupported cobbles and pebbles. These sediments appear to be artificial and related to military activity. They also coincide with the "Pit" soil map unit of the local soil survey (Taylor et al. 1991). 


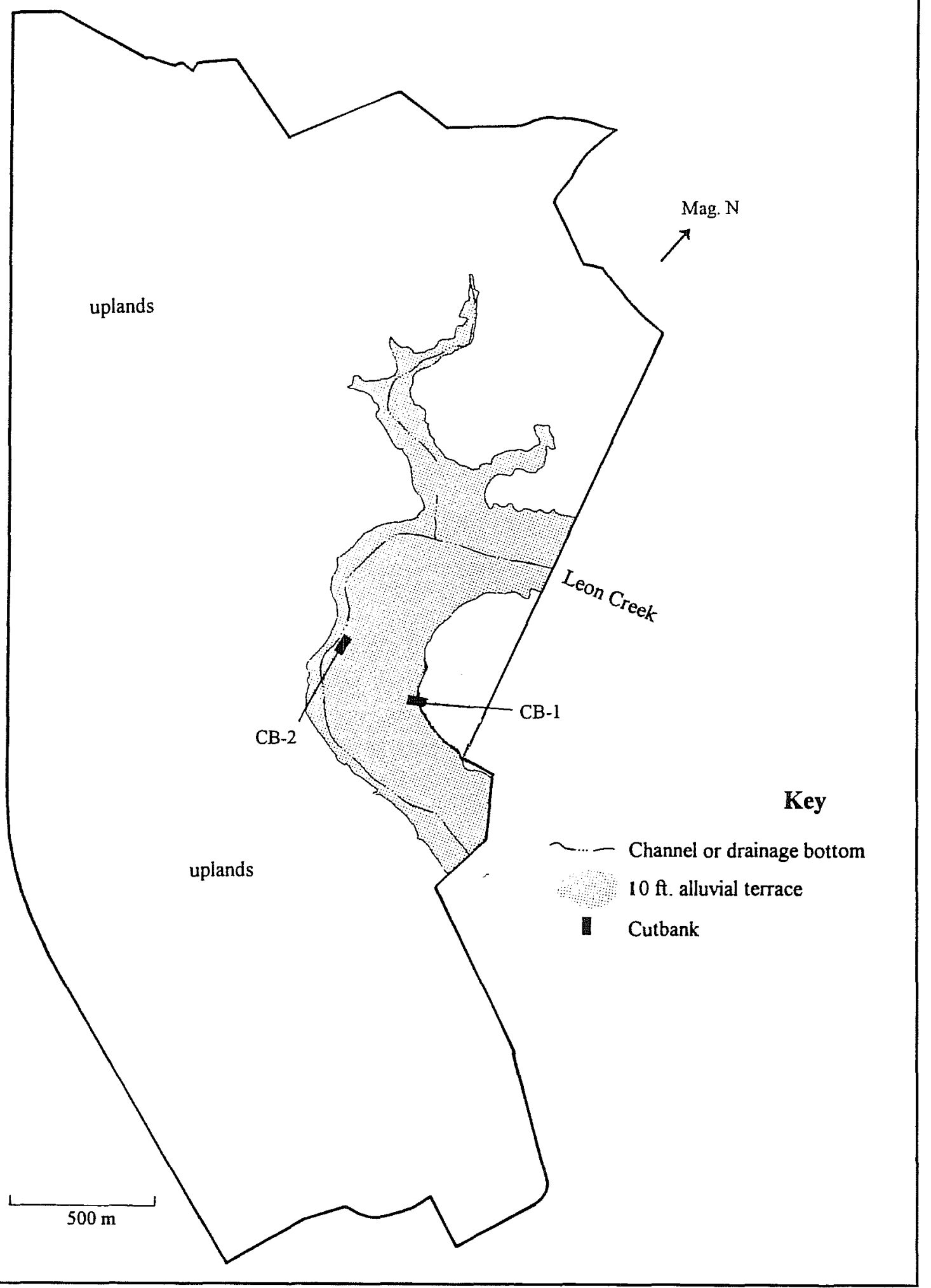

Figure 3-4. Map of the Leon Creek alluvial valley in the project area showing localities of cutbank (CB) exposures. 
Unit II was identified in a narrow, undisturbed section of channel CB 1 (Figure 3-4). Below $65 \mathrm{~cm}$ of artificial overburden, this unit exhibited a fining upward sequence from moderately well-sorted and clast-supported basal gravels to loamy upper deposits. Occasional pebble lines also occur within the alluvial fill. This sedimentological sequence is typical for meandering streams carrying a mixed sediment load. The soil at the top of this unit begins with very dark grayish brown sandy clay loam surface horizons grading down to a brown and dark yellowish brown subsoil containing filaments of $\mathrm{CaCO}_{3}$. It is unknown whether this soil formed the T0 ground surface before military disturbance and subsequent burial.

Based on stratigraphic position and degree of soil development, Unit II is younger than Unit I. Based on stratigraphic position and minimal pedogenesis, Unit II is probably late Holocene in age.

\section{Geoarchaeology}

The T2/Unit I complex of Medio Creek appears to be late Pleistocene in age and probably too old to contain buried cultural sites. The Holocene valley fill associated with $\mathrm{T} 1$ and $\mathrm{T} 0$ may, however, contain buried cultural materials. $\mathrm{A}^{14} \mathrm{C}$ age from the T1/Unit II complex indicates that it is early Holocene in age. Unit II may consequently contain buried Early Archaic components. ${ }^{14} \mathrm{C}$ ages from Unit III of Medio Creek, whether associated with $\mathrm{T} 1$ or $\mathrm{T} 0$, date to the last 2,000 years. This shows that sites no older than Late Archaic will be found buried in this fill. Middle Archaic sites will either be missing, or deeply buried in Unit III below the observation depth of the backhoe trenches.

T2 may have surface sites dating to all known cultural periods in central Texas. Uneroded areas of T1 will have Unit II exposed to the surface. In these areas, T1 is probably 4,000 to 5,000 years old and will consequently have surface sites dating to the Middle Archaic and younger. Where Unit III overlaps Unit II, the T1 flood terrace should be no older than 2,000 years old. Surface sites here will consequently date to no older than the Late Archaic.
The chronology of the Leon Creek valley within the project area is poorly understood. It appears that Unit I may be early Holocene in age and Unit II late Holocene in age. As a result, the entrenched alluvial valley of Leon Creek probably has potential for containing buried cultural sites.

The ages of the alluvial landforms and stratigraphic units along Medio and Leon creeks generally correlate with other late Quaternary alluvial stratigraphies in central Texas. Blum and Valastro $(1989,1994)$ and Nordt $(1992,1995)$ identified a late Pleistocene terrace dating to between 14,000 to 20,000 B.P. This terrace appears to correlate with T2 and Unit I in the Lackland AFB project area. These same authors also identified early Holocene and late Holocene alluvial units similar to Unit II and Unit III within the current project area. 


\title{
Chapter 4: Paleontology and Stratigraphy
}

\author{
James O. Jones
}

\section{Introduction}

Lackland AFB is located on Uvalde Gravel and Leona Gravel of Pliocene-Pleistocene age. Some Holocene alluvium is present. The Upper Taylor Marl Group and the Navarro Marl Group of Upper Cretaceous Age are exposed in very small areas of the base. The Tertiary age Midway Group occupies the near subsurface bed rock of the southern region of the base (Table 4-1).

\section{Stratigraphic Setting}

About one-third of the north-central area of the base has the best exposures of Cretaceous age rocks; however, there are only a few exposures because most of the Cretaceous age rocks are covered by Quaternary alluvium and gravel. Late Tertiary age marine rocks were not observed, but are very near the surface and covered with younger alluvium. The Pleistocene age Leona Formation is composed of unconsolidated sand beds and gravel beds and occupies the eastern third of the base. Unconsolidated Pliocene/Pleistocene age Uvalde Gravel covers about one-fourth of the base, mostly in the western area. Smaller areas of the base have Pleistocene river-terrace deposits, Quaternary alluvium, and Holocene floodplain deposits (Barnes 1983).
Well-exposed and reasonably fresh exposures of Cretaceous and Tertiary age marine rocks are not present on the Main Base or the Medina Annex. Weathered exposures and mostly covered areas of Upper Cretaceous age rocks do exist, mostly in the banks of drainage systems. Four useful outcrops were investigated and all were found to contain significant numbers of marine fossils. Two on the Medina Annex have both mega- and microfossils and two on the Main Base have only microfossils (Figure 4-1). On Median Annex, outcrops containing both mega- and microfossils are best exposed in Medio Creek at map coordinates L21 (Figure 4-2). Stratigraphically equivalent rocks are poorly exposed in a small drainage tributary on the west side of Service Road No. 2 between ammunition bunkers 402 and 403, coordinates G21. However, the best preserved and greatest variety of fossil species are located at coordinates L21; a few of the same species were recovered at locality G21. Two sites are located on the Main Base in the Upper Taylor Marl Group: one is in the west bank of Leon Creek west of Kelly AFB Road at map coordinates J8 (Figure 4-3); the second is in the south bank of a tributary to Leon Creek at the west side of the rope climb in the Confidence Course Area, First Cliff, obstacle number eight, at map coordinates L3 (Figure 4-4). All available fossils were classified taxonomically (Frizzell 1954; Howe et al. 1958; Moore 1961) (Appendix B). There should be no doubt that if any area of the base is excavated to these stratigraphic units, fossils will be encountered. 
Table 4-1. Stratigraphic Column at Lackland Air Force Base

\begin{tabular}{|c|c|c|l|}
\hline Geologic Period & Epoch & Group & \multicolumn{1}{|c|}{ Formation } \\
\hline \multirow{2}{*}{ Quaternary } & Holocene & & $\begin{array}{l}\text { Alluvium } \\
\text { Fluvial Terrace Deposits }\end{array}$ \\
\cline { 2 - 4 } & Pleistocene & & Leona Gravel \\
\hline \multirow{2}{*}{ Tertiary } & Pliocene & & Uvalde Gravel \\
\cline { 2 - 4 } & Paleocene & Midway & \\
\hline \multirow{2}{*}{$\begin{array}{c}\text { Upper Cretaceous } \\
\text { (Gulf) }\end{array}$} & & Navarro & \\
\cline { 2 - 4 } & & Taylor (Upper) & \\
\hline
\end{tabular}

As the final results of this investigation were being prepared, excavation and construction were being undertaken to rechannelize Leon Creek just east of Kelly AFB Road, near the main base collecting sites discussed in this chapter. Less weathered Upper Taylor Marl was exposed in the new channel. One rock sample was taken and processed to make a cursory examination for microfossils, including a search for types of fossils and the quality of preservation. Abundant and well-preserved specimens were observed. A detailed identification process was not undertaken, therefore no additional genera or species from the sample are included in these results. Megafossils were not observed in the samples.

Although no plant and vertebrate fossils were discovered, a high possibility exits that their remains may be preserved in the Tertiary/Pleistocene age clay and gravel that dominates the surface and near surface deposits of the area. Plant remains have been observed in slightly younger age rocks a few miles south of San Antonio, and vertebrate remains have been recovered to the south and west of the city.

Well-rounded limestone and chert boulders, cobbles, and pebbles in modern and ancient streamtransported deposits contain megafossils. Mollusks are the dominant fossils recovered and include various gastropods and diagnostic bivalves, especially caprinid forms of rudistids. These rocks are an erosional product originating with the older Cretaceous age Edwards Group limestone and dolomite beds exposed along the Balcones Escarpment 20-25 km north of Lackland.

\section{Methods}

The base was searched for bedrock exposures and the best outcrops were at a few locations in the valley walls of the drainage systems of Medio and Leon creeks. Rock samples were collected from the sites in both Medio and Leon creeks and megafossils were systematically collected at the sites in Medio Creek. All samples were returned to the laboratory for cleaning and processing to make a detailed taxonomic identification of the fossils. Rock samples were soaked in water to cause the clay minerals to expand and disaggregate the sample. The wet sediment that was generated was washed through progressively smaller Tyler equivalent screen sizes of $12,32,60$, and 115 mesh to flush away the very fine-grained sediment, clean the microfossils, and to concentrate approximate-sized sedimentary particles and specimens on the screens. Samples from each screen were permitted to air dry at room temperature for 48 hours. Samples of each size group were stored in vials for safe keeping. Each size group was searched for microfossils under 


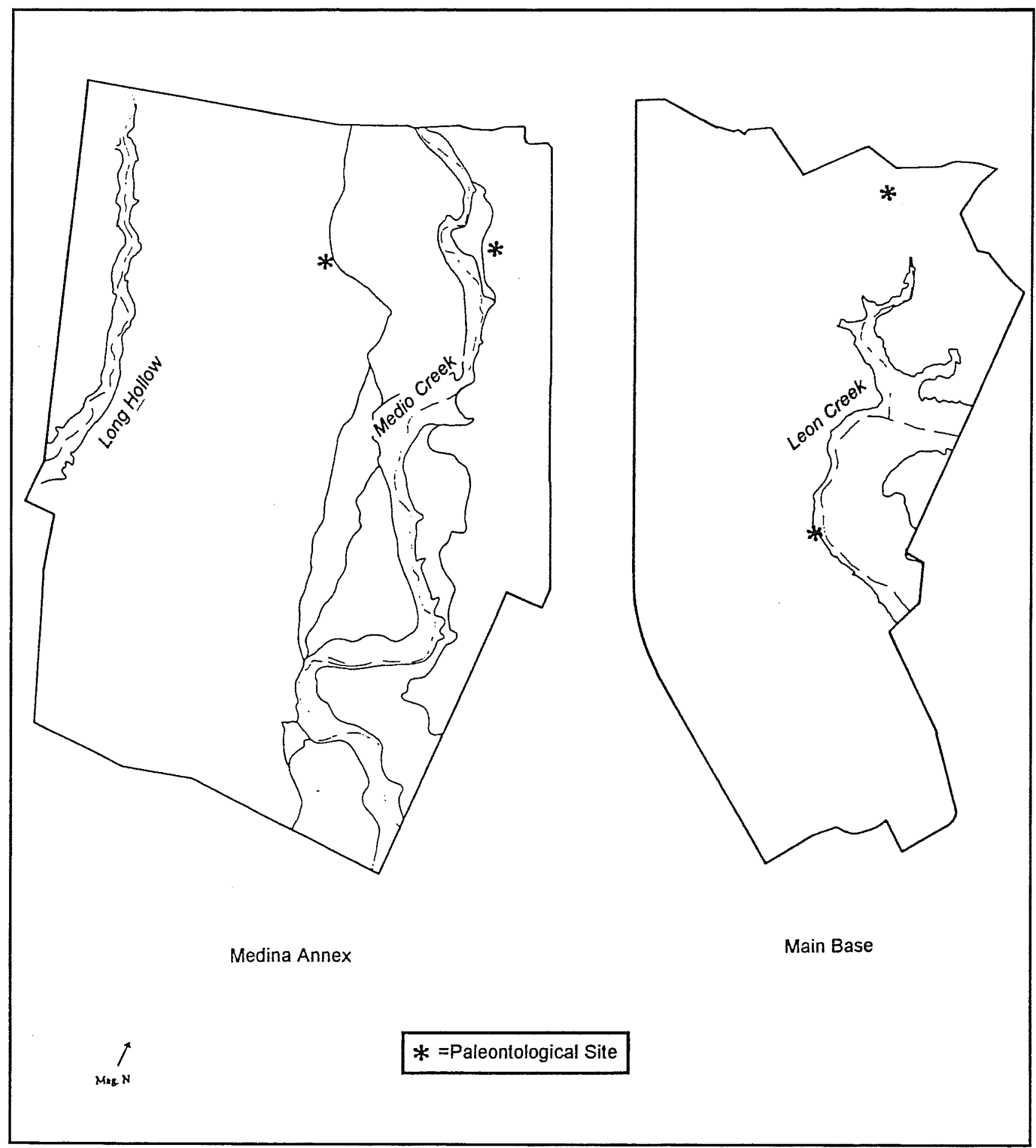

Figure 4-1. Location of paleontological sites on the Main Base and Medina Annex. 


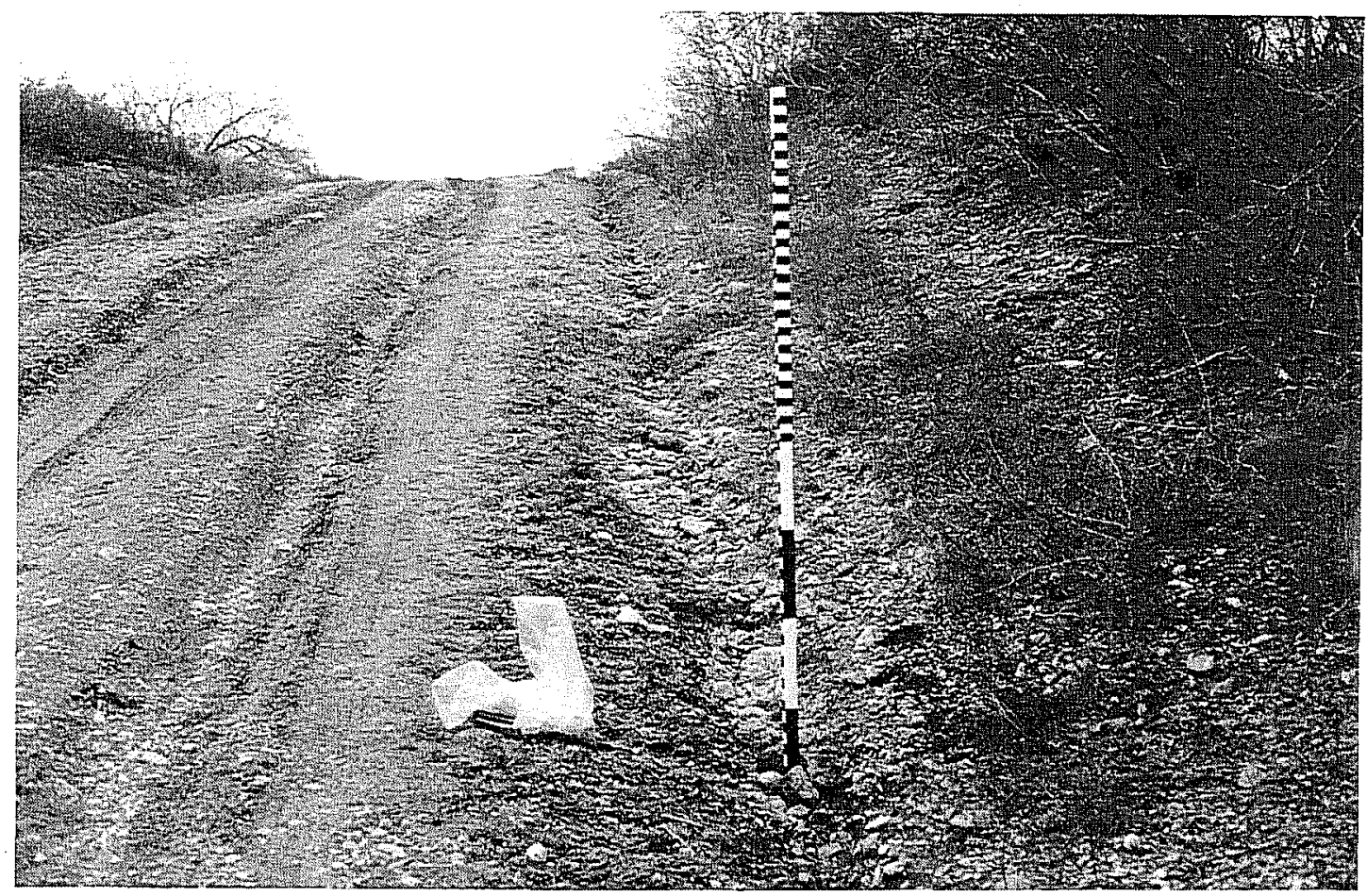

Figure 4-2. Navarro Formation exposed in Medio Creek valley at coordinates L21. Jacob's staff is two meters, small black-and-white marks are $2.5 \mathrm{~cm}$ each. Approximately five meters of rock are exposed. Both micro- and megafossils are present throughout the outcrop.

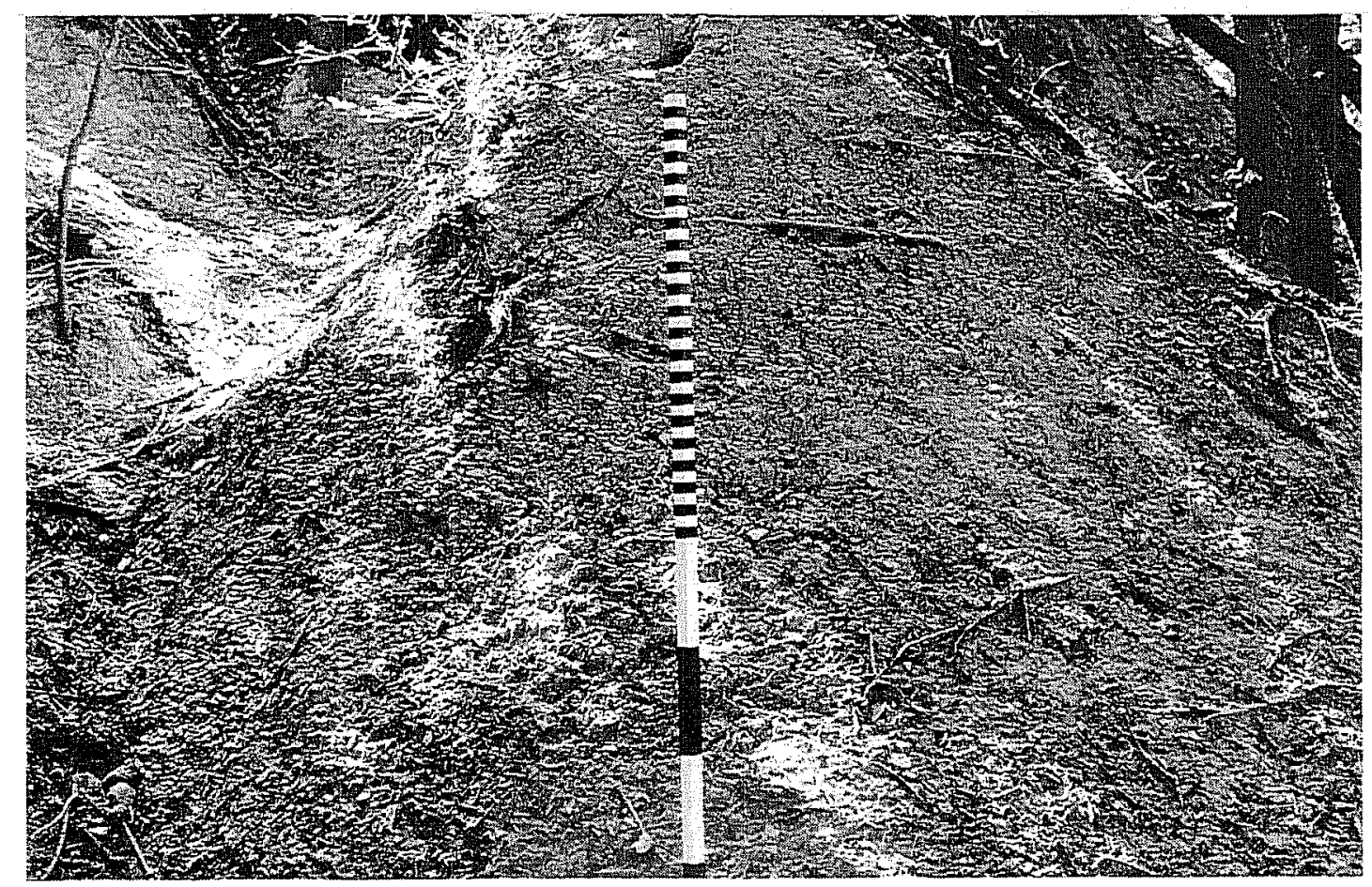

Figure 4-3. Upper Taylor Marl exposed in the south bank of the west side of Leon Creek at Kelly Air Force Base Road, coordinates J8. Bedding is preserved in weathered marl. Jacob's staff is two meters, small black-and-white marks are $2.5 \mathrm{~cm}$ each. Approximately eight meters of rock are exposed. Microfossils are present throughout the outcrop. 


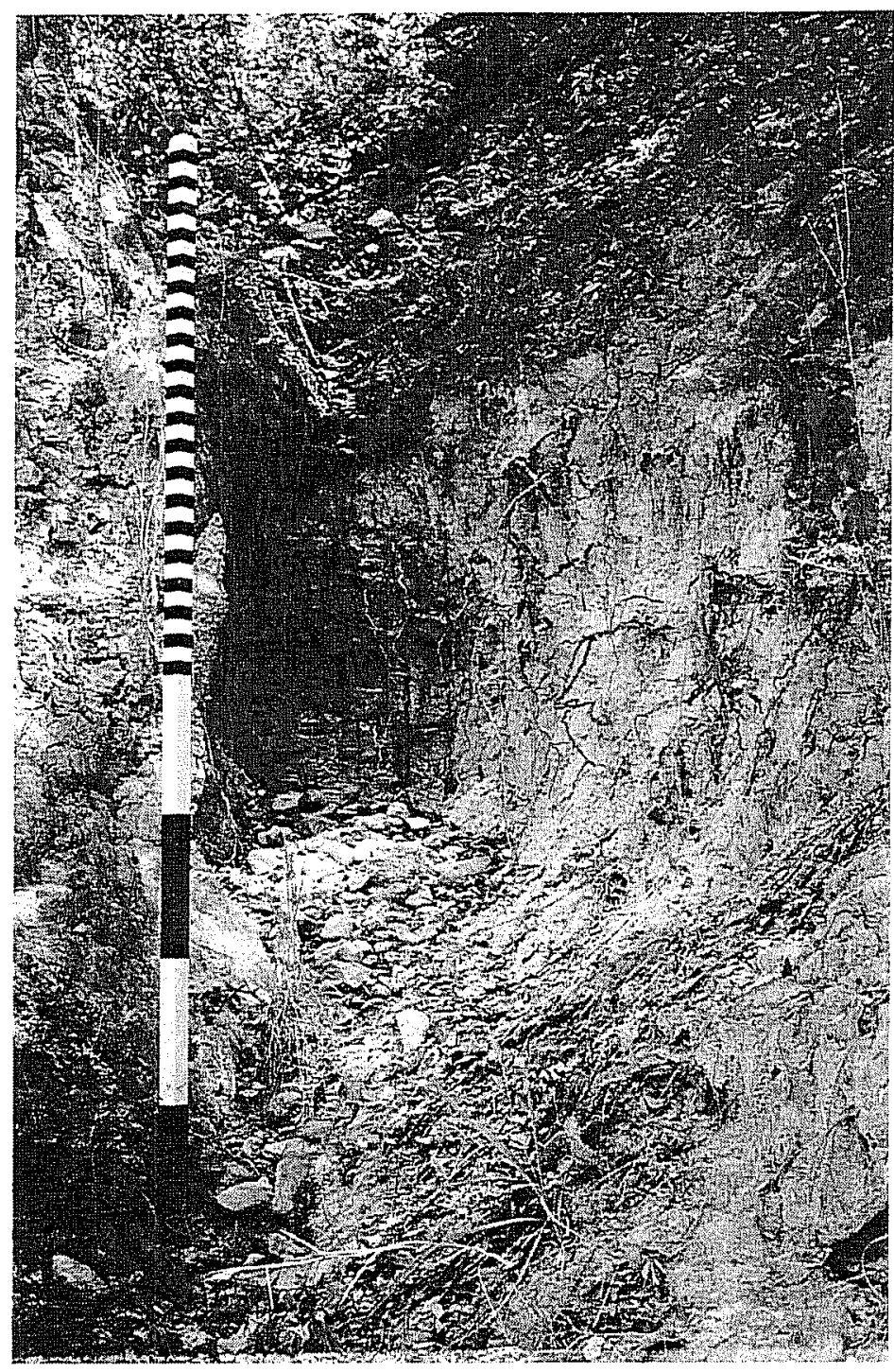

Figure 4-4. Upper Taylor Marl exposed in the south side of the east bank of a tributary to Leon Creek at coordinates L3. Upper meter of sediment is darker terrace gravel. Bedding is poorly preserved in the lighter marl. Jacob's staff is two meters, small black-and-white marks are $2.5 \mathrm{~cm}$ each. Approximately two meters of marl are exposed. Microfossils are present throughout the marl.

a stereoscopic binocular microscope at 10X-40X magnification. Representative specimens of each species were recovered, one at a time, with a wet $5 / 0$ camel hair brush. Each specimen was glued to a prepared 60 grid slide tray for ease of identification. All identifiable fossils (Appendix B) were classified taxonomically (Frizzell 1954; Howe et al. 1958; Moore 1961).

\section{Navarro Marl Group}

Large numbers of fossils are present in the Medio Creek bank at coordinates L21 (Figure 4-2), with two large heavy-shelled bivalves being the most obvious. They are Exogyra costata and Flemingostrea sp. (Figure 4-5, nos. 1, 2, and 3). Gastropods (snails) and smaller bivalves are present. Most of the gastropods are preserved as internal molds (shells absent) and not identifiable. Heavyshelled bivalves have numerous borings on both the body chamber side and the outside of the shell indicating that they were bored after death, probably by sponges. Some heavyshelled bivalves have serpulid worm tubes and oyster shells that grew in the body cavity indicating post mortem development by the worms and oysters (Figure 4-5, no. 2). Others in their early stage grew around the shell of other oysters. Specimens of echinoids were not recovered; however, small echinoid spines are present with the microfossil samples. Many microfossils were recovered, but their preservation was generally not good. Dissolution is evident in many specimens indicating that chemical corrosion at and near the surface has been very active. A greater variety and quantity of specimens of betterquality preservation would be recovered from deeper excavations or drill cores.

Genera and species from the collecting site at coordinates $\mathrm{G} 21$ are the same types as those at L21; however, fewer were recovered at G21 because of the degraded quality of the rocks. Eight genera with eight species of megafossils, 17 genera with 23 species of foraminifers, and eight genera with 10 species of ostracods were observed in the Navarro Formation (Appendix B, Tables B-2 and B-3). Two other megafossils were recovered, but were not identifiable to the generic level. Many burrows are present, probably formed by irregular echinoids. Borings in the shells of megafossils were probably the result of sponge activity. Microscopic vertebrate teeth were recovered. 
The megafossils indicate that the environment of deposition of the Navarro Formation in this area was in a very shallow marine bay with good transfer of water to the open ocean or a shallow marine shelf. Abundant open marine planktonic (floating) foraminifers are present in these rocks, further supporting such a depositional site. Benthonic (bottom-dwelling) foraminifers are present, but are not as definitive when determining depositional environment. Large heavy-shelled bivalves are not easily transported and at this site do not have any indications of transportation such as abrasion. Therefore, they were deposited at the site of death.

Likewise, the delicate spines on the bivalve Spondylopecten sp. are well preserved and do not show abrasion, indicating that they too were not transported. Therefore, megafossils and some microfossils in the Navarro Formation in this area were deposited as a biocoenosis or life assemblage (not transported to the burial site after death or thanatocoenosis).

\section{Upper Taylor Marl Group}

Abundant microfossils are present in the Upper Taylor Marl in the banks of the Leon Creek and at least one tributary (Figure 4-1), coordinates J8 and L3 respectively. Megafossils were not discovered in these rocks. Dissolution of the microfossils in these rocks is widespread, indicating that chemical corrosion at and near surface has been very active. Usually, naturally occurring acidic rain water is the cause of near-surface dissolution. Some specimens had so much destruction that they were not identifiable. A great variety and number of species are present and drill cores or excavations to fresh bedrock exposures would probably yield even larger numbers. In general the genera and species from the collecting site in Leon Creek at coordinates $\mathrm{J} 8$ and those from the collecting site in the tributary to the Leon Creek at coordinates L3 are the same. A few different genera and species are present at each site,

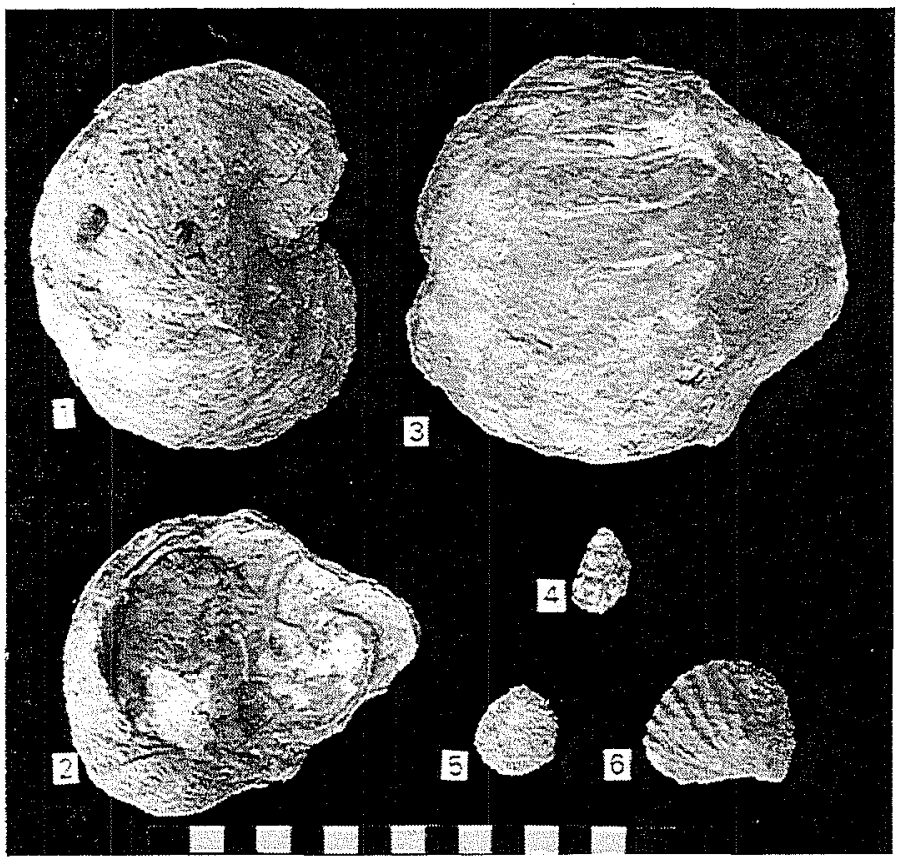

Figure 4-5. Megafossils from the Navarro Marl. Specimens 1 and 2 are Exogyra costata. Note the worm tube starting near the margin of the upper central area and extending down about $2 \mathrm{~cm}$, and an interior view of a partially coiled oyster shell on the right side of the interior view of Specimen 2. Both the worm and oyster grew in the shell after the host died. Small holes in Specimen 1 are borings made by sponges. Specimen 3 is the oyster Flemingostrea (?) sp. and contains a few sponge borings. Specimen 4 is a gastropod, Pyropsis (?) sp.; some shell ornamentation is preserved. Specimens 5 and 6 are pelecypods, Spondylopecten sp. with small spines and Trigonia sp. with prominent ribs. Black-andwhite marks on the scale are $1 \mathrm{~cm}$ each.

probably a result of preservation characteristics and recoverability rather than major ecological variations. Twenty-eight species among 14 genera of foraminifers and six species among five genera of ostracods were recovered from the Upper Taylor Marl (Appendix B, Tables B-4 and B-5). Although no megafossils were recovered, spines of echinoids were recovered in the microsamples.

The microfossils and very fine-grained sediment (clay size) indicate that the environment of deposition for the Upper Taylor Marl in this area was probably in the interior region of a large inland 
seaway or large deep lagoon with adequate transfer of open ocean water, and with lowlands surrounding the area. Abundant open marine planktonic (floating) foraminifers are present in these rocks. As the planktonic forms died, they settled to the ocean bottom. Benthonic (bottom-dwelling) varieties are present in significantly lesser amounts than those of the Navarro Marl. Water circulation at the sediment water interface was probably not significant. Abundant microscopic pyrite/marcasite (sulfide minerals) concretions and a few larger concretions are present. These minerals indicate that at least the near surface sediment was, at least partially, in a reducing environment (oxygen deficient). Primary and secondary sedimentary structures were not observed.

\section{Conclusions}

Within the boundary of the Main Base and the Medina Annex are Upper Cretaceous age marine deposits containing abundant micro- and megafossils. Although there are very few exposures of these rocks, core drilling and excavations would certainly expose fresh fossiliferous rock almost any place on the base and annex. Vertebrate and plant remains were not observed, but should be expected in excavations of Tertiary and Quaternary age gravel, sand, clay and soil beds resulting from fluvial deposition.

\section{Recommendations}

The scope of this investigation did not provide for large-scale excavations; however, the possibility of such excavations for construction purposes in the future is reasonable. If such excavations are undertaken, the material should be investigated before and throughout the process by a paleontologist and sedimentologist. 


\section{Chapter 5: Previous Archeological Research}

Professional archaeology has been conducted in Texas for over 60 years, but some regions have been more intensely studied and documented than others. The formative groundwork for central Texas archaeology was laid some 45 years ago (Collins 1995) with the publication of An Introductory Handbook of Texas Archeology (Suhm et al. 1954). Since that time, a central Texas chronological sequence has been worked out (Black 1989c; Prewitt 1981,1985; Turner and Hester 1993), although not without considerable discussion over both details and fundamental assumptions (Collins 1995; Johnson and Goode 1994; Potter and Black 1995). Similarly, extensive work has been carried out in south Texas only within the past three decades (Hester 1995), resulting in a cultural chronology for that region that is less well understood and explicitly tentative.

In Bexar County, interest in archaeology was heightened when the Witte Memorial Museum of San Antonio was established in 1926 and began conducting research locally and in adjacent areas such as the Pecos River region (Fehrenbach 1978:195; Martin 1933). Artifacts from these expeditions were displayed at the museum, increasing local interest in the region's prehistoric past. During the last two decades, activities of the Center for Archaeological Research (CAR) and the Southern Texas Archaeological Association (STAA) have bolstered the identification and preservation of cultural resources in Bexar County.

Bexar County was one of the first in central Texas to be formally investigated by professional archaeologists. Interest in the region was initially stimulated by its wealth of Spanish colonial sites, which prompted interest in the county's prehistory as well. Before the 1960s, prehistoric investigations were conducted by amateur collectors and avocational archaeologists, but involved only a few professionals. In 1932, J. E. Pearce of The University of Texas at Austin investigated "kitchen middens," or burned rock middens in the area while attempting to determine their functions (Weir 1976). Later investigators such as Woolford (1935), Orchard (1938), and Orchard and Campbell (1954) worked on prehistoric sites in the Olmos Basin north of downtown San Antonio.

During the 1970s, the pace of prehistoric archaeological research accelerated rapidly in Bexar County, due in part to the creation of CAR. Initially, CAR focused its attention on previously investigated locations such as the St. Mary's Hall site, 41BX229, and the Olmos Dam site, 41BX1 (Kelly and Eaton 1979; Lukowski 1988). The role of CAR in the cultural resource management of Bexar County has greatly expanded research in the area and significantly increased the number of sites studied.

Large-scale surveys covering thousands of acres along the Balcones Escarpment and the eastern Edwards Plateau have been highly effective in discovering archaeological sites. CAR recorded 72 sites on 5,600 acres at Camp Bullis in northern Bexar County (Gerstle et al. 1978). The survey covered the watersheds of upper Cibolo Creek, Ranger Creek, and upper Salado Creek. Of those sites, 34 were associated with diagnostic lithic tools from the Paleoindian through Late Prehistoric periods. During a 2,500-acre survey of the East and West Elm Creek branches of the upper Salado Creek in the Encino Park area of northern Bexar County, 34 sites containing Paleoindian through 
Late Archaic components were recorded (McGraw et al. 1977:10-29). CAR researchers found 31 prehistoric sites dating from the Paleoindian through Late Prehistoric periods during a 604-acre survey of the upper Cibolo Creek in southern Kendall County (Bass and Hester 1975:9-24; Kelly and Hester 1976:29). Paul McGuff recorded 28 prehistoric sites along Leon Creek in northern Bexar County in 1970 and 1971 (site reports on file at CAR). McGraw (1977) recorded 11 prehistoric sites on upper terraces along Medio Creek both north and south of the project area. A survey of the land south of Medina Annex that is now the Covel Gardens landfill revealed one prehistoric site on a terrace of Medio Creek (Potter 1990:2-4).

Local research has also involved organizations based beyond the limits of Bexar County. Prewitt and Associates of Austin has conducted research at numerous sites including the Rolling Mill Plant (Boyd and Freeman 1990) and several sites on Camp Bullis (Boyd et al. 1990). Quigg (1988) conducted a cultural resource reconnaissance along stretches of Salado Creek in Camp Bullis and Fort Sam Houston.

The Center for Environmental Archaeology at Texas A\&M University performed a number of projects in southern Bexar County, including intensive investigations of one of the more significant sites in the region. The Richard Beene site (41BX831) is located on the Medina River, in the Applewhite Reservoir project area, $12 \mathrm{~km}$ south of Medina Annex. It was excavated in 1991 and further tested in 1995 during an STAA field school. The site is deeply buried in the first terrace above the Medina River. Its well-defined stratigraphy yielded artifacts and fauna representing sporadic occupations from the Paleoindian through Late Prehistoric periods (Thoms 1992:17-26; Thoms et al. 1996:13-27).

Also the focus of considerable work, the Panther Springs Creek site (41BX228) on the Salado Creek drainage, $20 \mathrm{~km}$ north of the project area, was tested in 1979 by CAR (Black and McGraw 1985) and again in 1992 as part of the Wurzbach Parkway project by the Texas Archeological Research Laboratory (TARL) of The University of Texas at Austin. Early Archaic through Late Prehistoric components were defined by diagnostic stone tools (Potter and Black 1995:23-54). Tested heavily in $1995,41 B X 47$ is a deeply buried, intact Paleoindian through Middle Archaic campsite on the terraces of Leon Creek, $25 \mathrm{~km}$ north of Lackland (Tennis 1996; Tennis and Hard 1995). Although not well published, 41BX52, in the Leon Creek floodplain at Loop 1604, is a Clovis and Folsom lithic workshop tested by the Texas Department of Transportation (Henderson 1980).

TARL is compiling a comprehensive assessment of the area being affected by construction of the Wurzbach Parkway, part of which is now underway. This includes the Walker Ranch Historic District on Panther Springs Creek and other sites in the upper-middle Salado Creek watershed. The approach taken by TARL has been innovative and thorough. This is exemplified by the work at the Higgens site (41BX184) (Black et al. 1993), and the manner in which the Wurzbach research is being reported: a series of modules presenting the conceptual framework (Potter et al. 1995) and testing results from several prehistoric sites (Potter and Black 1995). The first module is particularly useful for its explication of the concept of historic contexts and because it presents an intermediate framework in the absence of a regional planning document (Black and Potter 1995:45-51). The Wurzbach research also sets out a modern theoretical approach well suited for local prehistoric research into hunter-gatherer mobility and subsistence in the light of human and cultural ecology.

Since Bexar County represents a transitional zone among three biotic provinces, with significant variation in land forms and resources, the potential for diversity of site function across the county is high. The study of archaeological sites in the watershed areas of Salado Creek (Katz 1987; Quigg 1988), Leon Creek (Espey, Huston and Associates 1989; Henderson 1980; Tennis 1996; Tennis and Hard 1995), and Olmos Creek (Lukowshi 1988; Stothert 1989) has helped with assessment of site distribution and variation along watercourses.

The recent and on-going projects listed above have direct implications for prehistoric cultural resources 
within the Lackland project area. In the immediate project vicinity, 15 prehistoric sites were found in a survey of Medio Creek both north and south of Lackland AFB (McGraw 1977). In 1987 CAR surveyed 3,539 acres and documented 52 sites along the Medina River for a cultural assessment of the area to be affected by the proposed Applewhite Reservoir (McGraw and Hindes 1987). The findings indicate many archaeological sites are located within the areas where Olmos, Salado, Leon, and Medio creeks converge with the Medina River.

\section{Previous Research at Lackland AFB}

Before CAR's survey of the base, several assessments and overviews were made. Espey, Huston and Associates (EH\&A) was commissioned by Carter and Burgess to conduct a survey for cultural resources on Kelly Air Force Base and a small area of Lackland's Main Base along Leon Creek (EH\&A 1989). No archaeological sites were recorded by EH\&A, but the high level of disturbance noted by their survey was confirmed by CAR's reconnaissance of the same area. Two prehistoric sites (41BX1107 and 41BX1108) located and recorded by CAR staff on Lackland's golf course fell within the EH\&A study area, but outside their survey zone.

Cleveland and McLain (1992) compiled a comprehensive catalog of flora and fauna on Medina Annex. Petraglia and Knepper (1993) conducted an archaeological survey of the Prime RIBS training area. They also recorded a prehistoric quarrey site (41BX1006) in the southwest corner of Medina Annex.

Under contract with the United States Army Corps of Engineers (COE), Dalbey (1993) constructed an overview of established and potential cultural resources to advise Lackland of its responsibilities regarding such resources on base property. Nine potential and non-designated sites were identified during his reconnaissance, including one historic and eight prehistoric locations.
Later, the COE commissioned Geo-Marine to conduct an overview of the prehistoric and historic heritage of Lackland (Reese et al. 1994). While fieldwork was not part of this effort, documents from previous surveys and other archival information were consulted. Using early USGS topographic maps, Geo-Marine identified several historic structures along Medio and Leon creeks (Reese et al. 1994:38). Several structures were identified outside the boundaries of base property, but the CAR survey was only concerned with GeoMarine's identification of three possible sites along Medio Creek on the Medina Annex and two on the Main Base near Leon Creek. One of these was said to be on Leon Creek near the present golf course, the other in the southwestern corner of the Main Base in a highly developed area excluded from the CAR survey area. CAR survey crews were unable to locate the former, which according to its mapped position would have been in an area now highly disturbed by development.

CAR's assessment of the USGS map (1903) and a COE tactical map (1942) found discrepancies in Geo-Marine's positioning of the historic structures. Field reconnaissance by CAR staff confirmed the presence of three historic sites as indicated on the USGS map. These include the historic component at 41BX1002 (Dalbey 1993; De Vore 1993) and a location undetected by Geo-Marine (Reese et al. 1994). The three sites designated by CAR are 41BX1128, 41BX1129, and 41BX1130. One additional historic site (41BX1061) located by CAR was not on the USGS map.

A cultural resource assessment of base property was conducted by Steven De Vore of the NPS between August 16-20, 1993. The assessment focused on determining archaeological site potential, historic structure identification, and a paleontological overview of the base. De Vore's pedestrian survey along Medio Creek relocated three sites identified by Dalbey. These were officially recorded as only two sites (41BX1001 and 41BX1002) by De Vore (1993). Based on his limited survey and Dalbey's (1993) COE report, De Vore recommended a complete baseline survey of those areas with 
moderate to high potential for archaeological sites. Developed and highly disturbed zones omitted on the main base were those areas outside the Leon Creek floodplain and terrace system where extensive construction activities had occurred (NPS 1993). Excluded from survey on the Medina Annex were highly developed and disturbed areas, including sensitive communications facilities, radioactive waste burial sites, and a large plot containing weapons storage bunkers in the northwest quadrant of the annex.

During De Vore's assessment, several areas were designated as potential zones of development (NPS 1993). CAR survey and shovel testing revealed seven prehistoric sites (41BX1055-41BX1059, 41BX1065, 41BX1066) and one historic site (41BX1061) in those areas (Appendixes C, D, and E).

\section{Cultural History}

The importance of the wide variety of landform and vegetation regions in the area, along with the presence of permanent water, cannot be overemphasized in considering the history of Lackland AFB. This variety of resources, including the plants and animals of differing biotic zones and the lithic resources available within a short distance, made this a rich region from the viewpoint of its prehistoric inhabitants. More importantly, the diversity provided a kind of "insurance" against the vagaries of seasonal and climatic variation. Problems associated with these variations could be ameliorated by simply moving a few miles-and into a different resource zone. Availability of water would seldom have been a problem, for throughout the area were numerous rivers, creeks, and springs (Brune 1975).

The profusion of archaeological sites recorded in Bexar County contrasts sharply with the significantly smaller site inventories in neighboring Medina and Atascosa counties (J. Hughes, personal communication 1994). In part, this surely results from the concentration of professional and avocational archaeologists in the San Antonio/Austin area (Story 1985:31). It is also likely to be a natural concomitant of urban growth and public works. Nevertheless, studies of site locations in south and central Texas (Boyd et al. 1990; Greer 1979; McGraw and Hindes 1987; Quigg 1988; Story 1985) make it clear that Bexar County has had a relatively high population for the past 10,000 years.

The high population of the area has resulted in a rich archaeological heritage. Unfortunately, this high population, which continues to grow, has also resulted in rapid urban development of San Antonio and surrounding areas, contributing to the destruction of large numbers of archaeological sites.

While more work on the cultural sequence along the Balcones Escarpment is still needed, the general cultural history in the Lackland AFB area is fairly well known. No diagnostic artifacts of the Paleoindian period have yet been identified, but diagnostic artifacts spanning the Archaic and Late Prehistoric have been recovered in the project area. The quantity and distribution of these artifacts is described in Chapter 10.

As noted in Chapter 2, Lackland AFB lies in a biotic transition zone between the Edwards Plateau and the South Texas Plains. The biotic ecotone is reflected in an archaeological ecotone along the Balcones Escarpment where south and central Texas meet (Hester 1995:427). The culture history of the Lackland area cannot be understood without considering the archaeology of both these areas.

Systematic study of central Texas artifact assemblages began with J. Charles Kelley (1947a, $1947 \mathrm{~b}, 1959)$, who attempted to group projectile points within McKern's (1939) Midwestern Taxonomic System and relate central Texas culture periods to those accepted in other regions of North America. Kelley established an Archaic stage "Edwards Plateau Aspect" and a post-Archaic "Central Texas Aspect" that he thought could be linked to historic Indian groups. Kelley's constructs served as a starting point for Suhm et al. (1954), who studied several large collections of lithic and ceramic artifacts and attempted to draw tentative trait lists for culture history divisions and subdivisions in Texas. On the basis of subsequent 
research, Suhm (1960) refined the Central Texas aspect, accepting that the Austin focus preceded the Toyah focus, and assigned a broad geographical area to the Edwards Plateau aspect in central Texas.

It was Suhm, who suggested defining temporal subdivisions for central Texas Archaic during the investigations at Canyon Reservoir (Johnson and Goode 1994:17; Johnson et al. 1962). The resulting scheme set out four periods for the Archaic: Early, Middle, Late, and Transitional, along with a listing of typical projectile points associated with each period (Johnson et al. 1962:121, Figure 45). Not all scholars have accepted the need for a Transitional Archaic, although the concept is used in the present study. Revisions to the Canyon Lake chronology began very soon, when Johnson (1964) dropped the Transitional Archaic period and pushed back the beginning of the Early Archaic based on dates from the Lower Pecos. However, other investigators, beginning with Sorrow et al. (1967: Figure 72), have attempted even further refinement of the Archaic culture sequence in central Texas, proposing as few as five chronological divisions (Weir 1976) to as many as 11 "phases" (Prewitt 1981 , 1985), along with specific statements of culture content.

Culture chronologies such as Prewitt's (1981, 1985) have been strongly criticized by some scholars on grounds there is presently not enough evidence in the archaeological record to warrant such detail (Black 1989c:24; Johnson 1987:12). Some also assert that central Texas is much too diverse environmentally to allow broad cultural constructs which retain regional validity (Ellis et al. 1995:421-422; McGraw 1985:319-321; Peter et al. 1982:21-1-21-5). However, because it is so often cited, Prewitt's $(1981,1985)$ scheme is often brought out for comparison (Black 1989a, 1989b; Story 1985).

South Texas has suffered comparative neglect. Although the region received equal treatment under the Southwest Texas heading in An Introductory Handbook of Texas Archeology (Suhm et al. 1954), six years later when Story (1960) refined the central Texas concept and others contributed review articles to the Bulletin of the Texas Archeological Society (BTAS) updating the Lower Pecos and Coastal regions, the South Texas Plains was ignored. Not until Hester (1968a, 1977, 1980) began concerted efforts in southern Texas was interest in the region revived. The Choke Canyon reservoir project (Hall et al. 1982, 1986), the Loma Sandia investigations (Taylor and Highley 1995), and numerous smaller projects have contributed considerably to our understanding of the region's prehistory (Black 1989a, 1995). Nevertheless, certain limitations in the nature of the archaeological record in south Texas continue to present difficulties for investigators. Some of these challenges include shallow sites with little or no stratigraphy, deflated open campsites denuded of diagnostic artifacts by generations of collectors, and linear streamside occupation zones with few overlapping components offering little opportunity to study culture sequences (Black 1989a; Hester 1995). The cultural chronologies developed by Hall et al. $(1982,1986)$ and Black (1989a) remain the most reliable for south Texas (Hester 1995).

\section{Prehistoric Chronology}

The following discussion follows the cultural chronologies set out in Collins (1995) for central Texas and Hester (1995) for south Texas.

\section{Paleoindian}

This period is generally agreed to span the interval between ca. 11,500-8800 B.P. in central Texas (Collins 1995:381-383) and between 11,200-7,950 in south Texas (Hester 1995:433-436), although a few claims for older sites are made (Alexander 1963, 1983). An early Paleoindian subperiod is recognized between 11,200 and 10,900 B.P., and a later division between 10,200 and 8800 B.P. The Paleoindian period began as the Pleistocene drew to a close. Diagnostic artifacts include Clovis and Folsom projectile points. Clovis points-the apparent tool of choice in the early phase-are large, lanceolate chipped stone points with fine, parallel flaking and concave bases. These points are 
ground on the base and lateral edges near the base, and have a characteristic "flute," a large flake scar removed from the base on each face, presumably to facilitate hafting (Turner and Hester 1993:90). Folsom points are somewhat smaller, thinner, and the fluting tends to run almost to the tip (Turner and Hester 1993:120). The distribution of Clovis points across most of North America and into Central and South America, and the variety of high-grade lithic raw materials used indicate that Clovis groups traveled and traded widely (Kelly 1993; Wenke 1990:201). Other artifacts associated with the Clovis culture include bifaces and prismatic blades, engraved stones, bone and ivory points, stone bolas, ochre, and shaft straighteners.

The Paleoindian adaptation has generally been considered to consist of small bands of nomadic, big-game hunters following herds of now-extinct Late Pleistocene fauna including mammoth, mastodons, giant bison, camel, and horse across North America (Black 1989c). More recently, emphasis has been on the great diversity of plants and animals exploited by these early Americans (Black 1989c; Hester 1983), such as turtles, tortoises, alligators, mice, badgers, and raccoons (Collins 1995:381), although the large animals were certainly hunted (Dibble and Lorraine 1968). The Clovis archaeological record includes kill sites, quarries, caches, open campsites, ritual sites, and burials (Collins 1995:381-383; Hester 1995:433-436).

Plainview, Angostura, Scottsbluff, and Golondrina points are characteristic of the later part of the Paleoindian period (Black 1989c; Hester 1978; Prewitt 1981; Turner and Hester 1993:52). These points have occasionally been associated with kill sites of extinct animals including mammoth (Hester 1977:3-4) and Bison antiquus, an extinct form of the modern bison (Dibble and Lorrain 1968; Johnson 1981; Johnson and Holliday 1980).

Most Paleoindian finds in central and south Texas have consisted of surface lithic scatters on upland terraces and ridges (Black 1989b:48, 1989c:25). A few Paleoindian sites deeply buried in alluvium have been discovered at the Berger Bluff Site (Brown
1987), the Kincaid Rockshelter (Collins et al. 1989), and at recent excavations of the Wilson-Leonard Site (Collins et al. 1993). Many Paleoindian projectile points have been recovered from surface contexts in Bexar and nearby counties (Chandler and Hindes 1993; Hester 1968a, 1968b; Howard 1974; Meltzer and Bever 1995). A late Paleoindian component has also been reported at the St. Mary's Hall site in Bexar County (Hester 1991:14-17, 1995:435).

As global climatic warming began to take effect in Texas, prehistoric inhabitants adapted with changes in lifestyle. The decline and extinction of mammoth, mastodon, horse, camel, and giant bison (Bison antiquus) demanded adjustments. Apparently after 8000 B.P., no large gregarious game animals remained in Texas; even the small modern bison (Bison bison) had virtually disappeared from the region (Dillehay 1974). Human hunters were forced to concentrate on deer, antelope, and other mediumsized or smaller game. Changes in the subsistence base required technological shifts that mark the beginning of a new cultural period known as the Archaic.

\section{Early Archaic}

Collins dates the Early Archaic from $8800-6000$ B.P. in central Texas, with three divisions based on projectile point types (Collins 1995:383). Based on changes in regional cultural patterns, Hester suggests that the cultural traits of the period may have persisted up to approximately 4450 B.P. in south Texas (Hester 1995:438).

The extinction of large herds of megafauna and the changing climate at the beginning of the Holocene forced cultural response by the Prehistoric inhabitants of South Texas (McKinney 1981). While a hunter-gatherer adaptation continued, a shift of emphasis away from big game herds was needed. In central Texas, more intensive exploitation of local resources such as deer, fish, and plant bulbs is indicated by the presence in archaeological deposits of more ground stone artifacts, cooking features of fire-cracked rock, and more specialized tools such as Clear Fork and Guadalupe bifaces (Turner and 
Hester 1993:246, 256). Weir (1976) speculates that Early Archaic groups were small and highly mobile, an inference from the fact that Early Archaic sites are thinly distributed and that diagnostic types are seen across a wide area, including most of Texas and northern Mexico. Story (1985) believes that population densities were low during this period, and that groups consisted of related individuals in small bands with "few constraints on their mobility" (Story 1985:39). Their economy was based on utilization of a wide range of resources, especially such resources as prickly pear and sotol as well as rodents, rabbits, and deer (Story 1985:38).

Early Archaic projectile point types found in south and central Texas are distinctively different from their predecessors. After the Angostura interval from 9000-8000 B.P. (Collins 1995), lanceolate styles disappear and stemmed types become common, although the types from the subsequent Early Split Stem interval-Gower, Wells, and Hoxie-are still basally ground (Turner and Hester 1993:52). The Martindale-Uvalde interval (7000-6000 B.P.) closes out the Early Archaic (Collins 1995). Sites near the study area with components from this period include 41BX47 (Tennis 1996; Tennis and Hard 1995), Richard Beene (Thoms et al. 1996), and several located on Camp Bullis in northern Bexar County (Gerstle et al. 1978) and at Choke Canyon (Hall et al. 1986).

\section{Middle Archaic}

Collins (1995:383) defines this intermediate interval of the Archaic as lasting from about 6000-4000 B.P. in central Texas. Hester refers to point styles in south Texas that suggest a Middle Archaic period from about $4450-2350$ B.P.

The Middle Archaic appears to have been a time of increased population, based on the large number of sites from this period in south and central Texas (Black 1989c:28; Story 1985:40). The reasons for this increase are not known, but the amelioration of a very dry period (Altithermal) during the Middle Holocene is often seen as the prime mover (Sollberger and Hester 1972:338; Story 1985:40).
Exploitation of widely scattered resources such as prickly pear continued on the South Texas Plains (Campbell and Campbell 1981:13-15), as did hunting deer and rabbit. However, there also seems to have been a shift to concentrated, seasonal nut harvests in the riverine environments of the Balcones Escarpment (Black 1989c). Weir (1976) believes that an expansion of oak on the Edwards Plateau and Balcones Escarpment led to intensive plant gathering and processing of acorns. He also believes that the widely scattered bands prevalent in the Early Archaic now began to coalesce, at least during the acorn-gathering season, into larger groups who shared the intensive work of gathering and processing the acorn harvest (Weir 1976:126). Several prominent researchers believe burned rock middens were formed during such activities (Creel 1986; Prewitt 1991; Weir 1976). Other investigators, however, doubt that burned rock middens are the results of acorn processing (Black et al. 1993; Goode 1991; Rector 1993). The exact processes which formed these features are still a matter of controversy (Black 1989c:28; Black et al. 1997; Bousman 1997).

The presence of deer remains in many burned rock middens supports the view that deer hunting was very much a part of the economic system reflected in many burned rock midden sites (Black and McGraw 1985:278; Weir 1976:125). Bison bone is occasionally encountered in archaeological sites in central and south Texas during all but the earliest part of the Middle Archaic (Dillehay 1974). There has been a tendency to equate presence of burned rock middens with absence of bison (Prewitt 1981); however, examinations of several recent faunal reports show that after about 4500 B.P., bison and burned rock middens are contemporaneous, though not at the same sites, at least in the southern Edwards Plateau and northern South Texas Plain (Meissner 1993).

Collins (1995:383-384), in part following Johnson and Goode (1994), defines three projectile point style intervals during the Middle Archaic: Bell-Andice-Calf Creek (ca. 6000-5000 B.P.), Taylor (ca. 5000-4000 B.P.), and Nolan-Travis (ca. $4500-4000$ B.P.). Under this chronological ordering, Bulverde points and the 
ubiquitous Pedernales point style are relegated to the Late Archaic, a circumstance still not comfortably accepted by some archaeologists. Potter and Black (1995:7), for example, write, "we would place the Bulverde point, a form that Johnson and Goode (1994) see as intrusive and early in the Late Archaic, in the later part of the Middle Archaic."

Sites in the vicinity of Lackland AFB with components from this period include Olmos Dam, 41BX1 (Lukowski 1988); Panther Springs Creek (Black and McGraw 1985); Quinta Medina (Guderjan et al. 1992, 1993); Scorpion Cave, 41ME8 (Highley et al. 1978); 41BX534 (McGraw and Hindes 1987:179); the Richard Beene Site, 41BX831 (Thoms 1992); and several sites on Camp Bullis, including 41BX36 (Gerstle et al. 1978), 41BX318 (Quigg 1988), and 41BX420 (Boyd et al. 1990).

\section{Late Archaic}

Collins (1995:384) dates this phase of the Archaic from ca. 4000 to 1200 or 1300 B.P. in central Texas. Following the Middle Archaic pattern identified by Hester (1995:438-440), the Late Archaic began in south Texas ca. 2350 B.P. and continued until ca. 1250 or 1350 B.P. For the purposes of this study, the Late Archaic is deemed to have ended ca. 2300 B.P. Archaic projectile points after that time are assigned to the Transitional Archaic. (See the following section.)

Some researchers believe populations increased throughout the Late Archaic (Prewitt 1985), while others assert that populations remained the same or fell during this period (Black 1989c:30). Prewitt (1981:80-81) holds that the formation of burned rock middens nearly ceased during this period, however excavations at the Blue Hole site (Mueggenborg 1994:1-74) in Uvalde County, the Honey Creek midden at 41MS32 (Black et al. 1997), and the Mingo site (Houk and Lohse 1993:193-248) in Bandera County provide evidence that large cooking features up to $15 \mathrm{~m}$ in diameter were still very much in use (see also Black et al. 1997). Subsistence is assumed to have become less focused on acorns, in favor of a broad-spectrum subsistence base (Black 1989b:30). By about 1450 B.P., bison had again disappeared (Dillehay 1974).

A proliferation of distinguishable human cemeteries has been attributed to this period, while the earliest occurrences date to the south Texas Middle Archaic (Hester 1995:439-440). At Loma Sandia (Taylor and Highley 1995), human burials occurred between ca. 2550 and 2750 B.P. Cemeteries such as the Ernest Witt (Hall 1981); Hitzfelder Cave, 41BX26 (Givens 1968); and Olmos Dam (Lukowski 1988) have been interpreted to mean that Late Archaic populations in central and south Texas were increasing, becoming more territorial and less mobile (Story 1985:44-45).

As noted above, Late Archaic time periods based on point styles begin with a Bulverde interval, followed by a Pedernales interval (Collins 1995) and intervals characterized by later types such as Marshall, Montell, Castroville, and Marcos, all of which are broad, fairly thin points with distinct barbs. Pedernales points, which are probably the most commonly found of all Middle and Late Archaic points, are extremely variable in morphology, while remaining quite consistent in size and stem shape (Turner and Hester 1993:171). Some Pedernales points have shoulders, while others are heavily barbed (Turner and Hester 1993:171-173). Castroville points have been associated with a bison jump kill site at Bonfire Shelter in the Lower Pecos region (Dibble and Lorraine 1968).

Inhabitants of the South Texas Plain near Brownsville and Rockport had begun to make pottery by about 1750 B.P. However, the northern part of the plain was still "pre-ceramic" until 1,000 years later (Story 1985:45-47).

The projectile points of the latter half of the Late Archaic-the Late Archaic II of Johnson and Goode (1994)-tend to be much smaller than earlier dart points. The most common are Ensor and Frio types (Turner and Hester 1993:114,122), both of which are short, triangular points with side notches. The Frio point also has a notched base (Turner and Hester 1993:122). 


\section{Transitional Archaic}

A late subperiod of the Late Archaic is frequently referred to as the Terminal or Transitional Archaic. Weir (1976) defines the Terminal Archaic as 1650-1150 B.P. Turner and Hester (1993) bracket the Transitional Archaic between 2250 and 1250 B.P., although they note that the period is essentially a continuation of the Late Archaic. They attribute point styles such as Darl, Ensor, Edgewood, Fairland, Figueroa, and Frio to the Transitional Archaic, and date the Marcos type from Late to Transitional Archaic. Johnson and Goode (1994) date their comparable Late Archaic II period from 2550-1350 B.P., beginning it with Marcos projectile points and including Darl, Ensor, Figueroa, and Frio points. For this study, the Transitional Archaic is dated 2300-1300 B.P.

Weir (1976) believes this period in central Texas marked a transition to small-scale sites, a disappearance of burned rock middens and bison, and a reappearance of highly mobile hunters and gatherers. Prewitt (1981:82) suggests the period-which he calls the Driftwood phase-was marked by an intensification of gathering subsistence with decreased reliance on hunting. Others (Black and McGraw 1985; Peter 1982; Skelton 1977) argue that in some locations burned rock middens did not disappear and sites were more intensely occupied during the Transitional Archaic period.

In south Texas, there is little support as yet for either a two-period Late Archaic or a separate Transitional Archaic. Hester (1995:442), however, cautions that more evidence may eventually result in dividing the Late Archaic period or definition of what may be termed a regional "terminal Archaic" period. This south Texas Terminal Archaic would be represented by such diagnostics as Ensor, Frio, Catán, and Matamoros points, which appear in both the Late Archaic and Late Prehistoric periods (Hester 1995; Turner and Hester 1993:89, 153).

\section{Late Prehistoric}

Collins (1995:385) recognizes that the commonly used date of 1200 B.P. for the end of the Archaic in central Texas is arbitrary. In south Texas, materials from Loma Sandia imply a slightly later onset for the Late Prehistoric with a range between ca. 1090 and 700 B.P. (Hester 1995:443). For this study, the date used for the beginning of the Late Prehistoric is 1300 B.P.

A series of distinctive traits marks the shift from the Archaic to the Late Prehistoric period, including the technological shift to the bow and arrow and the introduction of pottery to central Texas and the northern South Texas Plain (Black 1989c:32; Story 1985:45-47). Though attempts to divide the Archaic into phases have not been universally accepted (Black 1989c; Johnson 1987), there is a generally accepted division of the Late Prehistoric into Austin and Toyah phases (Black 1989c; Jelks 1962; Prewitt 1981, 1985). The Austin phase is dated roughly to $1150-650$ B.P., and is characterized by expanding stem arrow points, especially the Edwards and Scallorn types (Turner and Hester 1993). Though these two point types are often found together (Guderjan et al. 1993), Edwards is considered to be older (Hester 1971; Turner and Hester 1993).

It appears that the early Late Prehistoric period was a time of population decrease (Black 1989c:32). Though small burned rock middens associated with Scallorn and Edwards points have been found (Goode 1991:71), they are rare. Settlement shifts into rockshelters have been noted (Shafer 1977; Skinner 1981). Cemeteries from this period often reveal evidence of conflict (Black 1989c:32); for example, one burial at the Cottonwood Terrace site had a Scallom point embedded in the cervical spine (Benfer and Benfer 1965), and an excavation of a burial just north of San Antonio (41BX952) revealed an Edwards point between two lumbar vertebrae (Meissner 1991). Sites from the Austin phase include 41BX274 (McGraw and Hindes 1987); Quinta Medina (Guderjan et al. 1992,1993); and Panther Springs Creek, 41BX228 (Black and McGraw 1985). 
About 650 B.P., an abrupt shift in technology occurred. The Toyah phase is characterized by the introduction of blade technology, the first ceramics in central Texas (bone-tempered plainwares), the change to Perdiz arrow points, and alternately beveled bifaces (Black 1989c:32; Huebner 1991:346). Prewitt (1985) and Black (1989c) both hypothesize that the Toyah phase, like the Austin phase which preceded it, came out of north-central Texas and possibly from the southern Plains. Patterson (1988), however, argues that Perdiz points were first seen in southeast Texas about 1350 B.P., and were introduced to the west some $600-700$ years later. Hester $(1995: 444)$ recognizes the Toyah phase as the "best documented Late Prehistoric pattern" throughout south Texas, with dates ranging between ca. 650/700-300/350 B.P.

Steele and Assad (1986) argue for the occurrence of a distinct change in diet between the Late Archaic and the Late Prehistoric components in two sites in Choke Canyon Reservoir in south Texas. Analysis of the number of identified specimens (NISP) shows a marked increase in artiodactyl elements present during the late Late Prehistoric, an increase largely due to the addition of bison to the "menu" (Steele and Assad 1986:468). Huebner (1991) suggests that the sudden return of bison to south and central Texas resulted from a more xeric climate in the plains north of Texas, and increased grassiness in the Cross-Timbers and Post Oak Savannah in north central Texas, forming a "bison corridor" into the South Texas Plain along the eastern edge of the Edwards Plateau (Huebner 1991:354-355). Sites from this period frequently have associated bison (Black 1986; Black and McGraw 1985; Henderson 1978; Hulbert 1985; Prewitt 1974). Sites near Lackland AFB from the Toyah phase include Cueva Corbin, 41ME13 (Guderjan 1991); and Panther Springs Creek, 41BX228 (Black and McGraw 1985).

The only archaeological evidence that domesticated plants were ever introduced in south or central Texas is a single corncob found in Late Prehistoric context in Timmeron Rock Shelter (Harris 1985). This single cob is not enough to postulate there was ever a significant presence of maize in the area.
Only the arrival of the Spanish brought significant cultivars to south and central Texas.

\section{Historic Period}

This section describes historical research documenting the presence of certain populations in the Bexar County area, and summarizes the major archaeological research in the region. With the arrival of a significant number of Europeans during the seventeenth century, the indigenous populations of central and south Texas were forever changed. Some groups were forced to move northeast to escape the Spanish, and others southeast to avoid the Apaches who by then had obtained domestic horses introduced by the Europeans. Out of necessity, mixed ethnic groups moved throughout the two regions. Missionization and acculturation further disrupted native cultures, so that by the twentieth century only remnants of nomadic groups remained (Collins 1995:386). Specifically for south Texas, Hester (1995:449-450) prefers to consider the period immediately before significant Spanish colonial influence in the indigenous Late Prehistoric economy as Protohistoric, with no precise dates but probably ending in most areas by the mid-1700s.

The numerous small groups of Coahuiltecans encountered by the early explorers and later Spanish intrusions are addressed in several sources (Campbell 1983; Campbell and Campbell 1985; Hester 1989; John 1975; Newcomb 1961; Swanton 1952). The various later intrusive groups such as the Tonkawa, Lipan Apache, and Comanche also have been well documented (cf. Berlandier 1969[ca. 1840s]; Hester 1989; Jones 1969; Newcomb 1961; Sjoberg 1953).

Various scholars have discussed the establishment of missions in San Antonio (Campbell and Campbell 1985; Chipman 1992; de la Teja 1968; Habig 1968). Numerous archaeological excavations have been carried out at San Antonio mission sites since the first investigations at Mission San Antonio de Valero (the Alamo) in 1966 (Greer 1967). Later investigations at the Alamo and within the mission compound on Alamo Plaza have been reported by 
Sorrow (1972), Fox et al. (1976), Eaton (1980), Fox (1980, 1992), Hard (1994), and Meissner (1996). Extensive excavations also have been carried out at Mission San Juan Capistrano (Schuetz 1968, 1969) and Mission Concepción (Ivy and Fox 1982). Spanish ranching is described by Jackson (1986) and in a series of reports concerning five seasons of investigations at Rancho de las Cabras (41WN30), established in the mid-1700s as a livestock ranching operation of Mission San Francisco de la Espada on a high terrace overlooking the San Antonio River (Ivey 1983; Ivey and Fox 1981; Jones 1983; Taylor and Fox 1985; Valdez 1983). Excavations of Spanish sites in the downtown San Antonio area include San Fernando Cathedral, site of the original town church (Fox et al. 1977), where Colonial and Post-Colonial remains were found among earlier foundations; and the Spanish Governor's Palace (Fox 1977, 1997), where evidence was found of several construction episodes beginning with the building of the presidio in the early 1700s. Other investigations were conducted on property in the general area of the Villa de San Fernando de Béjar once owned by the Salinas family, including a house facing on main plaza (Fox et al. 1989). In the La Villita neighborhood, excavations at the Dolores Alderete property (Fox et al. 1978) cast light on the life of a military widow and investigations revealed the probable location of one of Santa Ana's cannon emplacements during the Battle of the Alamo (Labidie 1986). The political environment of the early government is addressed by Espey, Huston and Associates (1989). Archaeological testing on the Medina River gained the first look at an early 1800 s ranch headquarters (McGraw and Hindes 1987). The near-complete European desertion of San Antonio following the Mexican War for Independence is described by Fehrenbach (1968) and Garrett (1968). The repopulation of the area, including the establishment of ranches as far away as the Medina River, is discussed by McGraw and Hindes (1987) and de la Teja (1988).

Flanagan (1974) and Lehmann (1969) describe the emergence of sheep and cattle ranching in San Antonio and south Texas. Post-Civil War changes and the introduction of twentieth-century technologies, such as mills and improved methods of production, have shaped the metropolis as it exists today (Fox 1989; Webb 1952).

The first quarter of the twentieth century saw the expansion to the southwest of the military presence in San Antonio. The history of Lackland AFB as a training area and bombing range dates from the early 1920s and 1930s, with later developments during World War II. Establishing the Lackland AFB Training Annex was a result of the acquisition of property for the Air Force Special Weapons Program in 1954 (Dalbey 1993).

The cultural context for historic groups of the project area is largely conditioned by intrusions of outside ethnic groups and by regional power struggles. The following paragraphs describe the chronological ordering of events through the modern era.

\section{Overview of Historic Indians}

At the beginning of the seventeenth century, many south Texas Indian groups were being pushed northward by continual Spanish expansion. In the mid-seventeenth century, a new pressure on the indigenous Indian groups began to be felt from the north: the Apache. The Apaches practiced limited agriculture but changed to a more nomadic, Plainsstyle lifeway based on bison hunting once they acquired horses from the Spaniards (Campbell and Campbell 1981:345, 1985:27). The Apaches later were displaced by another group of horse-mounted bison hunters from the north, the Comanches (Campbell 1991:111).

A combination of disease, inter-group conflict, demoralization, and displacement repeatedly fragmented and commingled the native Indian groups (Bolton 1970[1915]; Campbell 1975, 1991:345; León et al. 1961). Fear of the invading Apache pressured many of the Indians to seek the protection of the missions (Campbell 1975:2, 1991:346-347), thus saving them from the Apache and the Comanche but exposing them to the exploitation of the Spanish. 
One such dislocated group, the Payaya, had apparently moved regularly between the Medina River and the general area of present-day San Antonio. In 1690 Father Massanet reported encountering six Indian groups on the Medina River where it flows west to east near the present boundary between Medina and Bexar counties, just west of the location of Lackland AFB (Campbell 1975:6). Included in Massanet's list were the Tilpayai (Payaya), Cauya, Semomam, Saracuam, Pulacuam, and Anxau. Reports from expeditions passing through the area in the next two decades indicate that the Payaya were continually present. The Terán de los Ríos expedition in 1691 noted the presence of the Payaya on the San Antonio River (Mazanet 1968:238). In 1693 Captain Gregorio Salinas Verona reported three Payaya camps southwest of present-day San Antonio, beyond the Medina River, in what would now be southeastern Medina County (Campbell 1975:7; Salinas Verona 1968:302-303). Apparently, by the time of the founding of San Antonio in 1718, the Payaya had moved to the coastal plain (Campbell and Campbell 1985:27), possibly because of Apache pressure, and some of them entered Mission San Antonio de Valero in that year. While many other groups were represented among the mission Indians, the Payaya appear to be the only ones who consistently camped in the San Antonio area.

Before the early 1800s, Apaches were observed ranging the area between San Antonio and Laredo, pushed southward by the invading Comanche who had entered the Hill Country of central Texas about the mid-eighteenth century (Campbell and Campbell 1985:27). By this time, a few Apache were beginning to seek asylum in the missions (McGraw and Hindes 1987:367; West 1904:50). The few Comanche who entered the missions apparently were women and children captured during punitive raids by Spanish soldiers (Campbell and Campbell $1985: 26$ ). In the autumn of 1785 , a peace treaty with the Comanches signaled the opening of a period of peaceful coexistence in which Comanches brought hides, meat, and tallow to San Antonio to trade for goods and services not available elsewhere, such as blacksmithing and gun repair (Poyo and Hinojosa 1991:125-126).

\section{Spanish Colonization: Missions and the Ranches}

In 1718 the Mission San Francisco Solano, along with a complement of soldiers, was transferred from the Rio Grande to San Pedro Creek just west of San Antonio Springs. The resulting settlement, the Mission San Antonio de Valero and the Presidio de Béxar, attracted Indians from northern Mexico, south Texas, and the San Antonio area. In 1720 the new Mission San José y San Miguel de Aguayo joined the chain of missions across the region.

In 1731 the settlement was greatly enlarged by the addition of three missions from the failed efforts to establish missions in east Texas, and the arrival of a group of settlers from the Canary Islands. The newly established missions gathered representatives of native Indian groups, many of whom had previously been recorded by the Spanish as ranging through south Texas and the areas to the southwest of San Antonio (Campbell and Campbell 1985). Thus in a short time, San Antonio became the largest and most important Spanish town on the Texas frontier and continued in that role for nearly 100 years.

The missions grew and prospered in their role of converting the Native Americans to Spanish ways and the Catholic religion until the 1770s, when the number of neophytes began to dwindle and the political influence of the missionary effort waned. Secularization of the missions began in the 1790 s and was virtually complete when Mexico gained independence from Spain in 1821 (Habig 1968).

The battle for Mexican independence was particularly hard on San Antonians, many of whom were directly involved in various intrigues and battles during the period between 1800 and 1821 . In 1813 , for instance, a revolutionary force recruited mainly in the United States invaded Texas and conquered San Antonio. Joined by local citizens sympathetic to their cause, they were devastatingly defeated south of the Medina River by a large army from Mexico. The ensuing barbarities of the victorious army caused a large part of the citizenry 
of San Antonio to retreat to Mexico or the southern United States, leaving the town nearly deserted.

Although by the early 1800 s pasture land as far from town as the Medina River began to be granted to local inhabitants (McGraw and Hindes 1987:380; Jackson 1986:623-624), few landowners dared to live on their outlying lands until about 1840 . At that time a treaty with the Apaches brought peace for a while (de la Teja 1988:167).

\section{European Settlement}

The property on which Lackland AFB is located today was divided in 1836 when the original Spanish land grants were brought under the administration of the newly formed government of the Republic of Texas. The land grants were large, each consisting of one league and one labor, a total of almost 5,000 acres. Most of the five or six new property owners were Mexican-Americans. The land appears to have remained undeveloped until 1870, when many landowners began selling their holdings to speculative investors. Part of their eagerness to sell may have been due to disillusionment with attempts to protect the properties from the continuing raids by local Indian groups, such as the Comanches, who had been displaced from their hunting territories by the continued encroachment of settlers.

\section{European and American Settlement in Western Bexar County}

In the 1840 s, settlers from Germany, AlsaceLorraine, and the United States began to flood into San Antonio. Many of the Germans moved into the Hill Country, settling communities such as New Braunfels and Fredericksburg. In 1844 group of Alsatians led by Henri Castro began a settlement at Castroville, on the Medina River just west of the Lackland AFB area. This was the westernmost settlement in Texas at that time (Webb 1952:168). On their first night out of San Antonio, the group camped on Medio Creek (Finger 1983:3-4), possibly in the vicinity of Lackland AFB. By 1850 Castroville had 76 families with 335 individuals
(Noonan 1976) and, by 1876, 5,630 Germans and Alsatians were among the inhabitants of San Antonio (Fehrenbach 1978:117). British-American settlers purchased or otherwise obtained title to the original land grants in northern Atascosa County (Webb 1952 Vol.I:75) and on the Medina River. Some of the settlers set up small plantation-type operations utilizing slave labor (McGraw and Hindes 1987:381).

By the 1900 s these land holdings had been reduced to even smaller parcels of 300-400 acres owned by European-American settlers such as Belgians; many of their descendants retain land in the area today. The lands were used primarily for small-scale farming and some cattle grazing (Nesmith 1982).

\section{The Military}

With the death of the Confederacy after the Civil War, the United States military returned to San Antonio, and again the city became a major headquarters, heading a chain of forts on the Indian frontier stretching to the Rio Grande at Laredo. The military presence stimulated trade and economic enterprises, a role the U.S. military continues today in San Antonio.

As the United States entered World War I, the city of San Antonio was recognized as an ideal place to train troops for deployment to the battlefields of Europe. The government initiated the construction of training facilities for over 60,000 troops. Among the facilities selected were three tracts of land to the west of San Antonio near the Laredo Highway, designated Kelly Field, and used as the primary flight training area. With the entry of the United States into World War II, the need for a facility to process and train aviation cadets for entry into flight training was soon recognized. In 1942 a section of Kelly Field was designated the San Antonio Aviation Cadet Center. This facility was transferred to the U. S. Army Air Force Personnel Distribution command on June 30, 1945, when it was renamed the San Antonio District, Army Air Force Personnel Distribution Command. In February of the following year, the installation was returned to Air 
Training Command and designated the Army Air Force Training Center. In 1946 the facility became the Indoctrination Division, Air Training Command, thus becoming the entry point for all basic trainees into the Air Force. On July 11, 1947, the facility was named Lackland Air Base. Six months later it was renamed Lackland Air Force Base and became the primary site for both officer and enlisted personnel training.

In 1954 and 1955, land was procured for the Lackland Training Annex, referred to as Medina Base. The annex has been the site of various training and storage activities throughout its history. During the Cold War that followed World War II, an extensive, camouflaged installation was constructed to serve as storage and assembly facilities for atomic weapons. This area is now used for storing conventional weapons. 


\section{Chapter 6: Methodology}

The primary objective of the Lackland project was to conduct a 100-percent-pedestrian survey of approximately 3,860 acres, much of it undeveloped. CAR's investigation included pre-fieldwork, site discovery during the pedestrian survey, then revisiting and recording sites. The pedestrian survey was carried out between November 1994 and April 1995. Site locations recorded during the survey were revisited through July 1995. Survey and site recording crews ranged from two to 11 members.

\section{Pre-fieldwork}

CAR staff conducted an intensive literature search to determine the extent of previous archaeological work in the survey area and in the region. Most of this information was obtained from CAR files and from the Texas Archaeological Research Laboratory (TARL) at The University of Texas at Austin. Maps, photographs, and archival documents were obtained from files at Lackland. Of particular interest was information on ranch houses as well as the ethnohistoric literature on Native American, Spanish, Mexican, and Euro-American populations known to have inhabited the area. Data concerning the settlement patterns, site types, roads and trails, water sources, and land usage during the Historic period were obtained from archaeological reports and published personal accounts.

Previously reported sites in the vicinity were used as a gauge for anticipating site type and density in the project area. Current literature on the cultural chronology and paleoenvironment of the region was reviewed to help develop a basic framework for predicting the density, character, and distribution of cultural and natural phenomena within the project area. In preparation for the survey, the principal investigator and project archaeologist briefed CAR field staff about expected site and artifact types and organized a visit for field crew members to examine examples of artifacts and materials in situ.

\section{Fieldwork}

\section{Pedestrian Survey}

For the survey, Lackland was subdivided into two broad, ecologically determined areas: uplands and drainages. Definition of each area was based on vegetation, landforms, soils, and current use. The two major areas are summarized in Table 6-1.

Table 6-1. Lackland Air Force Base Pedestrian Survey Areas

\begin{tabular}{||c|c|c|c|c||}
\hline Area & Acreage & Vegetation & Landforms & $\begin{array}{c}\text { Surface } \\
\text { Visibility }\end{array}$ \\
\hline upland & 2,590 & shrub & upland hills and flats & $0-40 \%$ \\
\hline creek & 1,270 & $\begin{array}{c}\text { dense } \\
\text { shrub }\end{array}$ & $\begin{array}{c}\text { floodplain, alluvial terraces, and areas within } \\
100 \text { m of floodplain }\end{array}$ & $0-20 \%$ \\
\hline
\end{tabular}


Extensive portions of Lackland were excluded from archaeological investigations because of development. Excluded areas on the Main Base were the developed and highly disturbed areas outside the Leon Creek floodplain and terrace system where extensive construction had occurred (NPS 1993). A large area of the Medina Annex containing weapons storage bunkers, sensitive communications installations, and other highly disturbed areas was likewise excluded.

The upland zone is about 67.1 percent of the total project area. Soils in the upland areas are predominantly Houston Black gravelly clay vertisols which experience substantial cracking and allow vertical displacement of artifacts. Sediment deposition is unlikely in these higher elevations, suggesting that buried and intact archaeological deposits are also unlikely. Surface visibility is low due to dense vegetation. Within the uplands are two tracts dedicated to specific military use: combat arms training and Wherry Housing.

The combat arms area in the southwestern part of Medina Annex (Figure 6-1) was surveyed separately because of the need to provide early archaeological clearance for planned construction. This area generally consists of uplands, except along the western edge where intermittent drainages descend into the floodplain of Long Hollow. The vegetation is typical of that previously for upland and creek zones (Appendix C).

The Wherry Housing area on the main base (Figure 6-2) was also surveyed separately to accommodate development priorities. This area generally consists of uplands formed on Pliocene or early Pleistocene alluvial terraces with an intermittent drainage crosscutting from north to south and eventually descending into Leon Creek. Much of the area is cleared and developed, but remaining natural vegetation is typical of an upland zone (Appendix D).

The creek zone is about 32.9 percent of the total project area. The creek areas encompass the floodplains and alluvial terraces associated with approximately $18 \mathrm{~km}$ of Leon and Medio creeks and with the Long Hollow intermittent drainage. Sizes of the adjacent terrace systems vary according to shifts in elevation. The terraces generally have a high tree canopy, heavy leaf litter, and poor surface visibility. Lower shrubs and moderately dense grasses make up the understory. Site preservation is normally good in this zone.

CAR crews conducted the pedestrian survey in transects. The project archaeologist or crew chief established manageable survey parcels by using natural and artificial boundaries such as the major drainages, firebreaks, roads, or fence lines. Then the project archaeologist or crew chief calculated transect degree headings using a hand-held compass. Each transect end point was marked with flagging tape. Survey area, transect letter, orientation, and date were noted on each strand of tape by the survey team. Transect spacing was based on the location of the survey parcel. In upland areas transects were spaced at $30-\mathrm{m}$ intervals, while $15-\mathrm{m}$ intervals were used in creek areas.

Two-member teams worked seven days a week during the pedestrian survey phase, depending on weather and access to restricted areas of the base. Extremely dense vegetation required that the two crew members maintain close contact for both safety and accuracy. This involved one surveyor (the compass reader) using a hand-held compass to orient the other member (the front runner) along the designated bearing. Often, orientation along the transect depended entirely on sound, with the front runner calling out and the compass reader responding with corrections. Only in floodplains, with less dense vegetation and unhampered visibility, could shorter length transects be walked by one person alone. Field notes were made regarding vegetation type and density, topography, geology, paleontology, and naturally or artificially disturbed areas.

On some occasions, when the parcel of land requiring survey was a narrow band or small and irregular in shape, such as the base golf course, a sweep survey was conducted. In these cases, crew members were evenly spaced in a line at the designated starting point and then systematically moved through the survey area, all the while maintaining a constant lateral formation. 


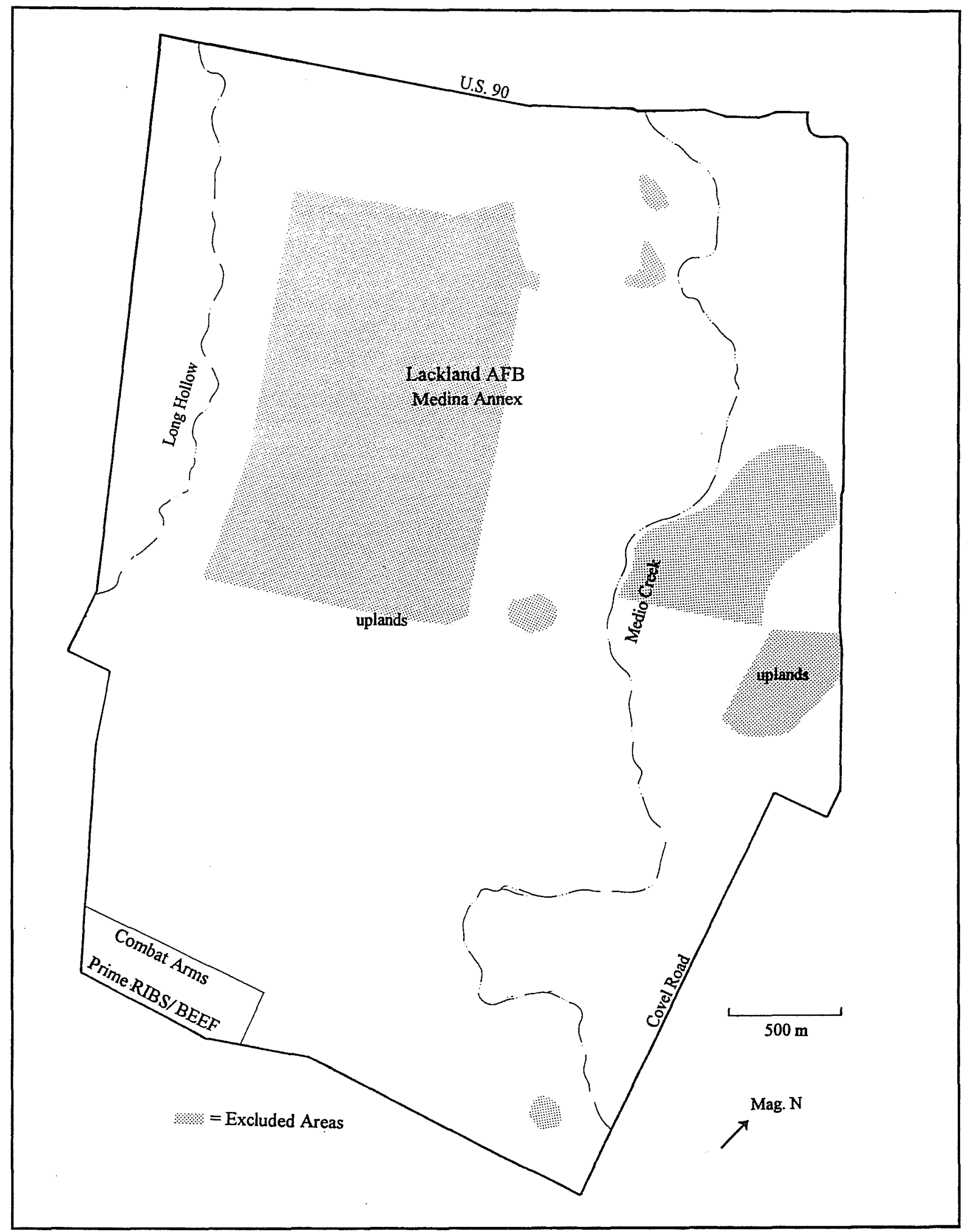

Figure 6-1. Lackland AFB, Medina Annex 


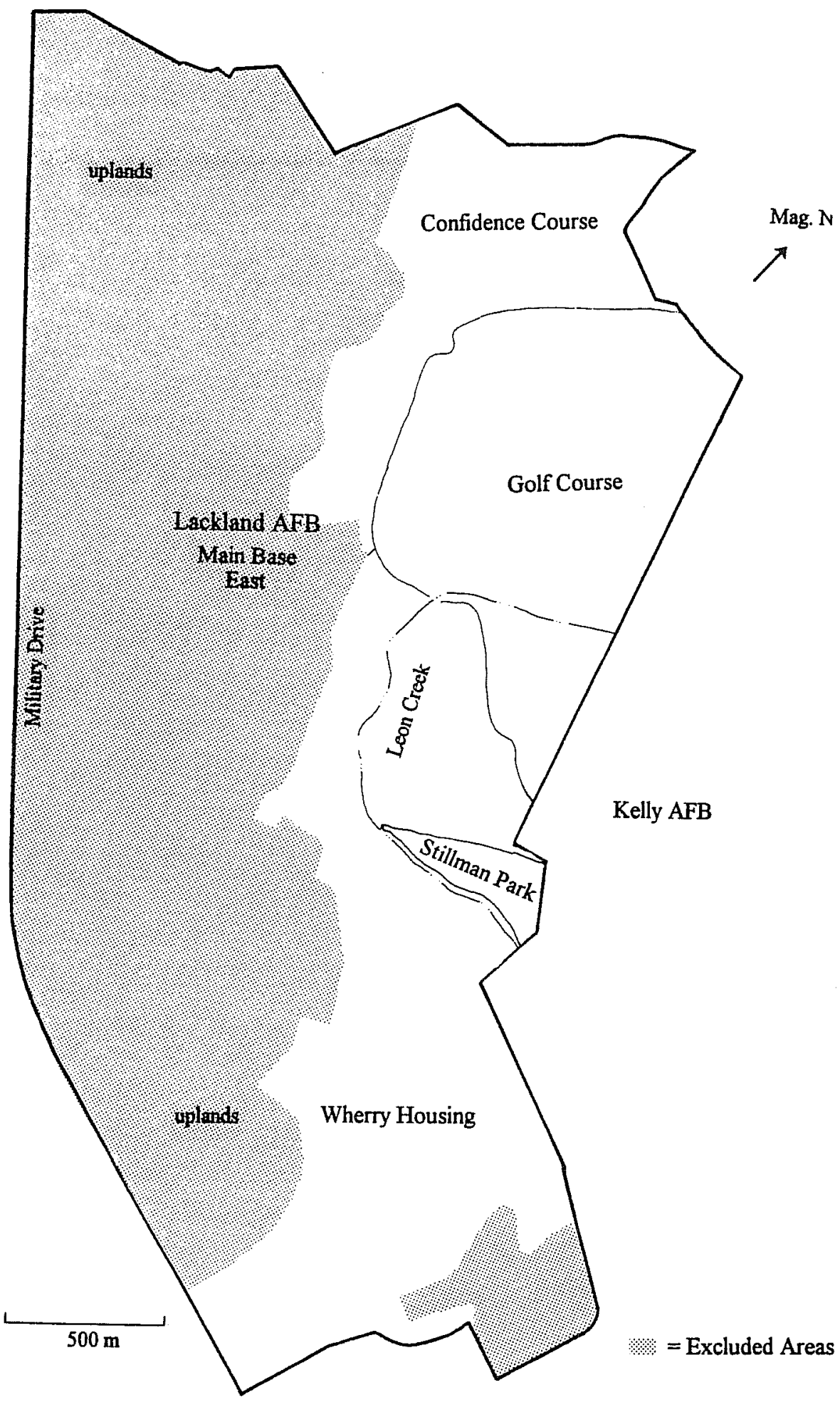

Figure 6-2. Lackland AFB, Main Base. 
Whether in a creek or uplands zone, stations along transects were spaced at 30-m intervals. Each station was marked with white biodegradable flags. This helped maintain even spacing between transects and stations, and later proved quite useful in relocating sites. In creek zones, where site potential is highest, heavy to moderate stands of hackberry trees produced dense leaf litter which made it difficult to locate sites. At each station where the ground surface was obscured, leaf litter was quickly removed from a square-meter area. If artifacts were revealed, more ground surface was cleared. This method proved quite effective for discovering archaeological sites that were otherwise invisible.

Artifact-bearing locations were marked with flagging tape, noting transect, station, and date. Each site was intensively surveyed, artifacts were flagged, and a preliminary assessment of quantity and type of artifacts present was made. A quick field observation often was adequate to determine if enough artifacts were present to constitute a site.

\section{Definition of Archaeological Occurrences}

Management categories for cultural manifestations were systematically defined. Categories include large sites, small sites, and isolated finds (Table 6-2). Large sites have 20 artifacts or more within a $25 \mathrm{~m}^{2}$ area, and/or are $100 \mathrm{~m}^{2}$ or larger, and/or contain two or more cultural features. Small sites have 5-19 artifacts within a $25 \mathrm{~m}^{2}$ area, and/or are less than $100 \mathrm{~m}^{2}$, and/or contain a single cultural feature. Isolated find designations were given to locations of fewer than 5 artifacts and no cultural features.
Sites are defined as open campsites, lithic quarries, or burned rock middens. Open campsites often contain varying quantities of fire-cracked rock from small hearth-like features and a lithic scatter, suggesting an occupational episode. Lithic quarries are those characterized by the presence of chert gravel exposures. Exploitation of the exposure is indicated by light to heavy scatters of chipped stone debris, including artifacts such as cores, quarry blanks, preforms, flakes, and (rarely) informal or formal tools. Definitions for these artifact classes are given below. Burned rock middens are concentrations or mounds of angular, fire-cracked rock (usually limestone in central Texas).

Isolated finds were recorded on separate forms by noting location, size, the percentage of cortex, and number of flake scars for chipped stone artifacts. The formal documentation of isolated finds was completed during the site discovery phase; these areas were not revisited during the site-recording phase. At the conclusion of the site-discovery phase of the fieldwork, CAR survey teams had noted approximately 259 locations with sufficient artifact density to be labeled as potential sites. Revisiting these locations for detailed inspection formed the second phase of fieldwork.

\section{Revisiting and Documenting Sites}

The project archaeologist or a crew chief and three to six members made up a site-documenting team. Once a potential site was relocated, the ground surface was intensively examined, artifacts were flagged, and high-density concentrations were noted. After the

Table 6-2. Size Definitions for Archaeological Occurrences.

\begin{tabular}{|c|c|c|c|}
\hline $\begin{array}{c}\text { Occurrence } \\
\text { Size }\end{array}$ & $\begin{array}{c}\text { Artifact Density/ } \\
\mathbf{2 5} \mathbf{~ m}^{\mathbf{2}}\end{array}$ & Area & Features Present \\
\hline Large & $20+$ & $>100 \mathrm{~m}^{2}$ & $2+$ \\
\hline Small & $5-19$ & $<100 \mathrm{~m}^{2}$ & 1 \\
\hline Isolate & $0-4$ & $<100 \mathrm{~m}^{2}$ & \\
\hline
\end{tabular}


location was confirmed as a site, boundaries were established according to observed patterns of artifact density. Examples of the forms used in documenting the sites are included in Appendix F. Site documentation included the following:

1) A field copy of the State of Texas Archeological Site Data Form was started by the project archaeologist. Each site was assigned a temporary field number until given a trinomial site designation in the lab. Trinomials were obtained from TARL.

2) At least one shovel test was conducted at each site to test for subsurface cultural materials. The crew chief or project archaeologist determined the number of shovel tests, taking into consideration site size, artifact frequency, and topographical variation. When the potential for in situ buried remains looked promising, additional shovel tests were excavated. Shovel tests were numbered sequentially by site (e.g. ST 39-1 is the first shovel test at Lackland site number 39). Levels were excavated in arbitrary $10-\mathrm{cm}$ increments to a depth of at least $30 \mathrm{~cm}$, where gravel was usually evident at upland sites, and at least $60 \mathrm{~cm}$ at sites on alluvial terraces. Excavation of shovel tests below $60 \mathrm{~cm}$ in the floodplain was extremely difficult due to the firmness of the clayey deposits. All sediment was screened through $1 / 4$-inch wire mesh. Additional levels were excavated if artifacts were encountered throughout the deposit and the potential for subsurface cultural materials was deemed high.

Notes were made concerning sediment characteristics, including texture, consistency, structure, and color (using a Munsell color chart); gravel sizes and frequency; and artifact content. Artifacts removed from subsurface contexts were bagged and logged. Features were rarely encountered, but when they were present, sediment samples were collected. Special samples, such as faunal and charred plant remains, were bagged and logged on a separate form.

3) Site recording crews used one of two methods to sample the artifact assemblage at each site. If the site was small and artifact density low, a 100-percent inventory was taken. On larger or denser sites, artifacts from one or more circular dogleash sample unit areas were inventoried. All sample units used a five-meter radius area placed over high artifact densities. Sample units were sequentially numbered at each site and by temporary site field numbers (e.g. DL 5-2 is the second dogleash recorded at Lackland site number 5).

Within an inventory area, each artifact was measured and recorded. (Artifact types used in recording assemblages are defined in the following chapter.) Counts of fire-cracked rock, tested cobbles, raw limestone, and raw chert cobbles were also made. Temporally diagnostic artifacts, finished formal tools, thin bifaces or biface fragments, and unusual or unique items were collected and logged wherever found. Samples of ceramic, brick, glass, and metal items were collected to assist in assigning an occupation age estimate to historic sites.

4) To establish the site datum, a metal rebar stake was hammered into the ground at the site's center or at the best vantage point. An aluminum tag was affixed to the datum with "CAR," the date, permanent trinomial site number, and Universal Transverse Mercator (UTM) coordinates. USGS 7.5' topographic maps and a Trimble Scoutmaster Global Positioning System (GPS) were used to determine UTM coordinates.

5) Graph paper of varying scales (most frequently $1 \mathrm{~cm}=5 \mathrm{~m}$ ) was used for site maps. Site boundaries, datum locations, shovel tests, dogleashes, collected items, features, areas of high artifact density, directions to visible landmarks, and 
landscape features were recorded. Sites were mapped by pacing off distances or by using a 50-m tape. Where pacing was not possible because of the dense brush, CAR surveyors crawled over the site surface or estimated distance to map points.

6) At least two black-and-white prints and two color slides were taken and logged to document the setting of each site.

\section{Historic Methodology}

\section{Archival: Predictive Methods}

This section discusses the archival sources consulted to predict the character, location, and distribution of historic sites. These sources were used to augment the information on file at Lackland AFB concerning known historic European-American homesteads. Historic maps were used to provide information pertinent to site location or size. Among the archival resources sought at the Lackland AFB Property Department were documents pertaining to the acquisition of the base lands by the Department of Defense. Included among those documents were appraisals of the properties, deed transfers, and photographs of the structures on the original properties. Other sources were used for background data on such as farm, ranch, or multi-activity sites. Tobin Survey, of San Antonio, was consulted regarding the availability of historic photographs of Lackland AFB.

Original land grants were examined at the Texas General Land Office to determine how the land was first divided. Information pertaining to the original and subsequent owners also was obtained from documents kept on file at the base property office and from Bexar County Deed Records at the District Clerk's Office, San Antonio, Texas, where marriage records, wills, and probate records also were studied. Deed records were also a source of information on property modifications and railroad land acquisitions.
Oral interviews were conducted with families or descendants of the landowners noted in the deed records to augment the archival data and help determine ethnicity, gender, and ages of owners. Such information, along with data from newspapers and from microfilm documents at the Barker Center at The University of Texas at Austin and from Special Collections at the John Peace Library at The University of Texas at San Antonio provided links to important events or persons and broadened the historic context.

\section{Surface and Subsurface: Predictive Methods}

Potter et al. (1994:100) state that "archeology and geomorphology, if pursued in an integrated way, can have a strong symbiotic relationship." For the Lackland AFB project, the research problems centered on historic homesteads extended this relationship to biotic communities. To the extend feasible, given project scope and budget limitations, an essential component of the field survey and testing was a historic landscape settlement study.

\section{Survey Procedures}

Four methodological procedures were used during the historic site survey:

1) Natural and cultural processes that may have compromised the integrity of the landscape, such as grading, construction, flooding, alteration of hydrology, erosion, and accelerated land degradation from years of stock raising and farming, were noted on the Lackland maps.

2) The second procedure was to map the spatial relationships of biotic communities, soils, and topography to cultural materials. Boundaries and densities were noted on the site maps. Existing soil survey maps, contour maps, and aerial photographs provided baseline data which were verified during the field survey. 
3) Profiles were recorded from selected shovel tests and all 1-x-1-m test units. Soil descriptions included Munsell colors.

4) Soil and botanical samples were taken when appropriate. A reference collection for botanical species is available at UTSA and identifications were made by Dr. Oscar Van Auken. Soil samples were analyzed with the assistance of the project geomorphologist.

The following indices could be noted in surface and/or subsurface patterns, suggesting land use, spatial arrangement of settlements, and/or economic activities:

1) Former ditches, pits, or other features related to farming or ranching leave irregular features which may be visible on the surface. The in-filling of these features often creates complexly stratified lenses which denote specific land-use activities (Butzer 1990:149).

2) Plowing would show up in disturbed profiles, and as Butzer notes "particularly in abandoned farmlands" (1990:133). Careful observation of profiled test units and selected shovel tests could provide sensitive records of the individual effects of human impact on the landscape.

3) Historic trails or roads could be detected by rock alignments or "depressed linear features" (Butzer 1990:151). Vegetation patterns would also be affected by these features.

4) The location of ancient springs may be indicated on the surface by the presence of differing biotic communities. A visual survey would allow predictions to be made regarding the location of human settlement or economic activities based on these water sources.
The above indices were not intended to be a complete discussion of all features which might be related to human settlement or economic activities in the project area during the Historic period. However, they were intended to provide a baseline for the immediate research design objectives. 


\section{Part II: Prehistoric Sites}

\section{Chapter 7. Theoretical Background and Research Design for Prehistoric Sites}

\section{Introduction}

This chapter considers several general themes, some of which were addressed during the study. Others are research issues that could be addressed by future investigations at Lackland Air Force Base. These topics are 1) subsistence and seasonality in prehistoric sites; 2) the forager/collector continuum in hunter-gatherer subsistence strategies; 3) the relationships among archaeological regions in prehistory; 4) the processes that affect site formation in both prehistoric and historic sites; and 5) the role of the Lackland area in the cultural history of Texas.

Identifying and addressing these research themes during the survey provides a framework within which the significance of the cultural resources and data from the project can be evaluated. Extensive surveys such as this produce site data that address uses of the landscape in terms of settlement patterns, mobility systems, and economic systems. The significance of data can best be evaluated within a conceptual framework centered on patterns and systems.

\section{Geographic Limits of Proposed Research Issues}

In this report, geographic regions follow those defined in the archaeological and bioarchaeological overview of south Texas prepared for the U.S. Army Corps of Engineers (Hester et al. 1989). The study areas are located within the South Texas Plains subregion (Hester et al. 1989). This region encompasses the area south of the Edwards Plateau from the Rio Grande to the Gulf of Mexico and consists of 22.5 million acres crossed by several major rivers (Hester 1980).

The South Texas Plains region has been subdivided into five biogeographical areas: Rio Grande Plain, Rio Grande Delta, Nueces-Guadalupe Plain, Sand Sheet, and Coastal Bend (Black 1989b). The project area is located within the Nueces-Guadalupe subarea, described by Black (1989b) as bands of differing vegetation zones, including oak-hickory forests, rolling prairies, and bush savannahs, transected by riverine environments along southeastward flowing rivers.

\section{Time Periods}

The archaeological record of the South Texas Plains attests to thousands of years of prehistoric occupation (Black 1989a). Data presented in the Cultural History section of this report (Chapter 5) indicate that areas along creeks and rivers, such as Medio and Leon creeks within Lackland AFB, were repeatedly used by native inhabitants from the Paleoindian period until the time of Spanish contact. Therefore, sites from any or all these time periods could potentially be encountered in the study area. 


\section{Research Issues}

\section{Subsistence and Seasonality in Prehistoric Sites}

The earliest evidence of human occupation in the part of the South Texas Plains occupied by the study area reflects the highly mobile "big game hunter" adaptation associated with the Clovis and Folsom cultures across all North America (Hester 1989; Shafer 1986). Around 10,000 B.P., the climate in Texas became warmer and drier and the "big game" became less plentiful. People along the Balcones Escarpment began to explore new adaptive strategies which centered on the exploitation of small game and natural plant resources present in these two regions. The flexibility and mobility of this hunting and gathering way of life enabled the people of these two regions to adapt successfully without major changes to the continuing drying trend that occurred over the next 5,000-6,000 years.

The paleoenvironment in the South Texas Plains, discussed in Chapter 2, is also characterized by a gradually increasing aridity broken by several mesic interludes. Hester (1977) has described the postPleistocene environment as similar to that present today, with savannah-like vegetation and some trees on the uplands, and prairie grasses and wooded areas along streams and rivers. The invasion of thorny brush, especially mesquite, occurred only in the last $300-400$ years (Hester 1977). The presentday modified sub-tropical climate is characterized by mild winters and hot summers. Rainfall averages $70.8 \mathrm{~cm}$ and is fairly evenly distributed throughout the year (Taylor et al 1991:118).

Seasonal land-use patterns for the part of the South Texas Plains area that includes Lackland AFB comes primarily from ethnohistoric data found in the chronicles of Cabeza de Vaca and later Spanish travelers (e.g., Campbell 1975; Campbell and Campbell 1981; Weddle 1968). According to Cabeza de Vaca, during the several years he lived among the Native Americans in south Texas, the fall and winter months were spent along the rivers, where pecans and wild roots were harvested and game was hunted. In the summer months, the Indians left the rivers and harvested prickly pear tuna. According to Campbell and Campbell (1981), these two seasonal subsistence ranges encompassed a possible annual mobility range of $290 \mathrm{~km}$, from the lower Guadalupe River just southeast of Bexar County to areas much farther south. Campbell (1975) also reports on a group of Native Americans visited by Spaniards during the seventeenth and eighteenth century. This group, the Payaya, was observed along the San Antonio and Medina rivers during the spring and summer months. One visitor reported an April encounter along the Medina River, where he noted that pecans were collected and stored in subterranean pits.

Based on archaeological data from an investigation in north Bexar County, a seasonal exploitation model encompassing portions of south-central Texas has been proposed (Potter et al. 1995). The model posits a pattern of fall and spring utilization of the chert-rich oak-juniper woodlands to the north of Bexar County, where deer, turkey, and walnut were exploited in the fall and sotol and yucca were collected in the spring. Prickly pear fruit and small mammals would have been exploited during summer rounds in the savannahs to the south of Bexar County. Lackland AFB lies at the northernmost edge of the mesquite-chaparral savannah, very near the edge of the Balcones Escarpment. This area is seen as a prehistoric fall/winter/spring source for pecans, bison, antelope, fish, shellfish, and small mammals. Results from the proposed testing phase of investigations at Lackland AFB could supply important data to further develop this use model.

\section{The Forager/Collector Continuum}

Beyond the usefulness of the data derived from the current project in making cultural resources management decisions, the data may also play an important part in developing or refining regionalscale models of hunter-gatherer subsistence and settlement/mobility systems. Although numerous problem-oriented archaeological investigations employing state-of-the-art methodology and addressing more general hunter-gatherer issues have 
been conducted in south Texas, not much theoretical framework for examining the issues of subsistence and settlement systems has been formulated for the area. Most of the earlier investigations have attempted only to address chronological and culture historical issues.

Since the 1960s, hunter-gatherer behavior has been interpreted in terms of cultural ecology rather than through use of strictly unilinear models to explain long-term equilibrium in cultural systems. Binford (1980, 1983) used ethnographic observations to make inferences about patterns of subsistence and mobility as they relate to ecological characteristics of an area in order to better interpret the archaeological record.

Hunter-gatherer groups organize their economic and settlement systems based on the ecological characteristics of their environment. Binford (1980) described their adaptive strategies as a continuum between "foraging" and "collecting" adaptations, based on the group resource-procurement behavioral patterns. Such an approach provides a basis for developing models of subsistence and mobility patterns for the project area.

Foragers acquire their resources by moving the people or group to the resources, which is accomplished through a residential mobility pattern defined as the movement of all members of a group from one camp location to another location as foods near a specific camp are depleted. Such groups do not usually store resources, but instead gather food on a daily basis. A forager strategy is usually employed in environments in which the resource structure is rather homogenous, both spatially and temporally. Some of the characteristics of a forager system are that it employs residential mobility; is generally highly mobile; does not use bulk storage or processing; increases variation in group size; produces two types of sites-residential base and locations; does not intensively reuse specific loci; and produces site assemblages with little diversity and small size (Binford 1980; Kelly 1983).

Collectors, on the other hand, employ a strategy of using small task groups to bring the resources to the group through a logistical mobility pattern defined as movements of individuals or a small team from a residential camp for a task-specific purpose. A collector strategy is usually employed in environments that are heterogenous in resource structure. This system uses storage to overcome the incongruences in the spatial and temporal distribution of resources. The characteristics of a collector system are that it employs logistical mobility; uses low residential mobility; uses bulk storage and processing; reduces variation in group size; produces several types of sites, including residential, location, field camp, station, and cache; reuses specific loci; and produces site assemblages with greater diversity and size (Binford 1980; Kelly 1983).

It is important to note that groups are not organized as "pure" foragers or "pure" collectors, but rather used a mix of both strategies which varied with the ecological setting (Kelly 1983). The adaptive strategy employed by any particular group lies on a continuum between the pure forms of these two strategies.

\section{Interregional Relationships}

Potter et al. (1995) propose that the transitional zone between the Edwards Plateau and the South Texas Plain had characteristics of both the wet/dry seasonality of tropical zones, and the seasonal resource pattern typical of colder climates as seen in the nut-producing tree species of the Edwards Plateau. Therefore, a "bipolar mobility model" (Potter et al. 1995) is offered in which a foraging system is used on the South Texas Plains during the summer season and a collector system is employed in the fall/winter/spring season in the transitional zone in northern Bexar County. Thus what is referred to as "dualistic" economic behavior shifts along the forager-collector continuum as an adaptive response to the seasonal change in the resource structure in the two biotic exploitation zones.

In the suggested bimodal mobility model, the location and primary biomass of the Lackland area indicate the region would have been exploited principally by foraging during the summer. If a 
foraging system was employed and summer resources were exploited, then certain site attributes and distribution could be expected. A foraging system exploiting summer resources should have few burned rock middens, as only a limited number of resources (sotol and lechuguilla) would require such processing. Nuts, especially acorns, which require processing or cooking would not be exploited as a summer resource in this area; consequently the use of middens should be much less than in the collector component of mobility systems used in the fall/winter season on the Edwards Plateau. With the exception of sites near water sources, campsites and lithic processing stations should be spread homogeneously over the landscape relative to the resources. Only ephemeral occupations and faintly defined characteristics or boundaries should be present, with little palimpsest effect, indicating shorter occupation periods and higher mobility. Caches or storage features would probably be rare.

Sites and tool assemblages should be limited in diversity, as would be expected in a forager system. The tool assemblages should be expedient in nature, with few formal tools. The assemblage technology should be adapted primarily to the exploitation of plant resources and small game on an opportunistic basis.

The current survey was designed to provide settlement and site data to test and evaluate the expectations of the bimodal mobility-settlement model. Such a model provides a conceptual framework to analyze and give meaning to the data from the project.

\section{Site Formation Processes}

The collaboration of archaeologists and geomorphologists is one which increases the information available to both disciplines (Potter et al. 1995). The Lackland study promises to advance understanding of the changing landscape of the project area and to elucidate the processes by which prehistoric and historic archaeological sites are preserved.
Archaeological sites are places where changes in the structure of the ground are the result of a combination of human and natural processes (Black and McGraw 1985:51; Waters 1992:11). Unraveling the cultural and non-cultural processes that form sites is a fundamental part of archaeological analysis. Although understanding the culture which left the artifacts and features behind is the main focus of archaeology, understanding the other factors which go into site formation helps to sharpen that focus (Waters 1992:163). It is important to understand "the physical, chemical and biological factors responsible for the burial, alteration and destruction of the systemic context at a site" (Waters 1992:11).

When humans abandon a place, they usually leave behind their material goods. These artifacts and features are then changed in various ways. Perishable things rot, and non-perishable objects are weathered to a greater or lesser extent. Before burial, artifacts are prone to disturbance from a wide range of processes, from sheet erosion, to being stepped on or kicked by animals and humans. Artifacts may eventually become buried, but even when buried they are often moved around by various forces. In cold climates, frost heaving is a problem (Butzer 1982:107), but in warmer climates other pedogenic factors play a more significant role. When artifacts are buried in montmorillonite or smectite clays, they are subject to displacement because these clays shrink when dry, forming cracks into which artifacts can fall, and then swell when wet, recovering the displaced artifacts (Butzer 1982:109). Bioturbation, the disturbance caused by burrowing animals and the actions of plant roots, especially those of trees, can also be a major source of artifact displacement (Butzer 1982:110). Frequently, the biggest disturbance factor at archaeological sites is the activities of later human occupants (Butzer 1982:99).

Most archaeological sites are close to water and are altered by hydrodynamic mechanisms. The following is a brief consideration of alluvial processes as they relate to archaeological site formation. Erosion, transport, and deposition of sediments provide the context within which most archaeological sites are buried. 
Displacement of sediment is a function of water flow velocity and grain size (Waters 1992:120). Because large grains are heavy and small grains are cohesive, both large grains of sand and fine grains of clay require higher water velocities to be entrained. Clays are difficult to erode, but once entered into suspension will continue to move even at very low velocities (Waters 1992:120). Movement of the water eventually ceases, the sediments settle and are deposited. Where and when this happens is largely a factor of grain size and transport energy (Waters 1992:122). The sediments are temporarily or permanently stored in the stream bed or along the floodplain (Waters 1992:122). It is the permanent or semi-permanent storage of sediments on archaeological sites which helps to bury them.

Geomorphologists use the word "stream" to mean any flowing water confined to a channel. Thus, a stream can be a tiny creek or a large river (Waters 1992:116). Land adjacent to a stream channel that is subject to occasional overbank flooding is known as a floodplain. Floodplains gradually accumulate as each flood episode deposits more sediment (Waters 1992:138). These areas are particularly suited to preservation of archaeological sites (Butzer 1982:101). Archaeological sites on floodplains may actually accumulate sediment at a somewhat faster rate than surrounding areas. This is because humans usually leave behind organic materials such as plant remains, animal remains, and feces. When these materials have decomposed, they increase the organic content of the soil, encouraging plant growth. Flood water flowing around plants is slowed, allowing the deposition of entrained sediments (Butzer 1982:91). In addition, dense growth on an alluvial surface can help protect it from further erosion (Waters 1992:126).

In contrast to these site preserving processes are the effects of meandering rivers within their floodplains. The time it takes a river to meander completely across its valley varies considerably (Ritter 1978: 256-257), but each time it does, archaeological sites on the floodplain are destroyed and their artifacts are redeposited in secondary contexts (Waters 1992:138). In addition, fast-moving flood waters can completely strip a site, or rearrange the artifacts into secondary contexts that may be difficult to detect (Waters 1992:126).

On alluvial terraces, archaeological sites are somewhat protected from more violent forms of erosion. These terraces consist of two parts, named after stair components which terrace systems often resemble. The flat surfaces are called "treads" (Ritter 1978:267; Waters 1992:149), while the steep scarps between treads are called "risers" (Waters 1992:149). Terraces can form in one of two ways: depositional terraces are formed when an episode of valley filling is followed by an episode in which the stream downcuts through the fill, leaving the uneroded part of the fill in steps (Ritter 1978: 267-269, Figure 7.10); erosional terraces are steps formed by lateral erosion of bedrock during a downcutting episode (Ritter 1978:269). Archaeological sites are common on terraces which provide flat spaces to camp, with some protection from wind, and easy access to both riverine and upland resources.

Modern terraces can have sites on or near the surface, or deeply buried. In the latter case, the site was occupied when the area was part of the floodplain of the stream, during the valley-filling episode before the down-cutting which produced the terraced landform (Waters 1992:151). If this filling and cutting has taken place several times during the time of human occupation, the sites buried in fill deposits may exhibit complex chronological and stratigraphic relationships (Waters 1992:153). Sites on the surface of erosional terraces may exhibit chronological spacing, that is, older sites might be found on the highest terraces while more recent sites are found on lower terraces, which were formed by the erosion at a later time (Waters 1992:151). Sites on terraces can be buried by colluvium from the slope above, by deposit of wind-borne (aeolian) sediment, or by alluvial deposits during floods (Waters 1992:153).

In dry climates, many rivers and creeks are actually arroyos, entrenched channels which are dry most of the year, flowing only during and shortly after periods of heavy rain (Waters 1992:145). The beds of arroyos are similar to braided stream channels because of the high energy and large bedload of the 
water when it is flowing (Waters 1992:146). Arroyos usually empty into delta-like fans (Waters 1992:147). Artifacts found in the bed of an arroyo are almost always in secondary context, but occasionally sites on arroyo-mouth fans are buried without serious disturbance (Waters 1992:148).

Several important aspects of site formation could be addressed by data from sites in the project area. Examination of vertisols on the uplands of the Main Base and Medina Annex would probably contribute to an understanding of these processes. The disturbance of archaeological artifacts and features by the expansion and shrinking of clays is known to occur, but needs further study.

Another important aspect of the potential historic context of sites in the study area would be an analysis of the terrace systems. An understanding of the geomorphology of the terraces could improve understanding of the changes in landforms over time, and could improve understanding of the environment within which archaeological sites are laid down, altered, and preserved.

These studies can be related to work currently being done north and south of the project area in Bexar County (Potter et al. 1995; Thoms 1992), allowing considerable improvement in our understanding of site formation differences along the Balcones ecotone.

\section{Research Design}

The prehistoric research design focuses on those archaeological aspects of the project area that can be addressed by the types of data obtained through pedestrian survey, shovel testing, and very limited excavation as specified in the Request For Proposal (NPS 1993). The issues that can most appropriately and productively be addressed are those of site type, distribution, density, and size, as well as the depth and stratigraphy of those cultural deposits. The research objectives are to identify sites, examine and record these characteristics, and analyze the data obtained in terms of the archaeological record and theory. The theoretical framework is structured around patterns of settlement, mobility, subsistence, and social system.

\section{Environment}

Research in prehistory is tightly bound to environment and therefore, must be advanced in an ecological context (Butzer 1982). The modern environment of the project area and the state of current ideas on paleoenvironments and climatic change for the surrounding region are given in detail in Chapter 2. Below, a brief description of microenvironments in the project area is given to convey the importance of understanding the local ecology and how it shapes prehistoric research, and to serve as an introduction to the discussion on the current project's research objectives.

The riverine environment in the bottoms and terraces of Leon and Medio creeks and Long Hollow provides a place for plants and animals adapted to a more mesic environment. The two creeks still flow, while Long Hollow is today only an intermittent stream. All three were probably more energetic before the local water table was lowered by pumping directly from the aquifer. In the past, as today, these waterways were subject to flash flooding during locally heavy thunderstorms. In the creek bottoms, tall trees shade the ground, leaving little light for understory growth, while the higher alluvial terraces are covered with small trees and medium to heavy brush cover. Aquatic animals, including fish, turtles and frogs, and hydrophytic plants such as cattails would have provided food resources in prehistory. Lithic resources are rich in these stream beds; in places, the bottoms are paved with chert cobbles. Also, large exposures of Uvalde Gravels occur over much of the upland zones of the area, including Long Hollow.

The alluvial floodplains and upland zones support mesquite and agarita, while large live oaks still survive along the creeks. All three species are potential food resources. The terraces offer flat spaces, providing room for camps, quick and easy access to the resources of the creeks and uplands, some shade, and protection from flash floods. 


\section{Prehistoric Site Density and Distribution}

Although the northern area of Bexar County has been extensively examined for archaeological sites, the southern part of the county, below the Balcones Escarpment, has received much less attention (Potter et al. 1992:5). For the most part, the area around Lackland AFB has been visited only by avocational archaeologists (Howard 1974; McReynolds 1982). Fortunately, a number of local artifact collections have been documented by members of avocational archaeological groups. Exceptions to this lack of formal surveys include preparatory work for the proposed, then abandoned, Applewhite Reservoir project, on the Medina River south of Lackland AFB (McGraw and Hindes 1987; Thoms 1992), and McGraw's (1977) survey of Medio Creek north and south of the project area.

Although surveys in Bexar County south of the Balcones Escarpment have been rare, some indications of expected site density are available. Along a nine-kilometer section of the Medina River in the area of the proposed Applewhite Project, a Geological Survey map (7.5' series) on file at the Texas Archeological Research Laboratory, shows 37 sites on the first or second terrace above the river. These sites were recorded during various surveys, including unpublished work by Texas A\&M University. This equates to a site density of 4.11 sites $/ \mathrm{km}$ of water course. Although many of these are historic sites, virtually all have prehistoric components. McGraw's (1977) survey upstream on Medio Creek two decades ago was not complete, but indicates, at least in certain areas, that site density is not nearly as high. One eight-kilometer segment of the creek had only four sites (McGraw 1977:Figure 1). However, the map of recorded sites does not indicate how much of this segment was actually surveyed. McGraw notes that access through some landowners was not possible (McGraw 1977:1). This uncertainty about the extent of survey coverage makes any inference on site density for the surrounding area problematic.

Surveys in northern Bexar County, especially along the Salado Creek watershed (Boyd et al. 1990; Gerstle et al. 1978; Quigg 1988), support the inference that site density along the first and second terraces of creeks is fairly high. For instance, along approximately eight kilometers of Upper Salado Creek on Camp Bullis Military Reservation, Quigg (1988:Figure 2) shows 10 sites on the first or second terrace, or about 1.25 sites $/ \mathrm{km}$ of water course.

Systematic surveys of upland areas have been few, even in northern Bexar County. Quigg's (1988) survey was limited to the terraces of Salado Creek, and the Applewhite surveys were intended to cover only those areas of the Medina River Valley expected to be flooded by the reservoir (McGraw and Hindes 1987). Boyd et al. (1990) conducted a survey of the Upper Salado in 1989, which included uplands. Numerous small sites were recorded, but all were thin lithic scatters, usually on slight slopes, and usually eroded to within a few centimeters of bedrock. While this may give some idea what to expect on the uplands of the project area in terms of site type, some differences are likely. The uplands of Lackland AFB are not tall, steep, nearly bare limestone hills, but rather low and flat with somewhat deeper soils.

\section{Anticipated Site Characteristics}

The results from these surveys indicated that the majority of sites in the project area would probably be found on the first or second terraces of the creeks. Site density along both Medio and Leon creeks is expected to be between one and four sites per kilometer of water course, probably about three. However, it should be noted that while much of the terrace area above Medio Creek is minimally disturbed or undisturbed, the same is true for only a small area of Leon Creek. An unsystematic avocational survey of Leon Creek conducted almost 30 years ago revealed extensive artifacts accumulations along the bluff above the creek, especially in the middle section of its passage through the base (Tom Kelly, personal communication 1994). Although two sites (41BX1065 and 41BX1066) recorded by CAR may represent remnants of those previously found sites, development of base facilities since that time has apparently destroyed most of them. 
Sites along linear stretches of terrace are likely to be what McGraw (1977:6) described as "an extensive preferred occupational zone rather than a locally defined and limited area." If uplands sites are present, their density on the landscape and the density of the artifact assemblages they contain would probably not be great, and many would be only a thin scatter of lithic debitage.

Site density along Long Hollow on the west side of Medina Annex should also be quite high, although perhaps not as high as Medio Creek, since the drainage may have been intermittent even in prehistoric times. Expected site density is about two sites per kilometer of water course.

Potter (et al. 1992:5-6) note that archaeological sites in northern Bexar County tend to be both larger and deeper the further downstream they are located. Therefore, some of the sites along Medio and Leon creeks and Long Hollow are expected to be very deep. McGraw and Hindes (1987) noted several very deep multi-component sites along the Medina River, where Early Archaic materials have been found under as much as three meters of alluvium. In addition, the Richard Beene site, in the footing trench for the proposed Applewhite dam, was found to have more than $10 \mathrm{~m}$ of alluvium over the late Paleoindian component (Thoms 1992).

\section{Prehistoric Site Types}

Five types of prehistoric sites are routinely found in the area around Lackland AFB. These are 1) open camp sites, with either single or multiple temporary occupations; 2) burned rock midden sites, with or without associated camp sites; 3) rock shelters; 4) chert quarry sites; and 5) burial sites.

\section{Open campsites}

Open campsites result from temporary habitation of a location by a group of hunter-gatherers. The site may consist of a thin lithic scatter representing a single occupation (Boyd et al. 1992), or a deeply stratified, multicomponent site to which groups repeatedly returned for thousands of years (Black and McGraw 1985; Guderjan et al. 1992). During the Applewhite project survey, open campsites dating from Paleoindian to Historic Indian periods were found on the surface or near enough to the surface to be exposed by plowing (McGraw and Hindes 1987).

\section{Burned Rock Middens}

These sites are common in central and west Texas. They consist of piles of heat-fractured limestone, usually in a dome-shaped mound, but occasionally in rings or crescent shapes. These piles can measure tens of meters in diameter and a meter or more thick. Although the manner in which these sites were used and how they formed is still a matter of intense debate (Black et al. 1993; Creel 1986; Hester 1970; Jones 1981; McGraw and Valdez 1978; Prewitt 1991; Witkind 1977), they are clearly the result of intensive use of some resource in a logistically oriented subsistence strategy (Binford 1980). Though burned rock middens are rare south of the Balcones Escarpment (Black 1989b), a few have been located in southwestern Bexar County (McReynolds 1982:13), usually near water sources (Creel 1986).

\section{Rockshelters}

These sites are found in solution cavities along creeks where water has cut into limestone bedrock. Repeated use of these shelters by prehistoric and historic populations is documented in many parts of Texas and they are common in northern Bexar County along creeks cutting through the Balcones Escarpment. Generally, limestone overhangs are not present south of the escarpment, including Lackland AFB. Unfortunately, most rockshelters have been heavily looted (Boyd et al. 1990; Guderjan 1991).

\section{Chert quarry sites}

Some lithic resource procurement sites in Bexar County consist of bedrock outcroppings of limestone 
containing numerous chert nodules, while other areas have large numbers of chert nodules that have been washed into stream beds. Within the project area, a third possibility occurs in upland zones, where extensive chert gravel exposures are common. These are lag deposits from extinct drainage systems. Quarry sites usually have great quantities of primary and secondary flakes, cores, and tested cobbles, and large numbers of roughedout bifaces or quarry blanks, many broken during manufacture (Potter et al. 1992).

\section{Burials}

Though not common, prehistoric burials have been found in Bexar County. These are usually single burials associated with occupation sites. Prehistoric cemeteries first emerge in the Middle Archaic, becoming more common in the Late Archaic and Late Prehistoric (Prewitt 1981). Associated grave goods are rare. Occasionally, especially in Austin phase (early Late Prehistoric [Collins 1995]) cemeteries, evidence of conflict appears with apparent arrow wound fatalities (Prewitt 1974; Shoup 1988). A burial salvaged by CAR in 1991 contained an Edwards point associated with the vertebral column. Even though no damage to the vertebrae was detected, the context of the arrow point was evidence that it was probably the primary cause of death (Barbara Meissner, excavation notes on file at CAR).

While the presence of all five site types listed above was a possibility, the most common site, by far, should be open campsites. Burned rock middens are rare south of the Balcones Escarpment. Quarry sites are possible, though the wide-spread chert sources available in the creek beds and in the Houston Black clay soils on the uplands should mean that specialized quarry sites were not necessary in this area. However, at least one possible quarry site was encountered on Leon Creek by a surface collector at Lackland many years ago (Tom Kelly, personal communication 1994). Rockshelters are unlikely because of the local geomorphology, and any present would most likely have suffered heavy looting. Locating burials is a possibility, but not particularly likely during survey work. However, a number of burials were supposedly found by looters just west of the Medina Annex about 20 years ago (Jimmy Mitchell, personal communication 1994).

\section{Prehistoric Technological Strategies}

In theory, foragers produce and use a simpler, more generalized, and expedient lithic assemblage than the formal tool kits assembled by collectors; thus, it is assumed that an expedient technology would have been employed by groups exploiting resources in the project area. Based on that assumption, certain theoretical expectations of lithic technology can be postulated and tested against the lithic samples collected during the survey.

Expectations for two general characteristics of lithic technology are presented for:

1) the variability or diversity of the lithic assemblages versus the quantity of the assemblages; and

2) the reduction stages of the samples.

The relationship between tool type variability relative to sample size is indicative of site function and the length of occupation. Camilli (1983) suggests that different types of sites will have different correlations between assemblage variability and sample size, while Thomas (1985) further posits that residential site assemblage variability increases at a faster rate relative to sample size than does logistical site variability. Thus, base camp locations will be expected to have a wider range of tools (given a constant sample size) than either forager location sites or logistical sites.

The second general characteristic for which expectations are posited is the reduction stage of the lithics found in the project area. The expedient lithic technology of a forager system suggests that there would be little use of curated tools, and local materials would be utilized. Thus, the lithics should have been produced from the local chert. Also, the use of an expedient lithic technology of a forager system would be indicated by a greater frequency of 
utilized interior flakes over formal tools. Both the nature of the settlement system and the nature of the resource structure for the survey area leads to the expectation that the percentage of formal tools in any assemblage will be limited.

Temporally diagnostic artifacts-such as dart and arrow points, Guadalupe tools, and Clear Fork tools-will be used in association with established chronologies to place sites in the regional time frame (e.g., Black 1989a, 1989c; Collins 1995; Hester 1995; Johnson and Goode 1994; Prewitt 1981; Turner and Hester 1993; Turpin 1991).

\section{Summary of Research Goals}

In view of the fact that the research design for Lackland focuses on issues of site characteristics and patterns, the goals are reiterated as follows:

(1) to locate and record cultural locations and sites in the project area using a systematic survey methodology;

(2) to further document, quantify, and analyze site characteristics to provide a data base upon which to make interpretations concerning settlement, mobility and subsistence systems;

(3) to document, quantify, and analyze lithic samples in order to make interpretations concerning subsistence and mobility systems;

(4) and to make cultural resource assessments of the sites relative to their qualification for inclusion in the National Register of Historic Places and to recommend their treatment in this regard. 


\section{Chapter 8. Archaeological Sites}

\section{Introduction}

Sixty-eight prehistoric sites were recorded during the 1994-1995 CAR survey, four of which (41BX1074, 41BX1121, 41BX1124, and 41BX1130) include a historic component. Three sites (41BX1061, 41BX1128, and 41BX1129) have only historic components. Three prehistoric sites (41BX1001, 41BX1002, and 41BX1006) recorded during previous surveys were revisited but are discussed elsewhere (De Vore 1993; Petraglia and Knepper 1993).

Appendix $\mathrm{G}$ offers a concise presentation of data from each site, with information on context, artifact content, and subsurface cultural materials. Age estimates are made for sites yielding diagnostic artifacts. These are indicated as projectile points or other diagnostics under remarks. Projectile point typology follows Turner and Hester (1993) and Bement (1991), while dates are derived from Collins (1995) and Turner and Hester (1993). The major time periods are defined as Early Archaic (8800-6000 B.P.), Middle Archaic (6000-4000 B.P.), Late Archaic (4000-1300 or 1200 B.P.), a possibly overlapping Transitional Archaic (2300-1300 or 1200 B.P.), Late Prehistoric (1200-350 B.P.), and Historic (350 B.P.-present). Johnson and Goode (1994) and Collins (1995) have recently restudied the cultural chronology and time depth of the central Texas Archaic, and their views are considered in discussions and analyses of site ages in the summary. CAR surveyors did not locate any diagnostics definitely attributable to the Paleoindian period. Interpretations regarding prehistoric activities are based on the observation and data collected. Artifact collectors have removed material, primarily points and bifaces, but there is no easy way to determine the extent of this bias.
In the following discussion, prehistoric sites are grouped according to the drainage (Leon Creek, Medio Creek, Long Hollow) or upland area where the are located. Historic sites are discussed in Chapter 12.

\section{Leon Creek Prehistoric Sites}

Despite the extensive alteration of the landscape, CAR crews located and recorded four prehistoric sites-41BX1065, 41BX1066, 41BX1107, and 41BX1108-along the Leon Creek drainage. Based on temporally diagnostic artifacts recovered from site surfaces, the estimated ages of these sites ranges from the Middle through Transitional Archaic. The following brief descriptions include site types and settings, associated artifact assemblages, disturbances, known future impacts, and research potential.

\section{BX1065}

This site is a prehistoric open campsite located on the bluff directly above Leon Creek. The site was discovered in August 1994, and revisited in May 1995. Most of the western section of the site appears to be disturbed, but eastern portions remain intact. Limited testing of 41BX1065 was conducted after the survey. The results of testing and the site map are presented in Appendix $\mathrm{H}$. Four diagnostic projectile points were recovered from the surface, indicating a Middle or Late Archaic through Transitional Archaic occupation. The limited testing indicated apparent intact cultural deposits $20-30 \mathrm{~cm}$ 
below the surface (Appendix $\mathrm{H}$ ). The parcel of land on which the site rests has been slated for development, but a strategy of avoidance has been recommended for the eastern part of the site where the best preserved portion of the prehistoric occupation exists.

\section{$41 B X 1066$}

41BX1066 (Figure 8-1) is located on the same bluff edge as 41BX1065, positioned well above Leon Creek $120 \mathrm{~m}$ to the north, and set in Houston Black gravelly clays. It is a small prehistoric open campsite with a light surface scatter of debitage and fire-cracked rock which may represent a feature. The predominance of interior and bifacial thinning flakes indicates late phases of reduction. One formal tool-an endscraper-was recovered from the surface. While the site surface has been disturbed, possibly by bulldozing, the damage appears to be limited. Although a shovel test produced no artifacts, some artifacts appeared to have been dug up by the bulldozer.

Considering its minimal disturbance and the presence of a possible fire-cracked limestone feature and formal tools, 41BX1066 has moderate research potential. Buried intact cultural deposits may exist. The site should be considered for inclusion in the NRHP and deserves some measure of protection.

\section{BX1107}

41BX1107 (Figure 8-2) is a prehistoric open campsite set in Venus clay loam on the broad alluvial terrace above Leon Creek, flowing $150 \mathrm{~m}$ to

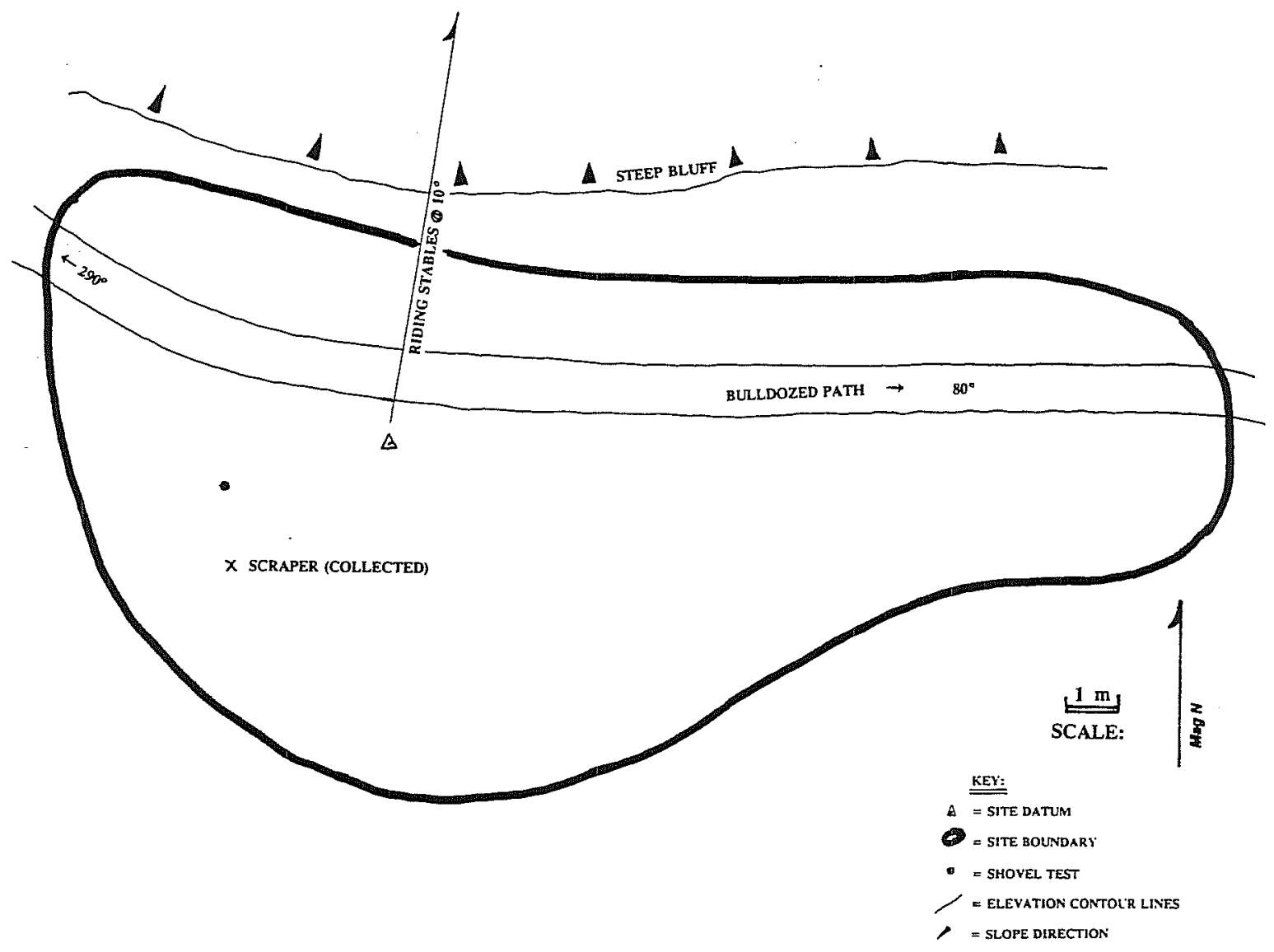

Figure 8-1. Site plan, 41BX1066. 
the north. The dense surface scatter is primarily composed of interior and bifacial thinning flakes, small pieces of chert debris, and fragments of firecracked limestone. A few greatly reduced core remnants are present, and three thin biface fragments were collected. Most of the lithic debris indicates late stages of reduction. An untyped projectile point collected from the surface has a bifurcated stem and heavy patination. The point is too fragmentary to be typed.
The site surface has been damaged because it is located on Lackland's golf course, near a gravel golf cart path. A shovel test revealed artifacts as deep as $50 \mathrm{~cm}$ below the surface. Research potential for the site is high, considering the extremely high density of surface artifacts and the possibility that subsurface features are present. This site is one of very few remaining intact along this segment of Leon Creek and it is recommended for inclusion in the NRHP.

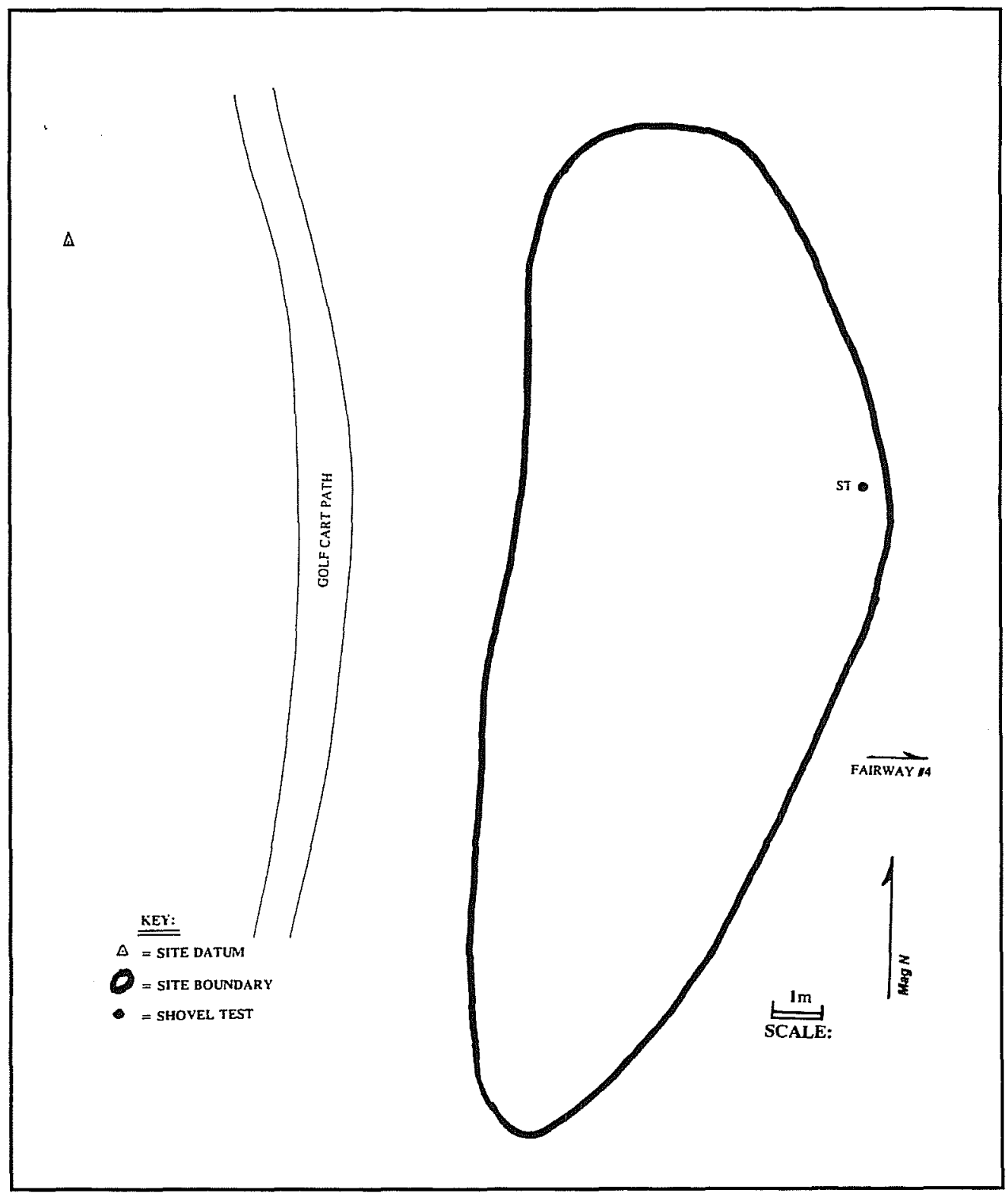

Figure 8-2. Site plan, 41BX1107. 


\section{BX1108}

41BX1108 (Figure 8-3) is a prehistoric open campsite set in Patrick soils on the broad alluvial terrace above Leon Creek, $250 \mathrm{~m}$ to the south. Only a light surface scatter of interior and bifacial thinning flakes offered a hint of the site's presence. Two shovel tests spaced $30 \mathrm{~m}$ apart yielded large quantities of fire-cracked rock, and provided evidence for the possibility of a large burned rock midden $37 \mathrm{~cm}$ below the surface. A few pieces of burned bone were recovered at $40 \mathrm{~cm}$. The site has suffered surface disturbance because of its location on the Lackland golf course and due to the proximity of a gravel service road. The silty clay soils suggest that the burned rock concentrations and possibly other cultural features have been sealed in situ by gentle flood episodes of Leon Creek. Research potential is very high considering the apparent presence of an extensive burned rock feature and possibly other intact cultural features. These attributes make the site worthy of inclusion in the NRHP. The absence of significantly high numbers of artifacts on the surface is undoubtedly due to the site's high visibility.

\section{Medio Creek Terrace Prehistoric Sites}

Twenty-two sites-41BX1060, 41BX1069, 41BX1077, 41BX1079, 41BX1086, 41BX1087, 41BX1092-94, 41BX1102, 41BX1103, 41BX1114, 41BX1115, 41BX1119-1123, 41BX1125-1127, and 41BX1130-were recorded along the Medio Creek terrace system during the current project. These

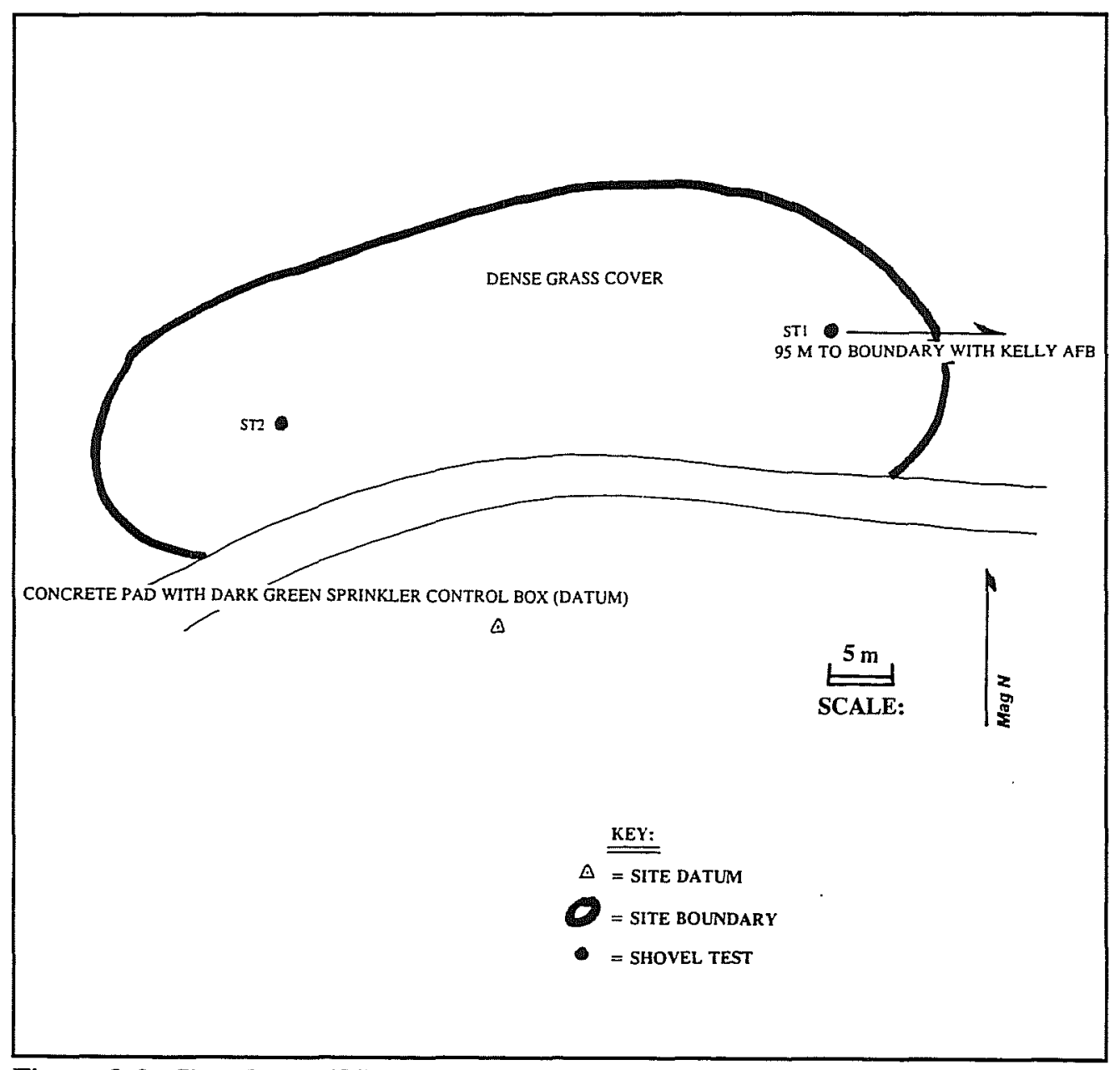

Figure 8-3. Site plan, 41BX1108. 
include 20 locations with only prehistoric components, and two with both prehistoric and historic components. Two locations with only historic remains were also found. The 22 prehistoric component sites are discussed below; the two historic-component sites are discussed in Chapter 12.

The prehistoric sites have an estimated age range from the Early Archaic through the Late Prehistoric. They are distributed across all elevations, from directly adjacent to the creek on the first terrace to the high uplands. Shovel testing showed that cultural material is buried in silty clay alluvial deposits that may be in situ. Both open campsites and quarries are present. A brief description of each site is given, including site type and setting, associated artifact assemblage, disturbance to the site, any known future impacts, and research potential.

\section{BX1060}

This open campsite sits in the broad, flat alluvial flood plain and meander of Medio Creek, $120 \mathrm{~m}$ to the southwest of the site (Figure 8-4). Dense upland vegetation covers the site. Cores, flakes, preforms, and an informal tool comprise the surface stone artifacts, indicating early stage reduction activities took place. A dense concentration of fire-cracked rock on the west edge of the site suggests a small burned rock feature. Shovel testing revealed artifacts to $30 \mathrm{~cm}$ below the surface. Minimal disturbance has been caused by animal burrowing.

41BX1060 has high research potential based on the presence of the burned rock feature and the possibility of a buried intact cultural deposit. This site should be considered for inclusion in the NRHP within a district context.

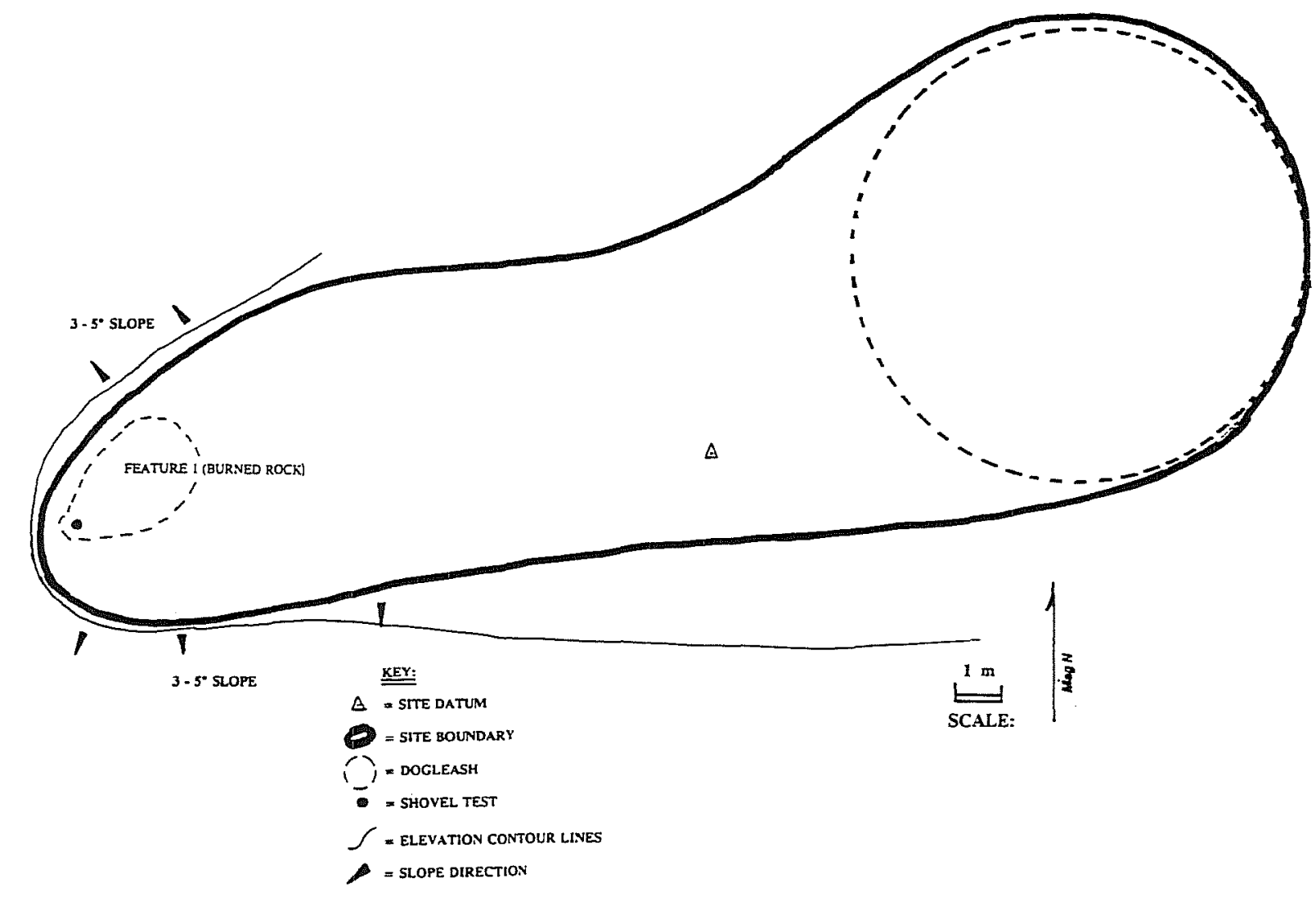

Figure 8-4. Site plan, 41BX1060. 


\section{BX1069}

Site 41BX1069 (Figure 8-5) is a prehistoric open campsite and lithic quarry station represented by a dense surface scatter of lithic artifacts and firecracked rock over a large area. The site area spans the lower Medio Creek floodplain and adjacent high uplands. The high terrace slopes abruptly to the creek's edge. Dense vegetation covers most of the site surface. One Pedernales dart point fragment was recovered, indicating a Middle Archaic component.
Most of the artifact assemblage is representative of early reduction stages, including larger exterior flakes and cores. Fire-cracked limestone is also present. Minimal damage has been done to the site by a road cut through the northwestern corner, and erosion has damaged the southern part. A shovel test produced artifacts to a depth of $20 \mathrm{~cm}$ below the surface, suggesting the potential for buried and intact cultural deposits. Research potential for the site is considered high. The extensive and dense

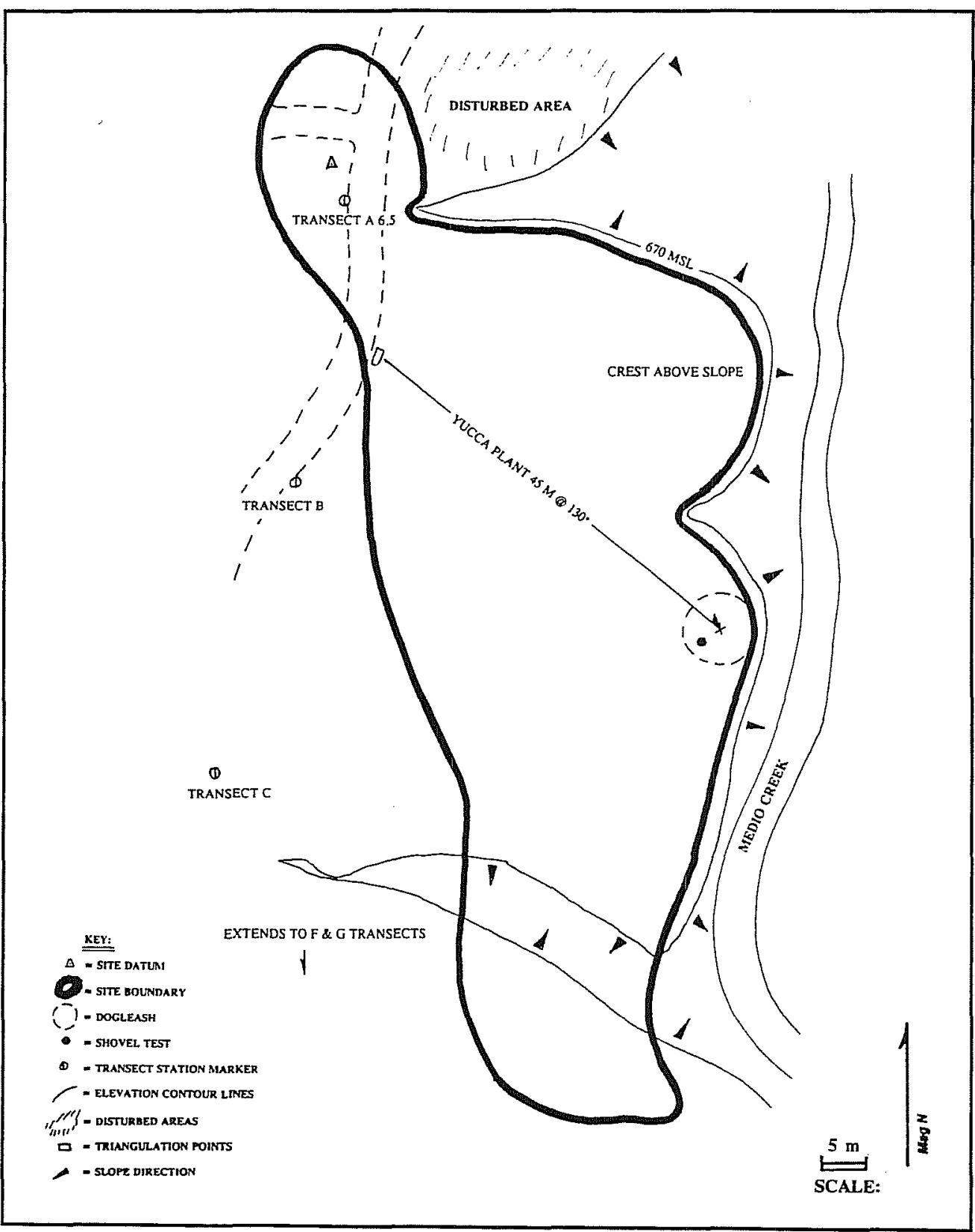

Figure 8-5. Site plan, 41BX1069. 
surface scatter and buried artifacts offer the potential for revealing additional chronological information. Fire-cracked rock on the surface hints that a burned rock feature may be present. 41BX1069 should be considered for inclusion in the NRHP within a district context.

\section{BX1077}

41 BX1077 (Figure 8-6) is a small, surface quarry station with a primary artifact assemblage of exterior flakes and cores, suggesting early stage reduction activities. It sits on the edge of an extinct creek channel on the first terrace above Medio Creek, which is $300 \mathrm{~m}$ to the east. Road construction and creek channeling have moderately disturbed the site. Although the one shovel test revealed no artifacts below surface, the site's location on an alluvial terrace suggests the possibility of buried and intact cultural deposits. The research potential of $41 \mathrm{BX} 1077$ is moderate; therefore, the site should be considered for inclusion in the NRHP within a district context.

\section{BX1079}

This small quarry station is located in upland vegetation (Figure 8-7), but on the higher alluvial terrace above Medio Creek, which flows $300 \mathrm{~m}$ to the southeast. Cores and exterior flakes from early

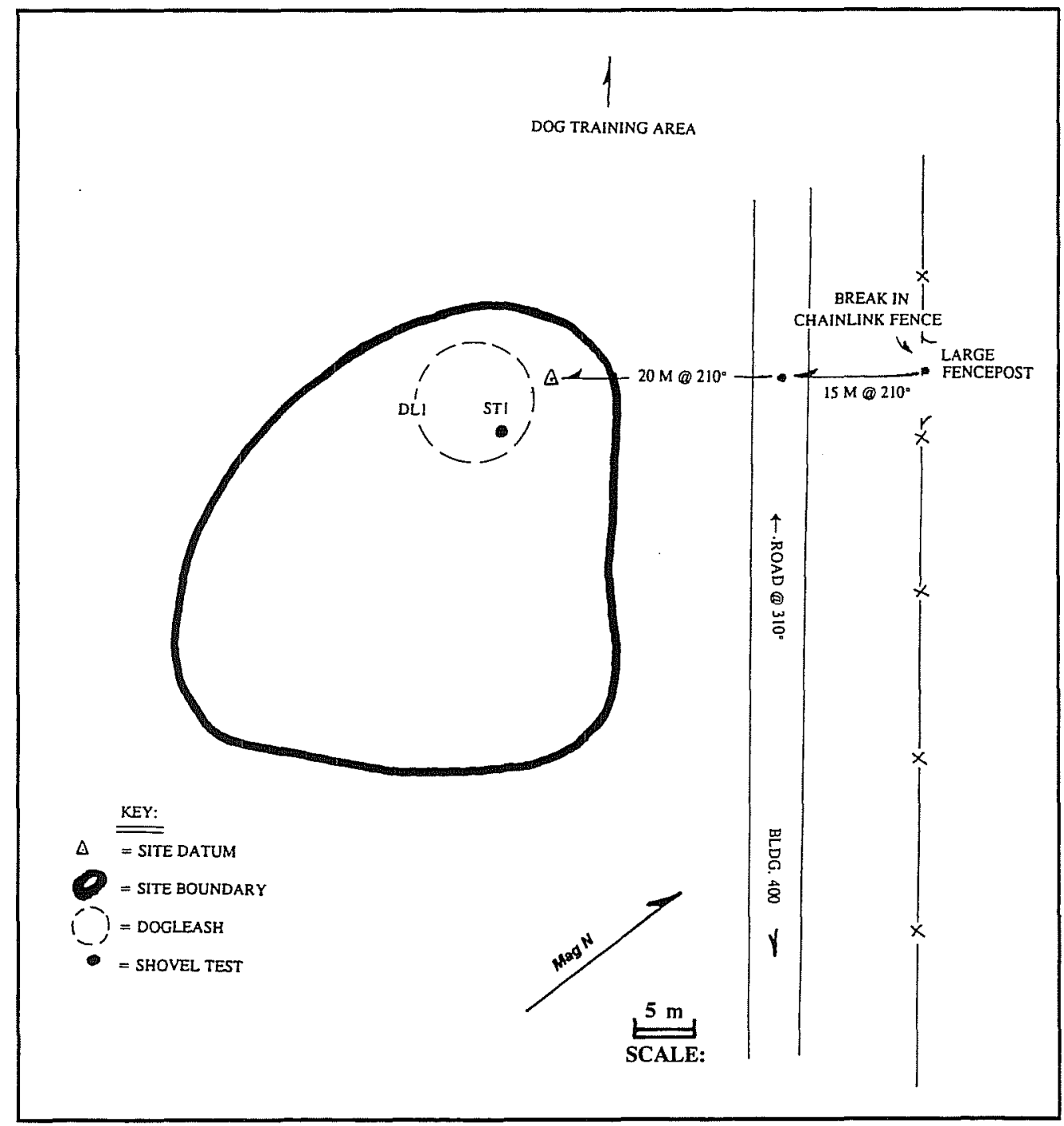

Figure 8-6. Site plan, $41 B \times 1077$. 


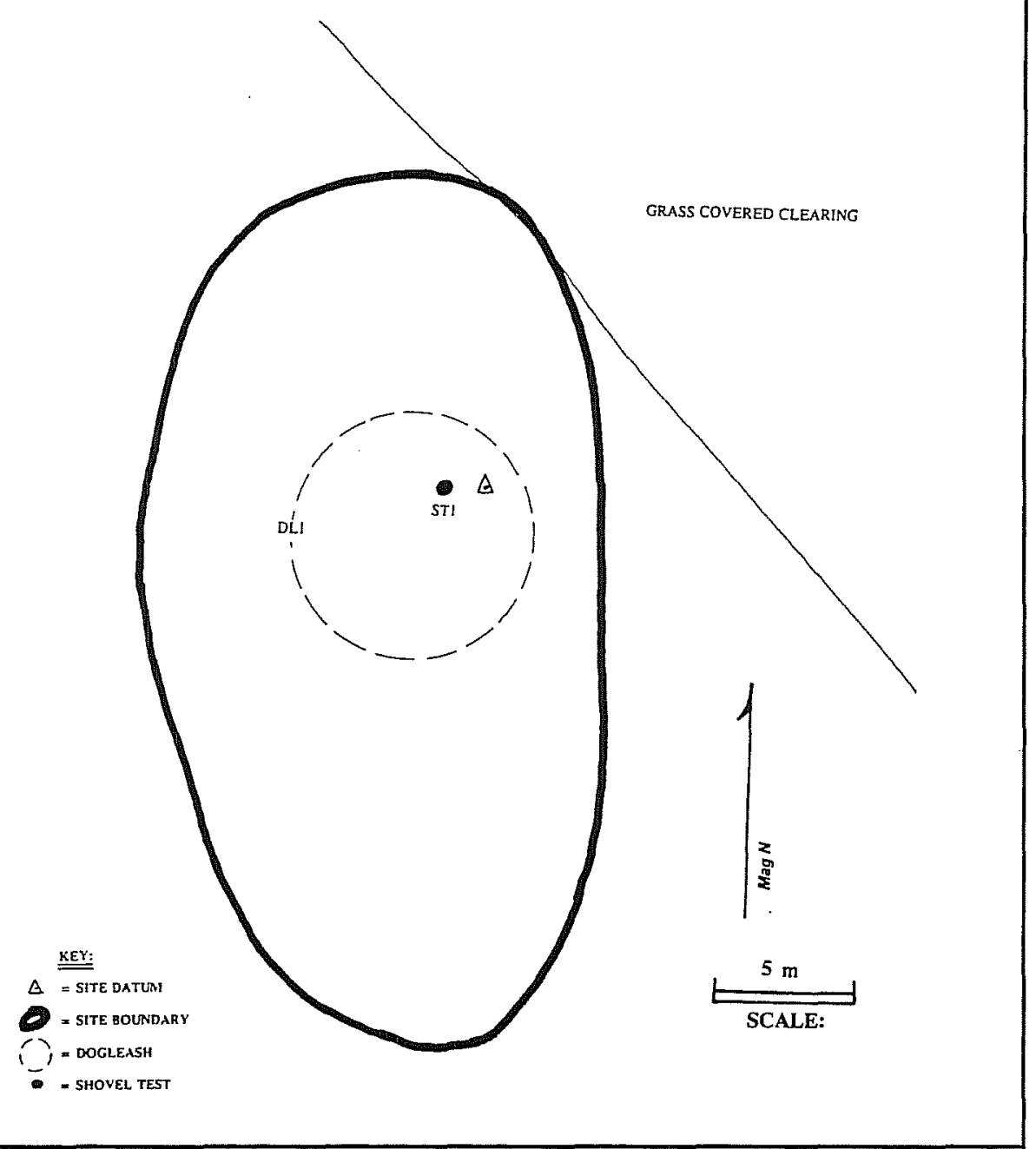

Figure 8-7. Site plan, 41BX1079.

stage reduction activities dominate the surface scatter. The site appears to be minimally disturbed, but borders on developed acreage. One shovel test revealed no artifacts below the surface. The research value of $41 \mathrm{BX} 1079$ is moderate; therefore, the site should be considered for inclusion in the NRHP within a district context.

\section{BX1086}

At 41BX1086 (Figure 8-8), fire-cracked rock is associated with lithic reduction ranging from cores to formal and informal tools, suggesting the site is an open campsite and lithic quarry with a full lithic reduction sequence. A shovel test indicated the possibility of buried and stratigraphically separated cultural deposits from $0-10 \mathrm{~cm}$, and at $40-50 \mathrm{~cm}$ below the surface. The site is covered with extremely dense stands of whitebrush, and rests on the broad, level first terrace of Medio Creek, $400 \mathrm{~m}$ to the southwest.

The research potential for this site is great because of a high density of lithics on the surface in a relatively small area, as well as the possibility of an intact buried cultural deposit. The range of core and flake types and their presence in high numbers is unique among the sites surveyed. 41BX1086 should be considered for inclusion in the NRHP within a district context. 


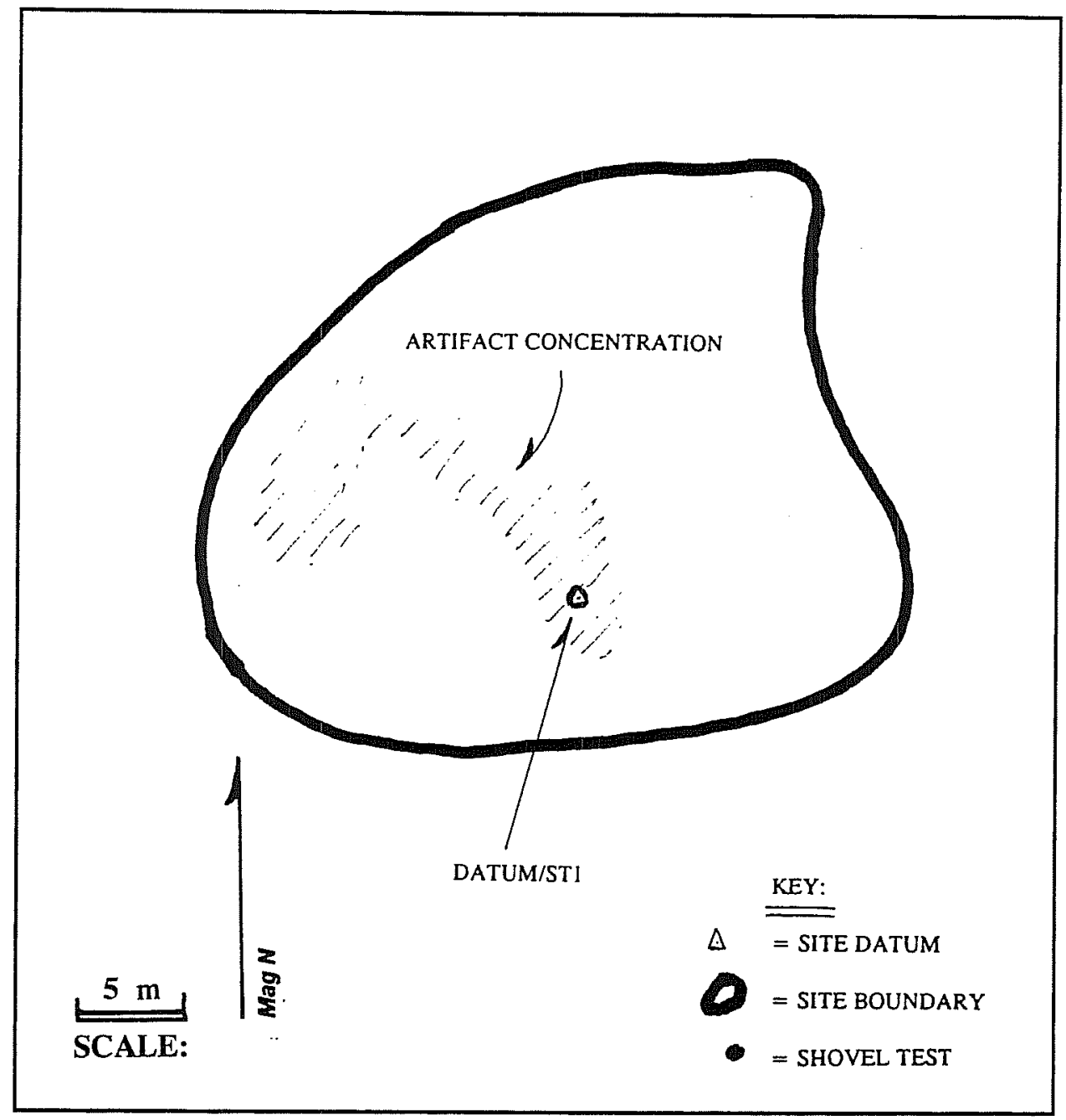

Figure 8-8. Site plan, 41BX1086.

\section{BX1087}

This relatively small open campsite (Figure 8-9) rests on a broad, flat lower terrace between an intermittent drainage and Medio Creek, $200 \mathrm{~m}$ to the southwest. Creek/upland vegetation densely covers the site, yet a relatively high number of lithic artifacts representing all stages of reduction was still observable. A Matamoras projectile point found on the surface defines the site as Late Archaic to Late Prehistoric in age.

Fire-cracked rock was observed in sufficient quantities to suggest that one or more hearth features could be identified with further investigation. Although a walking trail is adjacent to the western edge of the site, the site itself appears to have experienced minimal disturbance. A shovel test indicates the potential for an intact buried cultural deposit ca. $20 \mathrm{~cm}$ below the surface.

The research potential for 41BX1087 is moderate to high considering the high density of artifacts that occur in a relatively small, discrete area and the possibility of intact cultural deposits below the surface. This site should be considered for inclusion in the NRHP within a district context. 


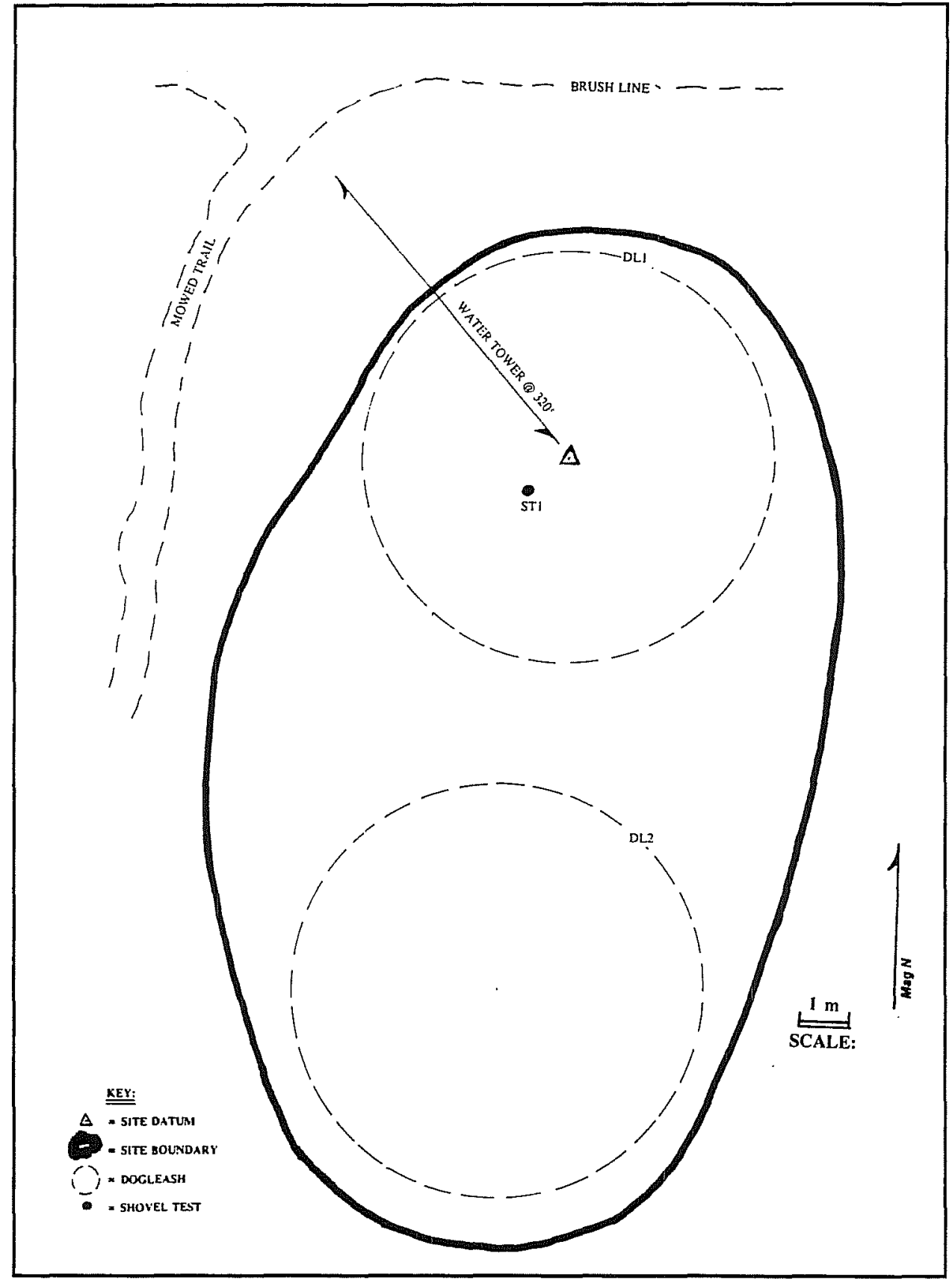

Figure 8-9. Site plan, 41BX1087.

\section{BX1092}

$41 B X 1092$ (Figure 8-10) is an open campsite located $90 \mathrm{~m}$ west of Medio Creek, on the first terrace. Surface artifacts indicate phases of lithic reduction from cores to preforms and formal tools. A small scatter of fire-cracked rock indicates that a hearth feature may still exist below the surface. Shovel testing yielded artifacts to depths of $20-50 \mathrm{~cm}$. The site is covered with moderate densities of creek/ upland vegetation. Although the site has been adversely affected by road and fence construction, artifacts recovered to a depth of $50 \mathrm{~cm}$ and the site's location on an alluvial terrace suggest a moderate 


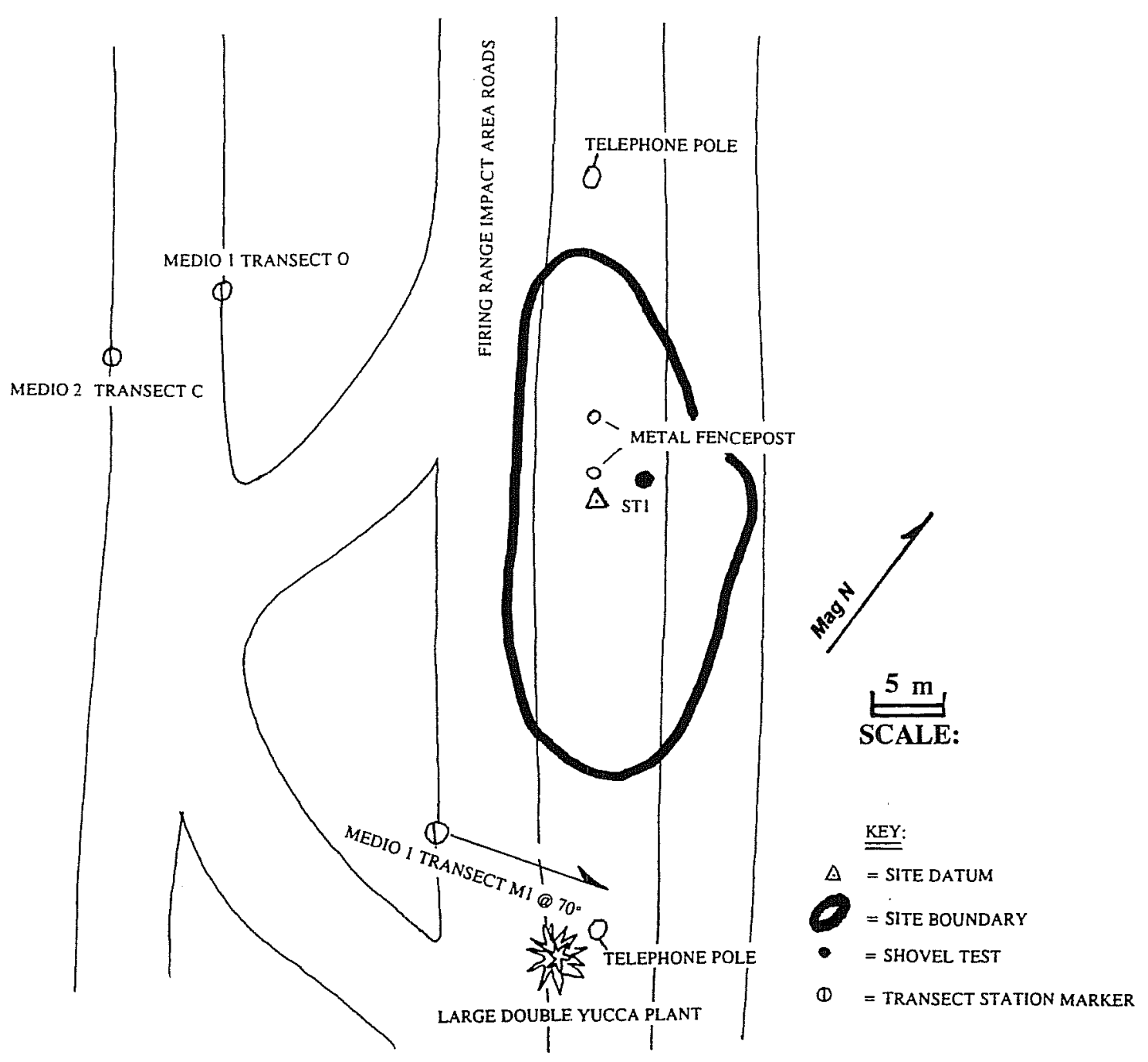

Figure 8-10. Site plan, 41BX1092.

research potential. Therefore, 41BX1092 should be considered for inclusion in the NRHP within a district context.

\section{BX1093}

41BX1093 spans the edge of the lower terrace and floodplain of Medio Creek. The creek is $45 \mathrm{~m}$ to the east (Figure 8-11). Dense vegetation covering the site consists of creek/upland species. Chert cobbles along the edge of the terrace provided raw materials for the cores, flakes, informal tools, and a blank observed on the surface. Shovel testing revealed that the site may have two cultural subsurface strata: one from surface to $20 \mathrm{~cm}$, and a second from 30 to at least $60 \mathrm{~cm}$ below the surface. Burned caliche, firecracked rock, and a relatively high quantity of lithic material in the lower deposit implies an open campsite with a hearth feature. This site appears to have been minimally affected by erosion along the terrace edge. This site has high research potential based on the likelihood of an intact buried cultural deposit underlying the surface component. With this in mind, 41BX1093 should be considered for inclusion in the NRHP within a district context. 


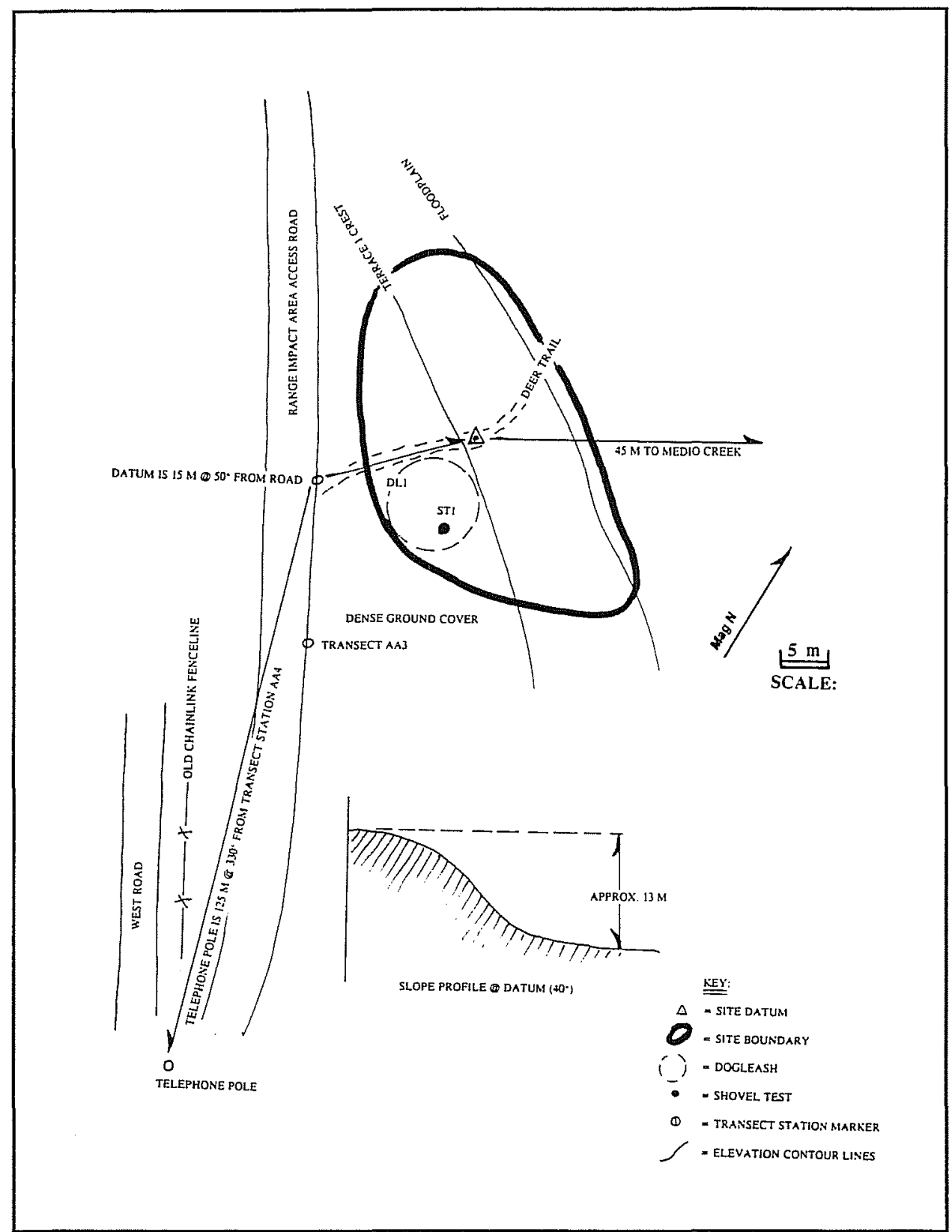

Figure 8-11. Site plan, 41BX1093.

\section{BX1094}

41BX1094 (Figure 8-12) is a quarry exhibiting evidence of lithic reduction phases from chert cobbles to blanks, preforms, and informal tools. Shovel testing indicates that the site may have a depth of up to $20 \mathrm{~cm}$. Located on the second terrace above Medio Creek, $230 \mathrm{~m}$ to the east, the site is covered with upland vegetation. Minimal disturbance has occurred from rodent burrowing. With moderate research possibilities, the site should be considered for inclusion in the NRHP within a district context.

\section{$41 B \times 1102$}

41BX1102 (Figure 8-13) is an open campsite resting on the broad, flat first terrace of Medio Creek. The 


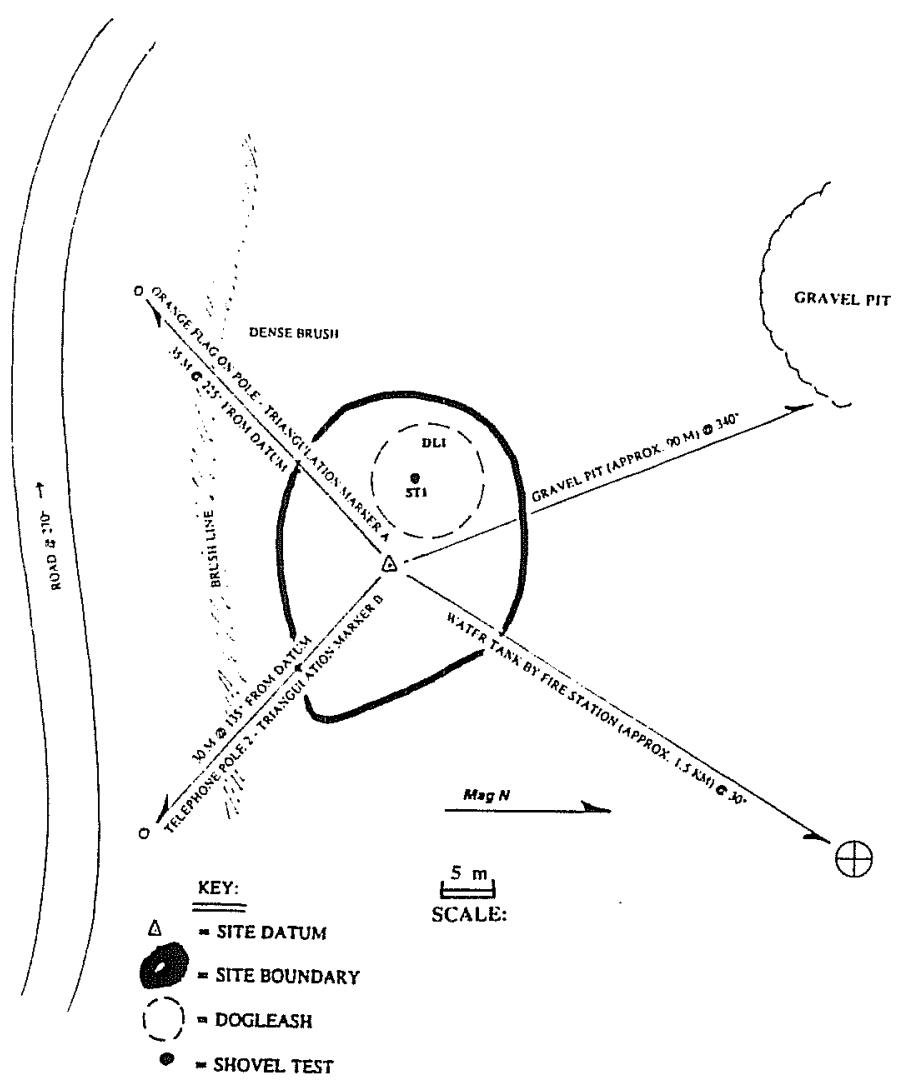

Figure 8-12. Site plan, 41BX1094. $\mathrm{cm}$ below the surface. This was followed by a sterile zone, after which cultural debris was again recovered at $50-60 \mathrm{~cm}$ below the surface. Vegetation on the site includes primarily upland species. Aside from a dirt exercise track and a two-track road on the northwest edge, the site appears to have suffered minimal disturbance.

41BX1102 has a high research potential based on the following criteria: 1) the full array of cultural debris recorded on the surface, including Middle Archaic diagnostics; 2) the probable presence of a buried, intact cultural deposit of the same or earlier time period; 3) the possibility that a burned rock feature survives intact; and 4) the minimal level of disturbance suffered by the site. This site should be considered for inclusion in the NRHP within a district context. site is located $150 \mathrm{~m}$ southwest of the channel. A Pedernales projectile point found on the surface places at least one occupational component in the Middle Archaic period. Chipped stone debris on the surface indicates that cobbles were reduced to cores, preforms, formal and informal tools, and possibly to points. Significant scatters of fire-cracked rock suggest one or more hearth features. One shovel test revealed artifacts to 20

Figure 8-13. Site plan, 41BX1102.

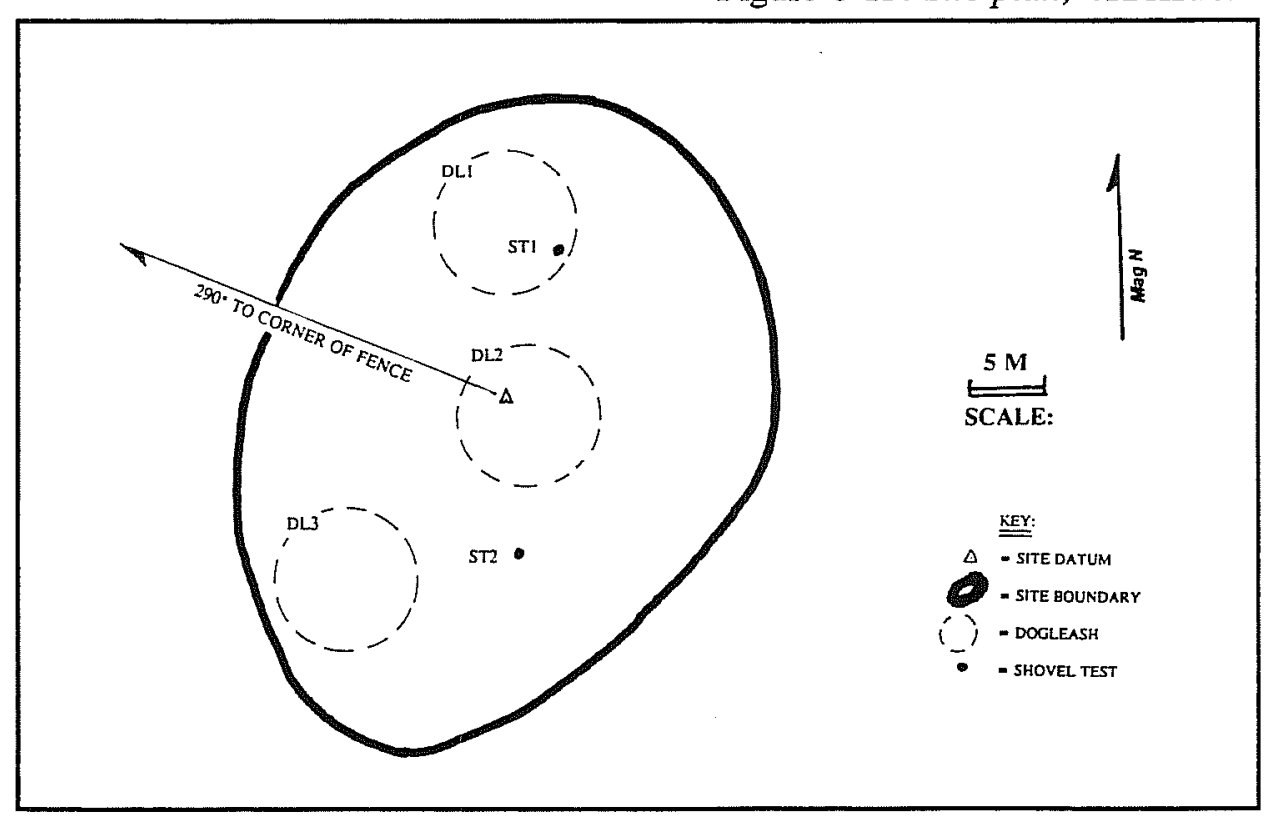




\section{BX1103}

41BX1103 (Figure 8-14) is an open campsite on the broad, flat, first terrace of Medio Creek between 41BX1102 and the creek channel $70 \mathrm{~m}$ to the north. A Transitional Archaic component is indicated by an Edgewood projectile point recovered from the surface. A shallow, intermittent west-east drainage in front of the southern edge of the site has exposed Uvalde Gravels, and most likely offered a source for raw materials. Chipped stone artifacts on the surface indicate that the gravel cobbles were reduced to cores, preforms, thin bifaces, and finally to points. A small scatter of firecracked rock indicates a possible hearth feature was present and may still be intact. One shovel test produced a continuum of stone artifacts to a depth of $80 \mathrm{~cm}$ below the surface. Fire-cracked rock was also present from 50 to $70 \mathrm{~cm}$, indicating the possibility of a buried hearth feature. Soils from the subsurface test suggest that gentle flooding episodes sealed the cultural deposits in situ.

This site has high research potential as an intact Transitional Archaic campsite based on the following criteria: 1) the presence of diagnostic materials on the surface indicating a Transitional Archaic component; 2) the likelihood of at least one, possibly two burned rock features at different levels; 3) the dense and continuous presence of chipped stone debris through all levels of the shovel test; and 4) the presence of faunal remains in the shovel test. This site deserves special attention because of these criteria, and therefore should be considered for inclusion in the NRHP within a district context.

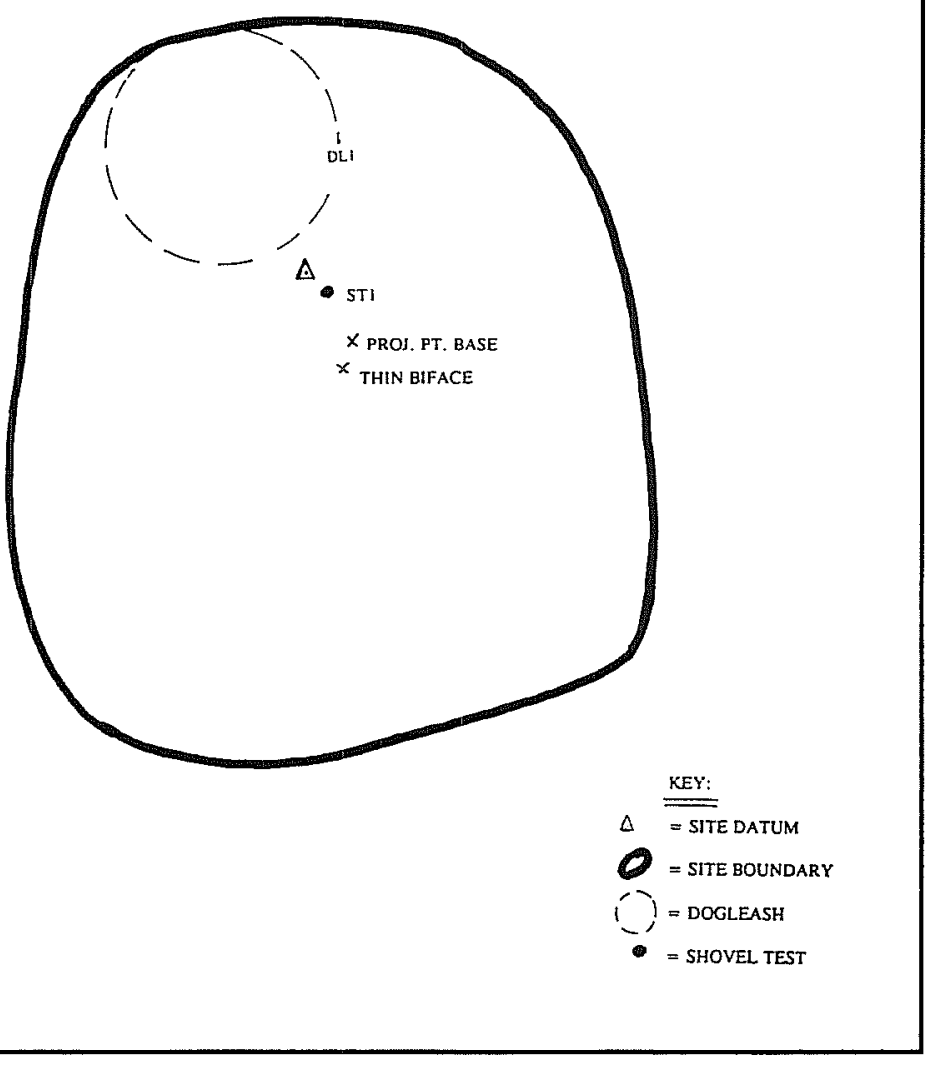

Figure 8-14. Site plan, 41BX1103.

\section{BX1114}

This large quarry and open campsite spans the edge of a high terrace and adjacent uplands above Medio Creek (Figure 8-15). Extensive outcrops of chert and fossils are exposed along its steep western edge. Surface artifacts, including cores, flakes, and blanks indicate early reduction stages. A Guadalupe biface of possible Early Archaic age was collected from the intersection of the roads that quarter the site. Blading the road exposed more artifacts than are visible in the dense vegetation that surrounds the site. Shovel testing revealed artifacts down to $30 \mathrm{~cm}$ below the surface.

The research potential of 41BX1114 is moderate to high. One shovel test revealed interior and exterior flakes and fire-cracked rocks in the upper $10 \mathrm{~cm}$, suggesting the potential of an intact cultural deposit with a hearth feature. This site should be considered for inclusion in the NRHP within a district context. 


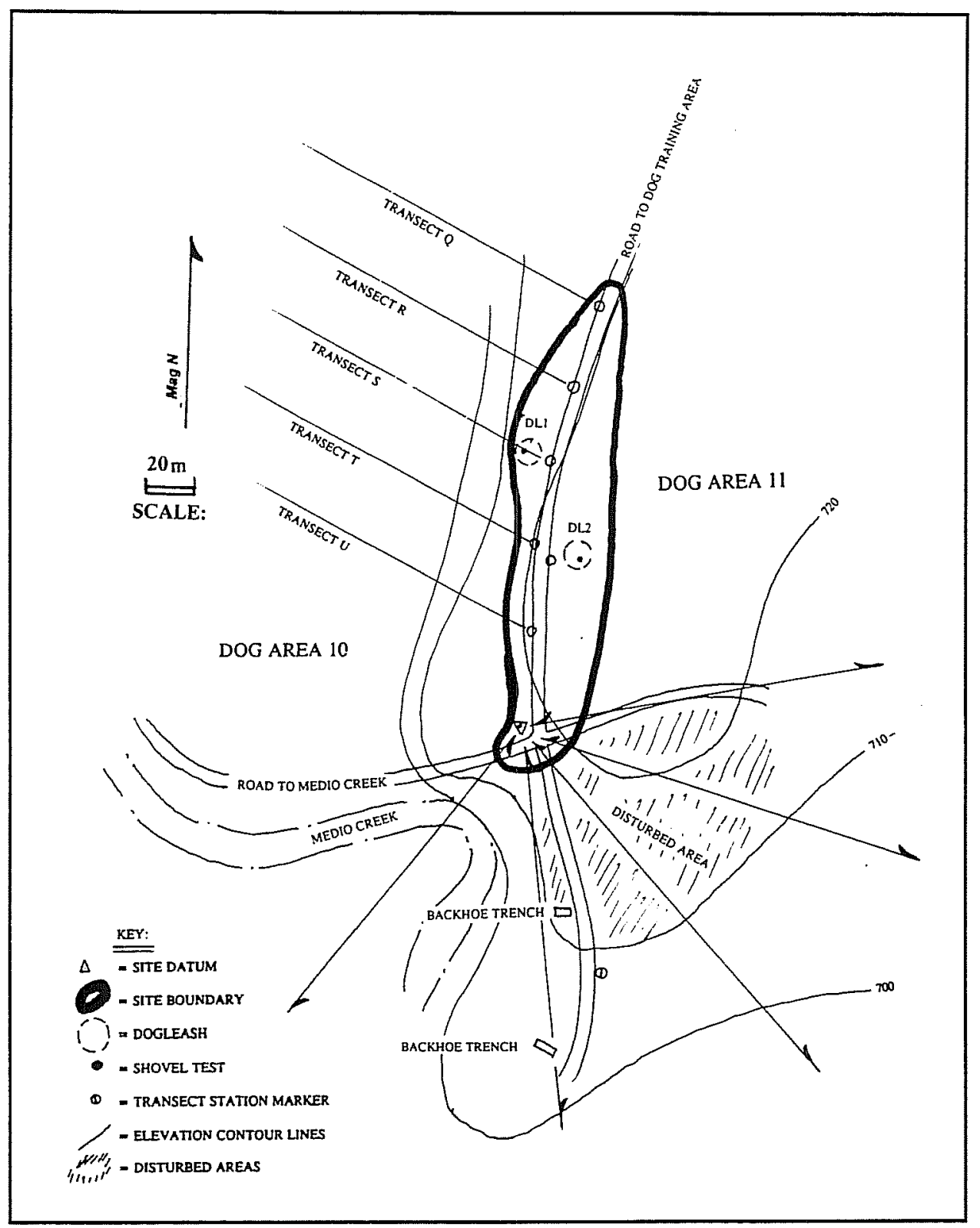

Figure 8-15. Site plan, $41 B X 1114$.

\section{BX1115}

41BX1115 (Figure 8-16) is an open campsite near the edge of the first terrace above Medio Creek. A dense covering of creek/upland flora severely hampered efforts to determine the full extent of the site. Erosion from an intermittent drainage has exposed raw chert cobbles on the east edge of the site. Various stages of lithic reduction and a relatively large quantity of firecracked rock on the surface suggest a campsite with one or more hearth features. A single shovel test revealed no subsurface artifacts. However, the site's location on an alluvial terrace suggests that a buried intact cultural deposit exists in the Lewisville silty clays. Research potential of $41 \mathrm{BX} 1115$ is moderate to high based on the evidence for advanced phases of lithic reduction, and the possibility of a burned rock feature. This site should be considered for inclusion in the NRHP within a district context. 


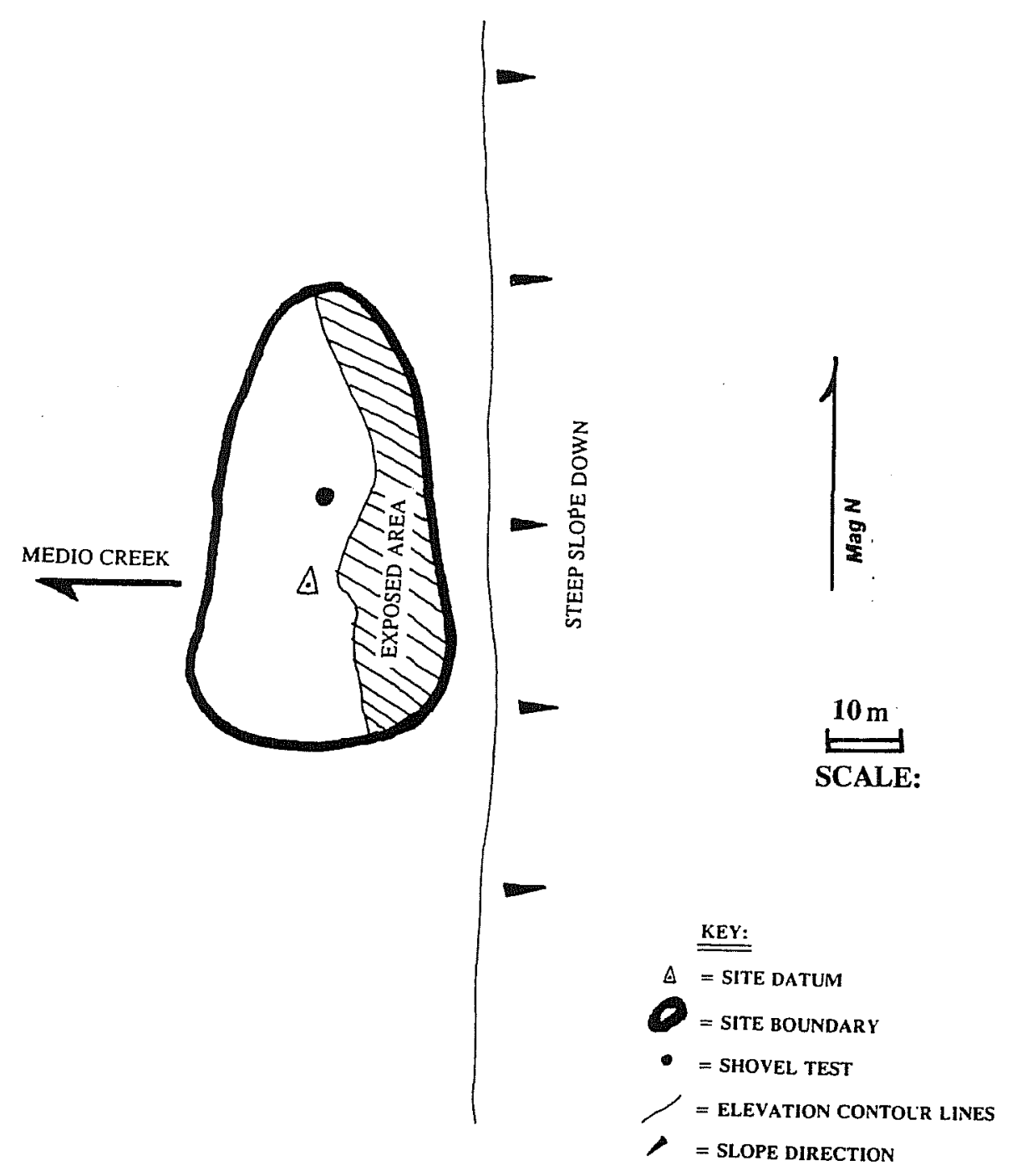

Figure 8-16. Site plan, 41BX1115.

\section{BX1119}

This lithic quarry (Figure 8-17) rests on the flat, first terrace with Medio Creek $65 \mathrm{~m}$ to the south. Early stage lithic reduction activities are represented by a light scatter of cores, exterior and interior flakes, and informal tools. Flora across the site includes typical creek and upland species. The site has experienced only minimal disturbance from animal burrowing and possible plowing. Shovel testing yielded no artifacts below the surface, but the site's location on an alluvial terrace indicates that buried intact cultural deposit(s) might be present. The research potential of $41 \mathrm{BX} 1119$ is moderate; therefore, the site should be considered for inclusion in the NRHP within a district context. 


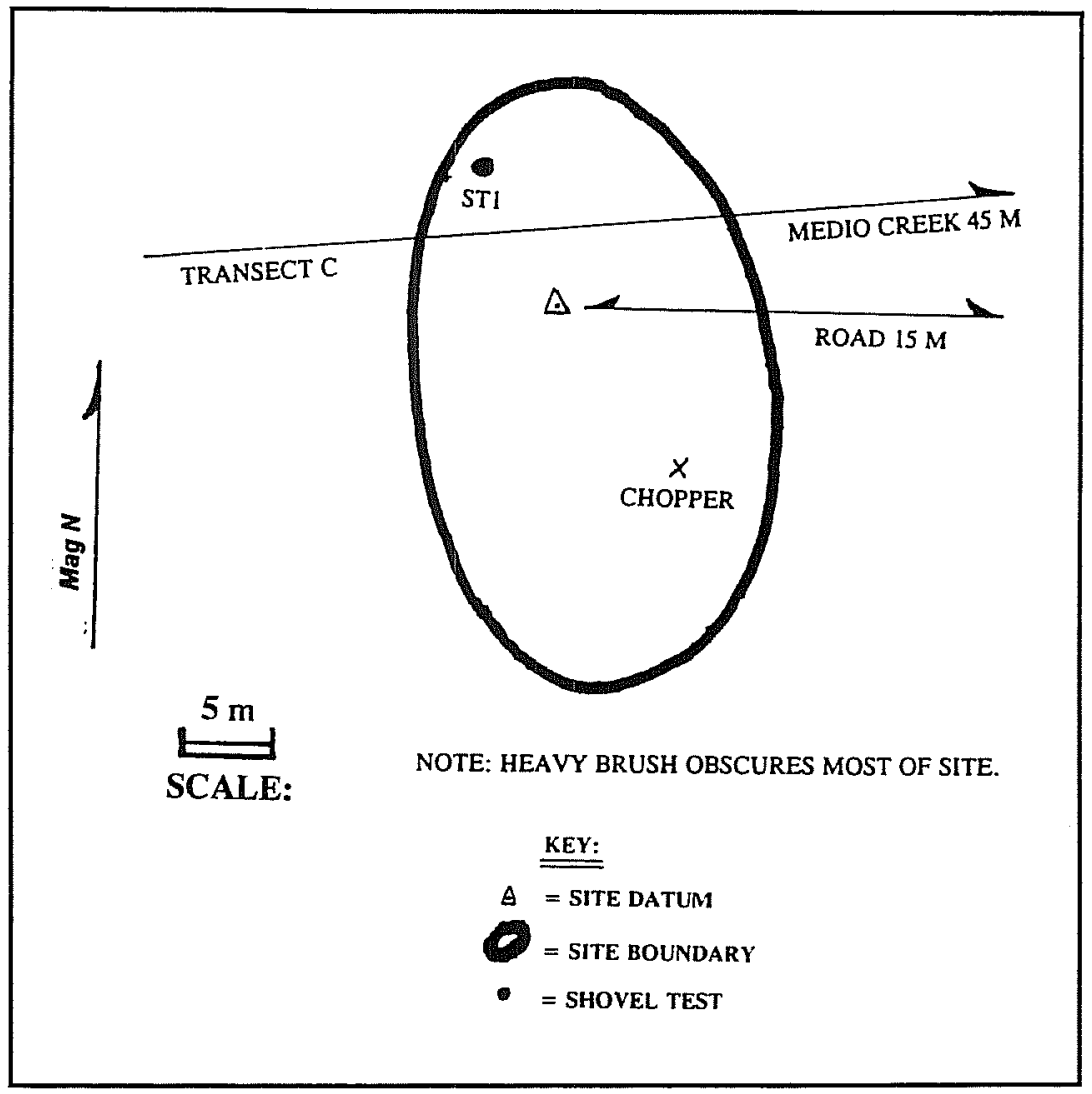

bifacial thinning flakes to $30 \mathrm{~cm}$ below the surface. Creek/upland vegetation covers this first terrace above Medio Creek (200 $\mathrm{m}$ to the east). Minimal disturbance was caused by animal burrowing and machinery.

41BX1120 has high research potential as a largely intact campsite. Subsurface cultural material revealed in a shovel test suggests a potential for buried features, formal tools, and diagnostic artifacts. This site deserves special attention because of its exceptional integrity. This site should be considered for inclusion in the NRHP within a district context.

Figure 8-17. Site plan, 41BX1119.

\section{BX1120}

This open campsite is unusual for the very high quantity of fire-cracked rock within a single 5-m radius dogleash sample unit. Exterior, interior, and thinning flakes, as well as cores suggest a wide range of lithic reduction occurred at the site. Even though formal and informal tools were not located, the evidence suggests that $41 \mathrm{BX} 1120$ (Figure 8-18) was an open campsite. A single shovel test revealed exterior, interior, and

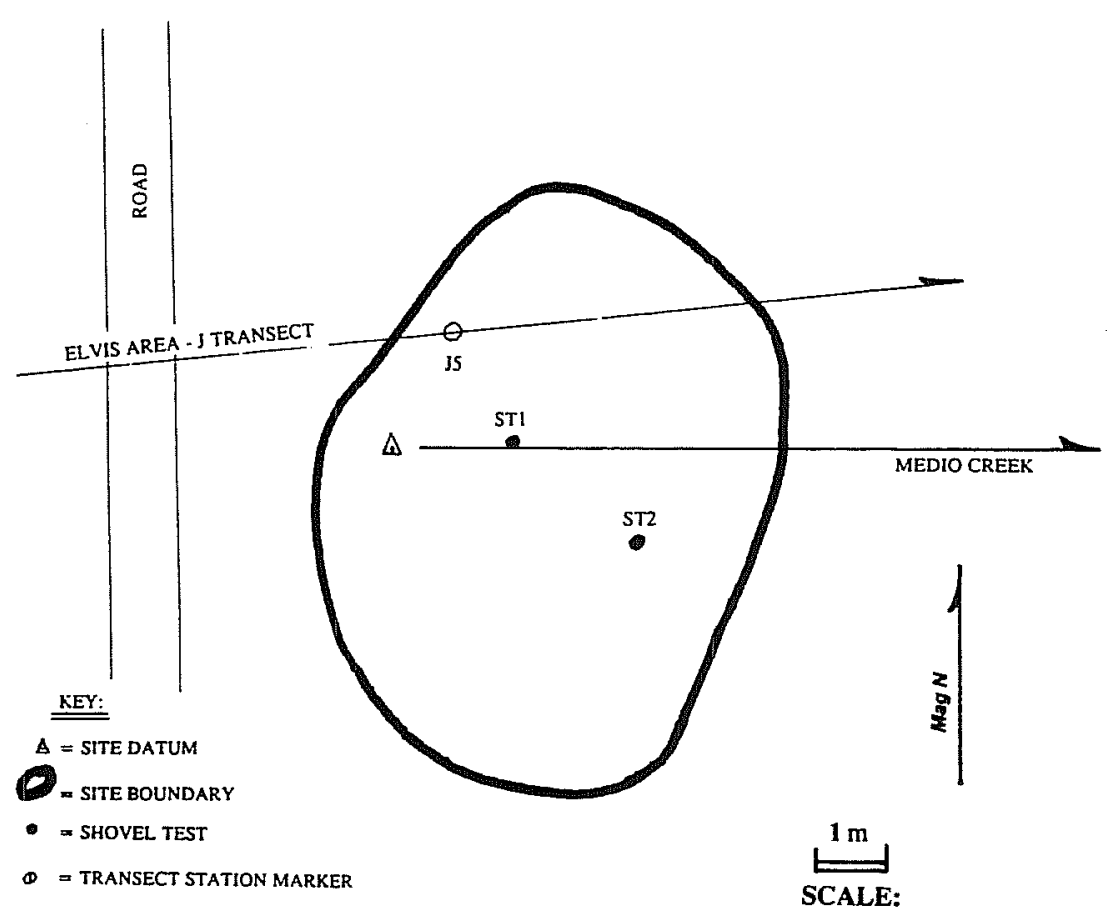

Figure 8-18. Site plan, 41BX1120. 


\section{BX1121}

$41 \mathrm{BX} 1121$ is a prehistoric campsite and quarry, with a historic component consisting of a collapsed stone structure (Figure 8-19). The site rests on the edge of a broad and flat first terrace which abruptly drops to Medio Creek $35 \mathrm{~m}$ to the west. A large quantity of densely clustered artifacts, including cores, flakes, a thin biface, and a Pedernales dart point (Middle to Late Archaic) were found beneath the dense upland vegetation. A possible groundstone fragment was also located on the surface. The remarkable quantity of fire-cracked rock suggests one or more hearth features may be present. Disturbance caused by natural and artificial action has been minimal. A shovel test produced artifacts to a depth of $60 \mathrm{~cm}$ below the surface.

41BX1121 has high research potential as an intact Middle or early Late Archaic campsite. The positive shovel tests indicate that buried cultural features and other archaeological materials are likely, and thus this site deserves special attention because of its exceptional integrity. This site should be considered for inclusion in the NRHP within a district context.

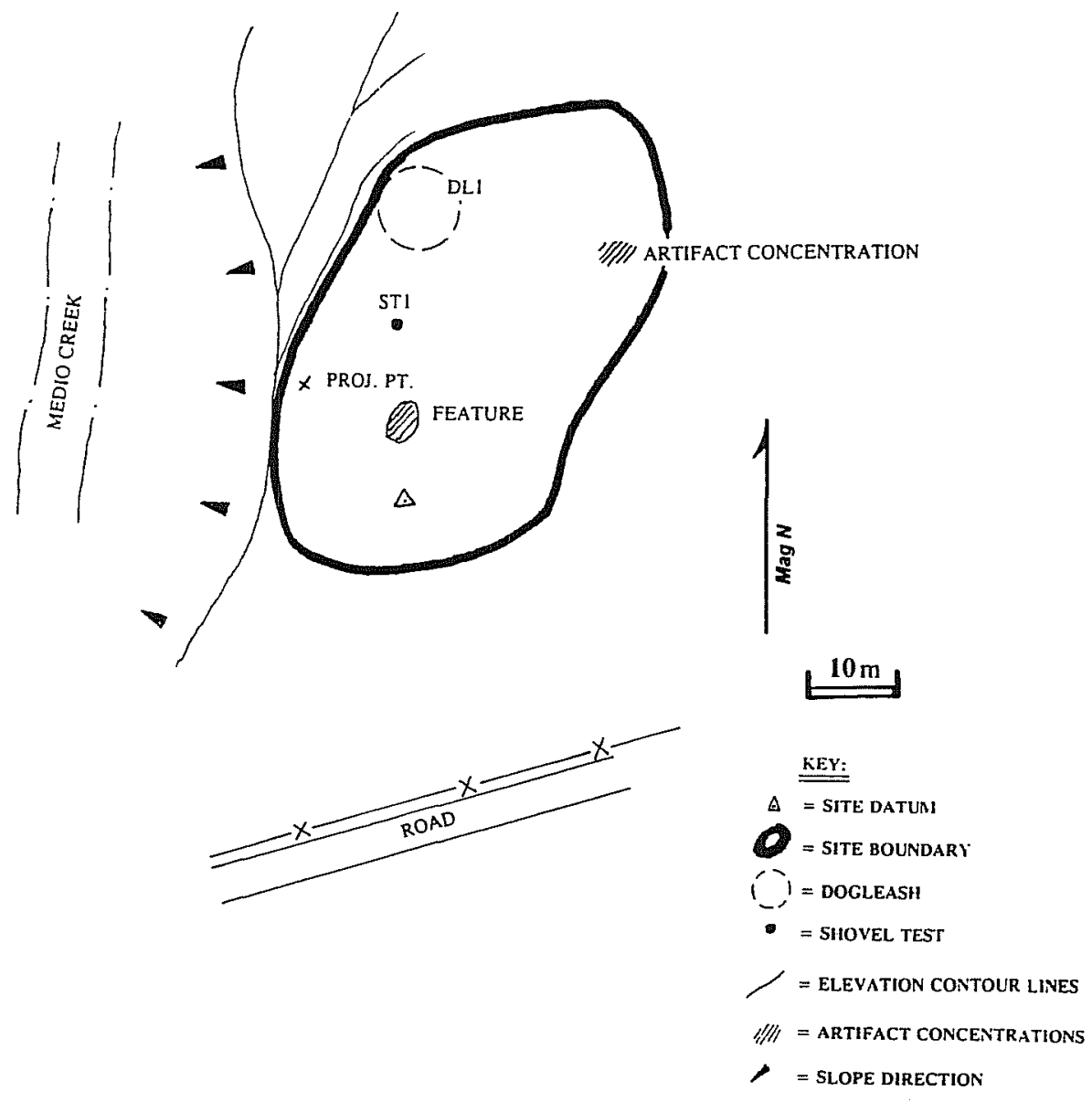

Figure 8-19. Site plan, 41BX1121. 


\section{BX1122}

$41 B X 1122$ (Figure 8-20) is an open campsite and quarry on the edge of the broad, flat first terrace, 10 m south of Medio Creek. Dense upland vegetation obscures the surface. High numbers of artifacts were concentrated in some areas of the site. An Edwards arrow point (Late Prehistoric) was found on the surface, with cores, flakes, a blank, a preform, an informal tool, and a thin biface. Collectively these suggest that a full range of lithic- reduction activities occurred on this site. The possible presence of burned rock features is indicated by a high quantity of firecracked rock. Erosion and a two-track road on the site's borders have caused minimal disturbance. Shovel testing revealed artifacts present in silty clay

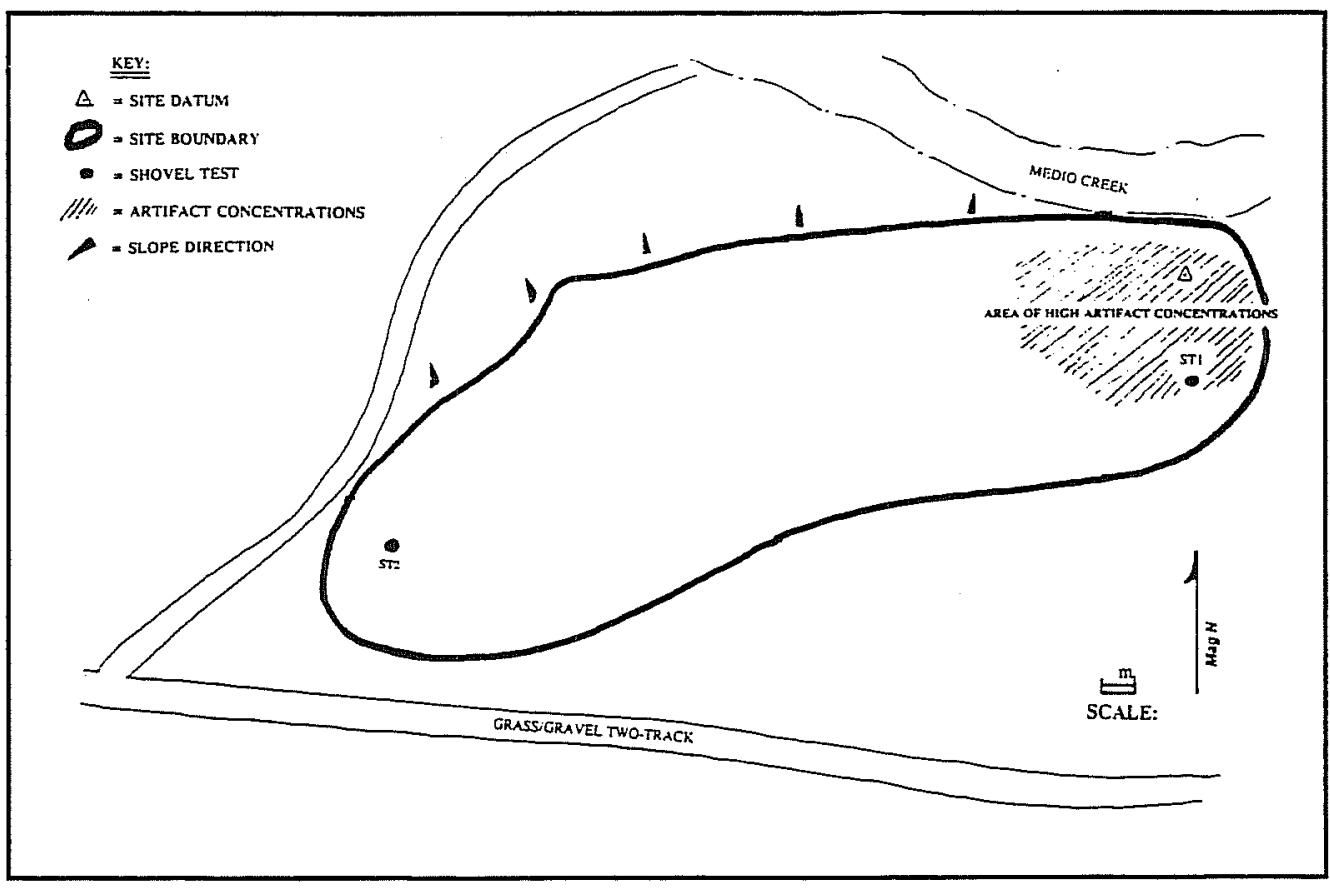

Figure 8-21. Site plan, 41BX1123.

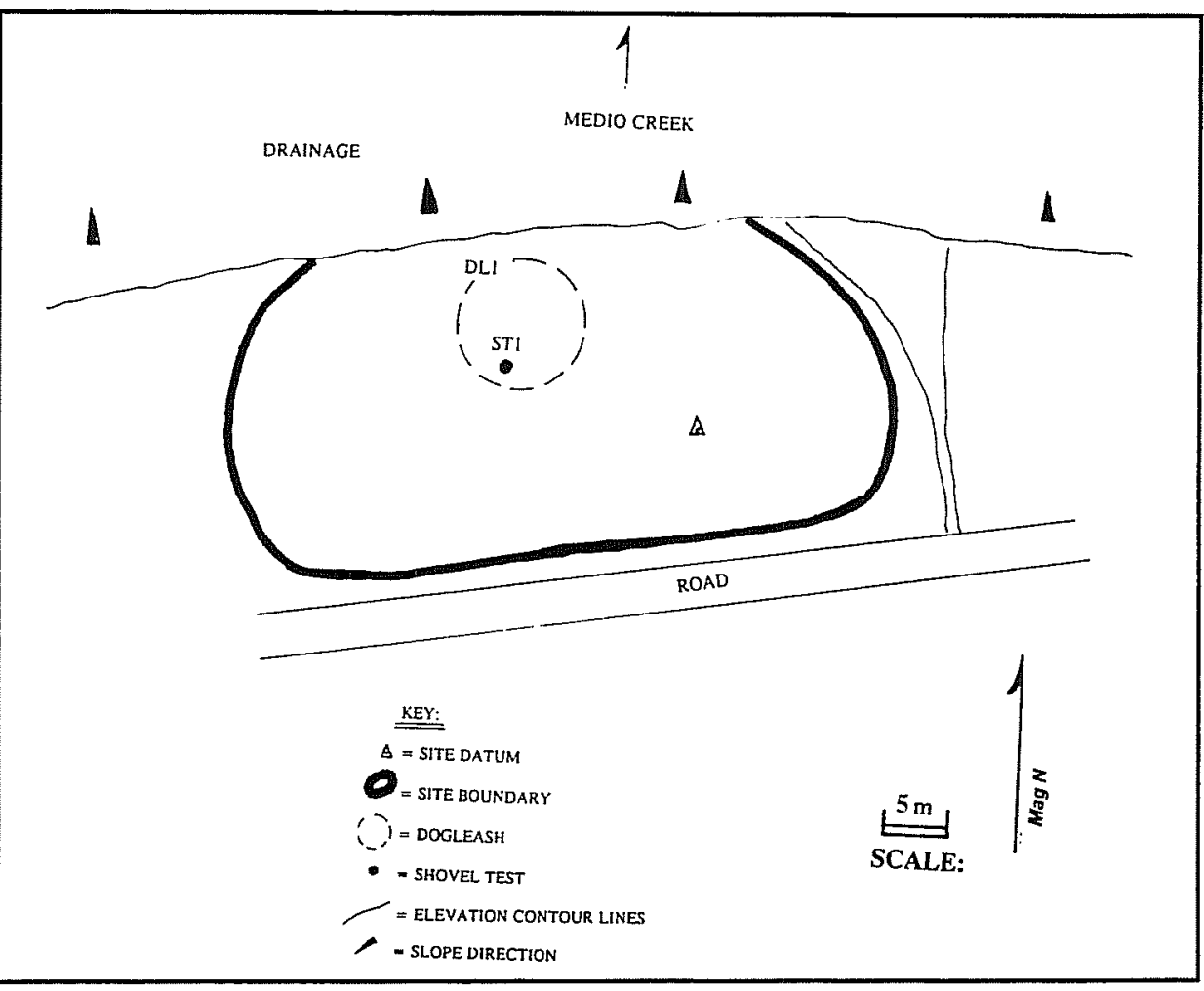

Figure 8-20. Site plan, 41BX1122.

to $50 \mathrm{~cm}$ below the surface, suggesting gentle flooding episodes may have sealed cultural strata in situ. Based on its research potential, 41BX1122 should be considered for inclusion in the NRHP within a district context.

\section{BX1123}

This quarry site lies $60 \mathrm{~m}$ southwest of Medio Creek (Figure 8-21), on the edge of the second terrace above the creek. Flora on the site are upland species. The lithic artifacts, which include one blank, cores, flakes, and an informal tool, suggest early stage 
reduction activities. All were probably made from the raw chert sources that outcrop along the northern site edge. Erosion and a two-track road have minimally disturbed the site. Two shovel tests at the site revealed artifacts to a depth of $30 \mathrm{~cm}$ below the surface. Shovel tests suggest the potential for buried intact cultural deposits, giving a moderate research potential for 41BX1123. The site should be considered for inclusion in the NRHP within a district context.

\section{BX1125}

This open campsite (Figure 8-22) has a relatively high quantity of fire-cracked rock, possibly from a hearth feature. The unusually high number of exterior, interior, and thinning flakes suggests latestage lithic-reduction activities. The creek has cut into the western edge of the site, where artifacts are eroding from below the surface. A shovel test revealed artifacts to $10 \mathrm{~cm}$ below the surface, but the creek bank indicates cultural debris eroding from a depth of approximately $50 \mathrm{~cm}$ below the surface. It is ideally situated as a campsite in the floodplain, and immediately adjacent to Medio Creek. The dense vegetation covering the area consists of creek/upland species.

Despite disturbance from erosion, the artifact assemblage, possible hearth feature, and potential for buried cultural deposits offer a moderate to high research potential for 41BX1125. This site should be considered for inclusion in the NRHP within a district context.

\section{BX1126}

A drainage forms the eastern boundary of this open campsite, where three small burned rock features are eroding from below the surface (Figure 8-23). The dense upland/creek vegetation was cleared to reveal lithic debris characteristic of an intermediate reduction phase (interior and bifacial thinning flakes) and more fire-cracked rock on the surface. A shovel test and scrutiny of the drainage cutbank indicates the potential for a buried intact cultural deposit 40 to $60 \mathrm{~cm}$ below the surface. The adjacent drainage flows into Medio Creek, $83 \mathrm{~m}$ to the west.

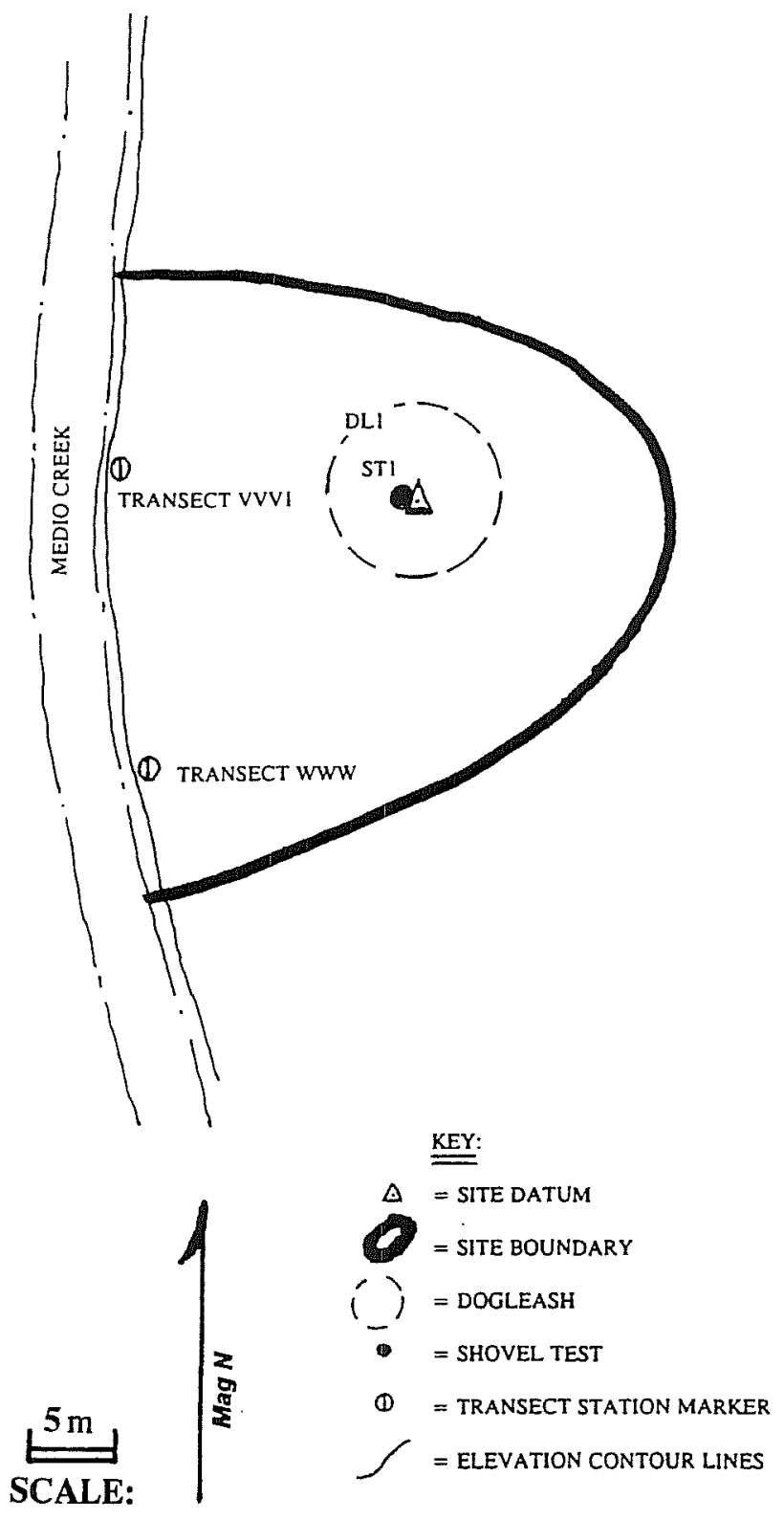

Figure 8-22. Site plan, 41BX1125. 


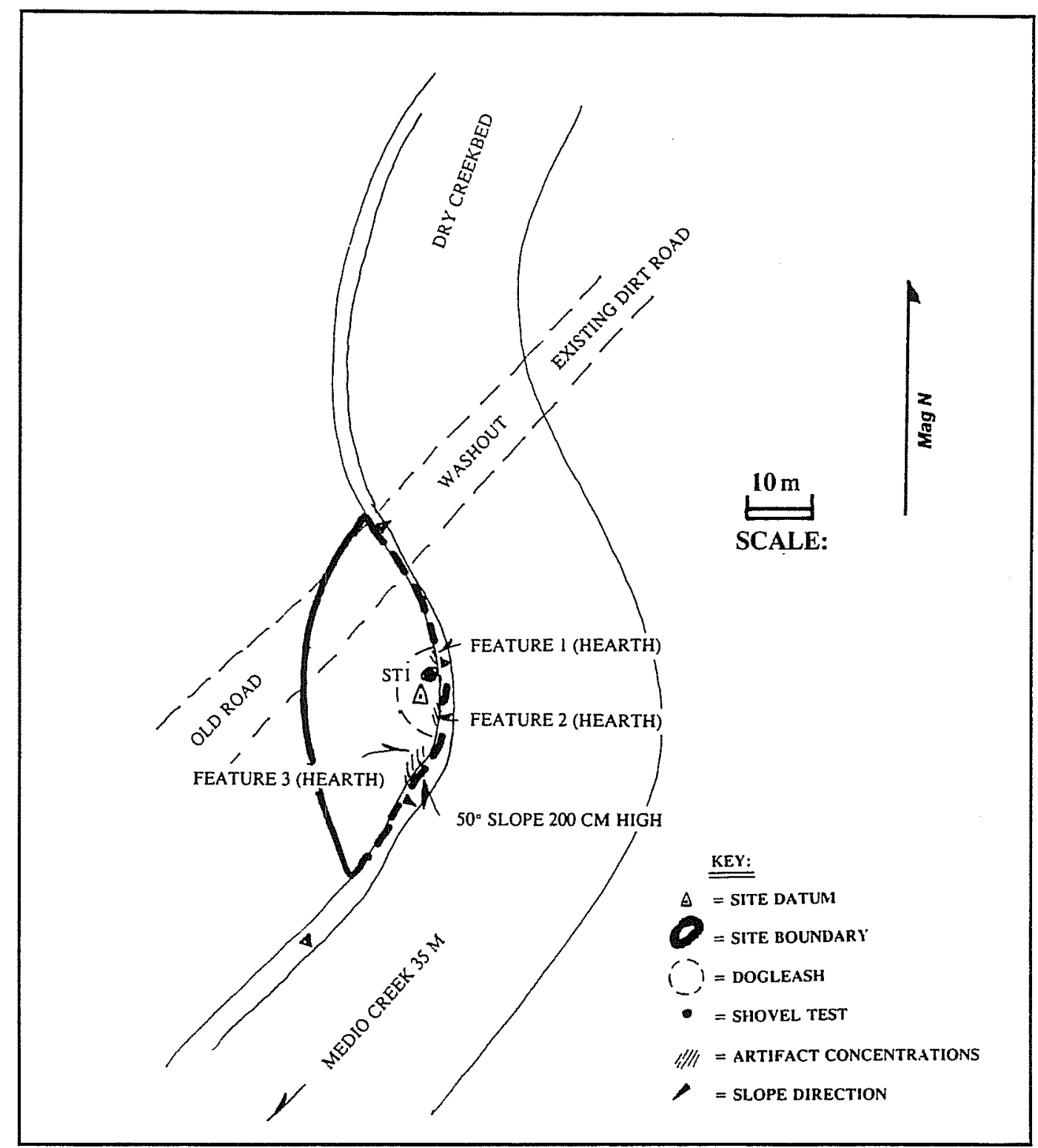

Figure 8-23. Site plan, 41BX1126.

Despite erosion, much of the site appears to remain intact. The three hearth features and positive shovel tests strongly suggest a buried campsite. Therefore, the research potential of 41BX1126 is high, and the site should be considered for inclusion in the NRHP within a district context.

\section{BX1127}

$41 B X 1127$ (Figure 8-24) is an open campsite on the first terrace above Medio Creek, $75 \mathrm{~m}$ to the west.
The dense vegetation covering the site consists of creek/upland species. Some animal burrowing has disturbed the site, but only slightly. This site has an unusually high number of fire-cracked rocks occurring in a concentrated area, strongly suggesting at least one hearth feature. The lithic assemblage indicates reduction stages from cores to a formal tool and a thin biface. A single shovel test revealed lithics, deer bone, and charcoal from 20 to $30 \mathrm{~cm}$ below the surface. In the same level, silty clays suggest that gentle flooding episodes may have sealed components of the site. In view of the possible 


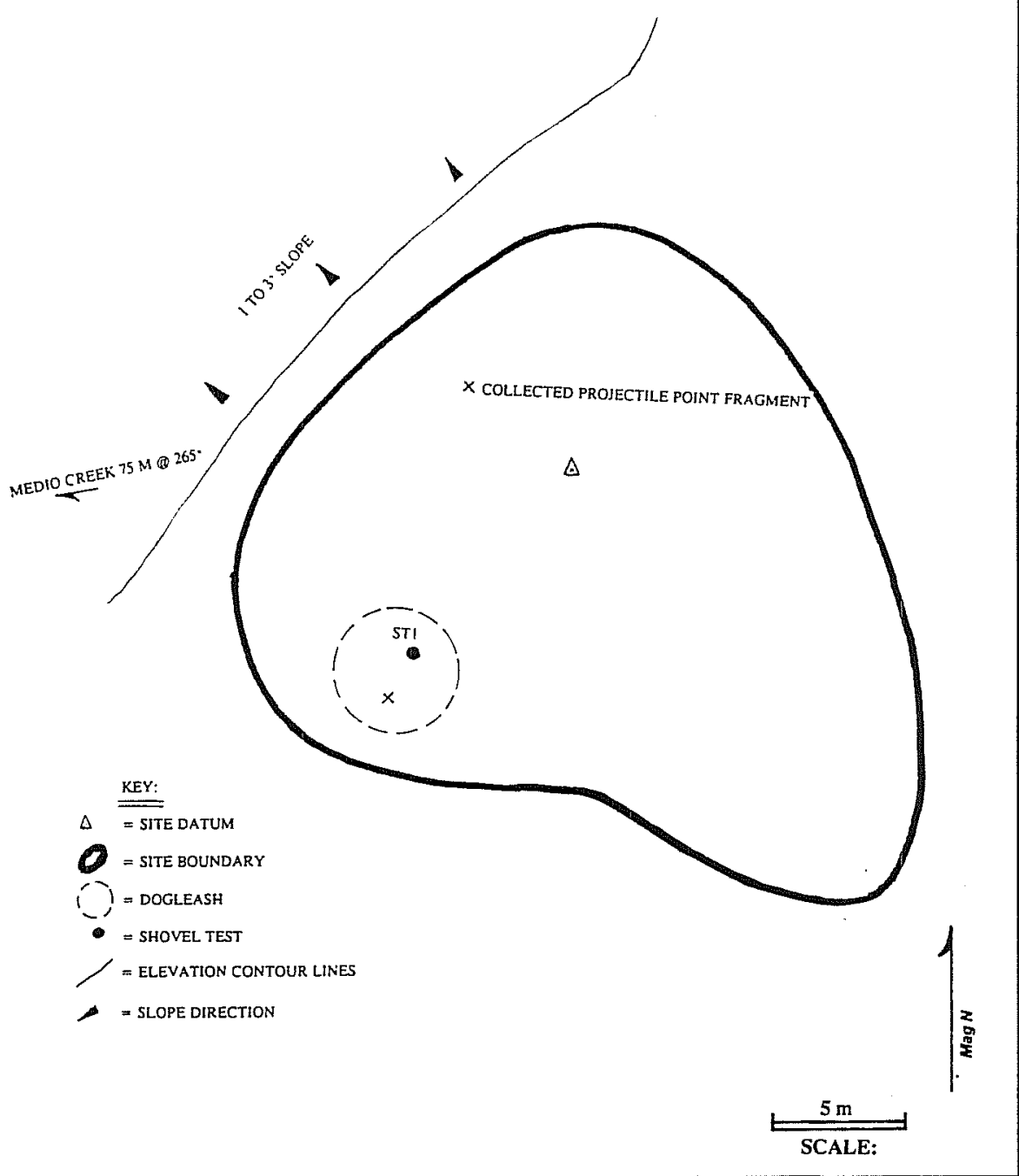

Figure 8-24. Site plan, $41 B X 1127$.

buried intact cultural strata, the research potential at 41BX1127 is high. This site should be considered for inclusion in the NRHP within a district context.

\section{BX1130}

This lithic quarry sits on the surface of the first terrace above Medio Creek, $150 \mathrm{~m}$ to the northeast. A small number of thinning flakes and a biface suggesting late-stage reduction activities were found among and around the remains of a historic structure (Figure 8-25). Dense upland vegetation covers the area. Although few artifacts were observed, many others may be hidden by historic construction materials (e.g., tin and lumber) that litter the site surface. It appears that the site has been heavily disturbed by the historic occupation. While the one shovel test revealed no subsurface artifacts, the site's location on an alluvial terrace suggests that a buried intact cultural deposit could exist.

The research potential of $41 \mathrm{BX} 1130$ is minimal as a single analytical unit, but should be considered for inclusion in the NRHP within a district framework.

\section{Long Hollow Prehistoric Sites}

Nineteen prehistoric open campsites and quarries were found in Long Hollow: 41BX1055-1059, 41BX1072, 41BX1073, $41 \mathrm{~B} \mathrm{X} 1098-1101$, 41BX1104, 41BX1110-1113, and 41BX1116-1118. Collectively, they have an estimated age range of Early Archaic through Late Prehistoric. The higher elevations above the drainage bottom were exploited as prehistoric quarry sources, with archaeological sites occurring where surface exposures of the gravels are extensive, the cobbles are larger in size, and their density great. The largest and clearest example of this relationship is site $41 \mathrm{BX} 1104$ which spans more than $1,300 \mathrm{~m}$ along the southern half of the western slope. A brief description of each site is given, with particular reference to site type and setting, associated artifact assemblage, disturbance suffered by the site, known future impacts, and research potential. 


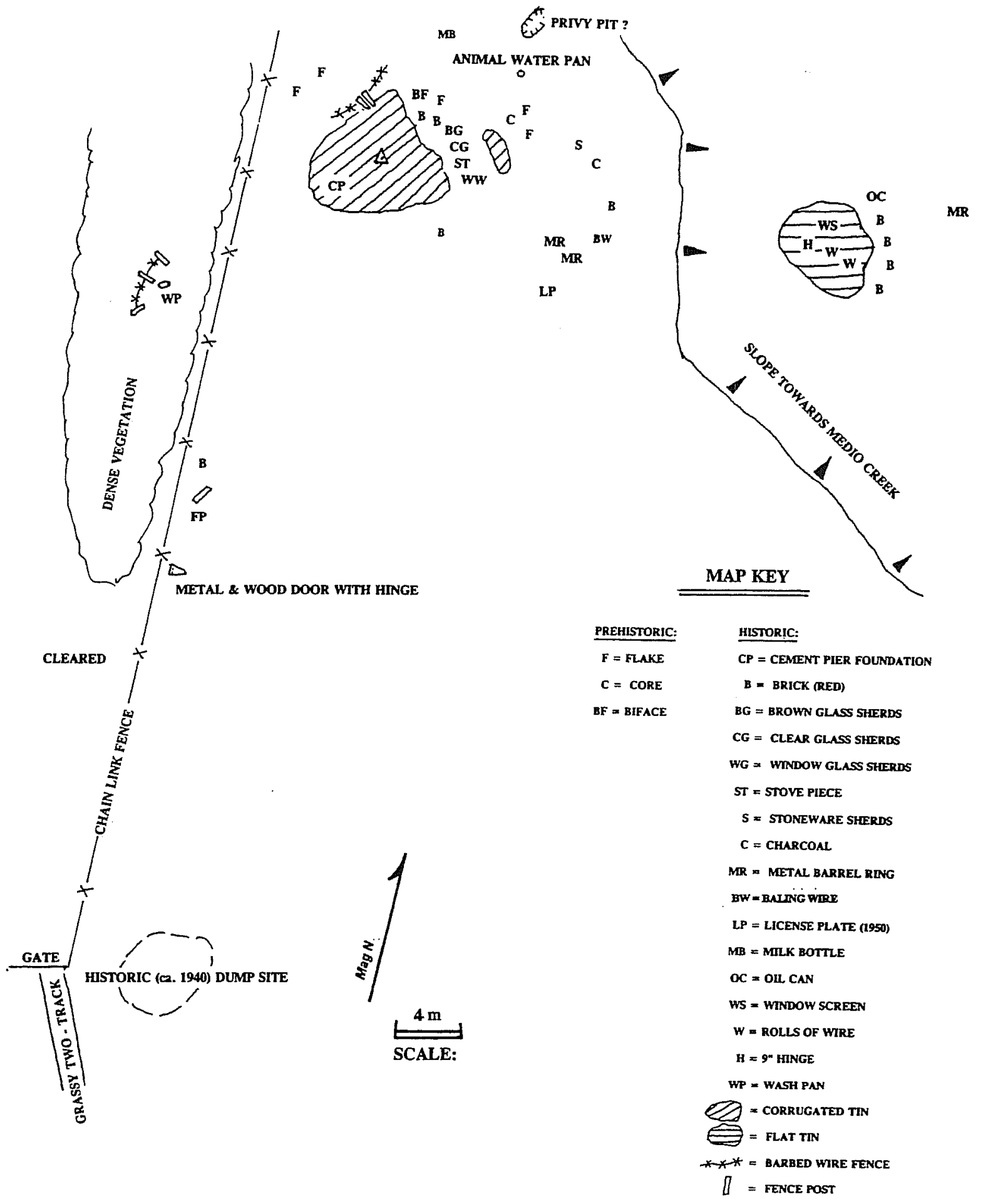

Figure 8-25. Site plan, 41BX1130. 


\section{BX1055}

41BX1055 (Figure 8-26) is a quarry with upland vegetation, $375 \mathrm{~m}$ east of the Long Hollow drainage. A runoff channel cuts through the site, where chert gravels crop out along both edges. A light assemblage of early and intermediate stage reduced cores, flakes, and a formal tool were widely dispersed over the surface. Three shovel tests revealed no subsurface artifacts. The site has been moderately disturbed by erosion and military training exercises.

The potential of this small quarry is moderate; therefore, the site should be considered for inclusion in the NRHP within a district context.

\section{$41 B \times 1056$}

This quarry is set in the uplands overlooking Long Hollow, $350 \mathrm{~m}$ to the west (Figure 8-27). A runoff channel cuts through the site, exposing raw chert cobbles. Artifacts on the surface are thinly scattered flakes and cores, suggesting that early stage lithic reduction activities occurred on the site. A shovel test produced bifacial thinning flakes at $0-10$ and $30-40 \mathrm{~cm}$ below the surface. The site has been heavily disturbed on the surface by land clearing, erosion, and animal burrowing. However, the positive shovel test results suggests a buried and possibly intact cultural deposit. The potential of this small quarry is moderate; therefore, the site should be considered for inclusion in the NRHP within a district context.

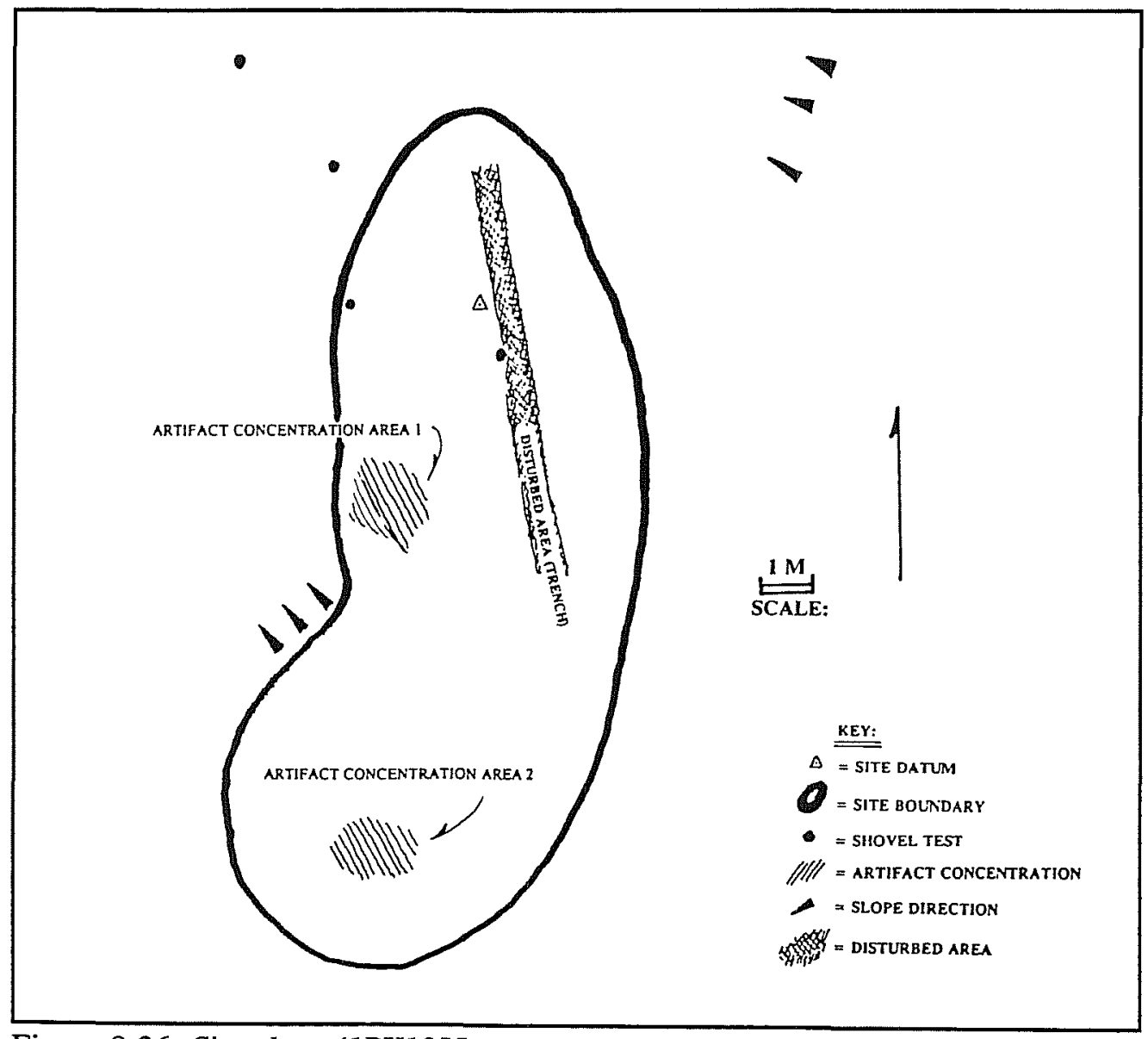

Figure 8-26. Site plan, 41BX1055. 


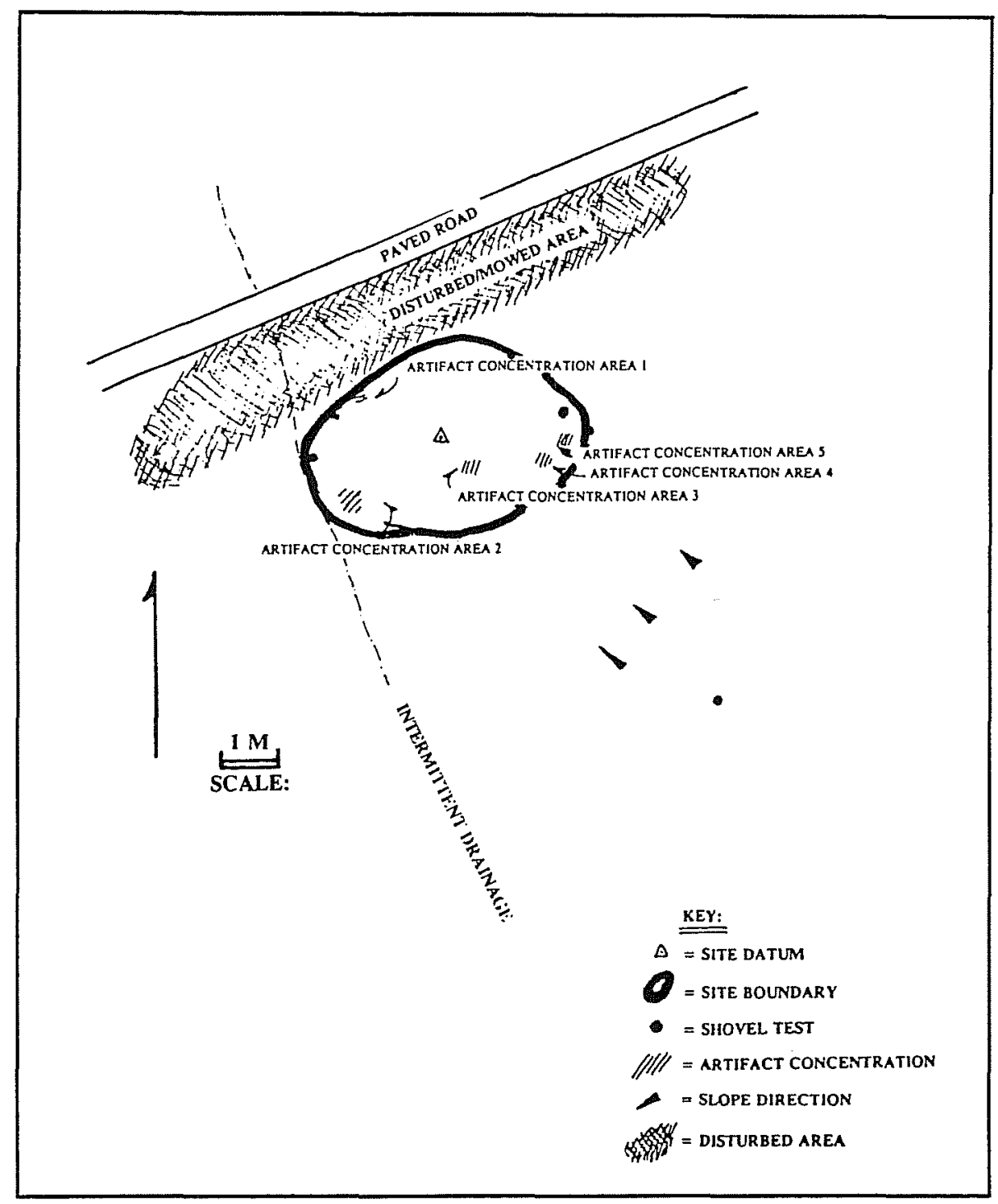

Figure 8-27. Site plan, 41BX1056.

\section{BX1057}

41BX1057 is a quarry on the abrupt edge of an uplands slope (Figure 8-28), facing Long Hollow 400 $\mathrm{m}$ to the west. Cores, flakes, a quarry blank, and an informal tool dominate an assemblage characteristic of early reduction stages. A shovel test revealed no subsurface artifacts. A road cut, military bunkers and foxholes, erosion, and animal burrowing have heavily damaged the site. The research potential of 41BX1057 is moderate; therefore, the site should be considered for inclusion in the NRHP within a district context.

\section{BX1058}

41BX1058 (Figure 8-29) is a quarry consisting of cores, flakes, and a quarry blank on the surface, suggesting early stage reduction activities. A shovel test revealed artifacts to $10 \mathrm{~cm}$ below the surface. The site sits in the uplands with Long Hollow $385 \mathrm{~m}$ to the west. Military training exercises, animal burrowing, and erosion have moderately disturbed the site. The research value of this small quarry is moderate; therefore the site should be considered for inclusion in the NRHP within a district context. 


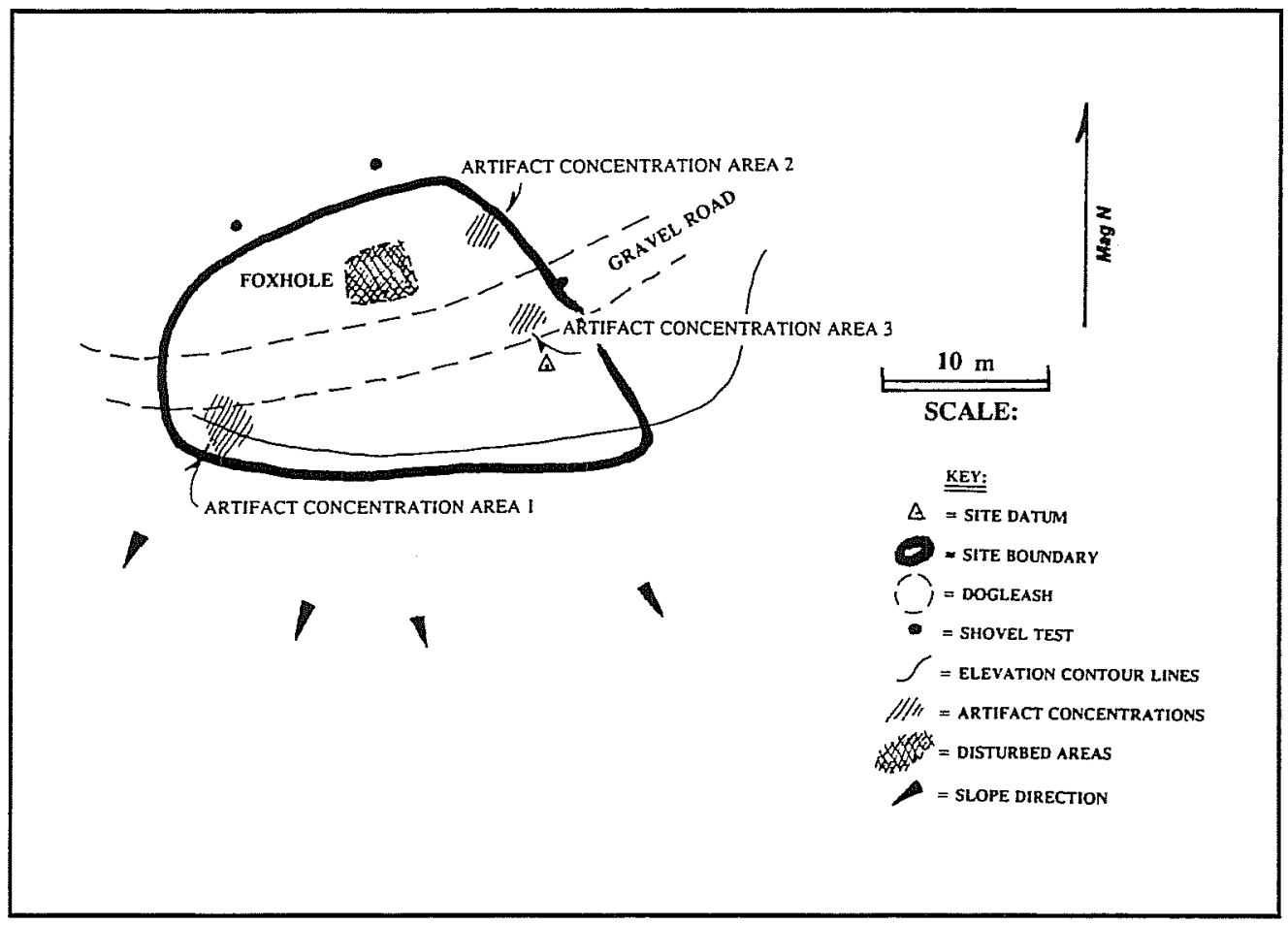

Figure 8-28. Site plan, $41 B X 1057$.

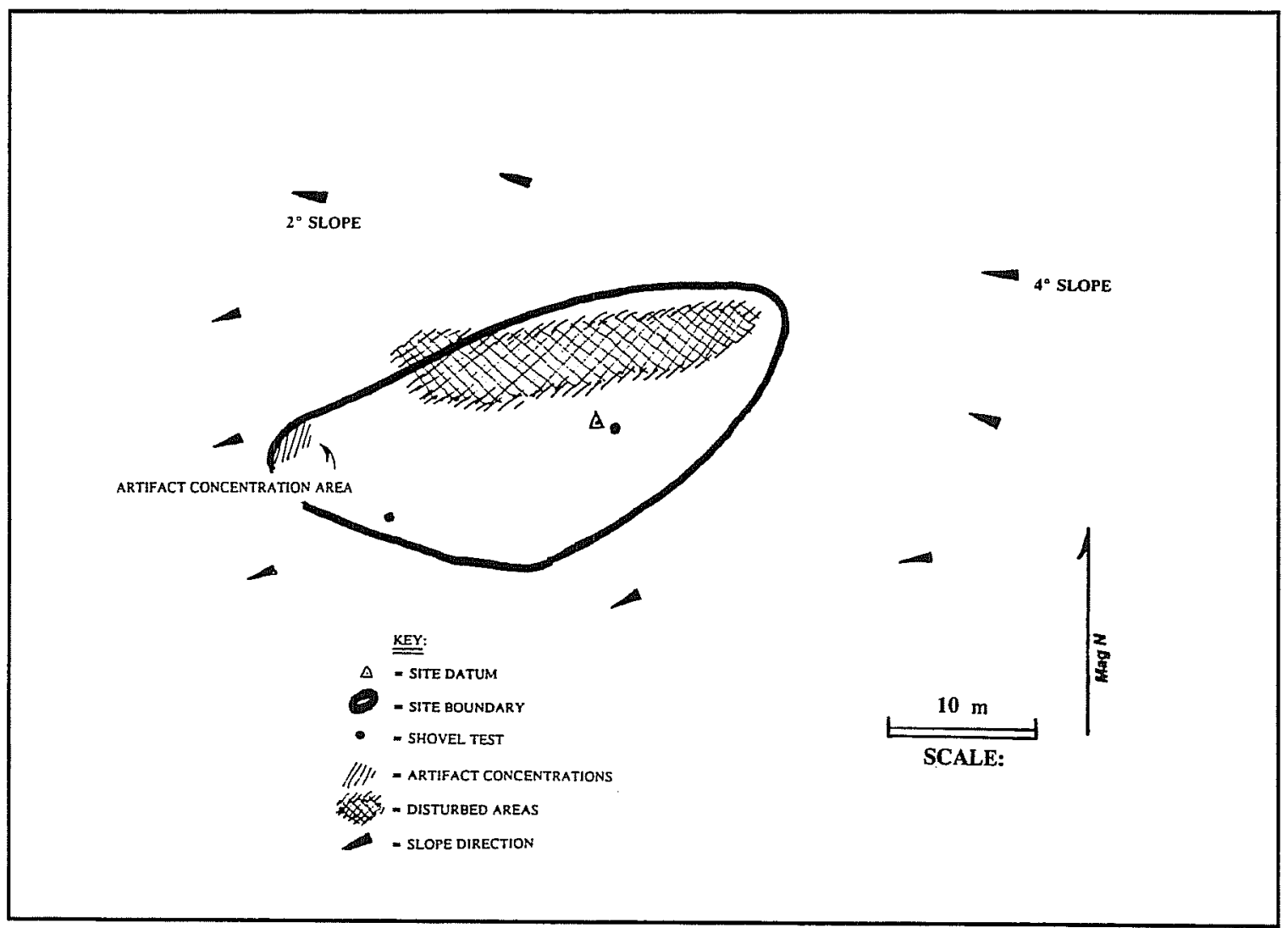

Figure 8-29. Site plan, $41 B X 1058$. 


\section{BX1059}

This open campsite and quarry sits on a gradual uplands slope which faces Long Hollow $310 \mathrm{~m}$ to the west (Figure 8-30). Cores and flakes were the only chipped-stone artifacts observed, but the site has an unusually high quantity of fire-cracked rock. The predominance of cores and exterior flakes represents early stages in lithic reduction activities. A shovel test revealed 12 interior flakes within the first $10 \mathrm{~cm}$ below the surface. The site has been moderately disturbed by military training exercises and possible land clearing.

Despite the disturbance, the high number of firecracked rocks on the surface suggests one or more hearth features may be present, while the positive shovel test implies a possible buried intact cultural deposit. Therefore 41BX1059 has moderate site potential and should be considered for inclusion in the NRHP within a district context.

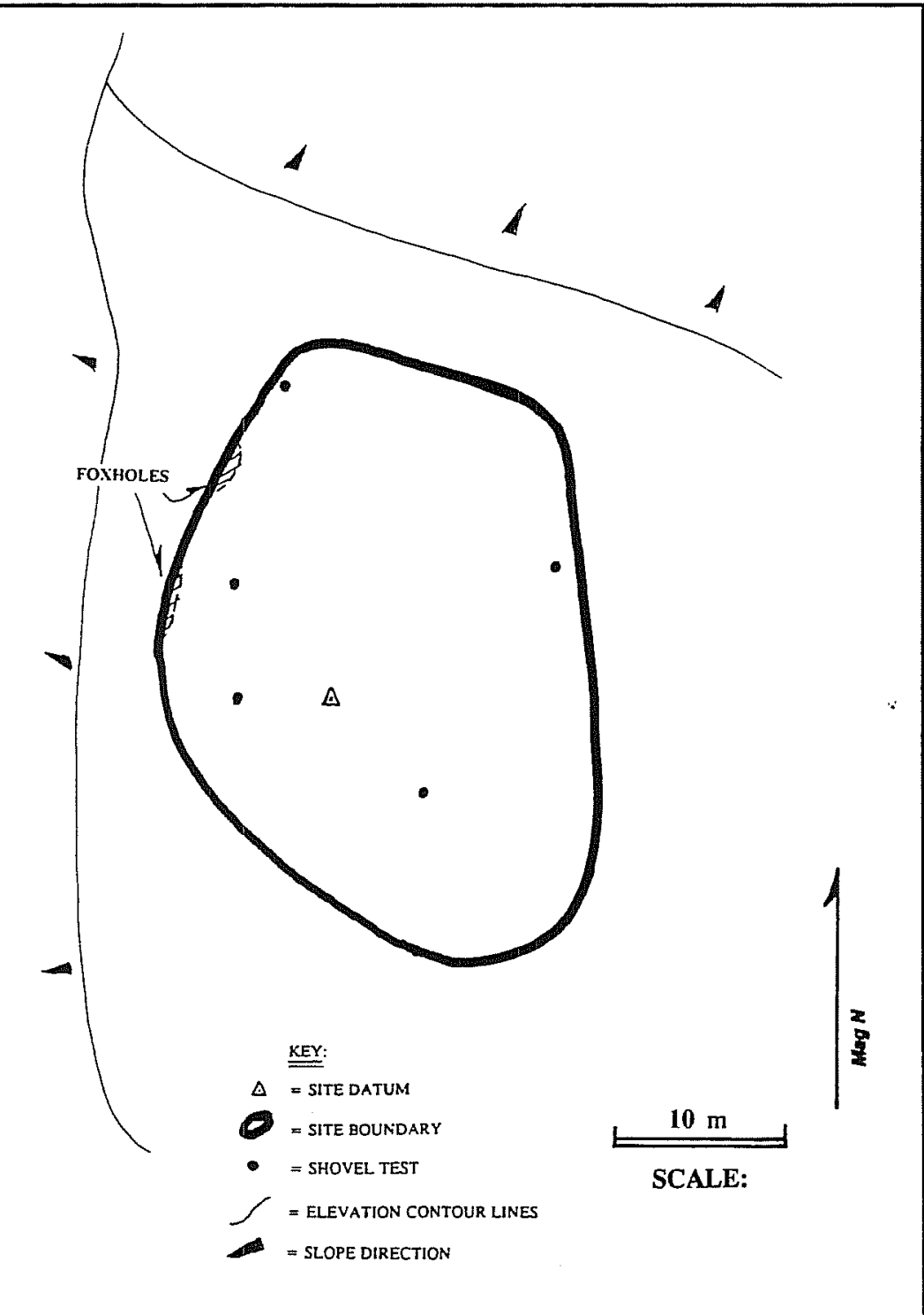

Figure 8-30. Site plan, 41BX1059. 


\section{BX1072}

41BX1072 (Figure 8-31) is a prehistoric quarry represented by a heavy, yet diffuse, surface scatter of artifacts which provide evidence for all stages of lithic reduction. Shovel test results indicate a potential for intact subsurface cultural deposits at $10-20 \mathrm{~cm}$ and again at $30-40 \mathrm{~cm}$ below the surface. A Clear Fork uniface collected from the surface implies an Early Archaic component at the site. The site is in an uplands setting on a prominent point $270 \mathrm{~m}$ east of Long Hollow. and yucca. Shovel testing in two locations revealed the potential for subsurface cultural deposits at 0-20 $\mathrm{cm}$ in one shovel test, and $30-60 \mathrm{~cm}$ below the surface in the other. The positive shovel tests suggests the possibility of buried intact cultural deposits.

The site has suffered considerable surface disturbance, but still has moderate research potential and should be considered for inclusion in the NRHP within a district context.
A road cut through the site resulted in the destruction of a significant portion of its west end. The eastern part appears to be only lightly disturbed. The positive shovel test suggests the possibility of an intact buried cultural deposit, indicating moderate research potential for this site. Therefore 41BX1072 should be considered for inclusion in the NRHP within a district context.

\section{BX1073}

Site 41BX1073 (Figure $8-32$ ) is a small quarry with early stage lithic-reduction materials, primarily cores and flakes. The site is set on a small drainage course $100 \mathrm{~m}$ south of $41 \mathrm{BX} 1072$, and $310 \mathrm{~m}$ west of Long Hollow. The area is covered by grasses, mesquites,

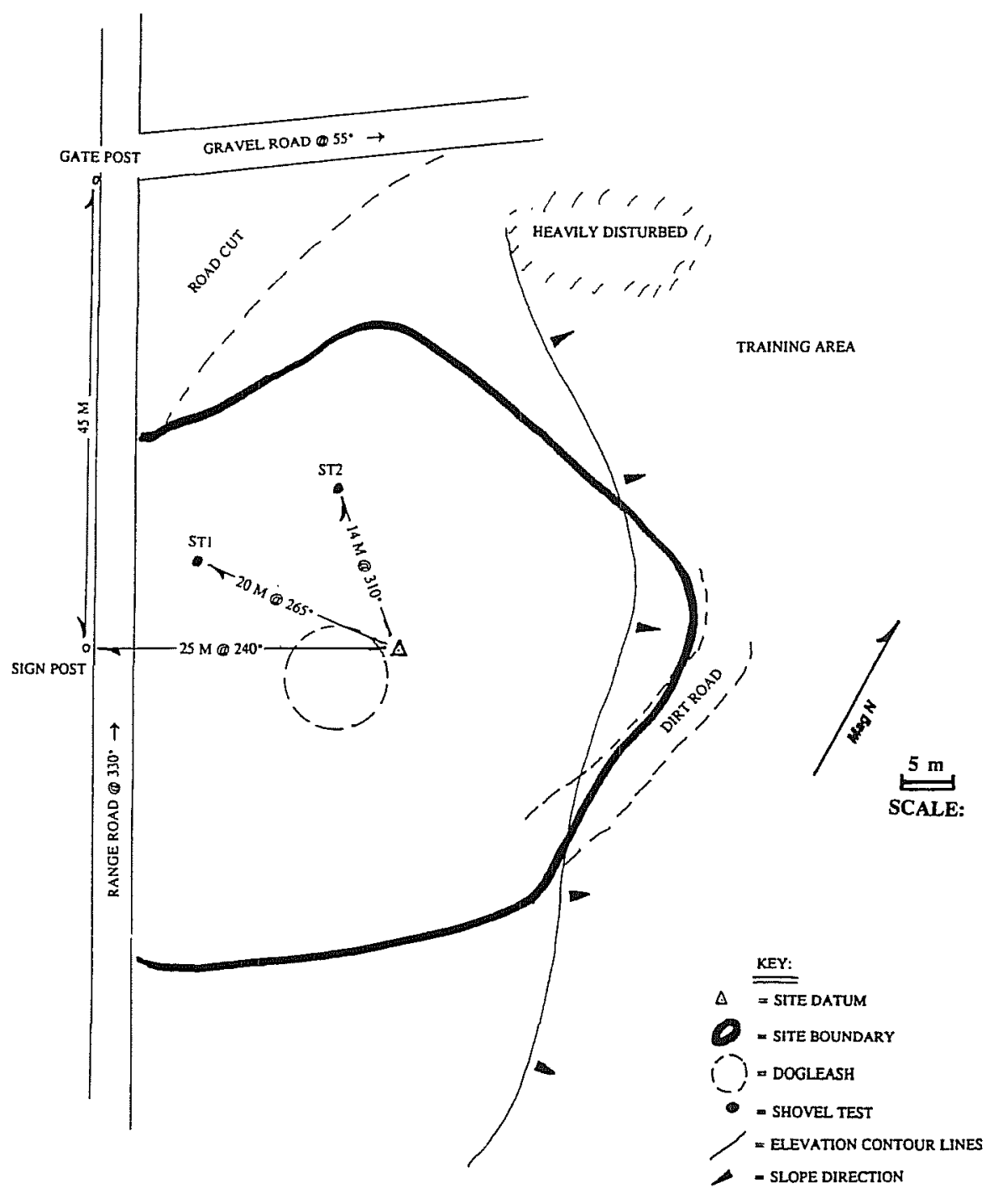

Figure 8-31. Site plan, 41BX1072. 


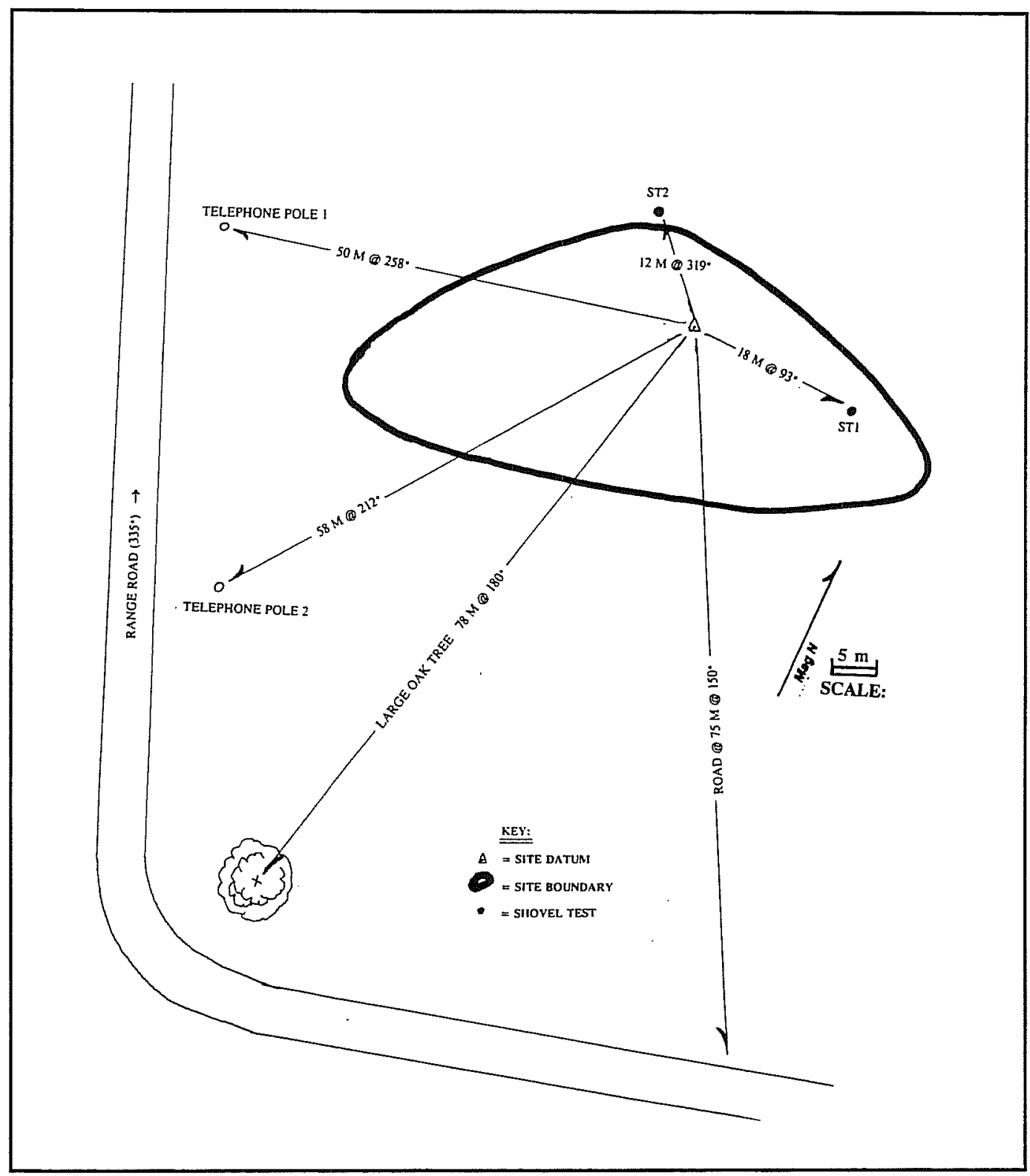

Figure 8-32. Site plan, 41BX1073.

\section{BX1098}

41BX1098 (Figure 8-33) is a small lithic quarry primarily composed of exterior flakes from the early stages of lithic reduction. The site sits in the uplands above and $100 \mathrm{~m}$ east of Long Hollow. Upland vegetation covers the site. A shovel test revealed flakes and a fire-cracked rock $0-20 \mathrm{~cm}$ below the surface, suggesting the possibility of a buried intact cultural deposit.
The site does not appear to have suffered any considerable damage, only limited erosion and rodent burrowing. It has moderate research potential and should be considered for inclusion in the NRHP within a district context. 


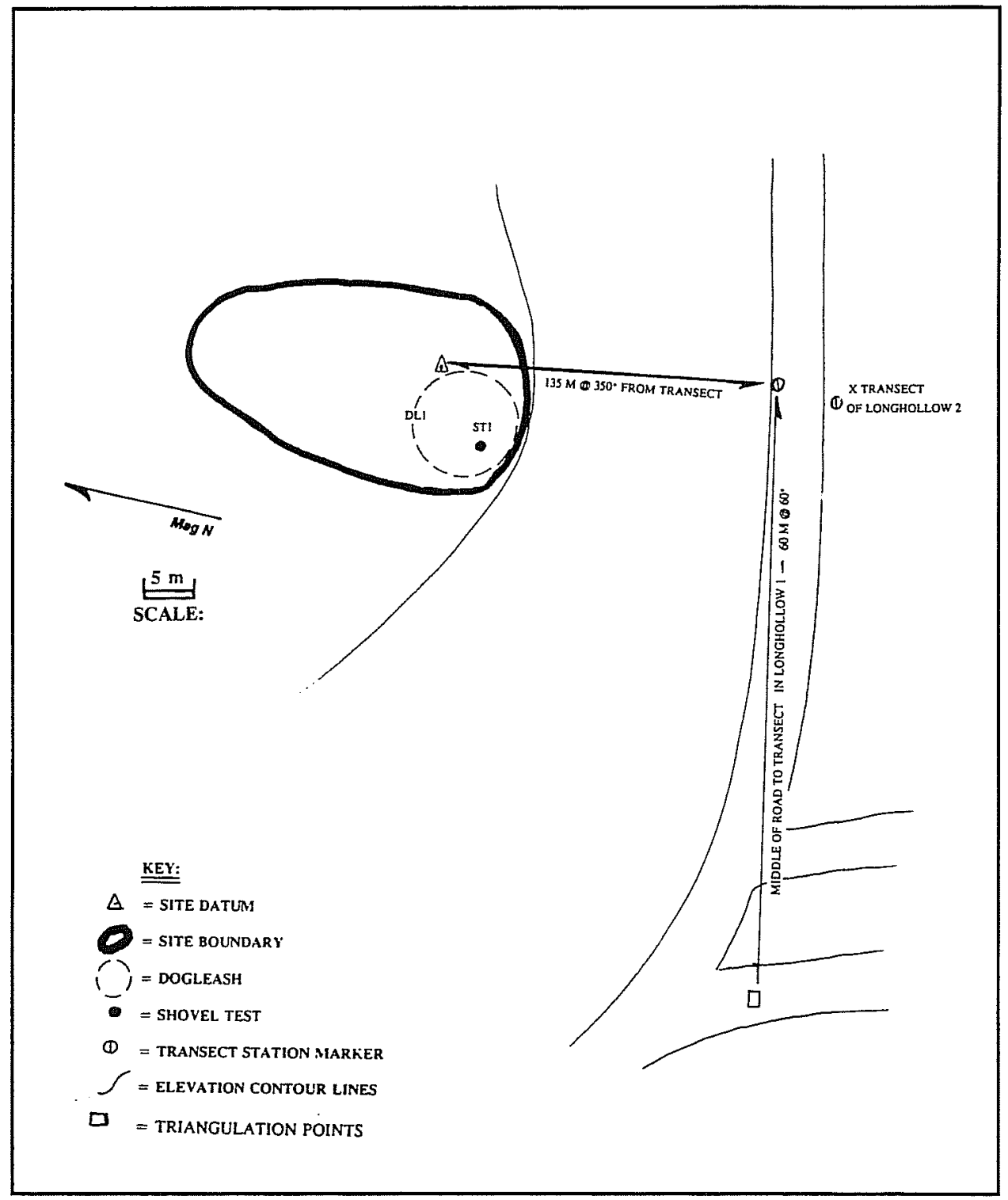

Figure 8-33. Site plan, 41BX1098.

\section{BX1099}

41BX1099 (Figure 8-34) is a quarry site divided into two zones of moderate artifact density. The sparse presence of fire-cracked rock and several informal tools suggests that it also may have served as an open campsite. Cores, flakes, informal tools, and a preform on the surface are evidence for early stage reduction activities. A shovel test revealed flakes occurring between $30-50 \mathrm{~cm}$ below the surface. The site is set on the gradual eastern slope of Long Hollow, $100 \mathrm{~m}$ to the west. Moderate to dense upland flora covers the site. 41BX1099 has suffered significant damage from the service road cut between the site and the weapons storage complex to the east. However, shovel testing revealed the possibility of a buried and intact cultural deposit, suggesting the site has moderate research potential. It should be considered for inclusion in the NRHP within a district context. 


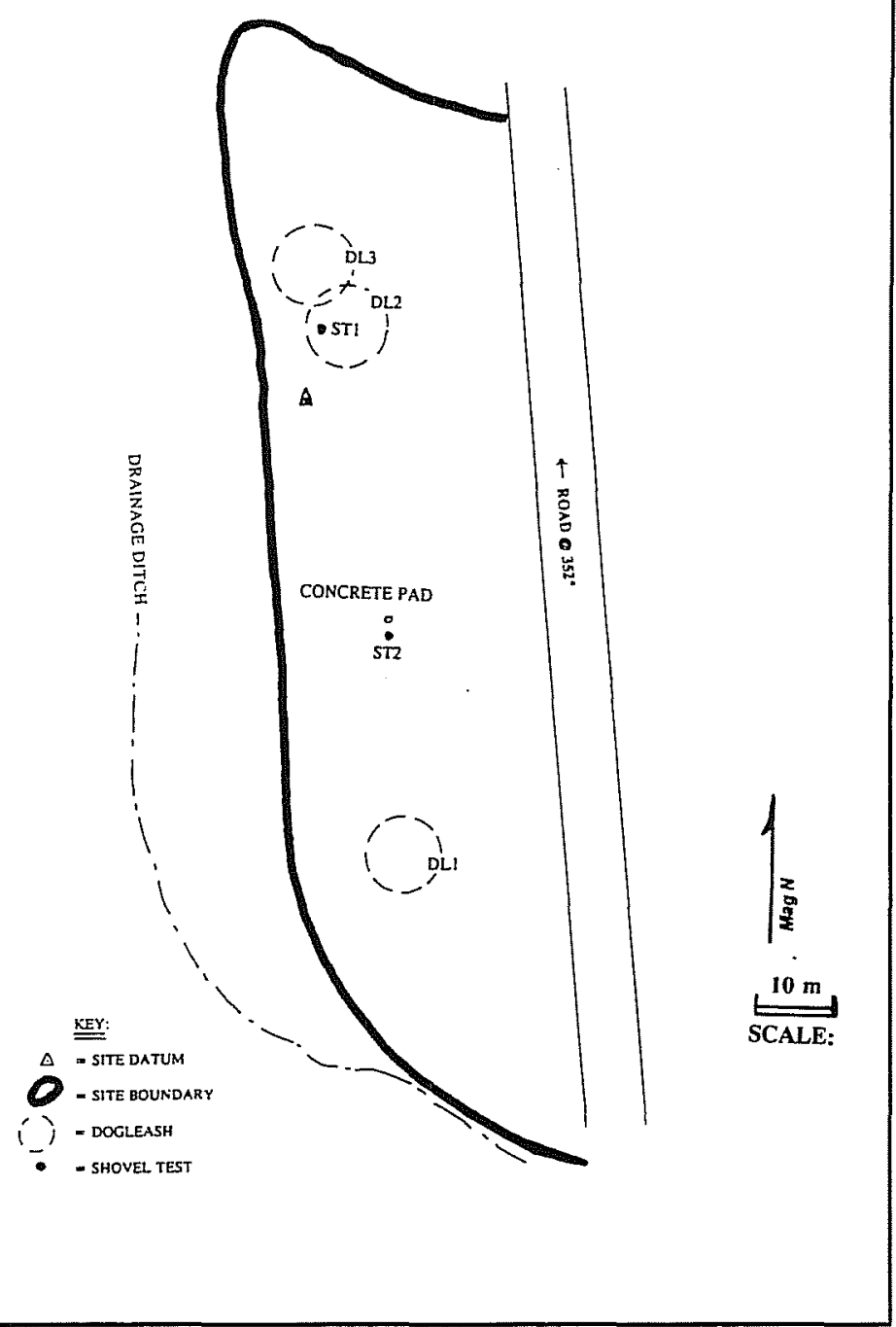

Figure 8-34. Site plan, 41BX1099.

\section{BX1100}

41BX1100 (Figure 8-35) is a large quarry and open campsite complex located on the eastern slope of Long Hollow. The site spans the width of the valley, from the drainage bottom to the higher elevations along the perimeter fence of the weapons storage complex. Creek and upland vegetation covers the site. Extensive exposures of Uvalde Gravels run across the full width of the valley, offering abundant raw materials. High counts of exterior flakes and cores suggest at least early stage reduction activities occurred at the site. Fire-cracked rock occurs sporadically over the surface. Recovered artifacts include a Guadalupe biface and a Castroville dart point, which respectively suggest Early and Late Archaic occupational components at the site. Seven shovel tests indicate the possibility of buried intact deposits to a depth of $40 \mathrm{~cm}$ below the surface. The site has suffered considerable disturbance along its southeastern edge, where a service road cuts along the weapons storage complex. However, the remainder of the site has moderate research potential and should be considered for inclusion in the NRHP within a district context. 


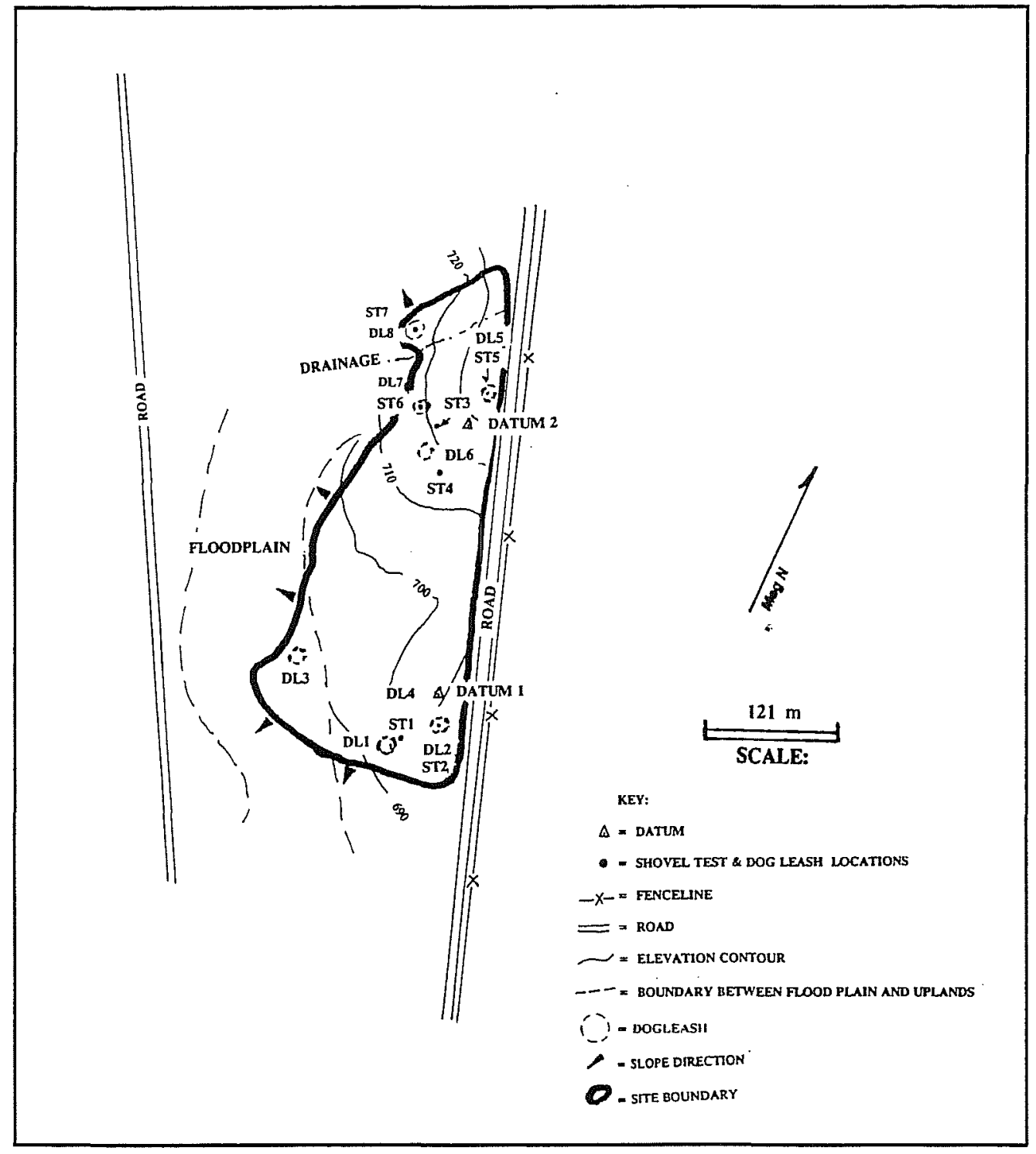

Figure 8-35. Site plan, 41BX1100.

\section{BX1101}

Site 41BX1101 (Figure 8-36) is a prehistoric open campsite and lithic quarry located near the base of Long Hollow. It is characterized by a rather compact and dense surface scatter of artifacts and fire-cracked rock directly above the drainage bottom, only $30 \mathrm{~m}$ to the east. The most numerous early stage reduction artifact types are flakes and cores, but a few retouched pieces are also present. Most notable is the high proportion of projectile points $(n=4)$ for the relatively small area of the site, suggesting that late-stage lithic-reduction activities also occurred. Three of the points are diagnostic types: Ellis, Castroville, and Frio. These suggest Late Archaic through Transitional Archaic utilization of the site. Dense creek/upland vegetation covers the area, dominated by whitebrush and scattered mesquite trees. A shovel test revealed flakes to a depth of $10 \mathrm{~cm}$ below the surface.

$41 \mathrm{BX} 1101$ is of special interest because of its compact size and the amount of diagnostic information it has thus far revealed. It has high research potential and should be considered for inclusion in the NRHP within a district context. 


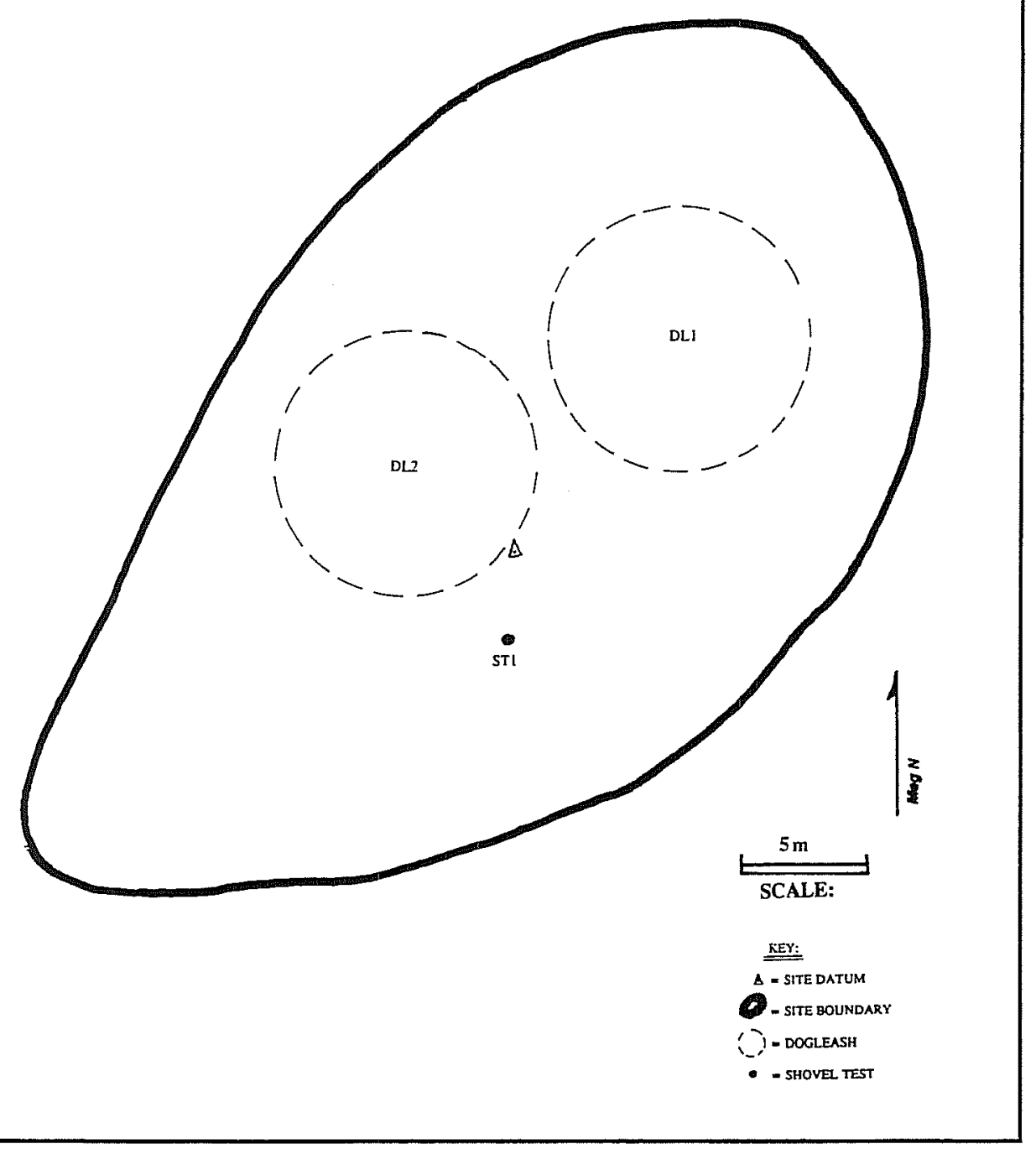

Figure 8-36. Site plan, 41BX1101.

\section{BX1104}

41BX1104 (Figure 8-37) is a site complex covering approximately 124 acres along the western slope of Long Hollow. The site spans the west valley slope, from the drainage bottom to the higher elevations along the western boundary of Medina Annex. Vegetation consists of both creek and upland species. The presence of the site and its great size is due to extensive exposures of Uvalde Gravels spanning the full breadth and much of the length of the valley. While chert quality varies widely, cobble size appears to have dictated the choicest locations for raw material procurement by prehistoric inhabitants of the area. The stages of lithic reduction range from early through late. The close proximity to a constant water source certainly added to the area's popularity.

The site is primarily a quarry complex, but some areas offer evidence that it was also used as an open campsite. Generally, low densities of firecracked rock are widely distributed over the site surface. A few informal and even fewer formal tools were identified, while the sample of projectile points and other diagnostic tools is low. Recovered projectile point types are Bulverde, Arenosa (a variant of Langtry), Tortugas, Castroville, and Perdiz. A single Clear Fork uniface was also collected. Among these there does not appear to be any spatial distribution across the landscape by age, but rather they suggest longterm exploitation of the area, from the Late Archaic into the Late Prehistoric. Nineteen shovel tests at various points on the site indicate the possibility of subsurface cultural deposits down to $50 \mathrm{~cm}$ below the surface, but these were few in number. Disturbance to the site is evident in many locations, due to road cuts, blading, or bulldozing.

The research potential for site $41 \mathrm{BX} 1104$ is very high considering its size and that it appears to have been exploited over much of the Holocene, as indicated by diagnostic artifacts. This site offers a view of extensive prehistoric quarrying activities outside of the Edwards Plateau. It should be considered for inclusion in the NRHP within a district context. 


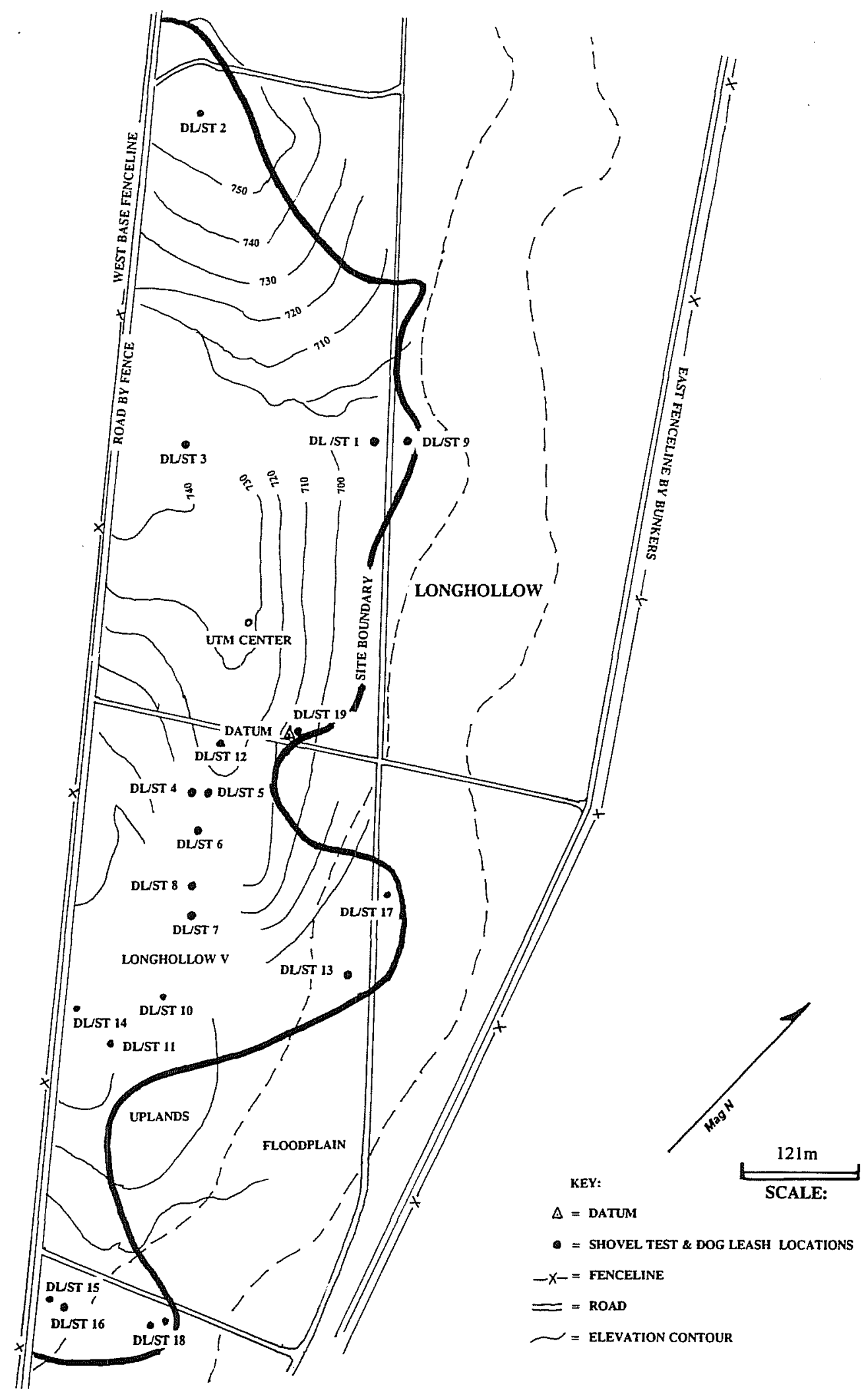

Figure 8-37. Site plan, 41BX1104. 


\section{BX1110}

Site $41 \mathrm{BX} 1110$ is a quarry site (Figure 8-38) composed of a small surface scatter of early reduction stage lithics such as cores, a quarry blank, and exterior flakes. A possible ground stone was recovered from the surface. The site is set in the uplands above the drainage bottom, $120 \mathrm{~m}$ to the east. Dense upland flora covers the site. A shovel test revealed two fire-cracked rocks and flakes to 30 $\mathrm{cm}$ below the surface.

Disturbance to the site has been minimal and its research potential is moderate. It should be considered for inclusion in the NRHP within a district context.

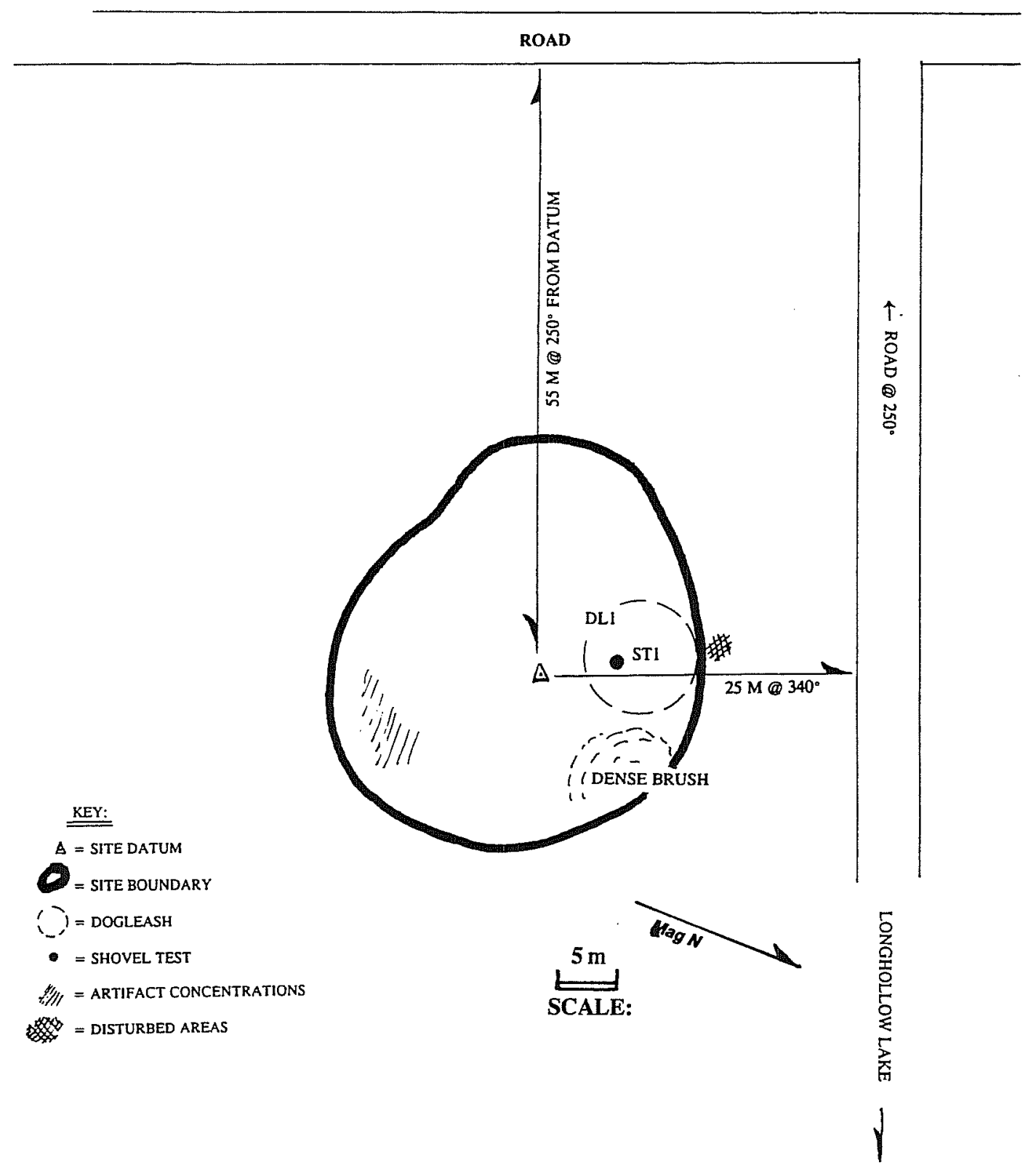

Figure 8-38. Site plan, 41BX1110. 


\section{BX1111}

This small quarry site (Figure 839 ) is characterized by a surface scatter of cores, flakes, and an informal utilized flake, all suggesting early stages of reduction. It is located near the drainage bottom. A heavily disturbed area borders the site to the south, while the majority of the area remains intact. The vegetation consists of upland species. The one shovel test revealed no subsurface artifacts.

This small site has moderate research potential. It should be considered for inclusion in the NRHP within a district context.

\section{BX1112}

41BX1112 (Figure $8-40$ ) is a small quarry site and early reduction stage station with only
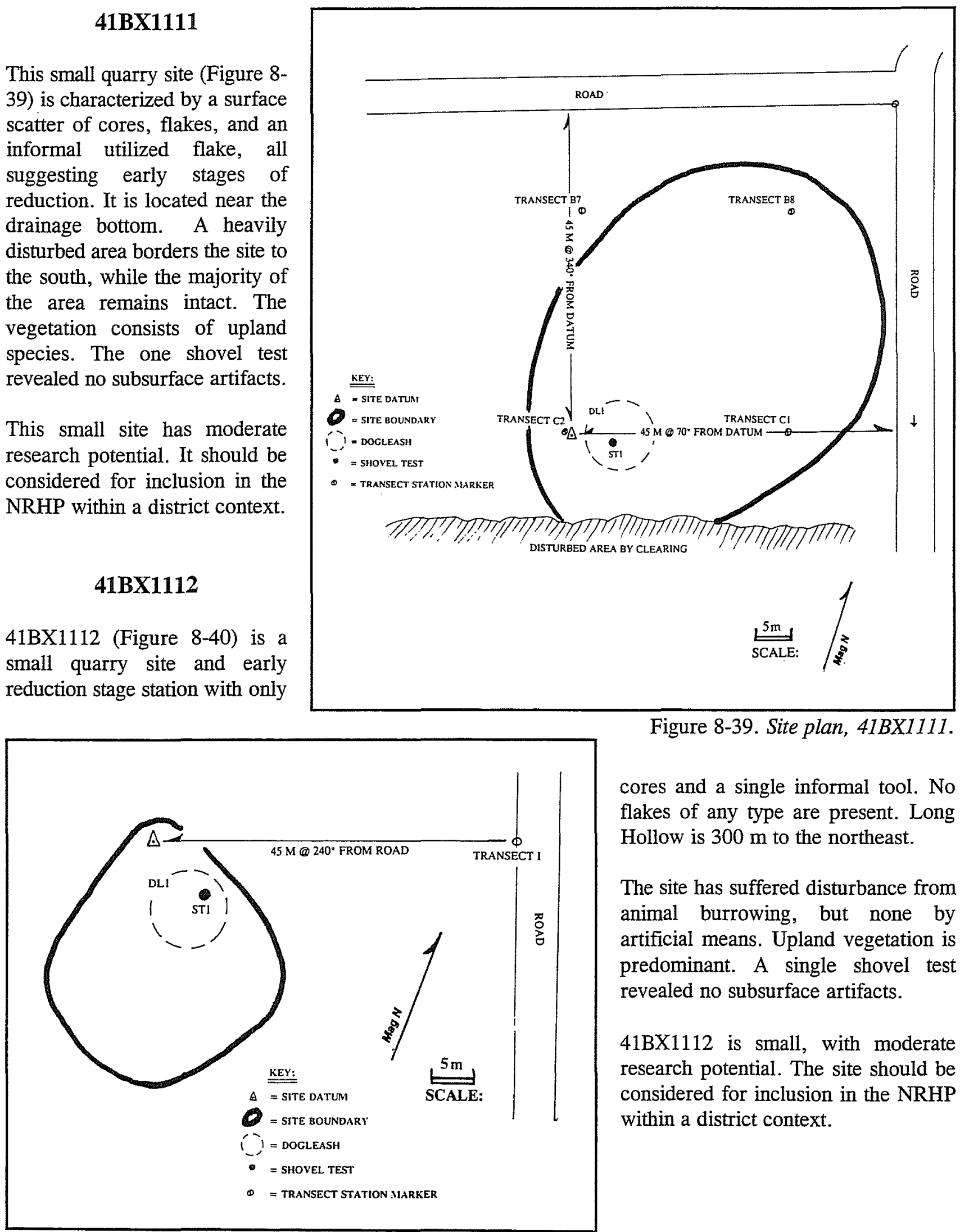

Figure 8-39. Site plan, 41BX1111.

cores and a single informal tool. No flakes of any type are present. Long Hollow is $300 \mathrm{~m}$ to the northeast.

The site has suffered disturbance from animal burrowing, but none by artificial means. Upland vegetation is predominant. A single shovel test revealed no subsurface artifacts.

41BX1112 is small, with moderate research potential. The site should be considered for inclusion in the NRHP within a district context.

Figure 8-40. Site plan, 41BX1112. 


\section{BX1113}

$41 B X 1113$ (Figure 8-41) is light scatter of exterior flakes, cores, and two utilized pieces, indicating a small quarry site where early reduction activities took place. It is set in the uplands above the drainage bottom, $140 \mathrm{~m}$ to the east. Predominantly upland vegetation covers the site. Two shovel tests revealed no artifacts below the surface. The site is moderately disturbed by surface erosion and construction of a road, fox holes, and bunkers. However, it has moderate research potential and should be considered for inclusion in the NRHP within a district context.

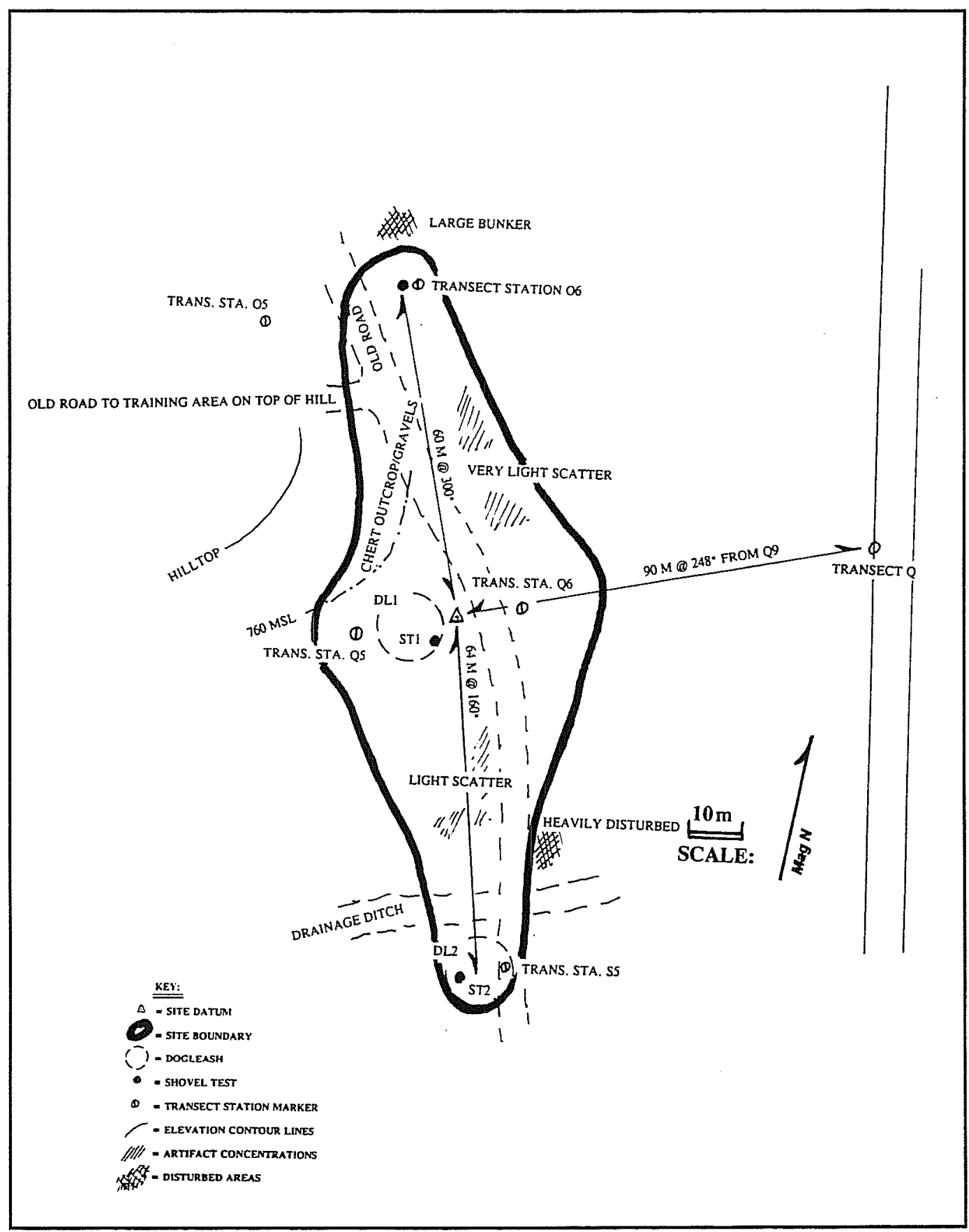

Figure 8-41. Site plan, 41BX1113. 


\section{BX1116}

This quarry (Figure 8-42) consists of cores and flakes from early lithic-reduction activities, mixed with cobbles outcropping along the gradual slope of the site. A permanent seep in the drainage bottom is $200 \mathrm{~m}$ to the west. The uplands surrounding this site support dense vegetation. A shallow two-track road cut and animal burrowing have minimally disturbed the site. A shovel test revealed no artifacts below surface.

The research potential of $41 \mathrm{BX} 1116$ is moderate; therefore, the site should be considered for inclusion in the NRHP within a district context.

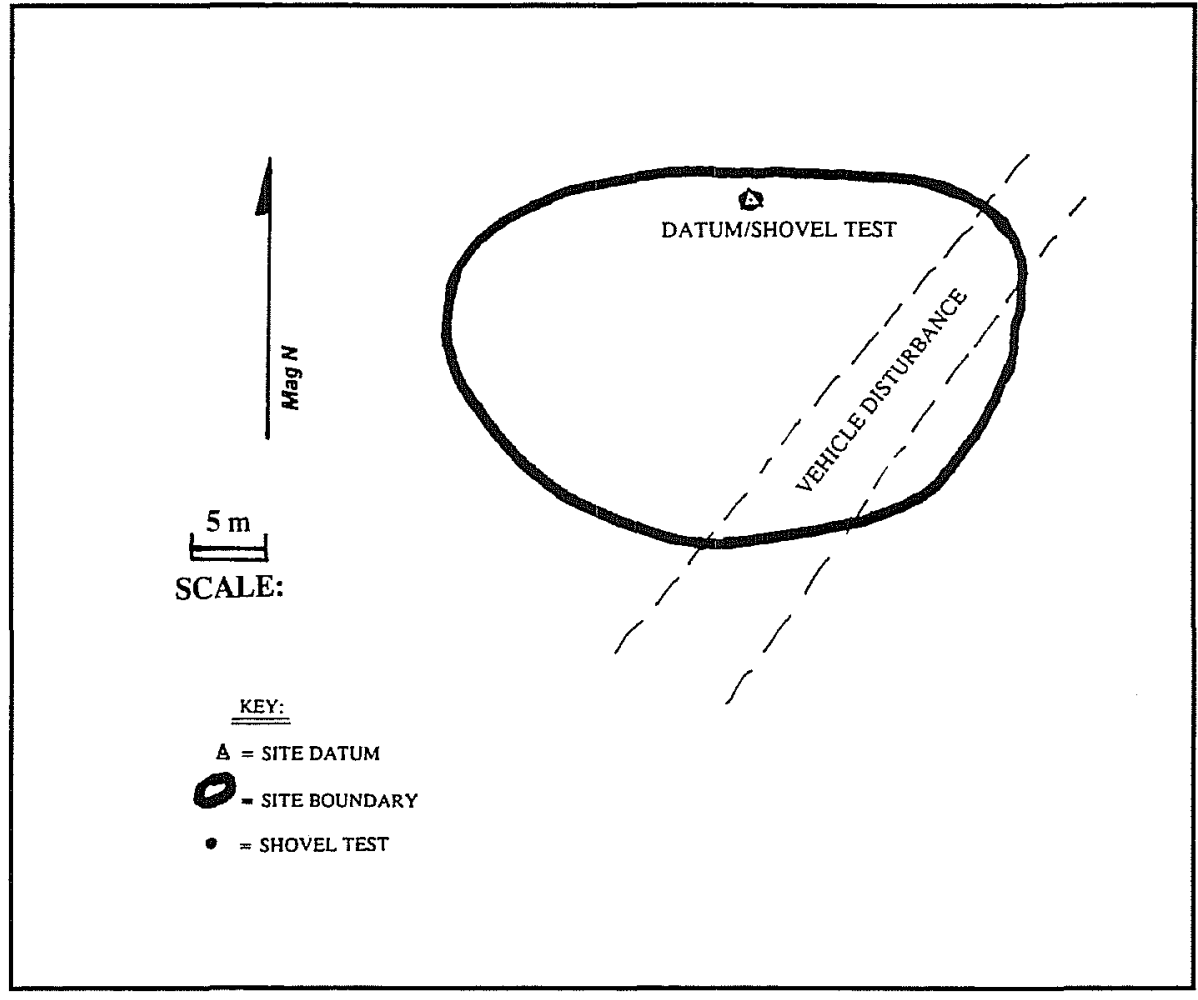

Figure 8-42. Site plan, 41BX1116.

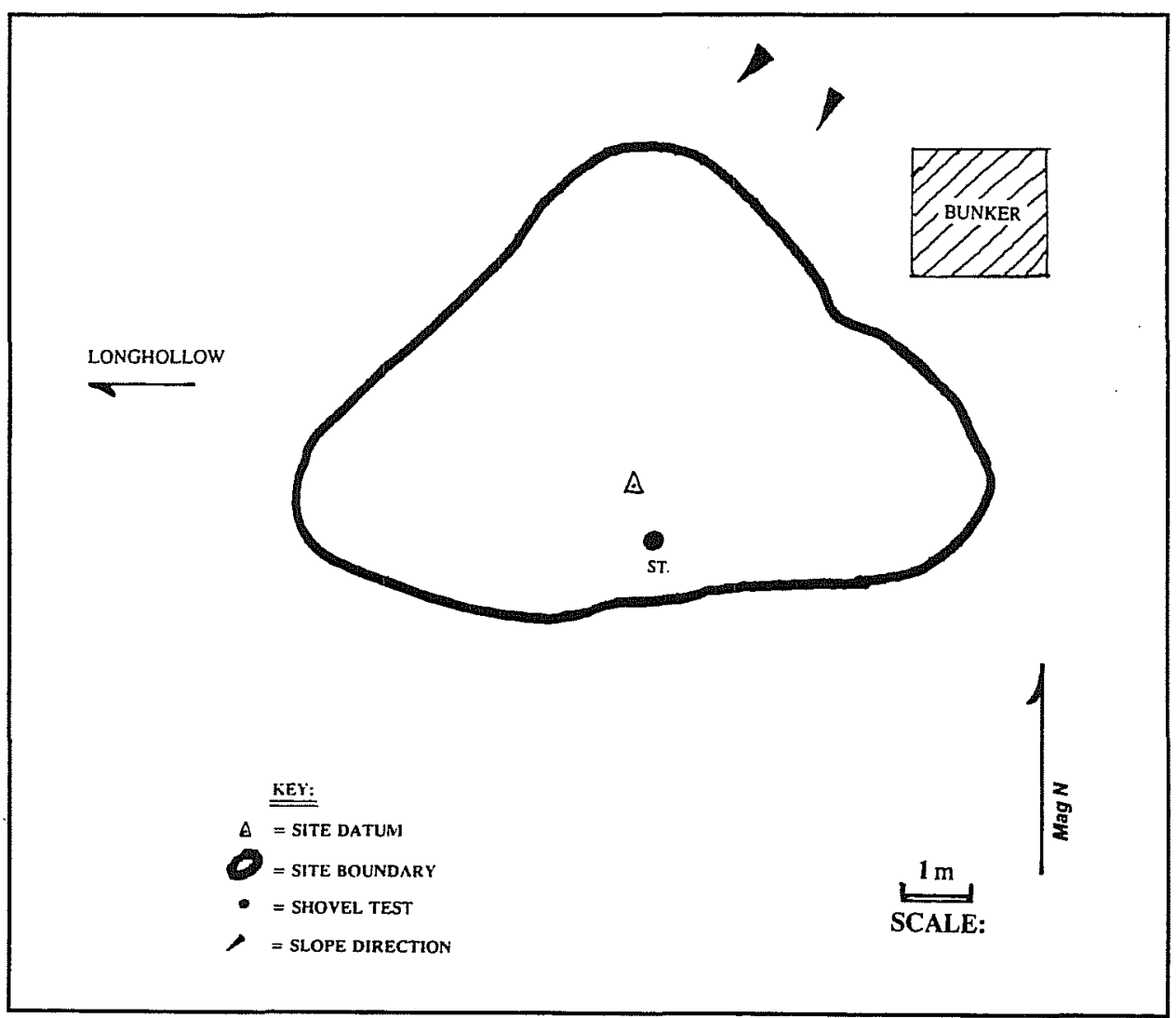

Figure 8-43. Site plan, 41BX1117.

\section{BX1117}

41BX1117 (Figure 8-43) is a quarry in the uplands above a permanent seep in Long Hollow, $150 \mathrm{~m}$ to the west. Cores and exterior flakes dominate the artifact assemblage, suggesting that early stage reduction activities occurred at this site. Dense upland vegetation covers this moderately disturbed area. A shovel test revealed flakes to a depth of $10 \mathrm{~cm}$ below the surface. The research potential of $41 \mathrm{BX} 1116$ is moderate; therefore, the site should be considered for inclusion in the NRHP within a district context. 


\section{BX1118}

An outcropping of chert cobbles along a gradual slope provided raw materials for the cores and exterior flakes present at this quarry site, 41BX1118 (Figure 8-44). These artifacts suggest early stages of lithic reduction. Upland vegetation covers the site. A permanent seep in the bottom of the Long Hollow drainage is $400 \mathrm{~m}$ to the northwest. A road cut through part of the site has caused moderate disturbance. Shovel testing produced a core from $10-20 \mathrm{~cm}$ below the surface, suggesting the possibility of a buried intact cultural deposit.

The research potential of $41 B X 1118$ is moderate; therefore, the site should be considered for inclusion in the NRHP within a district context.

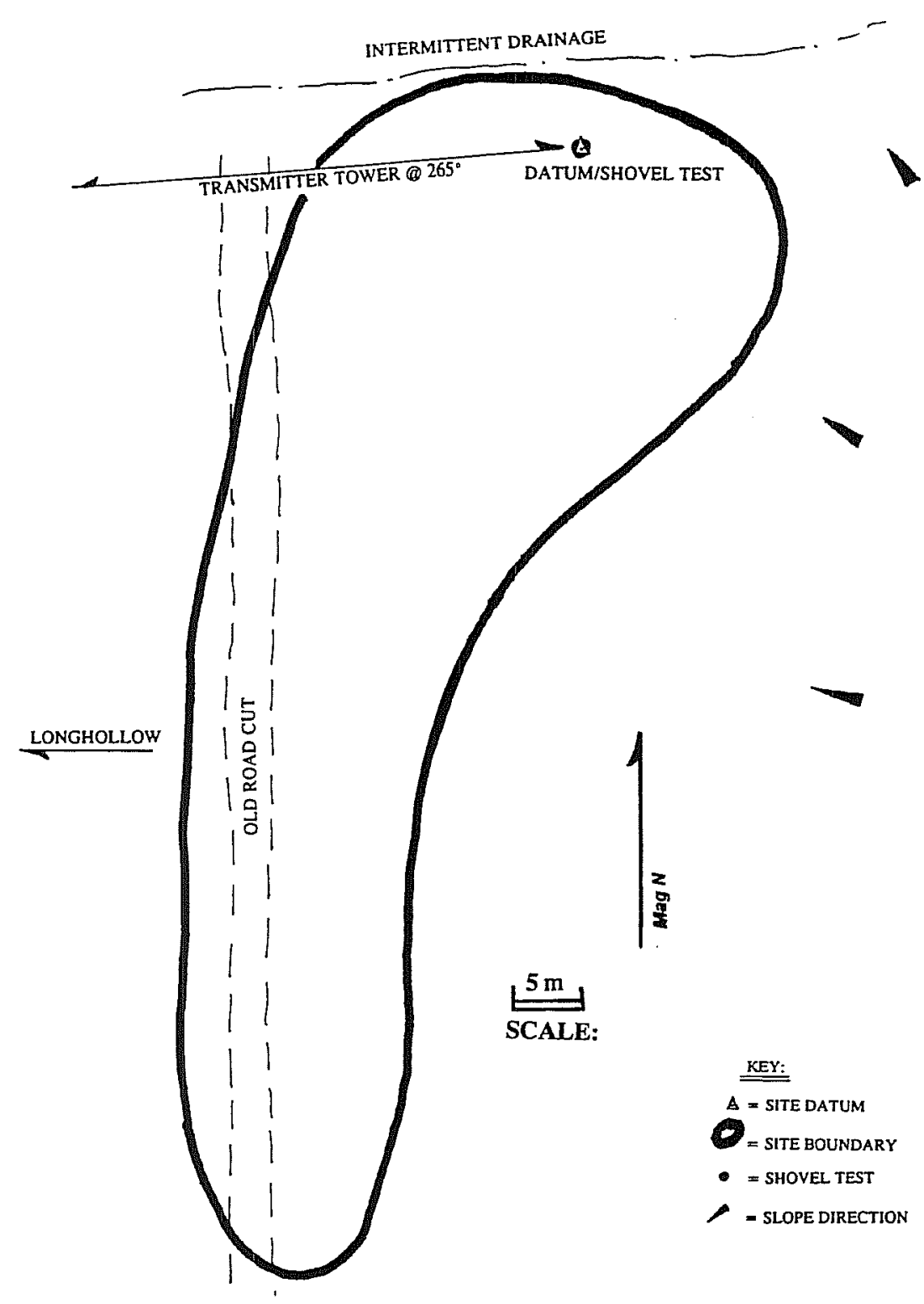

Figure 8-44. Site plan, 41BX1118. 


\section{The Upland Periphery Prehistoric Sites}

Twenty-three prehistoric sites were found in the upland periphery of Medio Creek and Long Hollow during the current project. The sites are designated 41BX1070, 41BX1071, 41BX1074-1076, 41BX1078, 41BX1080-1085, 41BX1088-1091, 41BX1095-1097, 41BX1105, 41BX1106, 41BX1109, and 41BX1124. These are open campsites and quarries with ages estimated to range between the Early Archaic and Late Prehistoric. Upland sites are generally associated with outcroppings of Uvalde Gravels. A brief description of each site is given with particular reference to site type and setting, associated artifact assemblage, disturbance suffered by the site, any known future impacts, and research potential.

\section{BX1070}

Site 41BX1070 (Figure 8-45) is a small quarry with a light surface scatter of cores and exterior flakes representing early stages of reduction. It is on the edge of an intermittent drainage in an uplands environment, with Medio Creek $200 \mathrm{~m}$ to the southwest. Raw chert cobbles outcrop along the drainage edge. The area has suffered little disturbance, but is in an active military dog-training area. One shovel test revealed no artifacts below the surface.

Research potential of this site is moderate. Therefore, 41BX1070 should be considered for inclusion in the NRHP.

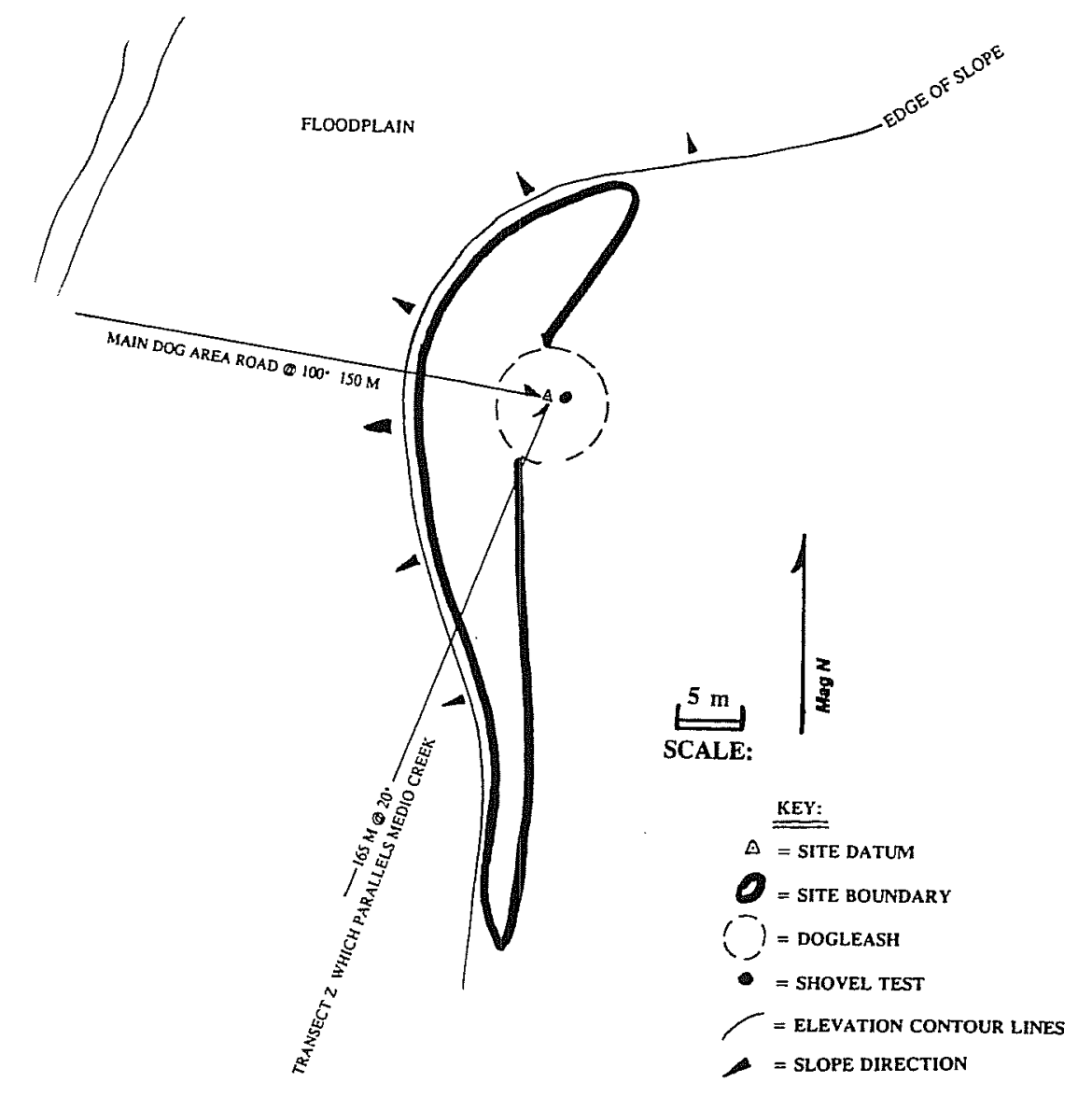

Figure 8-45. Site plan, 41BX1070. 


\section{BX1071}

41BX1071 (Figure 8-46) is a small quarry and open campsite in an upland setting, less than one kilometer east of Medio Creek. The site is represented by a light surface scatter of primarily cores and flakes, but several utilized or retouched pieces and one diagnostic projectile point were also recorded. The dart point, an Edgewood, indicates a Transitional Archaic component at the site. The site has been damaged by surface clearing and road construction. One shovel test revealed no artifacts below the surface. Research potential of this site is moderate; therefore, 41BX1071 should be considered for inclusion in the NRHP.

\section{BX1074}

41BX1074 (Figure 8-47) has both a prehistoric and historic component, represented by a light surface scatter of cores and flakes, ceramic sherds, a soda bottle dating to 1936 , and other historic trash dump items. The prehistoric lithics suggest early stage reduction activities. It is located in the uplands above the creek, $700 \mathrm{~m}$ to the northeast. Disturbance to the site is minimal. One shovel test revealed no artifacts below the surface.

Research potential for this site is moderate considering the context and that only a limited number of sites have been identified with both historic and prehistoric components. Therefore, 41BX1074 should be considered for inclusion in the NRHP.

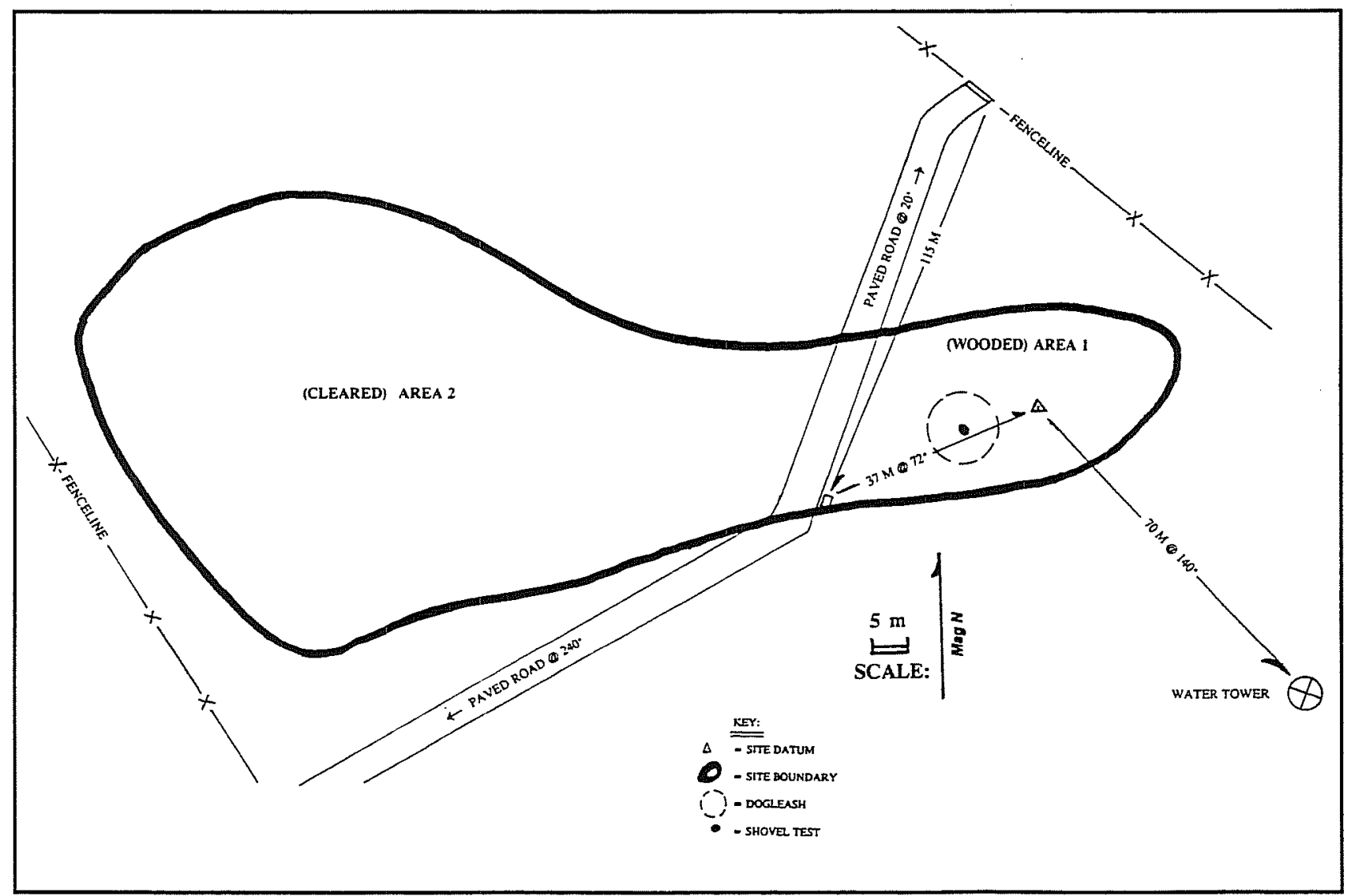

Figure 8-46. Site plan, 41BX1071. 


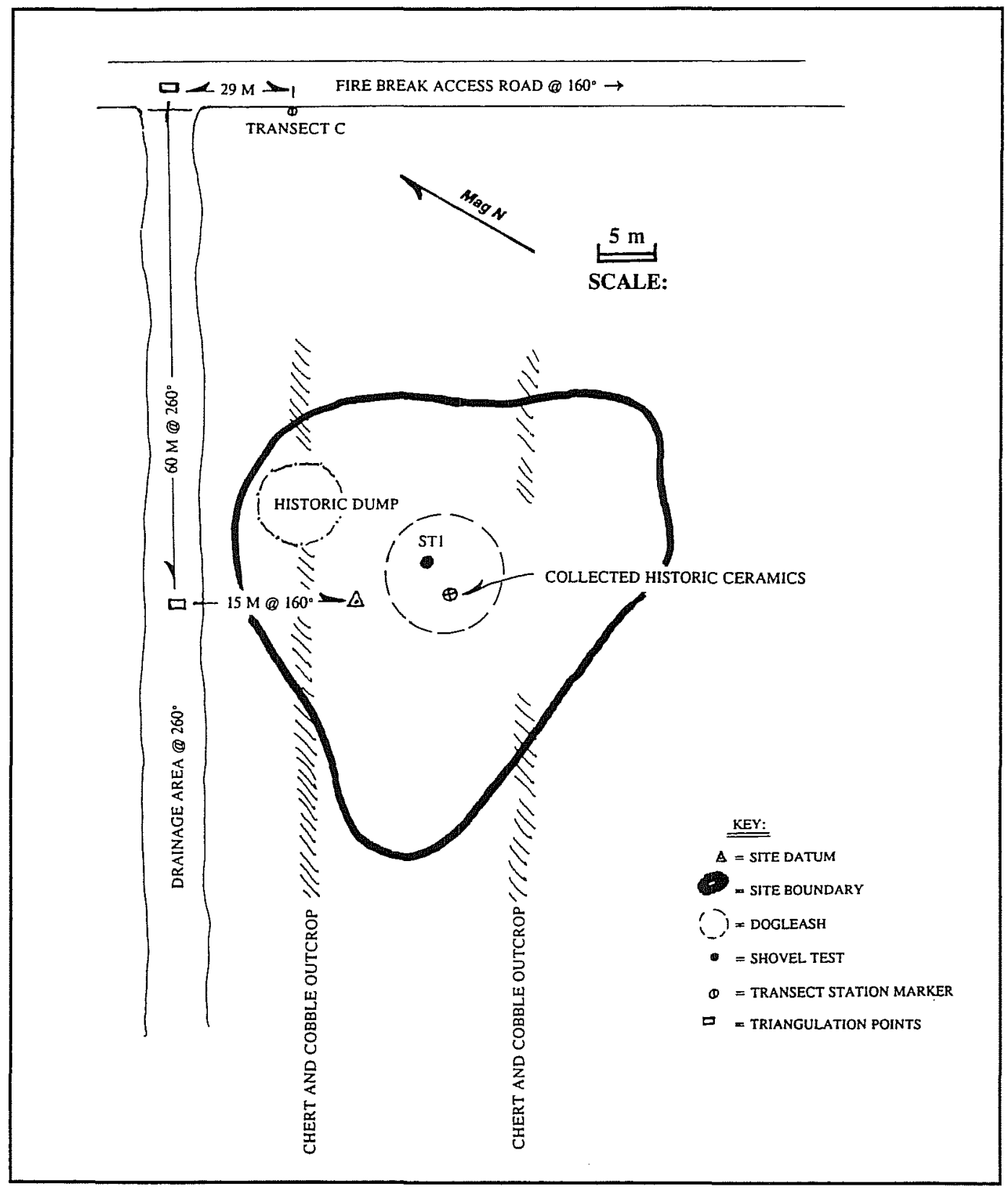

Figure 8-47. Site plan, 41BX1074.

\section{BX1075}

41BX1075 (Figure 8-48) consists of a light lithic surface scatter in the uplands above Medio Creek, which is $750 \mathrm{~m}$ to the north. The artifact assemblage consists primarily of cores and exterior flakes, with a few informal tools. These suggest a quarry station where early stage reduction activities occurred. Raw chert cobbles prevail across the site, while disturbance is minimal. One shovel test revealed no artifacts below the surface. The site has moderate research potential and should be considered for inclusion in the NRHP. 


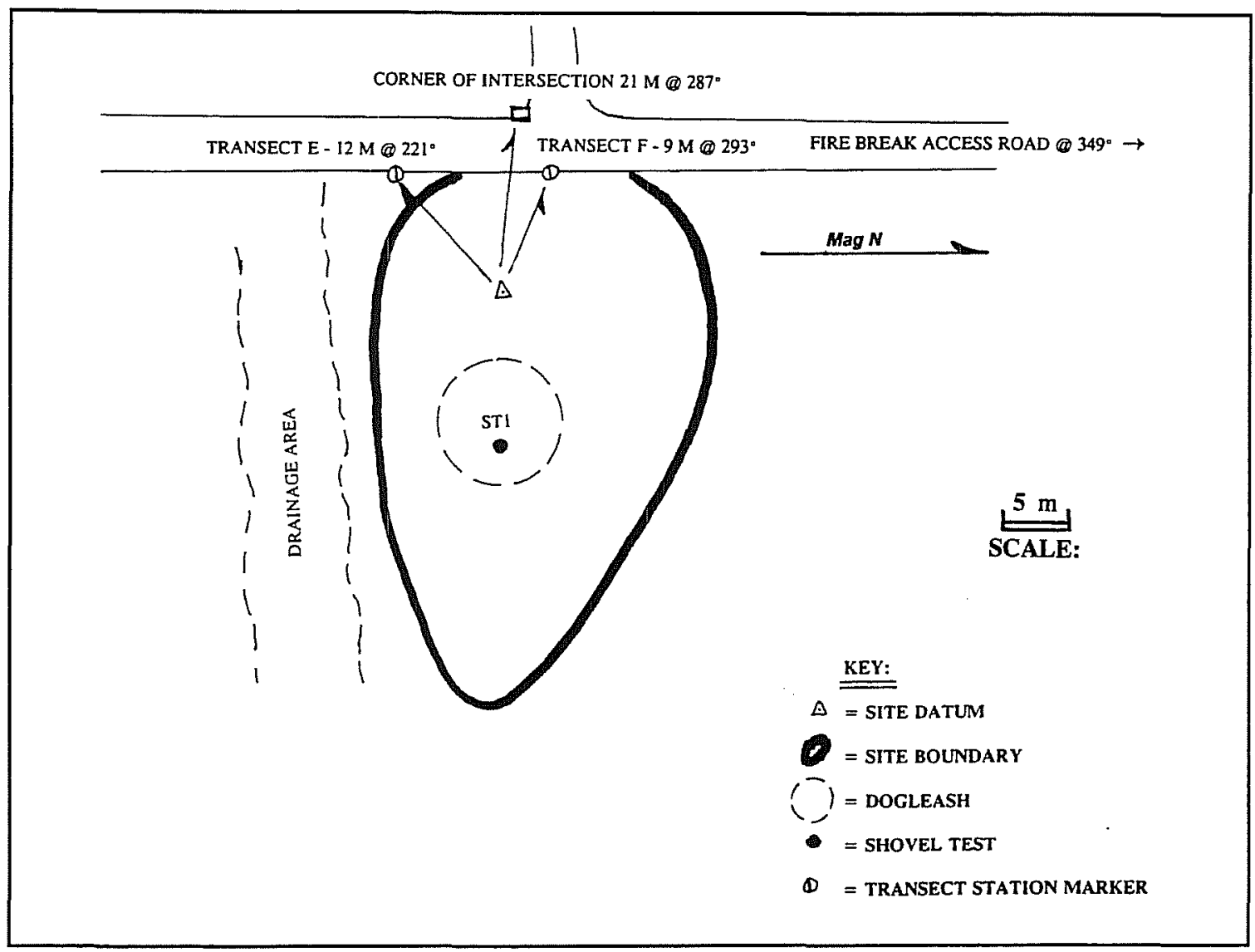

Figure 8-48. Site plan, 41BX1075.

\section{BX1076}

Site 41BX1076 (Figure 8-49) is a prehistoric open campsite and quarry composed of a broad and often dense surface scatter of lithic debris and firecracked rock. The site sits on a prominent knoll in the uplands above Medio Creek, $500 \mathrm{~m}$ to the north. The location provides a remarkable setting for visibility in all directions, as well as access to raw materials. The surface artifact inventory suggests more early stage reduction activities occurred here, indicated by a high number of flakes and cores, but a diagnostic artifact and a few formal pieces are also present. One arrow point (Scallorn) recovered on the surface indicates a Late Prehistoric component at the site, and significant numbers of fire-cracked rock hint at the presence of a burned rock feature. The site has suffered some natural disturbance, primarily from animal burrowing, but the damage is minimal. Two shovel tests revealed artifacts to a depth of $30 \mathrm{~cm}$ below the surface.

Several attributes stand out and enhance the high research potential of the site: 1) the hearth feature; 2) the dense concentrations of artifacts; 3 ) a Late Prehistoric component; 4) the minimal degree of disturbance; 5) the potential for intact buried cultural deposits; and 6) its elevated location. Considering these qualities, 41BX1076 should be considered for inclusion in the NRHP. 


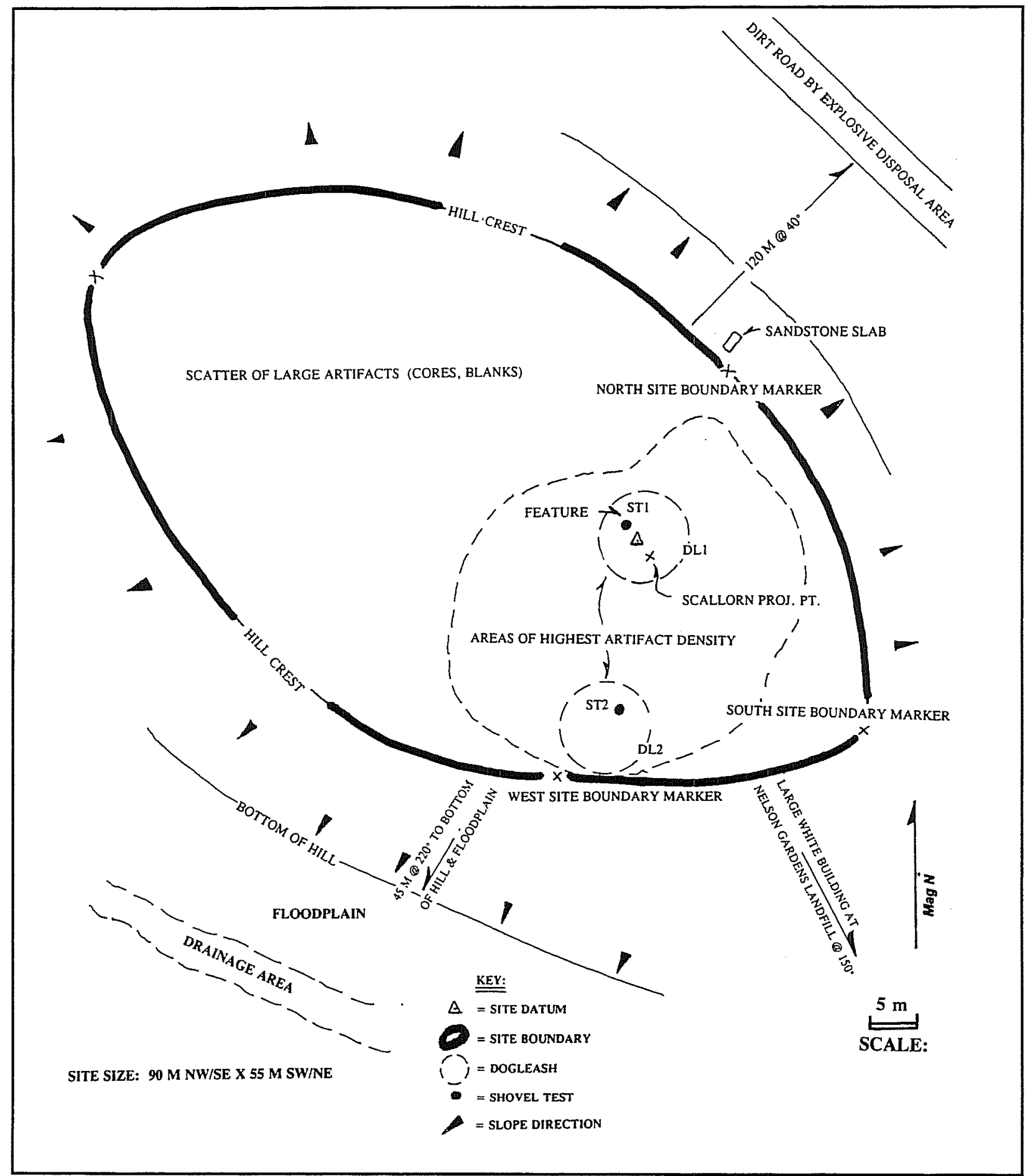

Figure 8-49. Site plan, 41BX1076. 


\section{$41 B X 1078$}

41BX1078 (Figure 8-50) is a small quarry set in the uplands above Medio Creek, $500 \mathrm{~m}$ to the southwest. The sparse surface inventory of exterior flakes and cores suggests early stage reduction activities. A thin biface fragment and one utilized flake were recovered from the site. Minimal disturbance from surface erosion has occurred. One shovel test revealed no subsurface artifacts. The site has moderate research potential and should be considered for inclusion in the NRHP.

\section{$41 B \times 1080$}

$41 B X 1080$ (Figure 8-51) is a small quarry workshop in an upland environment, $700 \mathrm{~m}$ west of Medio Creek. Surface and subsurface artifacts suggesting early stage lithic-reduction activities include primarily cores and exterior flakes. Dense brush hides the full extent of this site, although it appears to have been heavily disturbed by animal burrows and possible bulldozing. A shovel test revealed artifacts to a depth of $10 \mathrm{~cm}$ below the surface. Research potential of this site is moderate; therefore, it should be considered for inclusion in the NRHP.

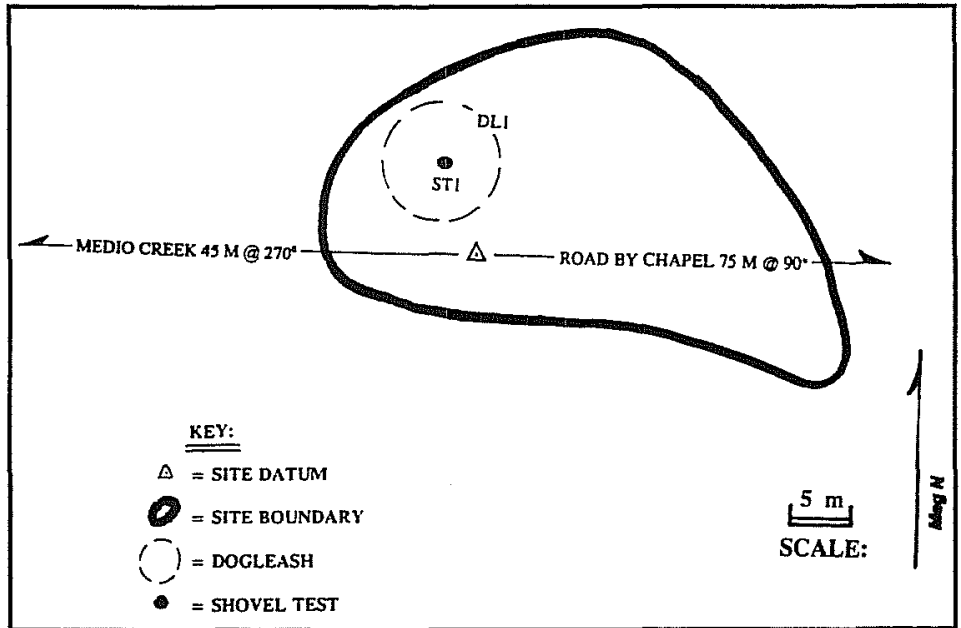

Figure 8-50. Site plan, 41BX1078.

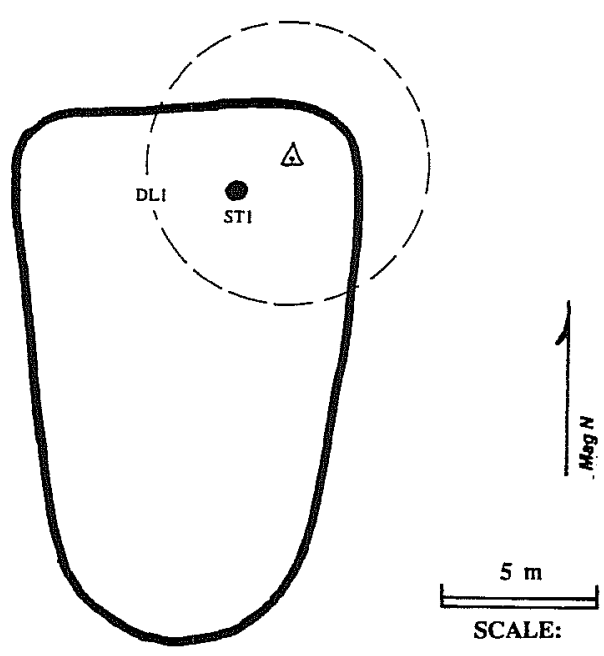

$$
\begin{aligned}
& \stackrel{\text { KEY: }}{=}=\text { SITE DATUM } \\
& \Delta=\text { SITE BOUNDARY } \\
& =\text { SHOVEL TEST }
\end{aligned}
$$

Figure 8-51. Site plan, $41 B X 1080$. 


\section{BX1081}

The surface scatter of artifacts at 41BX1081 indicates a lithic reduction/processing station in an exploited natural outcrop of chert cobbles (Figure 8-52). Artifacts range from cores to exterior and interior flakes, bifacial thinning flakes, and quarry blanks, suggesting early and intermediate lithic stage reduction activities. The site is in uplands overlooking the Medio Creek drainage, $570 \mathrm{~m}$ to the northwest.

The site may have suffered limited damage from early twentiethcentury plowing, but otherwise appears to be well preserved. Two shovel tests revealed no artifacts below the surface. The lithic reduction stages represented at 41BX1081 provides for a moderate research potential. Therefore, the site should be considered for inclusion in the NRHP.

\section{BX1082}

41BX1082 (Figure 8-53) is an open campsite and quarry covered with dense upland vegetation. Medio Creek flows $670 \mathrm{~m}$ to the northeast. Lithic artifacts include cores, thin bifaces, and formal and informal tools, suggesting that a wide range of reduction activities occurred on the site. Subsurface testing produced artifacts to a depth of $20 \mathrm{~cm}$ below the surface. The site as a whole appears to be minimally disturbed. Dense concentrations of fire-cracked rock are present on the surface and indicate that hearth features may be

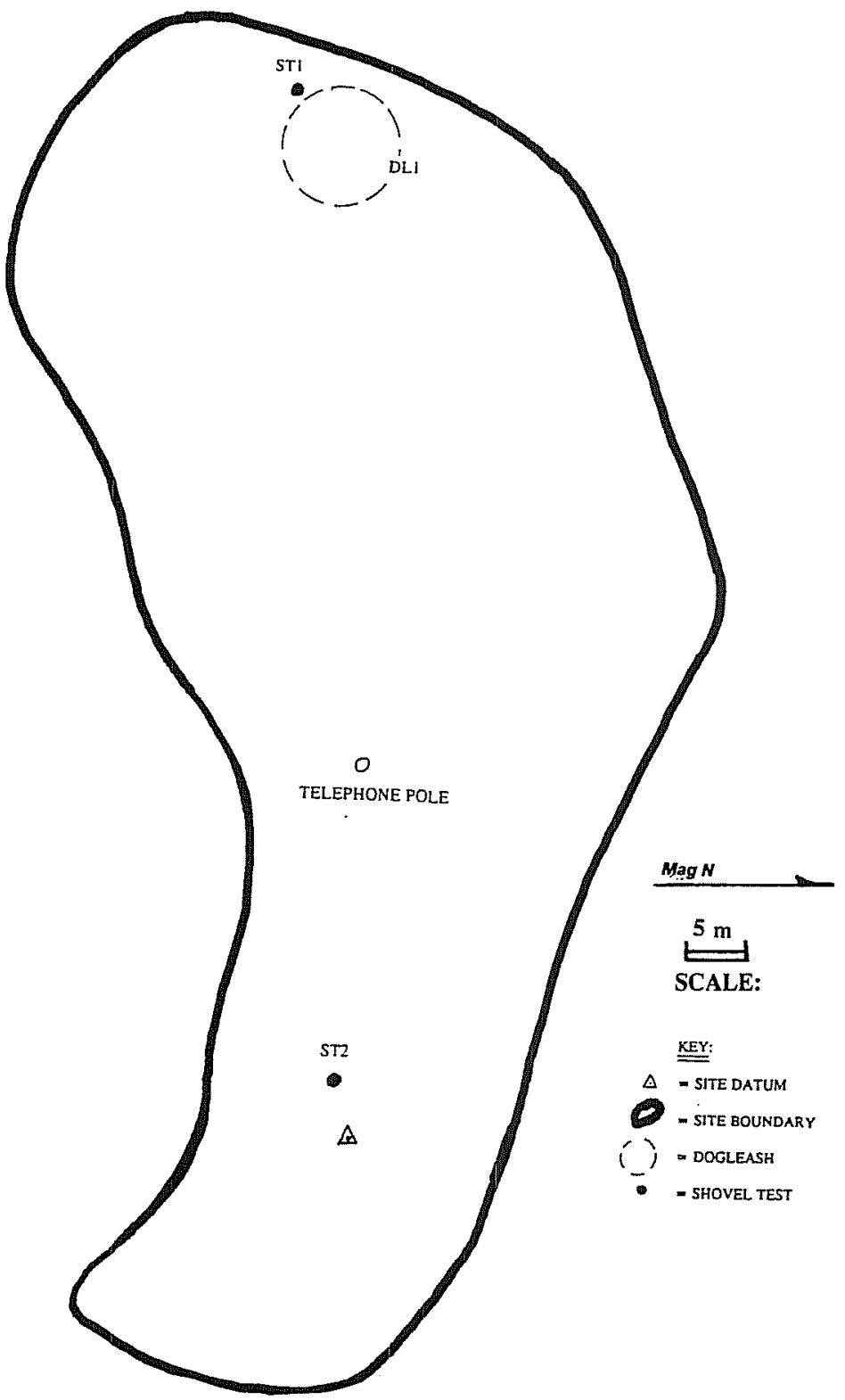

Figure 8-52. Site plan, 41BX1081.

present. The research potential for $41 \mathrm{BX} 1082$ is moderate, considering its setting, density and range of artifacts, and possible burned rock features. The site should be considered for inclusion in the NRHP. 


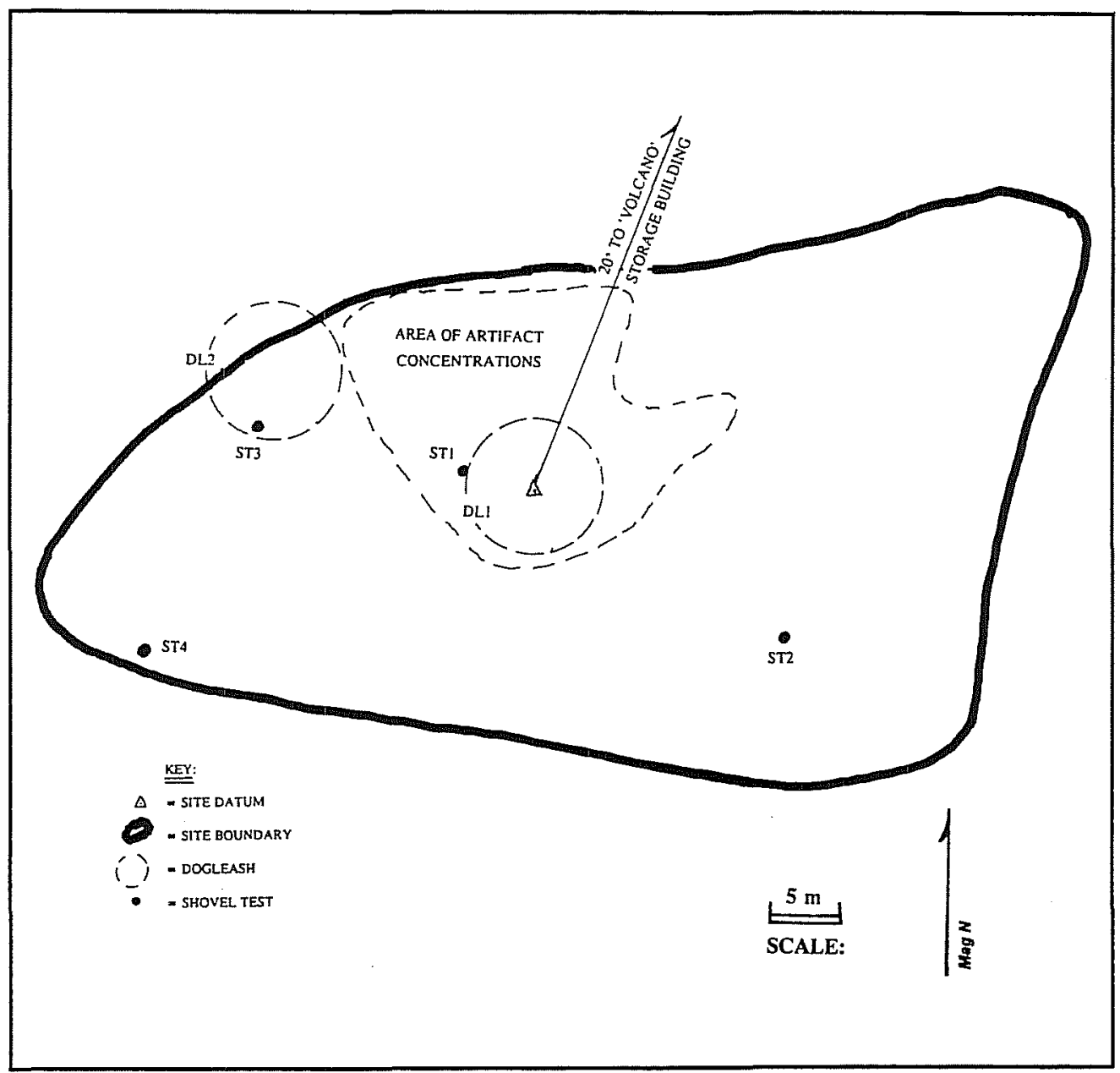

Figure 8-53. Site plan, 41BX1082.

\section{BX1083}

41BX1083 (Figure 8-54) is a small quarry covered with dense upland vegetation. The artifact assemblage of cores, flakes, and a quarry blank indicates early stage reduction activities. Medio Creek lies one kilometer to the east. Although some mechanically crushed rocks are present, disturbance to the site is minimal. The research potential of 41BX1083 is moderate; therefore, this site should be considered for inclusion in the NRHP.

\section{BX1084}

Dense upland vegetation covers this quarry (Figure 8-55). The broad outcrop of chert gravels along the slope of the site has provided raw material for early stage lithic-reduction activities, indicated by the surface scatter of cores, and exterior and interior flakes. Medio Creek flows one kilometer to the east. Minimal disturbance has occurred at the site, yet one shovel test revealed no artifacts below surface. The research potential of the site is moderate, so 41BX1084 should be considered for inclusion in the NRHP. 


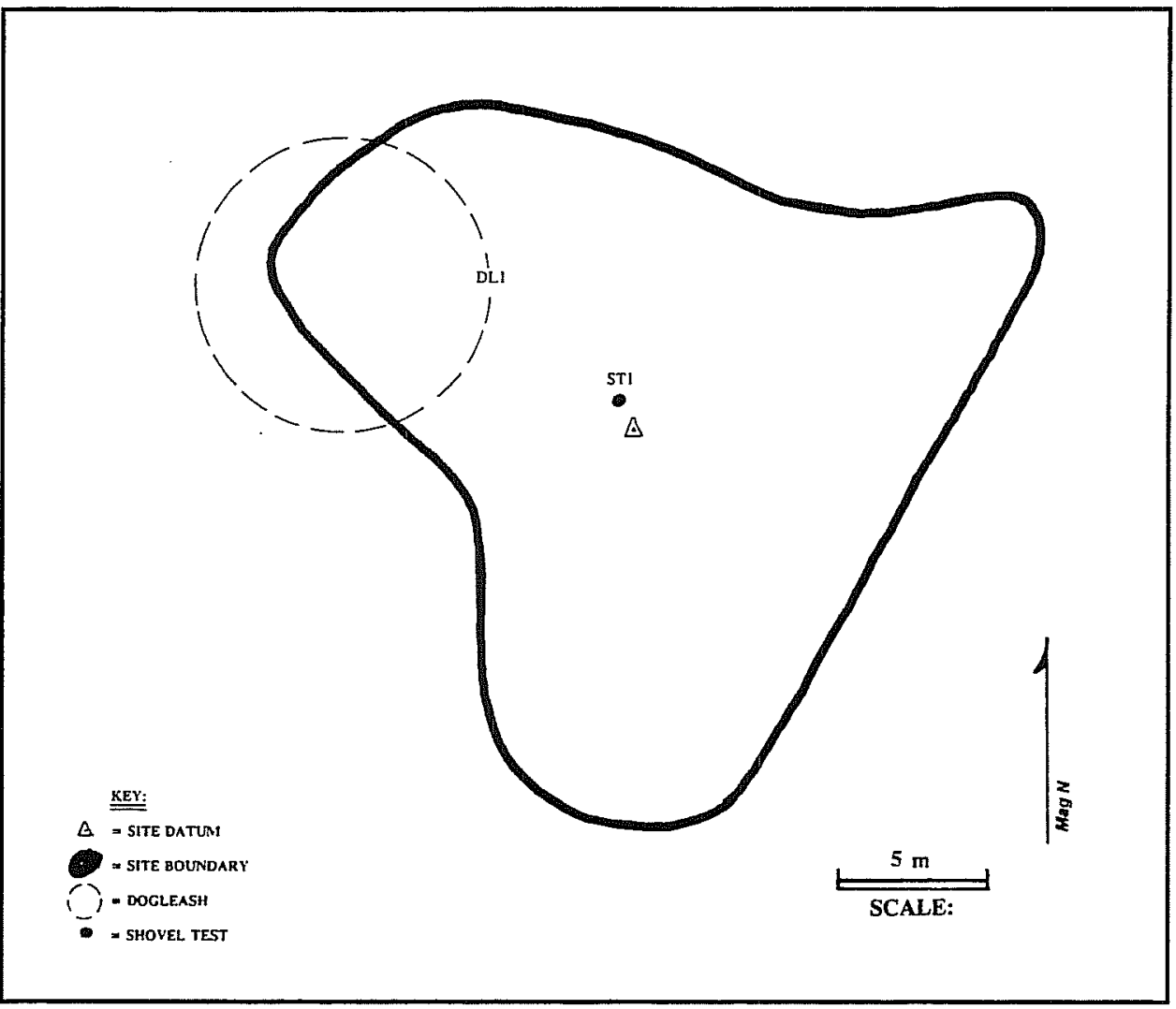

Figure 8-54. Site plan, 41BX1083.

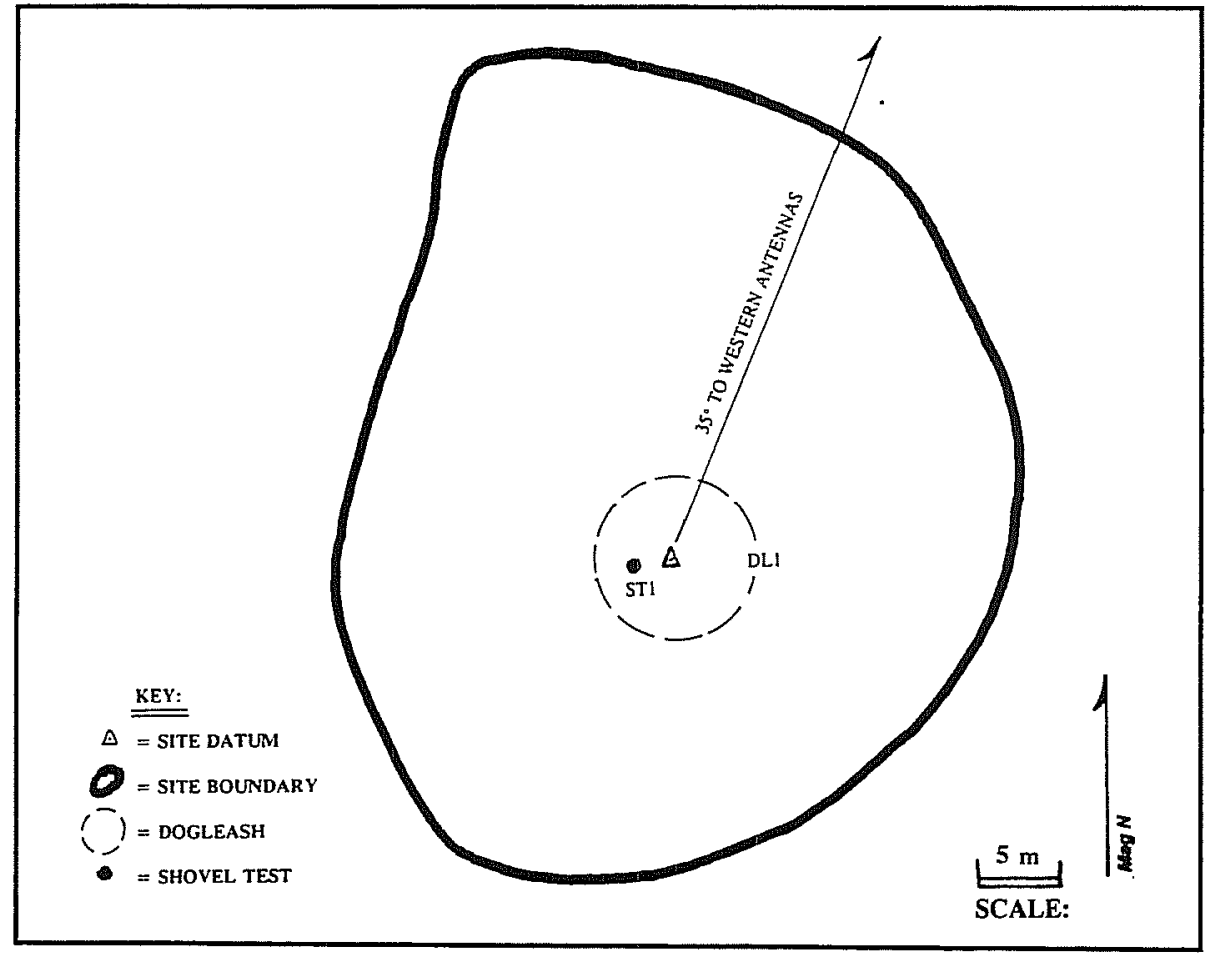

Figure 8-55. Site plan, 41BX1084. 


\section{BX1085}

$41 \mathrm{BX} 1085$ is a quarry in an area where chert gravels have been exposed by an adjacent intermittent drainage (Figure 8-56). Dense upland vegetation impedes surface visibility, but cores, flakes, and quarry blanks were inventoried during site recording, suggesting early stage reduction activities. Although some erosion has occurred, the site appears to be otherwise well preserved. One shovel test revealed no artifacts below the surface.

The research potential of 41BX1085 is moderate; therefore, this site should be considered for inclusion in the NRHP.

\section{BX1088}

This open campsite and quarry covers approximately 41 acres and sits in the uplands east of Medio Creek (Figure 8-57). Debris from all stages of lithic reduction is present. Three dogleash sample units yielded cores, flakes, quarry blanks, preforms, formal and informal tools, thin bifaces, a possible ground stone, and fire-cracked rocks. Two Guadalupe bifaces recovered from the surface indicate use of the site in the Early Archaic, while Pedernales and Lange points (also from the surface) suggest Middle and Late Archaic components respectively. The ground-stone fragment on the surface reflects possible Late Prehistoric use of the

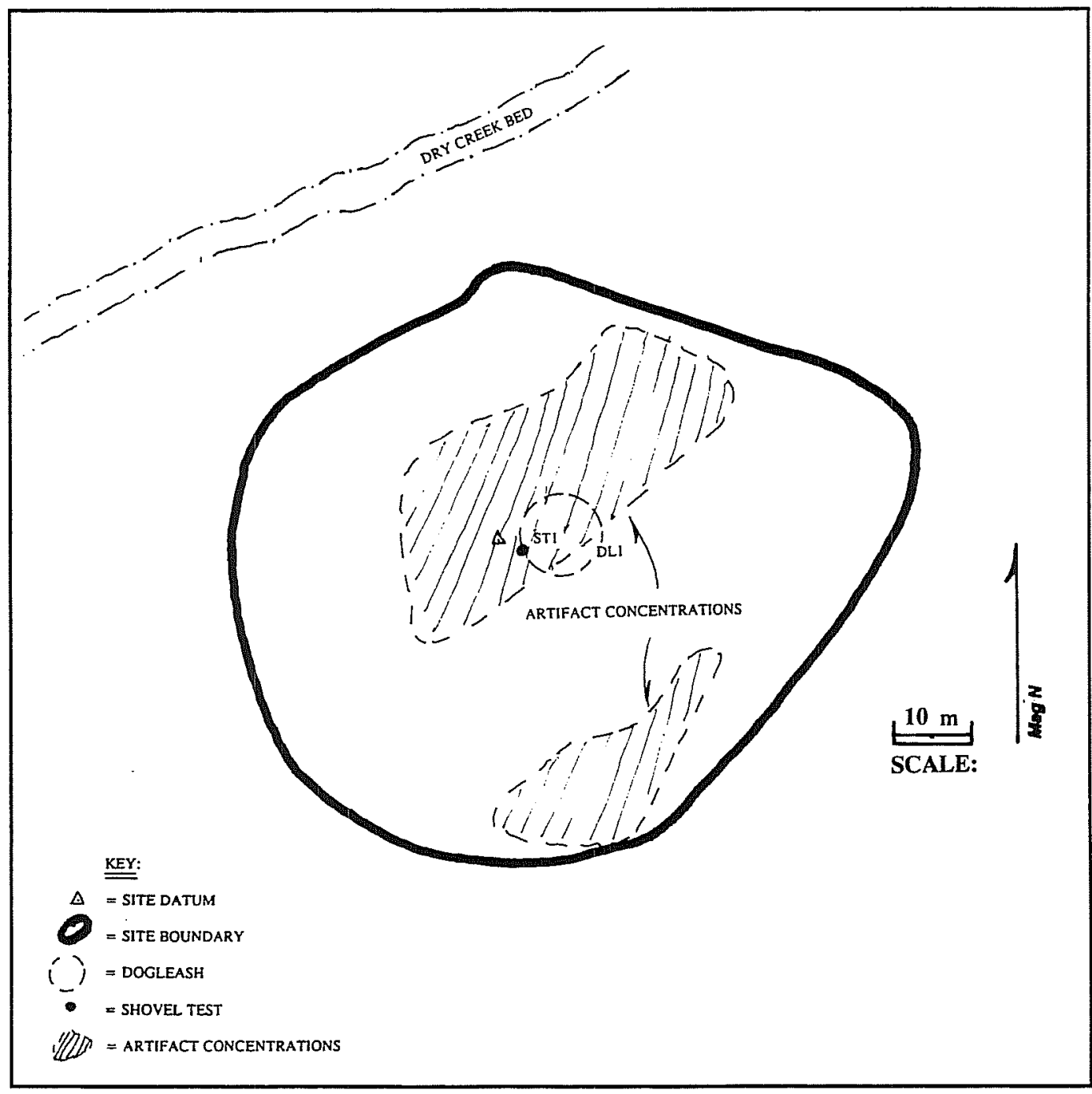

Figure 8-56. Site plan, 41BX1085. 


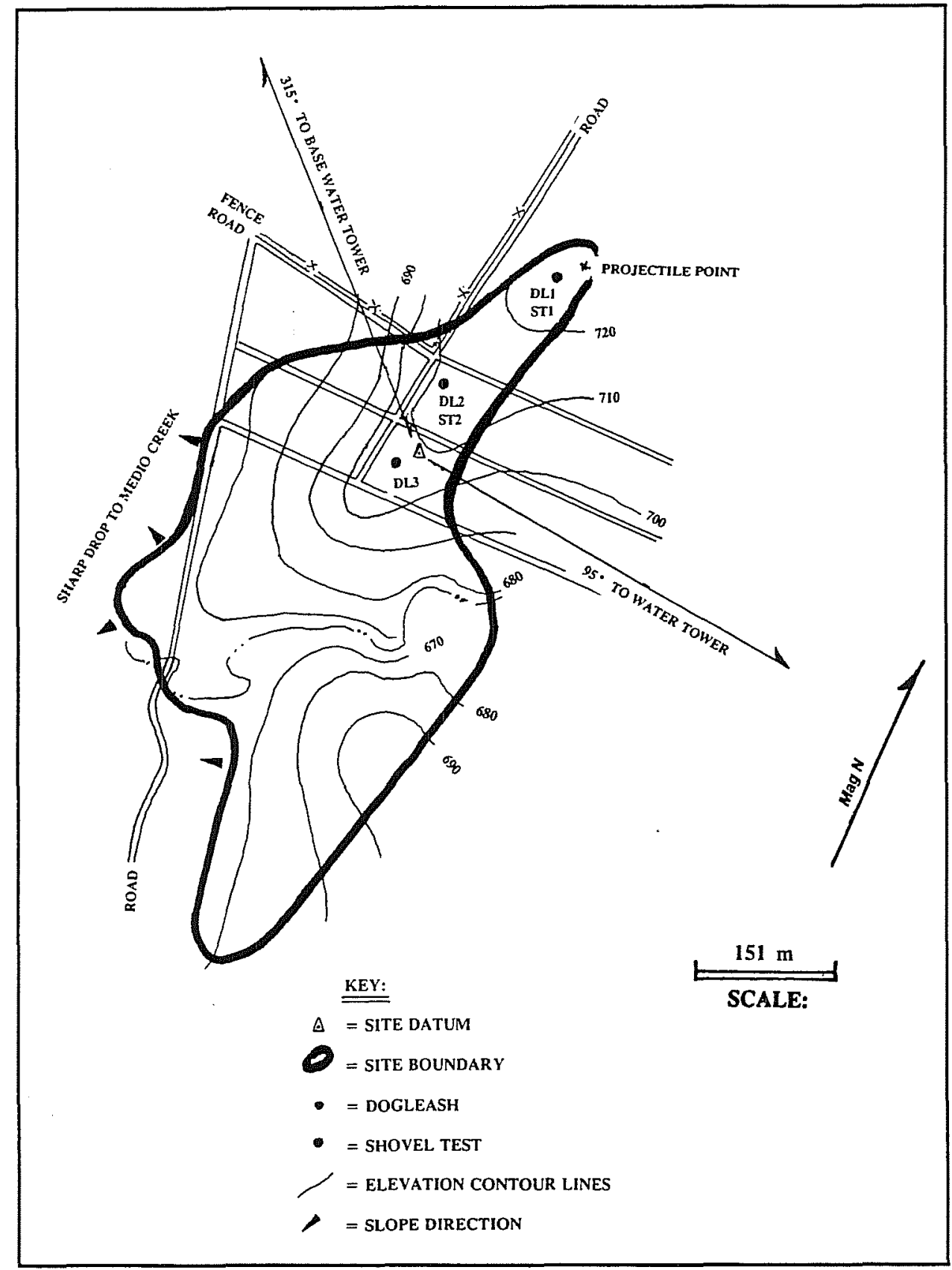

Figure 8-57. Site plan, 41BX1088.

Two shovel tests revealed buried artifacts to $30 \mathrm{~cm}$ below the surface in some parts of the site. Upland vegetation is dense over most of the area. Two-track roads and fire breaks run through the site and have caused some erosion, but the majority of the site appears to have experienced minimal disturbance.
41BX1088 has high research potential, considering its long period of occupation and the possibility for intact buried cultural features. This site should be considered for inclusion in the NRHP. 


\section{BX1089}

$41 \mathrm{BX} 1089$ (Figure 8-58) is a quarry, covered with dense vegetation. Cores, flakes, and informal tools make up a lithic assemblage of early reduction stages. The site is in uplands overlooking Medio Creek, $800 \mathrm{~m}$ to the west. Chert gravels outcrop on the slope of the site and must have provided a good source of raw materials. The site appears to have been minimally disturbed. One shovel test revealed no artifacts below the surface.

The research potential of this site is moderate; therefore, 41BX1089 should be considered for inclusion in the NRHP.

\section{$41 B \times 1090$}

A large outcrop of chert gravels along the slope of this open campsite and quarry (Figure 8-59) provided a convenient source of raw materials from which cores, flakes, and informal tools were manufactured. A small amount of fire-cracked rock indicates possible remains of a hearth feature. Lithic debris of cores and exterior flakes suggests early stage reduction activities. Dense vegetation covers the site, which rests on a high upland overlooking Medio Creek, $900 \mathrm{~m}$ to the southeast. The site appears to be only slightly disturbed. One shovel test revealed no artifacts below the surface. The research potential of $41 \mathrm{BX} 1090$ is moderate; therefore, the site should be considered for inclusion in the NRHP.

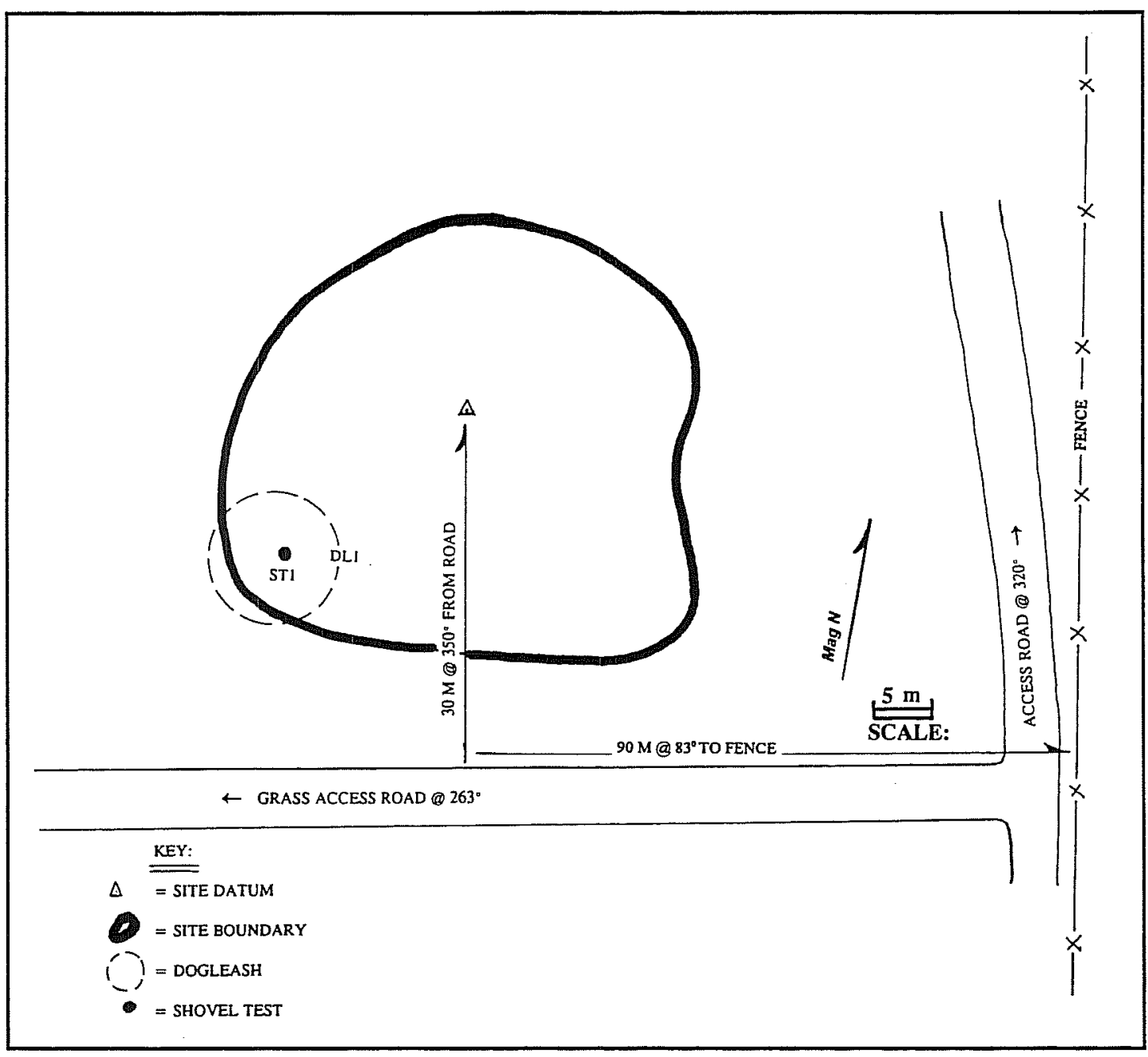

Figure 8-58. Site plan, 41BX1089. 


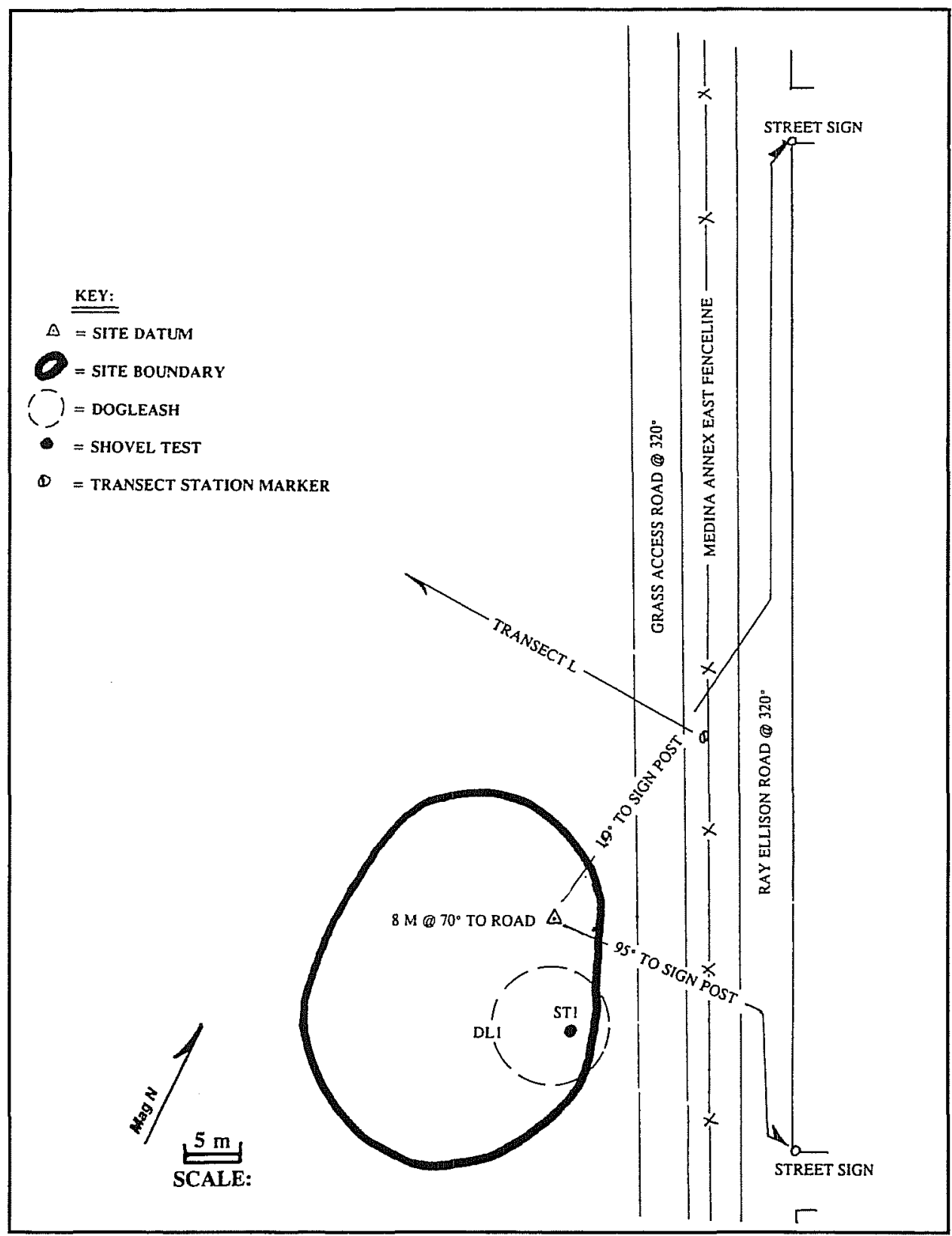

Figure 8-59. Site plan, 41BX1090.

\section{BX1091}

41BX1091 (Figure 8-60) is a moderately disturbed quarry area where chert gravels have outcropped across the slope of the site. The hilltop site overlooks Medio Creek, which is $550 \mathrm{~m}$ to the west, and supports dense upland vegetation. Early stages of lithic reduction are indicated by cores and quarry blanks. The site appears to be moderately disturbed, with machine-crushed chert among the artifacts. One shovel test revealed no artifacts below surface.

The research potential of $41 \mathrm{BX} 1091$ is moderate; therefore, the site should be considered for inclusion in the NRHP. 


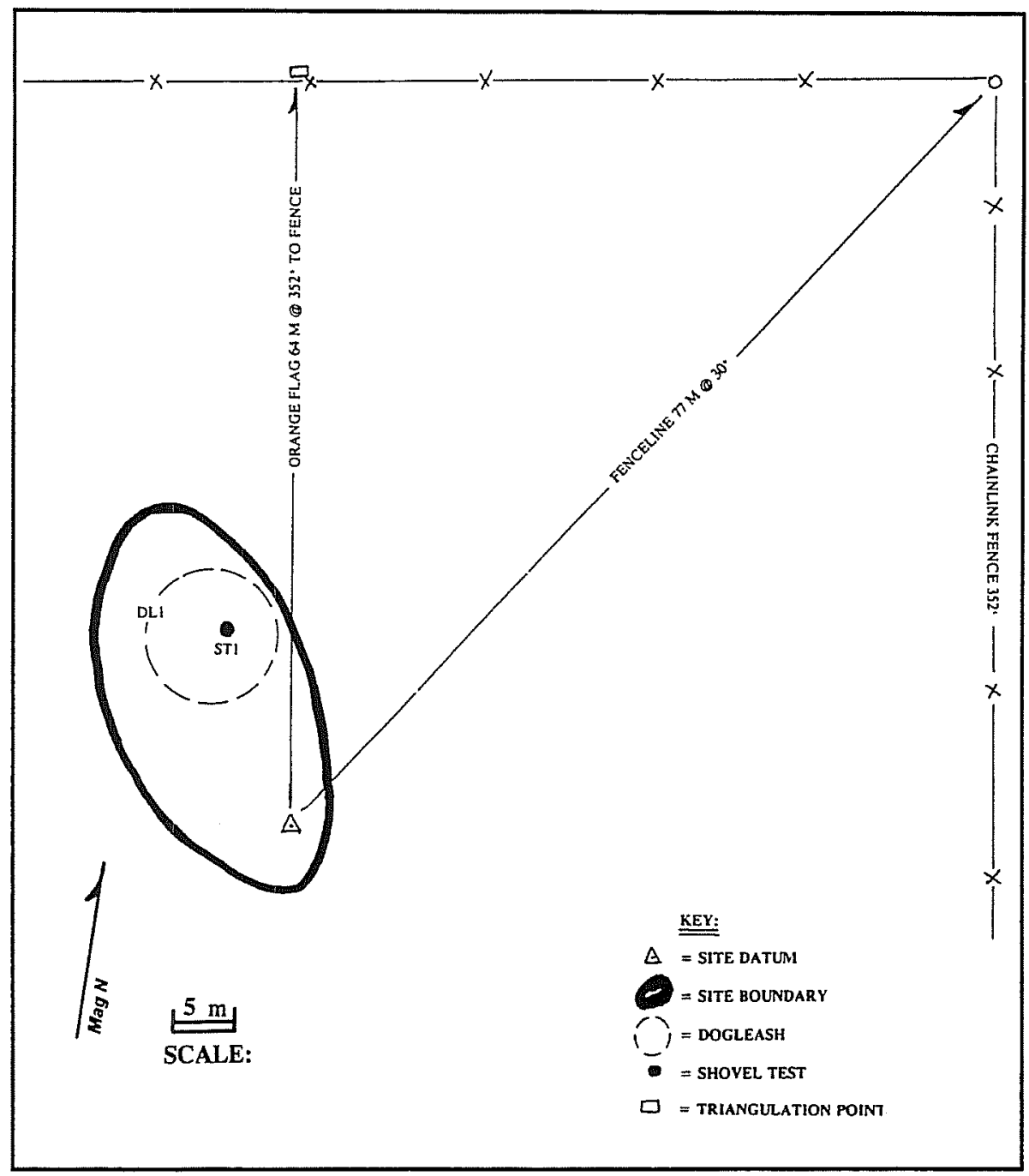

Figure 8-60. Site plan, 41BX1091.

\section{BX1095}

This quarry site (Figure 8-61) rests on an uplands slope, with Medio Creek $480 \mathrm{~m}$ to the east. Dense stands of vegetation cover the area. An outcrop of chert cobbles was exploited for raw materials, with early stage of reduction artifacts-including cores and blanks-left behind. This site appears to be heavily disturbed since machine-crushed gravels are mixed with the artifacts. One shovel test revealed no cultural debris below surface.

The research potential of $41 \mathrm{BX} 1095$ is moderate; therefore, this site should be considered for inclusion in the NRHP.

\section{BX1096}

41BX1096 is a quarry site (Figure 8-62) in an area where chert cobbles outcrop over the slope of the site. These were used as a source of raw material to produce the cores, flakes, and quarry blanks documented on the surface. The lithic debris suggests early stage reduction activities. Upland flora forms a dense cover on the site. Medio Creek is $500 \mathrm{~m}$ to the east. The site appears to have undergone minimal disturbance from rodent burrowing and other bioturbation. A single shovel test yielded no artifacts below surface. The research potential for 41BX1096 is moderate; therefore, this site should be considered for inclusion in the NRHP. 


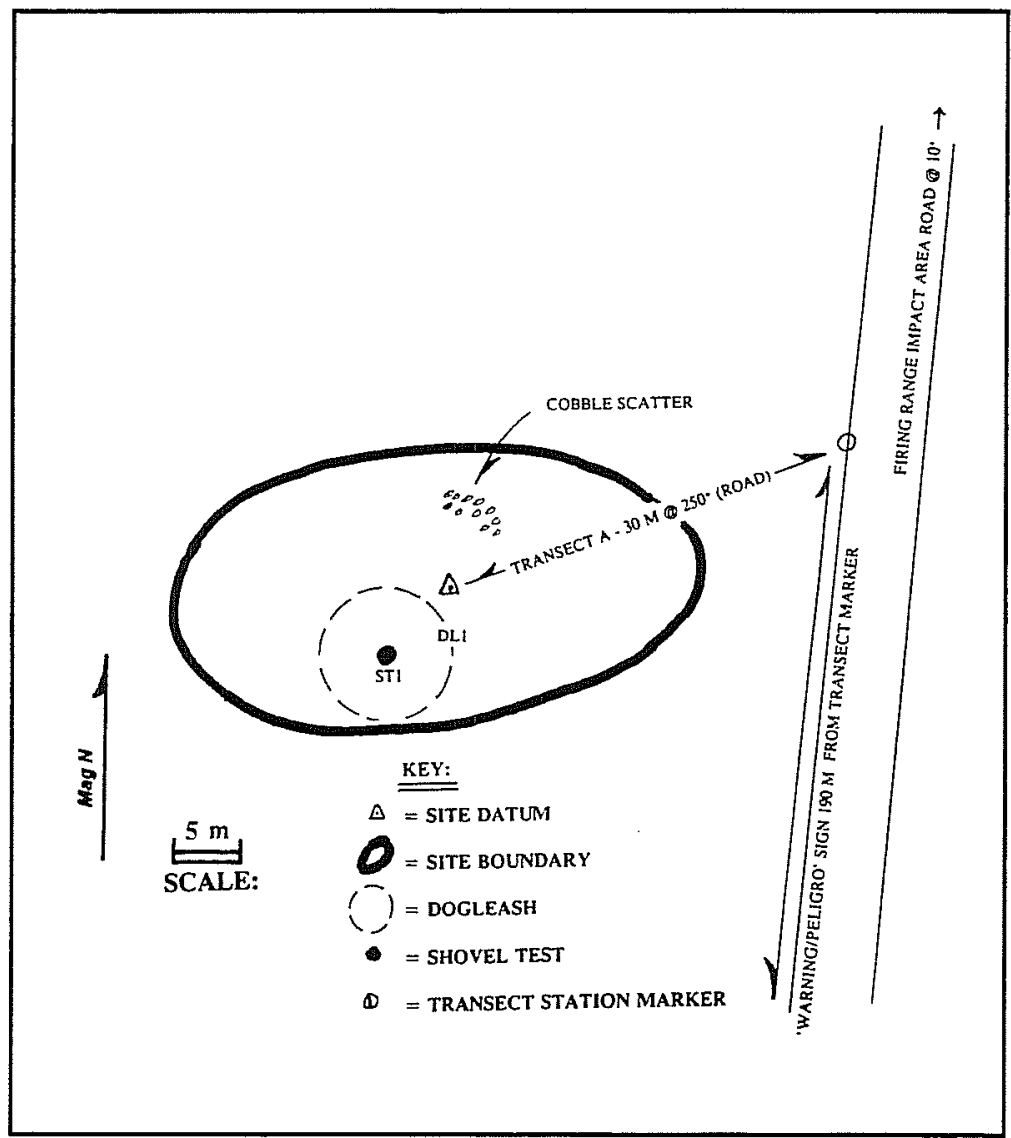

Figure 8-61. Site plan, 41BX1095.

KEY:

$\Delta=$ SITE DATUM

= SITE BOUNDARY

(́) = DOGLEASH

- = SHOVEL TEST

WHITE TRANSMITTER BUILDING

$\square$

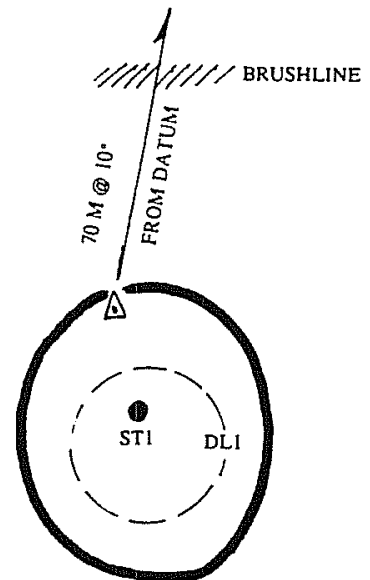

Figure 8-62. Site plan, 41BX1096. 


\section{BX1097}

A sparse scatter of flakes, a core, and a quarry blank were recorded at 41BX1097, suggesting it was used as a quarry where early stage lithicreduction activities occurred. The site rests near the crest of an uplands slope, $730 \mathrm{~m}$ west of Medio Creek (Figure 8-63). An outcrop of chert gravels provided a source for raw materials. A few limestone cobbles are also present. Upland vegetation covers the site. Rodent burrows and machine-crushed rock indicate that the site has suffered some degree of disturbance. A shovel test revealed no subsurface artifacts. The research potential of 41BX1097 is moderate; therefore, this site should be considered for inclusion in the NRHP.

\section{BX1105}

This quarry (Figure 8-64) is set along an intermittent stream that has a dense outcrop of chert gravels. Moderate to dense upland flora covers the area. Artifacts from early phases of lithic reduction include cores, a preform, and informal tools. Erosion has only minimally disturbed the north edge of the site. Medio Creek flows $320 \mathrm{~m}$ to the west. One shovel test revealed no subsurface artifacts. The research potential of $41 \mathrm{BX} 1105$ is moderate; therefore, this site should be considered for inclusion in the NRHP.

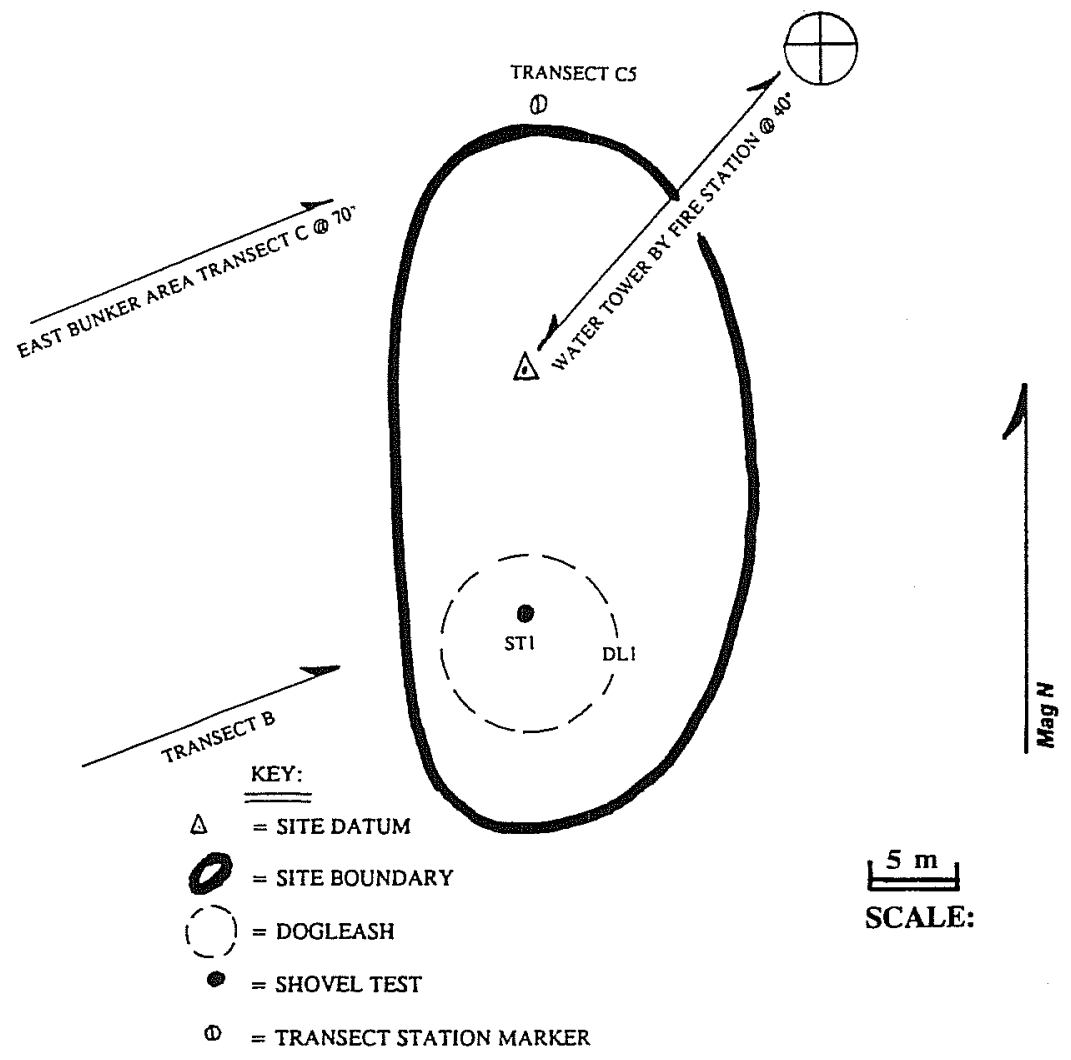

Figure 8-63. Site plan, 41BX1097. 


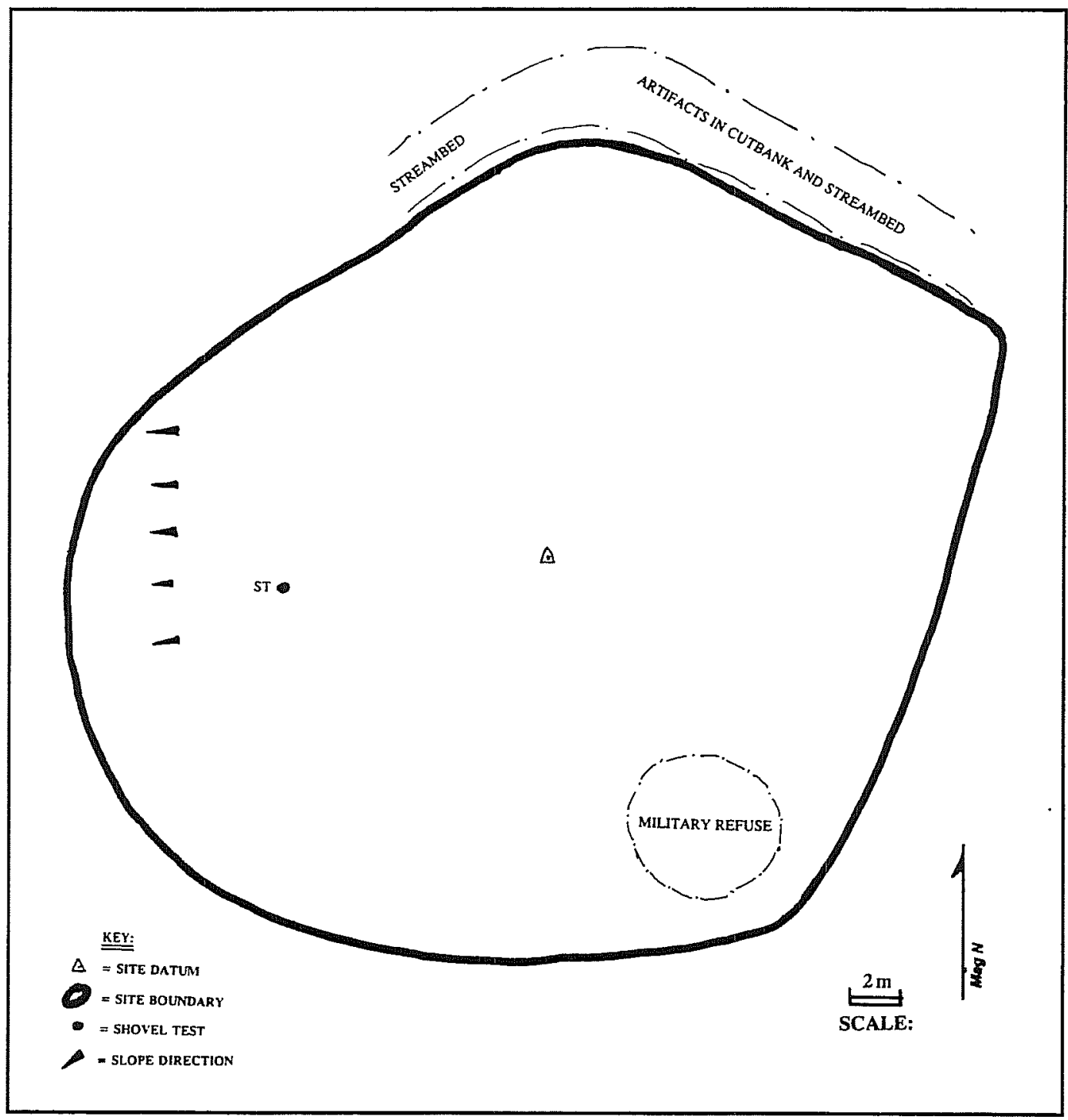

Figure 8-64. Site plan, 41BX1105.

\section{BX1106}

$41 \mathrm{BX} 1106$ (Figure $8-65$ ) is a quarry $300 \mathrm{~m}$ to the east of Medio Creek in adjacent uplands. Chert gravels crop out across the entire site, providing good raw materials for the manufacture of stone tools. A relatively high number of cores and exterior flakes suggests that the site was used for early stage lithic-reduction activities. The site has been slightly disturbed by erosion. The one shovel test at the site yielded two informal tools, suggesting the potential for an intact buried cultural deposit 20 $\mathrm{cm}$ below the surface. Research potential for $41 \mathrm{BX} 1106$ is moderate, so the site should be considered for inclusion in the NRHP. 


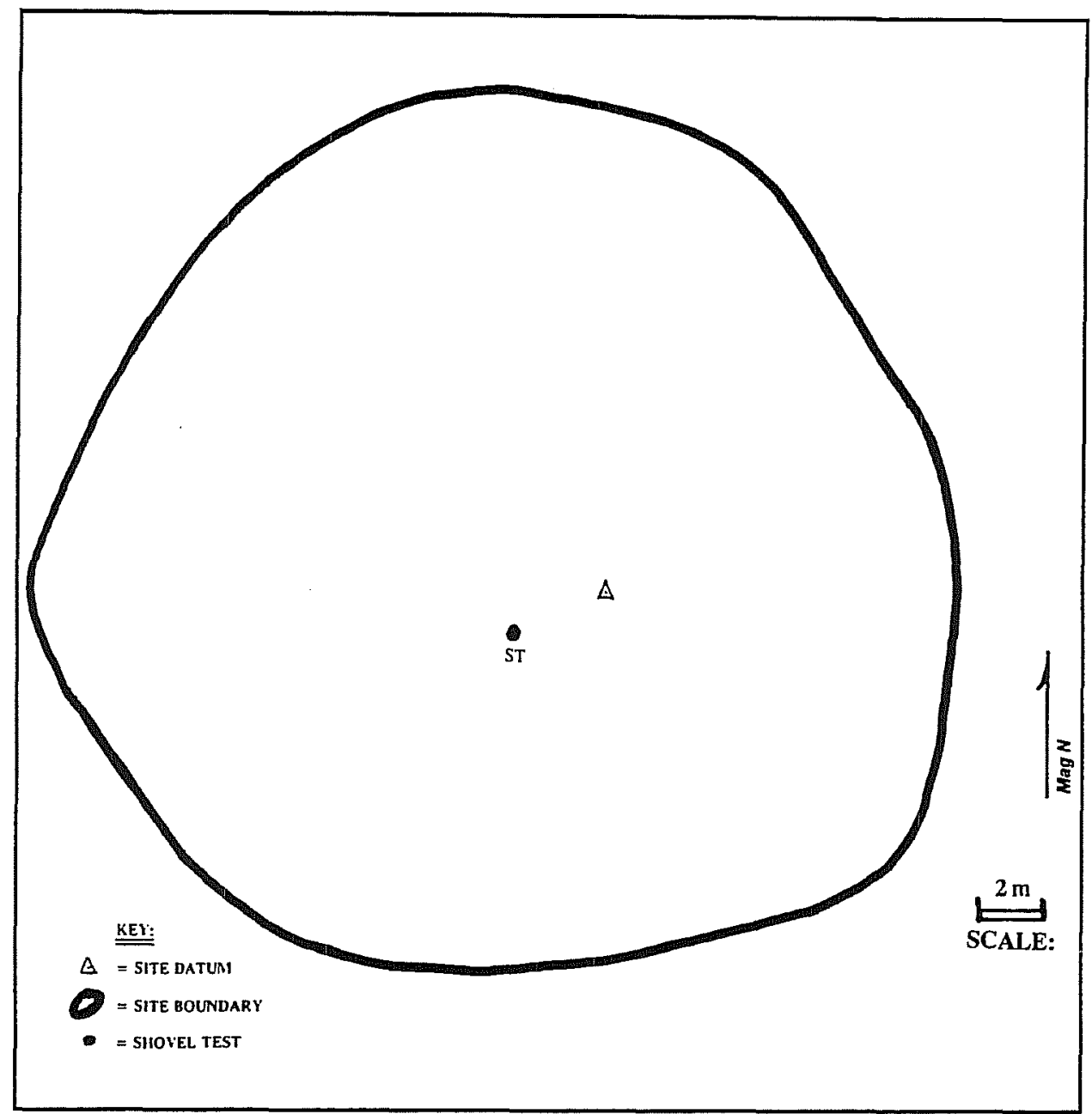

Figure 8-65. Site plan, 41BX1106.

\section{BX1109}

Site 41BX1109 (Figure 8-66) is a small prehistoric open campsite located approximately one kilometer east of and in the uplands above Long Hollow, where upland flora forms a dense cover. The light surface scatter of artifacts is composed of flakes and cores, suggesting early stage lithic-reduction activities. A butted knife biface suggests use of the site during the Late Archaic (Turner and Hester 1993:243). A shovel test revealed no artifacts below the surface. Disturbance to the site from animal burrowing is minimal and its research potential is moderate. 41BX1109 should be considered for inclusion in the NRHP.

\section{BX1124}

41BX1124 (Figure 8-67) is a prehistoric open campsite with a historic dump. The site is set in uplands $600 \mathrm{~m}$ southwest of Medio Creek and is covered with dense flora. Although the surface scatter of early reduction stage lithics is sparse, a concentration of fire-cracked rock suggests the presence of a hearth feature. A shovel test revealed artifacts to a depth of $30 \mathrm{~cm}$ below the surface. Animal burrowing has moderately disturbed the site. Disturbance slightly lessens research potential, but the presence of a hearth feature and a positive shovel test suggesting the possibility of buried intact cultural deposits offer an overall high research potential for this site. Therefore, it should be considered for inclusion in the NRHP. 


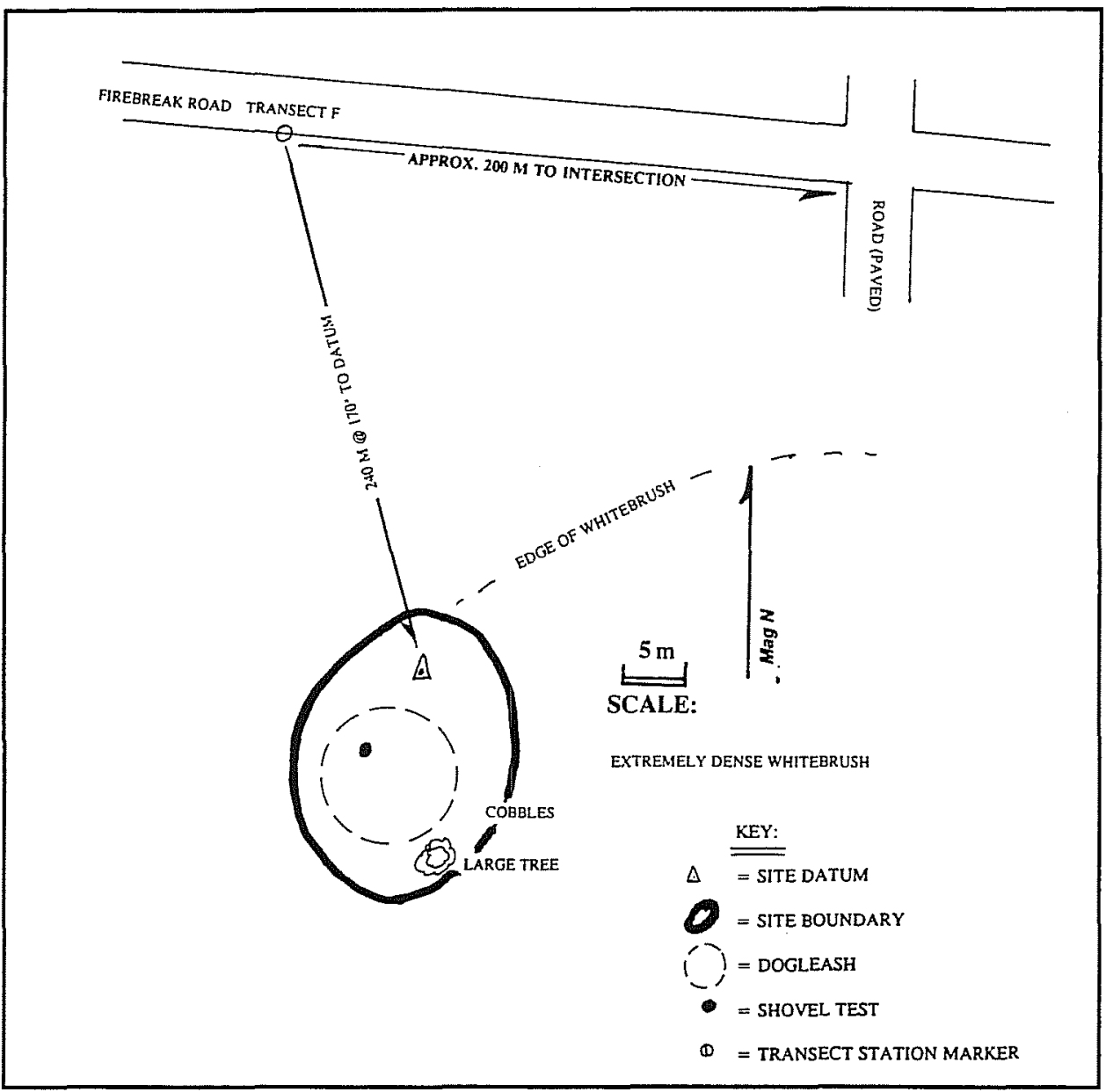

Figure 8-66. Site plan, 41BX1109.

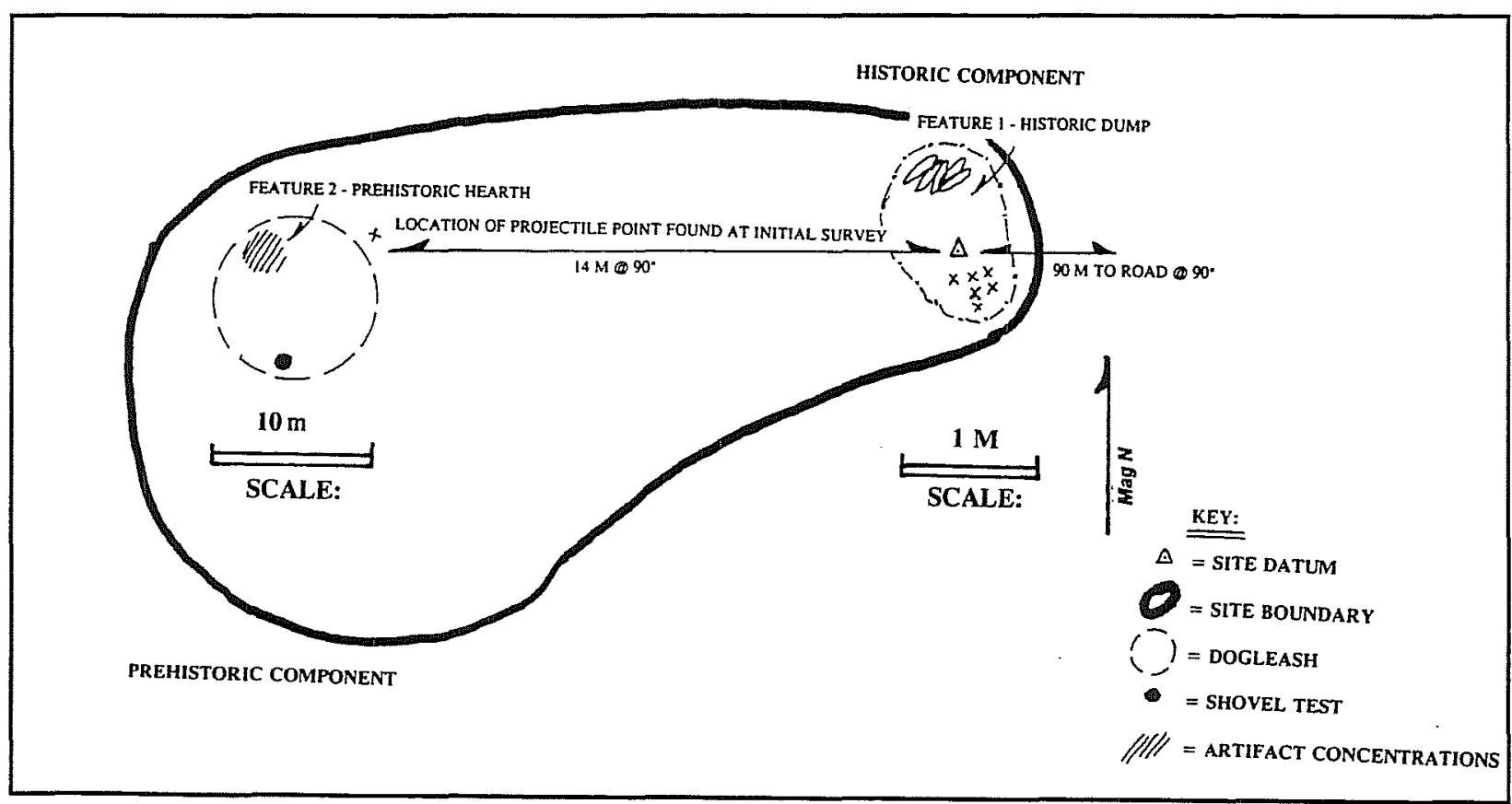

Figure 8-67. Site plan, 41BX1124. 


\section{Chapter 9. Isolated Finds}

The hundreds of isolated finds documented during the survey prohibited assigning individual field numbers to each item, but all were logged on isolated find forms (Appendix F). Only diagnostic artifacts (such as projectile points), thin bifaces, formal tools, and some historic items were given isolated find numbers. Forty-eight such items were collected and numbered sequentially. These include quarry blanks and preforms, formal and informal tools, thin bifaces, an adze, a drill, a notch, historic bottles, and three temporally diagnostic points: one La Jita projectile point (Middle Archaic), found in the north central part of Medina Annex, and two Guadalupe tools (Early Archaic) from the south central part. The additional 783 isolated finds, primarily flakes and cores, were recorded, but not collected. Table 9-1 gives an inventory of all isolated finds.

Table 9-1. Isolated Finds Inventory

\begin{tabular}{||l|c|c|c||}
\hline \multicolumn{1}{|c|}{ Artifacts } & Not Collected & Collected & Total \\
\hline Exterior flakes & 258 & 0 & $\mathbf{2 5 8}$ \\
\hline Interior flakes & 130 & 0 & $\mathbf{1 3 0}$ \\
\hline Thinning flakes & 5 & 0 & $\mathbf{5}$ \\
\hline Cores & 352 & 0 & $\mathbf{3 5 2}$ \\
\hline Quarry blanks & 11 & 13 & $\mathbf{2 4}$ \\
\hline Preforms & 10 & 5 & $\mathbf{1 5}$ \\
\hline Formal tools & 3 & 6 & $\mathbf{9}$ \\
\hline Informal tools & 14 & 12 & $\mathbf{2 6}$ \\
\hline Projectile points & 0 & 1 & $\mathbf{1}$ \\
\hline Thin bifaces & 0 & 3 & $\mathbf{3}$ \\
\hline Adzes & 0 & 1 & $\mathbf{1}$ \\
\hline Drills & 0 & 1 & $\mathbf{1}$ \\
\hline Notches & 0 & 1 & $\mathbf{1}$ \\
\hline Other & 0 & 2 Guadalupe tools, 3 bottles & $\mathbf{5}$ \\
\hline \multicolumn{1}{|c|}{ TOTAL } & $\mathbf{7 8 3}$ & $\mathbf{4 8}$ & $\mathbf{8 3 1}$ \\
\hline
\end{tabular}




\section{Chapter 10: Analysis of the Prehistoric Survey Data}

The prehistoric sites recorded in the project area are grouped below according to their location on Leon Creek, on Medio Creek's alluvial terrace system, in the upland zones of Medina Annex, or in the upland drainage system of Long Hollow. Grouping the sites in this fashion facilitated a coherent analytical structure and provided a foundation for a National Register of Historic Places evaluation scheme.

During the 1994-1995 CAR survey, 74 archaeological sites were recorded on Lackland AFB in the primarily undeveloped 3,860 acres on which the current project focused. Sixty-eight prehistoric sites were recorded during the project, four of which include a historic component (41BX1074, 41BX1121, 41BX1124, 41BX1130). Three additional sites have only a historic component (41BX1061, 41BX1128, 41BX1129). Three other prehistoric sites recorded by previous surveys (41BX1001 and 41BX1002 [De Vore 1993]; 41BX1006 [Petraglia and Knepper 1993]) were revisited by CAR teams and are therefore considered in the overall analysis of archaeological sites. Historic site descriptions and analyses are presented in Part III.

Below, an overview is given of site type, density, and distribution, according to location in the four major areas (Leon Creek, uplands of Medina Annex, terraces of Medio Creek, and Long Hollow) and general site time frame (prehistoric, historic, or both). Afterwards comparisons are made between specific site types and location, followed by a discussion of those sites with temporally diagnostic artifacts. These are considered in the contexts of specific site type and location.

A large part of the survey area along Medio Creek is considered to have great potential for buried, intact archaeological occurrences. Since a considerable number of sites in the project area revealed hints of subsurface cultural strata, the potential for buried sites is also discussed.

Beyond defined site boundaries, 831 isolated finds were recorded during the survey. These are described separately (Chapter 9), but as a separate data set they are compared to site data at the end of the chapter.

\section{Site Types}

Based on previous regional research, five prehistoric site types are possibel in the project area. These are: 1) open camp sites, 2) burned rock midden sites, 3) rock shelters, 4) quarry/lithic workshop sites, and 5) burial sites. Rockshelters and overhangs were not expected and none were located during CAR's survey. Reports of looting in and near the project area stimulated rumors that burials may present, but none were discovered. All recorded prehistoric sites were categorized as:
1) open campsites,
2) lithic quarry/workshop sites,
3) a combination of the above, or
4) burned rock middens sites.

Open campsites are defined by the presence of scattered fire-cracked rock (varying quantities), rare finished tools, and few thinning flakes or other advanced reduction stage debitage. Quarries are always set in exposed gravel sheets of varying sizes and contain related artifacts, such as tested cobbles, cores, exterior and interior flakes, and very rarely finished tools. When fire-cracked rock is present on 
quarry/workshops, the site is considered a camp and procurement location. Burned rock middens are distinguished by an accumulation of fire-cracked rock in concentrated clusters. Table 10-1 demonstrates the frequency of the various site types.

\section{General Site Density and Distribution}

\section{Leon Creek}

Only five sites are located on Lackland's Main Base. One of these is an early mid-twentieth century sewer line (41BX1061) connecting Kelly and Lackland AFB, described in Part III. The remainder are prehistoric sites near Leon Creek; two are located in the uplands just west of the creek and two on the broad alluvial floodplain below. This paucity of archaeological sites is undoubtedly due in part to an extensive history of base development occurring over the past five decades. Also, Leon Creek has long been known to amateur artifact collectors and site looters who have impacted the archaeological record.

\section{Medina Annex}

Medina Annex is more remote, less developed, and revealed a larger inventory of site: 69 . These are grouped by area into three physiographic categories and then compared to three general time period classifications according to the archaeological components present on the site (Table 10-2). The density and distribution of sites in each area are described below.

\section{Medina Annex Uplands}

The uplands are defined as areas of higher elevation beyond the alluvial terraces of Medio Creek, not including Long Hollow. Twenty-four prehistoric components were documented on 25 sites in upland areas, most of which are close to the terrace-uplands boundary.

\section{Medio Creek Terraces}

Of 25 sites documented in the floodplain and adjacent terraces of Medio Creek, two have both prehistoric and historic components and 22 have prehistoric cultural remains only. Medio Creek flows for approximately $7.4 \mathrm{~km}$ through the eastern half of Medina Annex, with an average site density of 3.38 sites per kilometer.

Nordt's work in Chapter 3 describes the terrace system for the stretch of Medio Creek flowing through the project area. The system contains at least three alluvial landforms: a second terrace (T2), a first terrace (T1), and a modern floodplain (T0). The T2, as the highest (ranging between $7.62 \mathrm{~m}$ and $9.14 \mathrm{~m}$ above the present low water channel) and oldest alluvial landform, is also the smallest in area. The available radiocarbon assays and general pedogenic development of soils and sediments in the terrace can be used to provide gross, estimated ages of older than Middle Holocene and probably Late Pleistocene.

Table 10-1. Frequency and Percentage of Site Types Recorded in Project Area

\begin{tabular}{|c|c|c|c|c|c|c|c|c|c|c||}
\hline \hline \multicolumn{2}{|c|}{ Open Campsite } & \multicolumn{2}{|c|}{$\begin{array}{c}\text { Quarry/ } \\
\text { Workshop }\end{array}$} & \multicolumn{2}{c|}{$\begin{array}{c}\text { Campsite and } \\
\text { Quarry }\end{array}$} & \multicolumn{2}{c|}{$\begin{array}{c}\text { Burned Rock } \\
\text { Midden }\end{array}$} & \multicolumn{2}{|c|}{ Historic Only } & Total \\
\hline$\#$ & $\%$ & $\#$ & $\%$ & $\#$ & $\%$ & $\#$ & $\%$ & $\#$ & $\%$ & $\#$ \\
\hline 20 & 27.0 & 31 & 41.9 & 19 & 25.7 & 1 & 1.4 & 3 & 4.1 & 74 \\
\hline
\end{tabular}


Table 10-2. Distribution of Archaeological Sites on Medina Annex

\begin{tabular}{|c|c|c|c|c|}
\hline Area & $\begin{array}{c}\text { Prehistoric } \\
\text { Sites }\end{array}$ & $\begin{array}{c}\text { Prehistoric/ } \\
\text { Historic Sites }\end{array}$ & $\begin{array}{c}\text { Historic } \\
\text { Sites }\end{array}$ & Total \\
\hline Medina Annex Uplands & 22 & 2 & 1 & 25 \\
\hline Medio Creek Terraces & 22 & 2 & 1 & 25 \\
\hline Long Hollow & 19 & - & - & 19 \\
\hline Total & 63 & 4 & 2 & 69 \\
\hline
\end{tabular}

The $\mathrm{T} 1$ is the largest alluvial landform and ranges between 3.05 and $4.57 \mathrm{~m}$ above the present low water channel, and is primarily confined to modern meanders. Absolute dates indicate that it is at least Middle Holocene to Late Holocene. Development of soils and sediments in the T1 terrace suggests that deposition may have begun as early as the Early Holocene. The modern floodplain, or T0, is actively aggrading and ranges in elevation between 1.83 and $2.44 \mathrm{~m}$ above the low water channel and within meanders. Absolute dates from the T0 terrace indicate that it accumulated during the Late Holocene. Table 10-3 demonstrates the distribution of archaeological sites across the alluvial terraces.

That the highest frequency of sites is on $\mathrm{T} 1$ is not surprising since it covers the greatest area. The fact that so few sites were located on the aggrading T0 floodplain was also to be expected. Collins's (1995:367-368) observation that the insides of channel meander belts typically reveal few or no surface cultural occurrences is substantiated by CAR's survey of Medio Creek in Lackland AFB. The few surface sites that were documented in this setting, and the high potential for subsurface cultural strata (revealed by shovel testing at each site) also support the hypothesis that pointbars were not overlooked as camping areas by prehistoric groups, but because of stream dynamics most occupation areas were buried in a low energy, fluvial depositional environment (see Chapter 3). It is here, within the meander belts, that the greatest potential occurs for high-resolution buried, stratified sites (Collins 1995:368).

\section{Long Hollow}

This upland intermittent drainage stretches for about $3.36 \mathrm{~km}$ along the northwestern edge of Medina Annex. CAR recorded 19 sites associated with the drainage, giving an average density of 5.65 sites per kilometer, with all sites dating to the Prehistoric period. However, such a high a frequency is misleading because much of the drainage is bounded on both sides by virtually continuous exposures of Uvalde Gravels. Most of the exposed areas were exploited as raw materials quarries and thus the sites are larger in comparison to most found elsewhere in the project area.

Table 10-3. Distribution of Archaeological Sites across Medio Creek Terraces

\begin{tabular}{||c|c|c|c|c||}
\hline Terrace & $\begin{array}{c}\text { Prehistoric } \\
\text { Sites }\end{array}$ & $\begin{array}{c}\text { Prehistoric/ } \\
\text { Historic Sites }\end{array}$ & $\begin{array}{c}\text { Historic } \\
\text { Sites }\end{array}$ & Total \\
\hline $\mathrm{T} 2$ & 4 & - & - & $\mathbf{4}$ \\
\hline $\mathrm{T} 1$ & 14 & 2 & - & $\mathbf{1 6}$ \\
\hline $\mathrm{T} 0$ & 4 & - & 1 & $\mathbf{5}$ \\
\hline Total & $\mathbf{2 2}$ & $\mathbf{2}$ & $\mathbf{1}$ & $\mathbf{2 5}$ \\
\hline
\end{tabular}




\section{Spatial Distribution of Prehistoric Site Types}

Appraising the way in which specific prehistoric site types are distributed across the landscape reveals some interesting patterns. Table 10-4 demonstrates the frequency of site type in each major geographic group.

\section{Open Campsites}

Twenty (ca. 28 percent) of the prehistoric sites located in the project area are open campsites. Table $10-5$ shows that 60 percent of all such sites occur on
Medio Creek's alluvial terraces. Open campsites occurring independently of other site types (i.e. quarry/workshops) are less frequent in the uplands (5 of 25 sites). This difference is most likely attributed to a greater distance from water, even though most uplands sites on Medina Annex are located near the alluvial terrace boundary, and not a great distance from the creek channel. In stark contrast, no exclusively open campsites were located in Long Hollow, defined above as an uplands intermittent drainage system. Only five (or slightly more than 26 percent) of all Long Hollow sites include evidence for ephemeral camps, primarily occurring as small quantities of firecracked rock on much larger quarry/workshop stations.

Table 10-4. Frequency and Percentage of Prehistoric Site Types by Geographic Area

\begin{tabular}{|c|c|c|c|c|c|c|c|c|c|c|}
\hline \multirow{4}{*}{\begin{tabular}{|r} 
Area \\
Leon Creek
\end{tabular}} & \multicolumn{8}{|c|}{ Prehistoric Site Type } & \multirow{2}{*}{\multicolumn{2}{|c|}{ Area Totals }} \\
\hline & \multirow{2}{*}{\multicolumn{2}{|c|}{$\begin{array}{c}\text { Open } \\
\text { Campsite }\end{array}$}} & \multirow{2}{*}{\multicolumn{2}{|c|}{$\begin{array}{l}\text { Quarry/ } \\
\text { Workshop }\end{array}$}} & \multirow{2}{*}{\multicolumn{2}{|c|}{$\begin{array}{l}\text { Campsite and } \\
\text { Quarry }\end{array}$}} & \multirow{2}{*}{\multicolumn{2}{|c|}{$\begin{array}{c}\text { Burned Rock } \\
\text { Midden }\end{array}$}} & & \\
\hline & & & & & & & & & $\#$ & $\%$ \\
\hline & 3 & 75.0 & - & - & - & - & 1 & 25.0 & 4 & 5.6 \\
\hline Medina Annex uplands & 5 & 20.8 & 14 & 58.3 & 5 & 20.8 & - & - & 24 & 33.8 \\
\hline Medio Creek terraces & 12 & 50.0 & 6 & 25.0 & 6 & 25.0 & - & - & 24 & 33.8 \\
\hline Long Hollow & - & & 11 & 57.9 & 8 & 42.1 & - & - & 19 & 26.8 \\
\hline Totals & 20 & 28.2 & 31 & 43.7 & 19 & 26.8 & $\overline{1}$ & 1.4 & 71 & 100 \\
\hline
\end{tabular}

Table 10-5. Frequency Distribution of Prehistoric Open Campsites

\begin{tabular}{||c|c|c|c|c|c|c|c|c||}
\hline \multicolumn{7}{||c|}{ Geographic Area } & \multirow{2}{*}{ Total } \\
\cline { 1 - 6 } \multicolumn{2}{||c|}{ Leon Creek } & \multicolumn{2}{|c|}{$\begin{array}{c}\text { Medina Annex } \\
\text { Uplands }\end{array}$} & \multicolumn{2}{c|}{$\begin{array}{c}\text { Medio Creek } \\
\text { Terraces }\end{array}$} & \multicolumn{2}{|c|}{ Long Hollow } & \\
\hline$\#$ & $\%$ & $\#$ & $\%$ & $\#$ & $\%$ & $\#$ & $\%$ & \\
\hline 3 & 15.0 & 5 & 25.0 & 12 & 60.0 & - & & 20 \\
\hline
\end{tabular}




\section{Quarry/Lithic Workshop Sites}

These locations were exploited for their exposures of raw chert cobbles. In some cases they represent veritable pavements of cobbles extending over a large area, while in other settings such a site may be represented by a small, scattered cluster. Quarry/workshops form almost half (43.7 percent) of the recorded prehistoric sites in the project area (Table 10-4). Table 10-6 demonstrates the geographic distribution of these sites.

The absence of quarry sites on Leon Creek is explained by two factors: 1) heavy disturbance has occurred on the Main Base along Leon Creek, and 2) the creek bottom, with a pavement of river cobbles, was probably used as a source for raw materials. The majority of quarry sites are concentrated in the upland zones adjacent to Medio Creek and Long Hollow, but in the latter, the frequency distribution figure fails to convey the true magnitude of use intensity. The alluvial terraces along Medio Creek yielded a lower frequency of quarry sites, due to the absence of significant gravel exposures.

\section{Camp/Quarry Sites}

Sites incorporating evidence for both habitation and raw materials procurement make up 26.8 percent of all recorded prehistoric sites (Table 10-4). These sites are characterized by a predominance of quarry related artifacts with light or rare associations of habitation related artifacts, such as fire-cracked rock, thinning flakes, or finished tools. Table 10-7 demonstrates the distribution of such sites through the project area.

The lack of camp/quarry sites on the Main Base along Leon Creek has been discussed. On Medina Annex, the sites are almost equally distributed across the three major areas, but are present primarily in higher elevations (uplands and Long Hollow) where gravel exposures are prevalent. Based on the surface artifactual evidence, these locations suggest that prehistoric groups frequently visited the exposures for raw materials, and periodically stayed long enough to build fires.

Table 10-6. Frequency Distribution of Prehistoric Quarry/Workshops

\begin{tabular}{|c|c|c|c|c|c|c|c|c|}
\hline \multicolumn{8}{|c|}{ Geographic Area } & \multirow[b]{2}{*}{ Total } \\
\hline \multicolumn{2}{|c|}{ Leon Creek } & \multicolumn{2}{|c|}{$\begin{array}{l}\text { Medina Annex } \\
\text { Uplands }\end{array}$} & \multicolumn{2}{|c|}{$\begin{array}{l}\text { Medio Creek } \\
\text { Terraces }\end{array}$} & \multicolumn{2}{|c|}{ Long Hollow } & \\
\hline \# & $\%$ & \# & $\%$ & \# & $\%$ & \# & $\%$ & \\
\hline- & & 14 & 45.2 & 6 & 19.4 & 11 & 35.5 & 31 \\
\hline
\end{tabular}

Table 10-7. Frequency Distribution of Prehistoric Camp/Quarry Sites

\begin{tabular}{|c|c|c|c|c|c|c|c|c||}
\hline \hline \multicolumn{7}{|c|}{ Geographic Area } & \\
\hline \multicolumn{2}{||c|}{ Leon Creek } & \multicolumn{2}{|c|}{$\begin{array}{c}\text { Medina Annex } \\
\text { Uplands }\end{array}$} & \multicolumn{2}{c|}{$\begin{array}{c}\text { Medio Creek } \\
\text { Terraces }\end{array}$} & \multicolumn{2}{|c|}{ Long Hollow } & Total \\
\hline$\#$ & $\%$ & $\#$ & $\%$ & $\#$ & $\%$ & $\#$ & $\%$ & \\
\hline- & & 5 & 26.3 & 6 & 31.6 & 8 & 42.1 & $\mathbf{1 9}$ \\
\hline
\end{tabular}


Heat-fractured chert is present in most areas of Medina Annex, both on and off archaeological sites. The assumption that heated chert and small quantities of fire-cracked rock indicate intentional thermal alteration for lithic manufacture must be regarded as only one possibility. Range fires that would have swept over the area are most likely to blame for the ubiquitous presence of heat damaged stone. Range fires were a natural part of the ecological cycle before human intervention in the post-Colonial era.

\section{Burned Rock Middens}

The only burned rock midden (41BX1108) located during the survey was detected by shovel testing, when dense concentrations of fired limestone were recorded in discrete levels. Two shovel tests placed $30 \mathrm{~m}$ apart detected the same deposits, indicating the probability of an extensive feature. In this case, the light surface scatter of a few small thinning flakes and interior flakes gave no indication of subsurface remains.

The importance of locating this site is underscored by the observation that burned rock middens are rare south of the Balcones Escarpment (Black 1989a:45). "Midden areas" have been identified in southwestern Bexar County on Live Oak Creek (also a tributary of the Medina River), but these are identified by altered sediments, ash, and a few pieces of fired limestone, chert, and quartzite, rather than large quantities of fire-cracked rock (McReynolds 1982:13). In central Texas, middens usually occur near water sources (Creel 1986). Black (1989:45) and Creel (1986) consider that the association of large middens with live oak mottes and water sources implies some level of acorn processing. At Lackland, a few large live oaks still survive along Medio Creek, and on Leon Creek several are close to $41 \mathrm{BX} 1108$. Several open campsites located on the alluvial terraces of Medio Creek contained varying quantities of fire-cracked rock. Intact burned rock middens or smaller hearth features are most likely present on these sites.

\section{The Distribution of Prehistoric Sites Across Medio Creek's Terraces}

The alluvial terraces of Medio Creek hold the greatest potential for buried, intact archaeological deposits. Above, Table 10-3 illustrates how prehistoric and historic sites, or sites that are a combination of both, are distributed across the terrace system. To refine that image, Table 10-8 shows how specific prehistoric site types occur in the same area.

Terrace $\mathrm{T} 2$ is the smallest in area and the highest in elevation, and thus, the closest to upland zones. Only four sites were recorded in this limited area, all of which are quarry sites. Sixty percent of the sites on $\mathrm{T} 1$ are open campsites, followed by a smaller proportion of combination camp/quarry sites. Only two sites are exclusively quarry/workshops. This distribution of site types reflects a closer proximity to water and fewer gravel exposures. On the floodplain of Medio Creek, or T0, only five sites were located, four ( 80 percent) of which are open campsites. The one camp/quarry site is primarily situated in the uplands, but spills onto the adjacent $\mathrm{TO}$ as well. The 24 prehistoric sites recorded by CAR on Medio Creek's terraces display a clear pattern indicating that lithic procurement sites and workshops are found at higher elevations. Primary habitation areas occur at lower elevations closer to water sources.

Table 10-8. Distribution of Prehistoric Site Types across Medio Creek Terraces

\begin{tabular}{|c|c|c|c|c|c|c|}
\hline \multirow[b]{2}{*}{ Terrace } & \multicolumn{4}{|c|}{ Site Type } & \multirow{2}{*}{\multicolumn{2}{|c|}{ Total }} \\
\hline & $\begin{array}{c}\text { Open } \\
\text { Campsite }\end{array}$ & $\begin{array}{l}\text { Quarry/ } \\
\text { Workshop }\end{array}$ & $\begin{array}{l}\text { Campsite } \\
\text { and Quarry }\end{array}$ & $\begin{array}{l}\text { Burned rock } \\
\text { Midden }\end{array}$ & & \\
\hline $\mathrm{T} 2$ & - & 4 & - & - & 4 & 16.7 \\
\hline $\mathrm{T} 1$ & 9 & 2 & 4 & - & 15 & 62.5 \\
\hline TO & 4 & - & 1 & - & 5 & 20.8 \\
\hline Total & 54.2 & 25.0 & 20.8 & - & 24 & 100 \\
\hline
\end{tabular}




\section{Diagnostic Artifacts and their Distribution: Evidence for an Extended Era of Use at Lackland AFB}

The results of the Phase 1 survey and shovel testing within the project area offer a broad picture of the time frame in which the land was exploited. This impression is solely based on temporally diagnostic recovered from site surfaces and as isolated finds. Limited shovel testing indicates the presence of a wealth of information buried below the surface of many sites. Even with the relatively low degree of resolution conveyed by surface data, the diverse topography and settings from which artifacts were recovered suggest that the entire landscape was favorable for prehistoric use and occupation.

Fortunately, several of the sites recorded during the current project yielded identifiable diagnostic tools and projectile points that facilitate formulation of a working chronology of the area. Below, a brief synopsis is given for the major cultural periods to which temporal diagnostics can be assigned (Collins 1995; Johnson and Goode 1994; Turner and Hester 1993).

\section{Paleoindian (ca. 11,500-8800 B.P.)}

The only diagnostic artifact found that could possibly be associated with a Paleoindian presence in the project area is a Clear Fork biface. This heavily patinated tool was recovered from a disturbed context (road cut) in an open campsite (41BX1114) straddling the second terrace and uplands of upper Medio Creek. Because no other evidence for Paleoindian occupation was encountered, this artifact is believed to be Early Archaic in age.

\section{Early Archaic (ca. 8800-6000 B.P.)}

Ten Early Archaic diagnostic artifacts (including the Clear Fork biface described above) were recorded in the project area. Table 10-9 gives the artifact type, general location, and associated terrace if on Medio Creek, and type of occurrence (whether site or isolated find). All were found in surface contexts, and 75 percent are associated with sites. These artifacts are illustrated in Figures 10-1 and 10-2.

Perhaps the most significant aspect of the spatial distribution is that most Early Archaic artifacts were recorded in the uplands or on high terraces adjacent to the uplands. This includes the artifacts from Long Hollow, Medina Annex uplands, and the T2 terrace of Medio Creek, which make up 75 percent of the Early Archaic specimens. Two Early Triangular dart points reported by Dalbey (1993) and De Vore (1993) have not been analyzed by CAR, and their present location is unknown.

Table 10-9. Early Archaic Artifacts by Location

\begin{tabular}{||l|c|c|c|c|c||}
\hline \multicolumn{1}{|c|}{ Artifact Type } & Leon Creek & $\begin{array}{c}\text { Medina Annex } \\
\text { Uplands }\end{array}$ & $\begin{array}{c}\text { Medio Creek } \\
\text { Terraces }\end{array}$ & Long Hollow & Total \\
\hline Clear Fork biface & - & - & $41 \mathrm{BX} 1114(\mathrm{~T} 2)$ & - & $\mathbf{1}$ \\
\hline Clear Fork uniface & - & - & - & $41 \mathrm{BX} 1104,1072$ & $\mathbf{2}$ \\
\hline Early Triangular dart point & - & - & $\begin{array}{c}41 \mathrm{BX} 1001(\mathrm{~T} 0), \\
41 \mathrm{BX} 1002(\mathrm{~T} 1)\end{array}$ & - & $\mathbf{2}$ \\
\hline Guadalupe biface & - & $\begin{array}{c}41 \mathrm{BX1088}(2), \\
\text { isolate }\end{array}$ & isolate (T1) & $41 \mathrm{BX} 1100$ & $\mathbf{5}$ \\
\hline LaJita (Middle Archaic) & - & isolate & - & - & \\
\hline \multicolumn{1}{|c|}{ Total } & - & $\mathbf{4}$ & $\mathbf{4}$ & $\mathbf{3}$ & $\mathbf{1 0}$ \\
\hline
\end{tabular}



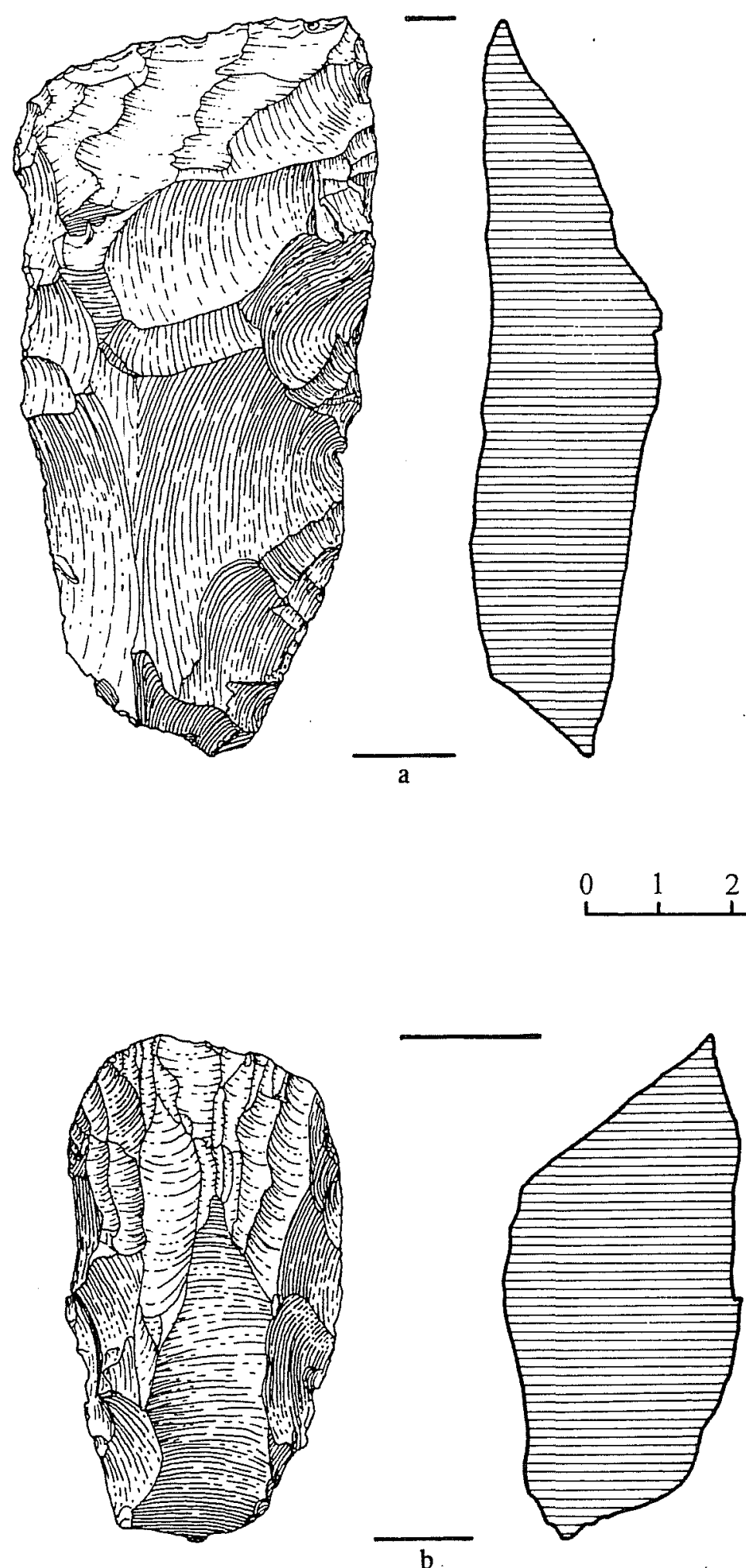

Figure 10-1. Early Archaic diagnostic artifacts. a. Clear Fork biface (41BX1114); b. Guadalupe biface (IF-53). 

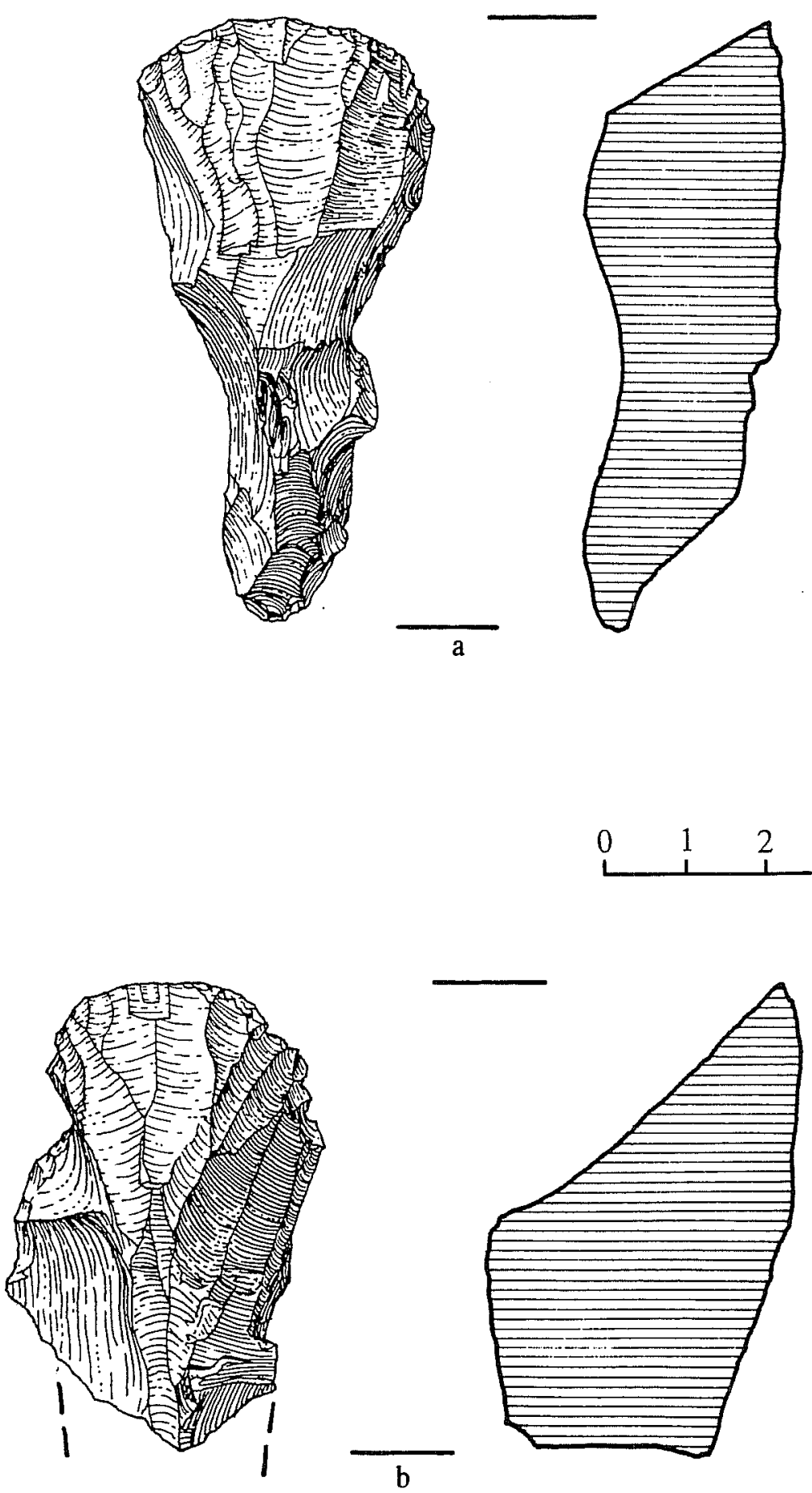

Figure 10-2. Archaic diagnostic artifacts. a. Early Archaic Guadalupe biface (DL-20-2); b. Early Archaic Guadalupe biface (DL 20-3). 


\section{Middle Archaic (6000-4000 B.P.)}

Two Middle Archaic diagnostic artifacts have been recorded from the project area. Table 10-10 shows the artifact type and general location for both of these dart points. The previously described Clear Fork tools may also be from the Middle Archaic but were not included here (Turner and Hester 1993:246-249).

A number of the dart point styles that previously would have been considered Middle Archaic diagnostics, such as the Pedernales type, are assigned here to the Late Archaic, following the recent reordering of the central Texas Archaic by Johnson and Goode (1994) and Collins (1995). These artifacts are listed in Table 10-11 and illustrated in Figure 10-3. However, the Bulverde point style, considered Late Archaic by Johnson and Goode (1994), is retained in the late Middle Archaic for the purposes of this study, following Potter and
Black (1995:7). On the other hand, an artifact style previously considered Early Archaic, the La Jita dart point, is assigned here to the Middle Archaic, part of a possible Nolan-Travis continuum just before the Bulverde intrusion (Johnson and Goode 1994; McKinney et al. 1997). The La Jita point was an isolated find in the uplands of the Medina Annex and the Bulverde point was recovered from Long Hollow.

\section{Late Archaic (4000-2300 B.P.)}

Eight Middle to Late Archaic and nine Late Archaic diagnostic artifacts (Figures 10-3 and 10-4) were recorded in the project area. Tables 10-11 and 10-12 list their type, general location, and number. The traditional assignment of the Pedernales, Langtry, Marshall, and Tortugas dart point styles to the Middle Archaic has been noted above.

Table 10-10. Middle Archaic Artifacts by Location

\begin{tabular}{||c|c|c|c|c|c|}
\hline \multicolumn{1}{|c|}{ Artifact Type } & Leon Creek & $\begin{array}{c}\text { Medina Annex } \\
\text { Uplands }\end{array}$ & $\begin{array}{c}\text { Medio Creek } \\
\text { Terraces }\end{array}$ & Long Hollow & Total \\
\hline LaJita dart point & - & isolate & - & - & 1 \\
\hline Bulverde dart point & - & - & - & $41 \mathrm{BX} 1104$ & 1 \\
\hline Total & - & $\mathbf{1}$ & - & 1 & 2 \\
\hline
\end{tabular}

Table 10-11. Middle to Late Archaic Artifacts by Location

\begin{tabular}{||l|c|c|c|c|c||}
\hline \multicolumn{1}{|c|}{ Artifact Type } & Leon Creek & $\begin{array}{c}\text { Medina Annex } \\
\text { Uplands }\end{array}$ & $\begin{array}{c}\text { Medio Creek } \\
\text { Terraces }\end{array}$ & Long Hollow & Total \\
\hline Langtry/Arenosa point & - & - & - & $41 \mathrm{BX} 1104$ & $\mathbf{1}$ \\
\hline Langtry dart point & $41 \mathrm{BX} 1065$ & - & - & & $\mathbf{1}$ \\
\hline Marshall dart point & - & - & $41 \mathrm{BX} 1069$ & - & $\mathbf{1}$ \\
\hline Pedernales dart points & - & $41 \mathrm{BX} 1088$ & $41 \mathrm{BX} 1069,1102,1121$ & - & $\mathbf{4}$ \\
\hline Tortugas dart point & - & & - & $41 \mathrm{BX} 1104$ & $\mathbf{1}$ \\
\hline \multicolumn{1}{|c|}{ Total } & $\mathbf{1}$ & $\mathbf{1}$ & $\mathbf{4}$ & $\mathbf{2}$ & $\mathbf{8}$ \\
\hline
\end{tabular}




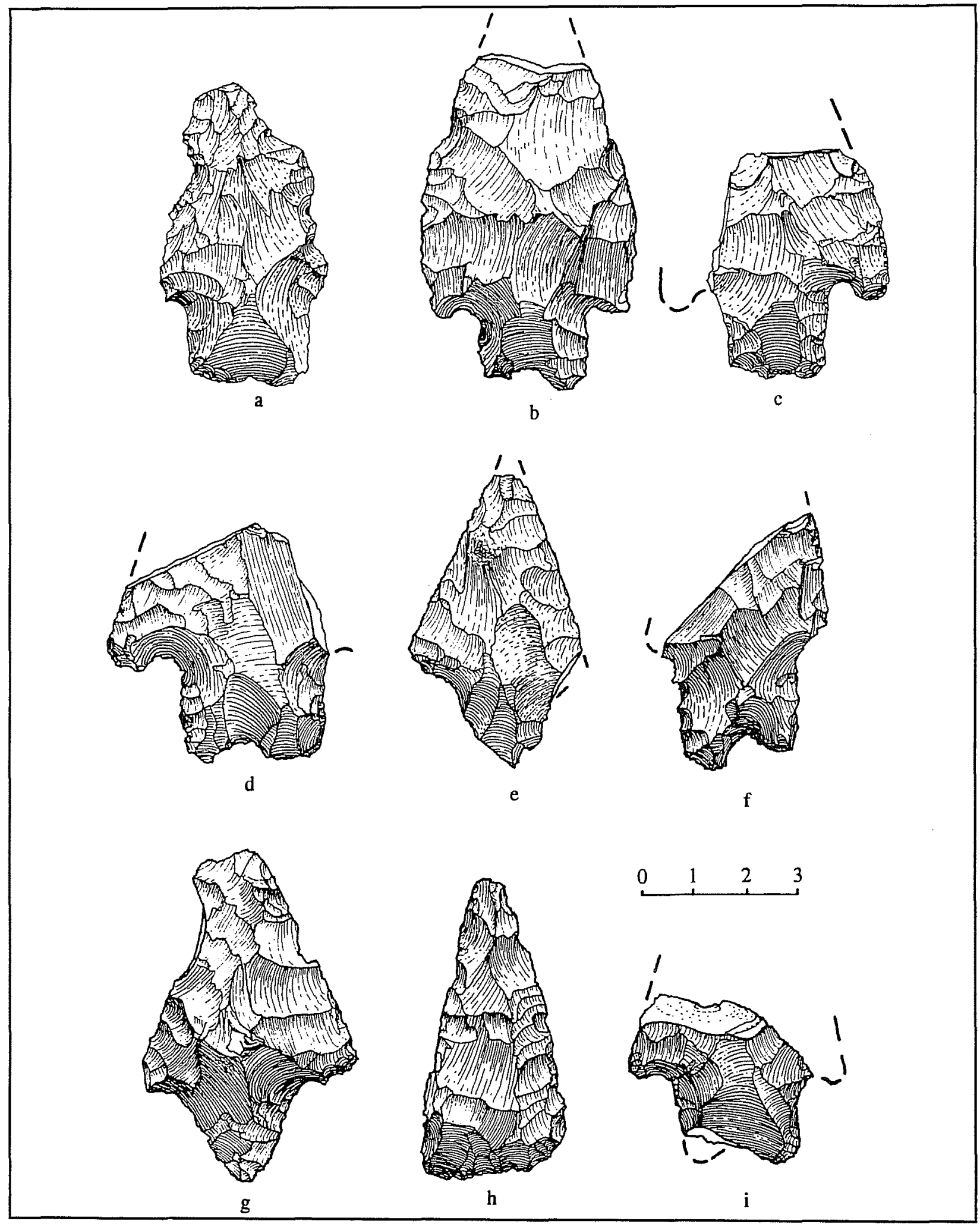

Figure 10-3. Middle to Late Archaic diagnostic artifacts. a. La Jita dart point (IF-2), b. Pedernales dart point (41BX1069); c. Bulverde dart point (41BX1104); d. Pedernales dart point (41BX1088); e. Langtry dart point (41BX1065); f. Pedernales dart point (41BX1102); g. Langtry/Arenosa dart point (41BX1104); h. Tortugas dart point (41BX1104); i. Pedernales dart point (41BX1121). 


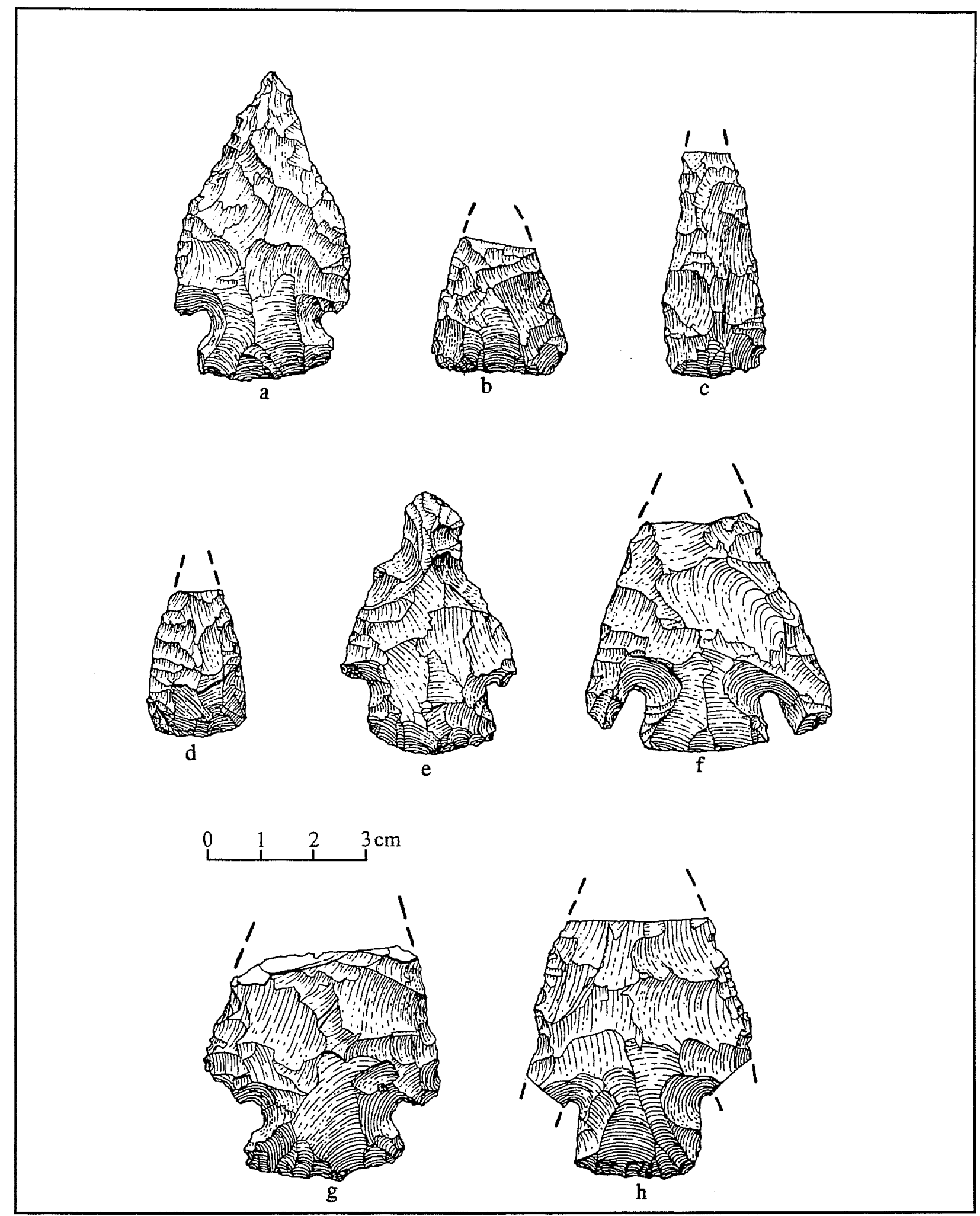

Figure 10-4. Late Archaic diagnostic artifacts. a. Marcos dart point (41BX1065); b. Matamoros dart point (41BX1065); c. Matamoros dart point (41BX1065); d. Matamoros dart point (41BX1087); e. Lange dart point (41BX1088); f. Castroville dart point (41BX1100); g. Castroville dart point (41BX1101); h. Castroville dart point (41BX1104). 
Table 10-12. Late Archaic Artifacts by Location

\begin{tabular}{||l|c|c|c|c|c||}
\hline \multicolumn{1}{|c|}{ Artifact Type } & Leon Creek & $\begin{array}{c}\text { Medina Annex } \\
\text { Uplands }\end{array}$ & $\begin{array}{c}\text { Medio Creek } \\
\text { Terraces }\end{array}$ & Long Hollow & Total \\
\hline Butted knife biface & - & - & - & $41 \mathrm{BX} 1109$ & $\mathbf{1}$ \\
\hline Castroville points & - & - & - & $41 \mathrm{BX} 1100,1101,1104$ & $\mathbf{3}$ \\
\hline Lange point & - & $41 \mathrm{BX} 1088$ & - & - & $\mathbf{1}$ \\
\hline Marcos point & $41 \mathrm{BX} 1065$ & - & - & - & $\mathbf{1}$ \\
\hline Matamoros points & $41 \mathrm{BX} 1065(2)$ & - & $41 \mathrm{BX} 1087(\mathrm{~T} 1)$ & - & $\mathbf{3}$ \\
\hline \multicolumn{1}{|c|}{ Total } & $\mathbf{3}$ & $\mathbf{1}$ & $\mathbf{1}$ & $\mathbf{4}$ & $\mathbf{9}$ \\
\hline
\end{tabular}

The Langtry point and the Langtry/Arenosa variant as proposed by Bement (1991) are tabulated separately in Table 10-11. Diagnostic of the Lower Pecos Archaic ca. 4100-3200 B.P. (Turpin 1991), Langtry is recognized as a highly variable type and the Arenosa variant has not yet gained full acceptance (McKinney et al. 1997). The Marshall dart point listed here was reported by Dalbey (1993:63), but has not been analyzed by CAR.

The general pattern conveyed by the distribution of the Middle to Late Archaic diagnostic artifacts is one of close proximity to water. Almost 56 percent of these specimens were recovered from directly on or above extant water channels (Medio and Leon creeks). Only one specimen was discovered in high uplands, yet not far from Medio Creek. A surprising number of finds was recorded in Long Hollow.

Today, Long Hollow is a dry and shallow channel, and probably was the same during earlier xeric periods which, according to some studies (Collins 1995), may have been frequent during much of the
Middle and Late Archaic. However, the seep holes surviving in the hollow today may have persisted through dry periods. The later Late Archaic artifacts-Castroville, Lange, Marcos, and south Texas Matamoros points-predominate ( 89 percent) in upland zones above Leon Creek (41BX1065 sits on a bluff west of the creek; see Appendix H) and in Long Hollow. One dart point was reported from the uplands of Medina Annex. Even so, their respective proveniences are not far from water sources. Only one artifact attributed to the later Late Archaic, a possibly intrusive Matamoros point from southern Texas/northeastern Mexico, was recovered from a Medio Creek terrace.

\section{Transitional Archaic (2300-1300 B.P.)}

Only five artifacts diagnostic of the Transitional Archaic period were recovered in the project area. These artifacts are listed in Table 10-13 and illustrated in Figure 10-5. All are from site context restricted to upland zones, but as in earlier periods they are not very far from water sources.

Table 10-13. Diagnostic Transitional Archaic Artifacts by Location

\begin{tabular}{|l|c|c|c|c|c||}
\hline \multicolumn{1}{|c|}{ Artifact Type } & Leon Creek & $\begin{array}{c}\text { Medina Annex } \\
\text { Uplands }\end{array}$ & $\begin{array}{c}\text { Medio Creek } \\
\text { Terraces }\end{array}$ & Long Hollow & Total \\
\hline Edgewood points & - & - & - & $41 \mathrm{~B} \times 1071,1103$ & $\mathbf{2}$ \\
\hline Ellis point & & - & $41 \mathrm{BX} 1101$ & $\mathbf{1}$ \\
\hline Ensor point & $41 \mathrm{BX} 1065$ & - & - & - & $\mathbf{1}$ \\
\hline Frio point & - & - & - & $41 \mathrm{BX} 1101$ & $\mathbf{1}$ \\
\hline \multicolumn{1}{|c|}{ Total } & $\mathbf{1}$ & - & - & $\mathbf{5}$ \\
\hline
\end{tabular}



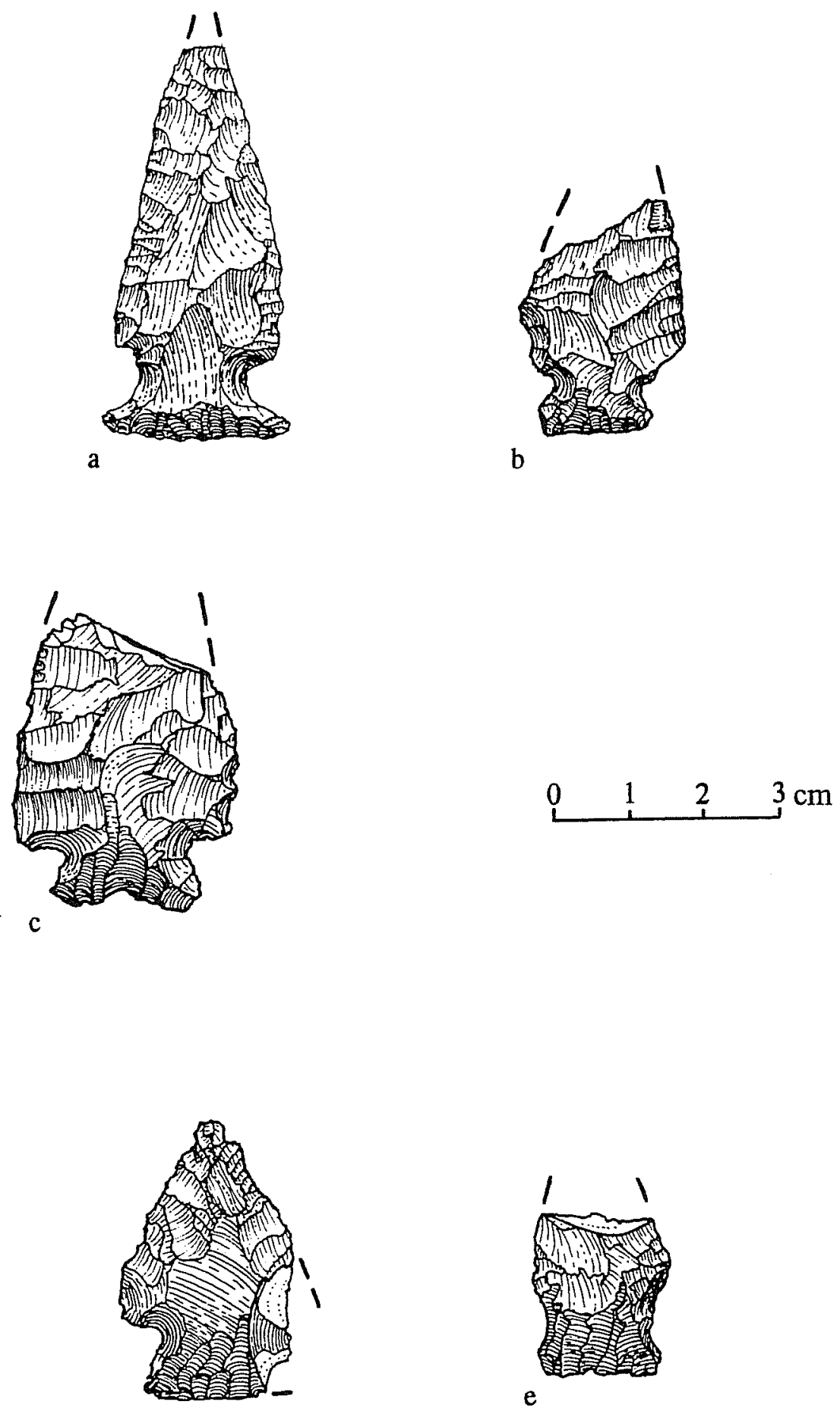

d

Figure 10-5. Transitional Archaic diagnostic artifacts. a. Ensor dart point (41BX1065); b. Edgewood dart point (41BX1071); c. Frio dart point (41BX1101); d. Ellis dart point (41BX1101); e. Edgewood dart point (41BX1103). 


\section{Late Prehistoric (from 1300 B.P.)}

Only three Late Prehistoric arrow points were recovered in the project area. This points are listed in Table 10-14 and illustrated in Figure 10-6. Late Prehistoric specimens, while very few in number, are distributed across all three physiographic areas of Medina Annex and are derived from site contexts.

\section{Use of the Lackland Landscape During the Holocene: An Overview}

The manner in which specific Holocene temporal diagnostics are distributed within the project area is discussed above for each cultural period. Below, Table 10-15 groups the artifacts by time period and compares them to geophysical setting. Several general observations can be made, but with the qualifier that only 37 specimens comprise the total sample of diagnostics from such a large area.

The geographic sample from the Main Base at Lackland along Leon Creek is not considered viable because of the small number of specimens recovered, a function of the high level of disturbance in the area and intensive artifact collecting over the years, which undoubtedly contributed to the small sample size.

On Medina Annex, the greatest number of artifacts was recovered in Long Hollow, a relatively small area when compared to the whole of the project area. The next largest sample of artifacts came from the Medio Creek terraces. The number of diagnostic artifacts overall peaks in the Late Archaic on the Medio Creek terraces and in Long Hollow.
Inmediately before and after this period the occurrence of diagnostic artifacts is confined to Long Hollow, with the exception of an isolated Middle Archaic point found in the uplands. A secondary peak in the number of diagnostic artifacts occurs in the Early Archaic. These artifacts consist of both projectile points and formal tools, and are distributed evenly across all three physiographic zones on the Annex.

The relative scarcity of Middle Archaic diagnostics along Medio Creek presents a problem. Two possible explanitory factors-the activities of collectors and alterations in the stream course-do not seem plausible in the light of the numbers of Early and Late Archaic diagnostics recovered in this zone. The evidence of continued use of Long Hollow, although argueably of a different nature from that of the Medio Creek terraces, seems to rule out abandonment as an explanation.

The paucity of Late Prehistoric diagnostics in all three zones is also a puzzle. Although this period is seen as a period of population decline in central Texas, at least during the earlier Austin interval (Black 1989c:32), in south Texas Late Prehistoric sites are very common and easily recognized because of the distinctive artifact assemblage (Black 1989a:52). The small sample from this period at the Medina Annex may be attributable in part to the diminutive size of the diagnostic Late Prehistoric projectile points and the difficulty of finding such small objects in the heavy ground cover encountered at the Annex. An alternative explanation is that most Late Prehistoric surfaces remain buried. Collins (1995:385) notes that Late Prehistoric gisements (stratified arecheological horizons) are by far the most numerous for all periods in central Texas.

Table 10-14. Late Prehistoric Artifacts by Location

\begin{tabular}{||l|c|c|c|c|c|}
\hline \multicolumn{1}{|c|}{ Artifact Type } & Leon Creek & $\begin{array}{c}\text { Medina Annex } \\
\text { Uplands }\end{array}$ & $\begin{array}{c}\text { Medio Creek } \\
\text { Terraces }\end{array}$ & Long Hollow & Total \\
\hline Edwards point & - & - & $41 \mathrm{BX} 1122(\mathrm{~T} 1)$ & - & $\mathbf{1}$ \\
\hline Perdiz point & - & - & - & $41 \mathrm{BX} 1104$ & $\mathbf{1}$ \\
\hline Scallorn point & - & $41 \mathrm{BX} 1076$ & - & - & $\mathbf{1}$ \\
\hline \multicolumn{1}{|c|}{ Total } & - & $\mathbf{1}$ & $\mathbf{1}$ & $\mathbf{1}$ & $\mathbf{3}$ \\
\hline
\end{tabular}




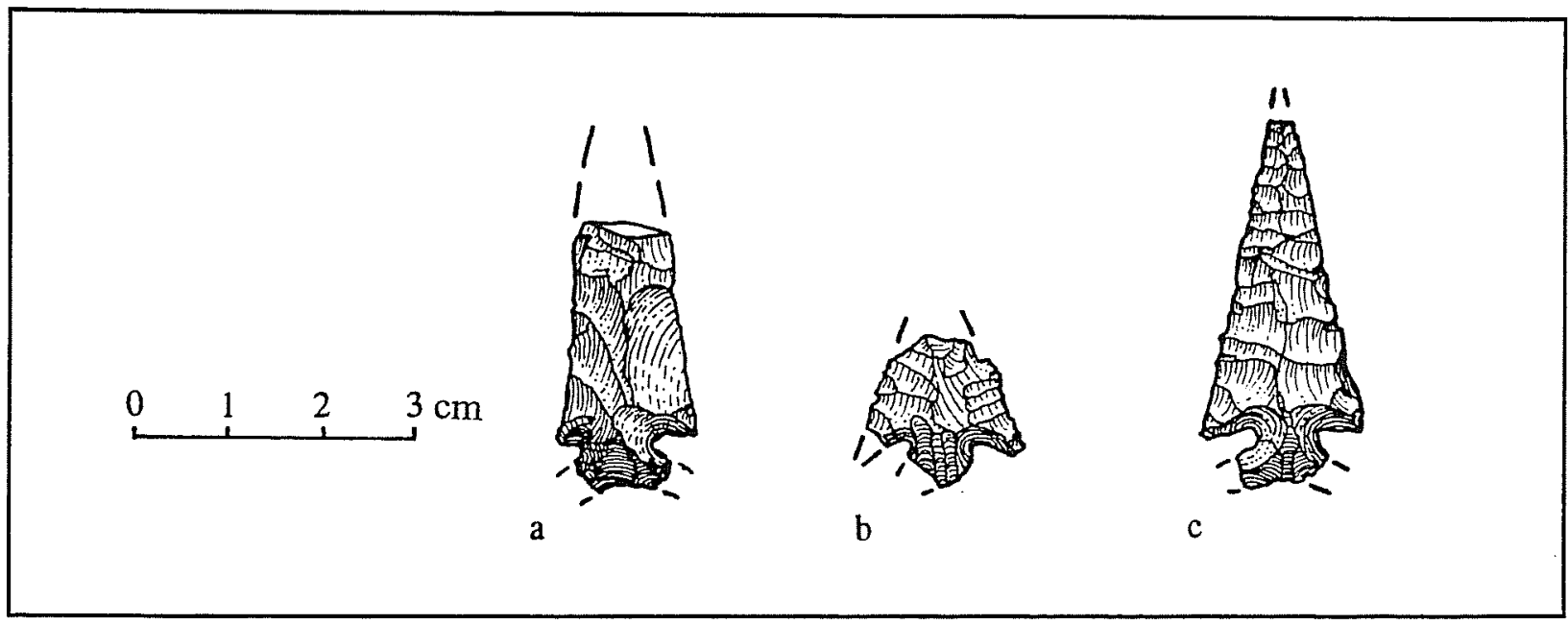

Figure 10-6. Late Prehistoric diagnostic artifacts. a. Scallorn arrow point (41BX1076); b. Untyped arrow point (41BX1104); c. Scallorn arrow point (41BX1102).

Table 10-15. All Lackland Temporal Diagnostics Grouped by Period and Area

\begin{tabular}{|c|c|c|c|c|c|c|c|c|c|c|}
\hline \multirow{3}{*}{$\begin{array}{l}\text { Cultural Period } \\
\text { Early Archaic }\end{array}$} & \multicolumn{8}{|c|}{ Area } & \multirow{2}{*}{\multicolumn{2}{|c|}{ Total }} \\
\hline & \multicolumn{2}{|c|}{ Leon Creek } & \multicolumn{2}{|c|}{$\begin{array}{l}\text { Medina Annex } \\
\text { Uplands }\end{array}$} & \multicolumn{2}{|c|}{$\begin{array}{c}\text { Medio Creek } \\
\text { Terraces }\end{array}$} & \multicolumn{2}{|c|}{ Long Hollow } & & \\
\hline & & 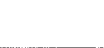 & & & & & & & 10 & 27.0 \\
\hline Middle Archaic & & & & & & & & & 4 & 10.8 \\
\hline Late Archaic & & & & & & & & & 15 & 40.5 \\
\hline Transitional & & & & & & & & & 5 & 13.5 \\
\hline Late Prehistoric & & & & & & & & & 3 & 8.2 \\
\hline Total & 5 & $13.5 \%$ & 7 & $18.9 \%$ & 10 & $27.1 \%$ & 15 & $40.5 \%$ & 37 & $100 \%$ \\
\hline
\end{tabular}

Geographically, the predominance of diagnostic artifacts recovered in Long Hollow is also noteworthy, and may be due to the area's remote location and lack of disturbance through development and artifact collection. The frequency of diagnostics shows a steady increase through the Transitional Archaic in contrast to the variation over time displayed in the sample as a whole. This trend may represent a persistent and increasing reliance on the resources of the area through time.

\section{Buried Site Potential}

Methodological specifications for the current project mandated that at least one shovel probe should be conducted at each documented site to test for subsurface cultural deposits (see Chapter 6 on
Project Methodology). Larger sites with multiple artifact concentrations and those spanning varied elevations or including different geophysical features, had more shovel tests than small sites. Obviously, shovel tests are limited in the amount of information they can reveal for any given site. Yet at the very least, shovel tests offer a first impression of subsurface cultural integrity, or lack thereof.

During the current project, 106 shovel tests were performed on archaeological sites. Not included in this total is the series of shovel tests placed over site 41BX1065, where Phase II testing was conducted in May 1995 (see Appendix H). The site data tables in Appendix A give a complete set of the results from the shovel-testing program. For the discussion below, shovel tests performed at sites on Lackland's Main Base, while often rewarding, are not included 
because of their small number and the high level of surface disturbance. Therefore, only the Medina Annex sites and the 102 shovel tests performed there are considered in the discussion on buried site potential.

Surface archaeological sites are located across all elevations of the project area. These elevations vary widely in their distance from water sources. Some sites at higher elevations are in fact very close in horizontal distance to drainage bottoms. Because of this variation and the impact that stream dynamics have on site formation processes, focusing on the maximum depths at which artifacts were recovered at various elevations above the nearest drainage bottoms may yield some interesting patterns. Table 10-16 presents the provenience, number, and depths on which this comparison is based.

\section{T0 of Medio Creek}

Five sites were documented in the lower floodplain of Medio Creek. Four of these were shovel tested by CAR, but one site (41BX1069) falls primarily in adjacent uplands. Therefore, the site shovel tests were placed in that setting and are counted accordingly. The fifth site (41BX1002) was documented by De Vore (1993) and shovel tested by CAR during a site revisit in 1995. The data from the three tests on 41BX1002 are included in Table 1015. Thus, seven shovel tests compose the area sample and five yielded artifacts below ground surface, two to a depth of $60 \mathrm{~cm}$.

\section{T1 of Medio Creek}

Several of the 15 shovel tests placed at sites on the T1 yielded artifacts at considerable depth (Table 1016). The deepest occurrence (at 41BX1103) was recorded at $70-80 \mathrm{~cm}$ in a shovel test that revealed artifacts throughout the deposit. Modest counts of fire-cracked rock and thinning flakes were recovered between $60-70 \mathrm{~cm}$, followed by a few thinning flakes to the base of the shovel test. At least one site $(41 \mathrm{BX} 1126)$ indicated a buried occurrence between $40-60 \mathrm{~cm}$ below surface that follows $20 \mathrm{~cm}$ of sterile deposit.

\section{T2 of Medio Creek}

Somewhat higher in elevation, the $\mathrm{T} 2$ shovel tests indicate shallow artifact occurrences. While only six

Table 10-16. Frequency and Percentage Distribution of Medina Annex Shovel Tests

\begin{tabular}{||c|c|c|c|c|c|c||}
\hline $\begin{array}{c}\text { Maximum depth } \\
\text { of artifact } \\
\text { occurrence }\end{array}$ & Medio T0 & Medio T1 & Medio T2 & $\begin{array}{c}\text { Medina Annex } \\
\text { Uplands }\end{array}$ & Long Hollow & Total \\
\hline $\begin{array}{c}\text { no artifacts } \\
\text { (negative ST) }\end{array}$ & 0 & 5 & 3 & 18 & 16 & 42 \\
\hline $10 \mathrm{~cm}$ & 3 & 2 & 1 & 3 & 12 & 21 \\
\hline $20 \mathrm{~cm}$ & 1 & 0 & 1 & 5 & 10 & 17 \\
\hline $30 \mathrm{~cm}$ & 1 & 1 & 1 & 2 & 1 & 6 \\
\hline $40 \mathrm{~cm}$ & 0 & 0 & 0 & 0 & 2 & 2 \\
\hline $50 \mathrm{~cm}$ & 0 & 3 & 0 & 0 & 4 & 7 \\
\hline $60 \mathrm{~cm}$ & 0 & 3 & 0 & 0 & 1 & 6 \\
\hline $70 \mathrm{~cm}$ & 0 & 1 & 0 & 0 & 0 & 0 \\
\hline $80 \mathrm{~cm}$ & $\mathbf{7}$ & $\mathbf{1 5}$ & $\mathbf{6}$ & $\mathbf{2 8}$ & $\mathbf{4 6}$ & $\mathbf{1 0 2}$ \\
\hline Total & $\mathbf{6 . 9}$ & $\mathbf{9 . 8}$ & $\mathbf{2 . 9}$ & $\mathbf{9 . 8}$ & $\mathbf{2 9 . 4}$ & $\mathbf{1 0 0}$ \\
\hline $\begin{array}{c}\text { Total \% of } \\
\text { positive STs }\end{array}$ & & & & & 0 & 1 \\
\hline
\end{tabular}


tests compose the sample, they do suggest a reduced potential for deeply buried archaeological components, as these shovel tests produced negative results. The small number of artifacts recovered from buried contexts may be a result of bioturbation at most sites.

\section{Medina Annex Uplands}

More shovel tests were placed at sites in the upland areas, yet they show the same pattern as the $\mathrm{T} 2$ tests. The shallow depth of artifact occurrences implies that the chance for stratified cultural components is somewhat limited.

\section{Long Hollow}

The sites in Long Hollow received an extensive Phase I testing program, totaling 46 shovel probes. Nineteen shovel tests were conducted at site 41BX1104 alone. As an upland intermittent drainage, the section of Long Hollow coursing through Medina Annex did not experience the typical cut and fill dynamics of continually flowing streams. Therefore, the probability of buried archaeological components was predicted to be very low. Table 10-16 demonstrates that this assumption was mistaken.

Eight shovel tests from widely separate locations on six different sites yielded artifacts from local depths ranging between 30 and $60 \mathrm{~cm}$. These sites are 41BX1056, 41BX1072, 41BX1073, 41BX1099, 41BX1100, and 41BX1104. While some of these buried occurrences are in locations closest to the drainage bottom, shovel tests at higher elevations were also significant. Conversely, several shovel tests placed within the Long Hollow floodplain did not yield artifacts in deeper levels. See Appendix G, Table G-1, for a breakdown of recovered artifacts and distance from and elevation above the drainage bottom.

\section{Summary}

CAR's survey of Lackland AFB documented three primary prehistoric site types: open campsites, quarry and workshop sites, and a burned rock midden (Table 10-1). Also found were sites that combine raw materials procurement and camping activities. Historic sites and prehistoric sites with historic components were documented along Medio Creek and one near Leon Creek on the Main Base (Table 10-2).

While sites occur in virtually every surveyed section of the base, the only burned rock midden (41BX1108) is located near Leon Creek on the base golf course. Most quarry/workshop sites are present in upland settings adjacent to Medio Creek and along Long Hollow (Table 10-6). Open campsites predominate on the $\mathrm{T} 1$ and $\mathrm{T} 0$ of Medio Creek (Tables 10-5 and 10-8), while those sites classified as camp and quarry sites are almost equally distributed across the different areas of Medina Annex (Table 10-7)

Only 36 temporally diagnostic artifacts were recovered from over 3,800 acres of survey area, well over 40 percent of which come from Long Hollow. More than 25 percent of all diagnostics were taken from the Medio Creek terraces. Considering the limited sample, the most obvious pattern offered by this collection is the steady decrease in quantities per period with time (Table 10-15). The general provenience of diagnostic artifacts emphasizes close proximity to reliable water sources.

Data from over 100 shovel tests at archaeological sites on Medina Annex imply that a high potential for buried archaeological components exists on the terraces of Medio Creek, as well as locations close to the drainage bottom of Long Hollow (Table 10-16). Sites with the highest potential for buried components are located near reliable sources of water. 


\section{Part III: Historic Sites}

\section{Chapter 11. Historical Background and Research Design for Historic Sites}

\section{Introduction}

An overview of the types of Historic sites, along with their locations and distribution in relationship to the past environment on Lackland AFB, is presented in this section. The information was obtained from numerous sources, primarily archaeological literature describing the results and patterns obtained from previous projects. Archival resources, including wills, deeds, probate and tax records, newspapers, railroad and irrigation records, military archives, and historic maps, were used to provide additional information pertinent to site occupation, size, and context. Interviews with base personnel and local inhabitants of the study area augmented the archival documents and archaeological data, thus leading to a more precise, predictive-testing methodology, and a betterintegrated archaeological research design. This discussion almost ignores the rich and fascinating Spanish and Mexican history of the area, as Lackland AFB lacked any archaeological evidence of use during those periods.

\section{Historic Background for the Anglo-American Historic Era}

\section{The Role of the Lackland Area in the History of Texas}

The Anglo-American historical frontier was a late and transitory development in Texas history. The Spanish and later Mexican peoples who settled this area in the eighteenth and early nineteenth centuries left behind an important legacy, but little evidence of their existence survives at Lackland AFB. The Anglo frontier was continually extended further southwest, as former frontier societies such as San Antonio became economic centers, and tributary settlements such as Del Rio sprang up on the frontier. Metropolis and tributary became inextricably connected in a relationship of economic dominance and dependency due to a combination of environmental, political, and economic factors as well as the values of the societies that shaped them. This changing landscape is the historic context of San Antonio.

\section{Lackland: The Early Setting}

In documenting their journeys, many Spanish explorers were more concerned with conquering territory abounding in mineral riches than with describing the environment of the lands they visited (Inglis 1964:4). They found the aridity and the brush covered lands of south Texas unsuitable for settlement, traveling on in their relentless search for wealth and Indians to convert. Before Spanish contact, Indians in the region practiced a huntingand-gathering way of life utilizing such wild plant resources as sotol, prickly pear tuna, acorns, roots, wild plants, and mesquite, and a variety of small animals such as rabbits, javelina, rodents, birds, and fish. The principal game animal was deer (Campbell 1991:344; Newcomb 1961:40). The descriptions of early explorers in the vicinity of Lackland AFB note 
the dense vegetation, especially trees, and abundant game animals such as bison (Weniger 1984:40).

The 1691 expedition led by Domingo Terán de los Ríos crossed Leon Creek in the vicinity of Lackland AFB on its way to the east Texas missions. The party camped for several days near a village of Payaya Indians, which they named San Antonio de Padua, from which the nearby river later took its name. Father Damián Massanet, the expedition diarist, describes the San Antonio River as being bordered with many cottonwoods, oaks, cedars, mulberry trees, and vines. There were a great many fish, and a multitude of prairie chickens in the highlands. During their march from the Medina River to San Antonio de Padua, the explorers encountered so many bison that the horses stampeded and 40 ran away (Foster 1995:57; Mazanet 1968:238).

The Aguayo military expedition, led by the Marqués de San Miguel de Aguayo, crossed the Medina River near Macdona in April 1721, then traveled through the area of present day Kelly AFB on Leon Creek before reaching its destination, San Antonio de Béjar (Foster 1995:149). Aguayo's diarist, Juan Antonio de la Peña, comments on the numbers of turkeys, quail, and the abundance of deer on the journey. He notes, "we traveled east-northeast about three leagues until we came to Leon Creek in which water can be found the greater part of the year, and in several esteros all year round" (Inglis 1964:20-21). Peña further observes that they crossed low hills and valleys and found a great quantity of flint stone (Buckley 1911; Chipman 1992; Forrestal 1934; Webb 1952:17). A later visitor, J. M. Sanchez, traveled on the Presidio Road south of San Antonio in the Lackland vicinity. Sanchez describes "walnuts" (probably pecans) and "evergreen oaks" and the presence of wild turkeys, horses, and deer on "beautiful land" which did not hinder travel (Inglis 1964:22).

\section{The Roads}

A cultural landscape includes features such as roads, which offer tangible evidence of the movement of populations into and through a geographical area. The presence of certain resources governed both the placement of roads and settlement. Water for example, was not only a critical resource to the prehistoric and historic Indian populations of the San Antonio, but to the early explorers and settlers as well.

Many of the old, informal trails of the Indians were soon adapted to the needs of the Spanish explorers and early settlers. Through its intricate system of irrigation ditches, roads, and caminos reales, San Antonio soon became a way station during Spanish exploration and for expeditions attempting to establish missions in east Texas in the late seventeenth century. However, initial growth of the town was confined to the fertile valley of San Pedro Creek and the San Antonio River, from the springs to Mission Espada, the southernmost mission (de la Teja 1988:167).

Viewing the opening of the frontier from a holistic perspective, the evolution of road systems can be understood in a context that includes the "extent of the network within or beyond a particular region, the function of points it connects, the contemporaneity of connected points, and the overall configuration of the system" (Trombold 1991:4). Incorporating an already-well-established system of aboriginal trails and colonial caminos, the cultural landscape of the San Antonio area in the eighteenth and nineteenth centuries reflected an increasingly complex network of economic and sociopolitical interactions.

\section{Protecting the Hinterland}

Following the Texas Revolution and the subsequent admission of Texas to the United States, the U.S. Army became dependent on the developing road network to maintain a strong frontier presence in Texas between 1848 and 1890. Some of the hastily constructed forts were built in response to the Mexican War, which ended with the signing of the Treaty of Guadalupe Hidalgo on February 2, 1848. As a result, Mexico renounced all claims to Texas and accepted the 
Rio Grande as the boundary between the United States and Mexico (Webb 1952b:185).

Because of its strategic location, Post San Antonio, founded in 1845, was the hub of the fort system. From San Antonio, the Army could readily supply all its western garrisons with both men and provisions (Miller and Sanders 1990:12). By 1848 the route had been surveyed for a military road from San Antonio toward the west (Clark et al. 1964:2), part of a series of roads and two interrelated chains of forts that the Army built in unsecured frontier areas (Figure 11-1). The first chain paralleled the U.S.-Mexican border, extending from Fort Brown at the mouth of the Rio Grande to Fort Duncan in Eagle Pass. The forts were situated to impede access to traditional Indian fords, but they were intended primarily to protect the international border. The second chain of forts extended from Fort Worth to Fort Martin Scott at Fredericksburg, and was designed to be slightly in advance of the expanding western frontier. These posts were specifically constructed to protect settlers against attacks by Native Americans (Bowden 1986:1-2).

The frontier had advanced beyond the fortification system by 1852 . A new line of forts was then

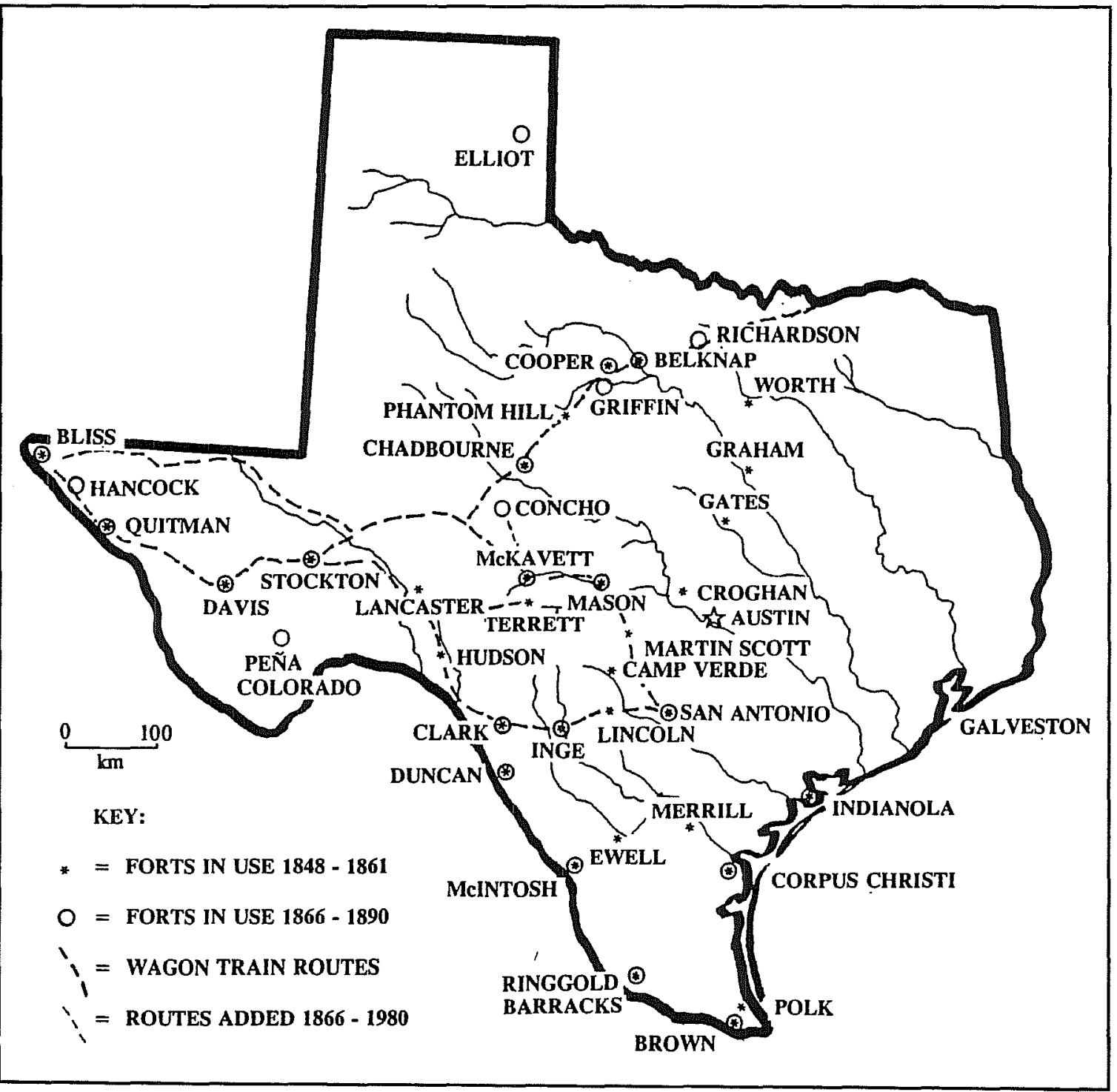

Figure 11-1. Forts and roads in Texas. 
constructed about $240 \mathrm{~km}$ farther west. Finally, the discovery of gold in California necessitated a third chain of forts spaced at irregular intervals along the El Paso-San Antonio road (Bowden 1986:1-2). The military occupied a constantly changing array of forts, sub-posts, and small temporary camps rather than a line of static defensive positions (Wooster 1987).

During the Civil War, all Texas's borderland forts were surrendered and troops evacuated. Thereafter, many of the officers enlisted with the Confederate Army, while a majority of the non-commissioned officers and enlisted men remained loyal to the Union.

Attempts to protect the western territories from Indians during the $1850 \mathrm{~s}$ had been largely unsuccessful, and after the distractions of the Civil War, the Federal government decided not to reoccupy all the forts that were part of the original 1850s line of borderlands defenses; instead a series of new forts further west was opened (Labadie 1993:3). In the 1880 s and 1890s, having eliminated the threat of attacks by Indians, the U.S. Army gradually abandoned its Texas posts (Wooster 1987).

\section{Ranching and the Railroad}

With the appearance of the railroad, the area around San Antonio gained added benefits from such geographical assets as good soil and abundant resources (e.g., Hassig 1991:26). Livestock, especially cattle, had thrived in the open grasslands along the settlements outlying the missions of San Antonio, firmly establishing ranching north of the Rio Grande (Lehmann 1969:15). Longhorn cattle, the legacy of the Spanish, became the mainstay of the frontier entrepreneurs, many of whom carved out empires and made fortunes in the San Antonio area.

The Civil War destroyed south Texas ranchers' ordinary markets in the Caribbean and the slave states of the southern Mississippi Valley. Consequently, cattle populations grew at an astonishing rate during the stagnant war years.
Great quantities of longhorns were freely roaming the areas south and east of San Antonio when the South capitulated in 1865 . Would-be cattlemen could start their own herds simply by capturing some of the semi-feral animals, branding them, and calling them their own (Cronon 1991:218).

Beef was far more valuable and in much greater demand in the East than in the South (Cronon 1991:218). As a result, San Antonio became the southern starting point for post-Civil War cattle drives to northern markets, which flourished until the railroads arrived in the late-1870s (Waynne Cox, personal communication 1994). South Texas cattle were frequently driven from the San Antonio area to Abilene, Kansas, then transported by rail to processing and manufacturing centers in the Midwest and the East (Cronon 1991; Wolf 1982).

Plans for constructing a rail system in San Antonio had been developed as early as 1852 . These plans did not come to fruition, however, until February 20, 1877. Under the direction of Colonel Thomas Pierce, the Galveston, Harrisburg and San Antonio Rail Road Company (GH\&SA) connected San Antonio to Mexican and eastern U.S. markets. Within the first week of railway service, the freight cars brought manufactured articles and finer stocks of horses, cattle, and pigs to the city. Soon after completion, Pierce made a proposal to extend the line south to the stockyards. Although there were initial fears this would move potential wealth out of San Antonio, the city council voted not to place any restrictions on the railroad (Everett 1961:52).

During the 1880 s, the railroad system became the major conduit from the frontier to the growing metropolis. San Antonians built four major rail routes into the hinterlands on the south and west, establishing the Alamo City as a service center and trading hub for ranchers and farmers in those areas (e.g., Johnson 1986:89). The raising of sheep or "wooly backs" became economically intertwined with the sudden growth of urban marketplaces such as San Antonio. One of the largest increases in volume production was in the wool market. "From the 1872 production of 677,503 pounds, the San Antonio market produced over three million pounds by 1879 , more than five million pounds in 1881 , 
and over seven million pounds in 1884" (Everett 1961:59). Interestingly, only a small amount of the wool shipped out of San Antonio at this time came from Bexar County.

\section{Rise of the Hinterland}

The railroad played a central role in the sudden interest in sheep and cattle raising. The railroad companies sold off sections of land to speculators to encourage the development of the railroad. Thus, the railroad's iron ties were to be partially responsible for the rise of a new economic empire in the southwest, the sheep industry. Sheep were a natural replacement for the cattle, which had overgrazed the land.

San Antonio entrepreneurs were quick to catch on to the booming wool market, with absentee land owners and investors such as Mr. Hildebrand and Mr. Harrison of San Antonio buying up former open range land for speculation. Many of the new breed of far-sighted investors ranged flocks of sheep next to herds of cattle (Carlson 1982:178). Vast range properties were assembled and leased to tenant ranchers, who operated them with inexpensive migrant Mexican labor. Migrant laborers were attracted by the opportunity to work for steady wages, and settlers came to provide other services to the ranchers in the small, growing communities. Absentee ownership may have been in part related to the fact that sheep ranching, in contrast to cattle raising, was held in low esteem. Goat raising also became established west of San Antonio and mohair became a popular textile for draperies, linings, rugs, and upholstery. Before 1900 , Texas supplied 71 percent of the nation's Angora goats and mohair. By 1930, that figure had increased to over 84 percent (Carlson 1982:200).

\section{Archaeological Expectations}

\section{Historic Indian Presence}

There is almost no archaeological information available pertaining to the relationship between the prehistoric and historic Indian populations southern Texas (Black 1989a:33). The difficulties in identifying the Coahuiltecan and other associated groups, their territorial ranges, and occupational sites in this area through cultural criteria have been described in Chapter 5. Encampments, discrete as they might be in the archaeological record, were also shared by different Indians groups, thus frustrating attempts to understand the degree of mobility and settlement of groups such as the Payaya who lived in this area of Texas (Campbell 1991:114).

Studies of artifacts produced and used by mission Indians (Fox 1979; Schuetz 1969) provide a guide to what may be expected be recovered at historic Indian sites. A site with bone-tempered earthenware and debitage and chipped stone tools, in assoication with evidence of contact with the Spanish (such as glass beads, metal knives, remnants of horse equipment, gun parts, and fragments of cast iron or copper cooking vessels), could be confidently identified as the remains of a historic Indian campsite. If found on the Medina River or nearby tributaries such as Medio or Leon creeks in the Lackland AFB area, a campsite is likely to represent a camp of the Payaya or some similar group (Campbell 1983; Anne Fox, personal communication 1994).

\section{Spanish Colonial Settlement}

Ranching is an economic activity noted along Medio and Leon creeks and the Medina River in early documents. The owners of early ranches in the Lackland area and along the banks of the San Antonio River were discouraged by frequent Indian raids during the $1700 \mathrm{~s}$, and for long periods were driven off their lands and their herds dispersed (Jackson 1986). Structural remains from this period have been documented in the defunct Applewhite Reservoir area (McGraw and Hinds 1987:367-382). The Upper Presidio Road, or Camino Real del Río Grande, passed north of Lackland AFB, crossing Medio, Leon, and Lucas creeks and traveling to the Medina River near present day Castroville and on to the Rio Grande. The Lower Presidio Road ran in a 
southwesterly direction from San Antonio, crossing the Medina River south of the base near its confluence with Leon Creek (McGraw and Hindes 1987:68). However, it was unlikely that evidence of either road would be encountered during the Lackland AFB survey.

\section{European-American Settlement}

The archaeology of European-American settlement in the western San Antonio area has not yet been well studied. Investigations of several small farmsteads on the lower Medina during the Applewhite Reservoir survey (McGraw and Hindes 1987), a small farmstead north of San Antonio (Fox 1979), and a series of small 1850s farmhouses at the Choke Canyon Reservoir in McMullen County (Fox 1986) had recorded the types of structures in use in the general area of central and south Texas. A number of well-built German and Spanish stone houses from this same time period are still standing in and around San Antonio as well as in the wellknown German settlements at New Braunfels and Fredericksburg. For the most part, houses and commercial buildings in the San Antonio area were built of locally quarried limestone and occasionally of adobe, until the arrival of the railroad reduced the price of milled lumber and brick to an amount affordable to the average builder. C. K. Chandler (personal communication 1993) recorded several mid-nineteenth-century stone houses, primarily north and northwest of the city.

The presence of house foundations on Lackland was noted by base personnel (G. D. Gonzales, personal communication 1994) and local relic collectors. Any wooden house which stood abandoned for a long period of time would have collapsed from decay, then gradually disappeared except for the pile of bricks or stone that represents the chimney. Archaeologists working on surveys in the countryside around San Antonio needed to be alert for scatters of nineteenth-century ceramics and glass, and traces of collapsed chimneys (Anne Fox, personal communication 1994).

\section{The Military Presence}

There is limited evidence of episodic military action in the Lackland area during the middle nineteenth century. Camp León was the temporary headquarters of Alexander Somervell's Southwestern Army from November 13 through about November 19, 1842 (Pierce 1969:92). The Somervell Expedition was a punitive mission against Mexico in retaliation for military raids in Texas in that same year (Webb 1952b:637). Camp León was on Leon Creek about $3.2 \mathrm{~km}$ south of Lackland AFB.

A second event occurred almost two decades later on May 9, 1861, about $2.4 \mathrm{~km}$ west of the Lackland Annex near Lucas Creek. More than 1,000 Confederate soldiers stationed at San Antonio forced evacuating Federal troops to surrender their arms (Noonan 1984:5). The Confederates had reneged on an agreement that allowed troops stationed at forts along the western frontier to depart with their weapons (Waynne Cox, personal communication 1994). The battle, known as the Battle of Adams Hill, was resolved without shots being fired.

A slight possibility existed that archaeologists could recover cultural material associated with either event. These materials could consist of buttons, armaments, bullets, ceramics, or glass.

\section{Research Questions}

Lackland AFB provided few clues relating to the location and types of buildings, and the early settlers who attempted to forge a living on the rich alluvial terraces of Medio and Leon creeks. One historical property was recorded on the base (41BX1002) following the survey conducted by De Vore (1993), and recommended as a possible candidate for National Register inclusion.

\section{The Homestead Site (41BX1002)}

A homestead foundation and possible cellar depression were located in a survey. De Vore 
(1993) interpreted the house as a historic (latenineteenth- to early twentieth-century) EuropeanAmerican dwelling. A surface scatter around the house foundation contained bricks, stones, bottles, glass, ceramics, and metal fragments (nails and machine parts) mixed with concentrations of prehistoric lithic material (De Vore 1993).

The homestead was located on a terrace on the left bank of Medio Creek, apparently in the vicinity of a prehistoric occupation. De Vore (1993:133) recommended the homestead be assessed further to determine the extent of the site, its possible significance, and its eligibility for the National Register of Historic Places.

Archival records of the Lackland AFB Properties Division were to be consulted to determine the original owners of the home, as well as other land owners who sold their property to the War Department in 1916 for the construction of Kelly Field. It could be possible to establish whether the house belonged to one of the European-American families who settled in this particular area of San Antonio. The site would be of special significance if it were of Belgian origin because information on the settlement of this ethnic group in the area is scarce. Photographs and property appraisals should give indications of where the homesteads would be, numbers of structures, and dimensions.

It was possible that many of the structures and other features such as outhouses, stables, storehouses, fences, roads, and wells were destroyed prior to construction of Lackland AFB. The proximity of Medina Road, and the use of this area of the base as a hunting and recreation area, magnified the possibility of casual relic hunting. Flooding from Medio Creek may also have altered many of the artifact distributions or destroyed frame structures. However, stone foundations could still be extant in the area, covered by the dense vegetation characteristic of the base. Artifact assemblages from Anglo-American homesteads in the vicinity of the project area typically include ceramics, metal, glass, barbed wire, horseshoes, and farming implements (cf. McGraw and Hindes 1987).

\section{Research Problem 1 - Spatial Relationships}

Survey and limited testing were expected to reveal additional homestead foundations or site features. If recovered, these structural remains would be expected to clarify the intra- and inter-site spatial relationships of an early farming and livestock raising community. Not only would this evidence provide insight into a turn-of-the-century European-American settlement, but it would also contribute to an understanding of the economic activities dated to this particular era.

\section{Research Problem 2 - Economic Activities}

This research problem focused on classes of data that have been overlooked in previous studies (Collins 1991:17).The goals of this research were combined with those of the first research problem in an attempt to elucidate specific economic activities at a European-American homestead, or at groups of homesteads, through observations of soils and biotic communities. Subtle changes in these features, related to anthropogenic or biogenic factors, e.g. types of construction or economic activities such as farming or cattle raising, could have been present in the study area.

Many of the features characteristic of particular activities such as grazing may have been destroyed by inundation from Medio Creek or bioturbation of soils. Past plowing episodes could be identified in profile by a "thick homogeneous layer at the top of a buried soil" or the association with "lynchets" at the base of the plow zone (Courty et al. 1989:130). Other formations resulting from cultivation could be "grain coatings, void infillings and pans" that appear in the agricultural horizon formed under long term, continuous cultivation (Courty et al. 1989:131). Many of these atypical features encouraged by cultivation and manuring could be identified. In addition, especially in rapidly buried soils, the type of cultivation such as shallow hoeing, cultivation ridges, or erosional episodes might be identified. Cultivated soils, in some cases, could also be identified on the basis of their high biological activity due to manuring practices (Courty et al. 1989:135-137). 


\section{Summary of Research Goals}

In summary, both research goals sought to recover physical, biotic, and geologic data that are anthropogenic in origin. These data are relevant to larger regional studies of the archaeological patterning of historic homesteads and provide a contrast to the patterning of ranching activities adapted to an arid environment in southwest Texas. 


\section{Chapter 12. Historic Sites}

\section{Site Descriptions}

Eight sites with historic components and estimated occupation periods in the late nineteenth or early to mid-twentieth century were recorded during the current survey. Seven are located on Medina Annex in close proximity to Medio Creek while the other is located on the Main Base. Four of the seven at Medina Annex overlie prehistoric components.

The historic sites were given the trinomials 41BX1002, 41BX1061, 41BX1074, 41BX1121, 41BX1124, and 41BX1128-1130. A brief description of each site is given with particular reference to site type and setting, associated artifact assemblage, disturbance suffered by the site, and any known future impacts to it.

\section{BX1002}

The late-nineteenth-century architectural remains at this site (De Vore 1993) include two foundations and remnants of collapsed, handhewn stone walls. A third feature is a burned mound, $3 \times 3$ meters in area and $30 \mathrm{~cm}$ high (Figure 12-1). The site is on a T1 terrace of Medio Creek. The historic structures and artifacts overlie a prehistoric component that yielded an Early Archaic dart point.
The research potential of $41 \mathrm{BX} 1002$ is moderate, with value placed on documenting early land use in the region, however this site does not merit recommendation for nomination to the NRHP.

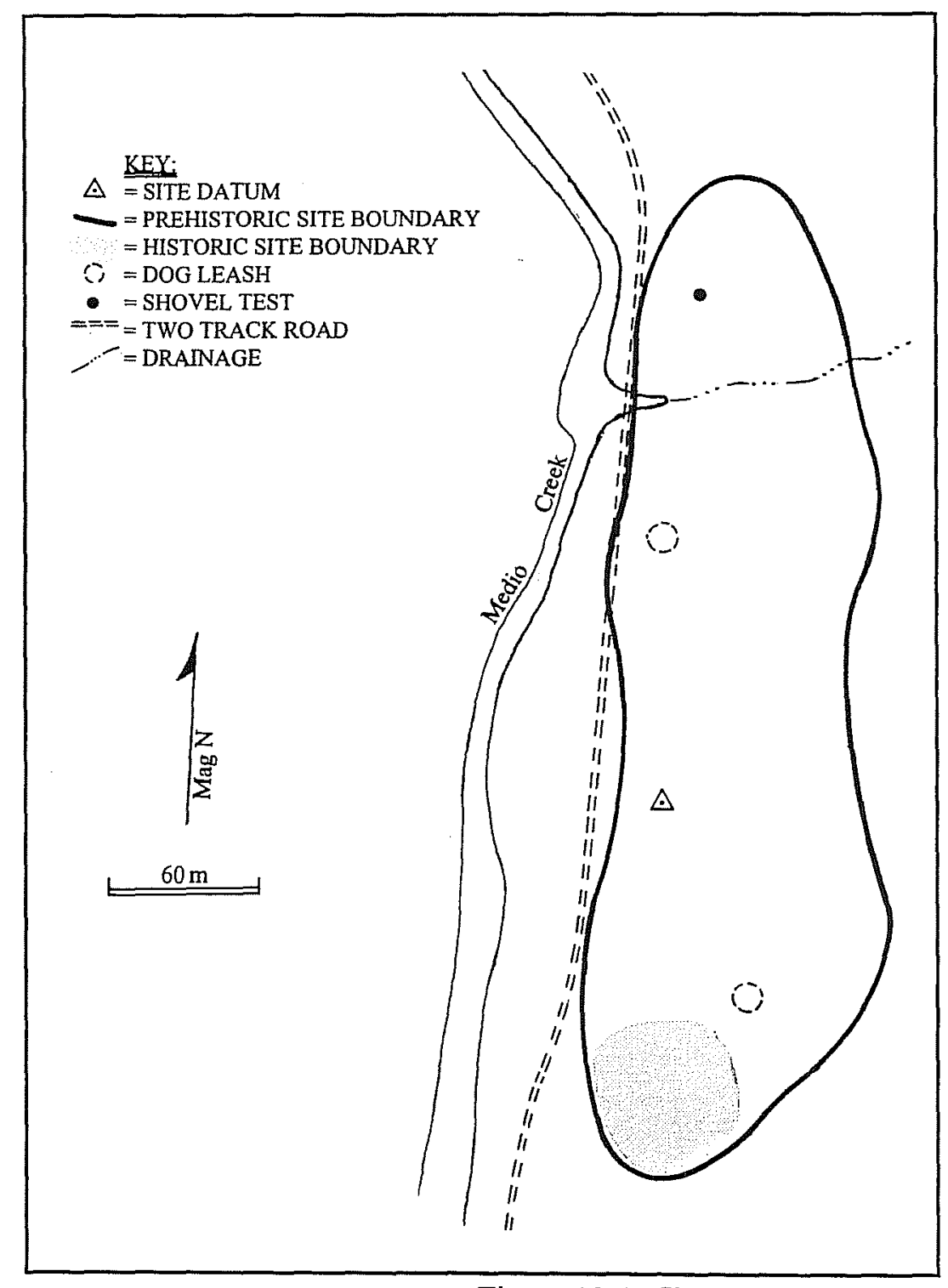

Figure 12-1. Site plan, 41BX1002. 


\section{BX1061}

Site 41BX1061 (Figure 12-2) represents a segment of an old sanitation system. The site is located about 700 m east of Leon Creek, behind an old firing range berm on Range Road. Remnants of the site include open, but partially infilled shafts leading to the sewer main, fragments of large brick aprons, cement curbs, and clay pipe fragments. Maker's marks on the bricks date to 1927 . The site has been disturbed by a road cut that passes through it. It has unknown research potential except for documenting early military base development and does not merit recommendation for nomination to the NRHP.

\section{BX1074}

This site (Figure 8-47) is an early to middletwentieth-century trash dump located adjacent to an intermittent drainage in an uplands setting, approximately $700 \mathrm{~m}$ from Medio Creek. Historic artifacts include rusted metal buckets, redware ceramics, tin cans, pickle jars, sauce bottles, barbed wire, and a Royal Crown Cola bottle. The research potential of 41BX1074 is moderate, primarily for documenting early twentieth-century land use in the region. See the site description under the uplands prehistoric section for the NRHP recommendations.

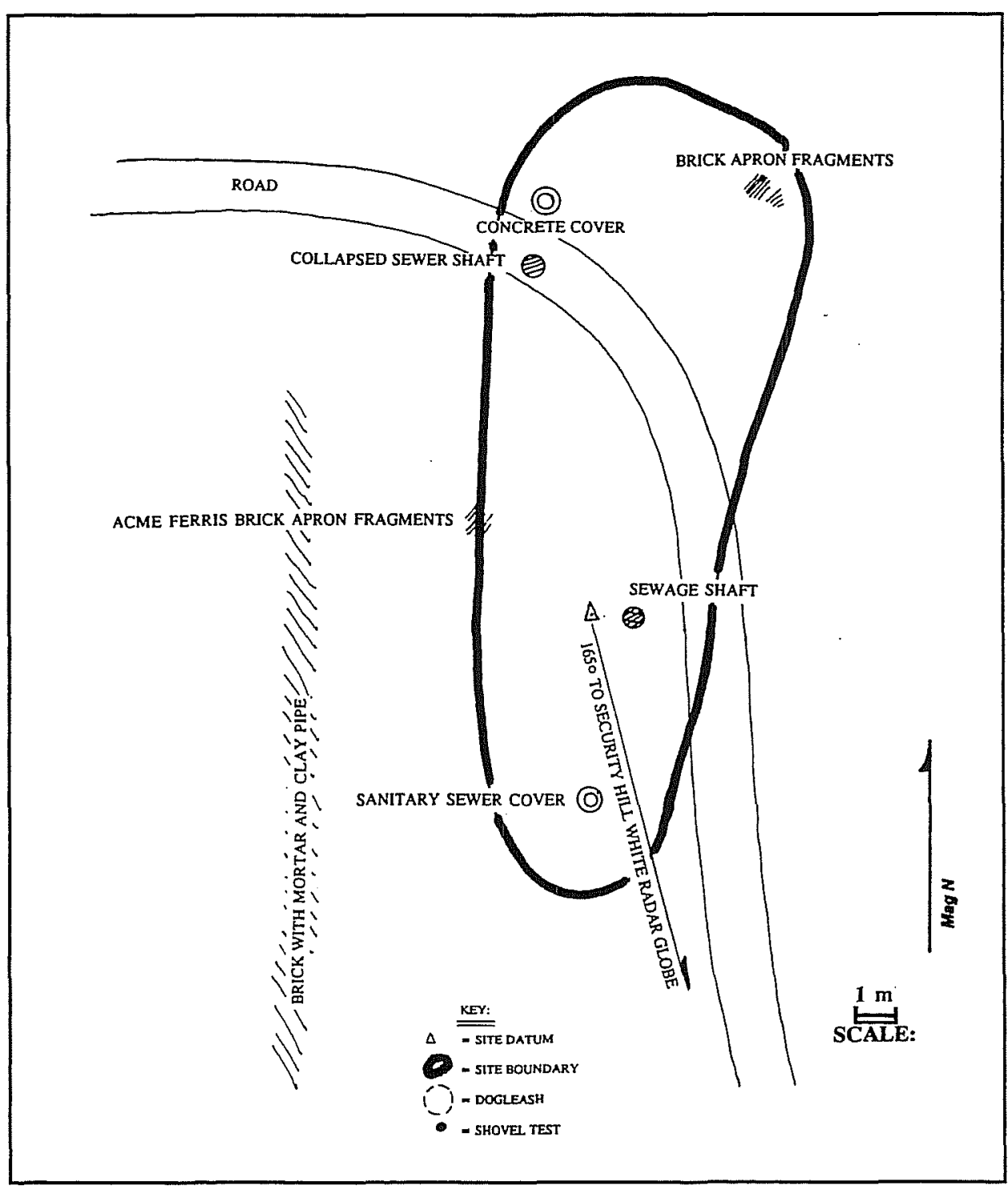

Figure 12-2. Site plan, 41BX1061. 


\section{BX1121}

41BX1121 (Figure 8-19) is the collapsed remains of a roughly $2-\mathrm{x}-3-\mathrm{m}$ hand-hewn sandstone slab structure that may date to the late-nineteenth or early twentieth century (the Feature in Figure 8-19). The structure sits atop a prehistoric open campsite and quarry that yielded a Middle Archaic diagnostic artifact. It is on the edge of a broad, flat second terrace 5 meters above Medio Creek, which is $35 \mathrm{~m}$ to the northeast. An intermittent northeast to southwest drainage downcutting the second terrace serves as part of the site boundary, as does the terrace lip. The historic occupation is in context with a series of five other historic sites along Medio Creek.

The historic component does not appear to have been disturbed since the structure collapsed. 41BX1121 has high potential for providing data on the types of buildings used in ranching activities in the region during the late-nineteenth through middle-twentieth centuries. See the site description under the Medio Creek prehistoric section for the NRHP recommendations.

\section{BX1124}

This historic dump from the 1920s lies atop a prehistoric open campsite of unknown age (Figure $8-67)$. The site is set in the uplands, $600 \mathrm{~m}$ southwest of Medio Creek. Remains in the dump include 16 barrel rings, stoneware sherds from at least two large (probably 10-quart) crocks, and glass sherds from at least two jugs, probably of fivegallon capacity. The absence of other remains suggests that this site may have been a storage or processing area for animal pesticides.

The research potential of 41BX1124 is moderate, with value placed on documenting early land use in the region. See the site description under the uplands prehistoric section for the NRHP recommendation.

\section{BX1128}

41BX1128 is a late-nineteenth-century brick factory, with a detached shed, and water tower (Figure 12-3). It is located on the edge of a broad, flat terrace $25 \mathrm{~m}$ above Medio Creek, which is $300 \mathrm{~m}$ to the northeast. The elevation at the site datum is approximately $233.3 \mathrm{~m}$ (700 ft) amsl. Although the structures and the water tower have collapsed, the site otherwise appears minimally disturbed. The remains of what was most likely the kiln were identified by a separate mound of highly fired red brick with traces of sandy mortar (Mound 4, Figure 12-3). Mounds 1, 2, and 3 are stacks of red bricks. Although the bricks on top of the stacks have crumbled and deteriorated, many are still intact underneath the rubble. None of the bricks contained diagnostic maker's marks. A fifth mound was most likely an outbuilding.

Other construction materials include plumbing items, tin, and lumber. Corrugated tin roofing is scattered predominantly around the shed. Wood boards, ceramic sherds, and glass fragments were noted in the same area. Fourteen meters to the east of the brick mounds is a collapsed wooden water tower. Water pipes were also observed on the site. Remains of the fence rows surrounding the property are in place. Bottle fragments date to the early twentieth century, and probably represent visits by curiosity seekers or by ranchers. A patent mark on the water tower structure appears to be 1894 .

Local brick manufacturers contributed significantly to a rapidly developing city during the $1880 \mathrm{~s}$. 41BX1128 has high potential for providing data on the brick-manufacturing process in the region during the late-nineteenth century and should be fully documented. Its integrity merits consideration for inclusion in the NRHP.

\section{BX1129}

This site contains the remains of a farmstead structure of late nineteenth- to early twentiethcentury origin (Figure 12-4). The remains of the 


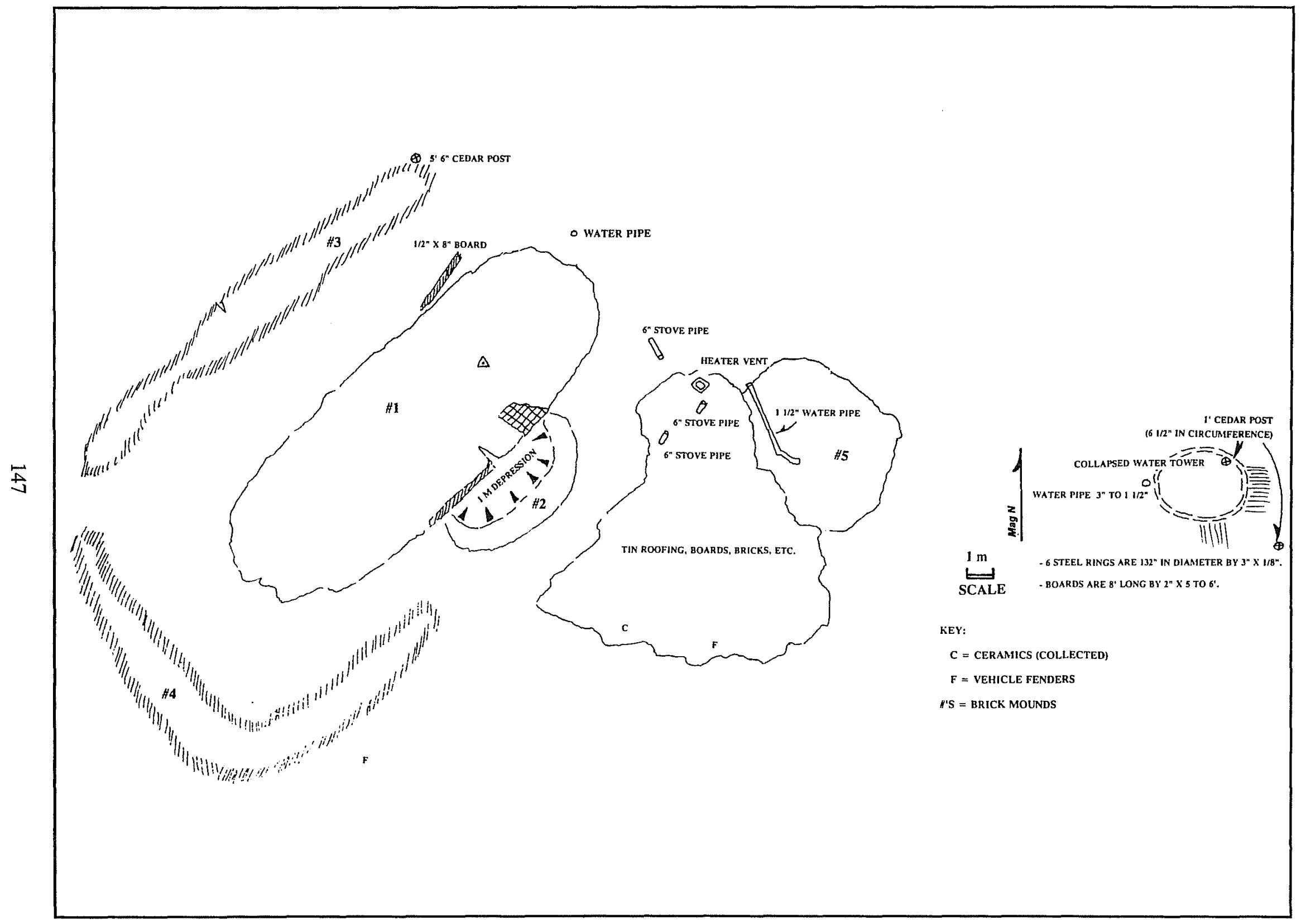

Figure 12-3. Site plan, 41BX1128. 


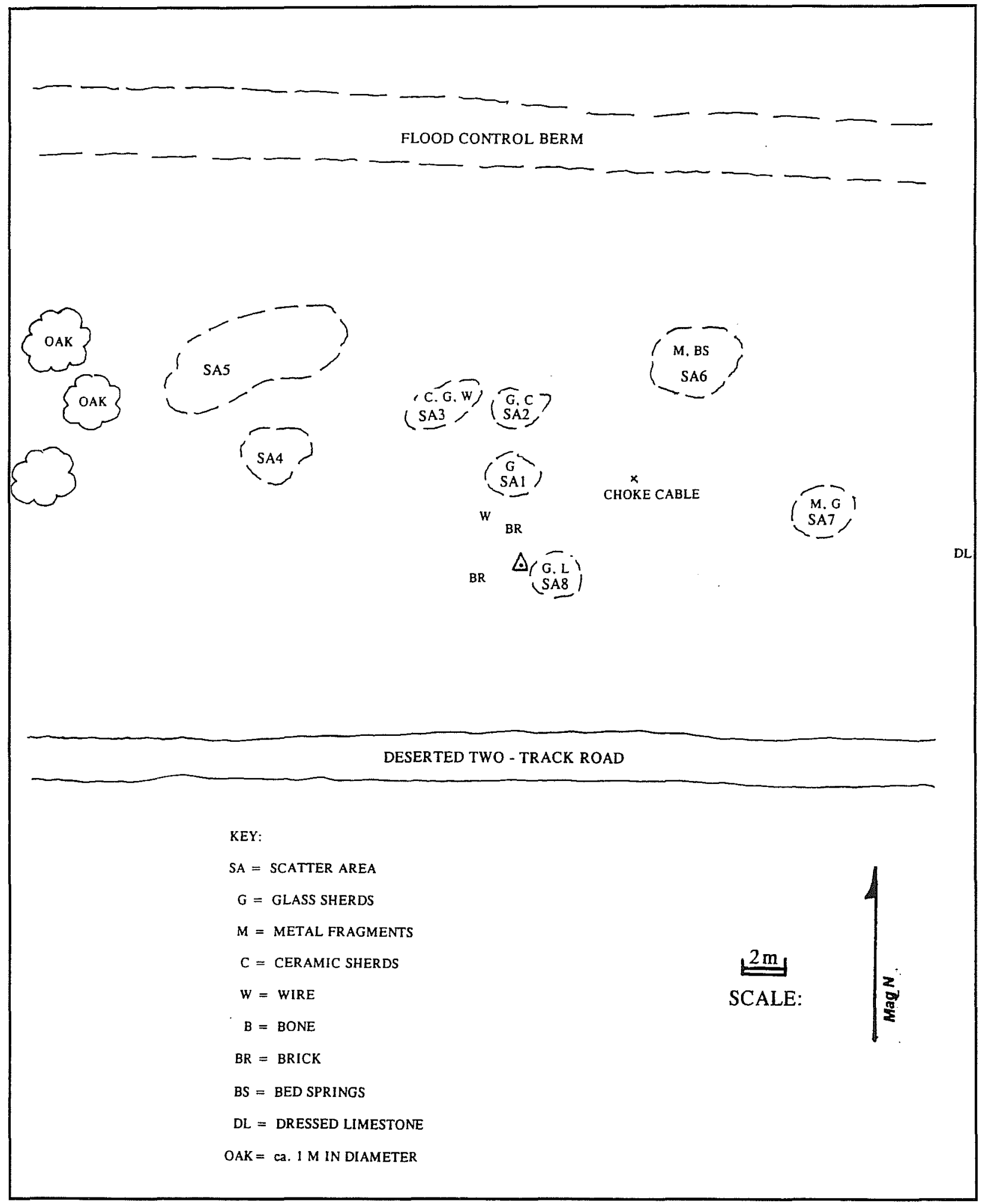

Figure 12-4. Site plan, 41BX1129. 
structure were identified by a sparse scatter of red bricks and a stone foundation support.

The site is located on the first terrace above Medio Creek, which is $50 \mathrm{~m}$ to the north. It appears that the site was either bulldozed or chained when a berm was constructed to hold back floodwaters on the north edge. The site shows the effects of overgrazing and subsequent regrowth of dense native vegetation. Four mature live oaks dominate the immediate area. The elevation at the site datum

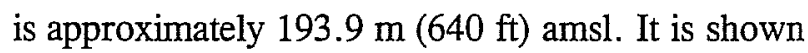
on a 1903 USGS San Antonio map and a 1942 COE map of the area.

This site is heavily disturbed. The remains of a structure were identified by a sparse surface scatter of construction materials and household items. Two red brick fragments with no trace of mortar and a dressed limestone foundation support block were the only construction materials found. Other items observed on the site were a set of bed springs, glass and ceramic sherds, metal cans, barbed wire, leather shoe fragments, a hand choke from an auto, a door clasp, and a sawed rib bone from a cow. Glass sherds recovered date to the early 1900s. Just west of the site are the remains of a washed-out dam across Medio Creek. The earthen berm from the dam continues along the north edge of the site.

The historic occupation can be considered in context with a series of five other historic sites on the upper terraces of Medio Creek within the boundary of Medina Annex: 41BX1074, 41BX1121, 41BX1124, $41 \mathrm{BX} 1128$, and 41BX1130. However, as a single site it does not merit recommendation for nomination to the NRHP.

\section{BX1130}

This site has a historic component superimposed over a prehistoric component of undetermined age (Figure 8-25). It is located on the edge of a broad, flat terrace $150 \mathrm{~m}$ southwest of Medio Creek. Outbuilding remains and artifacts contained in a dumpsite nearby appear to date to the early to midtwentieth century. The outbuildings are believed to be barns or sheds and a chicken coop. The main structure was not located and was most likely destroyed by the military in what is now a restricted ordnance disposal area adjacent to the site. The structural remains outside the impact area have collapsed, but otherwise the construction materials and artifacts have been minimally disturbed. A large quantity of early twentieth-century bottles were scattered across most of the site, and noted on adjacent transects during survey. Ceramic sherds and glass bottles recovered from the site date to the first half of the twentieth century.

With the main structure apparently destroyed, the outbuildings and artifacts have moderate research potential for providing more data on land usage and farming activities in the Lackland area during the first half of the twentieth century. See the site description under the Medio Creek prehistoric section for the NRHP recommendations. 


\section{Chapter 13. Analysis of the Historic Data}

\section{Introduction}

Archival research and oral interviews were conducted by CAR to provide the historical background of the Lackland Air Force Base area. This chapter presents the results of the research, followed by discussions of the Historic sites found or revisited during the CAR survey and their spatial distribution. Figure 13-1 shows the property owners just before the land was procured by the U.S. government.

\section{Historic Development}

Increased land use on and around Lackland AFB was stimulated by a growing demand for agricultural consumer goods in the early twentieth century. Medio and Leon creeks provided good sources of water, while the rich soils along both tributaries of the Medina River were suited for producing abundant crops and grasses for grazing.

Historical accounts of land use during the eighteenth through twentieth centuries around Lackland primarily involve ranching activities, including infrequent roundups in the later part of the eighteenth century to capture the feral cattle, untended and allowed to roam from the lands allotted to five missions in San Antonio (Jackson 1986:321-423). Division of the mission lands by 1794 accounted for an increase in the number of individual ranches and farms in the area. By 1809 at least seven ranches were located along Leon Creek and the Medina River (Jackson 1986:518). By 1913 the land that now occupies the main part of Lackland AFB and the Medina Annex had been divided among more than 30 landowners (Appler
Map of Bexar County, 1913, Special Collections, John Peace Library, The University of Texas at San Antonio).

San Antonio grew rapidly, so that by 1875 the city was overtaking farmland yet demanding more agricultural goods. The timing was right to launch the largest expansion of agriculture ever experienced in Bexar County. Initially, six families formed the Medina Farm Colony on land 15 miles southwest of San Antonio and bordering the Medina River.

The new settlers cleared the lands of mesquite and built log cabins from the larger trees along the creeks and the river. The land tracts were secured by deeds of trust or mortgages. Payments were made when crops were harvested. Until their first crops came in, the settlers lived off the profits from selling their properties in San Antonio and managed to put money down on farm machinery, wagons, horses, mules, and cows.

The Nentwich family was one of the first to settle in the Medina Farm Colony. They moved to their parcel in December 1874 (Mosebach 1934). The family was quite large, consisting of nine children, the three oldest of whom remained in town.

In 1875 Andrew (Andres) Braden quit his job as a carpenter in the city and moved to a tract of land near the Nentwichs. A few years later another carpenter, August Neumann, moved his family to the farm colony on an adjoining tract of land.

Ludwig and Augusta Wilke bought 250 acres near the Nentwich, Braden, and Neumann tracts in April 


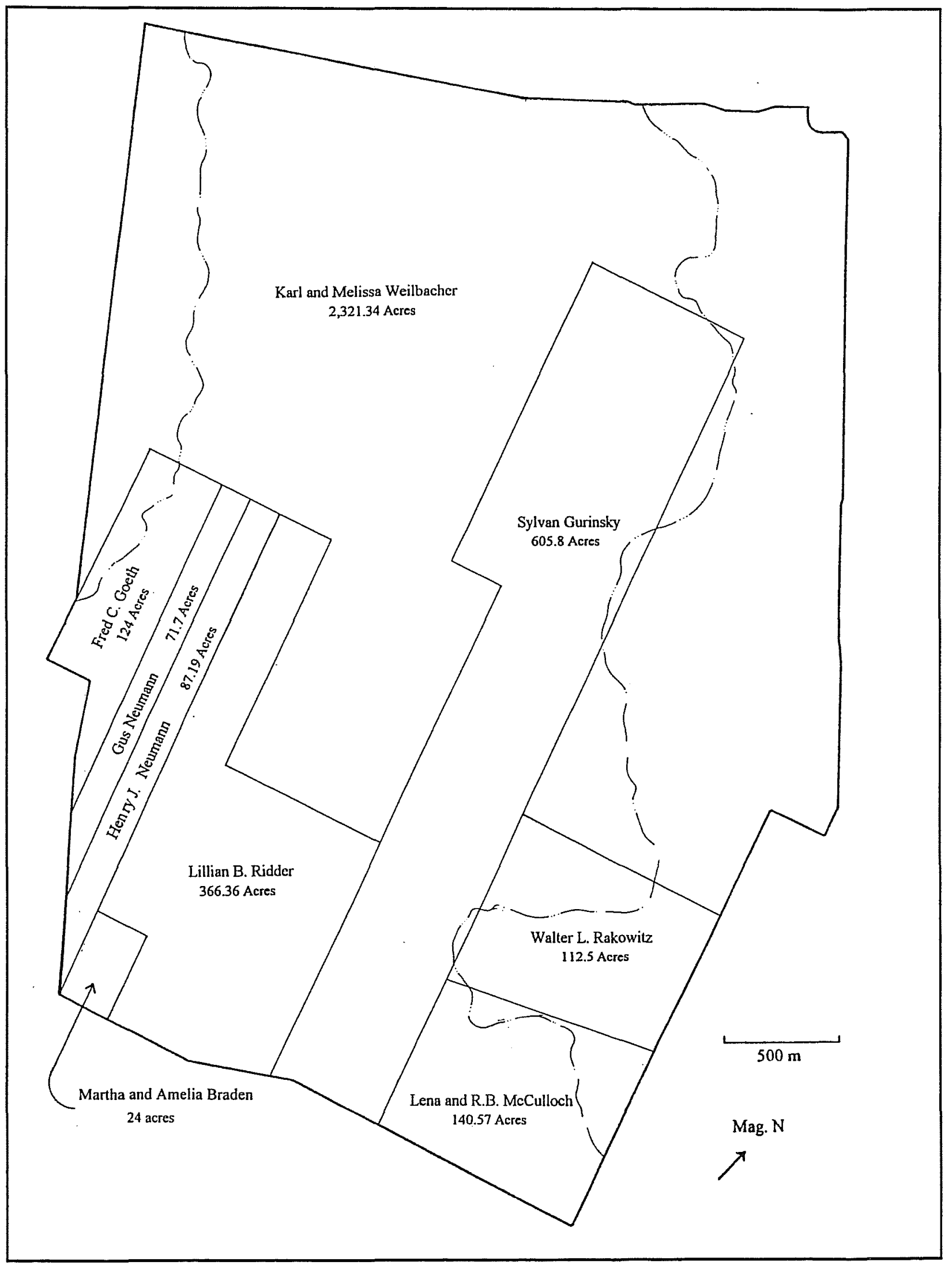

Figure 13-1. Prior landowners of the Medina Annex property. 
1880. Shortly after Ludwig's death in 1923, Herman Nentwich would affirm that he had lived in Bexar County 65 years and had known Ludwig and Augusta for 50 of those years (Bexar County Deed Records [BCDR] 1041:40). According to a previous investigator:

A check of the 1900 census records reveals that Ludwig was a farmer who immigrated to the U.S. in 1867. He was born in Germany in 1844. His wife, Augusta, was a native Texan, but her parents were from Germany. By 1900, they had four children, all of whom were born in Texas [Reese et al. 1994:41, 43].

Two of the children died young: Henry was born in 1883 and died at age eight, George was born in 1885 and died at age 12. A surviving daughter and son, Lena and W. C., eventually took over the 250 acres belonging to Ludwig and Augusta (Proof of Heirship June 13, 1926; BCDR 823:589, 717:294).

Continuing with the narrative by the earlier researcher:

Tax rolls for 1887 indicate that $\mathrm{Mr}$. Wilke was paying taxes on 250 acres, as well as 25 cows, two horses, two carriages/buggies/wagons, the total value of which was listed as $\$ 1465$. By 1894, although he had the same land, he was only paying on 20 cows, two horses, one carriage/buggy/wagon, and five miscellaneous properties, total value $\$ 1265$. In 1899 , his property remained the same, but he owned four horses, 15 cows, and 30 miscellaneous items for a total value of $\$ 1280$. In 1909 , he was still paying taxes on the same land, 15 cows, three horses, two carriages or other vehicles, and ten pieces of machinery or tools [Reese et al. 1994:43].

By 1885 deep wells and windmills had brought much-needed water to otherwise semi-arid lands (Graham 1994:49). As more settlers penetrated the agricultural lands, communities such as Von Ormy and Macdona developed. Von Ormy was named for Count Adolph Von Ormy, an Austrian nobleman who purchased 2,300 acres on the Medina River in 1885 (Webb 1952:846). The Southern Pacific
Railroad, then known as the Galveston, Harrisburg \& San Antonio Railroad (GH\&SA) pushed west of San Antonio in 1881. A station was established on a large tract of land owned in part by an eastern land promoter named Macdona, hence the name. Sunday afternoon outings under the pecan trees on the banks of the Medina River in Macdona became a real treat for hard-working farming families as well as for those wishing to escape growing San Antonio. Sunday round-trip excursions between San Antonio and Macdona aboard the GH\&SA cost 50 cents (Mosebach 1934).

With the help of large families, the pioneers of the Medina Farm Colony developed the area into one the state's largest producers of cotton and corn during the late-nineteenth and early twentieth centuries. By the 1930s a tremendous growth in the dairy industry prompted the farmers to plant grain as feed crops (Mosebach 1934). By the 1950s the land that is now Medina Annex was used primarily as rangeland for cattle, with some feed-grain rowcrop farming taking place (Gus Neumann and Denzil Harroun, personal communication 1996).

The descendants of the early pioneers often married into each other's families so that most of the landowners became related through the years. Land tracts became smaller as the original tracts were divided by dowries, inheritances, and sales. The close-knit community, the suitability of the land for providing a decent living, and the feeling of selfsufficiency must have been good to those who stayed, for many of the surnames of the colony pioneers appeared on the deeds of the land the government procured in 1954.

Gustav (Gus) Albert Neumann, Jr. is a descendant of Medina Farm Colony pioneer August Neumann. $\mathrm{He}$ and his wife, Francis (Hutzler) Neumann of Castroville, were interviewed for this project. Gus's father Gustav had owned 71.7 acres of land before the government took it over in 1954 (Figure 13-1). Gus Jr. grew up at his parents' home in Rio Medina, but remembered farming and ranching the Annex property with his dad. Francis grew up in Medina County, on acreage where Highway 90 crosses the Medina-Bexar county line. Gus and Francis married on June 19, 1954. Francis had not 
been on the Annex property, but was familiar with the Neumanns, Nentwiches, Bradens, and Weilbachers.

Gus Jr. has a sister, Anna Mae Haegelin, and had a brother, David, now deceased. His father, Gus Sr., died on April 9, 1965. His grandfather was August Neumann. His mother, Alice (Bourquine) Neumann, who was 89 years old at the time of the survey, was unavailable for an interview.

Henry John Neumann was Gus Jr.'s uncle. Henry owned the 87.19 acres adjoining Gus Sr.'s tract (Figure 13-1). Henry's first wife, Mary Nentwich, died in childbirth. He had two children by his second marriage.

Gus Jr. recalled coming with his dad from their home in Rio Medina to Macdona, and to the Annex to farm and tend cattle with Uncle Henry. There was no fence between the two tracts at first, so both brothers shared the land. While the land was used mostly for cattle, Gus Sr. did plant some row crops on the western portion (now the rifle, pistol, and grenade ranges). He described the land as sloping up from west to east.

In the beginning, his dad had a McCormick 1020 tractor with iron wheels. He removed the magneto for more power. Henry planted corn and maize with a John Deere-B, a new two-cylinder bought in 1942. With that you could plant two rows at a time. In 1945 Gus Sr. bought a Moline Model R. Gus Jr. couldn't recall what they planted at first, but from 1949 through 1951, they raised grain sorghum. The Johnson grass was thick, and it would take over and stunt the crops. Gus Jr. graduated from San Antonio's Main Avenue High School, now Fox Academic and Technical High School, and went into the military in January 1952. However, that was after his dad wrote a letter and got him a six-month deferment so he could help build a new fence around the properties, in the area of what would now be the perimeter fence in the southwest corner of the ranges.

Screw worms were very bad for the cattle. The blow flies would penetrate the cattle's nose and mouth and lay their eggs. The cattle then were a mixed herd, mostly Hereford. The cattle were always sold to Gus Sr.'s Uncle Frank Neumann, a cattle buyer by trade, who would take them to the stockyard in San Antonio.

Gus Jr. and Francis also recalled some of the adjoining property owners. To the southeast, Andrew Braden had given land to his daughter, Amelia. To the west, Albert Nentwich had two sons, Arthur and Fred. To the north, Minnie Weilbacher married John Schumann, and Thekla Nentwich married a Weilbacher. Ford Tractor Company came out in the late 1940 s to plow the Gurinsky property to test their tractors. For a long time, Homer Verstuyft, a Belgian, farmed the Gurinsky property. The Belgians were relocated when land was taken for Kelly Field.

Although not a descendent of the Medina Farm Colony pioneers, Mr. Denzil G. Harroun owned 113 acres of land north of the McCulloch tract in the 1940s (Figure 13-1) and was also interviewed for this project. Harroun and his wife, Marta, own and operate the Texas Lapidary shop at 1910 East Pyron Road, San Antonio.

Harroun talked about his parcel and others surrounding it. He bought the land from a man named Parker in the mid-1940s, and sold it to a man named Rakowitz in the late-1940s. Rakowitz was 70 years old then, so he wouldn't be alive today. A Frank Swentzen from Commercial Title handled the land transactions.

The Harrouns never lived on the property, but had intended to until they learned that the government was going to take it, at which time they sold it. In the meantime, Harroun had a well driven into the Edwards Aquifer. The water was pumped with a gear jack pump, and he even had a gas well put in for heat and power. In addition, he stated that he was the one who built the dam across Medio Creek in the 1940s. The dam was destroyed by a flood in 1976.

When asked about a cement foundation the survey crew had found on the northwest side of Medio Creek, Harroun stated that it was used as a shed or hay barn; he didn't build it but whoever did never 
really fully finished it. He stated that he had row crops of High Gear feed on the flat terrace adjacent to it. Primarily, he used the land for running cattle, selling them at the stockyards in San Antonio. His 113 acres would support about 30 head.

Harroun was not aware of a possible structure near the dam (41BX1129). When told that a structure appeared on a 1903 USGS map, and about the bedsprings, car parts, kitchen artifacts and pilings found there, he said he had seen stuff around there, but had just always assumed it was a trash dump. When the location and structural remains of 41BX1002 were described to Harroun, he stated he was not at all familiar with the place, where it would be, or who owned it. Harroun did confirm that $41 \mathrm{BX} 1130$ did in fact belong to Lena and Roy McCulloch. When showed where the outbuildings were located and that the main structure was now believed to have been inside the Explosive Ordnance Detachment (EOD) area and destroyed, he recalled the house as being a little further northeast of the EOD area, toward the creek.

Harroun has a clear recollection of 41BX1128. He stated that he believed it was an abandoned brick factory and once had a kiln fired by mesquite logs. He further stated that there was a shed there that for a long time had a Model A Ford inside. Harroun recalled the water tower also, he had procured some 2.5-inch pipe from there for his water well. He recalled that the pipe ran almost to the brick plant. In the 1940 s someone came to the site, stripped it, and took the automobile. He stated that the plant or factory was abandoned when he first saw it in the 1940s, and he had no idea who had operated it, or when it was in use.

In addition to the Medina Farm Colony members, the agriculturalists, industrialists, laborers, and entrepreneurs associated with land usage in the Lackland area were a diverse and colorful group. For instance, the secretary of Bexar Brick and Tile Manufacturing Company was Samuel Maverick III, whose father served in the volunteer army of Texas as a guide during the Siege of Bexar. Samuel A. Maverick Jr. was a signer of the Texas Declaration of Independence, mayor of San Antonio in 1839 and 1840 , and periodically served as a legislator between 1843 and 1862. Maverick County is named for him. In 1861, he was one of the Southern Confederacy Commissioners who accepted the surrender of the General Twigg's federal forces. After the Civil War, he started a lumber yard on Alamo Plaza and became involved in the lumber price wars of 1884 (Chabot 1937:251-252, 400; Tyler 1996:574-575).

Acting as trustee for the sale of the brick factory was Charles W. Campbell, who was first a drugstore clerk in 1883 (SACD 1883-1884:121), then dabbled in real estate before returning to work at the Crystal Ice Palace (SACD 1891:121, 1892-1893:216). A. B. Frank bought the property at public auction (BCDR 68:19). Frank was the manager of the largest drygoods firm in San Antonio at the time, shipping goods by rail and wagon train to all points west and into the heart of Mexico (SACD 1883-1884:50, 56). After Frank died, his widow, Sarah, sold the property in 1908 to Thomas Dolan, who was a shop engineer for the GH\&SA in San Antonio for many years (SACD 1884-1885:122; 1886-1887:125; 1889-1890: 142; $1891: 153 ; 1892-1893: 265 ; 1895-1896: 239)$, before retiring in San Antonio (SACD 1919-1920).

In 1910 Dolan sold the property to Albert Bitter, a bartender at the Eagle Saloon in San Antonio (SACD 1889-1890:95). Bitter then sold it to Friars of the Atonement, Inc. (BCDR 2069:616). The friars' society was (and still is) located in Graymore, New York. One of the friars, Father Paul, invested heavily in land, oil, and gas wells throughout the country. Besides owning property around Amarillo, he must have thought the Bitter property would be a sound investment. Although all his profits went toward supporting his society in Graymore, the Vatican decided that Father Paul should concentrate more on preaching than on mortal holdings. Therefore he began divesting himself of his holdings. After he died in 1946, the company continued divestiture proceedings (Father Phillips, personal communication 1996).

F. Groos and Company owned most of the north and northwest portion of the Annex during the 1940s. The Groos Company was owned by commercial bankers and merchants Frederick, 
Charles, and Gustav Groos (SACD 1883-1884), ancestors of today's Groos Bank family members. Frederick also served as president of the San Antonio Gas Company, "dealing in all orders for gas and the Brush Electric Arc Lights" (SACD 1889-1890:13). Edward Braden, possibly the son or younger brother of Andrew Braden, owned a large tract of land, the northern end of which entered the southwestern part of the Annex. Edward was a wellestablished merchant and San Antonio city alderman in the early 1900s (Chabot 1937:253; SACD 1895-1896). As a contractor and builder, Braden built the San Antonio City Hall in 1891 (Morrison 1891:61-62).

The land was indeed rich, not only from the grasses and water on the surface, but for the minerals, gas, and oil that lay underneath. The archives from the nineteenth and twentieth centuries are filled with lease agreements between speculators and previous Annex landholders. Mineral rights were often divided as properties changed hands through the years. One typical agreement outlines an oil, gas, and mineral lease on 460 acres on the Albert Bitter tract in 1940 for a five-year period.

The lessee agreed to pay an initial $\$ 10$ for the right to explore, and further to pay royalties on oneeighth of the oil, gas and minerals produced, except that he would only pay $\$ .50$ per long ton on sulphur. The lessee was to use all the oil, gas, coal, wood, and surface water he wanted from the land for free. Mr. Bitter was allowed to use any gas well on his land for stoves and residential inside lights. No well was to be drilled within $200 \mathrm{ft}$ of a house or barn without Mr. Bitter's consent, and all pipes were to be buried below the plow zone. No more than one well per 20 acres was allowed (BCDR 1741:496-499). Details on gas and oil production and personal consumption by the landowners are sketchy, but it is known that W. C. and Selina Wilke were receiving royalties from a gasproducing well in 1945 (BCDR 1041:41-42), and at least one person had a gas well which provided power for a water well pump in the 1950s (Denzil Harroun, personal communication 1996).
In 1954 and 1955 the United States government exercised the right of eminent domain and paid the landowners a fair market value for their land.

\section{Historic Sites}

\section{BX1002}

The structural remains and artifacts recovered from 41BX1002 provide few clues as to its function. The smaller structure has rounded bricks that appear to have served as a base for conical liquid holding tanks (Figure 13-2). A shovel probe in the burned mound yielded only charcoal. Construction materials present included yellow brick of the type commonly brought by rail from the Laredo area beginning in the late nineteenth century, as well as travertine blocks available in the adjacent creekbed. Some hand-hewn stone was mixed with common river cobbles in the collapsed walls of the larger structure.

There did not appear to be sufficient stone to represent a wall over a few feet tall, suggesting that the structure may have been a stone fence. The large depression contained a sparse scatter of red brick and stone. Only a handful of bottle glass sherds and metal fragments were found at the site. The paucity of household artifacts, and the presence of the tank platform and the large depression suggest that this could have been the site of an oil refining/storage area. The large number of oil and gas leases contained in the archives for the area make this likely. A 1903 USGS map shows a road leading north from the Southern Pacific railway and dead ending at the site. Though the site probably represents some type of manufacturing or industrial processing activity, nothing in the archives could be found which would confirm this assumption.

The depiction of a structure at this location on the 1903 USGS map and the presence of yellow brick which was not commonly available in the area until the late $1800 \mathrm{~s}$, indicates the building may have been constructed by the landowners around the turn of 
the century. George Bellerby and his son and daughter, Edward and Eidith, owned the property for 16 years, from 1883 through 1898 (Table 13-1). No record of the Bellerbys has been located in the census data for San Antonio. It is possible they were absentee landowners and leased out the land. From 1898 through 1901, the property was owned by Thomas E. George. A Thomas George is listed as living in San Antonio while running a livery and boarding stable from 1897 through 1901. John W. Judson purchased the property from George in 1901 and held it for four years before selling it in 1905 .

\section{BX1074}

The trash dump at 41BX1074 (Figure 8-47) may be that of Sylvan Gurinsky, his father Charles Gurinsky, or Albert Bitter (Table 13-2). Before the United States government procured the land in June 1954, Sylvan owned 605.4 acres surrounding 41BX1074 (BCDR 3515:35). Sylvan received the property as a gift from Charles in August 1949 (BCDR 2875:403). Although living in north San Antonio, Sylvan ran cattle on the property and frequently visited the parcel before the Air Force took it over (Sara Lee Gurinsky, personal communication 1996). Approximately $50 \mathrm{~m}$ east of the site are the remains of a cobble stone corral, possibly used in the cattle ranching activities. Charles only owned the land about four months, having purchased the land in April 1949, from the Friars of the Atonement (BCDR 2875:403). The Friars owned the parcel for investment purposes only and were absentee landowners; they did not build any dwellings (Father Phillips, personal communication 1996). Albert Bitter owned the land from 1910 through 1944 (BCDR 2069:616). Mr. Bitter resided in San Antonio (SACD 1890), suggesting he used the land for agricultural or ranching purposes only.

Artifacts present on the site suggest it was used beginning ca. 1930. A Royal Crown Cola bottle (Figure 13-3) and 29 redware ceramics were collected. The bottle bears a copyrighted label dated 1936, therefore it had to have been manufactured during that year or later. The label is an Applied Color Label, which came into use around 1920 and by 1930 had replaced embossing as one of the most common types of labeling. In addition, the label is red and white. Applied Color Labeling using more

Table 13-1. Landowners in the 41BX1002 Area

\begin{tabular}{|c|c|c|c|c|}
\hline Date & From & To & $\begin{array}{l}\text { BCDR } \\
\text { Vol:Page }\end{array}$ & Notes \\
\hline $04 / 12 / 1861$ & James B. \& Maria Jesusa Lee & Stribbling \& Dittman & $S 2: 10$ & \\
\hline $02 / 13 / 1862$ & Stribbling \& Dittman & William Sinke & S2:237 & \\
\hline $02 / 20 / 1874$ & William Sinke & William Woeffling & Unknown & \\
\hline $05 / 16 / 1883$ & William Woeffling & Nannie B. \& J.T. Hunter & $25: 526$ & 420 acres \\
\hline $05 / 24 / 1883$ & Nannie B. \& J.T. Hunter & George Bellerby & $25: 516$ & 420 acres \\
\hline $04 / 27 / 1896$ & George Bellerby & Eidith Agnes \& Edward Bellerby & $137: 708$ & 420 acres \\
\hline $10 / 20 / 1898$ & Eidith Agnes \& Edward Bellerby & Thomas E. George & $178: 195$ & 420 acres \\
\hline $09 / 25 / 1901$ & Thomas E. George & John W. Judson & 196:539 & 420 acres \\
\hline $10 / 17 / 1905$ & John W. Judson & P.J. Seidemann & $255: 424$ & 420 acres \\
\hline $12 / 29 / 1905$ & P.J. Seidemann & Henry Weid & $446: 199$ & $\begin{array}{l}\text { Lien released 1914; } \\
618.2 \text { acres }\end{array}$ \\
\hline $10 / 21 / 1922$ & Henry Weid & Jack M. Connor & $694: 269$ & $? ? ?$ \\
\hline $09 / 27 / 1929$ & Thekla Weilbacher & Karl and Melissa Weilbacher & $1151: 451$ & \\
\hline $\begin{array}{l}1944 \\
06 / 18 / 1954\end{array}$ & Karl and Melissa Weilbacher & $\begin{array}{l}\text { F. Groos \& Co. } \\
\text { U. S. Government }\end{array}$ & $3515: 37-38$ & 2,321.34 acres \\
\hline
\end{tabular}




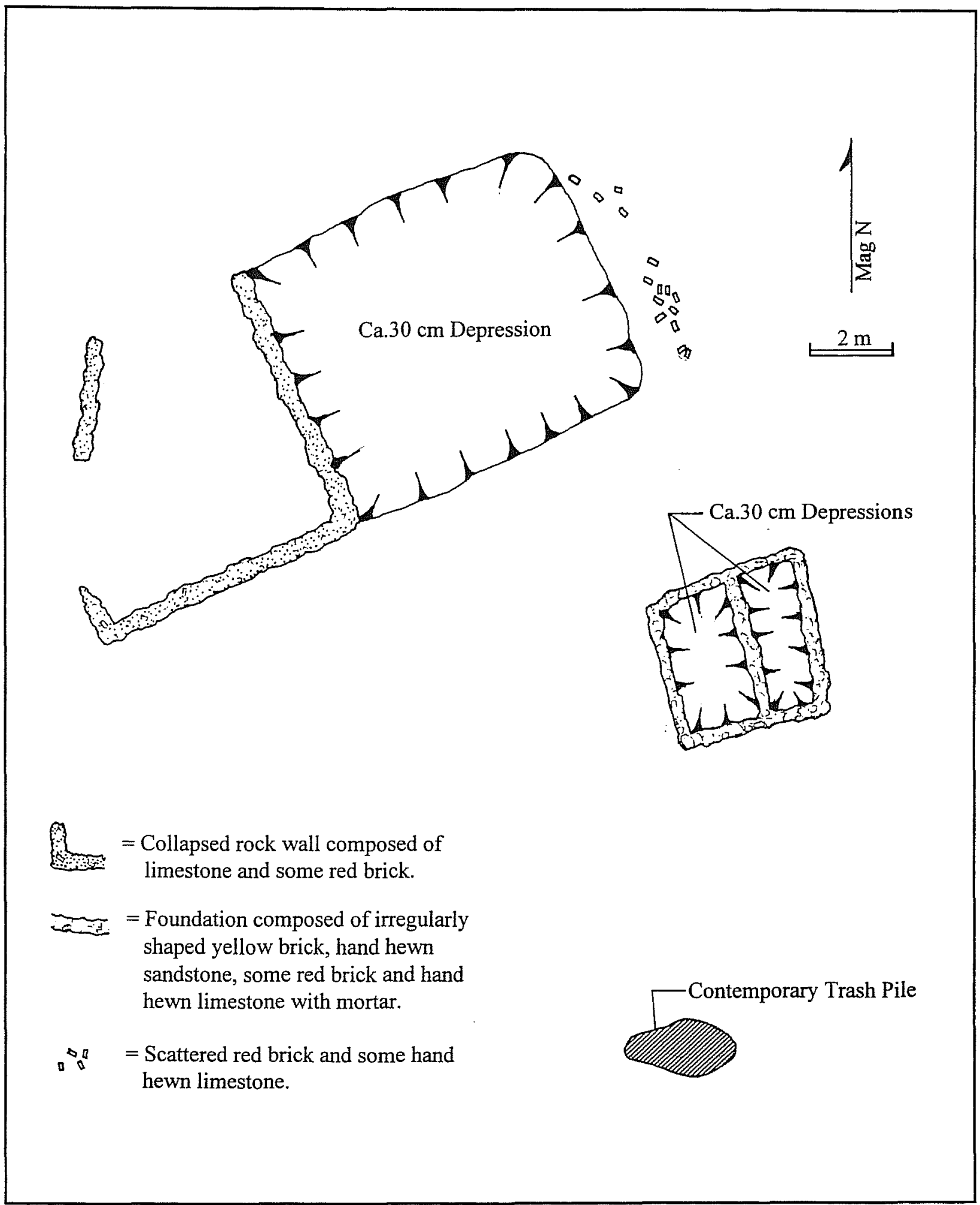

Figure 13-2. Details of structures on 41BX1002. 


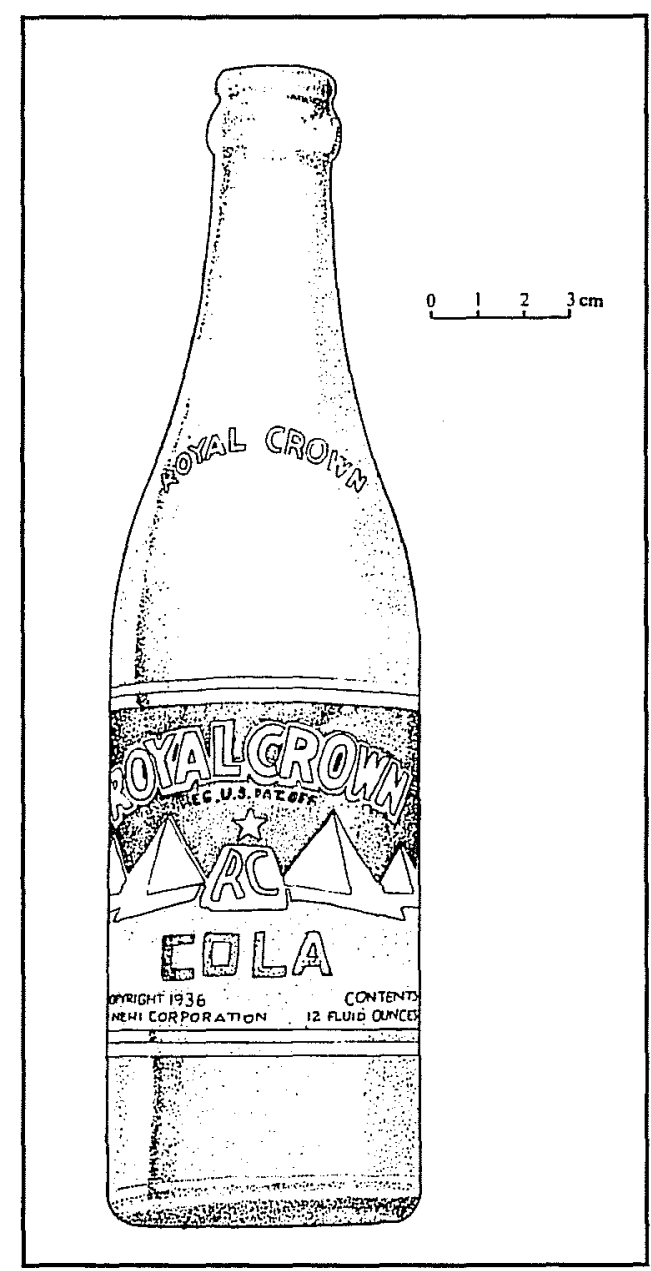

Figure 13-3. Royal Crown Cola bottle from the trash dump at $41 B \times 1074$. than one color was perfected in the late 1940 s (Munsey 1970:52). The maker's mark is that of the Glenshaw Glass Co., and has been used since 1932 (Toulouse 1971:211-213). Finally, the type and number of production scars on the bottle suggest it was machine-made.

The redware sherds are not diagnostic, but appear to be similar to plain ceramics manufactured during the late 1890 s and early to middle 1900 s. They are the remains of a large vessel, probably a jar, with a 15$\mathrm{cm}$ diameter opening at the top. The redware is plain, with no glaze or paint. This type of ceramic allows liquids to slowly seep through its pores and therefore was frequently used to keep water cool. The jar shows circular striations like those formed when a vessel is wheel-thrown (Anne Fox, personal communication 1996). The jars at the site were of the screw-top variety. None of these jars were collected. The continuous-thread design became the standard method of capping bottles in the 1930s and is still used today (Miller and Pacey 1985:45-46). The rusted tin cans are of the sanitary type, with locked end and side beams. The sanitary type became common by the early 1920 s and is still used today (Busch 1981:97-99).

Table 13-2. Landowners in the 41BX1074 Area

\begin{tabular}{|c|c|c|c|c|}
\hline Date & From & To & $\begin{array}{l}\text { BCDR } \\
\text { Vol:Page } \\
\end{array}$ & Notes \\
\hline $08 / 24 / 1837$ & Republic of Texas & Jose Maria Becerra & D1:29 & $\begin{array}{l}1 \text { league and } 1 \text { labor } \\
\text { Survey } \# 58\end{array}$ \\
\hline $08 / 24 / 1837$ & Jose Maria Becerra & Enoch Jones and J.W. Smith & $\mathrm{D} 1: 27$ & All of Survey \#58. \\
\hline Unknown & Enoch Jones and J.W. Smith & Various Owners & & \\
\hline $04 / 01 / 1890$ & $\begin{array}{l}\text { Bexar Brick \& Tile Manufacturing } \\
\text { Charles W. Campbell, Trustee }\end{array}$ & A. B. Frank & $68: 19$ & 52.29 acres \\
\hline $12 / 4 / 1908$ & A. B. Frank (Deceased) & Thomas H. Dolan & $303: 138$ & $\begin{array}{l}943.45 \text { acres; by } \\
\text { executor S. Frank. }\end{array}$ \\
\hline $03 / 21 / 1910$ & Thomas H. Dolan & Albert W. Bitter & $391: 358$ & 943.45 acres \\
\hline $09 / 08 / 1944$ & Albert W. Bitter & Friars of the Atonement, Inc. & $2069: 616$ & 943.5 acres \\
\hline 04/22/1949 & Friars of the Atonement, Inc. & Charles Gurinsky & $2683: 4$ & 943.5 acres \\
\hline $08 / 01 / 1949$ & Charles Gurinsky (Father) & Sylvan Gurinsky (Son) & $2875: 403$ & 943.5 acres \\
\hline $06 / 18 / 1954$ & Sylvan Gurinsky & U. S. Government & $3515: 39$ & 605.8 acres \\
\hline
\end{tabular}




\section{BX1121}

The historic component on site 41BX1121 (see Figure 8-19) consists of the collapsed remains of a roughly 2-x-3-m hand-hewed sandstone slab structure that may date to the late-nineteenth century (Figure 13-4). This structure is on the McCulloch tract and is most likely associated with the Ludwig and Augusta Wilke occupation soon after they bought the land in 1880 (Table 13-3).

Artifacts present on the site include seven whiteware sherds, glass sherds, and a rusted tin coffee boiler, suggesting a brief historic occupation from the 1860s through 1900 . Whiteware is a highly fired refined clay with a vitreous glaze. It was often hand painted or spattered with a cut sponge for decoration (Dial 1992:38). Three whiteware sherds found at the site are undecorated with a clear, shiny glaze. Whiteware was commonly imported to America from Britain during the $1800 \mathrm{~s}$, but the demand for undecorated types increased significantly in America by 1860. This type became a common tableware setting for middle-class families around San Antonio after the 1860s, replacing pewter and wooden wares (Fox et al. 1989:45). Three other whiteware sherds are handpainted underglaze, a style which-although a little more expensive than plain undecorated-was a popular import item during the early 1800s (Dial 1989:29-30). These particular sherds have wine-pink flowers with green leaves. One sherd was decorated using the cut sponge technique, that is, cutting patterns and designs in sponges and spattering the whiteware with colorful combinations. Although highly valued because it was pleasing to the eye, it was very inexpensive. These two attractive qualities made it a commonly imported item in the middle to late 1800s (Ray 1974:211-212).
The tin coffee boiler (Figure 13-5) found among the stone rubble is representative of kitchen tinware items distributed during the late-nineteenth century (Israel 1968:132).

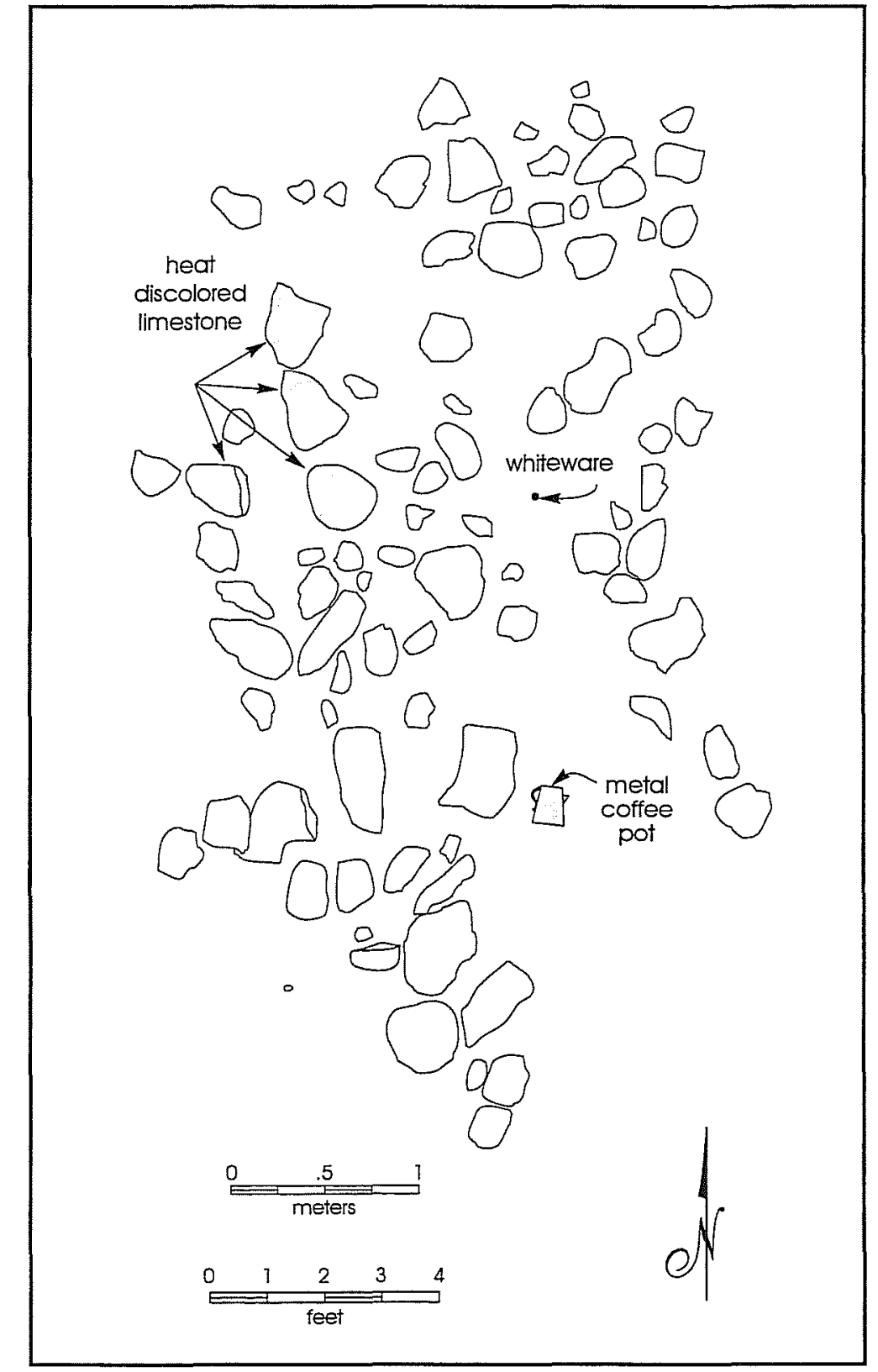

Figure 13-4. Remnants of sandstone-slab structure at 41BX1121. 
Table 13-3. Landowners in the 41BX1121 Area

\begin{tabular}{|c|c|c|c|c|}
\hline Date & From & To & $\begin{array}{l}\text { BCDR } \\
\text { Vol:Page }\end{array}$ & Notes \\
\hline $08 / 24 / 1837$ & Republic of Texas & Jose Maria Becerra & D1:29 & $\begin{array}{l}1 \text { league and } 1 \text { labor; } \\
\text { Survey \#58; }\end{array}$ \\
\hline $08 / 24 / 1837$ & Jose Maria Becerra & Enoch Jones and J.W. Smith & D1:27 & All of Survey \#58. \\
\hline $09 / 1856$ & Various Owners & Maria Jesusa (Lee) & & $\begin{array}{l}\text { A dowery for the } \\
\text { E. half of Survey } \# 58 \text {. }\end{array}$ \\
\hline $11 / 6 / 1878$ & $\begin{array}{l}\text { James B. and Maria Jesusa } \\
\text { Lee }\end{array}$ & George A. Barker & $9: 229$ & $\begin{array}{l}1,000 \text { acres from } \\
\text { Survey } \# 58 \text {, for } \$ 2,000 \text {. }\end{array}$ \\
\hline $04 / 101880$ & George A. Barker & Ludwig Wilke & $9: 640$ & $\begin{array}{l}250 \text { acres from Barker's } \\
\text { northern } 1,000 \text {, for } \$ 500 \text {. }\end{array}$ \\
\hline 06/13/1926 & Ludwig Wilke (Deceased) & W.C. Wilke (Son and heir) & $823: 589$ & $\begin{array}{l}250 \text { acres; Proof of heirship } \\
\text { to inherit property. }\end{array}$ \\
\hline $04 / 20 / 1923$ & W.C. and Selina Wilke & Lena and R.B. McCulloch & $717: 294$ & $\begin{array}{l}140.57 \text { acres out of } \\
\text { Ludwig's } 250 \text { acres }\end{array}$ \\
\hline $08 / 07 / 1954$ & Lena and R.B. McCulloch & U. S. Government & $3538: 285$ & 140.57 acres \\
\hline 1928, June 7 & W.C. and Selina Wilke & O.D. Edwards and J.E. Seale & $1041: 41$ & $\begin{array}{l}112.5 \text { acres out of } \\
\text { Ludwig's } 250 \text { acres }\end{array}$ \\
\hline
\end{tabular}

\section{BX1124}

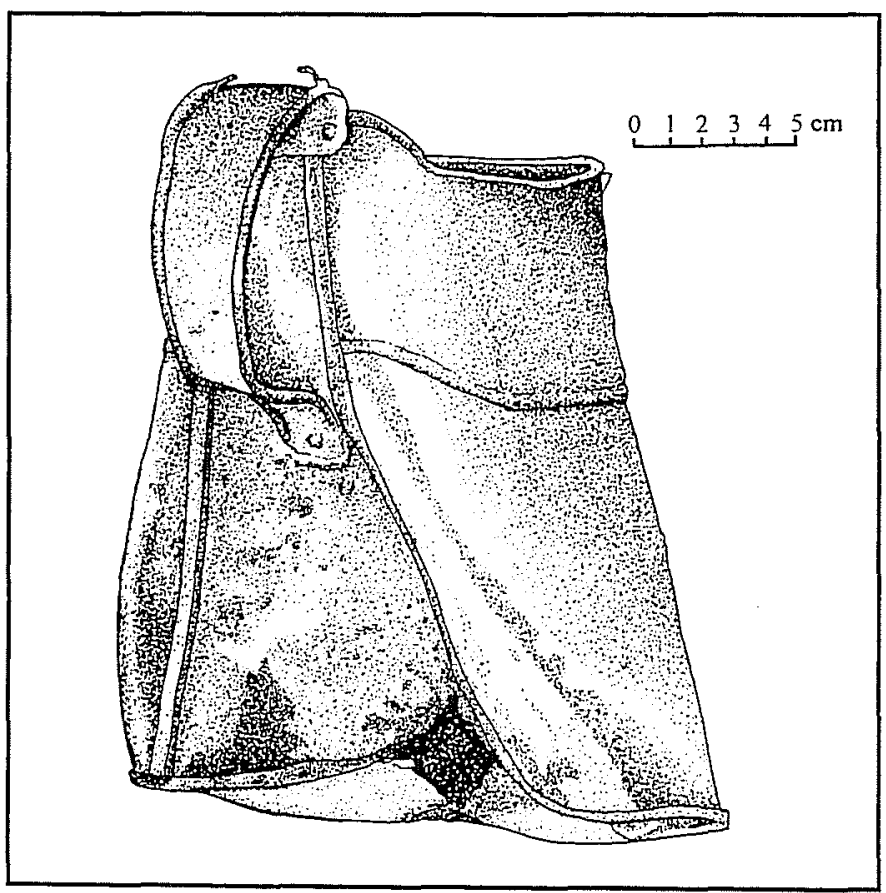

Figure 13-5. Tin coffee boiler from $41 B X 1121$.
The ceramic, glass, and metal artifacts from this historic dump (Figure 8-67) suggest it was used during the 1920s. Thirteen stoneware sherds were present. Stoneware is a utilitarian ware and was commonly used in the kitchen and dairy from 1860 through 1950 (Greer 1981:13-26). The stoneware sherds at $41 B X 1124$ contain a Bristol white glaze on the outside with an Albany type slip on the inside. Bristol white glaze was typically in household use by 1900 . The sherds also bear a maker's mark of Uhl Pottery Company, Huntingburg, Indiana, with the company's Acorn logo (Figure 13-6). The Uhl company made kitchen stoneware items in Huntingburg from 1891 through 1941 (Lehner 1988:478).

Two large light green glass jug bottoms were recovered. The bottom of one is date stamped "1927." The second bears a maker's mark patented by the Illinois Glass Company, Alton, Illinois. In 1915 the company was the first to use a machine to manufacture 5- to 13-gallon jugs. 


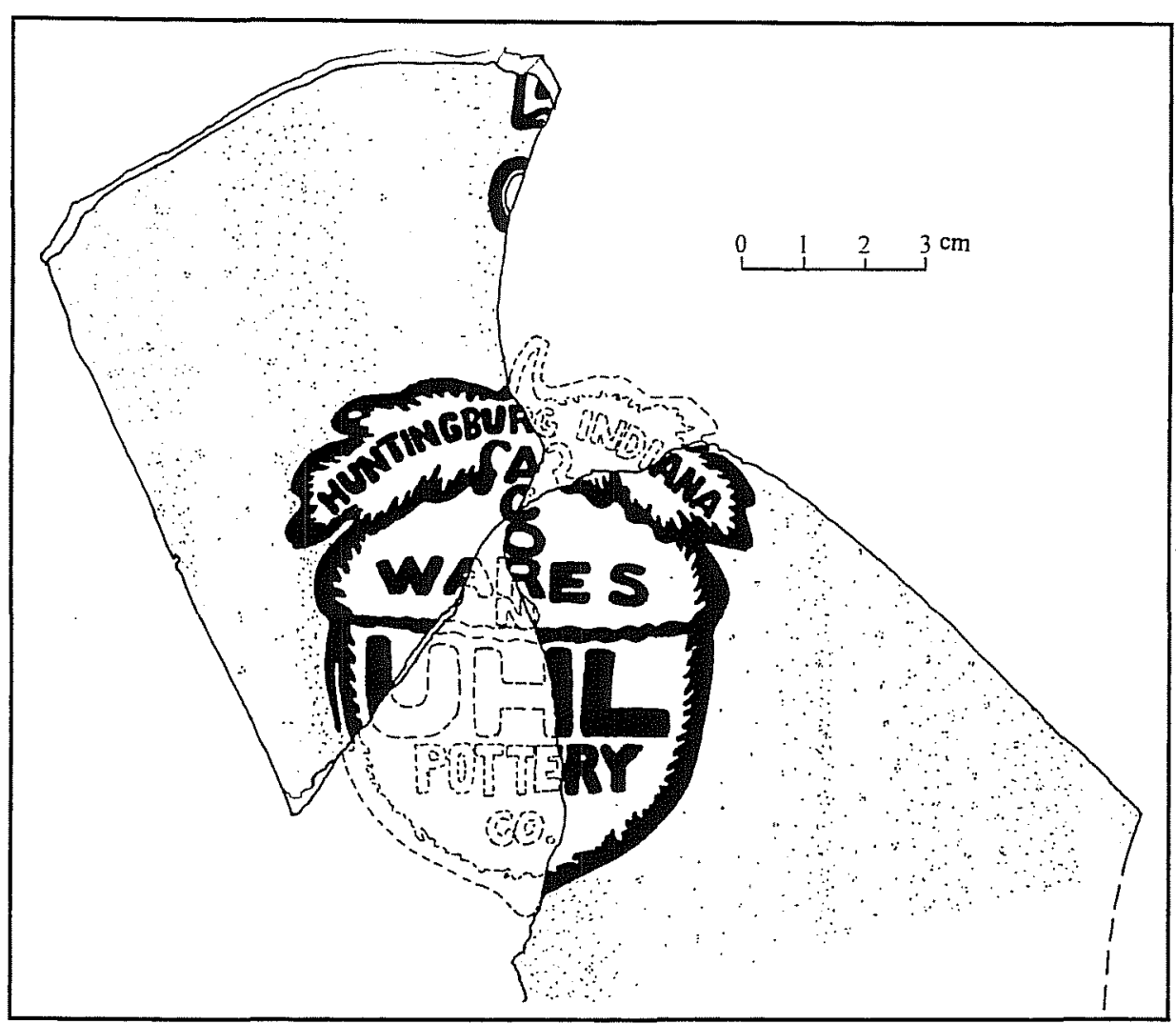

Figure 13-6. Uhl Pottery Company stoneware sherds from 41BX1124. trail drives in 1881 (Graham 1994:41). Texans fought the ticks with pesticides and vats for dipping cattle. The battle against Texas Fever was declared a victory in 1928 , when the United States Department of Agriculture announced that the ticks causing the disease had been eradicated in South Texas (Graham 1994:51). Screwworm infections were especially bad in the 1930 s. "In 1935, an estimated two to three million head of livestock in Texas were infested by screwworms" (Graham 1994:68-69). In 1927, pesticides were sold in quantities of one and five gallons. One gallon of disinfectant mixed with water would make 70 gallons of a potent mixture "for the extermination of parasites, lice, ticks, fleas and many other insects" (Mirken 1970:645). Feed supplements for cattle were sold in 54-gallon barrels for $\$ 9.98$ in 1927. Molasses mixed with corn for example, made steers gain weight faster than just plain corn (Mirken 1970:645). This site was most likely used by Albert Bitter who owned the property from 1910 through 1944 (BCDR 2069:616 and Table 13-2). Mr. Bitter resided in San Antonio (SACD 1890), suggesting he used the land for ranching purposes only.

\section{$41 B X 1128$}

The utilization time of 41BX1128 (Figure 12-3) as a brick factory can be framed from ca. 1888 through 1890. The property surrounding this site was owned by the Bexar Brick and Tile Manufacturing Company until they sold it on April 1, 1890 (Table 13-2). Records indicate that the company was chartered on January 2,1888 , by issuing $\$ 50,000$ worth of capital 
stock. Its officers were J. C. A. Piper, president; H. M. Schulthess, vice-president; Sam Maverick III, treasurer; Charles B. Wilson, general manager; and William E. Austin, secretary (SACD 1889-1890:63). Although the offices were located in the Maverick Building, 1 East Houston Street, their manufacturing yard was located "10 miles southwest of the city" (SACD 1889-1890:93), and was capable of producing 25,000 to 50,000 "Cremona Gulch" bricks per day (Figure 13-7) (SACD 1889-1890:72).

While the structure is shown on maps in later years (USGS, San Antonio:1903; U.S. Army Corps of Engineers, West San Antonio 1942), the company was apparently in operation less than three years. Just nine months after being chartered, the company was offered as collateral for a $\$ 4,000$ loan from
Charles and William Campbell (BCDR 62:219-220). By agreement, the first payment of $\$ 100$ was due January 1,1889 , and a second payment of $\$ 300$ due January 1, 1890. Apparently the payments were not made, because on April 1, 1890, Charles Campbell sold the property to the highest bidder, A. B. Frank, at the door of the Bexar County Courthouse (Figure 13-8). By 1891, the company was no longer in the general listings of the city directory.

Bricks were not commonly used as building materials in San Antonio until after the arrival of the railroad in February 1877. The rich clays around the city were excellent for making bricks, but had not been exploited. Even though the railroad provided a means to efficiently export bricks, craftsmen skilled in brickmaking were not

\section{SAN ANTONIO EITY DIRECTORY.}

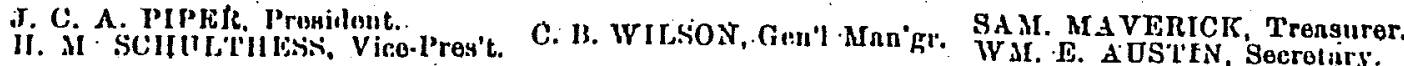

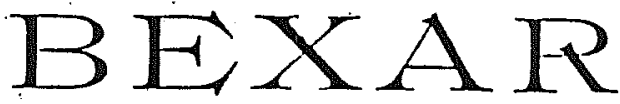

Brick and Tile Manufacturing Co.

MANUEAC'TURERS OF THI CELERRA'TED

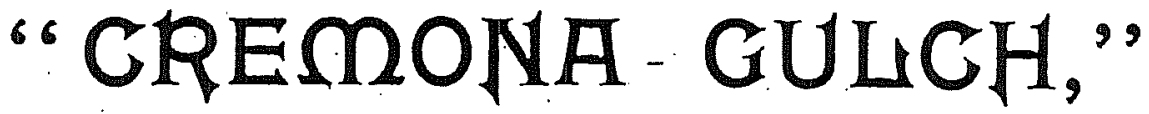

'IIIE -FINEST PIRESSFI) BIICK ON.TIE MARKIT.

Capacity, from 25,000 to 50,000 Daily.

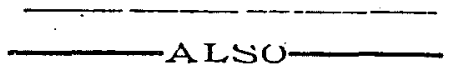

MANUFACTURERS OF TILING, Etc.

OFFICE, No: 1 E. HOUSTON STREET; SAN ANTONIO, TEXAS,

WF CAN CHMPETE IN PRICE AND QUAITTY WITI ANY .BRICK MANUlA(:TUREI)

Figure 13-7. Advertisement in the 1889 San Antonio City Directory. 
The Slate of Jesas:

County of Bexar: Whereas the Bexar Brick and Iile Manufacturing Company, a cosporation duly arganized under the laws of the Btate of Jexas, on the 13th day of September 1888, executed and delivered unto Charles W. Camplell its certain deeds to certain lande and personal property hersin specifically described, which said deed is secarded in the recards of Bexar County, Jeras, in Vol. 62, an pages 219-222 of the records of deeds of trust, and also duly filed in Chatlle (ar Chaltel) Mortgage records of Berar County. Jesas, in Volume 1, page 84 to lath of which references herely made for full and complete description of said property. And whereas said conweyance was made in trust for the purposes herein mentioned; and whereas the sum of money mentioned in said Deed, and the interest thereon, had become due and payable according to the terms thereof, and remained unpaid at and after the time specified in said deed for its payments. And whereas at the request of the legal owner and holder of said notes in said deed described, the said Charles W. Camplell, in purseance of the power and authority vested in him by the deed aforessid, did advertiss the property in said deed described for sale at pullic venduce, by publication of same in a newspaper, called the San Antonio Daily Jimes, printed and pultished in the cily of San Antonio, Bexar County, in the State of Jexas, as provided in said deed of trust, for at least twenty days next prior to the sale day. notifying the pullic and all whom it might cancern that the said property would be sold by him on Juesday the first day of April, A.D. 1890 at the Court House doar in San Antonis. Bexar Counity. Jexas, for cash in hand. And where the said Charles W. Campledl, an the day and year and at the place, and an the terms of aforesaid, did offer all the property aforesaid and hereinafler described for sale at public vendue, and A.B. Frank bing the highest and best bidder therefor, the same was knocked off to him, and he became the purchaser wherefor, at and for the sum of thinty eight hundred and fitty fise dollors, the receipt whereof is herely acknowledged. Now, therefore in consideration of the promises \&, the said Charles W. Campbill, by these presents do grant, atien, and conwey to the said A.B. Frank, his heirs and assigns all the title and interest which \& acquired to the property in said deed of trust described, which is as followes to wit: fifly-two and 29/100 acres of land, part of the original survey No $_{5} 58$ in the name of fose Maria Bacerra, in the County of Bexar and State of Jexas, said 52 29/100 acres of land bing more particularly described ly metes and hounds as follows: Beginning at a stake set for the northeast corner of said land, which stake is four hundred and thirly-two (432) feet south of the southeast corner of the Wilson and Stary burveref; thence running boutherly along the Westerly lines of the land of Wilke and Barker, a distance of One Thousand and ninaty-six and 6-10 (1,096.6-10) fet to the corner making the division between said lands, and continuing still Southerly a total distance of one thousand two hundred and surenty-eight $(1,278)$ feet to a stake and mound of stanes set for the boutheasterly corner of the land herdy canweyed from which a mesquite $15 \mathrm{in}$. diameter, marked 1 bears \&. 18 dey. W. 23 peet; thence westerly ane thousand $(1,000)$ feet to a stake and mound of stones set for the bouthuresterly corner of this land from which a mesquite $6 \mathrm{in}$. diameler, marked 1 bears N. 28 deg. 30 min. E. 65 feel; thence Easterly first crossing then on the north side of gulley, ane thousand $(1,000)$ to the place of beginning, together with all machinery. buildings and improvements of wery character situated upan said 52 29/100 acres of land at the time of the making of said Deed of Frust, and all other personal property ouned by the said Bexar Brick and Tile Manufacturing Campany at the time of the making of said deed of Irust, whether situated an the said land or not. The said machinery and improvements cansist principally of the following property: (1) The boiler made by the Erie Boiler Works of erie. Pennsylvania, and bing of about 65 harsepower. (2) One Westinghouse Engine made by the Westinghouse Campany, about 50 harse pouver. (3) One ne-press brick machine. (4) One Wateriown. Engine with boiler attached, of the Watertown Steam Engine Company make, of Watertown, New Yark, engine being of about 30 harse power. (5) One Nathan Sledman disintegrating mill for grinding day, said mill bing made by the Nathan Steadman Works of Surora, Andiana. (6) One L.B. Kennedy dry press brick machine buill by bmith. Beggs and rankin of St. Louis, Missouri. (7) One Empire Steam Pump. (8) One Chituatua Wagan. (9) One Spring Cart. (10). One Dump Cart. Also all shafling, caunter shafling, bell, pulleys, elevators, brickbearers, tructs and all other personal property belonging to the said Bexar Brick and Iile Manefacturing Company, whether an the above described premises or not. And all the rights, priveleges and appertenances therets belonging ly virtue of the above recited deed. To have and to hold the premises herely conveyed, together with all the rights, priveleges and appurtenances aforessid unto him the said A.B. Frank and his heirs and assigns, forever. In Witness Wherof t have heteto sulseribed my name this first day of April A.D. 1890.

$$
\begin{aligned}
& \text { (bigned) } \\
& \text { Charles W. Camplell } \\
& \text { Iruster }
\end{aligned}
$$

Figure 13-8. Reproduction of the Deed of Sale of the Bexar Brick and Tile Manufacturing Company (41BX1128). From BCDR 68:19. 
sufficiently available until around 1885. Brick imports into San Antonio from the east exceeded exports until more skilled brickmakers arrived in the area in the 1880s (SACD 1879-1880:51; 1885:38).

At the beginning of 1884, attorneys Tom and T. S. Harrison operated the only brick works listed in the city directory, San Antonio Brick Company, 329 Crockett Street (SACD 1883-1884:20). By the end of 1884 , there were brick factories all around the city (Land and Thompson 1977[1885]:38) and brick construction began to replace stone. In that same year, brick factories within 10 miles of the city limits shipped 190 carloads into San Antonio. When Bexar Brick and Tile Manufacturing Company was established in 1888, it was one of only four listed as doing business in San Antonio (SACD 1889-1890:413); by 1890 , it was one of six
(SACD1891:427). Perhaps the competition forced its demise; by 1891 only four companies remained (SACD 1892-1893:681).

The collapsed water tower (Figure 13-9) was made of 2 x 6-inch 8-foot cypress boards. Six steel rings, 132 inches in diameter, bore a patent date of March 1894, from Racine, Wisconsin. The tower, or "cistern" would have held approximately 5,000 gallons (Permian 1984:999-1000). Cistern manufacturers were quite common in San Antonio. The city directories during the late 1800s and early 1900s list several coopers who specialized in building cisterns. One large manufacturer, F. F. Collins, used over $1,000,000 \mathrm{ft}$ of cyprus lumber per year and specialized in cypress cisterns holding up to 100,000 gallons (Morrison 1891:100). Water pipes that apparently ran from the tower to the manufacturing

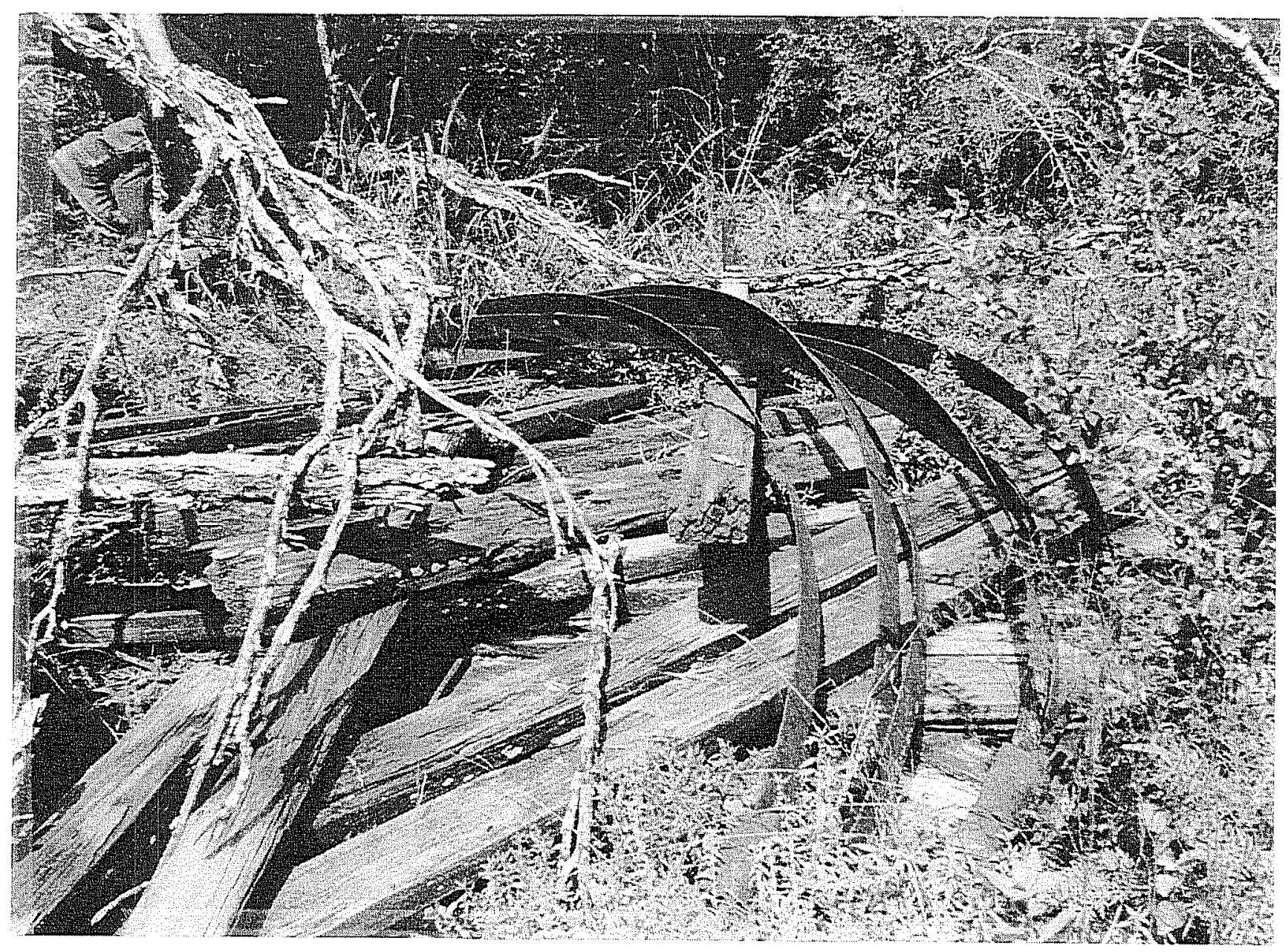

Figure 13-9. Collapsed cypress water tower at $41 B X 1128$. 
operation were reduced from 3 inches in diameter to 1.5 inches, and then to .75 inches. The raised tower coupled with reduced piping would have provided pressurized water for mixing clay throughout the operational area. It is probable that a windmill and well would have adjoined the water tower, although no evidence of either was found during the survey.

\section{BX1129}

The small amount of building materials recovered at the site suggests that the structure once there was most likely of wooden pole and beam construction. This site has been heavily disturbed, either by machinery when the adjacent flood control berm was constructed, or from flooding. The dam across Medio Creek was washed out in 1976, and a large flooding episode occurred in the area at that time (Gabriel Gonzales, personal communication 1995). The artifacts observed or collected on the site suggest it was used from the 1880 s through the 1920 s or later. Only two bricks were observed on the site, neither of which exhibited diagnostic maker's marks.
However, red bricks were not commonly used as building materials until after the arrival of the railroad in San Antonio in 1877, when brick began to be imported from the east. A structure appears at this location on a 1903 USGS map. It was most likely the home of the Wilke family, who owned the surrounding property from 1880 through 1928 (BCDR 9:640, 1041:41; Table 13-4).

Three porcelain sherds representing two bowls and a cup were all of the handpainted under-and-over glaze type. Porcelain is rarely present on eighteenthand early nineteenth-century sites because the fragile ware had to be transported from Europe (Ivey and Fox 1981:35), but becomes more frequent on historic sites after 1832, when it became commonly manufactured in the United States (Barber 1976:126-127). The type of porcelain found at $41 B X 1129$ can only be dated to the late-nineteenth and twentieth centuries. The one whiteware sherd with a blue spatter pattern found at the site is representative of an attractive yet inexpensive dinnerware commonly imported in the middle to late 1800s (Ray 1974:211-212).

Table 13-4. Landowners in the 41BX1129 Area

\begin{tabular}{|c|c|c|c|c|}
\hline Date & From & To & $\begin{array}{l}\text { BCDR } \\
\text { Vol:Page }\end{array}$ & Notes \\
\hline $08 / 24 / 1837$ & Republic of Texas & Jose Maria Becerra & $\mathrm{D} 1: 29$ & $\begin{array}{l}1 \text { league and } 1 \text { labor; } \\
\text { Survey } \# 58 \text {; }\end{array}$ \\
\hline $08 / 24 / 1837$ & Jose Maria Becerra & Enoch Jones and J.W. Smith & $\mathrm{D} 1: 27$ & All of Survey \#58. \\
\hline $09 / 1856$ & Various Owners & Maria Jesusa (Lee) & & $\begin{array}{l}\text { A dowery for the } \\
\text { E. half of Survey } \# 58 \text {. }\end{array}$ \\
\hline $11 / 06 / 1878$ & James B. and Maria Jesusa Lee & George A. Barker & $9: 229$ & $\begin{array}{l}1,000 \text { acres from } \\
\text { Survey } \# 58 \text {, for } \$ 2,000 \text {. }\end{array}$ \\
\hline $04 / 10 / 1880$ & George A. Barker & Ludwig Wilke & $9: 640$ & $\begin{array}{l}250 \text { acres from Barker's } \\
\text { northern } 1,000, \text { for } \$ 500 .\end{array}$ \\
\hline $06 / 13 / 1926$ & Ludwig Wilke (Deceased) & W.C. Wilke (Son and heir) & $823: 589$ & $\begin{array}{l}250 \text { acres; Proof of heirship } \\
\text { to inherit property. }\end{array}$ \\
\hline $06 / 07 / 1928$ & W.C. and Selina Wilke & O.D. Edwards and J.E. Seale & $1041: 41$ & $\begin{array}{l}112.5 \text { acres out of } \\
\text { Ludwig's } 250 \text { acres. }\end{array}$ \\
\hline 03/01/1945 & O.D. Edwards and J.E. Seale & W. J. Allen & $2115: 224$ & 112.5 acres \\
\hline $07 / 19 / 1946$ & W. J. Allen & Cal Parker & $2275: 274$ & 112.5 acres \\
\hline $03 / 18 / 1949$ & Cal Parker & Denzil G. Harroun & $2655: 463$ & 112.5 acres \\
\hline $11 / 09 / 1953$ & Denzil G. Harroun, et al. & Walter L. Rakowitz & $3403: 22$ & 112.5 acres \\
\hline $02 / 18 / 1955$ & Walter L. Rakowitz & U. S. Government & $3633: 454$ & 112.5 acres \\
\hline
\end{tabular}


Eighteen stoneware sherds were also recovered. Fourteen had white Bristol Glaze inside and out; four were unglazed on the outside, with a dark brown Albany Slip on the inside. Bristol white glaze was typically in household use by 1900 . However, the pieces containing Albany Slip are most likely pre-1900. Albany Slip became less favored and was replaced by Bristol Glaze (Greer 1981:170-171).

Two clear glass bottle lips were found. They are typical of soda, milk, and beer bottles manufactured by the Florida Glass Company from 1926 through 1947 (Toulouse 1971:199-200). A brown glass sherd from a bottle base carried a "Glovers" name. Although it could not be determined when Glovers was in operation, photos of Glovers bottles that held mange and distemper medicine are available. A base of a brown glass jug was embossed with "USG . . . ASSURES PURITY." Although this particular sherd could not be dated, records indicate that US Glass manufactured jugs and bottles from 1891 through 1964 (Toulouse 1971:234). One clear glass sherd from the bottom of a medicine bottle bore a maker's mark of "Illinois." This mark was used by the Owens-Illinois Pacific Coast Company from 1932 (Toulouse 1971:406-408). Three colored pieces of bottle glass present at the site are typical of the dark-greenish-amber, purple, and light green colors made until 1880 (Munsey 1970:37).

Three window glass sherds exhibit an aquamarine hue with heavily patinated surfaces. The hue is caused by adding sodium carbonate or sodium sulfate to glass mixtures to cause a lower melting point in the glass. This manufacturing technique was typically used during the late nineteenth century (Hunt 1959:34, as cited in Roberson 1974:24).

A rusted tin can recovered from the site is of the sanitary type, with locked end and side beams. The sanitary type became common by the early 1920s, and is still used today (Busch 1981:97-99). Two types of barbed wire collected are illustrated in Figure 13-10. One is "A. Burnell's Four Point," patented in June 1877; the other is "G. C. Baker's Flat Barb," which was manufactured as early as 1882 (Thurgood 1972:7, 23-28).

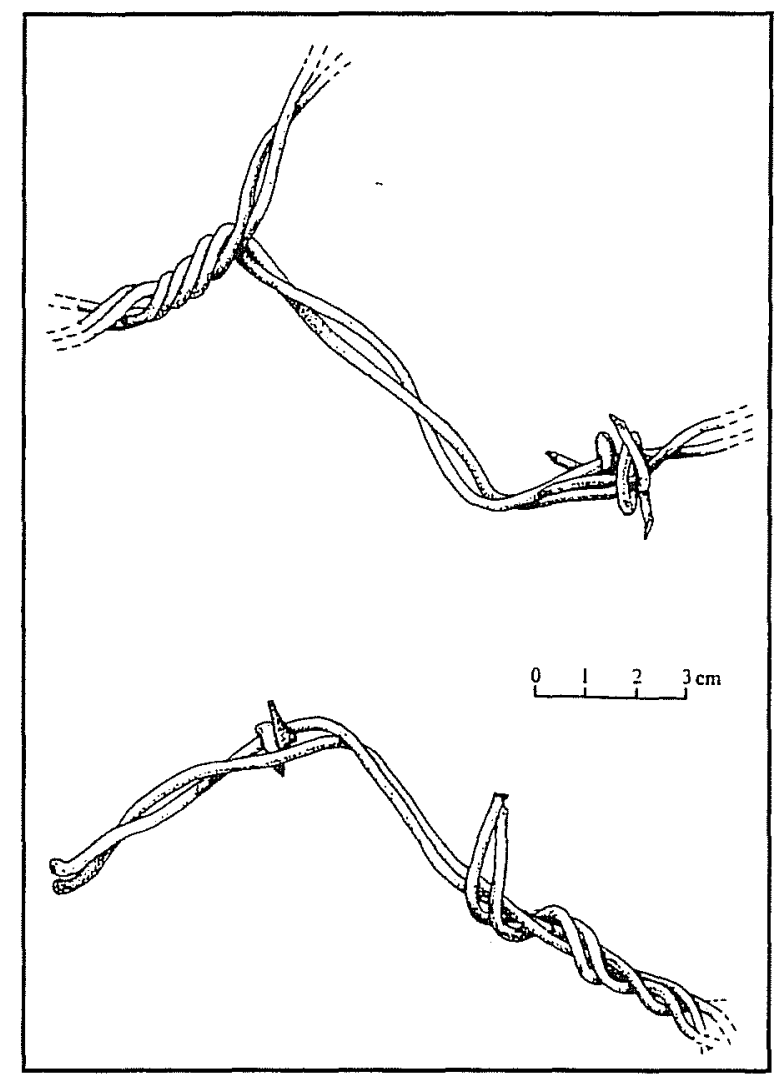

Figure 13-10. Barbed wire from 41BX1129. top- A. Burnell's Four Point; bottom- G. C. Baker's Flat Barb.

\section{BX1130}

The structural remains at 41BX1130 (Figure 8-25) are most probably those used by Lena and Roy $B$. McCulloch. The McCullochs occupied a house in the immediate proximity of $41 \mathrm{BX} 1130$ until the United States government procured the property in 1954 (Denzil G. Harroun, personal communication 1996; Table 13-4). Lena (Wilke) McCulloch was the daughter of Ludwig and Augusta Wilke. After Augusta died in 1922 and Ludwig in 1923, Lena and Roy ended up with a 140.57-acre tract surrounding 41BX1130 (Figure13-1). Records are not available to show when the house and out-buildings were constructed. However, Ludwig and Augusta purchased the property in 1880 , during a decade when several German pioneer families who sought to make a better, independent, and self-sufficient living quit the city and formed the Medina Farm Colony. 
Selected artifacts collected from the site, along with Harroun's oral account, suggest an occupation period from ca. 1910 through 1954. A clay flower vase $16 \mathrm{~cm}$ high with a 14-cm diameter base was found in the trash dump. It has a soft brown with yellow overtone Leon Slip glaze on the interior and exterior. The Meyer Pottery Company, in operation from 1887 through 1964 in nearby Atascosa, Texas, manufactured Leon Slip glazed pottery (Greer and Black 1971:1). The unique Leon Slip glazing was derived from yellow clays mined on Leon Creek, near the old Frio City road crossing. Workers continued to mine the clays in that area until 1944, when the landowner, Milton Friedrich, sold the property to the Air Force for Kelly Air Force Base (Greer and Black 1971:4). Although the pot cannot be specifically dated, the Meyer family more commonly made flower pots and "art pottery" in the 1940s (Black and Greer 1971:10).

Two clear glass fruit jar lid seals bore the name "ATLAS EDJ SEAL" (Figure 13-11a). Atlas was the trademark of the Atlas Glass and succeeding companies from 1896 through 1964. In 1900 the company began making glass caps for Mason jars (Toulouse 1971:55-56). The EDJ seal was designed for use on fruit jars ca. 1910 and was phased out ca. 1915 in favor of metal lids (Toulouse 1971: 241-242). Two clear glass bottles manu-factured by Owens Illinois Glass Company were also collected. One is a catsup bottle made in 1909. The other appears to be a pickle or pepper bottle and was made in 1911 (Toulouse 1971: 403-408).

A white glass Woodbury salve jar bore the trademark anchor symbol of the Anchor Hocking Glass Company. The symbol was first used in 1938 (Toulouse 1971:46-49). A clear glass Ball Perfect Mason fruit jar with smooth sides was also recovered. This type of jar with embossed labeling was manufactured between 1920 and 1933 (Stephens 1979:31). A painted sugar jar lid (Figure 13-11b), a discarded straight razor (Figure 13-11c), and a 1950 Texas license plate add to the story of human activity once present at the site.

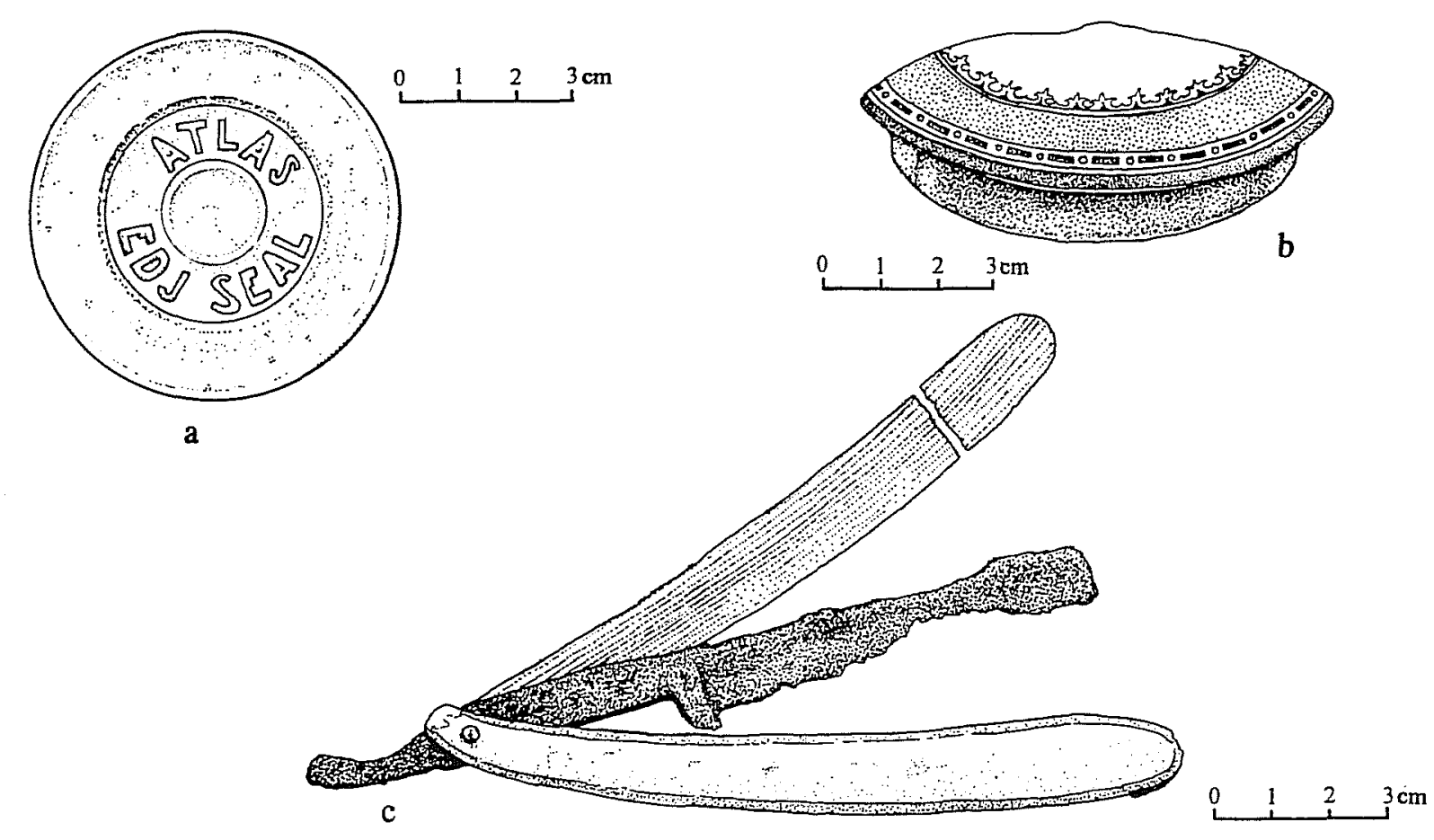

Figure 13-11. Artifacts from 41BX1130. a. fruit jar lid; b. painted sugar jar lid; c. straight razor. 


\section{Spatial Distribution of Historic Components by Type and Area}

Primarily because of the small sample size, little in the way of a pattern can be discerned in the distribution of the historic sites at Lackland (Table 13-5). The presence of but one historic site on the Main Base is simply a reflection of the large area not included in the survey and the degree of disturbance present. On Medina Annex a hint of a pattern can be suggested. The two farmsteads documented in the survey occur on Medio Creek terraces. The non-residential historic sites-the two dumps and the brick factory-occur at greater distances from water.
The farmsteads have scattered historic trash and thus they have discard areas, but specialized dumping clearly occurs away from habitation sites in more remote areas. Factors such as distance to raw materials or resources probably controlled selection of the two specialized sites, the brick factory and the line shack.

Long Hollow, in contrast to the abundant presence there of prehistoric sites, lacked any evidence of historic use.

Table 13-5. Frequency and Percentage of Historic Component Types by Geographic Area

\begin{tabular}{|c|c|c|c|c|c|c|c|}
\hline \multirow{3}{*}{\begin{tabular}{|c} 
Area \\
Leon Creek
\end{tabular}} & \multicolumn{5}{|c|}{ Historic site type } & \multirow{2}{*}{\multicolumn{2}{|c|}{ Total }} \\
\hline & Farmstead & $\begin{array}{l}\text { Brick } \\
\text { Factory }\end{array}$ & Dump & Line Shack & Sewer Line & & \\
\hline & & & & & 1 & 1 & $14.2 \%$ \\
\hline $\begin{array}{l}\text { Medina Annex } \\
\text { uplands }\end{array}$ & & 1 & 2 & & & 3 & $42.9 \%$ \\
\hline $\begin{array}{l}\text { Medio Creek } \\
\text { terraces }\end{array}$ & 2 & & & 1 & & 3 & $42.9 \%$ \\
\hline Long Hollow & & & & & & 0 & $0 \%$ \\
\hline Total & $28.7 \%$ & $1 \mid 14.2 \%$ & $28.7 \%$ & $14.2 \%$ & $14.2 \%$ & 7 & $100 \%$ \\
\hline
\end{tabular}




\section{Part IV: Summary and Recommendations}

\section{Chapter 14. Summary}

Archaeological surveys of 3,860 acres of undeveloped land at Lackland Main Base and Medina Annex has resulted in the recording of 74 sites. In addition, 831 prehistoric isolated finds not associated with sites were recorded. Seventy-one sites were discovered in 1995 by CAR, one in 1994 by CAR (1994), and two in 1993 by De Vore (1993). Eight sites have historic components and seventy-one sites have prehistoric components; four of these prehistoric sites also have historic components.

Only one historic site-a sewer line-was found on the Main Base. The remaining historic sites were discovered on Medina Annex. Two are farmsteads, two are artifact dumps, one is a line shack, another is a brick factory. All the historic sites date to the late-eighteenth to twentieth centuries. The farmsteads are near water in the Medio Creek valley bottom, while the dumps are in more isolated locations.

Four prehistoric sites were located on the Main Base. One is a burned rock midden (41BX1108), two others are open campsites (41BX1065 and 41BX1066), and the fourth site is a quarry/ workshop (41BX1107). The two open campsites are situated on a high bluff overlooking Leon Creek and the other two sites are on lower terraces of Leon Creek. 41BX1065 has evidence of occupation from the Middle Archaic through to the Transitional Archaic periods. Diagnostic artifacts were not discovered on the other three sites on the Main Base, but shovel tests at 41BX1108 did indicate the presence of a burned rock midden, usually associated with the Middle to Late Archaic. Analysis of site distributions on the Main Base were unwarranted due to development in this area.
The remaining prehistoric sites are at the Medina Annex, where three areas are identified: the Uplands, Long Hollow and the Medio Creek terraces. The distribution of prehistoric sites on the Medina Annex indicates that open campsites occur more frequently on the Medio Creek terraces or near the terraces on the Medina Annex uplands. Quarry/workshops are more frequent in the uplands near gravel outcrops, and when present on Medio Creek terraces, these sites are usually near the upslope edge of the terrace.

The distribution of prehistoric components by time period on the Medina Annex, based principally on the surface collection of diagnostic projectile points, is illustrated in Table 14-1. The frequencies are low, but a few patterns can be suggested. Early Archaic components are slightly more common at Long Hollow than elsewhere in the project area. On the Medio Creek terraces, Middle Archaic components are absent, while Late Archaic components are most common of the dated components. Transitional Archaic and Late Prehistoric components are too infrequent to suggest any patterning. Slightly more sites at Long Hollow had diagnostic artifacts that could identify a temporal component than did sites in the other areas. For the entire project, Late Archaic components predominated. Only one Middle Archaic component was identified.

Analysis of shovel test data indicates that sites on the uplands and the Medio Creek T2 terrace were less likely to produce subsurface artifacts than sites on the Medio Creek T0 and T1 terraces and at Long Hollow. This is no surprise, but it further indicates that the valley bottom at Long Hollow and the T0 and T1 Medio Creek terraces have high potential for containing many buried and undiscovered sites. 
Table 14-1. Distribution of Prehistoric Components by Time Period and Area at Medina Annex (based on surface-collected diagnostic lithics)

\begin{tabular}{|c|c|c|c|c|c|c|c|c|c|c|c|c|c|}
\hline \multirow[t]{2}{*}{ Area } & \multicolumn{2}{|c|}{$\begin{array}{c}\text { Early } \\
\text { Archaic }\end{array}$} & \multicolumn{2}{|c|}{$\begin{array}{l}\text { Middle } \\
\text { Archaic }\end{array}$} & \multicolumn{2}{|c|}{$\begin{array}{c}\text { Late } \\
\text { Archaic }\end{array}$} & \multicolumn{2}{|c|}{$\begin{array}{c}\text { Transitional } \\
\text { Archaic }\end{array}$} & \multicolumn{2}{|c|}{$\begin{array}{c}\text { Late } \\
\text { Prehistoric }\end{array}$} & \multicolumn{2}{|c|}{ Unknown } & \multirow[t]{2}{*}{ Total } \\
\hline & $\#$ & $\%$ & $\#$ & $\%$ & $\#$ & $\%$ & $\#$ & $\%$ & $\#$ & $\%$ & $\#$ & $\%$ & \\
\hline Medio Creek & 1 & 4.2 & & - & 4 & 16.7 & 1 & 4.2 & 1 & 4.2 & 17 & 70.7 & 24 \\
\hline Uplands & 1 & 4.3 & - & - & 2 & 8.6 & 1 & 4.3 & 1 & 4.3 & 19 & 82.6 & 23 \\
\hline Long Hollow & 3 & 12.5 & 1 & 4.2 & 3 & 12.5 & 1 & 4.2 & 1 & 4.2 & 15 & 62.5 & 24 \\
\hline Total & 5 & 7.0 & 1 & 1.4 & 9 & 12.7 & 3 & 4.2 & 3 & 4.2 & 50 & 70.4 & 71 \\
\hline
\end{tabular}




\section{Chapter 15. Recommendations}

\section{General Discussion}

Four prehistoric sites along Leon Creek in the northeastern portion of the Main Base are potentially eligible for inclusion in the National Register of Historic Places (NRHP) as individual sites. Twenty-three prehistoric sites on the alluvial terraces adjacent to Medio Creek on the eastern portion of Medina Annex are potentially eligible for inclusion in the NRHP as two separate districts divided by a highly disturbed zone. Nineteen prehistoric sites along Long Hollow in the western portion of Medina Annex are potentially eligible for inclusion in the NRHP as a district. Twenty-four prehistoric sites in the upland margins of the Long Hollow and Medio Creek drainages on the Medina Annex are potentially eligible for inclusion in the NRHP on an individual basis.

Four historic sites (41BX1074, 41BX1121, 41BX1124, and 41BX1130) on Medina Annex are deserving of further study in association with the spread of agriculture and ranching as well as historic land use in the 1800 s and 1900s. Further investigations at 41BX1128, a historic brick and tile manufacturing site, will provide information on latenineteenth-century regional industrial activities. These five historic sites are potentially eligible for inclusion in the NRHP. Two historic sites (41BX1061, 41BX1129) are highly disturbed and offer little or no integrity, and therefore should not be considered for inclusion in the NRHP. Recommendations are presented by area: Leon Creek, Upper and Lower Medio Creek, Long Hollow, and Upland Periphery.

\section{Leon Creek}

With supportive data from additional test excavations, four sites (41BX1065, 41BX1066, 41BX1107, and 41BX1108) on the Leon Creek drainage could be recommended for inclusion in the NRHP (Table 15-1). Prehistoric occupations along Leon Creek over several millennia have been documented by at least one other large-scale but unpublished survey by McGuff in 1970-1971, and by a study in northern Bexar County (Tennis 1996; Tennis and Hard 1995). However, the presence of four prehistoric sites on a short segment of Leon Creek, a significant tributary of the Medina River, appears to offer the integrity required for studies of subsistence, settlement pattern, and primitive technology within local and regional contexts.

As Collins (1995:388) argues, prehistoric subsistence and settlement patterns in central Texas shifted simultaneously with changes in climate and environment. However, spatial, ecological and climatic diversities in central and south Texas (Ellis et al. 1995) suggest that varying sources of wellpreserved paleoenvironmental and archaeological information will occur unevenly but in predictable locations, e.g., alluvial deposits along significant stream courses. Nevertheless, while the pointbars and other alluvial deposits along Leon Creek have the same original potential for buried and stratified sites as do those along Medio Creek, the high degree of artificial disturbance along Leon Creek has reduced this potential or at the very least made site identification more problematic.

Therefore, the four sites identified by CAR along Leon Creek are important because they represent 
surviving remnants of what must have been a much more extensive network of archaeological occurrences. Survey findings at 41BX1107 and 41BX1108, located on Leon Creek's alluvial terrace system, demonstrate that archaeological materials in well-preserved stratified contexts are likely present. Other sites of this kind are probably present below the surface in this vicinity. The four sites listed in Table 15-1 are worthy of further investigation to determine their eligibility for inclusion in the NRHP. Additional test investigations were undertaken at 41BX1065; those results are presented in Appendix B.

\section{Upper and Lower Medio Creek}

The 24 prehistoric sites along Medio Creek are listed in Table 15-2. In terms of NRHP eligibility, the Medio Creek sites are organized into two districts: Upper and Lower. The Upper Medio Creek District begins where the stream enters Lackland Air Force Base at Highway 90 and ends where it crosses Medina Base Road. The Lower Medio Creek District begins at Medina Base Road and includes the length of the creek to its exit from base property at Covel Road in the southeast corner.

The two districts are separated by an area of high disturbance, high security, and intensive development. This developed zone has significantly disturbed surface and buried sites, and provides an artificial but absolute boundary between the two proposed districts. Laterally from the creek bottom, both districts include adjacent alluvial terraces (as defined by Nordt; see Chapter 3) containing surface and buried sites, and have a high potential for additional well-stratified buried sites. The potential for well-stratified archaeological sites is optimal in areas of low-energy fluvial deposition. Although little research has identified areas with such high potential in south Texas, in central Texas most wellstratified and well-preserved archaeological sites have occurred in alluvium deposited by streams (Collins 1995:31). Recent Late Pleistocene and Holocene geomorphology studies in southern Bexar County on the Medina River proved that buried Late Paleoindian and Archaic sites can exist in situ within well-preserved Late Quaternary stream deposits (Thoms 1992). Medio Creek's gently sloping terraces are consistently composed of Trinity-Frio clays or clay loams which are usually flooded at least once a year, adjoined by Lewisville silty clays, a moderately deep, level alluvial soil (Taylor et al. 1991:25, 32). Nordt's investigations demonstrate that early Holocene through Late Holocene age deposits (Unit II and Unit III) constitute the T1 and T0 terraces of Medio Creek, and they span the period between $>5000$ B.P. and $<2000$ B.P. Few such areas have been studied in south and central Texas, so the archaeological database is biased toward sites discovered on well-exposed surfaces. More specifically, Medio Creek's natural meandering through the millennia has created pointbars and overbank alluvium which can provide excellent conditions for preserving stratified cultural and natural deposits (Chapter 3; Collins 1995: 367-368).

Although the chronology for central Texas has become more discrete with highly sophisticated dating techniques, continued collection and analysis of high resolution data sets will further this goal.

\section{5-1. Leon Creek Prehistoric Sites}

\begin{tabular}{||c|c|c|}
\hline Trinomial & Site Type & Est. Age Range \\
\hline $41 \mathrm{BX} 1065$ & Open Campsite & Late and Transitional Archaic \\
\hline $41 \mathrm{BX} 1066$ & Open Campsite & Unknown \\
\hline $41 \mathrm{BX} 1107$ & Open Campsite & Unknown \\
\hline $41 \mathrm{BX} 1108$ & Burned Rock Midden & Unknown \\
\hline
\end{tabular}


Table 15-2. Medio Creek Districts Prehistoric Sites

\begin{tabular}{|c|c|c|c|}
\hline Trinomial & Site Type & Estimated Age & Recommendation \\
\hline 41BX1001 & Open Campsite/Quarry & Unknown & Eligible \\
\hline 41BX1002 & Open Campsite/Quarry & Unknown & Eligible \\
\hline $41 B \times 1060$ & Open Campsite & Unknown & Eligible \\
\hline $41 \mathrm{BX} 1069$ & Open Campsite/Quarry & Late Archaic & Eligible \\
\hline 41BX1077 & Open Campsite/Quarry & Unknown & Eligible \\
\hline $41 B \times 1079$ & Quarry & Unknown & Eligible \\
\hline 41BX1086 & Open Campsite/Quarry & Unknown & Eligible \\
\hline $41 \mathrm{BX} 1087$ & Open Campsite & Late Archaic & Eligible \\
\hline 41BX1092 & Open Campsite & Unknown & Eligible \\
\hline $41 \mathrm{BX} 1093$ & Open Campsite & Unknown & Eligible \\
\hline 41BX1094 & Quarry & Unknown & Eligible \\
\hline $41 B X 1102$ & Open Campsite & Late Archaic & Eligible \\
\hline 41BX1103 & Open Campsite & Transitional Archaic & Eligible \\
\hline $41 \mathrm{BX} 1114$ & Quarry & Early Archaic & Eligible \\
\hline $41 B X 1115$ & Open Campsite & Unknown & Eligible \\
\hline 41BX1119 & Quarry & Unknown & Eligible \\
\hline $41 B X 1120$ & Open Campsite & Unknown & Eligible \\
\hline $41 B X 1121$ & Open Campsite/Quarry & Late Archaic & Eligible \\
\hline $41 \mathrm{BX} 1122$ & Open Campsite & Late Prehistoric & Eligible \\
\hline $41 B X 1123$ & Quarry & Unknown & Eligible \\
\hline $41 \mathrm{BX} 1125$ & Open Campsite & Unknown & Eligible \\
\hline $41 \mathrm{BX} 1126$ & Open Campsite & Unknown & Eligible \\
\hline $41 \mathrm{BX} 1127$ & Open Campsite & Unknown & Eligible \\
\hline $41 \mathrm{BX} 1130$ & Quarry & Unknown & Eligible \\
\hline
\end{tabular}

However, such gains have not been realized in south Texas because of the limited number and intensity of archaeological investigations (Hester 1995). The sites already recorded and those that may be buried within the Medio Creek terraces have the potential to add significantly to the body of archaeological data in south Texas. On another front, the analysis of stone tool assemblages from a regional perspective has resulted in a better understanding of hunter- gatherer subsistence patterns in central Texas (Collins 1995; Quigg and Peck 1995; Ricklis 1994).

Lacking in the archaeological record, however, is a functional and technological analysis of the tool and debitage assemblages of prehistoric sites in south Texas. An analysis of the assemblages available at the 24 known terrace sites along Medio Creek would fill a void in the archaeological record pertaining to prehistoric land use and resource 
exploitation in small drainage and upland settings (Collins 1995:368; see also Skinner 1974). The Medio Creek sites could provide important information if integrated into a regional analysis and synthesis of prehistoric land use, settlement patterns, mobility, resource exploitation, and technological organization.

Site 41BX1114, on a Medio Creek T2 terrace, has an Early Archaic diagnostic artifact. Although the archaeological data base currently reflects that Early Archaic sites are not uncommon near the Balcones Escarpment on the edge of central Texas, Medina Annex is some $25 \mathrm{~km}$ to the south and more properly considered as part of south Texas. The data offered by this Early Archaic site could be compared to those nearer the Balcones Escarpment, as well as those further south in the area of the nowdefunct Applewhite Reservoir project on the Medina River. In addition to comparative analysis on stone tool assemblages, any evidence of subsistence during the Early Archaic would significantly contribute to the sparse data on that topic (Collins 1995:383).

After the early Holocene-Early Archaic occupations, periods of alternating mesic and xeric conditions are generally associated with changes in stone tool assemblages, settlement patterns, and subsistence (Collins 1995; Hester 1995). The 24 sites range from the Early Archaic through the Late Prehistoric periods and present an archaeological continuum tracing occupation along Medio Creek over the past 9,000 years. As a unit, the 24 sites along Medio Creek should be considered potentially eligible for nomination to the NRHP.

\section{Long Hollow}

The 19 prehistoric sites in the Long Hollow valley (Table 15-3) are grouped into a district for NRHP eligibility assessment purposes. The district comprises the valley bottom, adjacent slopes, and upland sites overlooking the drainage. It is defined as the area spanning the western border of the Annex, following the general area of the drainage as it enters base property from the north at Highway 90 and courses to the south.

The drainage bottom exits the base just north of the developed Range Operations area and then runs roughly parallel to the annex boundary on its way to the Medina River. Some sites located in the far southwest corner of the annex overlook the drainage and thus warrant inclusion in the district.

Large quantities of Pleistocene age Uvalde Gravel outcroppings occur throughout Long Hollow. This rich source of raw material was quarried, and the valley floor and adjacent slopes were occupied for several millennia, as indicated by the presence of Early Archaic through Late Prehistoric diagnostic artifacts. The intensive lithic-procurement activities within a circumscribed area provide an opportunity to add significant information concerning prehistoric raw material use and exploitation to the regional data base, and to examine this lithic exploitation system outside of the Edwards Plateau where most studies have taken place (Shafer 1994). In addition, the valley floor in Long Hollow has an accumulation of alluvial deposits which could contain buried archaeological materials. As a unit, the 19 sites in the Long Hollow valley should be considered potentially eligible for nomination to the NRHP.

\section{Upland Periphery}

The 24 prehistoric upland sites on the Medina Annex (Table 15-4) are peripheral to the three Holocene terraces immediately adjacent to Medio Creek, and also to the highly exploited raw materials on the slopes and valley bottom of Long Hollow (Figure 79). Although situated on the upland periphery, these sites provide evidence for prehistoric occupation and exploitation of the complete landscape that is now Medina Annex. Sites range chronologically from Early Archaic through Late Prehistoric.

The diversity and dispersion of sites in the uplands offer a unique opportunity to compare paleoenvironmental, subsistence, technological, and settlement 
Table 15-3. Long Hollow District Prehistoric Sites

\begin{tabular}{|c|c|c|c|}
\hline Trinomial & Site Type & Estimated Age & Recommendation \\
\hline 41BX1055 & Open Campsite/Quarry & Unknown & Eligible \\
\hline 41BX1056 & Quarry & Unknown & Eligible \\
\hline 41BX1057 & Quarry & Unknown & Eligible \\
\hline $41 \mathrm{BX} 1058$ & Quarry & Unknown & Eligible \\
\hline 41BX1059 & Open Campsite/Quarry & Unknown & Eligible \\
\hline $41 \mathrm{BX} 1072$ & Open Campsite/Quarry & Early Archaic & Eligible \\
\hline $41 \mathrm{BX} 1073$ & Open Campsite/Quarry & Unknown & Eligible \\
\hline 41BX1098 & Quarry & Unknown & Eligible \\
\hline 41BX1099 & Open Campsite/Quarry & Unknown & Eligible \\
\hline $41 \mathrm{BX} 1100$ & Open Campsite/Quarry & Early, Late Archaic & Eligible \\
\hline 41BX1101 & Open Campsite/Quarry & $\begin{array}{c}\text { Late and Transitional } \\
\text { Archaic }\end{array}$ & Eligible \\
\hline 41BX1104 & Open Campsite/Quarry & $\begin{array}{l}\text { Early, Middle, and Late } \\
\text { Archaic/Late Prehistoric }\end{array}$ & Eligible \\
\hline $41 \mathrm{BX} 1110$ & Quarry & Unknown & Eligible \\
\hline $41 \mathrm{BX} 1111$ & Quarry & Unknown & Eligible \\
\hline $41 \mathrm{BX} 1112$ & Quarry & Unknown & Eligible \\
\hline $41 \mathrm{BX} 1113$ & Quarry & Unknown & Eligible \\
\hline $41 \mathrm{BX} 1116$ & Quarry & Unknown & Eligible \\
\hline 41BX1117 & Quarry & Unknown & Eligible \\
\hline 41BX1118 & Quarry & Unknown & Eligible \\
\hline
\end{tabular}

data to information recovered from the nearby Medio Creek and Long Hollow riverine ecosystems. Detailed investigation and analysis of prehistoric sites in upland settings have taken place rarely in central Texas, as is the case in south Texas with investigations of assemblage content and site distributions. Quantitative data from these Medina Annex sites can help fill these voids. Therefore, these sites should be considered potentially eligible for nomination to the NRHP. 
Table 15-4. Upland Periphery Prehistoric Sites

\begin{tabular}{||c|c|c|c||}
\hline Trinomial & Site Type & Estimated Age & Recommendation \\
\hline 41BX1070 & Quarry & Unknown & Eligible \\
\hline 41BX1071 & Open Campsite/Quarry & Transitional Archaic & Eligible \\
\hline 41BX1074 & Open Campsite & Unknown & Eligible \\
\hline 41BX1075 & Quarry & Unknown & Eligible \\
\hline 41BX1076 & Open Campsite/Quarry & Late Prehistoric & Eligible \\
\hline 41BX1078 & Quarry & Unknown & Eligible \\
\hline 41BX1080 & Quarry & Unknown & Eligible \\
\hline 41BX1081 & Quarry & Unknown & Eligible \\
\hline 41BX1082 & Open Campsite/Quarry & Unknown & Eligible \\
\hline 41BX1083 & Quarry & Unknown & Eligible \\
\hline 41BX1084 & Quarry & Unknown & Eligible \\
\hline 41BX1085 & Quarry & Unknown & Eligible \\
\hline 41BX1088 & Open Campsite/Quarry & Early and Late Archaic & Eligible \\
\hline 41BX1089 & Quarry & Unknown & Eligible \\
\hline 41BX1090 & Quarry & Unknown & Eligible \\
\hline 41BX1091 & Quarry & Unknown & Eligible \\
\hline 41BX1095 & Quarry & Unknown & Eligible \\
\hline 41BX1096 & Quarry & Unknown & Eligible \\
\hline 41BX1097 & Quarry & Unknown & Eligible \\
\hline 41BX1105 & Open Campsite & Unknown & Eligible \\
\hline 41BX1106 & Open Campsite & Unknown & Eligible \\
\hline 41BX1109 & Open Campsite & Late Archaic & Eligible \\
\hline 41BX1124 & Open Campsite & Unknown & Eligible \\
\hline
\end{tabular}




\section{Part V: References and Appendixes}

\section{References Cited}

Abbott, P. L., and C. M. Woodruff, Jr., editors

1986 The Balcones Escarpment: Geology, Hydrology, Ecology, and Social Development in Central Texas. Department of Geological Sciences, San Diego State University, San Diego.

Alexander, H. L.

1963 The Levi Site: A Paleo-Indian Campsite in Central Texas. American Antiquity 28:510-528.

1983 The Pre-Clovis and Clovis Occupations at the Levi Site. In Peopling of the New World, edited by J. E. Ericson, R. E. Taylor, and R. Berger, pp. 133-145. Ballena, Los Altos, California.

Aten, L. E.

1979 Indians of the Upper Texas Coast: Ethnohistoric and Archeological Frameworks. Ph.D. dissertation. The University of Texas at Austin.

Barber, E. A.

1976 The Pottery and Porcelain of the United States. J \& J, New York.

Barnes, V. E.

1983 Geologic Atlas Sheet, San Antonio, Texas. Bureau of Economic Geology. The University of Texas at Austin.

Bass F. A., Jr., and T. R. Hester

1975 An Archaeological Survey of the Upper Cibolo Creek Watershed, Central Texas. Archaeological Survey Report, No. 8. Center for Archaeological Research, The University of Texas at San Antonio.

Bement, L. C.

1991 The Statistical Analysis of Langtry Variants from Arenosa Shelter, Val Verde County, Texas. In Papers on Lower Pecos Prehistory, edited by S. A. Turpin, pp. 51-64. Studies in Archaeology 8. Texas Archeological Research Laboratory, The University of Texas at Austin.

Benfer, R., and A. Benfer

1965 An Austin Focus Burial. Texas Engineering and Science Magazine 1(1):74-79.

Berlandier, J. L.

1969[ca. 1840s] The Indians of Texas in 1830, edited by J. C. Ewers. Smithsonian Institution, Washington, D.C. 
Binford, L. R.

1980 Willow Smoke and Dogs' Tails: Hunter-Gatherer Settlement Systems and Archaeological Site Formation. American Antiquity 45:4-20.

1983 In Pursuit of the Past. Thames and Hudson, New York.

Black, S. L.

1986 The Clemente and Herminia Hinojosa Site, 41JW8: A Toyah Horizon Campsite in Southern Texas. Special Report, No. 18. Center for Archaeological Research, The University of Texas at San Antonio.

1989a South Texas Plain. In From the Gulf Coast to the Rio Grande: Human Adaptation in the Central, South, and Lower Pecos Texas, by T. R. Hester, S. L. Black, D. G. Steele, B. W. Olive, A. A. Fox, K. J. Reinhard, and L. C. Bement, pp. 39-62. Research Series 33. Arkansas Archeological Survey, Fayetteville.

1989b Environmental Setting. In From the Gulf Coast to the Rio Grande: Human Adaptation in the Central, South, and Lower Pecos Texas, by T. R. Hester, S. L. Black, D. G. Steele, B. W. Olive, A. A. Fox, K. J. Reinhard, and L. C. Bement, pp. 5-16. Research Series 33. Arkansas Archeological Survey, Fayetteville.

1989c Central Texas Plateau Prairie. In From the Gulf Coast to the Rio Grande: Human Adaptation in the Central, South, and Lower Pecos Texas, by T. R. Hester, S. L. Black, D. G. Steele, B. W. Olive, A. A. Fox, K. J. Reinhard, and L. C. Bement, pp. 17-38. Research Series 33. Arkansas Archeological Survey, Fayetteville.

1995 Archeological Background. In Archeological Investigations at the Loma Sandia Site

(41LK28), A Prehistoric Cemetery and Campsite in Live Oak County, Texas, by A. J. Taylor and C. L. Highley, pp. 31-45. Studies in Archeology 20. Texas Archeological Research Laboratory, The University of Texas at Austin.

Black, S. L., and A. J. McGraw

1985 The Panther Springs Creek Site: Cultural Change and Continuity within the Upper Salado Creek Watershed, South-Central Texas. Archaeological Survey Report, No. 100. Center for Archaeological Research, The University of Texas at San Antonio.

Black, S. L., and D. R. Potter

1995 Defining Historic Contexts for Prehistoric Sites along the Wurzbach Parkway. In Archaeology Along the Wurzbach Parkway: Module 1. Introduction, Conceptual Framework, and Contexts of Archaeological Investigations in Bexar County, South-Central Texas, edited by D. R. Potter, S. L. Black, and K. Jolly, pp. 45-51. Studies in Archeology 17. Texas Archaeological Research Laboratory, The University of Texas at Austin

Black, S. L., K. Jolly, and D. R. Potter

1993 The Higgins Experiment: Field Report. Wurzbach Project Working Papers. Texas Archeological Research Laboratory, The University of Texas at Austin.

Black, S. L., L. W. Ellis, D. G. Creel, and G. T. Goode

1997 Hot Rock Cooking on the Greater Edwards Plateau: Four Burned Rock Midden Sites in West Central Texas. Studies in Archaeology 22. Texas Archeological Research Laboratory, The University of Texas at Austin.

Blair, W. F.

1950 The Biotic Provinces of Texas. Texas Journal of Science 2(1):93-117. 
Blum M. D., and S. Valastro, Jr.

1989 Response of the Pedernales River of Central Texas to late Holocene Climatic Change. Annals of the Association of American Geographers 79:435-456.

1994 Late Quaternary Sedimentation, Lower Colorado River, Gulf Coastal Plain of Texas. Geological Society of America Bulletin 106:1002-1016.

Bolton, H. E.

1970[1915] Texas in the Middle Eighteenth Century: Studies in Spanish Colonial History and Administration. Volume 3, University of California publications in history, University of California, Berkeley.

Bousman, C. B.

1992 Preliminary Oxygen-Isotope Evidence for Late Pleistocene-Early Holocene Climatic Change. Current Research in the Pleistocene 11:79-81.

1994 The Central Texas Pollen Record: A Reinterpretation. Current Research in the Pleistocene 11:79-81.

1997 The Paleoindian Archeology at the Wilson-Leonard Site. In Archeological Investigations at the Wilson-Leonard Site, edited by M. B. Collins. Texas Archeological Research Laboratory, The University of Texas at Austin. Draft.

Bowden J. J.

1986 The Exodus of Federal Forces from Texas: 1861. Eakin, Austin.

Boyd, D. K., and M. D. Freeman

1990 Archeological Survey of a Proposed Aluminum Rolling Mill Plant in Southeastern Bexar County, Texas. Technical Report 17. Prewitt and Associates, Austin.

Boyd, D. K., I. W. Cox, and H. G. Uecker

1990 Archeological and Historical Investigations at Camp Bullis, Bexar and Comal Counties, Texas: The 1989 Season. Reports of Investigations 75. Prewitt and Associates, Austin.

Boyd, D. K., S. A. Tomka, C. B. Bousman, K. M. Gardner, and M. D. Freeman

1992 Data Recovery at Justiceburg Reservoir (Lake Alan Henry), Garza and Kent Counties, Texas: Phase III, Season 1. Reports of Investigation, No. 84. Prewitt and Associates, Austin.

Brown, K. M.

1987 Early Occupation at Berger Bluff, Goliad County, Texas. Current Research in the Pleistocene $4: 3-5$.

Brune, G.

1975 Major and Historic Springs of Texas. Report 189. Texas Water Development Board, Austin.

1981 Springs of Texas. Branch Smith, Fort Worth.

Bryant, V. M., Jr., and R. G. Holloway

1985 A Late-Quaternary Paleoenvironmental Record of Texas: An Overview of the Pollen Evidence. In Pollen Records of Late-Quaternary North American Sediments, edited by V. M Bryant and R. G. Holloway, pp. 39-70. American Association of Stratigraphic Palynologists Foundation, Dallas. 
Bryant, V. M., Jr., and H. J. Shafer

1977 The Late Quaternary Paleoenvironment of Texas: A Model for the Archaeologists. Bulletin of the Texas Archeological Society 48:1-25.

Buckley, E. C.

1911 The Aguayo Expedition into Texas and Louisiana, 1719-1722. Quarterly of the Texas State Historical Association 15:1-65.

Busch, J.

1981 An Introduction to the Tin Can. Historic Archaeology 15(1):95-104.

Butzer, K. W.

1982 Archaeology as Human Ecology. Cambridge University Press, Cambridge.

Camilli, E. L.

1983 Remote Sensing: Applications to Cultural Resources in Southwestern North America. Supplement No. 8 to Remote Sensing. National Park Service, Washington, D. C.

Campbell, T. N.

1975 The Payaya Indians of Southern Texas. Special Publications No. 1. Southern Texas Archaeological Association, San Antonio.

1983 Coahuiltecans and Their Neighbors. In Handbook of North American Indians Volume 10: Southwest, edited by A. Ortiz, pp. 343-358. Smithsonian Institution, Washington, D. C.

1991 Coahuiltecans and Their Neighbors. In Ethnology of Texas Indians, edited by T. R. Hester, pp. 109-126. Spanish Borderlands Sourcebooks 7. Garland, New York.

Campbell, T. N., and T. J. Campbell

1981 Historic Indians of the Choke Canyon Reservoir and Surrounding Area, Southern Texas. Choke Canyon Series 1. Center for Archaeological Research, The University of Texas at San Antonio.

1985 Indian Groups Associated with Spanish Missions of the San Antonio Missions National Historic Park. Special Report, No. 16. Center for Archaeological Research, The University of Texas at San Antonio.

Carlson, P.

1982 Texas Woolybacks. Texas A\&M University Press, College Station.

Chabot, F. C.

1937 With the Makers of San Antonio. Privately published, San Antonio.

Chandler, C. K., and K. Hindes

1993 Scottsbluff Points from Atascosa, Frio, and McMullen Counties, South-Central Texas. La Tierra 20(1):31-36.

Chipman, D. E.

1992 Spanish Texas, 1519-1821. University of Texas Press, Austin.

Clark, C. T., R. H. Ryan, J. H. Jones, and C. A. Pieper

1964 Del Rio, Border of Texas Industrialization. Area Economic Survey No. 21. Bureau of Business Research, The University of Texas at Austin. 
Cleveland, A. G., and D. D. McCain

1992 Habitat Study of the Lackland Air Force Base Medina Annex Flora and Fauna. Report submitted to the U.S. Air Force, Contract No. F4163691PF453. Lackland Air Force Base,San Antonio.

Collins, M. B.

1995 Forty Years of Archaeology in Texas. Bulletin of the Texas Archeological Society 66:361-400.

Collins, M. B., G. L. Evans, T. N. Campbell, M. C. Winans, and C. E. Mears

1989 Clovis Occupation at Kincaid Rockshelter. Current Research in the Pleistocene 6:3-5.

Collins, M. B., C. B. Bousman, P. Goldberg, P. R. Takac, J. C. Guy, J. L. Lantana, T. W. Stafford, and V. T. Holliday

1993 The Paleoindian Sequence at the Wilson-Leonard Site, Texas. Current Research in the Pleistocene 10:10-12.

Courty, M. A., P. Goldberg, and R. MacPhail

1989 Soils and Micromorphology in Archaeology. Cambridge University Press, Cambridge.

Creel, D. G.

1986 A Study of Prehistoric Burned Rock Middens in West Central Texas. Unpublished Ph. D. dissertation. University of Arizona, Tucson.

Cronan, W.

1991 Nature's Metropolis. W. W. Norton, New York.

Dalbey, T. S.

1993 An Overview Guide to Historic and Prehistoric Cultural Resources Potential on Lackland Air Force Base as Pertains to the National Historic Preservation Act of 1966, as Amended. U.S. Army Corps of Engineers, Planning Division, Fort Worth.

de Salinas Varona, G.

1968 Diario del Viaje del Capitán Gregorio de Salinas Varona, en su Expedición al Este de Texas (Tres de Mayo-Diez y Siete de Julio de 1693). In Primeras Exploraciones y Poblamiento de Texas (1686-1691), edited by L. Gómez Canedo, pp. 277-307. Serie Historia 6. Publicaciones del Instituto Tecnológico y de Estudios Superiores de Monterrey, Monterrey.

de la Teja, J. F.

1968 Land and Society in 18th Century San Antonio de Bexar, A Community in New Spain's Northern Frontier. Ph.D. dissertation. The University of Texas at Austin.

1988 Land and Society in 18th Century San Antonio de Bexar, A Community on New Spain's Northern Frontier. University of Michigan, Ann Arbor.

De Vore, S. L.

1993 Cultural Resource Assessment of Lackland Air Force Base and Training Annex, Bexar Country, Texas. U.S. Department of Interior, National Park Service, Rocky Mountain Regional Office, Interagency Archaeological Services, Denver.

Dial, S. W.

1989 An Analysis of Ceramic Artifacts from the Alamo Lunette Trench (41BX6), San Antonio, Texas. Maunscript on file. Center for Archaeological Research, The University of Texas at San Antonio. 
1992 Civilian Artifacts. In Archaeological Investigations in Alamo Plaza, San Antonio, Bexar County, Texas, 1988 and 1989, edited by A. A. Fox, pp. 29-46. Archaeological Survey Report, No. 205. Center for Archaeological Research, The University of Texas at San Antonio.

Dibble, D. S., and D. Lorrain

1968 Bonfire Shelter: A Stratified Bison Kill Site, Val Verde County, Texas. Miscellaneous Paper 1. Texas Memorial Museum, Austin.

Dillehay, $\mathrm{T}$.

1974 Late Quaternary Bison Population Changes on the Southern Plains. Plains Anthropologist 19(64):180-196.

Eaton, J. D.

1980 Excavations at the Alamo Shrine (Mission San Antonio de Valero). Special Report, No. 10. Center for Archaeological Research, The University of Texas at San Antonio.

Elias, S. A.

1994 Insect Fossil Evidence of Late Glacial Environments at the Aubrey Clovis Site, Texas (abstract). Programs and Abstracts of the 13th Biennial Meeting, p. 77. American Quaternary Association. University of Minnesota, Minneapolis.

Ellis, L. W., G. L. Ellis, and C. D. Frederick

1995 Implications of Environmental Diversity in the Central Texas Archeological Region. Bulletin of the Texas Archeological Society 66:401-426.

Espey, Huston and Associates, Inc.

1989 Archaeological Investigations of Kelly Air Force Base, Bexar County, Texas. M. W. Voellinger, principal investigator. Document No. 890604. Espey, Huston and Associates, Austin.

Everett, D. E.

1961 San Antonio Welcomes the "Sunset"-1877. Southwestern Historical Quarterly 65(1):47-60.

Fehrenbach, T. R.

1968 Lone Star, A History of Texas and the Texans. Macmillian, Toronto.

1978 The San Antonio Story. Continental Heritage, Tulsa, Oklahoma.

Finger, J.

1983 Early Exploration and Settlements. In The History of Medina County, Texas. Castro Colonies Heritage Association, pp. 3-4. National ShareGraphics, Dallas.

Flanagan, S.

1974 Trailing the Longhorns: A Century Later. Madrona, Austin.

Forrestal, P. P., translator

1934 Peña's Diary of the Aguayo Expedition. Preliminary Studies of the Texas Catholic Historical Society, Austin.

Foster, W. C.

1995 Spanish Expeditions into Texas, 1689-1768. University of Texas Press, Austin. 
Fox, A. A.

1977 The Archaeology and History of the Spanish Governor's Palace Park. Archaeological Survey Report, No. 31. Center for Archaeological Research, The University of Texas at San Antonio.

1986 Ceramics. In La Villita Earthworks (41BX677): San Antonio, Texas, assembled by J. H. Labadie, pp. 107-127. Archaeological Survey Report, No. 159. Center for Archaeological Research, The University of Texas at San Antonio.

1989 Historic Anglo-European Exploration and Colonization. In From the Gulf Coast to the Rio Grande: Human Adaptation in the Central, South, and Lower Pecos Texas, by T. R. Hester, S. L. Black, D. G. Steele, B. W. Olive, A. A. Fox, K. J. Reinhard, and L. C. Bement, pp. 85-92. Research Series 33. Arkansas Archeological Survey, Fayetteville.

1992 Archaeological Investigations in Alamo Plaza, San Antonio, Bexar County, Texas, 1988 and 1989. Archaeological Survey Report, No. 205. Center for Archaeological Research, The University of Texas at San Antonio.

1997 Archaeological and Historical Investigations at Rancho De Las Cabras, 41WN30, Wilson County Texas, Fourth Season. Archaeological Survey Report, No. 143. Center for Archaeological Research, The University of Texas at San Antonio. Draft.

Fox, A. A., F. A. Bass, and T. R. Hester

1976 The Archaeology and History of Alamo Plaza. Archaeological Survey Report, No. 16. Center for Archaeological Research, The University of Texas at San Antonio.

Fox, A. A., I. W. Cox, L. Highley, and D. Hafernik

1989 Archaeological and Historical Investigations at the Site of the New Bexar County Justice Center in Downtown San Antonio, Texas. Archaeological Survey Report, No. 184. Center for Archaeological Research, The University of Texas at San Antonio.

Fox, D. E.

1979 The Lithic Artifacts of Indians at the Spanish Colonial Missions, San Antonio, Texas. Special Report, No. 8. Center for Archaeological Research, The University of Texas at San Antonio.

Fox, D. E., D. Scurlock, and J. W. Clark, Jr.

1977 Archeological Excavations at San Fernando Cathedral, San Antonio, Texas: A Preliminary Report. Special Report 22. Office of the State Archeologist, Austin.

Fox, D. E., F. Valdez, Jr., and L. O. Bobbitt

1978 An Archaeological Assessment of The Dolores Aldrete House Property, San Antonio, Texas. Archaeological Survey Report, No. 58. Center for Archaeological Research. The University of Texas at San Antonio.

Fredlund, G.

1994 The Phytolith Record at the Wilson-Leonard Site (abstract). Program and Abstract of the 52nd Plains Conference. 65th Annual Meeting of the Texas Archeological Society, Lubbock.

Frizzell, D. L.

1954 Handbook of Cretaceous Foraminifera of Texas. Bureau of Economic Geology, The University of Texas at Austin.

Garrett, J. K.

1968 Green Flag Over Texas, A Story of the Last Years of Spain in Texas. Reprint of 1939 issue. Pemberton, Austin. 
Gerstle, A., T. C. Kelly, and C. Assad

1978 The Fort Sam Houston Project: An Archaeological and Historical Assessment. Archaeological Survey Report, No. 40. Center for Archaeological Research, The University of Texas at San Antonio.

Givens, R. D.

1968 A Preliminary Report on Excavations at Hitzfelder Cave. Bulletin of the Texas Archeological Society 38:47-50.

Goode, G. T.

1991 Late Prehistoric Burned Rock Middens in Central Texas. In The Burned Rock Middens of Texas: An Archeological Symposium, edited by T. R. Hester, pp.71-93. Studies in Archaeology 13. Texas Archaeological Research Laboratory, The University of Texas at Austin

Graham, J. S.

1994 El Rancho in South Texas. University of North Texas Press, Denton.

Greer, G. H.

1981 American Stonewares, The Art and Craft of Utilitarian Potters. Schiffer, Exton, Pennsylvania.

Greer, G. H., and H. Black

1971 The Meyer Family: Master Potters of Texas. Trinity University Press, San Antonio.

Greer, J. W.

1967 A Description of the Stratigraphy, Features and Artifacts from an Archaeological Excavation at the Alamo. Report 3. State Building Commission Archaeological Program, Austin.

1979 An Archaeological Reconnaissance of the Enchanted Rock Area of Llano and Gillespie Counties, Central Texas. In Enchanted Rock. edited by Griffin Smith, pp. 117-166. Natural Area Survey 14. L.B.J. School of Public Affairs, The University of Texas at Austin.

Guderjan, T. H.

1991 At the Escarpment's Edge: An Initial Report on Excavations at Cueva Corbin. La Tierra 18(4):4-9.

Guderjan, T. H., B. Baker, C. B. Bousman, C. K. Chandler, A. A. Fox, and B. A. Meissner

1992 Prehistoric Settlement in the Medina Valley and the 1991 STAA-ITC Field School. La Tierra 19(2):14-28.

Guderjan, T. H., B. A. Meissner, B. Baker, C. K. Chandler, S. Kennedy, D. McReynolds, H. R. Smith, F. Ward, J. Watts, and J. Zapata

1993 The Medina Valley Project and the 1992 STAA-ITC Field School. La Tierra 20(1):12-26.

Gunn, J., and R. Mahula

1977 Hop Hill: Culture and Climatic Change in Central Texas. Special Report, No. 5. Center for Archaeological Research, The University of Texas at San Antonio.

Habig, M. A.

1968 The Alamo Chain of Missions: A History of San Antonio's Five Old Missions. Franciscan Herald, Chicago. 
Hall, G. D.

1981 Allens Creek: A Study in the Cultural Prehistory of the Brazos River Valley, Texas. Research Report 61. Texas Archaeological Survey, The University of Texas at Austin.

Hall, G. D., S. L. Black, and C. Graves

1982 Archaeological Investigations at Choke Canyon Reservoir, South Texas: The Phase I Findings. Choke Canyon Series 5. Center for Archaeological Research, The University of Texas at San Antonio.

Hall, G. D., T. R. Hester, and S. L. Black

1986 The Prehistoric Sites at Choke Canyon Reservoir, Southern Texas: Results of Phase II Archaeological Investigations. Choke Canyon Series, 10. Center for Archaeological Research, The University of Texas at San Antonio.

Hard, R J.

1994 A Historical Overview of Alamo Plaza and Camposanto. Special Report, No. 20. Center for Archaeological Research, The University of Texas at San Antonio.

Harris, E. S.

1985 An Archaeological Study of the Timmeron Rockshelter (41HY95), Hays County, South Central Texas. Special Publication 4. Southern Texas Archaeological Association, San Antonio.

Hassig, R.

1991 Roads, Routes, and Ties that Bind. In Ancient Road Networks and Settlement Hierarchies in the New World, edited by C. D. Trombold. Cambridge University Press, Cambridge.

Henderson, J.

1978 Faunal Analysis of Site 41BX36, with Data Presented for 41BX377 and 41BX428. In The Fort Sam Houston Project: An Archaeological and Historical Assessment, by A. Gerstle, T. C. Kelly, and C. Assad, pp. 229-252. Archaeological Survey Report, No. 40. Center for Archaeological Research, The University of Texas at San Antonio.

1980 Update on the Texas Highway Department's Excavations at 41BX52 on Leon Creek. Paper presented at a meeting of the Southern Texas Archaeological Association, San Antonio.

Hester, T. R.

1968a Paleo-Indian Artifacts Along San Miguel Creek: Frio, Atascosa, and McMullen Counties, Texas. Bulletin of the Texas Archeological Society 39:147-162.

1968b Folsom Points from Southwest Texas. Plains Anthropologist 15(50):237-250.

1970 Burned Rock Midden Sites on the Southwestern Edge of the Edwards Plateau, Texas. Plains Anthropologist 15:237-248.

1971 Archeological Investigations at the La Jita Site, Uvalde County, Texas. Bulletin of the Texas Archeological Society 42:51-148.

1977 The Current Status of Paleo-Indian Studies in Southern Texas and Northeastern Mexico. In PaleoIndian Lifeways, edited by E. Johnson, pp. 169-186. The Museum Journal 17. Museum of Texas Tech University, Lubbock.

1978 Early Human Occupations in South Central and Southwestern Texas: Preliminary Papers on the Baker Cave and St. Mary's Hall Sites. Non-serial Publication 2. Center for Archaeological Research, The University of Texas at San Antonio.

1980 Digging into South Texas Prehistory. Corona, San Antonio. 
1983 Late Paleo-Indian Occupations at Baker Cave, Southwestern Texas. Bulletin of the Texas Archaeological Society 53:101-119.

1989 Historic Native American Populations. In From the Gulf to the Rio Grande: Human Adaptation in Central, South, and Lower Pecos Texas, edited by T. R. Hester, S. L. Black, D. G. Steele, B. W. Olive, A. A. Fox, K. J. Reinhard, and L. C. Bement, pp. 1-4. Research Series 33. Arkansas Archeological Survey, Fayetteville.

1991 The Plainview Points from the St. Mary's Hall Site, South Central Texas. La Tierra 18(2):1-4.

1995 The Prehistory of South Texas. Bulletin of the Texas Archeological Society 66:427-459.

Hester, T. R., S. L. Black, D. G. Steele, B. W. Olive, A. A. Fox, K. J. Reinhard, and L. C. Bement, editors 1989 From the Gulf to the Rio Grande: Human Adaptation in Central, South, and Lower Pecos Texas. Research Series 33. Arkansas Archeological Survey, Fayetteville.

Highley, L., C. Graves, and G. Judson

1978 Archaeological Investigations at Scorpion Cave (41ME7), Medina County, Texas. Bulletin of the Texas Archeological Society 49:139-194.

Houk, B. A., and J. C. Lohse

1993 Archaeological Investigations at the Mingo Site, Bandera County, Texas. Bulletin of the Texas Archeological Society 61:193-247.

Howard, C. D.

1974 Paleo-Indian Surface Finds in Bexar County. La Tierra 1(4):14-17.

Howe, H. V., and L. Laurencich

1958 Introduction to the Study of Cretaceous Ostracoda. Louisiana State University Press, Baton Rouge.

Huebner, J. A.

1991 Late Prehistoric Bison Populations in Central and Southern Texas. Plains Anthropologist 36(137):343-358.

Hulbert, R. C., Jr.

1985 Vertebrate Faunal Remains. In The Panther Springs Creek Site: Cultural Change and Continuity within the Upper Salado Creek Watershed, South-Central Texas, by S. L. Black and A. J. McGraw, pp. 209-215. Archaeological Survey Report, No. 100. Center for Archaeological Research, The University of Texas at San Antonio.

Humphrey, J. D., and C. R. Ferring

1994 Stable Isotopic Evidence for Latest Pleistocene and Holocene Climatic Change in North Central Texas. Quaternary Research 41:200-213.

Hunt, C. B.

1959 Dating of Mining Camps with Tin Cans and Bottles. Geotime 3(8):8-10, 34.

Inglis, J. M.

1964 A History of Vegetation on the Rio Grande Plain. Bulletin No. 45. Texas Parks and Wildlife Department, Austin.

Israel, F. L. (editor)

19681897 Sears Roebuck Catalogue. Reprinted by Chelsea House, New York. 
Ivey, J. E.

1983 Archaeological Testing at Rancho de las Cabras, 41WN30, Wilson County, Texas, Second Season. Archaeological Survey Report, No. 121. Center for Archaeological Research, The University of Texas at San Antonio.

Ivey, J. E., and A. A. Fox

1981 Archaeological Survey and Testing at Rancho de las Cabras, Wilson County, Texas. Archaeological Survey Report, No. 104. Center for Archaeological Research, The University of Texas at San Antonio.

1982 Archaeological Investigations at Mission Conception and Mission Parkway, Part I: Excavations at Mission Concepción. Archaeological Survey Report, No. 114. Center for Archaeological Research, The University of Texas at San Antonio.

Jackson, J.

1986 Los Mesteños. Texas A\&M University Press, College Station.

Jelks, E. B.

1962 The Kyle Site: A Stratified Central Texas Aspect Site in Hill County, Texas. Archaeology Series 5. Department of Anthropology, The University of Texas at Austin

John, E. A. H.

1975 Storms Brewed in Other Men's Worlds: The Confrontation of Indians, Spanish, and French in the Southwest, 1540-1795. Texas A\&M University Press, College Station.

Johnson, E.

1981 Late Paleo-Indian Activity at the Lubbock Lake Site. Plains Anthropologist 26(93):173-193.

1986 A Plague of Phases. Bulletin of the Texas Archeological Association 57:1-26.

Johnson, E., and V. T. Holliday

1980 A Plainview Kill/Butchering Locale on the Llano Estacado-the Lubbock Lake Site. Plains Anthropologist 25(88) Part 1:83-85.

Johnson, L., Jr.

1964 The Devil's Mouth Site: A Stratified Campsite at Amistad Reservoir, Texas. Archeology Series 6. Department of Anthropology, The University of Texas at Austin.

1987 A Plague of Phases. Bulletin of the Texas Archeological Society 57:1-26.

Johnson, L. Jr., and G. T. Goode

1994 A New Try at Dating and Characterizing Holocene Climates, as well as Archeological Periods, on the Eastern Edwards Plateau. Bulletin of the Texas Archeological Society 65:1-51.

Johnson, L., Jr., D. A. Suhm, and C. D. Tunnell

1962 Salvage Archaeology of Canyon Reservoir: The Wunderlich, Footbridge, and Oblate Sites. Bulletin No. 5. Texas Memorial Museum, Austin.

Jones, C. J.

1981 A Further Experiment in Stone Boiling: A Calcining Process for Acorns. La Tierra 8(2):31-38.

1983 Archaeological Testing at the Rancho de las Cabras, Wilson County, Texas, Third Season. Archaeological Survey Report, No. 123. Center for Archaeological Research, The University of Texas at San Antonio. 
Jones, W. K.

1969 Notes on the History and Material Culture of the Tonkawa Indians. Smithsonian Contributions to Anthropology 2(5). Smithsonian Institution, Washington, D. C.

Judson, S., and M. E. Kauffman

1990 Physical Geology, 8th ed. Prentice Hall, Englewood Cliffs, New Jersey.

Katz, P. R.

1987 Archaeological Mitigation at 41BX300, Salado Creek Watershed, South-Central Texas. Archaeological Survey Report, No. 130. Center for Archaeological Research, The University of Texas at San Antonio.

Kelley, J. C.

1947a The Cultural Affiliations and Chronological Position of the Clear Fork Focus. American Antiquity 13(2):97-108.

1947b The Lehmann Rockshelter: A Stratified Site of the Toyah, Uvalde and Round Rock Foci. Bulletin of the Texas Archeological and Paleontological Society 18:115-128.

1959 Desert Cultures and the Balcones Phase: Archaic Manifestations in the Southwest and Texas. American Antiquity 24(3):276-288.

Kelly, R. L.

1983 Hunter/Gatherer Mobility Strategies. Journal of Anthropological Research 39:277-306.

Kelly, T. C.

1993 Preceramic Projectile-Point Typology in Belize. Ancient Mesoamerica 4:205-227.

Kelly, T. C., and J. D. Eaton

1979 Archaeological Investigations at Site 41BX1, North of Olmos Dam, Bexar County, Texas. Archaeological Survey Report, No. 86. Center for Archaeological Research, The University of Texas at San Antonio.

Kelly, T. C., and T. R. Hester

1976 Archaeological Investigations at Sites in the Upper Cibolo Creek Watershed, Central Texas. Archaeological Survey Report, No. 17. Center for Archaeological Research, The University of Texas at San Antonio.

Labadie, J. H.

1993 An Overview of European History in the Amistad Basin. Manuscript on file. Center for Archaeological Research, The University of Texas at San Antonio.

1986 La Villita Earthworks (41BX677): San Antonio, Texas. Archaeological Survey Report, No. 159. Center for Archaeological Research, The University of Texas at San Antonio.

Land and Thompson, publishers

1977[1885] Historical and Descriptive Review of the Industries of San Antonio. Reprinted by Norman Brock, San Antonio.

Lehmann, V. W.

1969 Forgotten Legions. Texas Western, The University of Texas at El Paso. 
Lehner, L.

1988 Lehner's Encyclopedia of U.S. Marks on Pottery, Porcelain \& Clay. Schroeder, Paducah, Kentucky.

León, A., J. B. Chapa, and F. S. de Zamora

1961 Historia de Luevo León, con Noticias sobre Coahuila, Tamaulipas, Texas y Nuevo México. Estudio Preliminar y Notas de Israel Cavazos Garza. Centro de Estudios Humanisticos. Universidad de Nuevo León, Monterrey.

Lukowski, P. D.

1988 Archaeological Investigations at 41BX1, Bexar County, Texas. Archaeological Survey Report, No. 135. Center for Archaeological Research, The University of Texas at San Antonio.

Mazanet, D.

1968 Diario Derrotero a la Provincia de los Techas que se hizo el Año de Noventa y Uno, en la Jornada que se hizo por el Orden del Excelentísimo Señor Conde de Galve, Virrey y Capitán General desta Nueva España. In Primeras Exploraciones y Poblamiento de Texas (1686-1691), edited by L. Gómez Canedo, pp. 229-254. Publicaciones del Instituto Tecnológico y de Estudios Superiores de Monterrey, Serie Historia 6. Monterrey.

McGraw, A. J.

1977 A Preliminary Archaeological Survey Along The Medio Creek Drainage, Southwestern Bexar County, Texas. Regional Studies 3. Center for Archaeological Research, The University of Texas at San Antonio.

1985 An Overview of the Prehistory of the Upper Salado Creek Watershed. In The Panther Springs Creek Site: Cultural Change and Continuity within the Upper Salado Creek Watershed, SouthCentral Texas, by S. L. Black and A. J. McGraw, pp. 302-326. Archaeological Survey Report, No. 100. Center for Archaeological Research, The University of Texas at San Antonio.

McGraw, A. J., and K. Hindes

1987 Chipped Stone and Adobe: A Cultural Resource Assessment of the Proposed Applewhite Reservoir, Bexar County, Texas. Archaeological Survey Report, No. 163. Center for Archaeological Research, The University of Texas at San Antonio.

McGraw, A. J., and F. Valdez, Jr.

1978 Investigations of Prehistoric Rockshelter and Terrace Sites Along Portions of the Salado Creek Drainage, Northern Bexar County, Texas. Archaeological Survey Report, No. 55. Center for Archaeological Research, The University of Texas at San Antonio.

McGraw, A. J., F. Valdez, Jr., and I. W. Cox

1977 Archaeological Survey of Areas Proposed for Modification in the Encino Park Development, Northern Bexar County, Texas. Archaeological Survey Report, No. 39. Center for Archaeological Research, The University of Texas at San Antonio.

McKern, W. L.

1939 The Midwestern Taxonomic Method as an Aid to Archaeological Culture Studies. American Antiquity 4(4):301-313. 
McKinney, W. W.

1981 Early Holocene Adaptations in Central and Southern Texas: The Problem of the Paleo-IndianArchaic Transition. Bulletin of the Texas Archeological Society 52:91-120.

McKinney, W. W., C. B. Bousman, D. L. Nickels, and K. L. McRae

1998 Artifact Analysis. In Test Excavations at the Culebra Creek Site, 41BX126, Texas, edited by D. L. Nickels and C. B. Bouseman. Archaeological Survey Report, No. 265. Center for Archaeological Research, The University of Texas at San Antonio. Draft.

MacNeish, R. S.

1958 Preliminary Archaeological Investigations in the Sierra de Tamaulipas, Mexico. American Philosophical Transactions, n.s., 48(6), Philadelphia.

McReynolds, R. L.

1982 Marine Shell Artifacts from Southwest Bexar County. La Tierra 9(4):13-16.

Martin, G. C.

1933 Archaeological Exploration of the Shumla Caves. Bulletin 3, Southwest Texas Archaeological Society, Witte Memorial Museum, San Antonio.

Meissner, B. A.

1991 Notes on the Excavation of 41BX952. Manuscript on file. Center for Archaeological Research, The University of Texas at San Antonio.

1993 Where the Buffalo Roam: Archaeological Evidence of Bison Populations in South and Central Texas. Manuscript on file. Center for Archaeological Research, The University of Texas at San Antonio.

1996 The Alamo Restoration and Conservation Project: Excavations at the South Transept. Archaeological Survey Report, No. 245. Center for Archaeological Research, The University of Texas at San Antonio.

Meltzer, D. J., and M. R. Bever

1995 Paleoindians of Texas: An Update on the Texas Clovis Fluted Point Survey. Bulletin of the Texas Archeological Society 66:47-81.

Miller, G. L., and A. Pacey

1985 Impact of Mechanization in the Glass Container Industry: The Dominion Glass Company of Montreal, A Case Study. Historical Archaeology 19(1):38-50.

Miller, C. And H. T. Sanders, editors

1990 Urban Texas. Texas A\&M University Press, College Station.

Mirken, A.

1970 The 1927 Edition of the Sears, Roebuck Catalogue. Crown, New York.

Moore, R. C., editor

1961 Treatise on Vertebrate Paleontology. Parts C, I, N, and Q. Geological Society of America. University of Kansas Press, Lawrence, Kansas.

Morrison, A. (compiler)

1891 The City of San Antonio, Texas. Geo. W. Engelhardt, St. Louis. 
Mosebach, F.

1934 Grandchildren Carry on Since Pioneers Quit Overcrowded City to Establish Medina Farm Colony 60 Years Ago. San Antonio Express 1 July:C9.

Mueggenborg, H. E.

1994 Excavations at the Blue Hole Site, Uvalde County, Texas, 1990. Bulletin of the Texas Archeological Society 62:1-74.

Munsey, C.

1970 The Illustrated Guide to Collecting Bottles. Hawthorne, New York.

National Park Service (NPS)

1993 Request for Proposal. Archeological Inventory, National Register Evaluation and Documentation of Prehistoric and Historic Archeological Resources at Lackland and Laughlin Air Force Base, Texas. Two volumes. Solicitation No. 1443-RP-1200-94-005. U. S. Department of Interior, National Park Service, Rocky Mountain Region, Denver.

Nesmith, S. P.

1982 The Belgian Texans: The Texians and Texans. Institute of Texan Cultures, The University of Texas at San Antonio.

Newcomb, W. W., Jr.

1961 The Indians of Texas: From Prehistoric to Modern Times. University of Texas Press, Austin.

Noonan, M. O.

1976 Creation of Medina County. In History of Medina County Texas, pp. 5-15. Castro Colonies Heritage Association, Castroville, Texas.

1984 Battle of Adams Hill. In The History of Medina County Vol. 1, p. 5. Published by the Dallas National ShareGraphics for the Castroville Colonies Heritage Association, Dallas.

Nordt, L. C., T. W. Boutton, J. S. Jacob, and R. Mandel

1994 Late Quaternary Climates of Central Texas Based on the Stable Isotopic Composition of Organic Carbon (abstract). Program and Abstracts, 52nd Plains Conference. 65th Annual Meeting of the Texas Archaeological Society, Lubbock.

Nordt, L.C.

1992 Archaeological Geology of the Fort Hood Military Reservation, Fort Hood, Texas. United States Army Fort Hood. Archaeological Resource Management Series, Research Report Number 25. Texas A\&M University, College Station.

1995 Geoarchaeological Investigations of Henson Creek: A Low-order Tributary in Central Texas. Geoarchaeology 10:205-221.

Orchard, C. D.

1938 Letter to A. T. Jackson, concerning Bexar County archaeological sites. On file at the Texas Archaeological Research Laboratory, The University of Texas at Austin

Orchard, C. D., and T. N. Campbell

1954 Evidence of Early Man from the Vicinity of San Antonio, Texas. Texas Journal of Science 6(4):454-465. 
Patterson, L. W.

1988 Intergroup Conflict in Prehistoric Texas. Houston Archeological Society Journal 90:8-10.

Permian, J.

1984 The Home and Farm Manual: Classic 1884 Edition. Greenwich House, New York.

Peter, D. E., T. R. Hays, and M. Demuynck

1982 An Evaluation of the "Phase" Concept. In Archaeological Investigations at the San Gabriel Reservoir Districts, Central Texas, edited by T. R. Hays, Vol. 2, pp. 21-1-21-17. Archaeology Program Institute of Applied Sciences, North Texas State University (University of North Texas), Denton.

Petraglia, M. D., and D. A. Knepper

1993 Archaeological Survey at the Prime RIBS Training Area, Lackland Air Force Base Training Annex, Bexar County, Texas. Engineering-Sciences, Fairfax, Virginia.

Pierce, G. S.

1969 Texas Under Arms. Encino, Austin.

Potter, D. R.

1990 Archaeological Survey of the Covel Gardens Landfill Area in San Antonio, Bexar County, Texas.

Archaeological Survey Report, No. 202. Center for Archaeological Research, The University of Texas at San Antonio.

1995 Past and Present Environments. In Archeology Along the Wurzbach Parkway: Module 1. Introduction, Conceptual Framework, and Contexts of Archeological Investigations in Bexar County, South-Central Texas, edited by D. R. Potter, S. L. Black, and K. Jolly, pp. 45-51. Studies in Archeology 17. Texas Archeological Research Laboratory, The University of Texas at Austin.

Potter, D. R., and S. L. Black

1995 Archeology Along the Wurzbach Parkway: Module 2. Initial Testing and Evaluation of Five Prehistoric Sites in the Upper Salado Watershed, Bexar County, Texas. Studies in Archeology 18. Texas Archeological Research Laboratory, The University of Texas at Austin.

Potter, D. R., S. L. Black, and K. Jolly, editors

1995 Archeology Along the Wurzbach Parkway: Module 1. Introduction, Conceptual Framework, and Contexts of Archeological Investigations in Bexar County, South-Central Texas. Studies in Archeology 17. Texas Archeological Research Laboratory, The University of Texas at Austin.

Potter, D. R., C. K. Chandler, and E. Newcomb

1992 Archaeological Salvage Research at 41BX901, a Prehistoric Quarry in Bexar County, Texas. Archaeological Survey Report, No. 211. Center for Archaeological Research, The University of Texas at San Antonio.

Poyo, G. E., and G. M. Hinojosa, editors

1991 Tejano Origins in Eighteenth-Century San Antonio. University of Texas Press, Austin.

Prewitt, E. R.

1974 Archeological Investigations at the Loeve-Fox Site, Williams County, Texas. Research Report 49. Texas Archeological Survey, The University of Texas at Austin.

1981 Cultural Chronology in Central Texas. Bulletin of the Texas Archeological Society 52:65-89. 
1985 From Circleville to Toyah: Comments on Central Texas Chronology. Bulletin of the Texas Archeological Society 54:201-238.

1991 Burned Rock Middens: A Summary of Previous Investigations and Interpretations. In The Burned Rock Middens of Texas: An Archeological Symposium, edited by T. R. Hester, pp. 25-32. Studies in Archeology 13. Texas Archeological Research Laboratory, The University of Texas at Austin.

Quigg, J. M.

1988 Cultural Resources Reconnaissance in Secondary Impact Areas along Salado Creek at Brooke Army Medical Center, Fort Sam Houston and Camp Bullis, Bexar County, Texas. Technical Report 5. Prewitt and Associates, Austin.

Quigg, J. M., and J. Peck

1995 The Rush Site (41TG346): A Stratified Late Prehistoric Locale in Tom Green County, Texas. Technical Report 816C, Mariah Associates, Austin.

Ray, M.

1974 Collectible Ceramics. Crown, New York.

Rector, R. R.

1993 Live Oak Acorn Yield Studies in Relation to Hunter and Gathering Populations in Central Texas. Manuscript of unpublished Master's thesis on file. Center for Archaeological Research, The University of Texas at San Antonio.

Reese, N., F. Winchell, R. Proctor, and S. N. Allday

1994 Prehistoric and Historic Overview of the Lackland Air Force Base Area: San Antonio, Bexar County, Texas (10,000 B.C. to A.D. 1947). Special Report of Investigations 1. Geo-Marine, Plano, Texas.

Ricklis, R. A.

1994 Holocene Climatic and Environmental Change in the Texas Coastal Zone: Sifting through the Geoarchaeological and Ecofactual Evidence (abstract). Program and Abstracts, 52nd Plains Conference. 65th Annual Meeting of the Texas Archaeological Society, Lubbock.

Riskind, D. H., and D. D. Diamond

1986 Plant Communities of the Edwards Plateau of Texas: An Overview Emphasizing the Balcones Escarpment Zone Between San Antonio and Austin, with Special Attention to Landscape Contrasts and Natural Diversity. In The Balcones Excarpment, Geology, Hydrology, Ecology and Social Development in Central Texas, edited by P. L. Abbott and C. M. Woodruff, pp. 21-32. Department of Geological Sciences, San Diego State University, San Diego.

Ritter, D. F.

1978 Process Geomorphology. Second edition. William C. Brown, Dubuque, Iowa.

Roberson, W. R.

1974 The Carrington-Covert House: Archaeological Investigation of a 19th-Century Residence in Austin, Texas. Report No. 25. Office of the State Archaeologist, Texas Historical Commission, Austin. 
Robinson, R. L.

1979 Biosilica and Climatic Change at 41GD21 and 41GD21A. In Archaeological Investigations of Two Prehistoric Sites on the Coleto Creek Drainage, Goliad County, Texas, by D. E. Fox, pp. 102-113. Archaeological Survey Report, No. 69. Center for Archaeological Research, The University of Texas at San Antonio.

1982 Biosilica Analysis of Three Prehistoric Archaeological Sites in the Choke Canyon Reservoir, Live Oak County, Texas: Preliminary Summary of Climatic Implications. In Archaeological Investigations at Choke Canyon Reservoir, South Texas: The Phase I Findings by G. D. Hall, S. L. Black, and C. Graves, pp. 597-610. Choke Canyon Series 5. Center for Archaeological Research, The University of Texas at San Antonio.

Schuetz, M.

1968 The History and Archeology of Mission San Juan Capistrano, San Antonio, Texas. Volume I. Report 10. State Building Commission, Austin.

1969 The History and Archeology of Mission San Juan Capistrano, San Antonio Texas Vol 11. Report 11. Archeological Program. State Building Commission, Austin.

Shafer, H. J.

1977 Art and Territoriality in the Lower Pecos Region, Texas. Plains Anthropologist 22:13-22.

1986 Ancient Texans: Rock Art and Lifeways along the Lower Pecos. Texas Monthly, Austin.

1993 Research Potential of Prehistoric Quarry Sites. In Archaeological Site Testing and Evaluation on the Henson Mountain Helicopter Range AWSS Project Area, Fort Hood, Texas, edited by D. L. Carlson, pp. 45-59. Research Report, No. 16. United States Army Fort Hood Archaeological Management Series, Fort Hood, Texas.

Shoup. R. F.

1988 Skeletal and Dental Materials. In Archaeological Investigations at 41BX1, Bexar County, Texas, by P. D. Lukowski. Archaeological Survey Report, No. 135. Center for Archaeological Research, The University of Texas at San Antonio.

Sjoberg, A. F.

1953 Lipan Apache Culture in Historical Perspective. Southwestern Journal of Anthropology 9(1):76-98.

Skelton, D. W.

1977 Archeological Investigations at the Fayette Power Project, Fayette County, Texas. Research Report 60. Texas Archeological Survey, The University of Texas at Austin.

Skinner, S. A.

1974 Willow Creek Survey. Archaeology Research Program, Southern Methodist University. Letter report on file, Department of Antiquities Protection, Texas Historical Commission, Austin.

1981 Aboriginal Demographic Changes in Central Texas. Plains Anthropologist 26(92):111-118.

Soil Survey Staff

1981 Soil Survey Manual. Handbook 18. Soil Conservation Service, U.S. Department of Agriculture, Washington, D.C.

Sollberger, J., and T. R. Hester

1972 The Strohacker Site: A Review of Pre-Archaic Manifestations in Texas. Plains Anthropologist 17(58):326-344. 
Sorrow, W. M., H. J. Shafer, and R. E. Ross

1967 Excavations at Stillhouse Hollow Reservoir. Papers of the Texas Archeological Salvage Project, No. 11. The University of Texas at Austin.

1972 Archeological Salvage Excavations at the Alamo (Mission San Antonio de Valero), 1970. Research Report 4. Texas Archeological Salvage Project, The University of Texas at Austin.

Steele, D. G., and C. Assad Hunter

1986 Analysis of Vertebrate Faunal Remains from 41MC222 and 41MC296, McMullen County, Texas. In The Prehistoric Sites at Choke Canyon Reservoir, Southern Texas: Results of Phase II Archaeological Investigations, by G. D. Hall, T. R. Hester, and S. L. Black. Choke Canyon Series 10. Center for Archaeological Research, The University of Texas at San Antonio.

Stephens, C.

1979 The Antiques Journal. January.

Story, D. A.

1985 Adaptive Strategies of Archaic Cultures of the West Gulf Coast Plain. In Prehistoric Food Production in North America, edited by R. I. Ford, pp. 19-56. Anthropological Papers 75. Museum of Anthropology, University of Michigan, Ann Arbor.

Stothert, K.

1989 The Archaeology and Early History of the Head of the San Antonio River. Special Publication 5. Southern Texas Archaeological Association. Incarnate Word Archaeology Series 3, San Antonio.

Suhm, D. A.

1960 A Review of Central Texas Archaeology. Bulletin of the Texas Archeological Society 28:63-108.

Suhm, D. A., A. D. Krieger, and E. B. Jelks

1954 An Introductory Handbook of Texas Archaeology. Bulletin of the Texas Archeological Society 25.

Swanton, J. R.

1952 The Indian Tribes of North America. Bulletin 145. Bureau of American Ethnology, Washington, D. C.

Taylor, A. J., and A. A. Fox

1985 Archaeological Survey and Testing at Rancho de las Cabras, 41WN30, Wilson County, Texas, Fifth Season. Archaeological Survey Report, No. 144. Center for Archaeological Research, The University of Texas at San Antonio.

Taylor, A. J., and C. L. Highley

1995 Archeological Investigations at the Loma Sandia Site (41LK28): A Prehistoric Cemetery and Campsite in Live Oak County, Texas. Two volumes. Studies in Archeology 20. Texas Archeological Research Laboratory, The University of Texas at Austin.

Taylor, F. B., R. B. Hailey, and D. L. Richmond

1991 Soil Survey, Bexar County, Texas. Soil Conservation Service, U.S. Department of Agriculture, Washington, D.C. 
Tennis, C. L.

1996 Archaic Land Use of Upper Leon Creek Terraces: Archaeological Testing in Northern Bexar County, Texas. Archaeological Survey Report, No. 234. Center for Archaeological Research, The University of Texas at San Antonio.

Tennis, C., and R. J. Hard

1995 Archaeological Survey of Terraces Along Leon Creek, Bexar County, Texas. Archaeological Survey Report, No. 233. Center for Archaeological Research, The University of Texas at San Antonio.

Thomas, D. H.

1985 Hunter/Gatherer Cultural Geography. Paper presented at the 1984 Meeting of the Society for American Archaeology, Portland, Oregon.

Thoms, A. V.

1992 Late Pleistocene and Early Holocene Regional Land Use Patterns: A Perspective from the Preliminary Results of Archaeological Studies at the Richard Beene Site, 41BX831, Lower Medina River, South Texas. In Guidebook, 10th Annual Meeting, South-Central Friends of the Pleistocene: Late Cenozoic Alluvial Stratigraphy and Prehistory of the Inner Gulf Coastal Plain, South-Central Texas, edited by R. Mandel and C. Caran (draft). Lubbock Lake Landmark Quaternary Research Center Series 4, Lubbock.

Thoms, A. V., D. D. Kuehn, B. W. Olive, J. E. Dockall, P. A. Clabaugh, and R. D. Mandel

1996 Early and Middle Holocene Occupations at the Richard Beene Site: The 1995 Southern Texas Archaeological Association Field School Project. La Tierra 23(4):8-36.

Thurgood, R. J.

1972 The Complete Encyclopedia of Barbed Wire. Collector Books, Paducah, Kentucky.

Toomey, R. S., and T. W. Stafford, Jr.

1994 Paleoenvironmental and Radiocarbon Study of the Deposits from Hall's Cave, Kerr County, Texas (abstract). Program and Abstracts, 52nd Plains Conference. 65th Annual Meeting of the Texas Archaeological Society, Lubbock.

Toomey, R. S., M. D. Blum, and S. Valastro, Jr.

1993 Late Quaternary Climates and Environments of the Edwards Plateau, Texas. Global and Planetary Change 7:299-320.

Toulouse, J. H.

1971 Bottle Makers and Their Marks. Thomas Nelson, New York.

Trombold, C. D.

1991 An Introduction to the Study of Ancient New World Road Networks. In Ancient Road Networks and Settlement Hierarchies in the New World, edited by C. D. Trombold. Cambridge University Press, Cambridge.

Turner, E. S., and T. R. Hester

1993 A Field Guide to Stone Artifacts of Texas Indians. Texas Monthly Field Guide Series. Gulf, Houston. 
Turpin, S. A.

1991 Time out of Mind: The Radiocarbon Chronology of the Lower Pecos River Region. In Papers on Lower Pecos Prehistory, edited by S. A. Turpin, pp. 1-50. Studies in Archeology 8. Texas Archeological Research Laboratory, The University of Texas at Austin.

Tyler, R. (editor)

1996 The New Handbook of Texas. Six Volumes. Texas Historical Commission, Austin.

U.S. Department of the Interior

1991 National Register Bulletin 15. National Park Service, Washington, D. C.

Valdez, F., Jr., (assembler)

1983 Archaeological Survey and Testing at Rancho de las Cabras, 41WN30, Wilson County, Texas, Forth Season. Archaeological Survey Report, No. 143. Center for Archaeological Research, The University of Texas at San Antonio.

Van Auken, O. W.

1988 Woody Vegetation of the Southern Escarpment and Plateau. In Edwards Plateau Vegetation, edited by B. B. Amos and F. R. Gehlbach, pp. 43-55. Baylor University Press, Waco, Texas.

Waters, M. R.

1992 Principles of Geoarchaeology: A North American Perspective. University of Arizona Press, Tucson.

Webb, W. P. (editor)

1952 The Handbook of Texas. Two volumes. Texas State Historical Association, Austin.

Weddle, R. S.

1968 San Juan Bautista, Gateway to Spanish Texas. University of Texas Press, Austin.

Weir, F. A.

1976 The Central Texas Archaic. Unpublished Ph. D. dissertation, Washington State University. University Microfilms, Ann Arbor.

Weniger, D.

1984 The Explorers' Texas: The Lands and Waters. Eakin, Austin.

Wenke, R. J.

1990 Patterns in Prehistory: Humankind's First Three Million Years. 3rd Edition. Oxford University Press, Oxford, Endland.

West, E. H. (translator)

1904 A Brief Compendium of the Events Which Have Occurred in the Province of Texas from its Conquest, or Reduction to the Present Day, Written by Antonio Bonilla in 1772. Quarterly of the Texas State Historical Association VIII(1):1-78.

Witkind, W. M.

1977 An Experiment in Stone Boiling. In Hop Hill: Culture and Climatic Change in Central Texas, edited by J. Gunn and R. Mahula, pp. 205-208. Special Report, No. 5. Center for Archaeological Research, The University of Texas at San Antonio. 
Wolf, E. R.

1982 Europe and the People without History. University of California Press, Berkeley.

Woolford, S. W.

1935 Types of Archaeological Sites in Bexar County, Texas. Bulletin 4, Southwest Texas Archaeological Society. Witte Memorial Museum, San Antonio.

Wooster, R.

1987 Soldiers, Suttlers, and Settlers: Garrison Life on the Texas Frontier. Texas A\&M University Press, College Station. 


\title{
Appendix A: Soil-stratigraphic Descriptions
}

\author{
Lee C. Nordt
}

Medio Creek

BHT-1; T2 strath; $25 \mathrm{ft}$ above the modern channel; calcareous throughout.
A $\quad 0-25 \mathrm{~cm}$
black (10YR 2.5/1) clay; moderate medium subangular blocky; very firm; $2 \%$ pebbles 0.3 to 1 $\mathrm{cm}$ diameter, diffuse; gradual smooth.
Bssk1 25-61 cm very dark gray (2.5Y 3/1) clay; weak coarse angular blocky; extremely firm; 3 to $4 \%$ pebbles 0.5 to $1.5 \mathrm{~cm}$ diameter, angular chert; $1 \% \mathrm{CaCO}_{3}$ nodules $0.5 \mathrm{~cm}$ diameter; few distinct slickensides; gradual smooth.
Bssk2 $61-89 \mathrm{~cm} \quad$ very dark gray (2.5Y 3/1) and 50\% light olive brown (2.5Y 5/4) clay; weak coarse angular blocky; extremely firm; 1 to $2 \%$ pebbles 0.3 to $0.8 \mathrm{~cm}$ diameter; $1 \% \mathrm{CaCO}_{3}$ nodules $0.5 \mathrm{~cm}$ diameter; few distinct slickensides; gradual smooth.
Bssk3 89-124 cm olive (5Y 4/3) clay with 15\% light olive brown (2.5Y 5/4) and 10\% very dark gray (2.5 3/1); weak coarse angular blocky; extremely firm; few slickensides; $1 \% \mathrm{CaCO}_{3}$ nodules; abrupt smooth.
Cr $124-146+$ fossiliferous olive yellow and orange loam (Cretaceous).

BHT-2; T2 strath; $25 \mathrm{ft}$ above the modern channel; calcareous throughout.
A $\quad 0-25 \mathrm{~cm}$
very dark gray $(2.5 \mathrm{Y} 3 / 1)$ clay; moderate medium subangular blocky; friable; $1 \%$ pebbles 0.3 to $0.5 \mathrm{~cm}$ diameter; clear smooth.
C/B $\quad 25-41 \mathrm{~cm}$ olive brown (2.5Y 4/4) clay with $50 \%$ very dark grayish brown $(2.5 \mathrm{Y} 3 / 2) ; 25 \%$ fossiliferous pebbles 0.3 to $1 \mathrm{~cm}$ diameter; clear smooth.
Cr $\quad 41-72 \mathrm{~cm}$ olive, yellow and orange fossiliferous loam (Cretaceous).

BHT-3; T0; Unit III; 6-8 ft above modern channel; calcareous throughout.
A $\quad 0-11 \mathrm{~cm}$
very dark grayish brown (10YR 3/2) silty clay loam; firm; clear smooth.
$\begin{array}{ll}\text { Ab1 } & 11-25 \mathrm{~cm} \\ \text { Bwb1 } & 25-55 \mathrm{~cm} \\ \text { Cb1 } & 55-68 \mathrm{~cm}\end{array}$
very dark gray (10YR 3/1) silty clay; weak medium angular blocky; very firm; gradual smooth. dark grayish brown (2.5Y $3 / 2$ ) silty clay; weak coarse prismatic; extremely firm; abrupt smooth. olive (2.5Y 5/3) and yellowish brown (10YR 5/4) clay loam; 30 to $35 \%$ pebbles 0.3 to $1.5 \mathrm{~cm}$ diameter, subrounded, poorly sorted, and clast supported chert and limestone; shale clasts; abrupt smooth.
Ab2 68-87 cm very dark gray (2.5Y 3/1) clay; weak coarse angular blocky; extremely firm; $20 \%$ pebbles and cobbles 0.5 to $6 \mathrm{~cm}$ diameter, subrounded, poorly sorted, and clast supported chert and limestone; clear smooth.
Cb2 $87-148 \mathrm{~cm}$
dark grayish brown ( $2.5 \mathrm{Y} 4 / 2$ ) clay loam with $10 \%$ olive (5Y $5 / 3$ ); 30 to $40 \%$ pebbles 0.3 to 1.5 $\mathrm{cm}$ diameter, subrounded, poorly sorted, and matrix supported chert and limestone; shale clasts; clear smooth.
Agb3 148-168 cm dark grayish brown (2.5Y 4/2) clay with 5\% light olive brown (2.5Y 5/3) and few bluish gray (5B 6/1) redox depletion zones; weak coarse angular blocky; extremely firm; $1 \%$ pebbles 0.5 to $1 \mathrm{~cm}$ diameter; clear smooth (carbon-14 age of $1220 \pm 70$, Beta 90717).
Cgb3 168-188 cm bluish gray (5B 5/1) clay loam with common distinct light olive brown (2.5Y 5/4) diffuse redox 
concentrations; $20 \%$ pebbles and cobbles 0.3 to $3 \mathrm{~cm}$ diameter, poorly sorted, subrounded and clast supported; water table at $170 \mathrm{~cm}$.

\section{BHT-4; T1; 10-12 ft above modern channel; calcareous throughout.}

A $\quad 0-11 \mathrm{~cm} \quad$ (Unit III); very dark gray (2.5Y 3/1) silty clay loam; moderate fine subangular blocky; firm; few fine pebbles; clear smooth.

Ab1 11-29 cm (Unit III); black (10YR 2/1) clay loam; moderate medium subangular; firm; $15 \%$ pebbles 0.5 to $1.5 \mathrm{~cm}$ diameter, subrounded, moderately well sorted and matrix supported; gradual smooth.

Bwb1 29-71 cm (Unit III); very dark gray (10YR 3/1) clay; weak coarse prismatic; extremely firm; $2 \%$ pebbles 0.2 to $2 \mathrm{~cm}$ diameter, diffuse and subrounded; abrupt smooth.

Cb1 71-89 cm (Unit III); dark grayish brown (2.5Y 4/2) clay; massive; extremely firm; $15 \%$ pebbles and cobbles 0.2 to $4 \mathrm{~cm}$ diameter, poorly sorted, subrounded and diffuse; abrupt smooth.

Ab2 89-102 cm (Unit III); grayish brown (2.5Y 5/2) clay loam with common distinct light yellowish brown (2.5Y $6 / 3$ ) and few distinct orange diffuse redox concentrations; weak coarse angular blocky; extremely firm; $1 \%$ pebbles; abrupt smooth (carbon-14 age of 1830 \pm 70 , Beta 90718).

Bkb2 102-109 cm (Unit III); light brownish gray (2.5Y 6/2) silty clay loam with few distinct dark yellowish brown (10YR 4/6) diffuse redox concentrations; weak coarse angular blocky; very firm; 1 to $2 \%$ white and soft $\mathrm{CaCO}_{3}$ nodules $0.5 \mathrm{~cm}$ diameter; $5 \%$ fine pebbles, diffuse; shale fragments; abrupt smooth.

$\mathrm{Cb2} \quad 109-161 \mathrm{~cm}$ (Unit II); grayish brown (2.5Y 5/2), light olive brown (2.5Y 5/6), and dark yellowish brown (10YR 3/6); 60\% pebbles and cobbles 0.5 to $3 \mathrm{~cm}$ diameter, moderately well sorted, subrounded, and clast supported; abrupt wavy.

Cb2 161-295 cm (Unit II); pale olive (5Y 6/3) clay loam with common distinct brown and diffuse redox concentrations; $1 \%$ white and soft $\mathrm{CaCO}_{3}$ nodules $1 \mathrm{~cm}$ diameter; 15 to $20 \%$ pebbles 0.2 to $1 \mathrm{~cm}$ diameter; down to $295 \mathrm{~cm}$ cobbles increase in diameter to $10 \mathrm{~cm}$ water table at $295 \mathrm{~cm}$.

BHT-5; T0; Unit II; 6-8 ft above modern channel; calcareous throughout.

A $\quad 0-20 \mathrm{~cm} \quad$ very dark gray (2.5Y 2.5/1) silty clay; moderate fine subangular blocky; firm; few fine pebbles; clear smooth.

Ab1 20-48 cm very dark grayish brown (10YR 3/2) clay; weak coarse angular blocky; very firm; $25 \%$ pebbles 0.5 to $1.5 \mathrm{~cm}$ diameter, moderately well sorted, subrounded and matrix supported; clear smooth.

Bgb1 $48-58 \mathrm{~cm} \quad$ grayish brown (10YR 5/2) clay; weak coarse angular blocky; very firm; 2 to $3 \%$ pebbles 0.5 to $1.5 \mathrm{~cm}$ diameter, moderately well sorted, subrounded and matrix supported; clear smooth.

Bkgb1 $58-81 \mathrm{~cm} \quad$ gray $(2.5 \mathrm{Y} 6 / 1$ ) clay loam with common distinct olive yellow (2.5Y 5/6) diffuse redox concentrations; moderate coarse angular blocky; very firm; $1 \%$ white and soft $\mathrm{CaCO}_{3}$ nodules 1 cm diameter; abrupt wavy.

Cb1 81-95 cm dark gray (2.5Y 4/1) clay loam; massive; $40 \%$ pebbles and cobbles 0.5 to $6 \mathrm{~cm}$ diameter, poorly sorted, subrounded and matrix supported; abrupt wavy.

$\mathrm{Bkgb2} 95-120 \mathrm{~cm} \quad$ gray $(2.5 \mathrm{Y} 6 / 1)$ clay loam with common distinct light olive brown (2.5Y 5/6) diffuse redox concentrations; weak coarse prismatic; extremely firm; $1 \%$ white and soft $\mathrm{CaCO}_{3}$ nodules $1 \mathrm{~cm}$ diameter; shale clasts. 


\section{BHT-6; T0/T1 scarp; Unit III; 7-9 ft above modern channel; Calcareous throughout.}

A $\quad 0-11 \mathrm{~cm} \quad$ very dark grayish brown (10YR 3/2) silty clay loam; moderate medium subangular blocky; very firm; clear smooth.

A1b1 11-30 cm very dark gray (10YR 2.5/1) silty clay; weak coarse angular blocky; extremely firm; $2 \%$ fine pebbles; clear smooth.

A2b1 30-52 cm very dark gray (10YR 2.5/1) silty clay; weak coarse angular blocky; very firm; 5 to $8 \%$ fine pebbles 0.2 to $1 \mathrm{~cm}$ diameter; clear smooth.

$\mathrm{Cb} 152-70 \mathrm{~cm}$ dark gray $(2.5 \mathrm{Y} 5 / 1)$ clay loam; massive; very firm; 5 to $8 \%$ pebbles 0.2 to $1.5 \mathrm{~cm}$ diameter, moderately well sorted, subrounded and clast supported; abrupt smooth.

Ab2 70-82 cm dark gray (2.5Y 4.5/2) silty clay loam; weak coarse prismatic; very firm; $2 \%$ pebbles, gravel line at top; abrupt wavy.

Bgb2 82-115 cm light olive gray (5Y 6/2) silty clay loam with few patches of olive gray (2.5Y 4/2) and olive (5Y 5/6); weak coarse prismatic; very firm; $1 \%$ pebbles, poorly sorted; shale clasts; abrupt wavy.

Ab3 $\quad 115-130 \mathrm{~cm}$ very dark grayish brown (10YR 3.5/2) silty clay loam; weak coarse prismatic; very firm; $5 \%$ pebbles like above; abrupt wavy.

Cb3 130-152 cm dark grayish brown (2.5Y 4/2) clay loam; $60 \%$ pebbles and cobbles 0.5 to $5 \mathrm{~cm}$ diameter, moderately well sorted, subrounded and clast supported.

\section{BHT-7; T1; Unit II; 10-15 ft above modern channel. Calcareous throughout.}

A $\quad 0-22 \mathrm{~cm}$

Bw $\quad 22-49 \mathrm{~cm}$

Bk1 $\quad 49-79 \mathrm{~cm}$

$\mathrm{Bk} 2 \quad 79-111 \mathrm{~cm}$

Bk3 $\quad 111-170 \mathrm{~cm}$ black (10YR 2/1) silty clay loam; moderate medium angular blocky; very firm; $2 \%$ pebbles 0.5 to $1 \mathrm{~cm}$ diameter, subrounded and diffuse; gradual smooth.

very dark grayish brown (10YR 3/2) silty clay loam; weak coarse prismatic; very firm; 3 to $4 \%$ fine pebbles; abrupt smooth.

dark yellowish brown (10YR 4.5/4); 60\% pebbles 1 to $2 \mathrm{~cm}$ diameter, moderately well sorted, clast supported; $1-2 \% \mathrm{CaCO}_{3}$ filaments on gravel bottoms; clear smooth.

yellowish brown (10YR 5/4); $70 \%$ pebbles and cobbles 0.5 to $7 \mathrm{~cm}$ diameter, poorly sorted, clast supported and subrounded; $2 \% \mathrm{CaCO}_{3}$ filaments on gravel bottoms up to $3 \mathrm{~mm}$ thick; clear smooth.

gray (10YR 5/1) and yellowish brown (10YR 5/6); $70 \%$ pebbles and cobbles 0.5 to $7 \mathrm{~cm}$ diameter, poorly sorted, clast supported and subrounded; nearly continuous coating of $\mathrm{CaCQ}$ on gravel bottoms up to $3 \mathrm{~mm}$ thick.

\section{BHT-8; T2; Unit I; 25-30 ft above channel.}

A $\quad 0-10 \mathrm{~cm}$

A2 $\quad 10-18 \mathrm{~cm}$

$\mathrm{AB} \quad 18-45 \mathrm{~cm}$

Bss $\quad 45-83 \mathrm{~cm}$

Bssk $\quad 83-109 \mathrm{~cm}$

Bk1 $\quad 109-130 \mathrm{~cm}$ black (10YR 2/1) silty clay loam; moderate fine subangular blocky; friable; occasional $1 \mathrm{~cm}$ pebble; noncalcareous; gradual smooth.

black (10YR 2/1) silty clay; weak coarse angular blocky; very firm; occasional $1 \mathrm{~cm}$ pebble; moderately effervescent; gradual smooth.

very dark grayish brown (10YR 3/2) silty clay; weak coarse angular blocky; very firm; $2 \%$ pebbles 0.2 to $1 \mathrm{~cm}$ diameter; gradual smooth; calcareous; gradual smooth.

very dark grayish brown (10YR $3 / 2$ ) silty clay with $30 \%$ infills of olive brown ( $2.5 \mathrm{Y} 4 / 3)$ and $30 \%$ black (10YR 2/1); weak coarse angular blocky; very firm; few slickensides; 2 to $3 \%$ pebbles 0.5 to $1 \mathrm{~cm}$ diameter; calcareous; gradual smooth.

brown (10YR 5/3) silty clay with $30 \%$ very dark grayish brown (10YR $3 / 2)$ infills; weak coarse angular blocky; very firm; common slickensides; $1 \% \mathrm{CaCO}_{3}$ nodules $0.5 \mathrm{~cm}$ diameter; 2 to $3 \%$ pebbles 0.5 to $1 \mathrm{~cm}$ diameter; calcareous; gradual smooth.

brownish yellow (10YR 6/6) and olive brown (2.5Y 5/3) clay; weak coarse prismatic; firm; $2 \%$ $\mathrm{CaCO}_{3}$ nodules $0.5 \mathrm{~cm}$ diameter; 6 to $8 \%$ pebbles 0.5 to $1 \mathrm{~cm}$ diameter; calcareous; gradual smooth. 
Bk2 130-181 cm brownish yellow (10YR 6/6) silty clay loam with 5\% olive brown (2.5Y 5/3) and very dark grayish brown (10YR 3/2) infills; 8 to $10 \%$ brittle and white $\mathrm{CaCO}_{3}$ nodules 0.5 to $1 \mathrm{~cm}$ diameter; 6 to $8 \%$ pebbles 0.5 to $1 \mathrm{~cm}$ diameter; calcareous; clear smooth.

Bk3 181-190 cm yellowish brown (10YR 5/6) silty clay loam; weak coarse prismatic; very firm; $5 \%$ soft and white $\mathrm{CaCO}_{3}$ nodules; calcareous.

\section{BHT-9; T1; 10-15 ft above modern channel; calcareous throughout.}

A $\quad 0-21 \mathrm{~cm} \quad$ (Unit III); clay loam; moderate coarse subangular blocky; very firm; $1 \%$ pebbles 0.2 to $0.7 \mathrm{~cm}$ diameter; gradual smooth.

$\mathrm{Bw} \quad 21-63 \mathrm{~cm} \quad$ (Unit III); clay loam; weak coarse angular blocky; very firm; $1 \%$ pebbles 0.2 to $0.7 \mathrm{~cm}$ diameter; abrupt smooth.

$\mathrm{Ck} \quad 63-106 \mathrm{~cm} \quad$ (Unit III); 70\% pebbles and cobbles 1 to $5 \mathrm{~cm}$ diameter, moderately well sorted, subrounded and clast supported; $1 \% \mathrm{CaCO}_{3}$ filaments on gravel bottoms; abrupt smooth.

Bk1b 106-149 cm (Unit II); clay; weak coarse prismatic; extremely firm; $1 \%$ pebbles $0.5 \mathrm{~cm}$ diameter; $8 \%$ white and soft $\mathrm{CaCO}_{3}$ nodules $0.5 \mathrm{~cm}$ diameter; clear smooth (carbon-14 age of $4890 \pm 80$, Beta 90719).

$\mathrm{Bk} 2 \mathrm{~b} \quad 149-180 \mathrm{~cm} \quad$ (Unit II); clay loam; weak coarse prismatic extremely firm; 10 to $12 \%$ white and soft $\mathrm{CaCO}_{3}$ nodules $1 \mathrm{~cm}$ diameter.

\section{BHT-10; T0; Unit III; 6-8 ft above the modern channel; calcareous throughout.}

A1 $\quad 0-10 \mathrm{~cm} \quad$ black (10YR $2 / 1)$ silty clay; moderate fine subangular blocky; friable; 1 to $2 \%$ pebbles $0.5 \mathrm{~cm}$ diameter; clear smooth.

A2 $\quad 10-30 \mathrm{~cm} \quad$ black (10YR 2.5/1) silty clay loam; moderate medium subangular blocky; friable; $30 \%$ pebbles 0.5 to $2 \mathrm{~cm}$ diameter, moderately well sorted; clear wavy.

A3 $\quad 30-50 \mathrm{~cm} \quad$ very dark gray (10YR 3/1) silty clay; weak medium subangular blocky; friable; $55 \%$ pebbles and cobbles 0.5 to $8 \mathrm{~cm}$ diameter, poorly to moderately well sorted and clast supported; abrupt smooth.

Ab1 50-68 cm very dark grayish brown (2.5Y 3/2) clay with 5\% patches of olive brown (2.5Y 4/4); moderate coarse angular blocky; firm; $1 \%$ fine pebbles; gradual smooth.

Bkb1 $68-86 \mathrm{~cm} \quad$ very dark grayish brown (2.5Y 3.5/2) clay; weak coarse angular blocky; very firm; $1 \% \mathrm{CaCO}_{3}$ filaments; 5 to $8 \%$ pebbles and cobbles 0.5 to $3 \mathrm{~cm}$ diameter; clear smooth.

$\mathrm{Cb} 1 \quad 86-99 \mathrm{~cm} \quad$ olive brown $(2.5 \mathrm{Y} 4 / 4) ; 70 \%$ pebbles and cobbles 0.3 to $5 \mathrm{~cm}$ diameter, clast supported; abrupt smooth.

Akb2 99-118 cm very dark grayish brown (2.5Y 3/2) clay; weak coarse angular blocky; very firm; $5 \%$ white and brittle $\mathrm{CaCO}_{3}$ nodules 0.25 to 0.5 diameter; 6 to $8 \%$ pebbles $0.5 \mathrm{~cm}$ diameter; gradual smooth (carbon-14 age of $1780 \pm 90$, Beta 90720 ).

Bgb2 118-162 cm gray (5Y 6/1) clay; common distinct yellowish brown (10YR 5/6) diffuse redox concentrations; weak coarse prismatic; extremely firm; gravel line in middle of horizon; abrupt wavy.

$\mathrm{Cb} 2162-177+\mathrm{cm}$ dark greenish gray (5GY 4/1); $60 \%$ pebbles and cobbles 1 to $8 \mathrm{~cm}$ diameter. 


\section{Leon Creek}

CB-1; floodplain; $10 \mathrm{ft}$ above modern channel; calcareous throughout.

C $\quad 0-65 \mathrm{~cm}$ mixed very dark grayish brown (10YR 3/2), light olive brown (2.5Y 5/4), and light brownish gray (2.5Y 6/2) clay and clay loam artificial overburden; massive; $30 \%$ matrix supported pebbles and cobbles; scattered $\mathrm{CaCO}_{3}$ nodules; abrupt wavy.

$\mathrm{Ab} \quad 65-81 \mathrm{~cm} \quad$ very dark grayish brown (2.5Y 3/2) and dark grayish brown (2.5Y 4/2) sandy clay loam; massive to platy; firm; $5 \%$ siliceous cobbles; clear smooth.

$\mathrm{Bk} 1 \mathrm{~b} \quad 81-131 \mathrm{~cm} \quad$ brown (10YR 4/3) sandy clay loam; moderate coarse prismatic; very hard; $2 \% \mathrm{CaCO}_{3}$ filaments; $2 \%$ diffuse pebbles 0.3 to $0.5 \mathrm{~cm}$ diameter; sand patches in lower part; clear smooth.

$\mathrm{Bk} 2 \mathrm{~b} \quad 131-171 \mathrm{~cm}$ brown (10YR 5/3) sandy clay loam; moderate coarse prismatic; very hard; 3 to $4 \% \mathrm{CaCO}_{3}$ filaments; gradual smooth.

C1b 171-220 cm dark yellowish brown (10YR 4/4) sandy clay loam; massive; few diffuse pebbles in upper part; clear smooth.

$\mathrm{C} 2 \mathrm{~b} \quad 171-220+\mathrm{cm} 60 \%$ pebbles and cobbles 0.5 to $4 \mathrm{~cm}$ diameter, moderately well sorted, clast supported, and subrounded; water line at $4.0 \mathrm{~m}$.

\section{CB-2; terrace; $20 \mathrm{ft}$ above modern channel; calcareous throughout.}

C $\quad 0-15 \mathrm{~cm} \quad$ dark brown overburden with $30 \%$ cobbles.

A $\quad 15-25 \mathrm{~cm} \quad$ very dark grayish brown (10YR 3/2) clay loam; moderate medium subangular blocky; friable; $2 \%$ diffuse pebbles; clear smooth.

A2 25-54 cm black (10YR 2/1) clay loam; moderate medium subangular blocky; friable; $2 \%$ diffuse pebbles; clear smooth.

BA $\quad 54-71 \mathrm{~cm} \quad$ black (10YR 2/1) sandy clay loam; strong fine subangular blocky; friable; $30 \%$ pebbles 0.5 to $1 \mathrm{~cm}$ diameter, matrix supported; clear smooth.

Bk1 71-110 cm dark brown (10YR 3/3) sandy clay loam; thin patchy $\mathrm{CaCO}_{3}$ pendants on cobble bottoms; $50 \%$ pebbles and cobbles 0.5 to $3 \mathrm{~cm}$ diameter, moderately well sorted, clast supported, and subrounded; abrupt smooth.

Bk2 110-132 cm yellowish brown (10YR 5/4); 70\% pebbles and cobbles 0.2 to $0.5 \mathrm{~cm}$ and 1 to $5 \mathrm{~cm}$ diameter; abrupt smooth.

Bk3 132-158 cm brown (10YR 4/3) sandy clay loam; weak coarse prismatic; $10 \% \mathrm{CaCO}_{3}$ filaments and patchy pendants on cobble bottoms; 30 to $40 \%$ pebbles and cobbles 0.5 to $5 \mathrm{~cm}$ diameter, moderately well sorted, clast supported, and subrounded; dispersed charcoal; abrupt smooth.

Bk4 158-225 cm yellowish brown (10YR 5/6); 70\% pebbles and cobbles 0.5 to $5 \mathrm{~cm}$ diameter, moderately well sorted, clast supported, and subrounded, horizontal bedding planes; common patchy $\mathrm{CaCO}_{3}$ cobble pendants; abrupt wavy.

Bk5 225-255 cm yellowish brown (10YR 5/4) sandy clay loam; massive; few patchy $\mathrm{CaCO}_{3}$ cobbles pendants; $5 \%$ diffuse pebbles 0.5 to $2 \mathrm{~cm}$ diameter; abrupt wavy.

Bk6 255-303 cm strong brown (7.5YR 5/6) sandy clay loam; weak coarse prismatic; 7 to $8 \% \mathrm{CaCO}_{3}$ filaments; very firm; upper and lower boundaries marked by $15 \mathrm{~cm}$ thick gravel lines, 0.5 to $6 \mathrm{~cm}$ diameter; abrupt wavy.

Bk7 303-364 cm yellowish brown (10YR 5/4) sandy clay loam; weak coarse prismatic; firm; $3 \% \mathrm{CaCO}_{3}$ filaments; 2 to $3 \%$ pebbles and cobbles; abrupt wavy.

Bk8 364-381 cm yellowish brown (10YR 6/6) silty clay loam; weak coarse prismatic; very firm; $3 \% \mathrm{CaCO}_{3}$ filaments; abrupt smooth.

C $\quad 381-430 \mathrm{~cm}$ strong brown (7.5YR 5/6); 70\% pebbles and cobbles 0.5 to $5 \mathrm{~cm}$ diameter, well sorted, clast supported, and subrounded, horizontal bedding planes. 


\section{Appendix B: Taxonomic Lists of Fossils}

\section{James O. Jones}

Table B-1. Microfossils Recovered From The Navarro Group

Lackland Air Force Base Annex-Medio Creek Valley, L21, G21

\begin{tabular}{|c|c|}
\hline Kingdom & Protista \\
\hline Phylum & Protozoa \\
\hline Class & Rhizopoda \\
\hline Order & Foraminifera \\
\hline Suborder & Rotaliina \\
\hline Family & Alabaminidae \\
\hline Genus & Gyroidina \\
\hline species & depressa \\
\hline species & girardana \\
\hline species & semicomplanata \\
\hline Family & Anomalinidae \\
\hline Genus & Anomalina \\
\hline species & pinguis \\
\hline species & pseudopapillosa \\
\hline Family & Ceratobulininidae \\
\hline Genus & Epistomina \\
\hline species & limbata \\
\hline Family & Discorbidae \\
\hline Genus & Valvulineria \\
\hline species & umbilicata (?) \\
\hline Family & Globigerinidae \\
\hline Genus & Globigerina \\
\hline species & rugosa \\
\hline Genus & Heterohelix \\
\hline species & navarrowensis \\
\hline Genus & Pseudoguembelina \\
\hline species & excolata \\
\hline Family & Loxostomidae \\
\hline Genus & Loxostomum \\
\hline species & gemma (?) \\
\hline Family & Nodosariidae \\
\hline Genus & Frondicularia \\
\hline species & verneuiliana \\
\hline
\end{tabular}




\begin{tabular}{|c|c|}
\hline $\begin{array}{l}\text { Genus } \\
\text { species }\end{array}$ & $\begin{array}{l}\text { Lenticulina } \\
\text { navarrowensis }\end{array}$ \\
\hline $\begin{array}{l}\text { Genus } \\
\text { species } \\
\text { species } \\
\text { species } \\
\text { species }\end{array}$ & $\begin{array}{l}\text { Dentalina } \\
\text { basiplanata } \\
\text { gracilis } \\
\text { legumen } \\
\text { lorneiana }\end{array}$ \\
\hline $\begin{array}{l}\text { Genus } \\
\text { species }\end{array}$ & $\begin{array}{l}\text { Lagena } \\
\text { hispida }\end{array}$ \\
\hline Suborder & Textulariina \\
\hline Family & Ataxophragmiidae \\
\hline $\begin{array}{l}\text { Genus } \\
\text { species }\end{array}$ & $\begin{array}{l}\text { Gaudryina } \\
\text { navarroana }\end{array}$ \\
\hline $\begin{array}{l}\text { Family } \\
\text { Genus } \\
\text { species }\end{array}$ & $\begin{array}{l}\text { Lituolidae } \\
\text { Flabellllammina } \\
\text { magna }\end{array}$ \\
\hline $\begin{array}{l}\text { Genus } \\
\text { species }\end{array}$ & $\begin{array}{l}\text { Haplophragmoides } \\
\text { glaber }\end{array}$ \\
\hline $\begin{array}{l}\text { Family } \\
\text { Genus } \\
\text { species }\end{array}$ & $\begin{array}{l}\text { Textulariidae } \\
\text { Spiroplectammina } \\
\text { laevis }\end{array}$ \\
\hline $\begin{array}{l}\text { Suborder } \\
\text { Family } \\
\quad \text { Genus } \\
\text { species }\end{array}$ & $\begin{array}{l}\text { Miliolina } \\
\text { Miliolidae } \\
\text { Quinqueloculina } \\
\text { sp. }\end{array}$ \\
\hline
\end{tabular}

Kingdom

Phylum

Class

Subclass

Order

Family

Genus

species

Animalia

Arthropoda

Crustacea

Ostracoda

Podocopida

Bairdiidae

Bairdoppilata

magna

Family

Cytherellidae

Genus

Cytherella

species movemani

species navarroensis

species

tuberculifera

Family

Cytherideidae

Genus Haplocytherida

species sp. 


\begin{tabular}{|c|c|}
\hline $\begin{array}{l}\text { Family } \\
\quad \text { Genus } \\
\text { species }\end{array}$ & $\begin{array}{l}\text { Cytherideidae } \\
\text { Haplocytheridea } \\
\text { sp. }\end{array}$ \\
\hline $\begin{array}{l}\text { Family } \\
\text { Genus } \\
\text { species }\end{array}$ & $\begin{array}{l}\text { Loxoconchidae } \\
\text { Loxoconcha } \\
\text { cretacea }\end{array}$ \\
\hline $\begin{array}{l}\text { Family } \\
\qquad \begin{array}{l}\text { Genus } \\
\text { species }\end{array}\end{array}$ & $\begin{array}{l}\text { Trachyleberididae } \\
\text { Cythereis } \\
\text { huntensis }\end{array}$ \\
\hline $\begin{array}{l}\text { Family } \\
\text { Genus } \\
\quad \text { species }\end{array}$ & $\begin{array}{l}\text { Cytheruridae } \\
\text { Cytheropteron } \\
\text { navarroensis }\end{array}$ \\
\hline $\begin{array}{l}\text { Genus } \\
\text { species }\end{array}$ & $\begin{array}{l}\text { Cytherura } \\
\text { texana }\end{array}$ \\
\hline
\end{tabular}

Teeth (shark?)

Bored bivalve shells (sponge borings)

Burrows 
Table B-2. Megafossils Recovered From The Navarro Formation Medina Annex-Medio Creek Valley, L21, G21

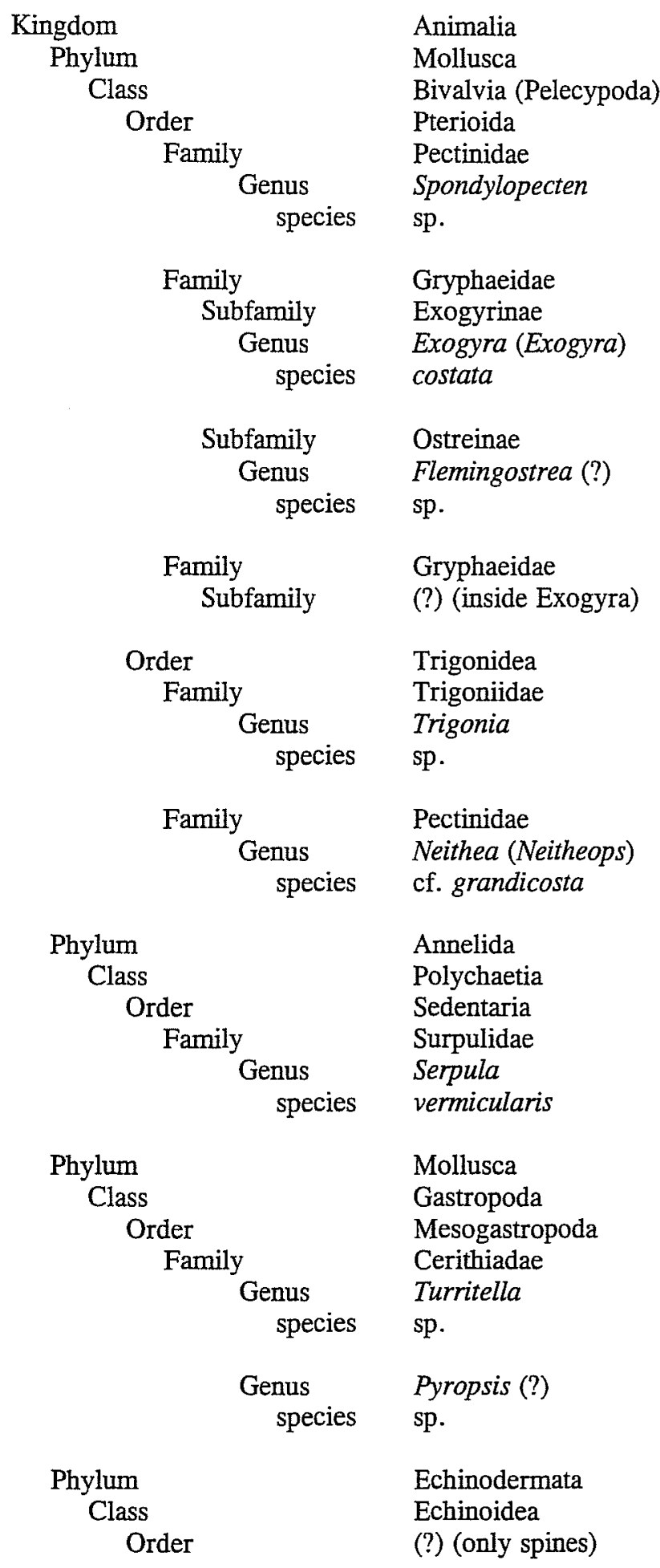

Numerous burrows in marl beds=Paleophycus (animal that caused them unknown) Numerous borings in shells $=$ sponge (?) 
Table B-3 . Microfossils Recovered From The Upper Taylor Group Lackland Air Force Base-Leon Creek Valley, J8, L3

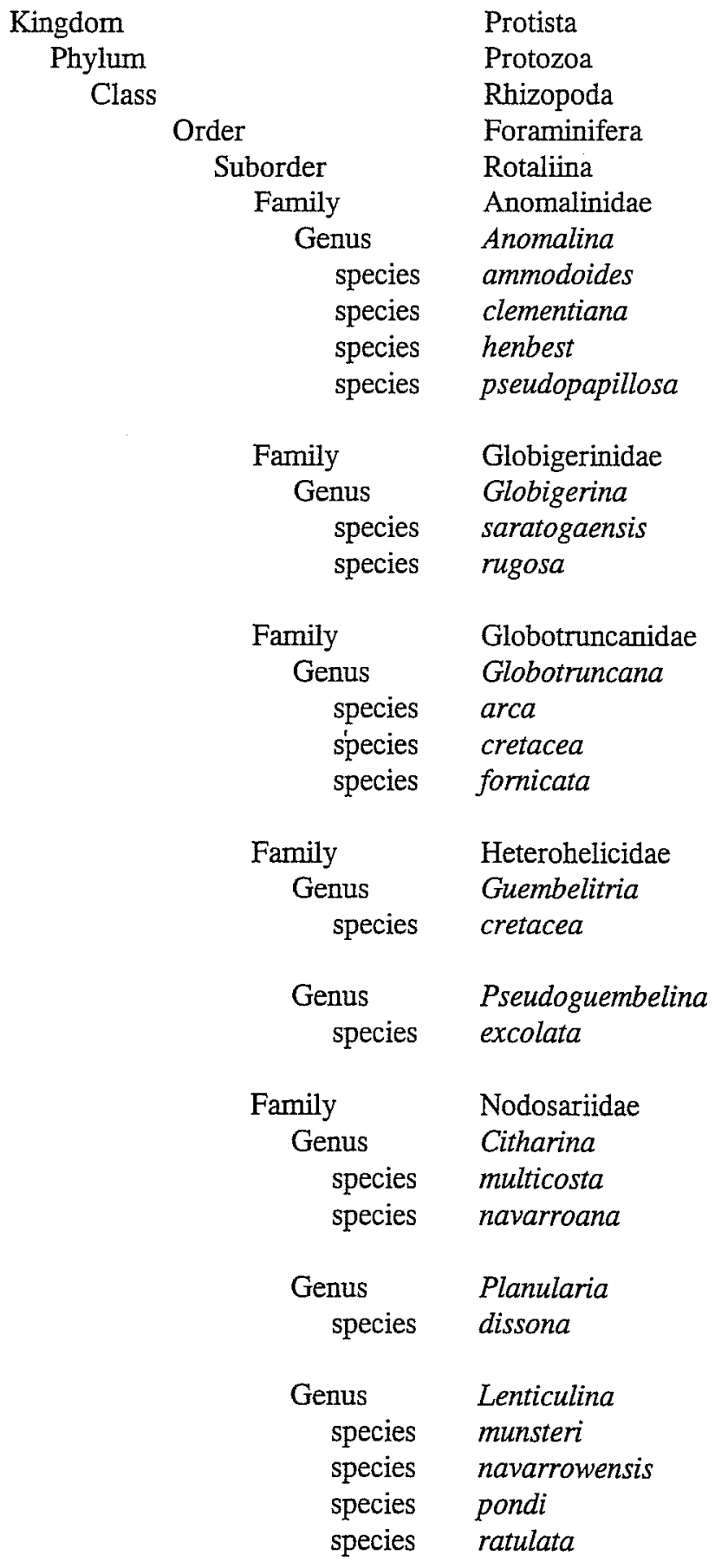




\begin{tabular}{|c|c|}
\hline $\begin{array}{l}\text { Genus } \\
\text { species } \\
\text { species } \\
\text { species } \\
\text { species } \\
\text { species }\end{array}$ & $\begin{array}{l}\text { Dentalina } \\
\text { alternata (?) } \\
\text { basitorta } \\
\text { intrasegma } \\
\text { lorneiana } \\
\text { megolopolitana }\end{array}$ \\
\hline $\begin{array}{l}\text { Genus } \\
\text { species } \\
\text { Genus } \\
\text { species }\end{array}$ & $\begin{array}{l}\text { Nodosaria } \\
\text { sp. } \\
\text { Lagena } \\
\text { cf. globosa }\end{array}$ \\
\hline $\begin{array}{l}\text { Family } \\
\text { Genus } \\
\text { species }\end{array}$ & $\begin{array}{l}\text { Planomalinidae } \\
\text { Planomalina (Anomalina) } \\
\text { dumblei (taylorensis) }\end{array}$ \\
\hline $\begin{array}{l}\text { Suborder } \\
\text { Family } \\
\text { Genus } \\
\text { species }\end{array}$ & $\begin{array}{l}\text { Textulariina } \\
\text { Ataxophragmiidae } \\
\text { Gaudryina } \\
\text { faujasi }\end{array}$ \\
\hline $\begin{array}{l}\text { Family } \\
\quad \text { Genus } \\
\text { species }\end{array}$ & $\begin{array}{l}\text { Lituolidae } \\
\text { Lituola } \\
\text { taylorensis }\end{array}$ \\
\hline
\end{tabular}

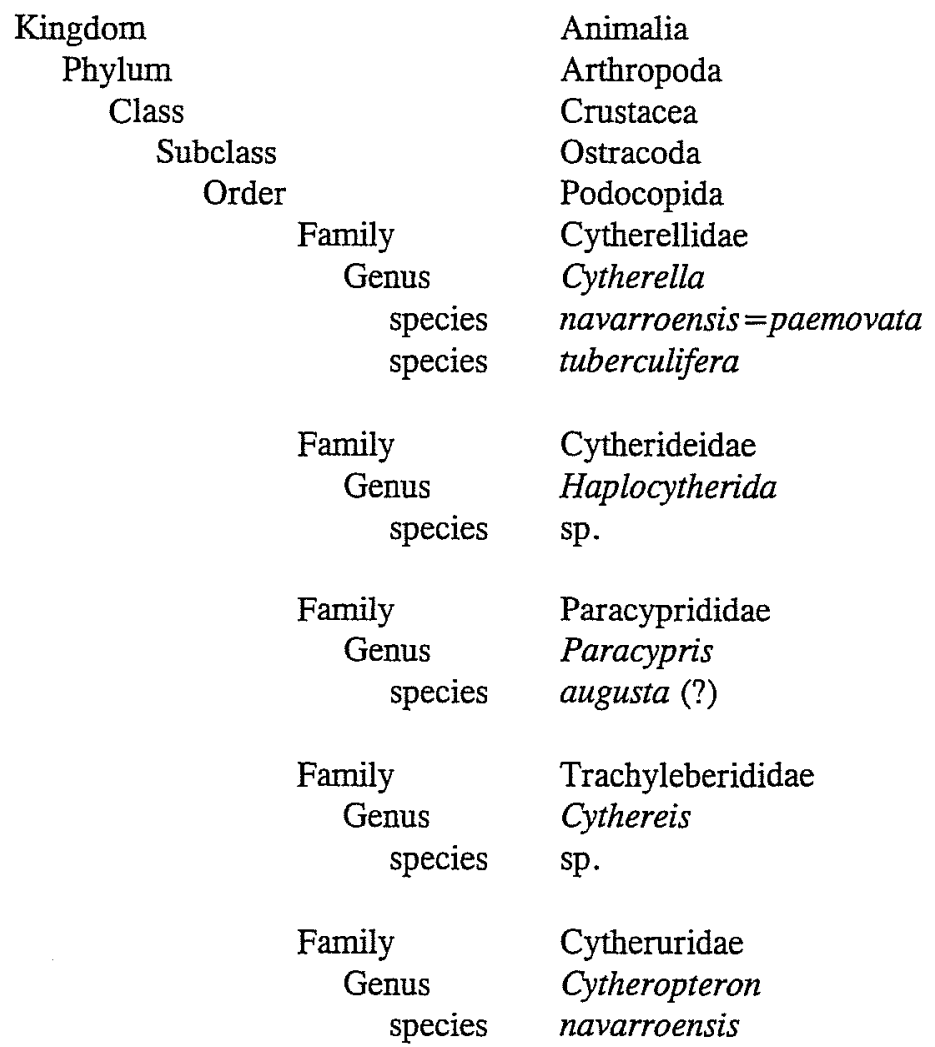


Table B-4. Megafossil Recovered From The Upper Taylor Group Lackland Air Force Base-Leon Creek Valley, J8, L3

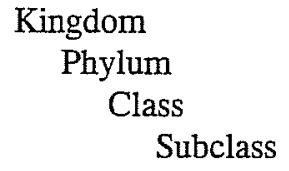

Animalia

Echinodermata

Echinoidea

(?) (only spines) 


\title{
Appendix C: Prime Beef-Prime RIBS Combat Arms Area Letter Report
}

\author{
Anna Jean Taylor
}

\section{Introduction}

In January 1994, the Center for Archaeological Research (CAR) of The University of Texas at San Antonio was contracted by the National Park Service to locate, evaluate, and report any prehistoric and historic cultural resources which might be affected by development of the Prime Beef-Prime RIB (PBPR) combat arms area at Lackland Air Force Base in southwestern San Antonio, Bexar County, Texas (Figure C-1). This area is located on the Macdona, Texas, USGS 7.5' topographic map. CAR staff archaeologist Anna J. Taylor, with the assistance of three to five crew members, conducted a pedestrian survey and shovel testing of the 62-acre proposed combat arms area from March 25-31, 1994. Surface visibility was extremely poor (0-10 percent) due to dense brush and leaf litter, so close-interval shovel testing was performed. A total of 294 shovel tests was excavated. Shovel test depths generally varied from $10-20 \mathrm{~cm}$, with the more shallow shovel tests located where thin soils and/or shallow subsurface chert gravel and cobble deposits occurred. Shovel tests were approximately $35 \mathrm{~cm}$ in diameter. The interval between shovel tests was approximately $30 \mathrm{~m}$. During the reconnaissance of the PBPR combat arms area, it became evident that certain parts of the survey area had been subjected to severe disturbance. Land modification, mainly indicated by mounding of earth and downed trees, was evident in the southwestern and south-central parts of the project area. A large pit, excavated as a land fill area, was present in the south-central project area. Construction of gravel or dirt roads within the area also resulted in disturbance. A drainage ditch or channel, possibly man-made, was observed in the northwestern part of the project area. Along the western boundary of the project area, modern trash had been discarded. Fire ant mounds and animal burrows and dens were evident in much of the survey area. In the eastern segment of the area, thorny brush was especially dense.

\section{Prehistoric Components}

Evidence of prehistoric human occupation of the project area consists of five lithic scatter sites with no surface evidence of chronologically diagnostic artifacts or cultural features, and six isolated finds consisting of chert debitage. All the prehistoric sites and isolated finds occurred in the western third of the project area. Each site and isolated find is discussed individually and site dimensions are presented in Table C-1. Table C-2 presents an inventory of artifacts recovered during shovel testing.

Table C-1. Listing of Dimensions and Area of Sites Prime 1 through Prime 5

\begin{tabular}{||c|c|c|c||}
\hline $\begin{array}{c}\text { Field } \\
\text { Designation }\end{array}$ & $\begin{array}{c}\text { N/S } \\
\text { Dimensions }\end{array}$ & $\begin{array}{c}\text { E/W } \\
\text { Dimensions }\end{array}$ & Area \\
\hline Prime 1 & $34.0 \mathrm{~m}$ & $20 \mathrm{~m}$ & $680 \mathrm{~m}^{2}$ \\
\hline Prime 2 & $13.5 \mathrm{~m}$ & $20 \mathrm{~m}$ & $270 \mathrm{~m}^{2}$ \\
\hline Prime 3 & $15.0 \mathrm{~m}$ & $38 \mathrm{~m}$ & $570 \mathrm{~m}^{2}$ \\
\hline Prime 4 & $20.0 \mathrm{~m}$ & $35 \mathrm{~m}$ & $700 \mathrm{~m}^{2}$ \\
\hline Prime 5 & $36.0 \mathrm{~m}$ & $26 \mathrm{~m}$ & $936 \mathrm{~m}^{2}$ \\
\hline
\end{tabular}




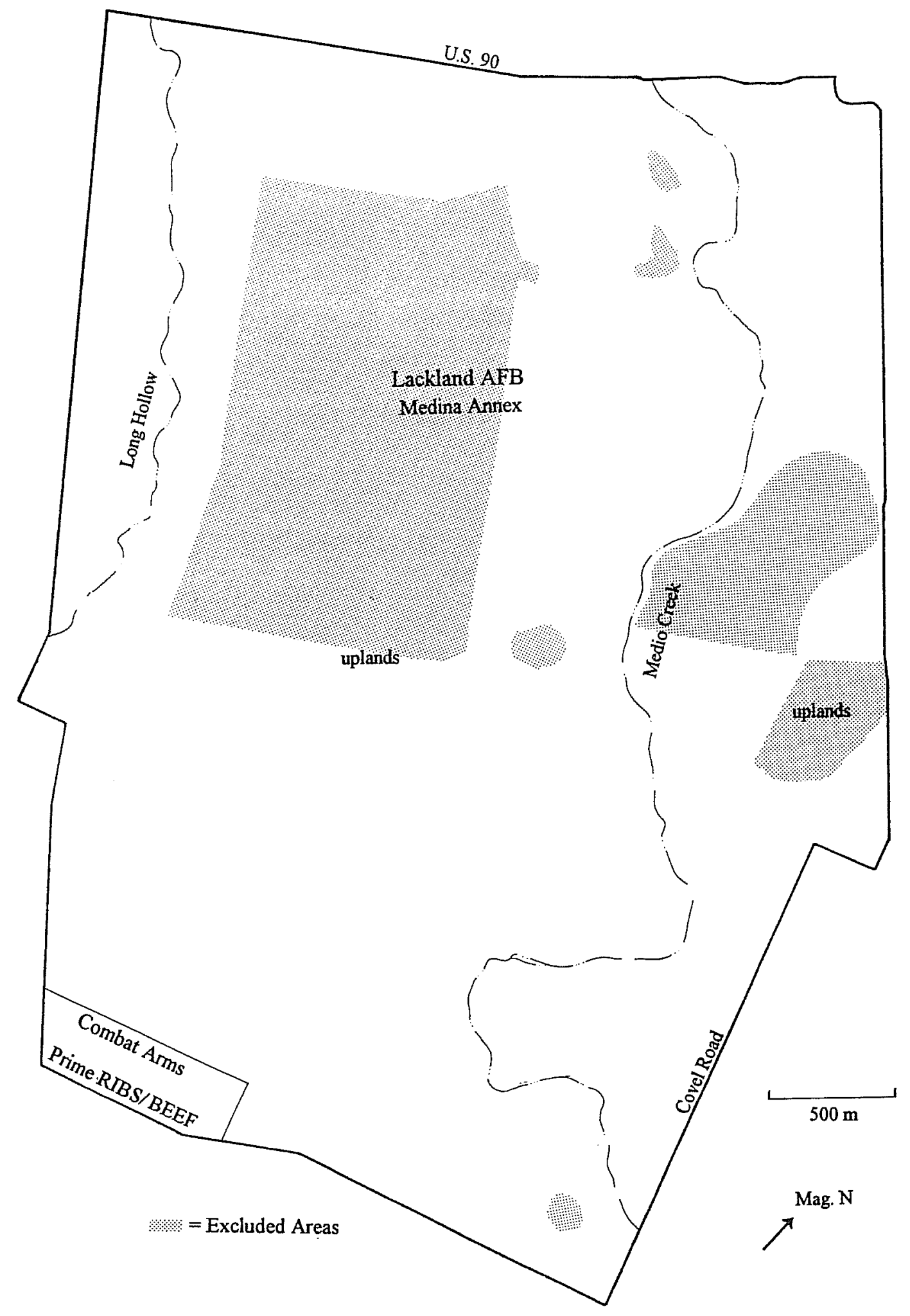

Figure C-1. Location of Prime Beef-Prime RIBS area. 
Table C-2. Artifacts Recovered from Shovel Tests on the Prime Beef-Prime RIBS Combat Arms Area

\begin{tabular}{|c|c|c|c|}
\hline Shovel Test & Site & $\overline{\text { Depth }}$ & Description \\
\hline \multicolumn{4}{|l|}{ Eastern Area } \\
\hline $\mathrm{AE} / 2$ & & $0-15 \mathrm{~cm}$ & 1 chert flake fragment \\
\hline \multicolumn{4}{|l|}{ Central Area } \\
\hline $\mathrm{FC} / 3$ & & $0-15 \mathrm{~cm}$ & 1 chert flake fragment \\
\hline $\mathrm{HC} / 3$ & & $0-15 \mathrm{~cm}$ & 1 chert flake fragment (heat fractured) \\
\hline $\mathrm{GC} / 3 \mathrm{~A}$ & & $0-15 \mathrm{~cm}$ & I chert flake fragment (heat fractured) \\
\hline \multirow[t]{2}{*}{$\mathrm{GC} / 3 \mathrm{~B}$} & & $0 \mathrm{~cm}$ & 1 chert flake \\
\hline & & $0-10 \mathrm{~cm}$ & 1 chert fragment (heat fractured) \\
\hline $\mathrm{JC} / 4$ & & $0-10 \mathrm{~cm}$ & 1 chert fragment (heat fractured) \\
\hline $\mathrm{KC} / 3$ & & $18-20 \mathrm{~cm}$ & 1 chert fragment (heat fractured) \\
\hline \multicolumn{4}{|l|}{ Western Area } \\
\hline $\mathrm{AW} / 6,5$ & Prime 5 & $\begin{array}{c}\text { surface, } \\
10 \mathrm{~m} \mathrm{w} \text {. of } \mathrm{AW} / 6\end{array}$ & 1 chert biface fragment \\
\hline $\mathrm{AW} / 9$ & Prime 5 & surface & 1 chert core \\
\hline $\mathrm{AW} / 9 \mathrm{~A}$ & Prime 5 & $2-10 \mathrm{~cm}$ & 6 chert flakes/fragments \\
\hline $\mathrm{AW} / 9 \mathrm{~B}$ & Prime 5 & $5 \mathrm{~cm}$ & 6 chert flakes, 5 fragments (some heat fractured) \\
\hline $\mathrm{AW} / 9 \mathrm{C}$ & Prime 5 & $10 \mathrm{~cm}$ & $\begin{array}{l}2 \text { split chert cobble fragments (fitted), } 1 \text { chert flake } \\
\text { fragment }\end{array}$ \\
\hline $\mathrm{AW} / 9 \mathrm{D}$ & Prime 5 & $10 \mathrm{~cm}$ & 2 chert flake fragments, 1 chert "chunk" from pebble \\
\hline $\mathrm{AW} / 9 \mathrm{E}$ & Prime 5 & $2-5 \mathrm{~cm}$ & 1 chert flake \\
\hline $\mathrm{GW} / 7 \mathrm{~B}$ & Prime 4 & $2 \mathrm{~cm}$ & 1 chert core fragment, 1 chert flake \\
\hline $\mathrm{IW} / 8$ & IF 1 & $0-5 \mathrm{~cm}$ & 1 chert flake \\
\hline $\mathrm{HW} / 8$ & IF 2 & $10 \mathrm{~cm}$ & 1 chert flake \\
\hline $\mathrm{KW} / 6$ & & $15 \mathrm{~cm}$ & 1 chert flake fragment \\
\hline $\mathrm{LW} / 12 \mathrm{~A}$ & & $10-30 \mathrm{~cm}$ & 1 cartridge, 1 chert flake fragment \\
\hline $\mathrm{LW} / 12 \mathrm{C}$ & & $0-50 \mathrm{~cm}$ & $\begin{array}{l}3 \text { chert fragments (heat fractured), } 1 \text { red ocher pebble } \\
\text { (unmodified) }\end{array}$ \\
\hline $\mathrm{XW} / 6$ & & $10 \mathrm{~cm}$ & 1 chert flake \\
\hline
\end{tabular}




\section{PBPR Sites}

\section{Prime 1}

Based on the spatial extent of lithic debitage, Prime 1 measures $34 \mathrm{~m}$ north-south and $20 \mathrm{~m}$ east-west. Prime 1 is a prehistoric site of unknown age consisting of a thin scatter of chert debitage located among an exposure of chert cobbles and pebbles, on a slight west-northwestern slope. Thin $(5-10 \mathrm{~cm}$ deep) deposits of grayish-brown loamy clay are present, as indicated by three shovel tests: IW/11B, $\mathrm{IW} / 11 \mathrm{~F}$, and $\mathrm{IW} / 12$ located at the western and eastern boundaries, and at the center of the site, respectively. Three additional shovel tests, were placed a short distance northwest and south of Prime 1. Natural impacts to the site include possible deflation, downslope erosion to the west, and animal burrows or dens. Moderate ground cover is present.

A possible man-made channel cuts across the center of the site and adjoins the western edge of site Prime 2. Prime 1 is located in the vicinity of the IW/11 shovel probe, and $30 \mathrm{~m}$ east of a paved road. The possible channel ran north-south, against the natural land slope, and is extremely straight with no meandering. An apparently disturbed earth mound is located approximately $25 \mathrm{~m}$ southwest of shovel probe IW/12 within site Prime 1.

Cultural materials, all made of chert, consist of primary, secondary, and tertiary flakes, a few of which are possibly modified; cores; scrapers; and a hammerstone. No chronologically diagnostic artifacts were found at Prime 1 . No cultural material was recovered from the shovel tests, and none of the cultural material on the surface was collected. On the northern side of the channel, five flakes were situated within a $1 \mathrm{~m}^{2}$ area. However, for the majority of this site, artifact density is considerably less. Heat-spalled chert was observed at Prime 1, and naturally occurring broken chert cobbles and pebbles are present along the channel within the site area. Pieces of asphalt with gravel inclusions are also located within the site.

\section{Prime 2}

Based on the spatial extent of lithic debitage, Prime 2 measures $13-14 \mathrm{~m}$ north-south and $20 \mathrm{~m}$ eastwest. Ground cover is moderately dense. This prehistoric site of unknown age consists of a thin scatter of chert debitage situated among an exposure of chert pebbles located on a slight westnorthwestern slope. Generally thin (from about 5-50 $\mathrm{cm}$ in depth) deposits of brown loamy clay are present, as indicated by three shovel tests (LW12, $\mathrm{LW} / 12 \mathrm{~A}$, and $\mathrm{LW} / 12 \mathrm{~B}$ ) located near the eastern and western site boundaries. An additional shovel probe, $\mathrm{LW} / 12 \mathrm{C}$, was located $19 \mathrm{~m}$ southeast of the site.

Prime 2 is located approximately six meters south of a paved road. A man-made channel is located immediately west of this site and also cuts through site Prime 1. A disturbed area with mounded earth is located immediately north of the site, and occurs along the southern side of a paved road, between the road and the site.

Cultural material observed at Prime 2 consists of three primary flakes, a secondary flake, a tertiary flake, and six cores, all of chert. From shovel test $\mathrm{LW} / 12 \mathrm{~A}$, excavated to a depth of $30-35 \mathrm{~cm}$, both a thinning flake and a spent cartridge were recovered about $10 \mathrm{~cm}$ below surface, and a second flake was recovered from ca. $30 \mathrm{~cm}$ below surface. From shovel test $\mathrm{LW} / 12 \mathrm{C}$, excavated to a depth of $50 \mathrm{~cm}$, four flakes and a piece of red ocher were recovered.

At this and the other prehistoric sites found within the PBPR area, discriminating between some of the cultural chert debitage and the chert debris resulting from road construction, land modification, brush burning, and stream rolling, is often difficult. Numerous spent cartridges, a railroad tie, a dummy grenade handle, and a few pieces of asphalt with gravel inclusions were also observed at this site. 


\section{Prime 3}

Based on the spatial extent of lithic debitage, Prime 3 measures $15 \mathrm{~m}$ north-south and $38 \mathrm{~m}$ east-west. Prime 3, a prehistoric site of unknown age, consists of a thin scatter of chert debitage, and was initially designated IF 4. It is located at the edge of a high rise, above a southern slope, upon an exposure of chert cobbles and pebbles. Based on shovel tests $\mathrm{BW} / 6$ and $\mathrm{BW} / 6 \mathrm{~A}$ within the east-central part of the site, and shovel tests BW/6B, BW/6C, and BW/6D immediately north and southeast of the site boundaries, the soil cover consists of a medium brown sandy clay loam. The soil is generally absent or very scanty (ca. $0-10 \mathrm{~cm}$ in depth). A dirt road cuts generally east-west through much of this site, and what appear to be military foxholes are present.

Lithic artifacts, all made of chert, consist of a "turtle back"-shaped flake scrape; two secondary flake, a tertiary flake, a tertiary flake that appears to be trimmed, a multi-directional core, a core fragment; and a tested cobble. Additionally, spent rifle cartridges were recovered to a depth of $10 \mathrm{~cm}$ in shovel test BW/6A.

\section{Prime 4}

Based on the spatial extent of lithic debitage, Prime 4 measures $20 \mathrm{~m}$ north-south and $35 \mathrm{~m}$ east-west. A prehistoric site of unknown age, Prime 4 is located at the top of the slope of a high rise which drops off to the west. A dirt road is located approximately 63 $\mathrm{m}$ south of the site. Vegetation at Prime 4 is moderately dense.

Based upon the findings from shovel tests FW/7A through FW/7D (located in the southwestern, northwestern, central, and southeastern parts of the site), the deposits of medium brown sandy clay loam present at Prime 4 appear deeper $(15-20 \mathrm{~cm}$ or more) than the soil deposits observed at other sites within the project area.

Site Prime 4 consists of a scatter of chert debitage. The site is largely disturbed by animal burrows or dens and military foxholes. Mounded earth possibly resulting from heavy machinery activity is also evident.

Artifacts, all chert, observed at Prime 4 consist of one primary flake; seven secondary flakes; four tertiary flakes, including one from shovel test GW/7B; four cores; one exhausted core; six core fragments, including one recovered from shovel test GW/7B; one core or core tool; one crude biface; and one small, thick biface with battered edges. Whether certain of these artifacts were culturally produced or resulted from colluvial activity or from modern land modification is difficult to determine.

\section{Prime 5}

Based on the extent of lithic debitage, Prime 5 measures $36 \mathrm{~m}$ north-south and $26 \mathrm{~m}$ east-west. Prime 5, a prehistoric site of unknown age, is located on the top and down the eastern slope of a small hill, a short distance north of Long Hollow Creek. Vegetation is moderately dense. The site consists of a thin scatter of chert debitage. Based on shovel tests $\mathrm{AW} / 9$ and AW/9A through AW/9D (in the north, east, west, and central parts of the site), the deposits of dark grayish-brown, sandy-clay loam present at the site are generally thin (about 5-20 cm deep). Dirt roads are located immediately north and west of the site.

Modern disturbance evident at Prime 5 includes military foxholes in the northern and western parts of the site, and road construction immediately north and west of the site. Natural disturbance includes erosion, animal burrows and dens, and fire ant mounds.

Artifacts observed on the site surface consist of one primary flake, six secondary flakse, four cores, and one core or core tool. Flakes were recovered from shovel tests AW/9A (from 2-10 cm depth), AW/9B (ca. $5 \mathrm{~cm}$ depth), AW/9C (ca. $10 \mathrm{~cm}$ depth), possibly AW/9D (10 cm depth), and AW/9E (ca. 2-5 cm depth). Numerous spent cartridges, dummy grenades, and plastic fragments are also present. 


\section{PBPR Isolated Finds}

\section{IF 1}

This find is located in the vicinity of the $\mathrm{TW} / 8$ shovel probe. Artifacts observed at IF 1 consist of one rough chert core located $1.5 \mathrm{~m}$ east of shovel test $\mathrm{IW} / 8$, and one chert flake recovered in shovel test IW/8 (the soil deposit in IW/8 was only five centimeters thick, overlying a cobble deposit).

\section{IF 2}

This find is located in the vicinity of the HW/8 shovel test. Observed artifacts consist of a core and a chert flake recovered from shovel test HW/8 (10 cm depth).

\section{IF 3}

This find is located in the vicinity of the GW/13 shovel test. Artifacts observed consist of a chert core and three chert flakes located within a $25-\mathrm{m}^{2}$ area. The core was found $10 \mathrm{~m}$ east of shovel test $\mathrm{GW} / 13$.

\section{IF 4}

This find is located in the vicinity of the BW/6 and $\mathrm{BW} / 7$ shovel tests. This IF, after further inspection, was designated site Prime 3.

\section{IF 5}

This find is located on a southern slope, near the base of the slope. Chert cobbles and pebbles are exposed across perhaps 50 percent or more of the general area. IF 5 is apparently largely disturbed with mounds of earth evident within the immediate vicinity. Additional earth mounds are present perhaps $15 \mathrm{~m}$ to the west and southwest of IF 5, at the slope base. A chert core or core pebble tool (ca. $8 \times 6 \times 4 \mathrm{~cm}$ ) and a secondary chert flake located within two meters of each other were observed at IF
5. A chert core fragment found about three meters west of the first two items was included with IF 5. Numerous spent cartridges were present in the vicinity of IF 5.

\section{IF 6}

This find is located on the lower part of a steep slope with exposed chert pebbles and cobbles. IF 6 is situated ca. $10 \mathrm{~m}$ upslope and north of IF 5. Little soil deposition is present in the vicinity. Observed artifacts consist of two chert cores, one of which may have served as a core tool, located about one meter apart. Numerous spent cartridges were present in the vicinity of IF 6 .

\section{IF 7}

This find is located ca. $18 \mathrm{~m}$ west of IF 5 in an apparently disturbed area with mounds of earth and exposed chert pebbles and cobbles. Artifacts consist of a primary and a secondary chert flake found in a backdirt pile. Numerous spent cartridges are present in the vicinity of IF 7 .

\section{Historic Components}

Other than modern debris resulting from military activities, such as dummy bombs and cartridges, and from dumping of mainly structural debris such as lumber, no evidence of historic occupation was located during the survey.

\section{Recommendations}

Because the five prehistoric sites located during the survey are concentrated in the western portion of the survey area, we recommend that this area be protected or that archaeological testing to determine significance be conducted there. The generally shallow nature of the deposits containing cultural materials, the absence of chronologically diagnostic artifacts and features, and evidence of extensive artificial and natural disturbance observed within 
much of the project area suggests the research potential of most of these sites may be low. However, the deeper, artifact-yielding deposits present at site Prime 5 suggest at least moderate research potential for this site.

Based on the findings of the archaeological survey of this area, we recommend that clearance be granted for development of the central and eastern segments of the PBPR area, and that the western portion of the project area should be protected until determinations of significance can be made through further testing. 


\title{
Appendix D: Wherry Housing Letter Report
}

\author{
Gerry R. Raymond
}

\section{Introduction}

In January 1994, the Center for Archaeological Research (CAR) of The University of Texas at San Antonio was contracted by the National Park Service to locate, evaluate, and report any cultural resources which might be affected by the construction of housing at Lackland Air Force Base in southwestern San Antonio, Bexar County, Texas (Figure D-1). This area is located on the San Antonio West and Terrell Wells, Texas, USGS 7.5' topographic maps. CAR staff archaeologists Anna J. Taylor and Shirley Mock, with the assistance of three to five crew members, conducted a pedestrian survey with shovel testing of the 120-acre proposed Wherry housing development area (Figure D-2) from March 17-24, 1994.

The extremely poor surface visibility, estimated to be $0-10$ percent and due mainly to dense brush and leaf litter, required close-interval shovel testing. A total of 729 shovel tests was excavated. Shovel test depths generally varied from $10-20 \mathrm{~cm}$, with the more shallow shovel tests located where thin soils and shallow subsurface chert gravel and cobble deposits occurred. Shovel tests were approximately $35 \mathrm{~cm}$ wide. The interval between shovel probes was ca. $30 \mathrm{~m}$ north-south and $15 \mathrm{~m}$ east-west.

During the archaeological reconnaissance of the Wherry housing area, it became evident that substantial portions of the survey area had been subjected to heavy disturbance by modern machinery and construction (Figure D-2). Two channels running east-west extend from the western boundary across perhaps one-third of the survey area. The area along the northern boundary and portions of the southwestern and west-central survey area appear extensively modified, with mounding of earth and downed trees evident. The skeet and trap range is extensively modified; matrix from the shovel probes was very compacted and contained numerous fragments of clay pigeons throughout. Construction of structures at the skeet and trap range and of gravel or dirt roads within the project area also caused disturbances. Adjacent to the northeastern and eastern edges of the skeet and trap range is a low-lying boggy area which is extensively modified, as evidenced by mounded earth, downed trees, and what appears to be exposed hardpan. This low-lying area, and another extensively modified area in the west-central project area, were both used as trash dumps during modern times, particularly for disposal of structural materials such as lumber and concrete. Heat-fractured chert pebbles and cobbles are present in surface and subsurface deposits throughout much of the project area.

Though vegetation is dense for all but the lowerlying land along the eastern project area boundary on the skeet and trap range and along the man-made channels, the brush in the northern quarter of the area, particularly the northwestern portion, is especially dense. For much of the survey area occurring north of the northern man-made channel and south of the disturbed northern boundary, the brush is judged to be impenetrable, so no shovel tests were dug there. Fire ant mounds and animal burrows and dens were observed throughout much of the survey area.

\section{Prehistoric Components}

No evidence of prehistoric occupation, other than one secondary and one tertiary chert flake noted on the surface, was observed.

\section{Historic Components}

Historic usage consisted mainly of modern trash dumps and evidence of extensive usage of this area by the military. The latter consisted of numerous 


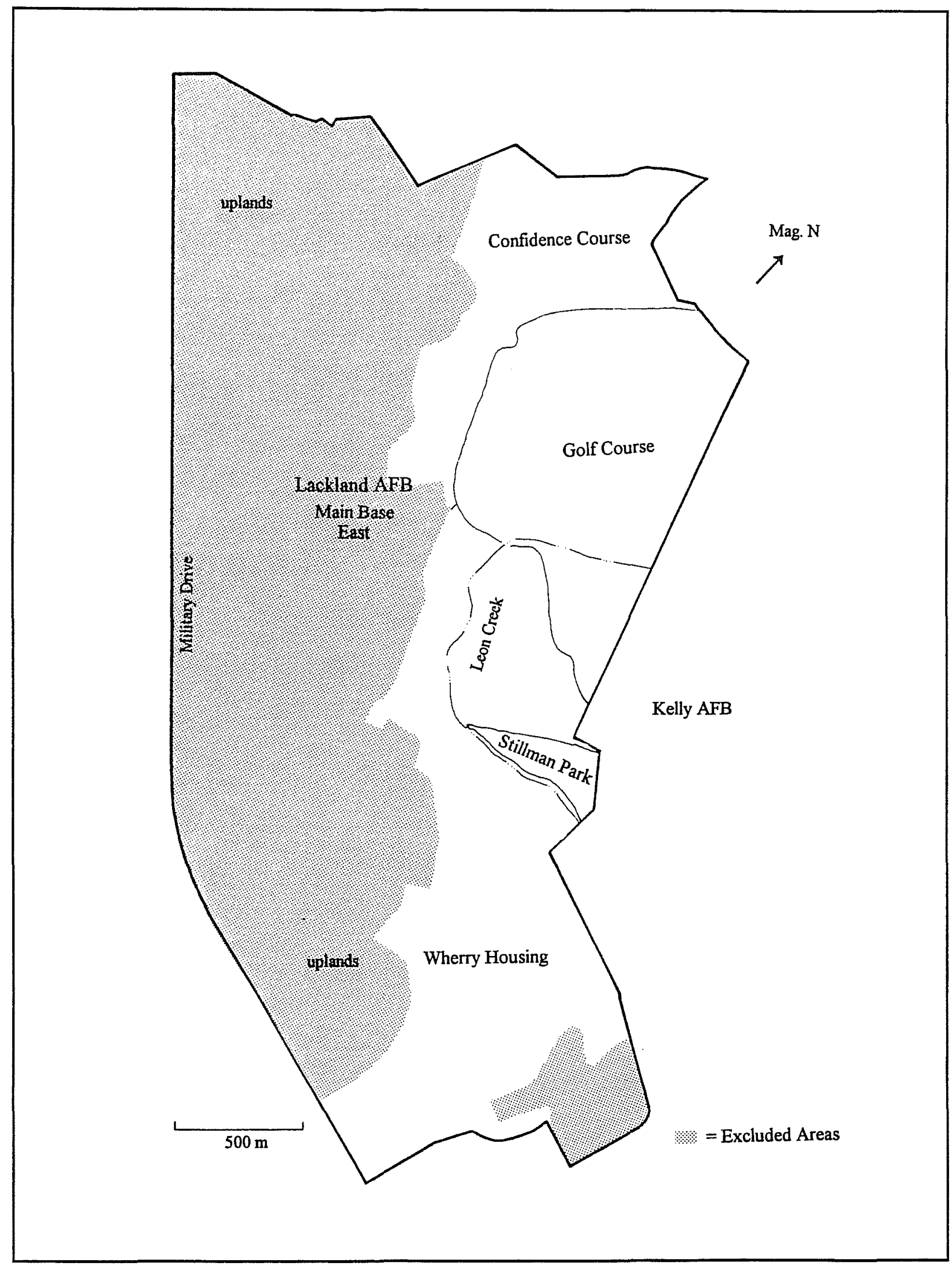

Figure D-1. Location of Wherry Housing area. 


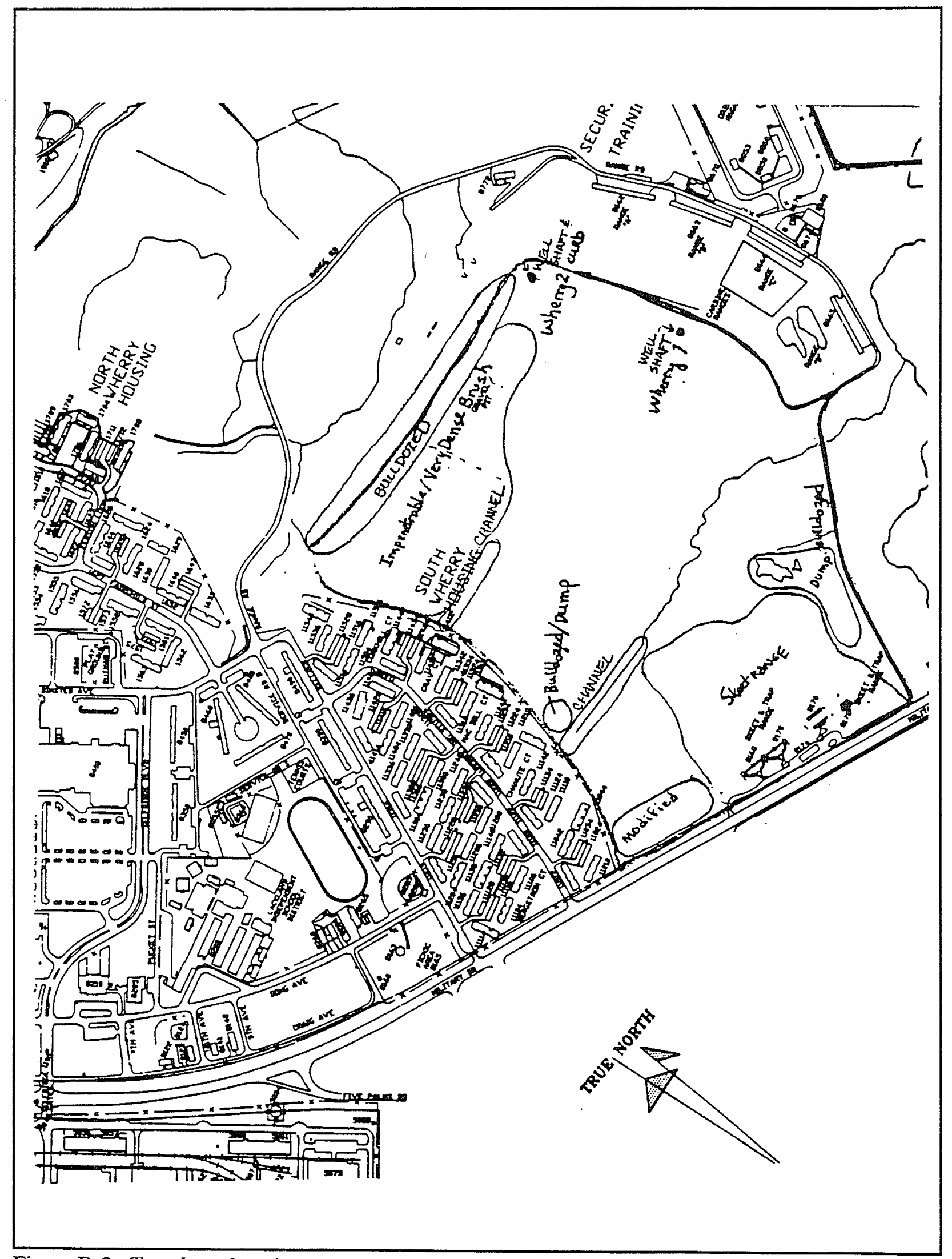

Figure D-2. Shovel test locations. 
spent cartridges, dummy grenades, dummy bombs, artillery targets, and archery targets. A fragment of brown glass was the only cultural material recovered from any of the shovel probes dug within the project area.

Two historic sites were designated within the Wherry area. Each is described below and site dimensions are summarized in Table D-1.

\section{Wherry Sites}

\section{Wherry 1}

This site is located approximately one meter east of the $A / 1 / 9$ shovel probe. This historic site consists of a well or cistern shaft measuring $1.7 \mathrm{~m}$ in diameter, of unknown depth. The site dimensions are $3.7 \mathrm{x}$ $3.7 \mathrm{~m}$, based upon the shaft dimensions, and a onemeter wide perimeter. Water was present in the bottom of the shaft. No habitational debris was found at this site.

\section{Wherry 2}

This site is located approximately four meters west of the $\mathrm{A} / 1 / 16$ shovel test and $12 \mathrm{~m}$ northwest of site Wherry 1 . The historic site dimensions are $30 \times 10$ $\mathrm{m}$, based on the distribution of brick fragments and two posts. The site includes an apparent well or cistern shaft, $80 \mathrm{~cm}$ in diameter and of unknown depth, and broken parts of what appeared to be a circular curb or apron for a well. The latter is built of brick stamped "ACME/FERRIS," manufactured between 1902 and 1926 (Gurcke 1987:234-235; Stienbomer 1983:58) with concrete mortar. The curb or apron is located $20-30 \mathrm{~m}$ north-northwest of the shaft. Two round wooden posts, each approximately $25 \mathrm{~cm}$ in diameter, are also located in the site area. The posts are located, respectively, ca. $3 \mathrm{~m}$ north-northwest and ca. $21 \mathrm{~m}$ north of the well shaft. The southernmost post is no longer set in the ground, but the northernmost post is still upright. No habitational debris was found at site Wherry 2.

\section{Recommendations}

Because of the absence of intact cultural resources in all but the northeastern and east-central parts of the project area, where the two well or cistern shafts and the well curb or apron are located, we recommend that clearance be granted for development of this part of the Wherry housing area. However, the well sites should be protected until additional significance testing and documentary research is conducted.

Note: Subsequent investigations established this locality (recorded as 41BX1061) as a historic sewer line, part of a 1920s sanitary system constructed when the property was being developed as a military installation.

Table D-1. Listing of Dimensions and Area of Sites Wherry 1 and Wherry 2

\begin{tabular}{|c|c|c|c|}
\hline Field Designation & $\begin{array}{c}\text { N/S } \\
\text { Dimensions }\end{array}$ & $\begin{array}{c}\text { E/W } \\
\text { Dimensions }\end{array}$ & Area \\
\hline Wherry 1 & $3.7 \mathrm{~m}$ & $3.7 \mathrm{~m}$ & $13.7 \mathrm{~m}^{2}$ \\
\hline Wherry 2 & $30.0 \mathrm{~m}$ & $10.0 \mathrm{~m}$ & $300 \mathrm{~m}^{2}$ \\
\hline
\end{tabular}




\section{References Cited}

Gurcke, K.

1987 Bricks and Brickmaking: A Handbook for Historical Archaeology. The University of Idaho Press, Moscow, Idaho.

Stienbomer, R.

1983 Brickmaking in Texas. Working, typed draft produced for the Texas Historical Commission, Austin. Copy on file at the San Antonio Conservation Society, San Antonio. 


\title{
Appendix E: Special Areas Letter Report
}

\author{
Jeffrey Durst
}

\section{Introduction}

From August 3,through August 18, 1994, staff archaeologists from the Center for Archaeological Research (CAR) of The University of Texas at San Antonio, under contract with the National Park Service (NPS), conducted an intensive archaeological study of two tracts of land on Lackland Air Force Main Base and two on the Medina Base Annex. These investigations were undertaken to determine if cultural assets, which would be adversely effected by construction on these tracts, are present. CAR crew members included Bobby Rector, Florencio Delgado, Tony Lyle, Andrew Scease, David Nickels, and Jeffrey Durst.

Phase II survey and shovel testing were conducted at four locations:

1. Space Command Expansion Project, Medina Annex

2. Area 300 Road Project, Medina Annex

3. Leon Creek Channel Modification Project, Main Base

4. Housing Expansion Project, Main Base

This report includes the environmental setting for each location, as well as descriptions of the field methodology, results, and conclusions for each.

\section{Space Command Expansion Project}

\section{Previous Work}

During the week of August 16-20, 1993, an archaeological investigation of the Space Command area (Figure E-1) was conducted under the direction of Steven L. De Vore of the NPS (De Vore 1993:21). This survey was conducted by one person walking non-regular transects. The area covered by this survey area extended $30 \mathrm{~m}$ to the east of the fence line of the Space Command facility (Gabriel Gonzales, personal communication 1994). This investigation revealed no archaeological resources in the area of the Space Command.

\section{Environmental Setting}

The survey area is located on an upland terrace of Medio Creek, comprising Uvalde gravels of natural chert usually covered by the Houston Black Gravelly Clay soil association (Taylor et al. 1991). The surface was covered by dense underbrush and numerous mature mesquite trees. Approximately one-third of the test area has been disturbed by heavy bulldozing. The remaining two-thirds appeared undisturbed.

\section{Field Methodology}

The area was investigated by a systematic shovel test survey. Twenty-three shovel tests were excavated at intervals of $20 \mathrm{~m}$ (Figure E-1). A study of the geomorphology in the Prime RIBS area of the Medina Annex was recently completed by Lee Nordt (1994). The results of this study indicate, because of the age of the underlying Uvalde Gravels, that any prehistoric cultural material should be found in the uppermost strata. The geomorphology in the Space Command area is generally analogous to that of the Prime RIBS area; therefore, test units were dug to a depth of $20 \mathrm{~cm}$ where Uvalde Gravels were encountered.

In the 23 shovel tests conducted in the area, only two pieces of lithic debitage were found in two separate test units (Figure E-1). These pieces of chert had all the characteristics of prehistoric artifacts, but in the context of naturally occurring chert and recent disturbance, it can not be ruled out that they may be products of recent mechanical disturbances. 


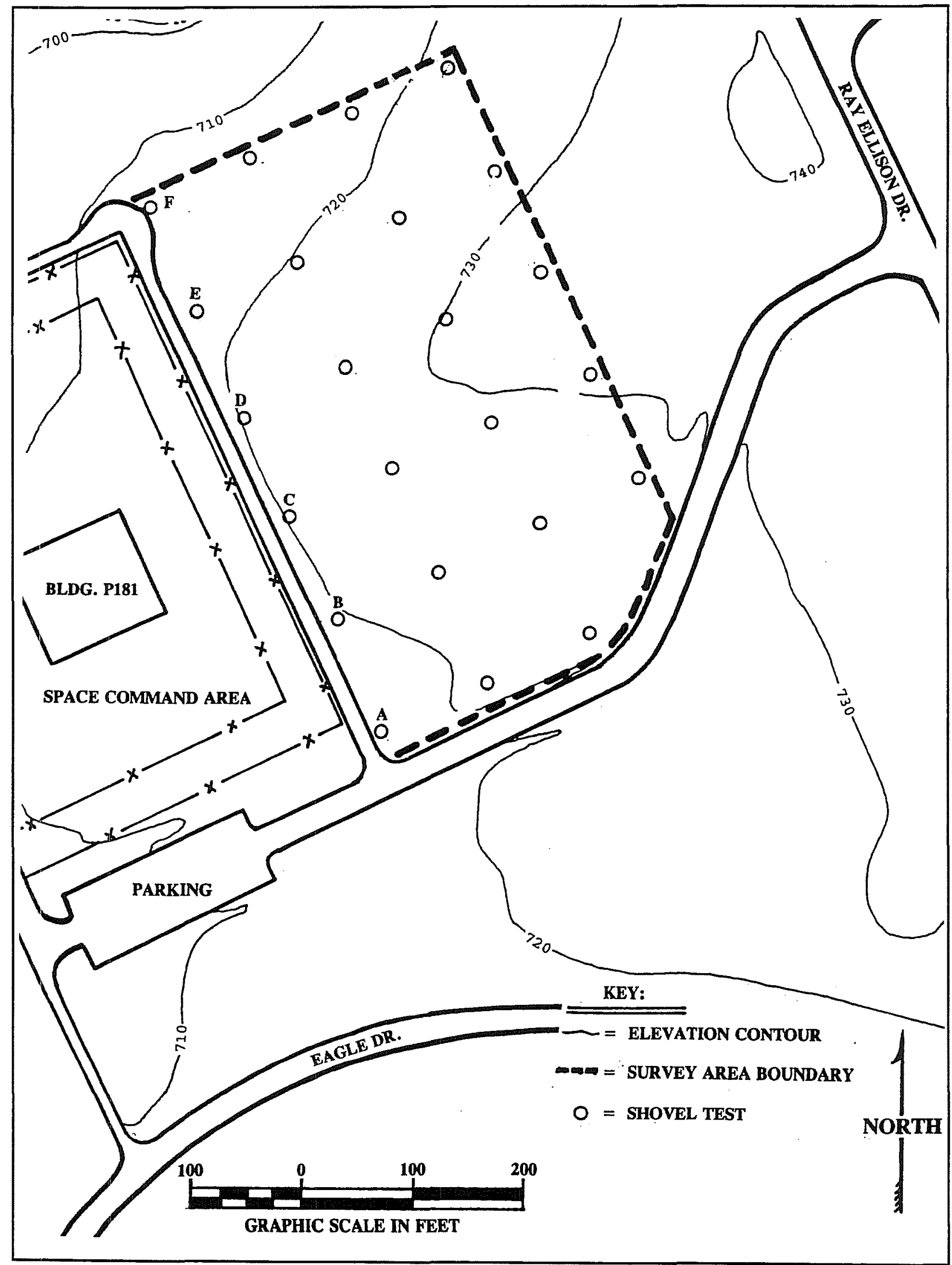

Figure E-1. Space Command Area, survey and testing area. 


\section{Conclusions and Recommendations}

This area contains a significant amount of naturally occurring chert cobbles on the surface, many of which display fracturing. Other than the two chert flakes mentioned above, nothing that appears to be of cultural origin was found. Therefore, future development will have no adverse impact and no further archaeological investigation is recommended.

\section{Area 300 Road Project}

\section{Environmental Setting}

The area is located on an upland terrace of Medio Creek comprising Uvalde Gravels of natural chert usually covered by the Houston Black gravelly clay soil association (Taylor et al. 1991). The surface was covered by high grass and weeds with zero visibility except in roadways. The area was devoid of any mature trees. The stratigraphic integrity of the soil has been disrupted by the burial of cables through the area and by blading activities.

\section{Field Methodology}

Six shovel tests, approximately $20 \mathrm{~cm}$ in diameter and $20 \mathrm{~cm}$ in depth, were placed at $20-\mathrm{m}$ intervals through the path of the proposed road expansion (Figure E-2). The geological make-up of the area is such that any prehistoric cultural material, if present, would be found in the top $20 \mathrm{~cm}$ (Nordt 1994). The visible presence of heavy disturbance on the surface preempted the need for any further investigation in this area.

\section{Results}

The six shovel tests revealed a layer of heavily disturbed soil in the test area. No cultural material was present in the shovel tests. The area was generally very hummocky, indicating the area may have been used as a landfill. The soil found in the shovel tests supported this supposition.

\section{Conclusions and Recommendations}

The lack of cultural material indicates that future development of this property should have no impact on any cultural resources; therefore no further archaeological investigation is recommended.

\section{Leon Creek Channel Modification Project}

\section{Previous Work}

An archaeological survey along parts of Leon Creek was conducted by Espey, Huston and Associates, as part of the cultural resource assessment for the Base Comprehensive Plan for Kelly Air Force Base (Carter and Burgess 1991). Approximately 146 ha (360 a) were surveyed, including the cutbanks along Leon Creek and the adjacent terraces and open areas believed to have been undisturbed in the past. Exhibit A-4 in the 1991 Base Comprehensive Plan (Carter and Burgess) shows this survey to cover the area currently scheduled for channel modification. The survey found no archaeological sites on either Kelly or Lackland (Carter and Burgess 1991:NRP30).

\section{Environmental Setting}

The area contains pits and quarries along Leon Creek (Taylor et al. 1991). Farthest to the east is the location of a quarry for material used to build a runway at Kelly Air Force Base. The surface is covered by low to medium grasses and Johnson weed, with zero visibility except in the abandoned asphalt roadway. A few mature mesquite trees are found at the north end of the area, with no older growth present on the main portion of the survey area. Immediately to the west of Leon Creek is a high bank which has collapsed and been stabilized several times (Gabriel Gonzales, personal communication 1994). The area immediately to the east of the creek has been utilized for numerous construction dumps as noted in an initial survey of the area by base staff. An abandoned asphalt road is found in the area and the ground surface is mostly hummocky, indicating disturbance. 


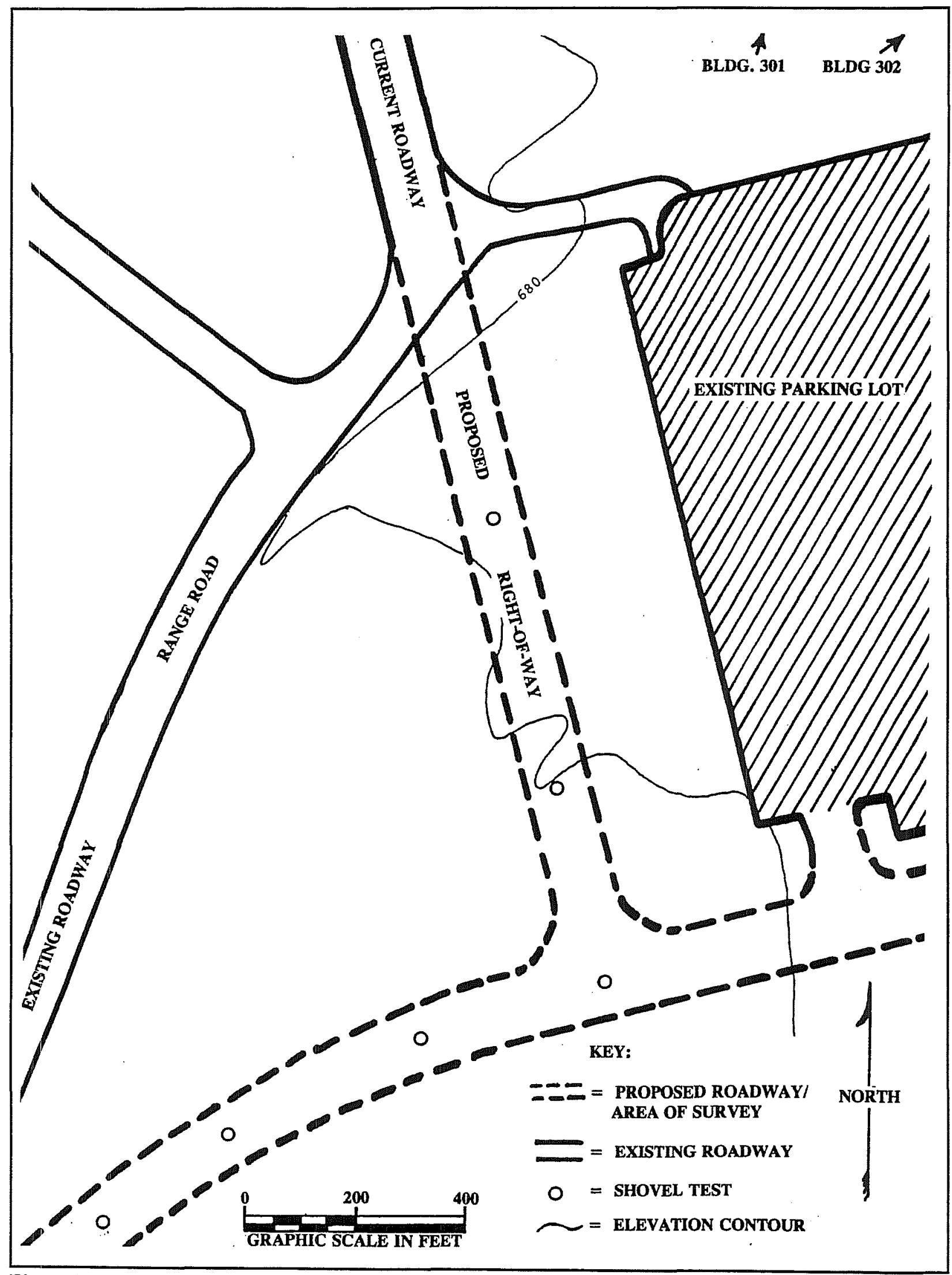

Figure E-2. Area 300 Road Project, survey and testing area. 


\section{Field Methodology}

Twelve shovel tests, approximately $20 \mathrm{~cm}$ in diameter and $20 \mathrm{~cm}$ in depth, were placed at $20-\mathrm{m}$ intervals across the only portion of the area that appeared undisturbed (Figure E-3). This was a relatively flat area located between the abandoned asphalt road and the quarry to the east. A depth of $20 \mathrm{~cm}$ was selected to determine if the soils are disturbed. The shovel tests produced a whitish grey soil which was apparently brought in to level the area immediately adjacent to the asphalt road.

\section{Results}

The 12 shovel tests were all negative. No cultural material was found during inspection of the property.

\section{Conclusions and Recommendations}

Neither the work conducted previously by Espey, Huston and Associates nor the CAR investigations produced any cultural evidence in this heavily disturbed area. The lack of cultural material and the degree of disturbance at this location indicates that future development should have no impact on any cultural resources; therefore no further archaeological investigation is recommended.

\section{Housing Expansion Project}

\section{Environmental Setting}

The area covers approximately 18.18 ha (45 a) and varies in elevation almost $30 \mathrm{~m}$ from first terrace to upland terrace (Figure E-4). The ground cover is comprised primarily of low mesquite scrub with zero ground visibility in the lower portion of the area and mowed grasses on the upper terrace behind the existing housing units. The area behind the housing facility, as well as the area to the north of the housing, is relatively flat for a distance varying from 30 to $100 \mathrm{~m}$. It then drops off sharply to an area of steeply sloping ground which extends approximately $60 \mathrm{~m}$ to the lower portion of the survey, an area of less severe slope. The lower portion of the survey area is covered by a heavy erosional drainage pattern emptying into the flood plain of Leon Creek. The overall survey area is in a zone of Uvalde Gravels of natural chert usually covered by the Houston Black gravelly clay soil association (Taylor et al. 1991).

\section{Field Methodology}

A total of 182 shovel tests was systematically placed across the entire area at 30-m intervals except in areas where prehistoric occupation was suspected. The survey was divided into three segmentsdesignated $\mathrm{A}, \mathrm{B}$, and $\mathrm{C}$-to facilitate data control (Figure E-4). An intensive study of the geomorphology of the Prime RIBS area was recently completed by Lee Nordt (1994). The results of this study indicate, because of the age of the underlying Uvalde gravels, that any prehistoric cultural material should be found in the uppermost strata. The geomorphology in the Housing Expansion area follows that of the Prime RIBS area (Taylor et al. 1991); therefore, tests were dug to depths varying from 20 to $50 \mathrm{~cm}$ depending upon underlying deposits.

Area A covered the largest portion of the survey and included all of the land north of Range Road up to the housing area, and up to the elevated area overlooking Leon Creek to the north. Ninety-three shovel tests were conducted in this area, at $30-\mathrm{m}$ intervals and to a depth of $20 \mathrm{~cm}$ (Figure E-4). Area $\mathrm{B}$ encompasses the portion of level ground outside the fence line of the housing area and to the edge of the sharp slope down to Leon Creek. This includes shovel tests A1 through W1, with a total of 35 test units placed in Area B. The units were placed at 30$\mathrm{m}$ intervals and dug to $20 \mathrm{~cm}$ in depth (Figure E-4).

Area $\mathrm{C}$ includes the level ground just inside the fence line of the housing area. Forty-two test units were spaced at $10-\mathrm{m}$ intervals to cover this area thoroughly, as diagnostic artifacts had been recovered from the surface in the adjacent area 


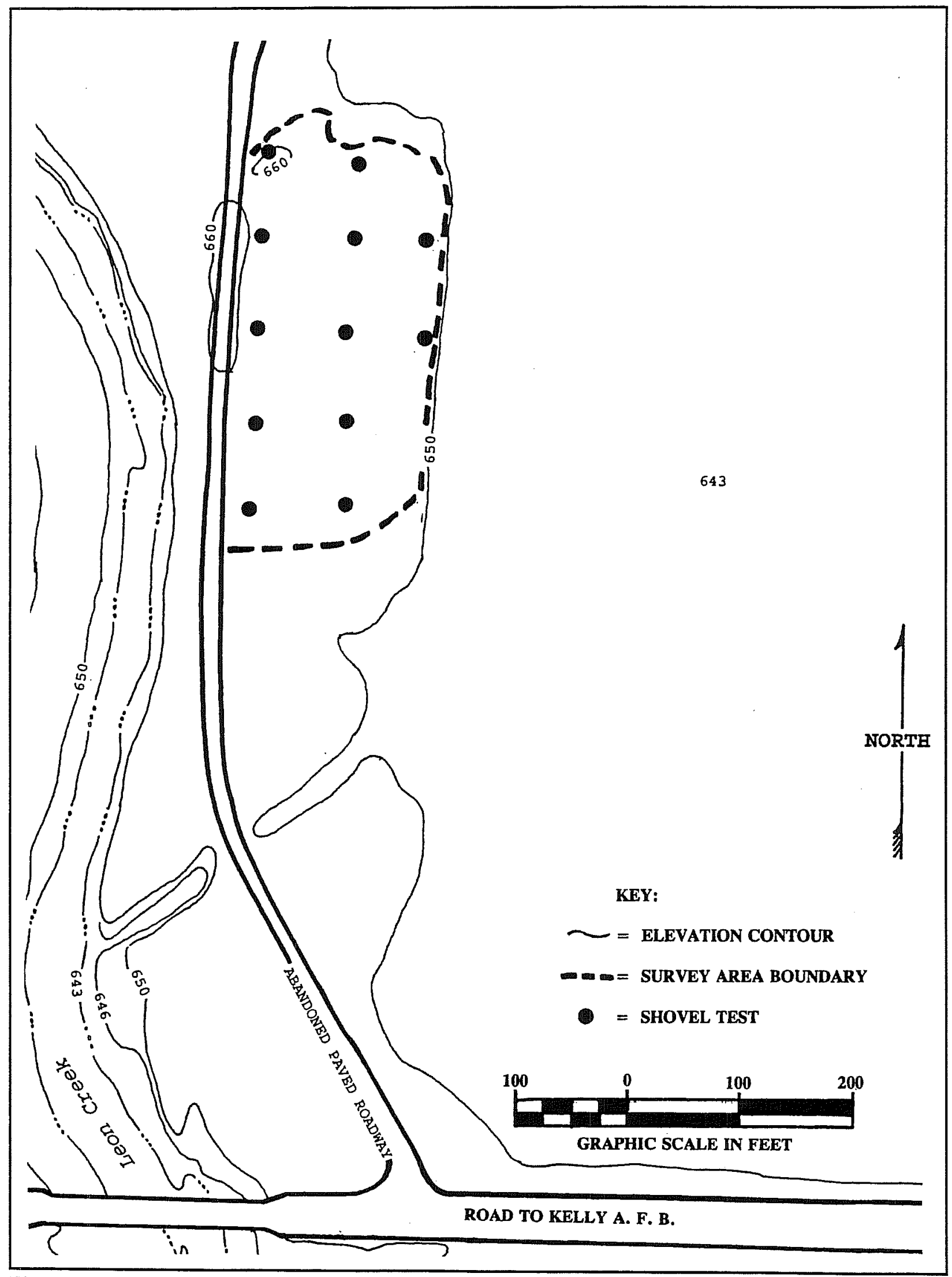

Figure E-3. Leon Creek Channel Modification Project, survey and testing area. 
outside the fence-line in Area B (Figure E-4). The depths at which Uvalde Gravels were encountered in this area varied, and shovel tests in this area were dug up to $50 \mathrm{~cm}$ to correspond to the depths of the gravels. The remaining test units in area C (D1 through P1) were completed as the previous tests at $30-\mathrm{m}$ intervals and to a depth of $20 \mathrm{~cm}$.

\section{Results}

A total of 182 shovel tests was completed in the overall survey area (Figure E-4), with 33 of the test units producing 68 artifacts (Tables E-1 and E-2). Two sites, 41BX1065 and 41BX1066, were located and recorded in this survey area. Site 41BX1065 is located in the level area to the north of the

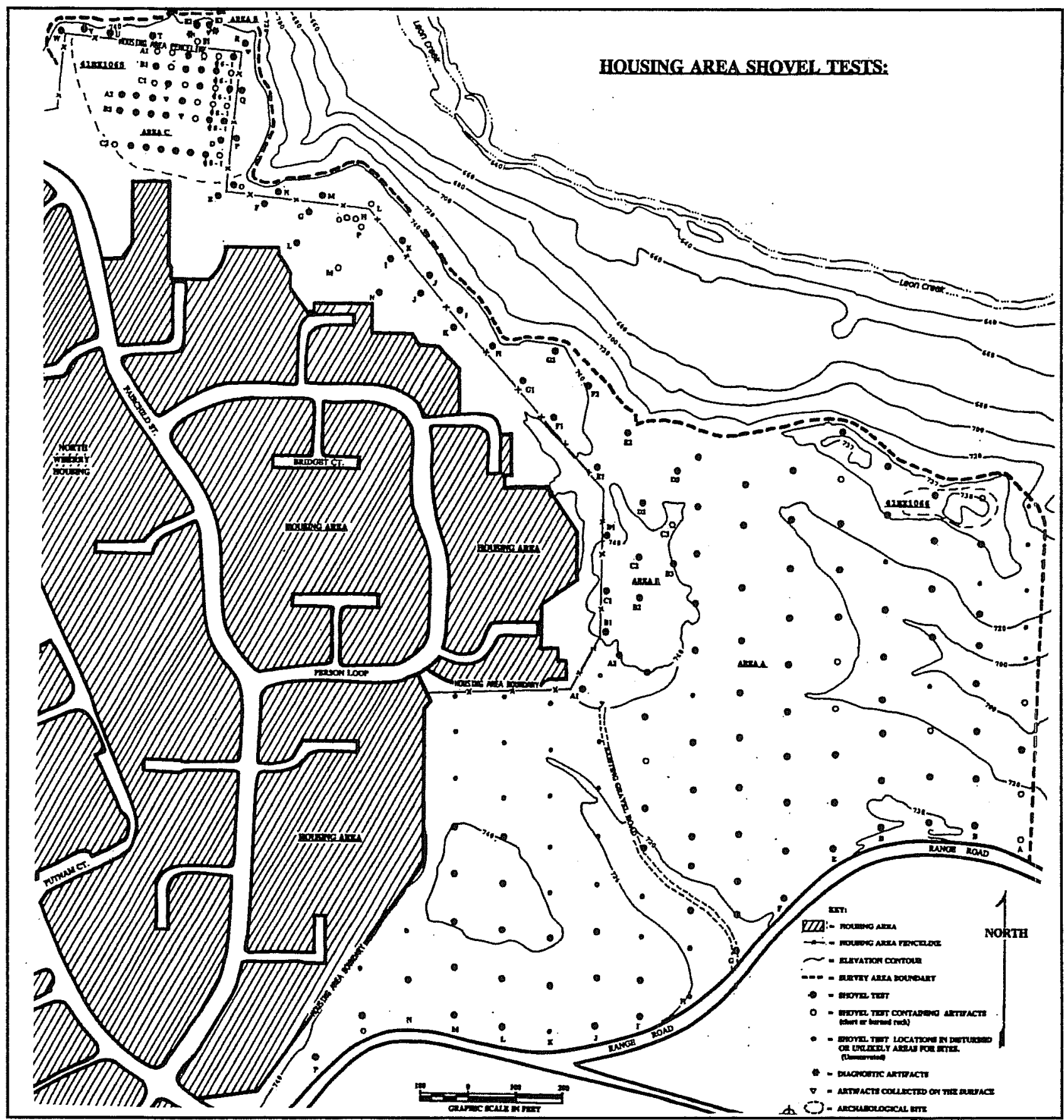

Figure E-4. Housing Expansion Project, survey and testing area. 
Table E-1. Artifact Distribution, Areas A, B, and C

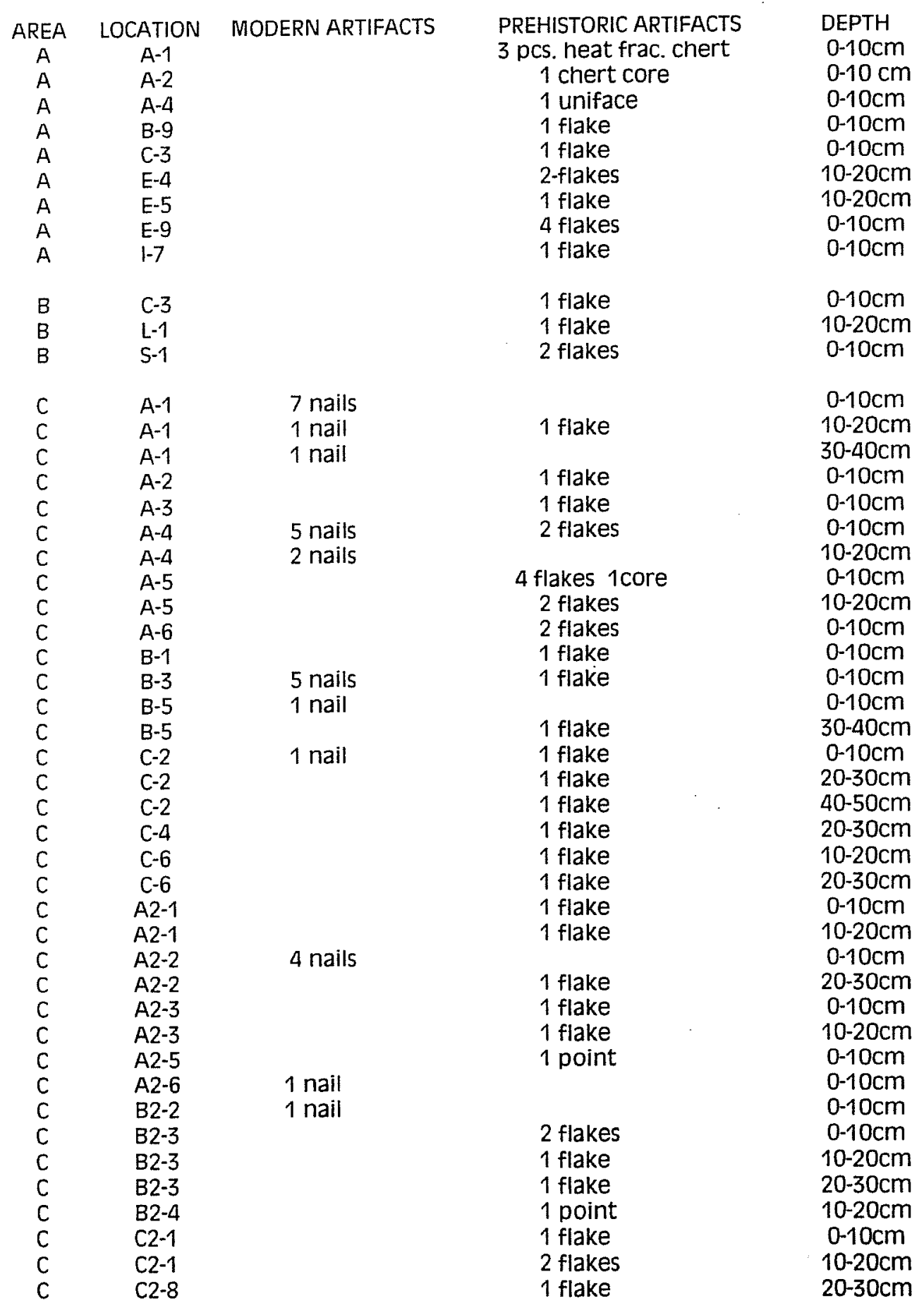


Table E-2. Artifacts from Shovel Tests

$\begin{array}{ccc}\begin{array}{c}\text { Depth } \\ \text { in } \mathrm{cm}\end{array} & \begin{array}{c}\text { \# of } \\ \text { Modern } \\ \text { Artifacts }\end{array} & \begin{array}{c}\text { \# of } \\ \text { Units with } \\ \text { Modern } \\ \text { Artifacts }\end{array} \\ 0-10 & 25 & 7 \\ 10-20 & 4 & 3 \\ 20-30 & 0 & 0 \\ 30-40 & 1 & 1 \\ 40-50 & 0 & 0 \\ \text { Total } & 30 & 11\end{array}$

housing units in Areas B and $\mathrm{C}$ and covers an area approximately $80 \times 80 \mathrm{~m}$. Three diagnostic projectile points and three bifaces were collected on the surface in Area B, at the northern edge of the site where there was no vegetation. Numerous chert flakes were also visible on the surface in this area, but were not collected. Two partial points, one diagnostic, were found at $0-20 \mathrm{~cm}$ below the surface in Area $\mathrm{C}$, along with numerous chert flakes also found in shovel tests. Of the four diagnostic points found, one is an Ensor dating to the Late Archaic; one is a Langtry dating to the Middle Archaic; and two are Tortugas, also dating to the Middle Archaic (Figure E-5). Thirty modern nails were also recovered from 11 shovel tests in area $C$; however, 25 of the 30 were found in the top $10 \mathrm{~cm}$, indicating that most of the modem disturbance is limited to the surface deposits (Table E-2).

A second concentration of artifacts was also found, approximately $100 \mathrm{~m}$ to the southeast of this site (shovel tests $\mathrm{H}, \mathrm{O}$, and $\mathrm{P}$; Figure E-4). This concentration lies along the chain-link fence surrounding the housing units. The soil inside the fence, where the concentration is found, is 40-50 $\mathrm{cm}$ above the soil just outside the fence. This indicates the concentration in this area is disturbed and out of context. Although this area is close enough to the main concentration to be considered part of 41BX1065, it is not being considered part of the site because of the heavy disturbance.

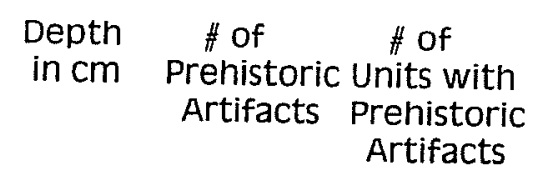

$0-10$
$10-20$
$20-30$
$30-40$
$40-50$
Total

$\begin{array}{cc}42 & 14 \\ 11 & 8 \\ 6 & 6 \\ 1 & 1 \\ 1 & 1 \\ 61 & 30\end{array}$

Site 41BX1066 is located on a level, high area overlooking Leon Creek (Figure E-4). This site is a small lithic scatter visible on the surface and covers an area approximately $30 \times 30 \mathrm{~m}$. Two shovel tests were conducted within the site boundaries and no artifacts were recovered.

\section{Conclusions and Recommendations}

Two prehistoric archaeological sites in the northern portion of the survey area, one with diagnostic artifacts present, were recorded during the survey. Site 41BX1065 may have research potential, but further testing would be required to document its integrity, age, and content. The recommended testing would include a pattern of $1-\mathrm{x}-1-\mathrm{m}$ excavation units placed over the concentration area, followed by a systematic scraping of the area with a Gradeall to search for archaeological features. While smaller in size and lacking visible diagnostics, 41BX1066 may have research potential as well; however, the limited testing and dense brush prevent further evaluation without further work. Should the location be involved in future construction, testing would need to be conducted. The remainder of the area contains no significant amount of cultural material, indicating that future development of this property should have no impact on any cultural resources and therefore no further archaeological investigation is recommended. 


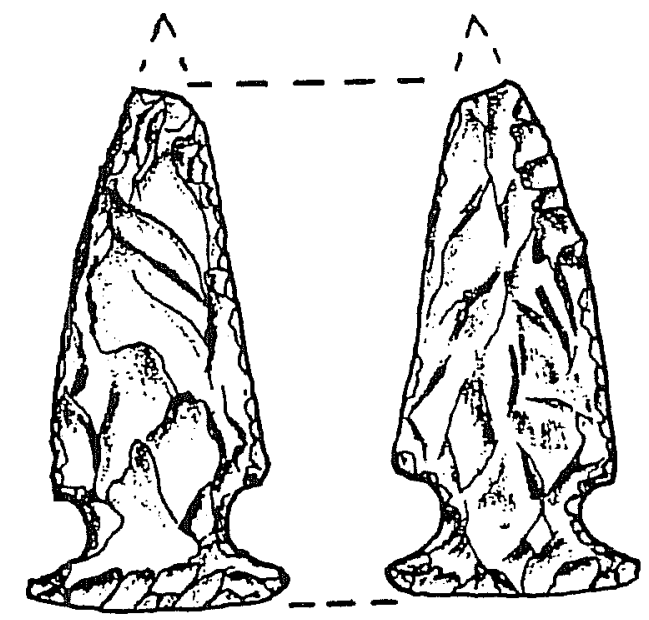

a.
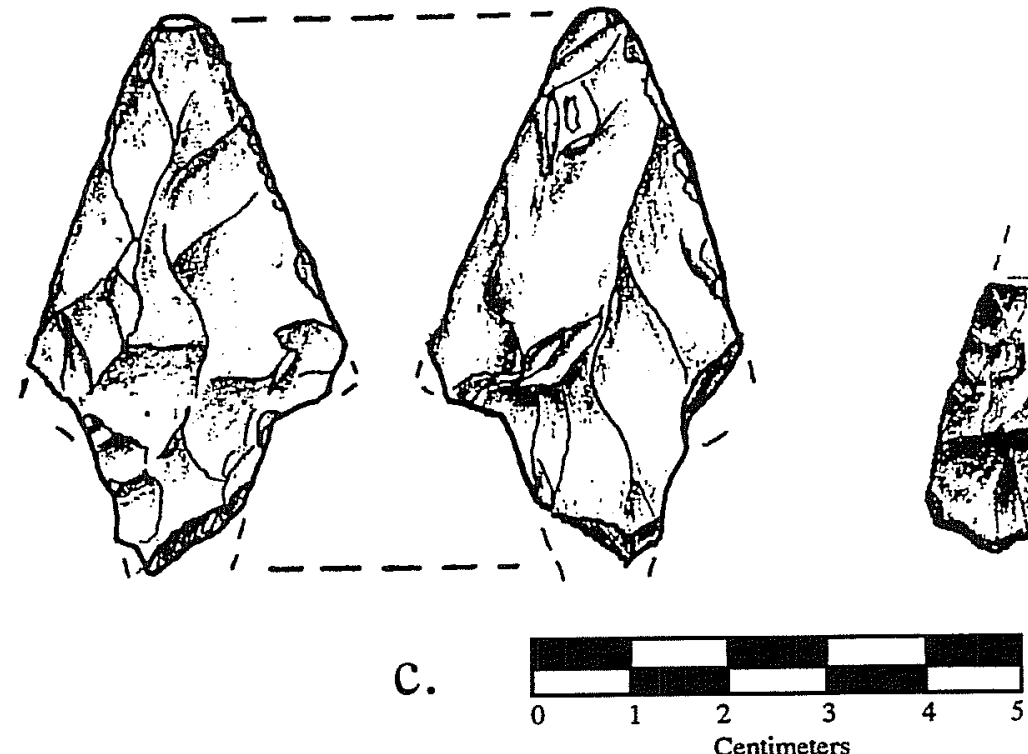

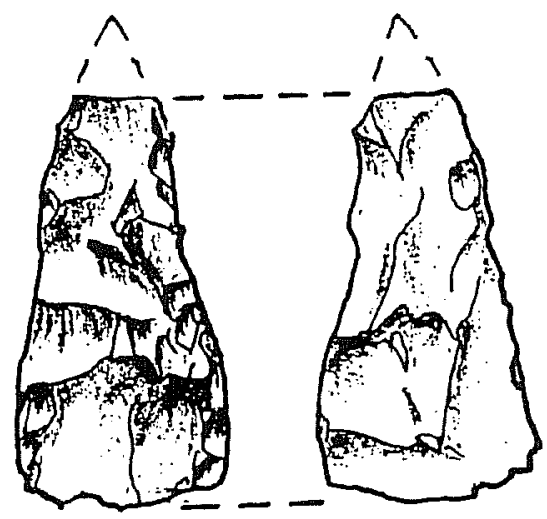

b.

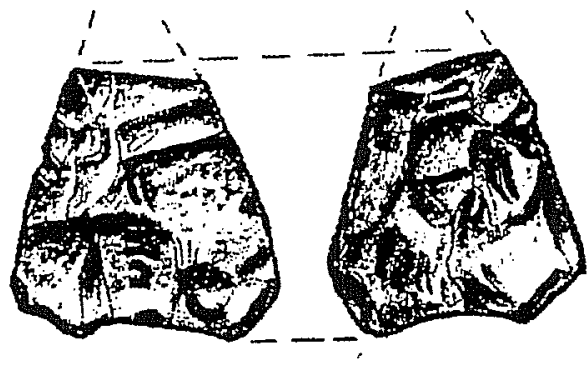

d.

Figure E-5. Diagnostic projectile points. a. Ensor; b. Tortugas; c. Langtry; d. Tortugas. 


\section{References Cited}

Carter and Burgess, Inc.

1991 Kelly Air Force Base: Base Comprehensive Plan. Manuscript on file. Center for Archaeological Research, The University of Texas at San Antonio.

De Vore, S. L.

1993 Cultural Resource Assessment of Lackland Air Force Base and Training Annex, Bexar Country, Texas. U.S. Department of Interior, National Park Service, Rocky Mountain Regional Office, Interagency Archaeological Services, Denver.

Nordt, L.

1994 Geoarchaeology of Site 41BX1006, Lackland Air Force Base. Manuscript on file, Center for Archaeological Research, The University of Texas at San Antonio.

Taylor, F. B., R. B. Hailey, and D. L. Richmond

1991 Soil Survey of Bexar County, Texas. Soil Conservation Service, U.S. Department of Agriculture, Washington, D.C. 


\section{Appendix F. Project Forms}


Center for Archaeological Research - UTSA

L \& L Project - Lackland Phase

ISOLATED FIND LOG

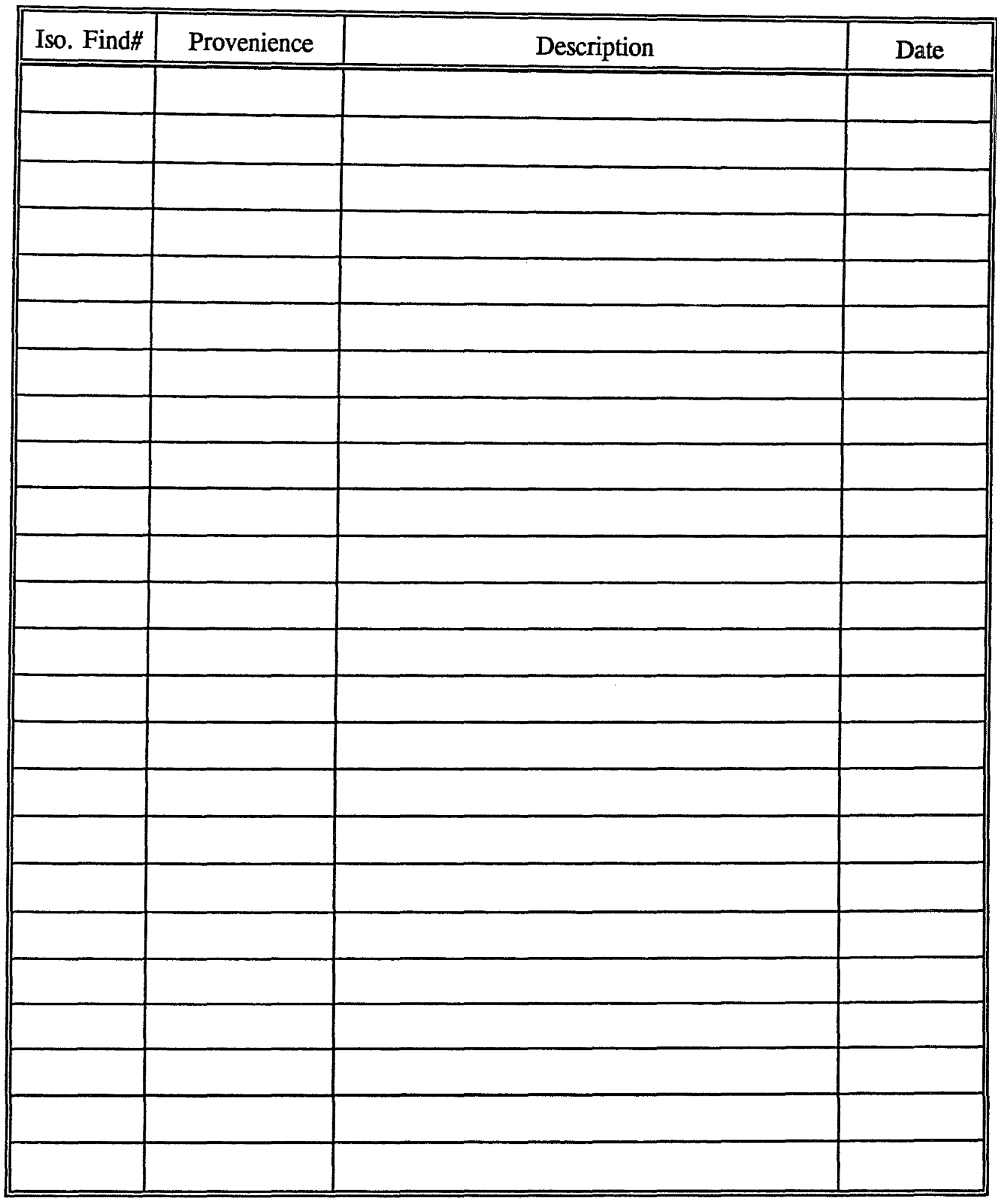




\section{Daily Journal \\ Lackland Survey Project}

Date/Day:

Depart from C.A.R.:

Return:

Crew members, crew chief(s):

Survey/Site recording teams:

Area surveyed/sites recorded, specifying which part of Lackland (annex or main base), survey name given to area, bearing, number and interval of transects; for site recording give designated area, bearings, transects, site numbers.

Comments: 
Center for Archaeological Research - UTSA

L \& L Project - Lackland Phase

ISOLATED FIND FORM

Iso. Find \#

Dimension: N/S

$\mathrm{E} / \mathrm{W}$

Recorder

Date

Location

Natural Setting

Artifacts

Area Integrity

Shovel Probe $\mathrm{Y}_{-} / \mathrm{N}$

if Yes: Total Depth

Artifact

Depth

Artifact

Depth

Artifact

Depth

Artifact

Depth

Comments: 
Center for Archaeological Research

Lackland Survey Project

Non-collected Isolated Finds

Date:

Recorded By:

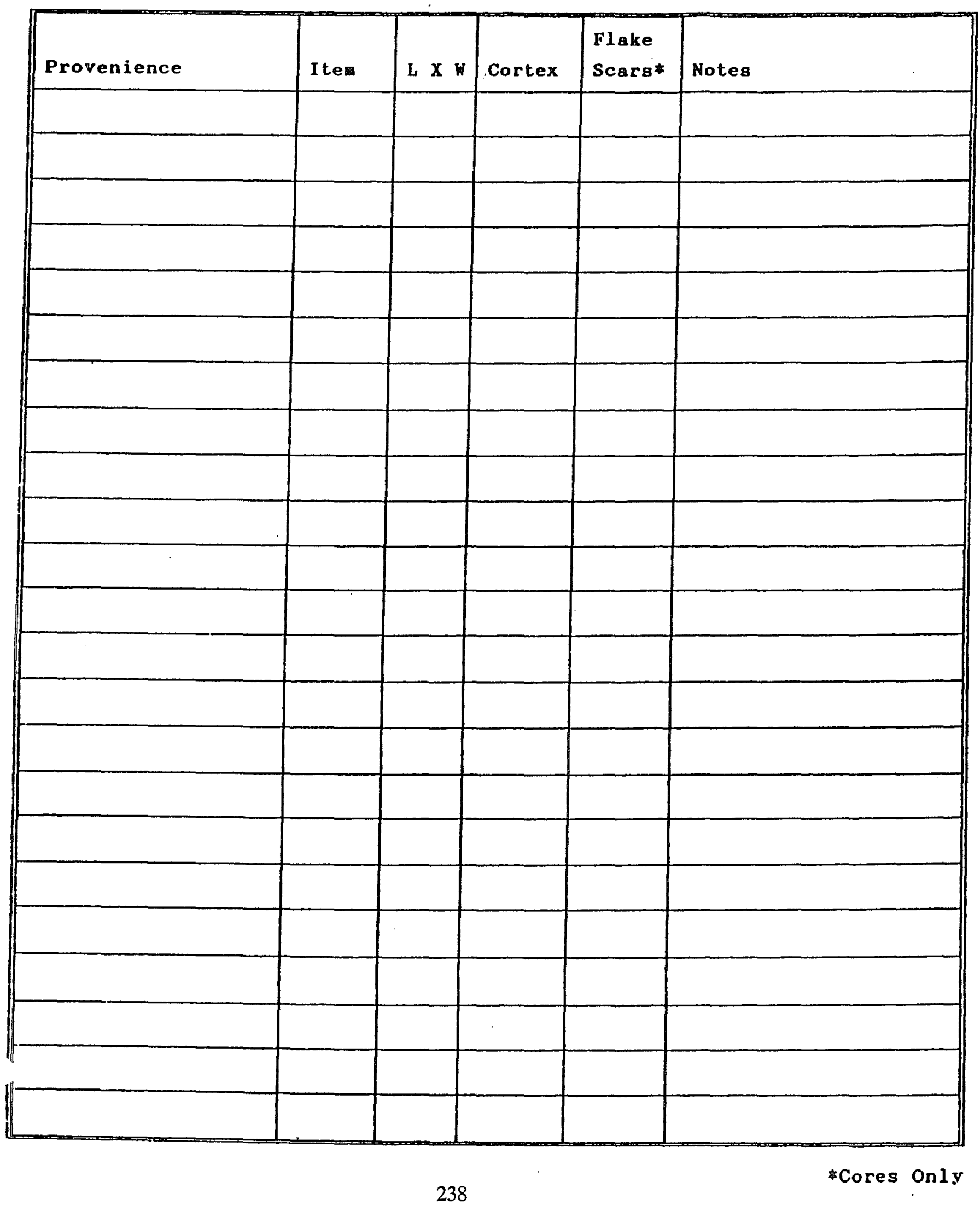


Center for Archaeological Research - UTSA

L \& L Project - Lackland Phase

FEATURE LOG

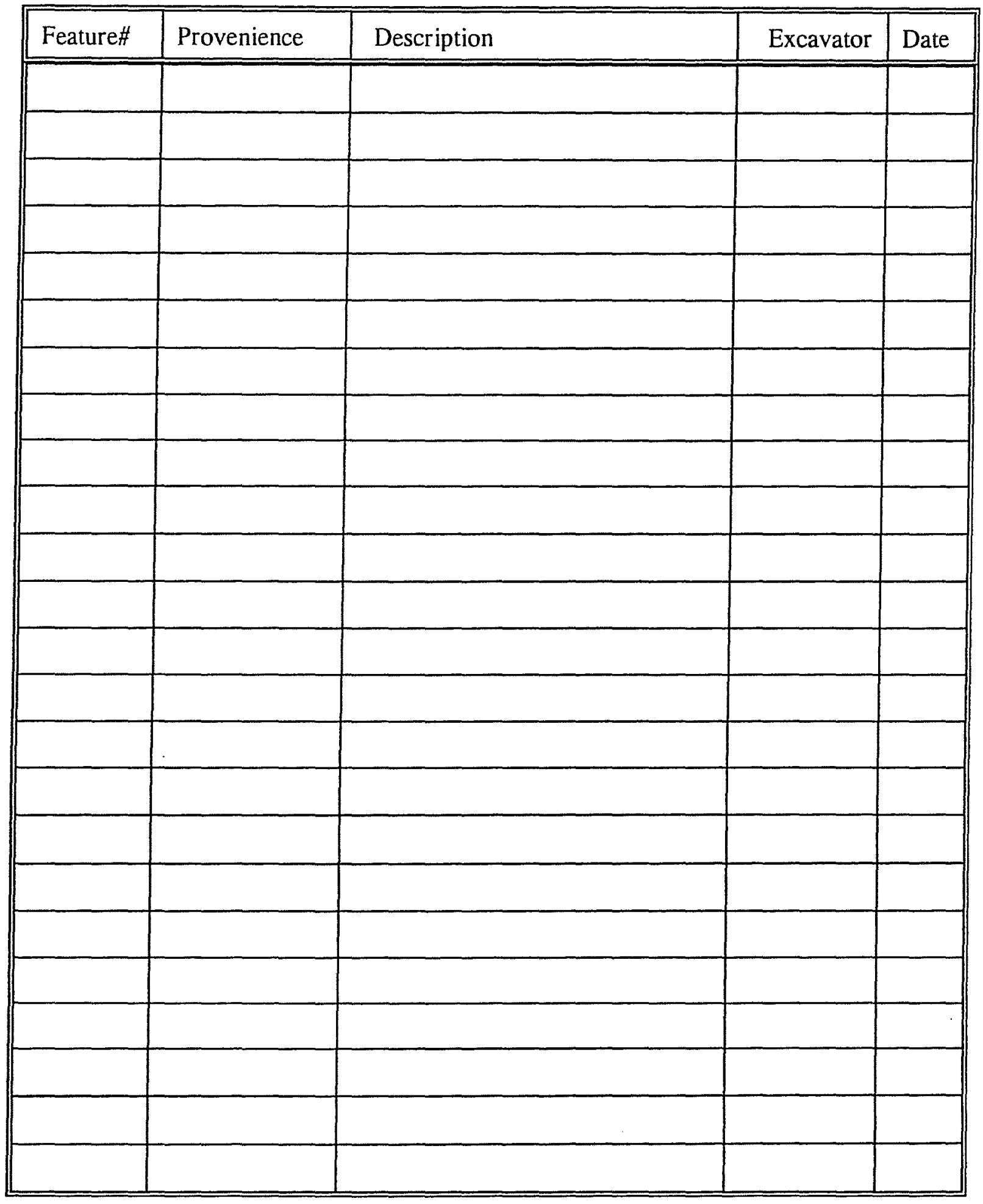


Center for Archaeological Research - UTSA

L \& L Project - Lackland Phase

SPECIAL SAMPLE LOG

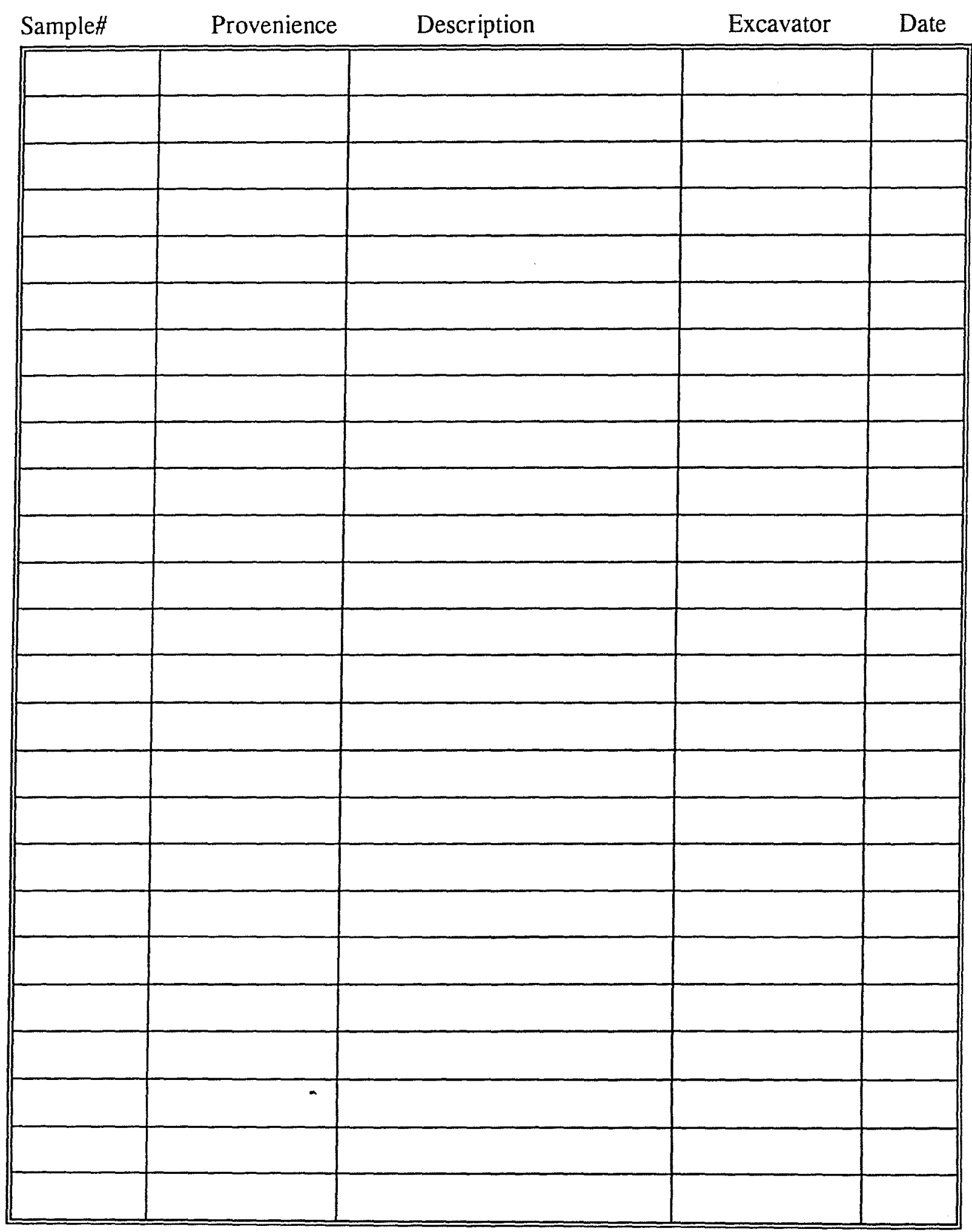


Center for Archaeological Research - UTSA

L \& L Project - Lackland Phase

UNIQUE ITEM LOG

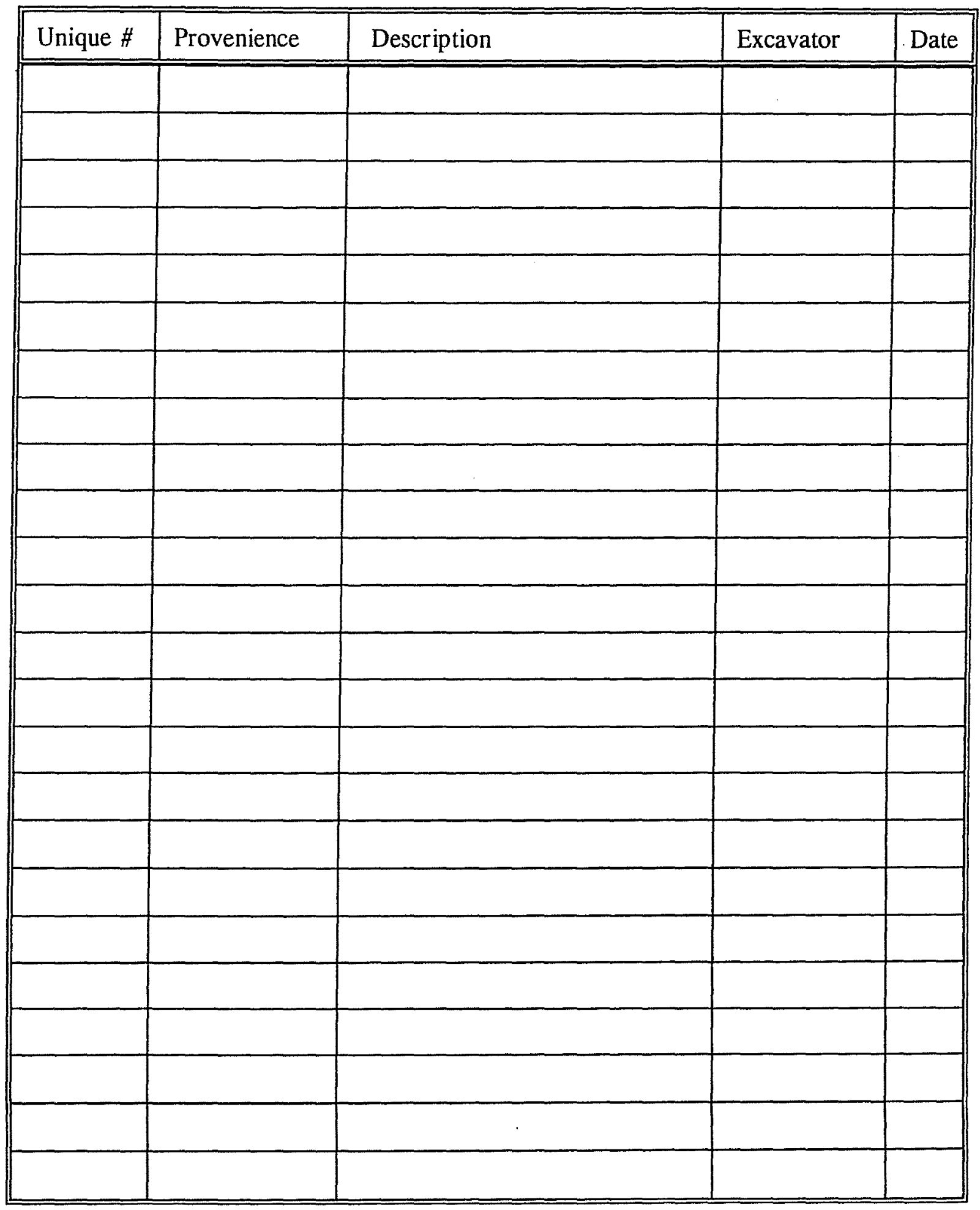


Center for Archaeological Research

LACKLAND SURVEY PROJECT

Site Inventory Form

Site \#:

Sample Area:

Date:

Recorded by:

Non-Collected Artifacts

Flakes

\begin{tabular}{|c|l|l|l|l|l|l|}
\cline { 2 - 6 } \multicolumn{1}{c|}{} & Exterior & To. & Interior & To. & Bifacial Thinning Flake & To. \\
\hline to $3 \mathrm{~cm}$ & & & & & & \\
\hline$>3 \mathrm{~cm}$ & & & & & & \\
\hline$>5 \mathrm{~cm}$ & & & & & & \\
\hline$>7 \mathrm{~cm}$ & & & & & & \\
\hline$>9 \mathrm{~cm}$ & & & & & & \\
\hline$>11 \mathrm{~cm}$ & & & & & & \\
\hline
\end{tabular}

Cores/ Preforms

\begin{tabular}{|l|l|l|l|l|l|l|}
\cline { 2 - 7 } \multicolumn{1}{c|}{} & Cores & To. & Blanks & To. & Preforms & To. \\
\hline$>3 \mathrm{~cm}$ & & & & & & \\
\hline$>5 \mathrm{~cm}$ & & & & & & \\
\hline$>7 \mathrm{~cm}$ & & & & & & \\
\hline$>9 \mathrm{~cm}$ & & & & & & \\
\hline$>11 \mathrm{~cm}$ & & & & & & \\
\hline$>13 \mathrm{~cm}$ & & & & & & \\
\hline$>15 \mathrm{~cm}$ & & & & & & \\
\hline
\end{tabular}

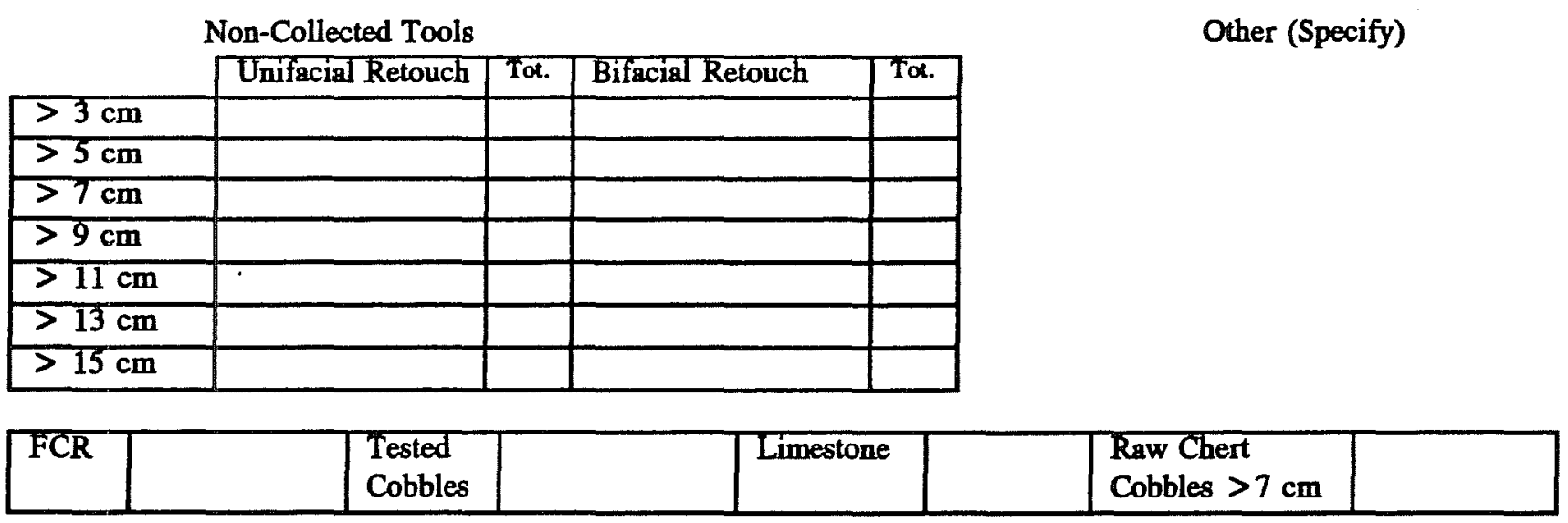

\section{Collected Diagnostic Tools}

\begin{tabular}{|l|l|l|}
\hline Bag \# & Tool Type & Provenience \\
\hline & & \\
\hline & & \\
\hline & & \\
\hline & & \\
\hline & & \\
\hline & & \\
\hline & & \\
\hline
\end{tabular}


Center for Archaeological Research - UTSA

L \& L Project - Lackland Phase

PHOTOGRAPHIC LOG

Color [ ] Black/ White [ ] Print [ ] Slide [ ] Film Type ___ Roll \#_ Camera:

Frame\#

Description

Facing Name Date

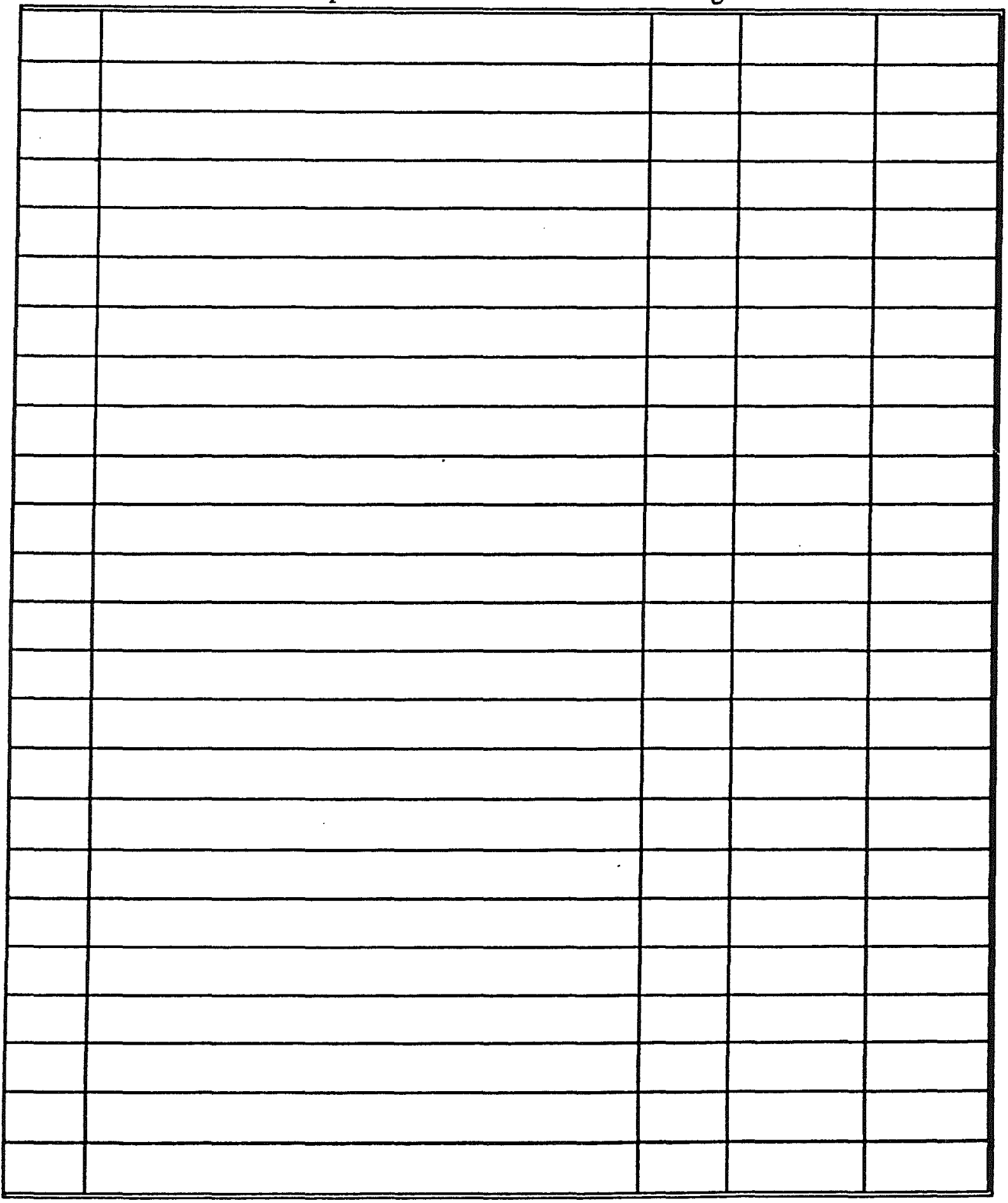


Center for Archaeological Research

LACKLAND SURVEY PROJECT

Site Collection Bag Log

\begin{tabular}{|c|c|c|c|c|c|}
\hline & \\
\hline Bag\# & Date & Site \# & Provenience & Description & 을 号 오 \\
\hline & & & & & $\square \square \square$ \\
\hline & & & & & $\square \square \square$ \\
\hline & & & & & $\square \square \square$ \\
\hline & & & & & $\square \square \square$ \\
\hline & & & & & $\square \square \square$ \\
\hline & & & & & $\square \square \square$ \\
\hline & & & & & $\square \square \square$ \\
\hline & & & & & $\square \square \square$ \\
\hline & & & & & $\square \square \square$ \\
\hline & & & & & $\square \square \square$ \\
\hline & & & & & $\square \square \square$ \\
\hline & & & & & $\square \square \square$ \\
\hline & & & & & $\square \square \square$ \\
\hline & & & & & $\square \square \square$ \\
\hline & & & & & $\square \square \square$ \\
\hline & & & & & $\square \square \square$ \\
\hline & & & & & $\square \square \square$ \\
\hline & & & & & $\square \square \square$ \\
\hline & & & & & $\square \square \square$ \\
\hline & & & & & $\square \square \square$ \\
\hline & & & & & $\square \square \square$ \\
\hline & & & & & $\square \square \square$ \\
\hline & & & & & $\square \square \square$ \\
\hline & & & & & $\square \square \square$ \\
\hline & & & & & $\square \square \square$ \\
\hline & & & & & $\square \square \square$ \\
\hline & & & & & $\square \square \square$ \\
\hline
\end{tabular}




\section{Appendix G. Site Data}

\section{Explanation of the Data}

Tables G-1 and G-2 detail the geophysical and archaeological variables for each site. The lowest depth of recovered artifacts in shovel tests are presented in centimeters.

Table G-1 explains the sampling method used at each site and provides an inventory of the artifact assemblage. Subsurface artifact quantities listed are either from a grab sample, controlled 5-m radius dogleashes, or 100-percent inventories. If a dogleash sample was inventoried, the number of the dogleash is given (i.e. 59-1). Some sites were sampled only by dogleash; others were 100 percent inventoried, either with or without a dogleash. An " $X$ " in the sample variable column indicates the type of sample from which the artifacts listed in that row were recovered. Artifacts from shovel tests are also presented in Table G-1.

In Table G-2, site size is determined by the maximum length multiplied by its maximum width. The elevation of each site datum is given in feet according to its position on USGS 7.5 minute topographic quadrant maps. The distance of a site to the nearest extant water source is in meters. Water sources are either permanently flowing (Leon and Medio creeks), or intermittent with seepage ponds (Long Hollow). Leon and Medio creeks have alluvial terraces. The terrace on which a site rests or spans is given as T0, T1, or T2. (See Chapter 3 for Nordt's geomorphological report.] The soil typology for the survey area is taken from the Soil Conservation Service (1991) survey for Bexar County.

Table G-2 identifies the surface visibility influenced by vegetation and terrain considered at each site. Surface visibility provides an indication of sampling adequacy. A percentage estimate of visibility was made at the time that a site was recorded, which varies across different terrain types and seasons. Also, a percentage estimate was made of how much a site remained intact since much of the ground surface at Lackland has been altered by human and natural agency. Diagnostic artifacts and an estimated age for site components are given when possible. 
Table G-1. Prehistoric Site Testing Data

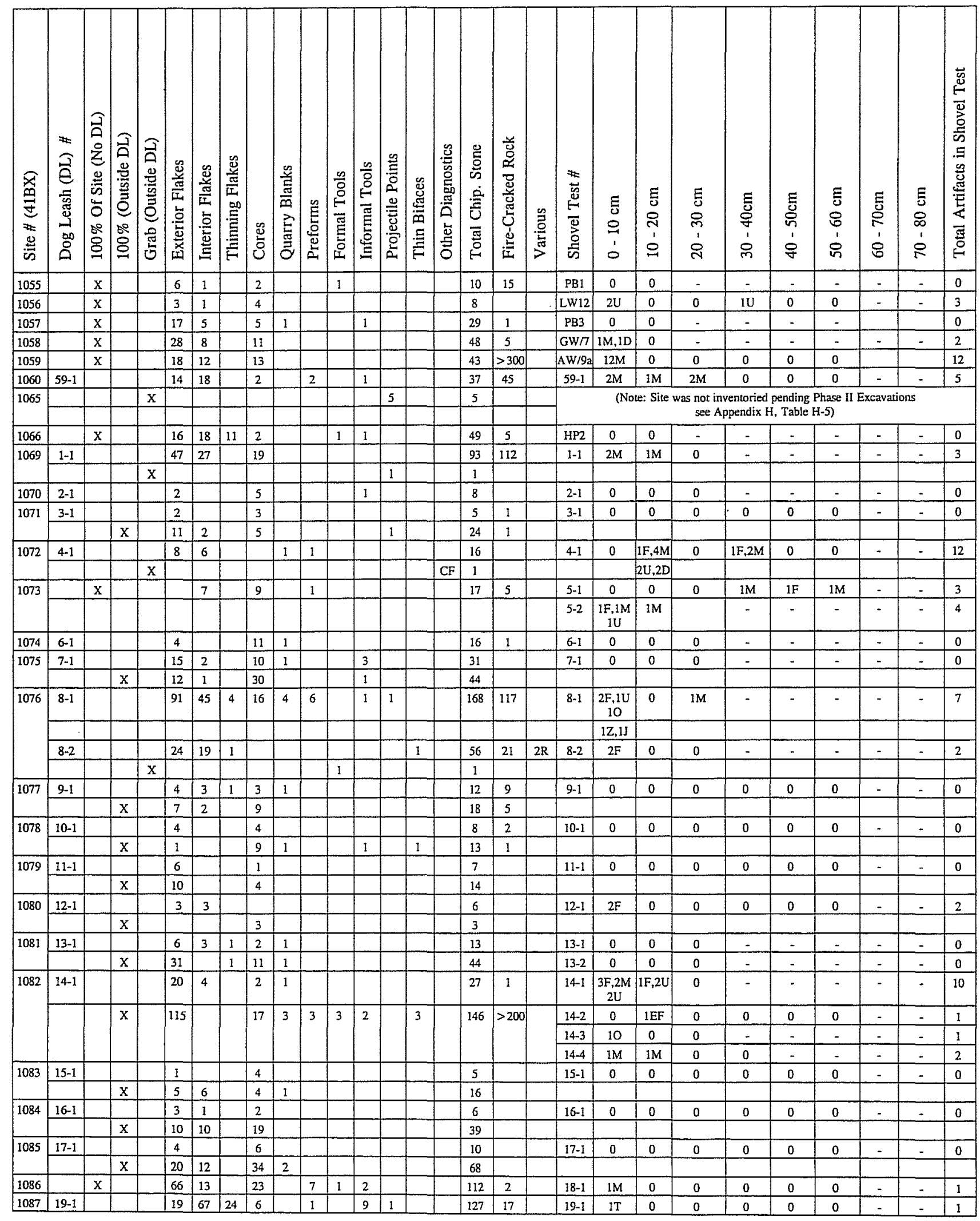


Table G-1. continued

\begin{tabular}{|c|c|c|c|c|c|c|c|c|c|c|c|c|c|c|c|c|c|c|c|c|c|c|c|c|c|c|c|c|}
\hline \multirow[t]{2}{*}{ 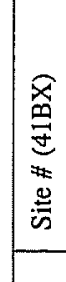 } & 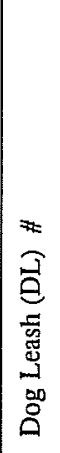 & 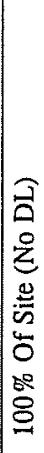 & 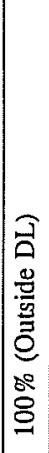 & 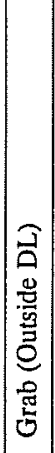 & 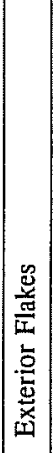 & 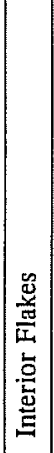 & 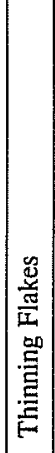 & $\begin{array}{l} \\
\\
0 \\
0 \\
0 \\
0\end{array}$ & 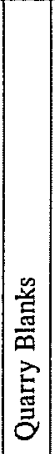 & 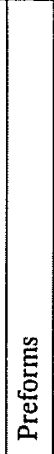 & 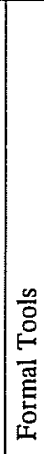 & 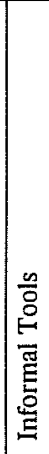 & 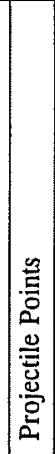 & | & 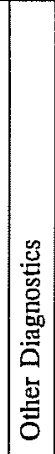 & 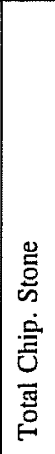 & 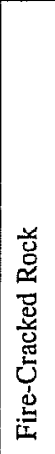 & 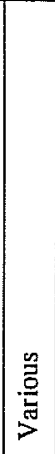 & 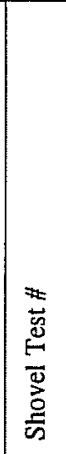 & $\begin{array}{l}E \\
\tilde{0} \\
0 \\
\vdots \\
0\end{array}$ & $\begin{array}{l}E \\
5 \\
0 \\
\\
1 \\
0\end{array}$ & $\begin{array}{l}E \\
E \\
0 \\
\stackrel{7}{1} \\
\dot{N}\end{array}$ & $\begin{array}{l}\text { E } \\
\text { 巳 } \\
\text { ' } \\
\text { ○े }\end{array}$ & $\begin{array}{l}\text { 평 } \\
\text { ஜ } \\
\dot{8}\end{array}$ & $\begin{array}{l}E \\
\text { E } \\
8 \\
\dot{D}\end{array}$ & $\begin{array}{l}\frac{E}{8} \\
0 \\
8\end{array}$ & $\begin{array}{l}E \\
5 \\
\infty \\
1 \\
尺\end{array}$ & 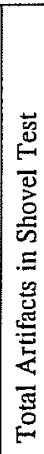 \\
\hline & $19-2$ & & & & 21 & 35 & 13 & 6 & & 2 & 1 & 1 & & & & 79 & 28 & & & & & & & & & & & \\
\hline \multirow[t]{4}{*}{1088} & $20-1$ & & & & 16 & 6 & 1 & 13 & & 1 & & & 1 & & & 38 & 26 & 3 & $20-1$ & $2 \mathrm{U}$ & $1 \mathrm{M}$ & 10 & 0 & 0 & - & - & - & 4 \\
\hline & $20-2$ & & & & 18 & 10 & 2 & 10 & & & & & & 2 & & 42 & 10 & & $20-2$ & 0 & 0 & 0 & 0 & 0 & 0 & . & - & 0 \\
\hline & $20-3$ & & & & 48 & 15 & 7 & 20 & 5 & 3 & 1 & 7 & 1 & 2 & GT & 109 & 7 & & & & & & & & & & & \\
\hline & & & & $x$ & & & & & & & & & & & $G T$ & 1 & & & & & & & & & & & & \\
\hline \multirow[t]{2}{*}{1089} & 21-1 & & & & 1 & & & 5 & & & & & & & & 6 & 1 & & $21-1$ & 0 & 0 & 0 & - & - & - & - & - & 0 \\
\hline & & & $x$ & & 9 & 1 & & 27 & & & & 2 & & & & 39 & 1 & & & & & & & & & & & \\
\hline \multirow{2}{*}{1090} & $22-1$ & & & & 2 & 1 & & 5 & & & & 2 & & & & 10 & 4 & & $22-1$ & 0 & 0 & 0 & - & - & - & - & - & 0 \\
\hline & & & $\mathrm{X}$ & & 22 & 1 & & 29 & & & & & & & & 52 & 5 & & & & & & & & & & & \\
\hline \multirow[t]{2}{*}{1091} & $23-1$ & & & & 8 & 3 & & 8 & 1 & & & & & & & 20 & & & $23-1$ & 0 & 0 & 0 & - & - & - & - & - & 0 \\
\hline & & & $x$ & & 3 & 4 & & 8 & 3 & & & & & & & 18 & & & & & & & & & & & & \\
\hline 1092 & & $\mathrm{x}$ & & & 6 & 13 & 3 & 2 & & 1 & 1 & & & & & 26 & 8 & & $24-1$ & $2 F, 1 M$ & IM & 0 & 0 & 10 & - & - & - & 5 \\
\hline \multirow[t]{2}{*}{1093} & 25-1 & & & & 18 & 14 & 10 & 2 & & & & & & & & 47 & 3 & $Y$ & $25-1$ & $2 \mathrm{~F}, 4 \mathrm{M}$ & $1 F, 4 \mathrm{U}$ & 0 & $1 \mathrm{~F}, 2 \mathrm{M}$ & $2 \mathrm{~F}, 7 \mathrm{M}$ & $3 \mathrm{M}, 1 \mathrm{X}$ & - & - & 41 \\
\hline & & & $x$ & & 11 & 7 & 5 & 7 & 1 & & & & & & & 31 & 7 & & & & & & $2 \mathrm{U}, 2 \mathrm{Z}$ & $2 \mathrm{U}, 5 \mathrm{Z}$ & $2 \mathrm{U}, 1 \mathrm{~W}$ & & & \\
\hline 1094 & $26-1$ & & & & 19 & 9 & 2 & 3 & 1 & 1 & & 2 & & & & 37 & & & $26-1$ & $2 \mathrm{U}$ & IM,1U & 0 & 0 & 0 & 0 & . & - & 41 \\
\hline 1095 & $27-1$ & & & & 2 & & & 2 & 3 & & & & & & & 7 & & & $27-1$ & 0 & \begin{tabular}{l|} 
\\
\end{tabular} & 0 & - & - & - & - & - & 0 \\
\hline 1096 & $28-1$ & & & & 1 & & & 6 & 1 & & & & & & & 8 & & & $28-1$ & 0 & 0 & 0 &. & - & - & - & - & 0 \\
\hline 1097 & $29-1$ & & & & 4 & 1 & & 1 & 3 & & & & & & & 9 & & & $29-1$ & 0 & 0 & 0 & - & - & - & - & - & 0 \\
\hline 1098 & $30-1$ & & & & 12 & 4 & & 2 & 1 & 1 & & 1 & & 1 & & 22 & & & $30-1$ & 0 & 0 & 0 & - & - & - & - & - & 0 \\
\hline \multirow[t]{3}{*}{1099} & $31-1$ & & & & 26 & 6 & & 3 & & 1 & & 7 & & & & 43 & 3 & & $31-1$ & 0 & 0 & 0 & $1 \mathrm{M}$ & $1 \mathrm{M}$ & 0 & . & $\therefore$ & 2 \\
\hline & $31-2$ & & & & 10 & 8 & & 3 & & & & & & & & 21 & & & & & & & & & & & & \\
\hline & $31-3$ & & & & 7 & 12 & & 7 & & & & & & & & 26 & & & & & & & & & & & & \\
\hline \multirow[t]{8}{*}{1100} & 32-1 & & & & 34 & 6 & & 19 & 2 & & & 2 & 1 & & & 64 & 2 & & $32-1$ & $1 \mathrm{~F}$ & 0 & 0 & - & - & - & - & - & 1 \\
\hline & \begin{tabular}{|l}
$32-3$ \\
\end{tabular} & & & & 12 & & & 11 & & & & 1 & & & & 24 & & & $32-3$ & $1 \mathrm{~F}, 1 \mathrm{M}$ & 0 & 0 & 0 & 0 & 0 & - & - & 2 \\
\hline & $32-4$ & & & & 15 & 2 & & 19 & & & & & & & & 36 & 1 & & $32-4$ & 0 & 0 & 0 & $1 \mathrm{~F}$ & - & - & . &. & 1 \\
\hline & $32-5$ & & & & 24 & & & 8 & 1 & 3 & & & & & & 36 & 60 & & $32-5$ & $1 \mathrm{~F}$ & 0 & 0 & - & - & - & - & - & 1 \\
\hline & $32-6$ & & & & 13 & 2 & & 3 & 2 & & & & & & & 20 & & & $32-6$ & 0 & 0 & 0 & - &. & - & - & - & 0 \\
\hline & $32-7$ & & & & 9 & 2 & & 6 & & & & & & & & 17 & & & $32-7$ & 0 & $1 \mathrm{M}$ & . & - & - & - & - & - & 1 \\
\hline & $32-8$ & & & & 17 & 9 & & 16 & 2 & & & 2 & & & & 46 & 2 & & & & & & & & & & & \\
\hline & & & & $x$ & & & & & & & & & 1 & & GT & 2 & & & $32-2$ & $1 F, 1 \mathrm{M}$ & $1 \mathrm{U}$ & 0 & - & - & - & - & - & 3 \\
\hline \multirow[t]{3}{*}{1101} & $33-1$ & & & & 22 & 6 & 2 & 2 & 1 & 2 & & 3 & 3 & & & 41 & 20 & & 33-1 & $2 \mathrm{~F}$ & 0 & 0 & 0 & 0 & 0 & - & - & 2 \\
\hline & $33-2$ & & & & 45 & 29 & 8 & 6 & 1 & 1 & & 5 & 1 & 1 & & 97 & 17 & & & & & & & & & & & \\
\hline & & & & & & & & & & & & & & & & & & & & & & & & & & & & \\
\hline \multirow[t]{3}{*}{1102} & \begin{tabular}{|l|}
$34-1$ \\
\end{tabular} & & & & 20 & 18 & 5 & 2 & & & & 2 & & & & 47 & 2 & & $34-1$ & $1 \mathrm{M}, 1 \mathrm{U}$ & $1 \mathrm{U}$ & 0 & 0 & 0 & 10 & - & - & 4 \\
\hline & $34-2$ & & & & 18 & 5 & 1 & 7 & & 1 & 1 & 1 & & & & 34 & 26 & & $34-2$ & 0 & 0 & 0 & 0 & 0 & 0 & - & - & 0 \\
\hline & $34-3$ & & & & 20 & 14 & 6 & 2 & & & & 4 & 1 & & & 47 & 26 & & & & & & & & & & & \\
\hline \multirow[t]{2}{*}{1103} & $35-1$ & & & & 15 & 16 & & 1 & & & & & & & & 32 & 7 & & $35-1$ & $1 F, 10$ & $2 \mathrm{~F}, 1 \mathrm{O}$ & $4 \mathrm{U}, 1 \mathrm{M}$ & $2 \mathrm{~F}, 1 \mathrm{U}$ & $1 F, 1 M$ & $1 \mathrm{M}, 10$ & $3 \mathrm{U}$ & $5 \mathrm{~S}$ & 38 \\
\hline & & & & $\mathrm{x}$ & & & & & & 1 & & & 1 & 1 & & 3 & & & & IZ & & IT & & $4 U, 1 D$ & 12 & 22 & & \\
\hline 1104 & & & & & & NOT & TE: D & DUE T & $\mathrm{TO} \mathrm{TH}$ & HE LA & ARG & EAM & IOUN & TT OF & AT & $A, 41 B$ & $\mathrm{x} 1104$ & $A$ & EARS S & EPARAT & TELY A & T THE ED & ND OF TH & HIS TABI & & & & \\
\hline 1105 & & $\mathrm{x}$ & & & 6 & 2 & & 6 & & 1 & & 1 & & & & 16 & & & $37-1$ & 0 & 0 & 0 & 0 & 0 & 0 & - & - & 0 \\
\hline 1106 & & $\mathrm{x}$ & & & \begin{tabular}{|l|}
18 \\
\end{tabular} & 2 & & 7 & & 1 & & & & & & 28 & & & $38-1$ & $1 \mathrm{M}$ & $\mathrm{IM}$ & 0 & $\cdot$ & - & - & - & - & 2 \\
\hline 1107 & & $x$ & & & 66 & 198 & 148 & 9 & & & & 5 & 1 & 3 & & 430 & 42 & & $39-1$ & $\begin{array}{c}1 \mathrm{~F}, 2 \mathrm{M} \\
6 \mathrm{U}, 23 \mathrm{Z}\end{array}$ & $\begin{array}{c}1 \mathrm{U}, 3 \mathrm{Z} \\
2 \mathrm{X}\end{array}$ & $2 M, 1 X$ & $1 \mathrm{M}, 1 \mathrm{X}$ & $1 \mathrm{U}$ & 0 & . & - & 44 \\
\hline 1108 & & $\mathrm{x}$ & & & 6 & 40 & 21 & 1 & & 1 & & & & 1 & & 70 & & & $40-1$ & $7 \mathrm{U}$ & $4 \mathrm{U}$ & $\begin{array}{l}1 \mathrm{~F}, 1 \mathrm{M}, \\
2 \mathrm{U}, 1 \mathrm{Z}\end{array}$ & $\begin{array}{c}3 \mathrm{U}, 1 \mathrm{D} \\
2 \mathrm{Z}\end{array}$ & $\begin{array}{c}1 F, 7 \mathrm{U} \\
10 \\
\end{array}$ & - & . & - & 31 \\
\hline & & & & & & & & & & & & & & & & & & & $40-2$ & $\begin{array}{c}4 \mathrm{~F}, 2 \mathrm{M} \\
2 \mathrm{Z}\end{array}$ & $\begin{array}{l}8 \mathrm{U}, \\
1 \mathrm{Z}\end{array}$ & $1 \mathrm{M}, 1 \mathrm{U}$ & $2 \mathrm{U}, 6 \mathrm{Z}$ & $\mid \begin{array}{c}1 \mathrm{M}, 6 \mathrm{U} \\
3 \mathrm{~A} \\
\mathrm{~J} \mathrm{Z}, 1 \mathrm{~W}\end{array}$ & $\frac{1 \mathrm{M}, 10 \mathrm{U}}{2 \mathrm{Z}}$ & $\begin{array}{c}1 \mathrm{~F}, 1 \mathrm{M} \\
17 \mathrm{Z}\end{array}$ & - & 100 \\
\hline 1109 & $41-1$ & & & & 1 & 1 & & 4 & & & 1 & 1 & & & & 7 & & & $41-1$ & 0 & 0 & 0 & - & $1-$ & - & - & - & 0 \\
\hline & & & & $x$ & & & & & & & 1 & & & & & 1 & & & & & & & & & & & & \\
\hline
\end{tabular}


Table G-1. continued

\begin{tabular}{|c|c|c|c|c|c|c|c|c|c|c|c|c|c|c|c|c|c|c|c|c|c|c|c|c|c|c|c|c|}
\hline 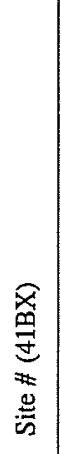 & 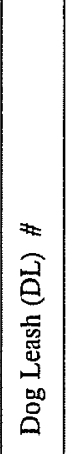 & 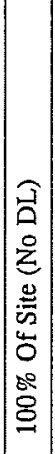 & 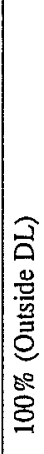 & 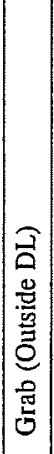 & 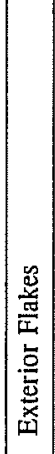 & 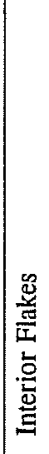 & 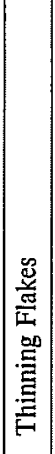 & 递 & 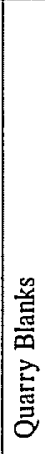 & 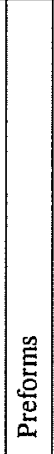 & 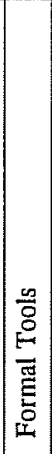 & 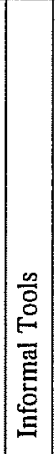 & 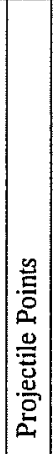 & 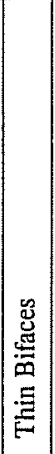 & 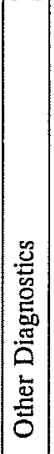 & 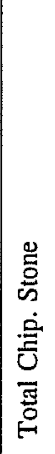 & 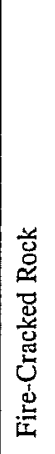 & 号 & 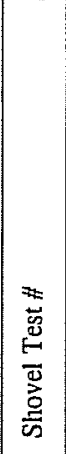 & $\begin{array}{l}E \\
\tilde{J} \\
0 \\
1 \\
0\end{array}$ & $\begin{array}{l}5 \\
5 \\
0 \\
0 \\
1 \\
0\end{array}$ & 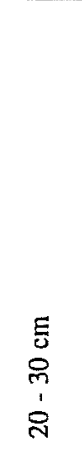 & $\begin{array}{l}E \\
\stackrel{E}{g} \\
\dot{g} \\
\dot{m}\end{array}$ & $\begin{array}{l}\text { E⿱丷⿹弔㇒ } \\
\stackrel{8}{n} \\
\dot{8}\end{array}$ & $\begin{array}{l}\text { 텽 } \\
8 \\
\dot{8} \\
\dot{n}\end{array}$ & $\begin{array}{l}E \\
8 \\
8 \\
8 \\
8\end{array}$ & $\begin{array}{l}\overline{5} \\
8 \\
0 \\
1 \\
0\end{array}$ & 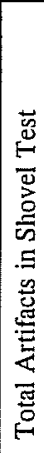 \\
\hline 1110 & $42-1$ & & & & 7 & & & 3 & 1 & & & & & & & 11 & & $\mathrm{~J}$ & $42-1$ & 0 & $2 Z$ & 0 & - & - & - & - & - & 2 \\
\hline \multirow[t]{2}{*}{1111} & $43-1$ & & & & 5 & 3 & & 6 & & & & & & & & 14 & 1 & & $43-1$ & 0 & 0 & 0 & - & - & - & - & - & 0 \\
\hline & & & & $\mathrm{x}$ & & & & & & & & 1 & & & & 1 & & & & & & & & & & & & \\
\hline 1112 & $44-1$ & & & & & & & 4 & & & & 1 & & & & 5 & & & $44-1$ & 0 & 0 & 0 & $=$ & - & - & - & - & 0 \\
\hline \multirow[t]{2}{*}{1113} & $45-1$ & & & & 14 & 4 & & 5 & & & & 1 & & & & 24 & & & $45-1$ & 0 & 0 & 0 & - & - & - & - & - & 0 \\
\hline & $45-2$ & & & & 1 & 1 & & 1 & & & & 1 & & & & 4 & & & $45-2$ & 0 & 0 & 0 & - & - & - & - & - & 0 \\
\hline \multirow[t]{3}{*}{1114} & $46-1$ & & & & 3 & 4 & & 3 & 1 & & & & & & & 11 & & & $46-1$ & 0 & 0 & 0 & - & $=$ & - & - & $=$ & 0 \\
\hline & $46-2$ & & & & 9 & 7 & & 7 & 1 & & & & & & & 24 & & & $46-2$ & $1 \mathrm{~F}, 4 \mathrm{M}$ & $2 \mathrm{~F}, 2 \mathrm{M}$ & $2 \mathrm{M}$ & - & - & - & - & - & 11 \\
\hline & & & & $\mathrm{x}$ & & & & & & & & & & & $\mathrm{K}$ & 1 & & & & & & & & & & 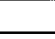 & - & \\
\hline 1115 & & $\mathrm{x}$ & & & 24 & 29 & 8 & 7 & & 2 & & 7 & & & & 77 & 43 & & $47-1$ & 0 & 0 & 0 & 0 & 0 & 0 & - & - & 0 \\
\hline 1116 & & $x$ & & & 29 & 10 & & 6 & & & & & & & & 45 & & & $48-1$ & 0 & 0 & 0 & - & - & - & - & - & 0 \\
\hline 1117 & & $\mathrm{x}$ & & & 9 & 3 & & 4 & 1 & & & & & & & 17 & & & $49-1$ & $1 \mathrm{D}, 10$ & 0 & 0 & - & - & - & - & - & 2 \\
\hline 1118 & $50-1$ & & & & 32 & 7 & & 18 & & & & & & & & 57 & & & $50-1$ & 0 & 1D & 0 & - & - & - & - & - & 1 \\
\hline 1119 & & $x$ & & & 6 & 2 & & 4 & & & & 1 & & & & 13 & 2 & & $51-1$ & 0 & 0 & 0 & 0 & 0 & 0 & 0 & 0 & 0 \\
\hline 1120 & $52-1$ & & & & 35 & 23 & 15 & 15 & 1 & & & & & 1 & & 90 & 86 & & $52-1$ & $2 \mathrm{~F}, 8 \mathrm{U}$ & $2 \mathrm{M}, 2 \mathrm{U}$ & $1 \mathrm{~F}$ & 0 & 0 & 0 & 0 & 0 & 15 \\
\hline \multirow[t]{2}{*}{1121} & $53-1$ & & & & 40 & 54 & 15 & 8 & & & & & & 1 & & 118 & 84 & & $53-1$ & $9 \mathrm{M}, 5 \mathrm{U}$, & $\mathrm{IF}$ & 0 & $2 \mathrm{M}$ & 0 & $1 M$ & 0 & - & 19 \\
\hline & & & & $x$ & & & & & & & & & 1 & & & 1 & & $\mathrm{~J}$ & & $1 \mathrm{~T}$ & & & & & & & & \\
\hline 1122 & $54-1$ & & & & 53 & 63 & 18 & 3 & 1 & 1 & & 1 & 1 & 1 & & 142 & 56 & & 54-1 & IF,IU & $1 \mathrm{~F}, 2 \mathrm{M}$ & $1 \mathrm{~F}, 5 \mathrm{U}$ & $2 \mathrm{M}$ & $1 \mathrm{M}$ & 0 & - & - & 14 \\
\hline \multirow{2}{*}{1123} & $55-1$ & & & & $33 \mid$ & 12 & & 10 & 1 & & & 1 & & & & 57 & 9 & & $55-1$ & $2 \mathrm{M}$ & 0 & 0 & - & - & - & - & - & 2 \\
\hline & & & & & & & & & & & & & & & & & & & $55-2$ & $5 \mathrm{M}$ & 0 & $1 \mathrm{~F}$ & - & - & - & - & - & 6 \\
\hline \multirow[t]{2}{*}{1124} & $56-1$ & & & & 5 & 1 & & 2 & & & & & & & & 8 & 21 & & $56-1$ & $2 \mathrm{~F}, 2 \mathrm{M}$ & $1 \mathrm{M}$ & 0 & - & - & - & - & - & 5 \\
\hline & & & & $x$ & & & & & & & & & & 1 & & 1 & & & & & & & & & & & & \\
\hline \multirow[t]{2}{*}{1125} & $57-1$ & & & & 14 & 30 & 20 & & 1 & & & & & & & 65 & 53 & & $57-1$ & IM & 0 & 0 & - & - & - & - & - & 1 \\
\hline & & & & $x$ & & & & & 1 & & & 1 & & & & 2 & & & & & & & & & & & & \\
\hline 1126 & $58-1$ & & & & 12 & 20 & 8 & 1 & & & & 1 & & & & 42 & & & \begin{tabular}{|l|}
$58-1$ \\
\end{tabular} & 10,12 & $4 Z$ & 0 & 0 & \begin{tabular}{|c|}
$1 F, 1 M$ \\
$3 Z$
\end{tabular} & $1 \mathrm{M}, 2 \mathrm{U}$ & - & - & 14 \\
\hline 1127 & $60-1$ & & & & 32 & 42 & & 6 & & & 1 & 1 & 1 & & & 83 & 122 & & $60-1$ & $1 \mathrm{M}, 10$ & $1 \mathrm{~F}, 3 \mathrm{M}$ & $\begin{array}{c}1 \mathrm{M}, 1 \mathrm{I} \\
10,1 \mathrm{~T} \\
1 \mathrm{Z}, 1 \mathrm{~A} \\
1 \mathrm{X}\end{array}$ & $\begin{array}{l}1 F, 2 M_{r} \\
1 U, 3 Z\end{array}$ & $\begin{array}{c}1 F, 2 U \\
1 X\end{array}$ & - & $\cdot$ & - & 24 \\
\hline 1130 & & $x$ & & & & 5 & & & & & & & & 1 & & 6 & & & 63-1 & 0 & 0 & 0 & - & - & - & - & - & 0 \\
\hline \multirow[t]{15}{*}{1104} & $36-1$ & & & & 40 & 15 & & 21 & 2 & 1 & & 3 & & & & 82 & 3 & & $36-1$ & 12 & 0 & 0 & 0 & 0 & 0 & - & - & 1 \\
\hline & $36-2$ & & & & 5 & 13 & 2 & & & & & 1 & & & & 21 & & & $36-2$ & $2 F, 4 Z$ & \begin{tabular}{|l|}
$1 F, 2 U$ \\
$1 D, 8 Z$ \\
\end{tabular} & 0 & - & - & - & - & - & 18 \\
\hline & $36-3$ & & & & 13 & 4 & 1 & 2 & & & & 3 & & & & 23 & 4 & & $36-3$ & 0 & \begin{tabular}{|l|}
0 \\
\end{tabular} & 0 & $=$ & - & $=$ & - & - & 0 \\
\hline & $36-4$ & & & & 24 & 19 & 2 & 19 & I & & 2 & & & & & 67 & 9 & & $36-4$ & $5 \mathrm{~F}, 3 \mathrm{U}$ & 0 & 0 & - & - & - & - & - & 8 \\
\hline & $36-5$ & & & & 25 & 10 & & 22 & 1 & & 3 & & & 1 & & 62 & 7 & & $36-5$ & 10 & 0 & 0 & - & - & $\therefore$ & - & - & 1 \\
\hline & $36-6$ & & & & 82 & 43 & 25 & 24 & 4 & 2 & 4 & & & & & 184 & 21 & & $36-6$ & $7 \mathrm{~F}, 4 \mathrm{M}$ & $3 \mathrm{~F}, 2 \mathrm{M}$ & $1 \mathrm{M}, 2 \mathrm{U}$ & $\begin{array}{c}1 \mathrm{~F}, 1 \mathrm{M}, \\
\mathrm{IU}\end{array}$ & $\begin{array}{c}2 \mathrm{M}, \mathrm{IU} \\
\mathrm{ID}\end{array}$ & - & 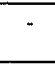 & - & 26 \\
\hline & $36-7$ & & & & 66 & 30 & 9 & 38 & 6 & 3 & 1 & 3 & 1 & & & 157 & 33 & & $36-7$ & 0 & $1 F, 1 \mathrm{U}$ & 0 & - & - & - & - & - & 2 \\
\hline & $36-8$ & & & & 15 & 10 & & 6 & & & & & & & & 31 & 6 & & $36-8$ & 0 & 0 & 0 & - & - & - & - & - & 0 \\
\hline & $36-9$ & & & & 24 & 6 & 1 & 6 & & & & 4 & & & & 41 & 10 & & 36-9 & $1 \mathrm{~F}$ & 0 & 0 & 0 & 0 & 0 & - & - & 1 \\
\hline & $36-10$ & & & & 2 & 3 & 2 & & & & & 1 & & & & 8 & 2 & & $36-10$ & 0 & 0 & 0 & - & - & - & - & - & 0 \\
\hline & $36-11$ & & & & 17 & 4 & 1 & 14 & 4 & & & & & & & 40 & 7 & & $36-11$ & 0 & 0 & 0 & - & - & - & - & - & 0 \\
\hline & $36-12$ & & & & 15 & 3 & & 17 & 4 & & & & & & & 39 & 1 & & 36-12 & $1 \mathrm{U}$ & $1 M$ & 0 & - & - & - & - & - & 2 \\
\hline & $36-13$ & & & & 52 & 39 & 1 & 82 & & & & 8 & & & & 182 & & & $36-13$ & $1 \mathrm{U}$ & $1 \mathrm{U}$ & 0 & 0 & 0 & 0 & $\because$ & - & 2 \\
\hline & $36-14$ & & & & 11 & 3 & & 4 & $I$ & & & & & & & 19 & 9 & & $36-14$ & 0 & 0 & 0 & - & - & - & - & - & 0 \\
\hline & $36-15$ & & & & 12 & 2 & & 6 & 1 & & & 2 & & & & 23 & 2 & & $36-15$ & \begin{tabular}{|c|}
$1 F_{1}, \mathrm{MM}$ \\
$\mathrm{lZ}$
\end{tabular} & 0 & 0 & 0 & 0 & - & - & - & 3 \\
\hline
\end{tabular}


Table G-1. continued

\begin{tabular}{|c|c|c|c|c|c|c|c|c|c|c|c|c|c|c|c|c|c|c|c|c|c|c|c|c|c|c|c|c|}
\hline 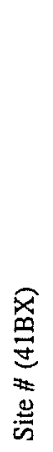 & 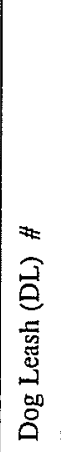 & 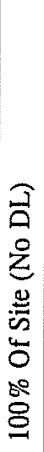 & 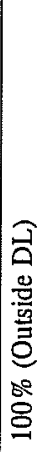 & 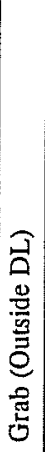 & 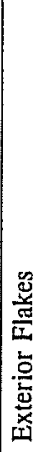 & 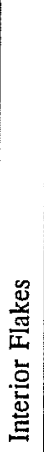 & 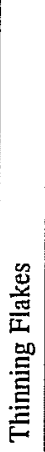 & $\stackrel{\mathscr{S}}{0}$ & 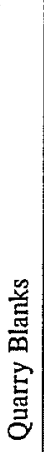 & 怘 & $\frac{\stackrel{n}{8}}{\stackrel{0}{0}}$ & $\frac{\text { 号 }}{0}$ & 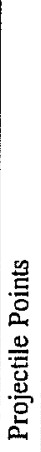 & 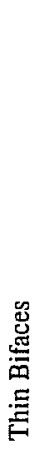 & 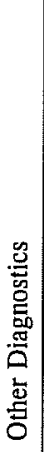 & 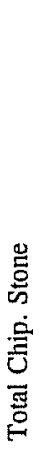 & 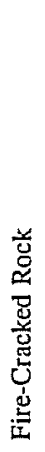 & $\stackrel{3}{0}$ & 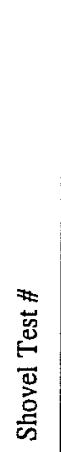 & $\begin{array}{c}E \\
E \\
0 \\
1 \\
0\end{array}$ & 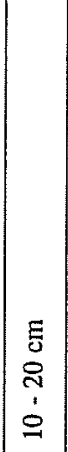 & 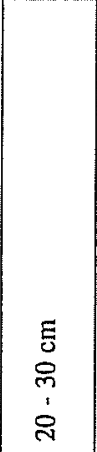 & $\begin{array}{l}\text { E } \\
\stackrel{y}{8} \\
\dot{m}\end{array}$ & 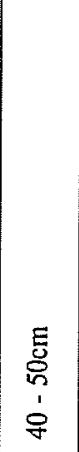 & $\begin{array}{l}E \\
0 \\
0 \\
0 \\
0\end{array}$ & $\underset{8}{\stackrel{E}{8}}$ & $\begin{array}{l}E \\
0 \\
0 \\
0 \\
1\end{array}$ & 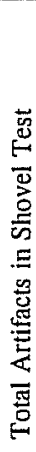 \\
\hline \multirow{6}{*}{$\begin{array}{c}1104 \\
\text { cont. }\end{array}$} & $36-16$ & & & & 10 & 9 & 1 & 3 & & & & & & & & 23 & 9 & & $36-16$ & $1 F$ & $8 \mathrm{M}, 4 \mathrm{U}$ & $12 \mathrm{M}, 10 \mathrm{U}$ & $5 \mathrm{M}, 8 \mathrm{U}$ & $2 \mathrm{M}, 1 \mathrm{U}$ & 0 & - & - & 51 \\
\hline & $36-17$ & & & & 50 & 20 & & 20 & & 1 & & 4 & & & & 95 & 37. & & $36-17$ & $2 U$ & $\begin{array}{c}1 \mathrm{~F} \\
13 \mathrm{Z} \\
\end{array}$ & $2 \mathrm{M}, 1 \mathrm{U}$ & $4 \mathrm{Z}$ & $2 Z$ & - & - & - & 27 \\
\hline & & & & & & & & & & & & & & & & & & & & & & $2 Z$ & & & & & & \\
\hline & $36-18$ & & & & 3 & 4 & & 1 & & & & & & & & 8 & & & $36-18$ & 0 & 0 & 0 & 0 & 0 & 0 & 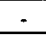 & - & 0 \\
\hline & $36-19$ & & & & 24 & 12 & & 18 & 1 & 2 & & & & & & 57 & & & $36-19$ & 0 & 0 & 0 & - & - & - & - & - & 0 \\
\hline & & & & $x$ & & & & & 1 & & 6 & & 5 & 6 & $E$ & 19 & & $3 \mathrm{~J}$ & & & & & & & & & & \\
\hline
\end{tabular}

Artifact Key

$A=$ bone
$B=$ butted knife biface
$C=$ burin
$D=$ core
$E=$ Clear Fork gouge
$F=$ exterior flake
$G=$ Fossil

$A=$ bone

$\mathrm{B}=$ butted knife biface

$\mathrm{C}=$ burin

$\mathrm{D}=$ core

$F=$ exterior flake

$\mathrm{G}=$ Fossi

\author{
$I=$ formal tool \\ $\mathrm{J}=$ ground stone \\ $\mathrm{K}=$ Guadalupe tool \\ $\mathrm{L}=$ hematite \\ $\mathrm{M}=$ interior flake \\ $\mathrm{N}=$ hearth \\ $\mathrm{O}=$ informal tool
}

$\mathrm{P}=$ preform
$\mathrm{Q}=$ projectile point
$\mathrm{R}=$ petrified wood
$\mathrm{S}=$ quarry blank
$\mathrm{T}=$ thin biface
$\mathrm{U}=$ thinning flake
$\mathrm{V}=$ turtle shell

$\mathrm{P}=$ preform

$\mathrm{R}=$ petrified wood

$\mathrm{S}=$ quarry blank

$\mathrm{U}=$ thinning flake

$\mathrm{V}=$ turtle shell

\author{
$\mathrm{W}=$ mollusk shell \\ $\mathrm{X}=$ snail shell \\ $\mathrm{Y}=$ burned caliche \\ $\mathrm{Z}=$ fire-cracked rock
}


Table G-2. Prehistoric Site Data

\begin{tabular}{|c|c|c|c|c|c|c|c|c|c|c|c|c|c|}
\hline 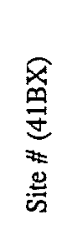 & $\stackrel{\mathscr{g}}{<}$ & 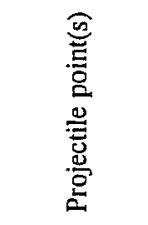 & 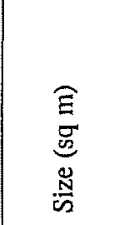 & 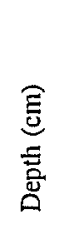 & 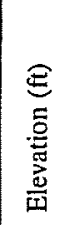 & 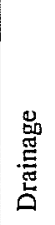 & 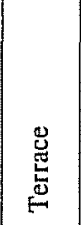 & 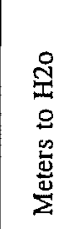 & 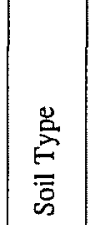 & $\begin{array}{l}\overrightarrow{\mathrm{J}} \\
\text { 莺 } \\
\text { so }\end{array}$ & 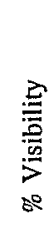 & 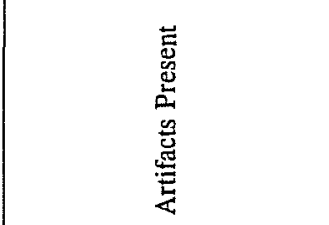 & 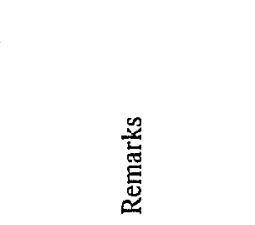 \\
\hline 1055 & unk & & 680 & 10 & 665 & $\mathrm{LH}$ & & 375 & $\mathrm{HuC}$ & 50 & 10 & CFHS & \\
\hline 1056 & unk & & 400 & 50 & 655 & $\mathrm{LH}$ & & 350 & $\mathrm{HuB}$ & 20 & 10 & CF & \\
\hline 1057 & unk & & 570 & 5 & 700 & $\mathrm{LH}$ & & 400 & $\mathrm{HuB}$ & 10 & 10 & CF & \\
\hline 1058 & unk & & 700 & 20 & 690 & LH & & 385 & HoD3 & 50 & 10 & C F B & \\
\hline 1059 & unk & & 936 & 20 & 730 & $\mathrm{LH}$ & & 310 & $\mathrm{HuB}$ & 50 & 10 & $C F$ & \\
\hline 1060 & unk & & 324 & 40 & 641 & $\mathrm{M}$ & To & 120 & LvA & 95 & 10 & C F P FCR & \\
\hline 1065 & LA & Langtry & 5600 & 40 & 742 & $\mathrm{~L}$ & UPL & 90 & $\mathrm{HuB}$ & 75 & 95 & C F B TF FCR TC & hearth, burin \\
\hline & LA & Marcos & & 40 & 742 & & UPL & 90 & $\mathrm{HuB}$ & 75 & & & \\
\hline & LA & Matamoras & & 40 & 742 & & UPL & 90 & $\mathrm{HuB}$ & 75 & & & \\
\hline & $\mathrm{TA}$ & Ensor & & 40 & 742 & & UPL & 90 & $\mathrm{HuB}$ & 75 & & & \\
\hline 1066 & unk & & 230 & 0 & 735 & $\mathrm{~L}$ & UPL & 120 & $\mathrm{HuD}$ & 50 & 75 & CF TF S FCR & \\
\hline 1069 & LA & Pedernales & 5400 & 20 & 670 & $\mathrm{M}$ & To & 30 & $\mathrm{HuC}$ & 80 & 15 & C F FCR & \\
\hline 1070 & unk & & 300 & 0 & 690 & $M$ & UPL & 200 & $\mathrm{HuC}$ & 80 & 30 & C F RF & \\
\hline 1071 & $\mathrm{TA}$ & Edgewood & 8800 & 0 & 730 & $\mathrm{M}$ & UPL & 800 & $\mathrm{HuC}$ & 25 & 30 & C F FCR TC RF & \\
\hline 1072 & EA & & 2750 & 50 & 680 & $\mathrm{LH}$ & & 270 & HoD3 & 70 & 40 & C F TF B P FCR CH QB & Clear Fork tool \\
\hline 1073 & unk & & 1950 & 50 & 665 & $\mathrm{LH}$ & & 310 & HoD3 & 80 & 30 & CF FCR P & \\
\hline 1074 & unk & & 1400 & 5 & 663 & $\mathrm{M}$ & UPL & 700 & $\mathrm{HsB}$ & 80 & 20 & C F P TC CH QB RF & + historic component \\
\hline 1075 & unk & & 1350 & 0 & 670 & $\mathrm{M}$ & UPL & 750 & $\mathrm{HsB}$ & 95 & 35 & CF S TC & \\
\hline 1076 & LP & Scallorn & 1500 & 50 & 640 & $\mathrm{M}$ & UPL & 10 & Tf & 85 & 5 & C F S TF B FCR & \\
\hline 1077 & unk & & 1600 & 0 & 678 & $\mathrm{M}$ & $\mathrm{T} 1$ & 300 & $\mathrm{HtB}$ & 90 & 5 & CF FCR & \\
\hline 1078 & unk & & 700 & 10 & 665 & $M$ & UPL & 500 & $\mathrm{HuD}$ & 95 & 10 & C F B FCR TC B QB & \\
\hline 1079 & unk & & 1125 & 0 & 685 & $\mathrm{M}$ & $\mathrm{T} 2$ & 300 & $\mathrm{HuC}$ & 80 & 50 & $\mathrm{CF}$ & \\
\hline 1080 & unk & & 160 & 0 & 715 & $\mathrm{M}$ & UPL & 700 & $\mathrm{HuB}$ & 25 & 10 & CF & \\
\hline 1081 & unk & & 6270 & 0 & 705 & $\mathrm{M}$ & UPL & 570 & $\mathrm{HuC}$ & 100 & 40 & C F TF TC QB & \\
\hline 1082 & unk & & 3431 & 30 & 730 & $M$ & UPL & 670 & $\mathrm{HuC}$ & 90 & 60 & $\begin{array}{c}\text { C F TF B S QB P TC FCR } \\
\text { RF }\end{array}$ & goundstone, fossil \\
\hline 1083 & unk & & 805 & 0 & 717 & M & UPL & 1000 & $\mathrm{HuC}$ & 90 & 30 & C F TC QB & \\
\hline 1084 & unk & & 1800 & 0 & 712 & $M$ & UPL & 1000 & $\mathrm{HuC}$ & 90 & 30 & CF TC & \\
\hline 1085 & unk & & 5694 & 0 & 710 & $M$ & UPL & 1000 & $\mathrm{HuC}$ & 90 & 20 & $\mathrm{CFQB}$ & \\
\hline 1086 & unk & & 896 & 10 & 687 & $\mathrm{M}$ & $\mathrm{T} 1$ & 400 & $\mathrm{H} t \mathrm{~B}$ & 95 & 60 & C F S FCR RF & hearth \\
\hline 1087 & LA & Matamoros & 315 & 40 & 656 & M & $\mathrm{T} 1$ & 200 & LvA & 90 & 20 & C F TF B FCR RF & \\
\hline \multirow[t]{3}{*}{1088} & EA & & 166,000 & 10 & 700 & $\mathrm{M}$ & UPL & 200 & $\mathrm{HnB}$ & 70 & 25 & CF TF B FCR TC & 2 Guadalupe tools \\
\hline & LA & Pedernales & & 10 & 700 & & UPL & 200 & $\mathrm{HnB}$ & 70 & & & \\
\hline & LA & Lange & & 10 & 700 & & UPL & 200 & $\mathrm{HnB}$ & 70 & & & \\
\hline 1089 & unk & & 1400 & 0 & 700 & $\mathrm{M}$ & UPL & 800 & $\mathrm{HuB}$ & 80 & 15 & CF S FCR & \\
\hline 1090 & unk & & 750 & 0 & 692 & $\mathrm{M}$ & UPL & 900 & $\mathrm{HuB}$ & 90 & 50 & C F TF FCR RF & \\
\hline 1091 & unk & & 540 & 0 & 702 & $\mathrm{M}$ & UPL & 550 & $\mathrm{HuC}$ & 50 & 5 & CF QB CH RF & \\
\hline
\end{tabular}


Table G-2. continued

\begin{tabular}{|c|c|c|c|c|c|c|c|c|c|c|c|c|c|}
\hline 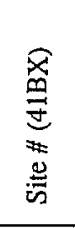 & $\stackrel{\&}{\&}$ & 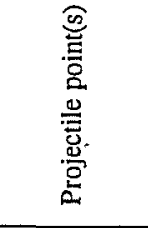 & 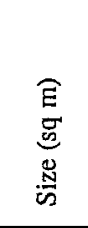 & $\begin{array}{l}\widehat{\widehat{E}} \\
\text { 䓌 } \\
\text { 总 }\end{array}$ & 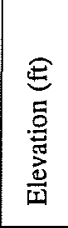 & 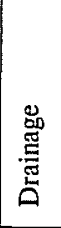 & 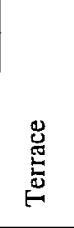 & 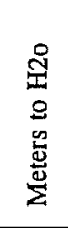 & 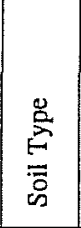 & 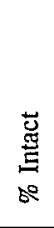 & 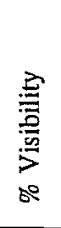 & 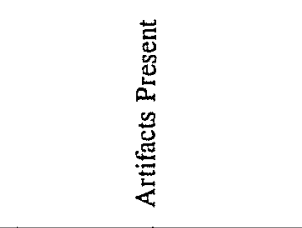 & $\begin{array}{l}\text { 号 } \\
\text { 意 } \\
\text { 品 }\end{array}$ \\
\hline 1092 & unk & & 525 & 50 & 660 & M & $\mathrm{T} 1$ & 90 & $\mathrm{HuB}$ & 50 & 15 & C F TF B P FCR G & \\
\hline 1093 & unk & & 1000 & 60 & 665 & $\mathrm{M}$ & T0 & 60 & $\mathrm{HuB}$ & 95 & 5 & C F TF FCR G & burned shell(st) \\
\hline 1094 & unk & & 500 & 40 & 675 & $\mathrm{M}$ & $\mathrm{T} 2$ & 230 & $\mathrm{HtB}$ & 90 & 5 & C F TF P RF & \\
\hline 1095 & unk & - & 400 & 0 & 685 & $\mathrm{M}$ & UPL & 480 & $\mathrm{HuB}$ & 20 & 5 & C F QB & \\
\hline 1096 & unk & & 300 & 0 & 690 & $\mathrm{M}$ & UPL & 500 & $\mathrm{HuB}$ & 90 & 5 & $\mathrm{CF} Q \mathrm{QB}$ & \\
\hline 1097 & unk & & 900 & 0 & 700 & $\mathrm{M}$ & UPL & 730 & $\mathrm{HuC}$ & 80 & 10 & $\mathrm{CF} Q \mathrm{~B}$ & \\
\hline 1098 & unk & & 600 & 20 & 752 & $\mathrm{LH}$ & & 100 & $\mathrm{HuD}$ & 90 & 40 & C F B P FCR TC RF & \\
\hline 1099 & unk & & 5250 & 50 & 670 & $\mathrm{LH}$ & & 100 & $\mathrm{HuD}$ & 70 & 20 & C F FCR TC RF & 2 cultural strata \\
\hline \multirow[t]{2}{*}{1100} & EA & & 49500 & 40 & 720 & $\mathrm{LH}$ & & 100 & $\mathrm{HuD}$ & 80 & 55 & C F TF B P FCR RF SS & Guadalupe tool \\
\hline & LA & Castroville & & 40 & 720 & & & 100 & $\mathrm{HuD}$ & 80 & & & \\
\hline \multirow[t]{3}{*}{1101} & TA & Ellis & 960 & 10 & 675 & $\mathrm{LH}$ & & 30 & $\mathrm{HuC}$ & 95 & 40 & C F P FCR QB RF & \\
\hline & LA & Castroville & & 10 & 675 & & & 30 & $\mathrm{HuC}$ & 95 & & & - \\
\hline & TA & Frio & & 10 & 675 & & & 30 & $\mathrm{HuC}$ & 95 & & & \\
\hline 1102 & LA & Pedernales & 1050 & 50 & 692 & $\mathrm{M}$ & $\mathrm{TI}$ & 150 & $\mathrm{HtB}$ & 90 & 10 & C F FCR RF D & \\
\hline 1103 & TA & Edgewood & 700 & 90 & 695 & $\mathrm{M}$ & $\mathrm{TI}$ & 70 & $\mathrm{HtB}$ & 95 & 5 & C F TF B P FCR RF & turtle shell(st) \\
\hline 1105 & unk & & 1054 & 0 & 715 & $\mathrm{M}$ & UPL & 320 & $\mathrm{HuD}$ & 85 & 20 & CF RF & \\
\hline 1106 & unk & & 840 & 20 & 708 & $\mathrm{M}$ & UPL & 300 & $\mathrm{HuC}$ & 95 & 20 & C F P TC RF & \\
\hline 1107 & unk & & 168 & 50 & 678 & $\mathrm{~L}$ & $\mathrm{~T}$ & 150 & $\mathrm{VcC}$ & 80 & 50 & C F B FCR RF & snail(st) \\
\hline 1108 & unk & & 1500 & 70 & 682 & L & $\mathrm{T}$ & 250 & $\mathrm{PaB}$ & 90 & 60 & F TF & $\begin{array}{c}\text { bone(st), fossil(st), } \\
\text { shell(st) }\end{array}$ \\
\hline 1109 & LA & & 300 & 20 & 750 & $\mathrm{LH}$ & & 300 & $\mathrm{HuB}$ & 80 & 20 & $\mathrm{CFCH}$ & butted knife biface \\
\hline 1110 & unk & & 1600 & 30 & 740 & $\mathrm{LH}$ & & 120 & $\mathrm{HuC}$ & 80 & 40 & C F P FCR GS & ground stone \\
\hline 1111 & unk & & 1600 & 0 & 735 & $\mathrm{LH}$ & & 60 & $\mathrm{HuC}$ & 70 & 5 & C F FCR RF & \\
\hline 1112 & unk & & 924 & 0 & 730 & $\mathrm{LH}$ & & 30 & $\mathrm{HuC}$ & 80 & 5 & C F RF & \\
\hline 1113 & unk & & 7000 & 20 & 740 & $\mathrm{LH}$ & & 140 & $\mathrm{HuC}$ & 70 & 20 & C F FCR TC RF & \\
\hline 1114 & EA & & 4500 & 30 & 720 & $\mathrm{M}$ & $\mathrm{T} 2$ & 150 & $\mathrm{HuD}$ & 50 & 30 & C F FCR CH QB RF & Guadalupe biface \\
\hline 1115 & unk & & 30 & 10 & 650 & $\mathrm{M}$ & $\mathrm{T} 1$ & 135 & LVA & 90 & 5 & C F B TF FCR & \\
\hline 1116 & unk & & 500 & 0 & 742 & LH & & 200 & $\mathrm{HuB}$ & 80 & 50 & C F RF & \\
\hline 1117 & unk & & 80 & 10 & 725 & $\mathrm{LH}$ & & 150 & $\mathrm{HuD}$ & 80 & 30 & CF & \\
\hline 1118 & unk & & 2550 & 20 & 745 & LH & & 400 & $\mathrm{HaD}$ & 80 & 60 & C F FCR CH & \\
\hline 1119 & unk & & 375 & 0 & 650 & M & $\mathrm{T} 1$ & 65 & $\mathrm{HuB}$ & 95 & 5 & CF FCR TC RF & \\
\hline 1120 & unk & & 70 & 30 & 650 & M & $\mathrm{T} 1$ & 200 & $\mathrm{HuB}$ & 90 & 5 & C F TF FCR RF & \\
\hline 1121 & LA & Pedernales & 200 & 60 & 640 & M & $\mathrm{T} 1$ & 35 & $\mathrm{Tf}$ & 90 & 40 & F TF B FCR & + historic component \\
\hline 1122 & LP & Edwards & 1500 & 50 & 640 & $\mathrm{M}$ & $\mathrm{TI}$ & 10 & Tf & 85 & 5 & C F TF B FCR & \\
\hline 1123 & unk & & 2640 & 15 & 648 & $\mathrm{M}$ & $\mathrm{T} 2$ & 60 & Tf & 80 & 45 & C F FCR TC RF & \\
\hline 1124 & unk & & 900 & 20 & 700 & $\mathrm{M}$ & UPL & 600 & $\mathrm{HuC}$ & 60 & 10 & C F B FCR & + historic component \\
\hline 1125 & unk & & 900 & 30 & 630 & $\mathrm{M}$ & T0 & 0 & LvA & 80 & 10 & F B FCR RF & \\
\hline
\end{tabular}


Table G-2. continued

\begin{tabular}{|c|c|c|c|c|c|c|c|c|c|c|c|c|c|}
\hline 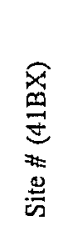 & $\stackrel{\Delta}{\sharp 0}$ & 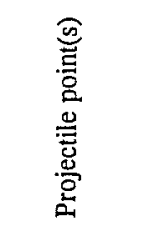 & 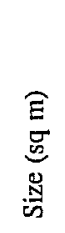 & 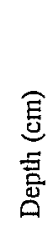 & 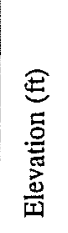 & 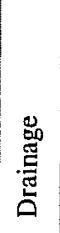 & 总 & 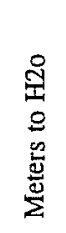 & $\frac{\stackrel{g}{D}}{\stackrel{5}{D}}$ & $\begin{array}{l}\text { 苞 } \\
\text { 吾 } \\
\text { se }\end{array}$ & 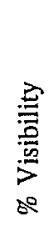 & 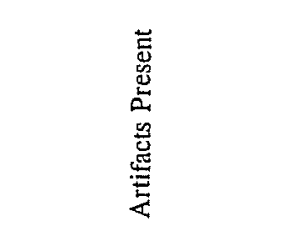 & 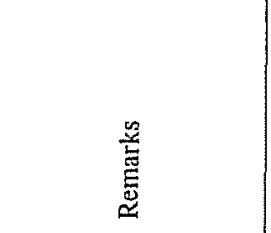 \\
\hline 1126 & unk & & 450 & 60 & 640 & $\mathrm{M}$ & $\mathrm{T} 1$ & 83 & LvA & 60 & 5 & C F TF FCR RF & hearth \\
\hline 1127 & unk & & 675 & 50 & 643 & $\mathrm{M}$ & $\mathrm{T} 1$ & 75 & LVA & 95 & 5 & C F B FCR RF A & charcoal(st) bone(st) \\
\hline 1130 & unk & & 100 & 0 & 635 & $\mathrm{M}$ & $\mathrm{T} 1$ & 150 & LvA & 15 & 5 & F B & + historic component \\
\hline \multirow[t]{6}{*}{1104} & MA & Bulverde & $*$ & 20 & 756 & LH & UPL & 30 & $\mathrm{HuC}$ & 85 & 50 & C F P FCR TC QB RF & \\
\hline & LA & Langtry & & 10 & 694 & & UPL & 60 & Tf & & & & (Arenosa variant) \\
\hline & LA & Tortugas & & 20 & 756 & & UPL & 330 & $\mathrm{HuC}$ & & & & \\
\hline & LA & Castroville & & 30 & 670 & & UPL & 30 & $\mathrm{Tf}$ & & & & \\
\hline & $\mathrm{EA}$ & & & 10 & 693 & & UPL & 50 & Tf & & & & Clear Forkuniface \\
\hline & LP & Perdiz & & 20 & 690 & & UPL & 250 & $\mathrm{HuC}$ & & & & \\
\hline
\end{tabular}

\section{Artifact Key}

$\begin{array}{llll}A=\text { Adze } & \text { F = Flake } & \text { QB = Quarry Blank } & \text { TC = Tested Cobble } \\ B=\text { Biface } & \text { FCR = Fire-Cracked Rock } & \text { RF = Retouched Flake } & \text { TF = Thinning Flake } \\ C=\text { Core } & \text { G }=\text { Gouge } & \text { S = Scraper } & \\ C H=\text { Chopper } & \text { H = Hammerstone } & \text { SS = Shaft Straightener } \\ D=\text { Drill } & \text { P = Preform } & \text { (ST) = Recovered from Shovel Test }\end{array}$

Age Key

$\begin{array}{lll}\mathrm{EA}=\text { Early Archaic } & \mathrm{LP}=\text { Late Prehistoric } & \text { TA = Transitional Archaic } \\ \mathrm{LA}=\text { Late Archaic } & \mathrm{MA}=\text { Middle Archaic } & \text { UNK }=\text { Unknown }\end{array}$

$\mathrm{HnB}=$ Houston Clay, 1 to $3 \%$ Slopes

HoD3 = Houston-Sumter Clays, 5 to $10 \%$ Slopes

HtB $=$ Houston Black Clay, Terrace, 1 to $3 \%$ Slopes

HuB $=$ Houston Black Gravelly Clay, 1 to $3 \%$ Slopes

$\mathrm{HuC}=$ Houston Black Gravelly Clay, 3 to $5 \%$ Slopes
Soils Key

$$
\begin{aligned}
& \mathrm{HuD}=\text { Houston Black Gravelly Clay, } 5 \text { to } 8 \% \text { Slopes } \\
& \text { LvA }=\text { Lewisville Silty Clay, } 0 \text { to } 1 \% \\
& \mathrm{PaB}=\text { Patrick Soils, } 1 \text { to } 3 \% \text { Slopes } \\
& \mathrm{Tf}=\text { Trinity and Frio Soils, Frequently Flooded } \\
& \mathrm{VcC}=\text { Venus Clay Loam,3 to } 5 \% \text { Slopes }
\end{aligned}
$$

$\mathrm{UPL}=\mathrm{Uplands}$

$\mathrm{L}=$ Leon Creek

\section{Drainage Key}

$$
M=\text { Medio Creek }
$$




\title{
Appendix H: Phase II Testing of 41BX1065, A Prehistoric Uplands Site on Leon Creek
}

\author{
Robert R. Rector
}

During the summer of 1994, the Center for Archaeological Research (CAR) at The University of Texas at San Antonio contracted with the National Park Service to conduct 100-percentpedestrian surveys of several tracts of land slated for development at Lackland AFB. The surveys were designed to determine or deny the presence of cultural resources that could be adversely affected by proposed construction. Survey in one of these areas, Wherry Housing, resulted in the location of two prehistoric open campsites (41BX1065 and 41BX1066). The former faced immediate destruction because of its location on land to be used for a new residential building.

Intensive scrutiny of the site surface and a battery of shovel tests yielded several diagnostic projectile points. All but one of these were surface finds, but the series of shovel tests indicated a strong potential for subsurface cultural materials. Data collected during Phase I survey and testing (Appendix G) and the imminent destruction of the site led CAR to propose Phase II testing to further explore site potential for revealing important chronological information, geological setting, and any possible buried archaeological features. This testing was conducted in May 1995.

\section{Location and Previous Fieldwork}

The site is located in a flat and open field in the northwest corner of the Wherry Housing area of Lackland's main base. The setting is a high prominent uplands bluff overlooking Leon Creek and its adjacent floodplain to the east-northeast. The surface geology is mapped as Qt-Pleistocene fluvial terrace deposit (Barnes 1983) and is the PlioPleistocene Leona Gravel (see Nordt, Chapter 3, and Jones, Chapter 4). Directly below the site on the bluff slope the Leona Gravel sits unconformably on Cretaceous bedrock which Jones (Chapter 4) identifies as the Upper Taylor Marl Group. The site sits approximately $60 \mathrm{~m}$ above the creek in Houston Black gravelly clay soil and offers a commanding view of the surrounding terrain. A chain-link fence separates the open part of the site from a steep bluff to the north and east.

Post-World War II aerial photographs indicate the location was used as a staging area for the construction of a residential neighborhood that now skirts the site. Use of the location in this manner raised doubts concerning the surviving integrity of the prehistoric site. CAR archaeologists were mindful of potential disturbances during the testing phase.

During the initial survey and shovel testing phase in 1994, moderate quantities of chert debris were described from the site surface and from shovel tests, including several diagnostic projectile points. The points were recovered and include Langtry, Marcos, Matamoros, and Ensor dart points. These suggest use of the space through the Middle, Late, and Transitional Archaic periods.

\section{Methods}

The testing phase at $41 \mathrm{BX} 1065$ began by relocating the initial set of shovel tests dug in 1994, and reestablishing the grid on which they were placed across the site. A datum was set in the northeast corner of the project area near the fence corner. The positions of the Phase II test units and trenches were plotted over the original grid. The placement of the current test units was designed to avoid the shovel tests excavated in 1994 and to sample artifact concentrations revealed by surface distributions and previous shovel tests. 
Testing began with a set of seven strategically placed Gradall trenches to allow for quick and efficient inspection of large areas across both axes of the site (Figure $\mathrm{H}-1$ ). In situ archaeologically bearing deposits and features were the primary targets of this effort. This was followed by seven $1-\mathrm{x}-1-\mathrm{m}$ test units intended to provide more information on promising deposits revealed by the Gradall trenches, and to further test areas inadequately exposed by the trenches. Finally, two backhoe trenches were used to expose to a greater depth the pre-cultural geological deposits at the site. Sediments from each Gradall trench, 1-x-1-m test unit, and backhoe trench were described and profiles drawn.

\section{Results}

The substantive results of the Phase II testing are presented below. These are divided into the types of excavation units and the sections include: Gradall Trenches, Backhoe Trenches, and Test Units.

\section{Gradall Trenches}

Four sediment zones were identified in the Gradall trenches. Profiles are presented in Figures $\mathrm{H}-2$ and $\mathrm{H}-3$, with the corresponding soil descriptions given in Table H-1. The seven Gradall trenches (noted as GT1-GT7 on Figure $\mathrm{H}-1$ ) yielded modern trash and construction debris in various areas in the top $20 \mathrm{~cm}$ in Zone 1 , as anticipated by the 1994 shovel tests (Table $\mathrm{H}-2)$. Zone 1 is classified as an A-horizon. Portions have suffered from recent disturbance or bioturbation, but much of the sediment appears intact. The trenches in the eastern and northwestern parts of the site (GT1-GT5) revealed an intact deposit containing archaeological materials between $10-30 \mathrm{~cm}$. This zone (Zone 2) contained apparent in situ prehistoric artifacts but lacked historic artifacts. Zone 2 is classified as the lower portion of the A horizon. Zone 3 calcium carbonate cemented fluvial gravels and alluvium form the basal unit observed in the bottoms of the Gradall trenches. The degree of calcium carbonate accumulation indicates that these deposits are fairly old, and it is clear that Zone 3 is the uppermost portion of the weathered Plio-Pleistocene Leona Formation. Zone 3 was typically exposed between 25 and $40 \mathrm{~cm}$ below ground surface, indicating the shallow nature of the deposits bearing cultural materials. The profiles in GT 1 and GT 4 suggest that shallow erosional rills may have eroded the underlying Leona Formation and these filled with Zone 2 sediments. GT 6 conveyed a different impression of integrity in the northern sector of the site. Here, an anchor and cable were uncovered at $88 \mathrm{~cm}$ below the surface amid gravels of varying sizes. The sediments composing the fill of the trench appear to be Zone 4 and redeposited Zone 3 sediments. These suggest that considerable mixing had occurred in some parts of the site due to recent laying of utility lines.

Near the eastern edge of the site, a small burned rock feature (Feature 1) resting on sterile gravels $26 \mathrm{~cm}$ below the surface was uncovered in GT 1 . Feature 1 is positioned approximately $20 \mathrm{~m}$ from the bluff edge overlooking Leon Creek. Since the Gradall trench revealed only part of the feature, a test unit (TU 6) was placed directly over it to remove adjacent overburden and fully expose the array of burned rock. Results of the test units are discussed below. The buried hearth and associated prehistoric artifacts suggest that some deposition during the Holocene did occur at the site. It is possible that the underlying Leona Formation eroded at some point in the Holocene and sediments then began to accumulate and soil formed after that time. Given the topographic setting of the site, it seems reasonable to suggest that at least some of the sediments that accumulated through aeolian processes.

\section{Backhoe Trenches}

Two backhoe trenches (BT 1 and BT 2) were dug to insure that cultural-bearing deposits did not occur below the Gradall trenches (Figure H-1). BT 1 was excavated below the floor of the northern end of GT3 to expose deposits below the profile illustrated for GT 3 (Figure $\mathrm{H}-4$ and Table $\mathrm{H}-3$ ). It reveals a highly weathered Leona Formation with $\mathrm{CaCO}_{3}$ cemented alluvium and gravels. No prehistoric cultural materials were observed in the fill or profiles in BT 1. 


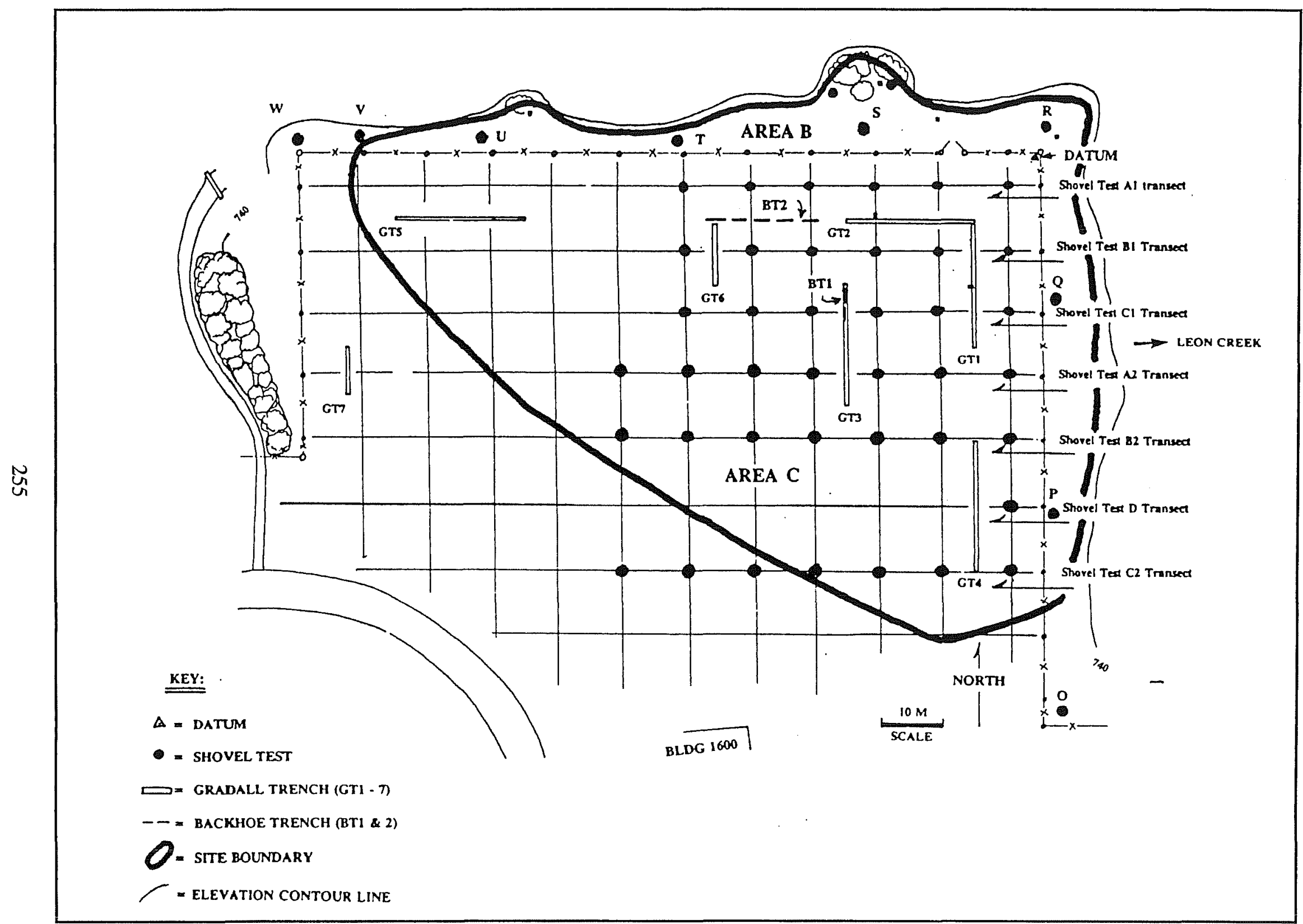

Figure H-1. Site plan, 41BX1065. 
GT 1- West Wall

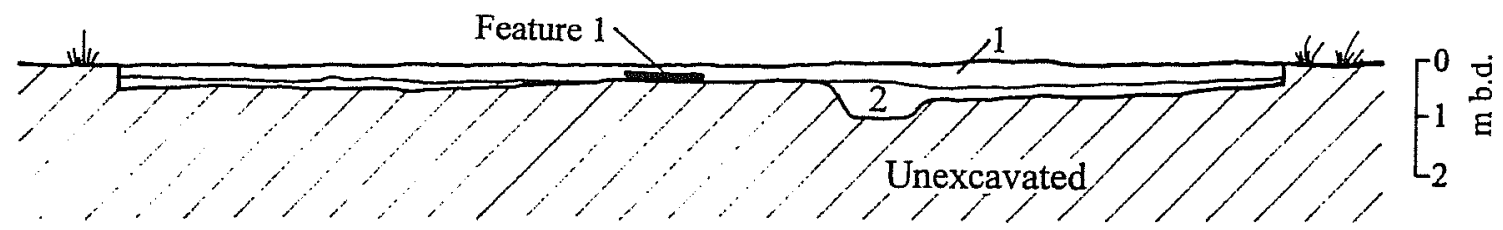

\section{GT 2- North Wall}

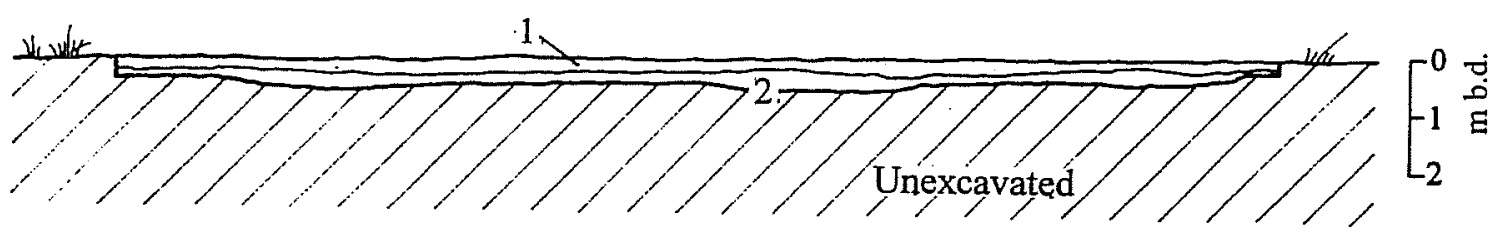

\section{GT 3- West Wall}

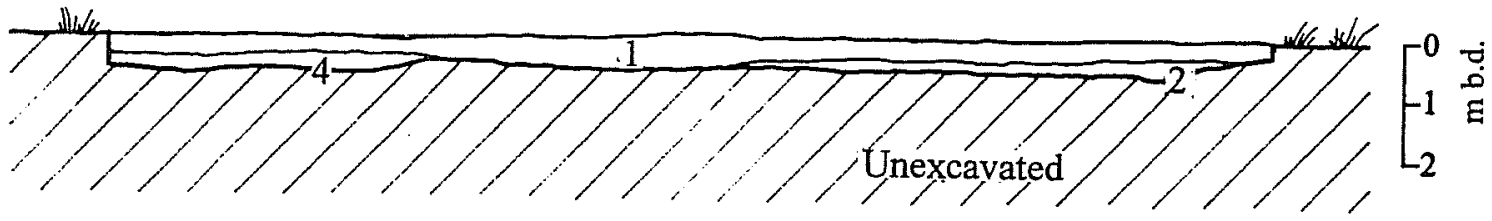

GT 4- West Wall

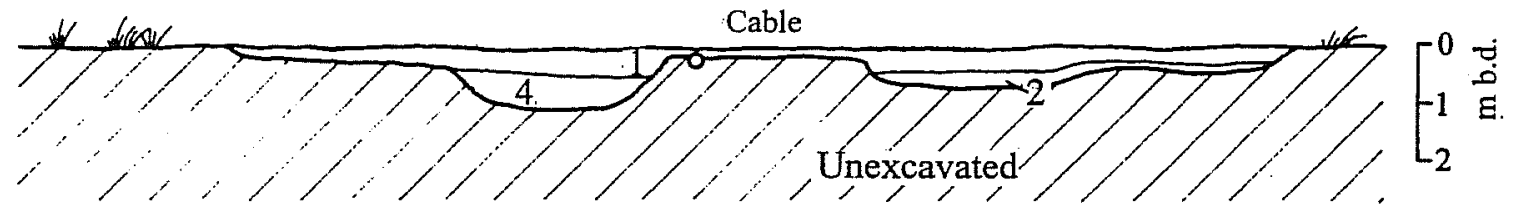

Figure H-2. Gradall frenches 1-4, profiles. 
GT 5- North Wall

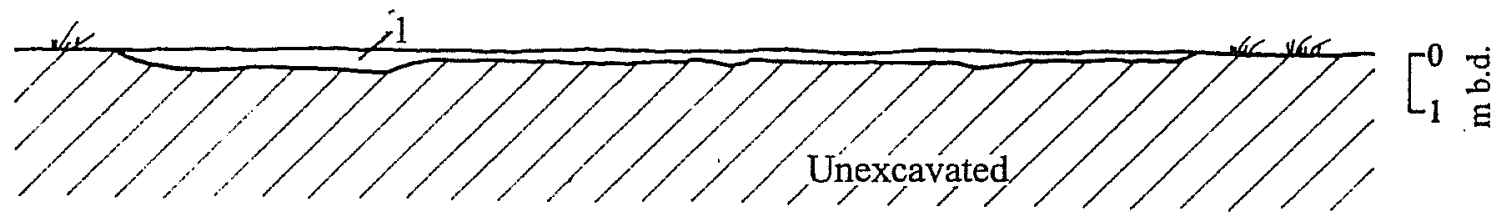

GT 6- East Wall

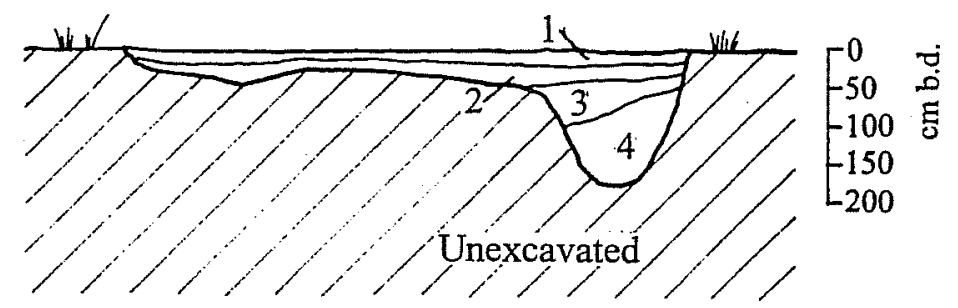

GT 7- East Wall
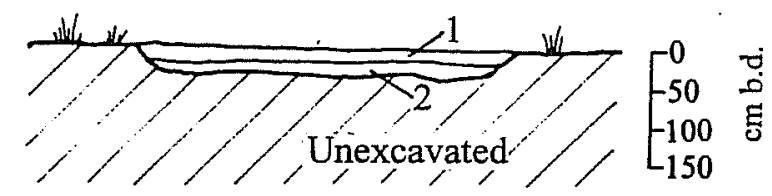

Figure H-3. Gradall Trenches 5-7, profiles.

Table H-1. Sediment Descriptions from Gradall Trenches

$\begin{array}{ll}\frac{\text { Zone }}{1} & \frac{\mathrm{cm} \mathrm{bs}}{0-10 / 20} \\ 2 & 10 / 20-30 \\ 3 & 30-35 / 50 \\ 4 & 5-12\end{array}$

Description

Black (10YR 2/1) to very dark grayish brown (10YR 3/2) clay loam with fine strong subangular blocky structure, common rootlets, small gravels and some prehistoric lithic artifacts, clear to abrupt smooth and sloping lower boundary, A1 horizon.

Dark brown (10YR 3/3) clay loam with fine moderate subangular blocky structure, few $\mathrm{CaCO}_{3}$ filaments and nodules, few pebbles and gravels, rare prehistoric lithic artifacts, abrupt irregular lower boundary, A2 horizon.

Grayish brown (10YR 5/2) to yellowish brown (10YR 4/3.5) clay loam with fine moderate granular structure, some areas stained with iron oxide, few gravels, few chert cobbles cemented with $\mathrm{CaCO}_{3}$, Bk horizon.

Dark brown (10YR 3/3) clay loam with moderate medium granular structure, few gravels, rootlets, $\mathrm{CaCO}_{3}$ nodules, and prehistoric lithic artifacts, abrupt wavy lower boundary, trench fill and trench backdirt. 
Table H-2. Artifacts Recovered from Gradall Trenches

\begin{tabular}{||c|c|l||}
\hline Trench & Depth $\mathbf{( c m )}$ & \multicolumn{1}{|c|}{ Artifacts } \\
\hline GT2 & $0-20$ & 5 double headed wire nails \\
\hline GT2 & $0-20$ & 1 biface \\
\hline GT3 & $0-20$ & 1 biface \\
\hline GT3 & $0-20$ & 1 double headed wire nail \\
\hline GT3 & $0-20$ & 1 flake \\
\hline GT5 & $0-25$ & 1 Marcos preform \\
\hline GT5 & $0-25$ & 5 bifaces \\
\hline
\end{tabular}

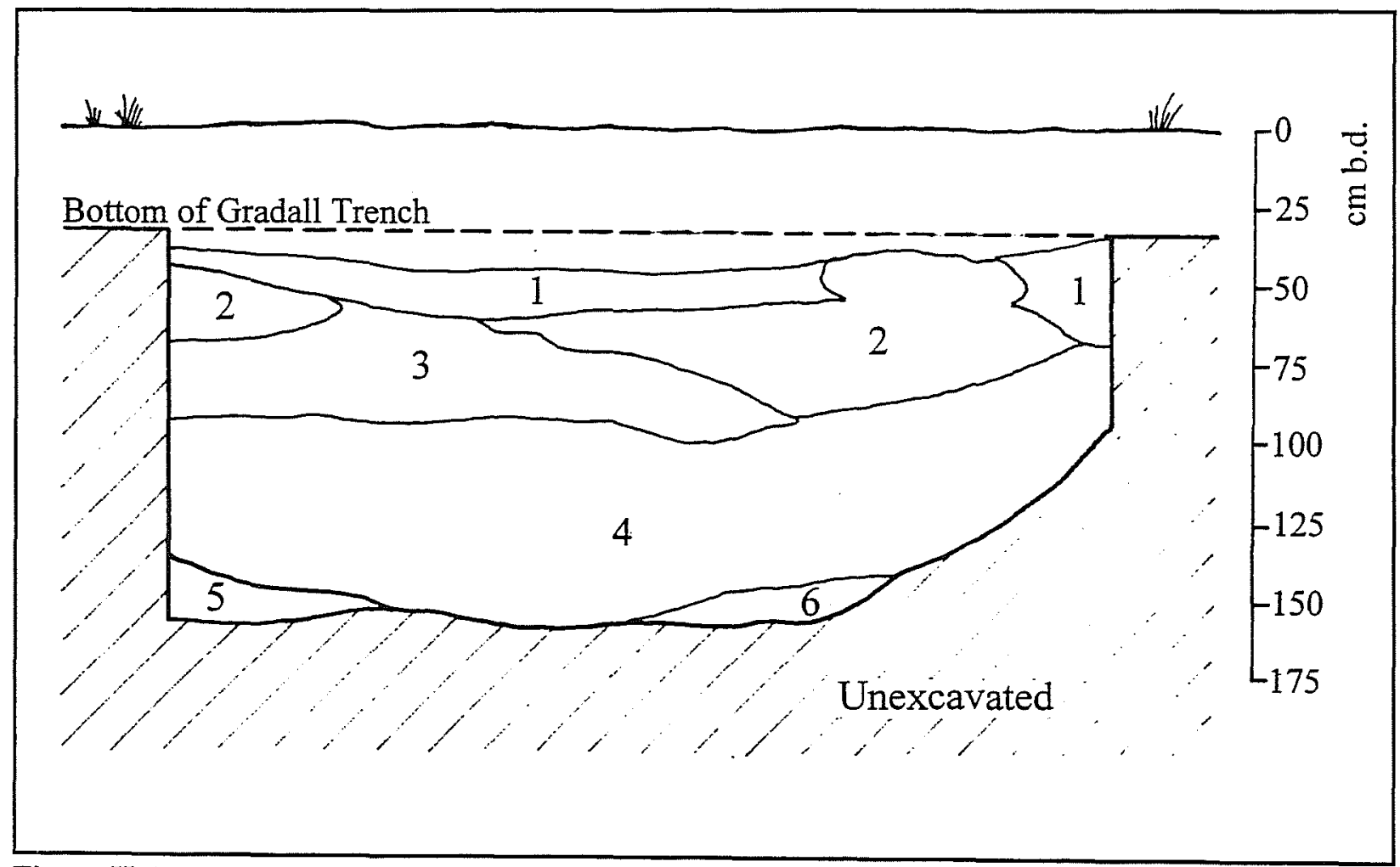

Figure H-4. Backhoe Trench 1, west wall profile. 
Table H-3. Sediment Descriptions from Backhoe Trench 1

$\begin{array}{ll}\frac{\text { Zone }}{1} & \frac{\mathrm{cm} \mathrm{bs}}{30-70} \\ 2 & 40-90 \\ 3 & 60-100 \\ 4 & 70-160 \\ 5 & 140-160 \\ 6 & 140-160\end{array}$

Description

Grayish brown (10YR 5/2) to yellowish brown (10YR 4/3.5) clay loam with fine moderate granular structure, some areas stained with iron oxide, few gravels, few chert cobbles cemented with $\mathrm{CaCO}_{3}$, $\mathrm{Bk}$ horizon and similar to Zone 3 in Gradall Trenches.

Large patches of cemented $\mathrm{CaCO}_{3}$, abrupt wavy lower boundary.

Medium-sized clast supported gravel lens with white (5YR 8/1) clay loam between gravels, impregnated with $\mathrm{CaCO}_{3}$ masses and $\mathrm{CaCO}_{3}$ coatings on gravels, abrupt irregular lower boundary.

? (10YR 6/4) friable sandy loam, few scattered pebbles with $\mathrm{CaCO}_{3}$ coatings, very abrupt lower boundary.

White (10YR 8/1) silt loam lens, abrupt wavy lower boundary.

Brownish yellow (10YR 6/6) clast supported gravel lens with $\mathrm{CaCO}_{3}$ coatings and sand between gravels, lower boundary not observed.

BT 2 was excavated in the northern portion of the site and between GT 6 and GT 7. It provides a similar view of the deposits at the site (Table H-4). The uppermost sediments (Zone 1 and Zone 2) are similar to Zone 1 and Zone 2 sediments in the Gradall trenches (Figure $\mathrm{H}-5$ and Table $\mathrm{H}-4$ ). These sediments contained prehistoric lithic artifacts and Zone 1 contained a few historic artifacts. This intact sequence rests on cemented calcium carbonate, caliche gravel lenses and calcium carbonate impregnated fluvial sediments that comprise the upper portion of the Leona Formation.

\section{Test Units}

Seven 1-x-1-m test units (Figure $\mathrm{H}-1$ ) were excavated to clarify the vertical and horizontal extent of the site, and to obtain a tightly controlled vertical data base. Five of the seven units (TU 1-5) were placed along the northern and eastern edges of the site, and outside the chain-link fence that cuts through it. Early aerial photographs indicate a set of structures were placed in this area during the construction phase mentioned above. Therefore, it was believed that the degree of disturbance suffered in this area would be minimal. Test Unit 6 was placed to further reveal a feature detected by Gradall trenching. The final test unit (TU 7) was placed closer to the site interior. Each unit was excavated to a depth of at least $40 \mathrm{~cm}$. Culturalbearing sediments ceased above $40 \mathrm{~cm}$ in all but one unit (TU 3). Table $\mathrm{H}-5$, given at the end the text, presents the results from each unit.

The sediments were described in the level notes for each test unit, as summarized below. In TU 1, Level 1 consisted of very dark gray (10YR 3/1) clay loam with a few gravels. In Level 2 the color changed slightly to a very dark gray (10YR $3 / 2$ ) clay loam and a small increase in gravel frequency. Level 3 consisted of a dark grayish brown (19YR 4/2) clay loam but with slightly more sand and, at approximately $28 \mathrm{~cm}$ below the surface, this shifted abruptly to a gravel lens with $\mathrm{CaCO}_{3}$ coatings. Clearly the sediments in TU 1 represent a surface A horizon sitting unconformably on weathered Leona Formation gravels. All artifacts were found above the gravel lens.

Test Unit 2, Levels 1 and 2, consisted of a very dark gray (7.5YR 3/1) clay loam with blocky structure and scattered gravels. Level 3 was similar to the sediments above except that it was slightly more compact and gravels increase in frequency. In Level 4 cemented $\mathrm{CaCO}_{3}$ sediments with a significant increase in gravels were encountered and excavation ceased. Again the sediments reflect an A-horizon sitting unconformably on cemented Leona Formation sediments. 


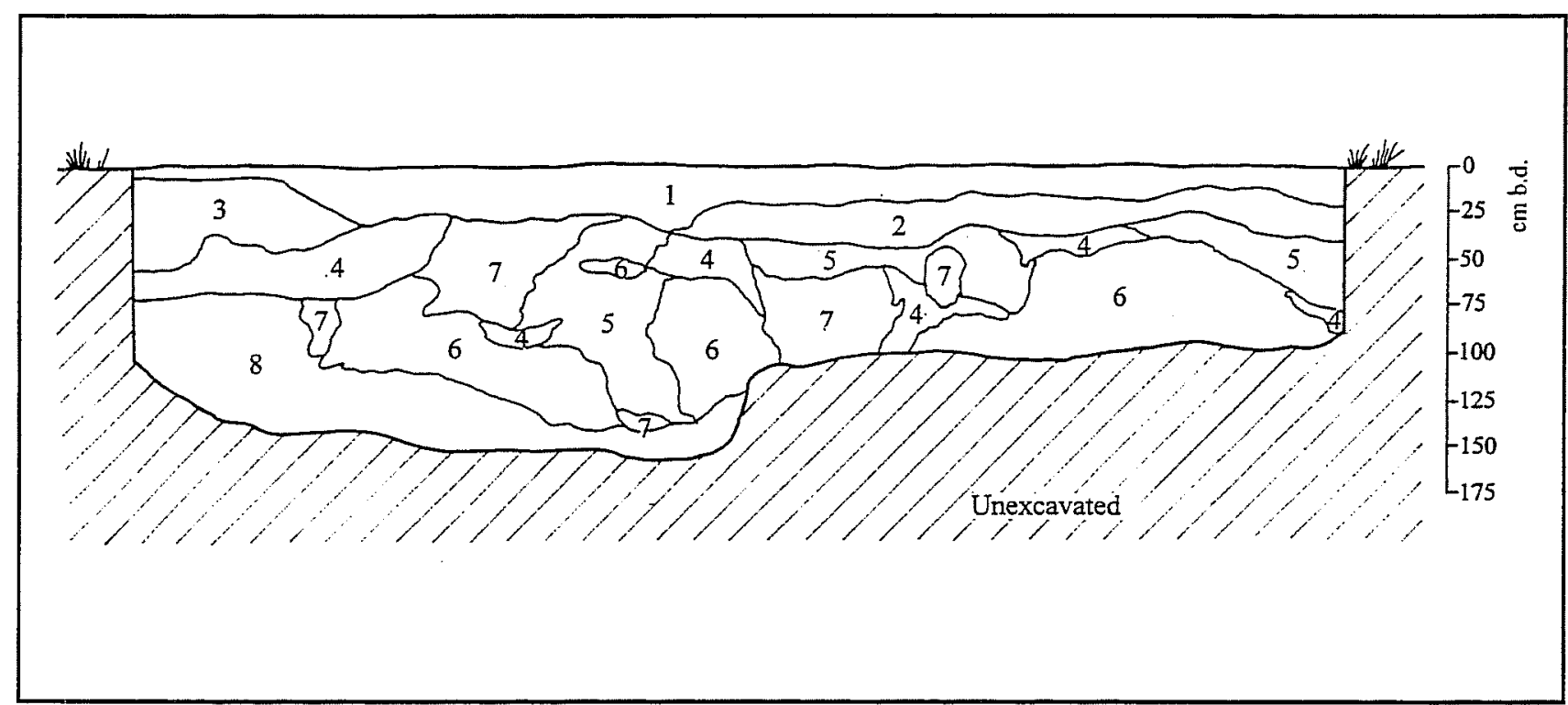

Figure H-5. Backhoe Trench 2, north wall profile.

Table H-4. Sediment Descriptions from Backhoe Trench 2

$\underline{\text { Zone }}$ cm bs $\quad$ Description

$1 \quad$ B-34 Black (10YR 2/1) to very dark grayish brown (10YR 3/2) clay loam with fine strong subangular blocky structure, common rootlets, small gravels and some prehistoric lithic artifacts, clear to abrupt smooth and sloping lower boundary, A1 horizon.

$2 \quad 10-55$

Dark brown (10YR 3/3) clay loam with fine moderate subangular blocky structure, few $\mathrm{CaCO}_{3}$ filaments and nodules, few pebbles and gravels, rare prehistoric lithic artifacts, abrupt irregular lower boundary, A2 horizon.

3 5-55 Dark brown (10YR 3/3) clay loam with moderate medium granular structure, few gravels, rootlets, $\mathrm{CaCO}_{3}$ nodules, and prehistoric lithic artifacts, abrupt wavy lower boundary, trench fill and trench backdirt.

$4 \quad 35-95$

Large irregular patches of cemented $\mathrm{CaCO}_{3}$, abrupt wavy lower boundary, $\mathrm{K}$ horizon.

$5 \quad 40-140$

Grayish brown (10YR 5/2) to yellowish brown (10YR 4/3.5) clay loam with fine moderate granular structure, some areas stained with iron oxide, few gravels, few chert cobbles cemented with $\mathrm{CaCO}_{3}$, Bk horizon.

6 60-100 Medium-sized clast-supported gravel multiple lenses with white (5YR 8/1) clay loam between gravels, impregnated with $\mathrm{CaCO}_{3}$ masses and $\mathrm{CaCO}_{3}$ coatings on gravels, abrupt irregular lower boundary.

$7 \quad 60-100 \quad$ Light gray (10YR 5/2) friable clay loam with fine moderate granular structure, few matrix-supported gravels, abrupt irregular lower boundary.

$8 \quad 70-150$

White (10YR 8/1) silt loam lens, lower boundary not observed. 
Test Unit 3, Levels 1 and 2 consists of dark grayish brown (10YR 4/2) clay loam with blocky structure. A distinctive amount of burned roots was mapped in Level 2. In Level 3 the sediments changed to slightly darker and were classified as a very dark brown (10YR 2/2) clay loam with a low frequency of gravels. Several burned limestone rocks were mapped in the southeast corner of the unit, but it is unclear if these actually comprise an intact prehistoric feature. In Level 4 the sediments change significantly below $33 \mathrm{~cm}$ and are characterized by a dramatic increase in gravels and a shift to a grayish brown (10YR 5/2) clay loam with more sand. Sediments in Level 5 show a continuation of the gravels and lighter-colored sediment that is now cemented with $\mathrm{CaCO}_{3}$. The sediments in Test Unit 3 also show an A-horizon in the upper levels that sits unconformably on weathered Leona Formation sediments.

Sediments in TU 4, Level 1 are composed of a very dark gray (10YR 3/1) clay loam with blocky structure and scattered gravels. In Level 2 the color changes slightly to a dark gray (7.5YR 3/1) and the top of a block of $\mathrm{CaCO}_{3}$-cemented sediment was exposed. In Level 3 the sediments are essentially unchanged and a greater portion of the $\mathrm{CaCO}_{3}$ cap was exposed. The only significant change in Level 4 is marked by an increase in gravels. Test Unit 4 also shows that artifact bearing A-horizon sediments overlie the weathered Leona Formation.

Test Unit 5 sediments consist primarily of dark brown (10YR 3/3) clay loam in Levels 1,2 , and 3. However, in Level 3 pebbles and gravels increase in frequency, making excavation very difficult. This gravel-laden stratum, almost certainly part of the Leona Formation, was overlain by an A horizon.

In TU 6 the sediments in Level 1 and most of Level 2 consisted of very dark grayish brown (10YR 3/2) clay loam with blocky structure and low frequency of gravels. Below $19 \mathrm{~cm}$ bs the texture changed to more sandy. In Level 3 the sediments are grayish brown (10YR 5/2) clay loam but with more sand than above and a blocky structure. Feature 1 occurs in Level 3 and consists of 20-25 fragments of burned limestone and 25-30 pieces of caliche. It is unclear if the caliche was used as hearth stones or not, but the limestone was obviously burned and thermally fractured. The feature appears to sit just above the weathered Leona Formation.

Sediments in Level $1-4$ in TU 7 consist of very dark gray (7.5YR 3/1) to very dark grayish brown (10YR $3 / 2$ ) blocky clay loam. Gravels gradually increase from Level 1 to Level 3, then dramatically increase in Level 4. It appears that sediments in Level 4 are probably weathered gravel lenses in the Leona Formation and the overlying sediments are the surface A horizon.

\section{Artifact Frequencies}

The frequency of archaeological materials in all test units suggests essentially intact deposits, as revealed by several patterns.

1) Historic artifact counts of more than one per level (TU 3, 4, 7) always occur in the uppermost level, even though in two units (TU 4, 7) these also correspond with the highest counts of flaked chert; thus, turbation was probably low.

2) Total counts of flaked chert usually form clear peaks in one excavation level (TU 2, $3,5,6$ ), or two (TU 1,4); chipped stone debris forms the bulk of total flaked chert in most levels.

3) Peaks in the frequencies of fire cracked rock (chert, limestone, or caliche) generally correspond with those of total flaked chert.

4) Frequencies of interior and exterior flakes tend to be comparatively low (except TU 3 ), but those levels with the highest counts for each show a negative correlation (TU $3-5)$. That is, in these units interior and exterior flakes peak in different levels.

5) Frequencies of bifacial thinning flakes, which represent advanced stages of reduction, are consistent with the total chert frequencies, except in two levels:

a) the 30-40 cm level of Unit 3 indicates a second peak that is not reflected in the total chert count; 
b) The $30-40 \mathrm{~cm}$ level of Unit 7 shows a higher frequency at the base of the cultural deposit, while the total chert flake count peaks in the uppermost level of the deposit.

6) Those unit levels containing cores (TU $2,20-30 \mathrm{~cm}$ and TU $5,10-20 \mathrm{~cm}$ ) correspond with levels containing high total chert flake counts, including interior and bifacial thinning flakes.

One snapped Marcos dart point reject was recovered from GT 5 . Uniform patination indicates the break occurred before trenching. Gradall trench 5 also yielded three quarry blanks (two of which are heavily patinated), a preform fragment, and a thin biface fragment. Both of the latter are lightly patinated.

Thin biface fragments were found in TU 2 (0-10 $\mathrm{cm})$ and TU $3(20-30 \mathrm{~cm})$. Some of the debris and thinning flakes surrounding the TU 3 fragment apparently emanate from the same core, although refitting efforts were unsuccessful.

A burin recovered from TU $5(10-20 \mathrm{~cm})$ was fashioned on an older flake (indicated by clear differences in patination) and then suffered heating damage. A possible burin spall recovered from the same unit level could not be refitted.

\section{Conclusions}

Phase II testing confirmed the extremely shallow nature of the cultural deposit in a surface A horizon at 41BX1065; nevertheless, much of the site still remains intact as reflected by Feature 1 and the vertical distribution of prehistoric and historic artifacts. Gradall trenching in the western part of the site indicates that the site has suffered some disturbance in that area, probably during construction activities after World War II. The vertical distribution of artifacts in the test units along the northern and eastern perimeter of the site suggest one, possibly two, subsurface occupational layers even though the site sediments do not show a stratigraphic break. Diagnostic artifacts were not recovered in any test units, but surface finds and an artifact from the Gradall trench indicate a fairly limited period of use between the Middle through Transitional Archaic. Based on these results it appears that significant archaeological materials may still survive on the northern and western parts of the site and these should be preserved or, if threatened, their loss mitigated by further excavation. 
Table H-5. Material Counts by Unit Level, 41BX1065

\begin{tabular}{|c|c|c|c|c|c|c|c|c|c|}
\hline Unit 1 & $\begin{array}{c}\text { interior } \\
\text { flakes }\end{array}$ & $\begin{array}{c}\text { exterior } \\
\text { flakes }\end{array}$ & $\begin{array}{c}\text { thinning } \\
\text { flakes }\end{array}$ & debris & $\begin{array}{c}\text { other } \\
\text { flaked } \\
\text { chert }\end{array}$ & $\begin{array}{l}\text { total } \\
\text { flaked } \\
\text { flaked } \\
\text { chert }\end{array}$ & $\begin{array}{c}\text { fïre } \\
\text { cracked } \\
\text { rock }\end{array}$ & $\begin{array}{l}\text { historic } \\
\text { artifacts }\end{array}$ & 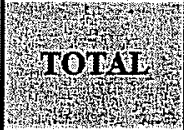 \\
\hline $0-10 \mathrm{~cm}$ & 4 & 3 & 12 & 24 & - & $3+43$ & 6 & - & ry \\
\hline $10-20 \mathrm{~cm}$ & 6 & 3 & 10 & 17 & - & 36 & 16 & 1 & Hor \\
\hline $20-30 \mathrm{~cm}$ & 6 & - & 6 & 3 & - & 15 & 4 & - & 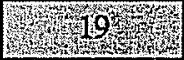 \\
\hline $30-40 \mathrm{~cm}$ & - & - & - & - & - & Woy & - & - & $y^{4}$ \\
\hline $40 \mathrm{~cm}+$ & - & - & - & - & - & Whary & - & - & $\begin{array}{l}1 \\
7\end{array}$ \\
\hline
\end{tabular}

\begin{tabular}{|c|c|c|c|c|c|c|c|c|c|}
\hline Unit 2 & $\begin{array}{l}\text { interi- } \\
\text { or } \\
\text { flakes }\end{array}$ & $\begin{array}{c}\text { exterior } \\
\text { flakes }\end{array}$ & $\begin{array}{l}\text { thinning } \\
\text { flakes }\end{array}$ & debris & $\begin{array}{l}\text { other } \\
\text { flaked } \\
\text { chert* }\end{array}$ & $\begin{array}{l}\text { toual } \\
\text { flaked } \\
\text { flaked } \\
\text { chert. }\end{array}$ & $\begin{array}{c}\text { fire } \\
\text { cracked } \\
\text { rock }\end{array}$ & $\begin{array}{l}\text { historic } \\
\text { artifacts }\end{array}$ & 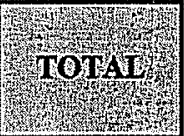 \\
\hline $0-10 \mathrm{~cm}$ & 5 & 3 & 5 & 27 & 2 & $x^{4} 2^{2}$ & 7 & - & $W_{2}$ \\
\hline $10-20 \mathrm{~cm}$ & 2 & 3 & 10 & 31 & - & $4 \sigma^{4}$ & 7 & - & Het \\
\hline $20-30 \mathrm{~cm}$ & 5 & 2 & 15 & 57 & 1 & 60 & 7 & - & 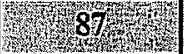 \\
\hline $30-40 \mathrm{~cm}$ & - & 2 & - & 4 & - & 64 & 9 & - & $a^{2}$ \\
\hline $40 \mathrm{~cm}+$ & - & - & - & - & - & Wry & - & - & (4) \\
\hline
\end{tabular}

${ }^{*} 0-10 \mathrm{~cm}=$ split cobble, thin biface fragment; $20-30 \mathrm{~cm}=$ core

\begin{tabular}{|c|c|c|c|c|c|c|c|c|c|}
\hline Unit 3 & $\begin{array}{l}\text { interior } \\
\text { flakes }\end{array}$ & $\begin{array}{c}\text { exterior } \\
\text { flakes }\end{array}$ & $\begin{array}{c}\text { thinning } \\
\text { flakes }\end{array}$ & debris & $\begin{array}{l}\text { other } \\
\text { flaked } \\
\text { chert* }\end{array}$ & $\begin{array}{l}\text { total } \\
\text { flaked } \\
\text { ilked } \\
\text { chert }\end{array}$ & $\begin{array}{c}\text { fire } \\
\text { cracked } \\
\text { rock }\end{array}$ & $\begin{array}{c}\text { historic } \\
\text { artifact } \\
\quad \mathrm{s}\end{array}$ & 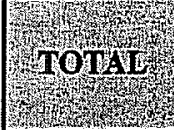 \\
\hline $0-10 \mathrm{~cm}$ & 2 & 2 & 3 & 7 & - & 144 & 15 & 11 & Dis \\
\hline $10-20 \mathrm{~cm}$ & 11 & 4 & 10 & 24 & - & H & 22 & - & r.t. \\
\hline $20-30 \mathrm{~cm}$ & 10 & 6 & 6 & 3 & 1 & $\begin{array}{rl}26 & 26 \\
2 & 26\end{array}$ & 18 & - & 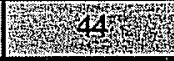 \\
\hline $30-40 \mathrm{~cm}$ & - & 1 & 12 & 5 & 2 & -20 & 11 & - & Wry \\
\hline $40 \mathrm{~cm}+$ & 3 & 7 & 2 & 2 & - & 147 & 8 & - & \\
\hline
\end{tabular}

$* 20-30 \mathrm{~cm}=$ thin biface fragment; $30-40 \mathrm{~cm}=$ tested cobbles 
Table H-5. continued

\begin{tabular}{|c|c|c|c|c|c|c|c|c|c|}
\hline Unit 4 & $\begin{array}{c}\text { interior } \\
\text { flakes }\end{array}$ & $\begin{array}{c}\text { exterior } \\
\text { flakes }\end{array}$ & $\begin{array}{c}\text { thinning } \\
\text { flakes }\end{array}$ & debris & $\begin{array}{l}\text { other } \\
\text { flaked } \\
\text { chert }\end{array}$ & $\begin{array}{l}\text { total } \\
\text { flaked } \\
\text { flared } \\
\text { chert }\end{array}$ & $\begin{array}{l}\text { fire } \\
\text { cracked } \\
\text { rock }\end{array}$ & $\begin{array}{l}\text { historic } \\
\text { artifacts }\end{array}$ & 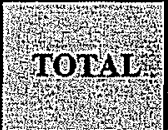 \\
\hline $0-10 \mathrm{~cm}$ & 3 & 7 & 4 & 32 & - & 46 & 12 & 7 & \\
\hline $10-20 \mathrm{~cm}$ & 5 & 3 & 3 & 30 & - & $4 x^{1}=x$ & 9 & - & 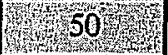 \\
\hline $20-30 \mathrm{~cm}$ & 3 & 1 & 1 & - & - & W & 9 & - & Mry \\
\hline $30-40 \mathrm{~cm}$ & 1 & 2 & 1 & - & - & 34t & 5 & - & Wy \\
\hline $40 \mathrm{~cm}+$ & - & - & - & - & - & Wh & - & - & 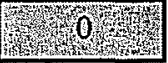 \\
\hline
\end{tabular}

\begin{tabular}{|c|c|c|c|c|c|c|c|c|c|}
\hline Unit 5 & $\begin{array}{c}\text { interior } \\
\text { flakes }\end{array}$ & $\begin{array}{c}\text { exterior } \\
\text { flakes }\end{array}$ & $\begin{array}{l}\text { thinning } \\
\text { flakes }\end{array}$ & debris & $\begin{array}{l}\text { other } \\
\text { flaked } \\
\text { chert* }\end{array}$ & $\begin{array}{l}\text { total } \\
\text { flaked } \\
\text { chert }\end{array}$ & $\begin{array}{c}\text { fire } \\
\text { cracked } \\
\text { rock }\end{array}$ & $\begin{array}{l}\text { historic } \\
\text { artifacts }\end{array}$ & 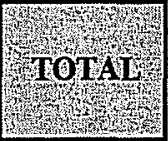 \\
\hline $0-10 \mathrm{~cm}$ & - & 1 & 2 & 9 & - & 127 & 27 & - & r. \\
\hline $10-20 \mathrm{~cm}$ & 3 & 5 & 9 & 24 & 3 & $44^{2}$ & 69 & - & -14 \\
\hline $20-30 \mathrm{~cm}$ & - & 8 & 7 & 11 & - & 26,4 & 34 & - & 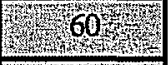 \\
\hline $30-40 \mathrm{~cm}$ & - & - & - & - & - & 0 & - & - & Wryty \\
\hline $40 \mathrm{~cm}+$ & - & - & - & - & - & Why & - & - & 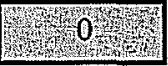 \\
\hline
\end{tabular}

$* 10-20 \mathrm{~cm}=$ core, burin, and burin spall

\begin{tabular}{|c|c|c|c|c|c|c|c|c|c|}
\hline Unit 6 & $\begin{array}{c}\text { interior } \\
\text { flakes }\end{array}$ & $\begin{array}{c}\text { exterior } \\
\text { flakes }\end{array}$ & $\begin{array}{l}\text { thinning } \\
\text { flakes }\end{array}$ & debris & $\begin{array}{c}\text { other } \\
\text { flaked } \\
\text { chert }\end{array}$ & $\begin{array}{l}\text { total } \\
\text { flaked } \\
\text { chert }\end{array}$ & $\begin{array}{c}\text { fire } \\
\text { cracked } \\
\text { rock }\end{array}$ & $\begin{array}{l}\text { historic } \\
\text { artifacts }\end{array}$ & 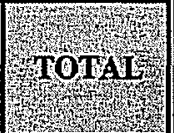 \\
\hline $0-10 \mathrm{~cm}$ & - & - & 3 & 1 & - & Why & 1 & - & 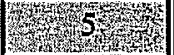 \\
\hline $10-20 \mathrm{~cm}$ & 1 & - & 3 & - & - & Whysy & - & - & 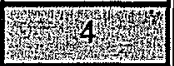 \\
\hline $20-30 \mathrm{~cm}$ & - & 1 & 7 & 1 & - & (3) & 9 & - & 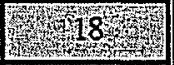 \\
\hline $30-40 \mathrm{~cm}$ & - & - & - & - & - & Why & - & - & W \\
\hline $40 \mathrm{~cm}+$ & - & - & - & - & - & Writy & - & - & r. \\
\hline
\end{tabular}


Table H-5. continued

\begin{tabular}{|c|c|c|c|c|c|c|c|c|c|}
\hline Unit 7 & $\begin{array}{c}\text { interior } \\
\text { flakes }\end{array}$ & $\begin{array}{c}\text { exterior } \\
\text { flakes }\end{array}$ & $\begin{array}{c}\text { thinning } \\
\text { flakes }\end{array}$ & debris & $\begin{array}{c}\text { other } \\
\text { flaked } \\
\text { chert }\end{array}$ & $\begin{array}{c}\text { total } \\
\text { flaked } \\
\text { chert }\end{array}$ & $\begin{array}{c}\text { fire } \\
\text { cracked } \\
\text { rock }\end{array}$ & $\begin{array}{c}\text { historic } \\
\text { artifacts }\end{array}$ & TOTAI \\
\hline $0-10 \mathrm{~cm}$ & - & 1 & 3 & 17 & - & 21 & - & 5 & 26 \\
\hline $10-20 \mathrm{~cm}$ & - & 1 & 4 & 5 & - & 10 & 2 & - & 12 \\
\hline $20-30 \mathrm{~cm}$ & 3 & 1 & 6 & 4 & - & 14 & - & - & 14 \\
\hline $30-40 \mathrm{~cm}$ & - & - & 9 & 4 & - & 13 & 3 & 1 & 17 \\
\hline $40 \mathrm{~cm}+$ & - & - & - & - & - & 0 & - & - & 0 \\
\hline
\end{tabular}


